

\section{LA SERPIENTE VENCIDA}

Sobre los orígenes de la misoginia en lo sobrenatural 


\title{
LA SERPIENTE VENCIDA \\ Sobre los orígenes de la misoginia en lo sobrenatural
}

\author{
Eudaldo Casanova \\ M. ${ }^{a}$ Ángeles Larumbe
}

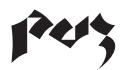

Prensas Universitarias de Zaragoza 


\section{FICHA CATALOGRÁFICA}

CASANOVA, Eudaldo

La serpiente vencida : sobre los orígenes de la misoginia en lo sobrenatural / Eudaldo Casanova, M. ${ }^{a}$ Ángeles Larumbe. - Zaragoza : Prensas Universitarias de Zaragoza, 2005

380 p. : il. col. ; 22 cm. — (Sagardiana : estudios feministas ; 6)

\section{ISBN 84-7733-746-2}

1. Misoginia-Historia. 2. Mujeres en la religión-Historia. I. Larumbe, M. ${ }^{a}$ Ángeles. II. Prensas Universitarias de Zaragoza. III. Título. IV. Serie: Sagardiana : estudios feministas (Prensas Universitarias de Zaragoza) ; 6

$$
\begin{aligned}
& \text { 316.647.82-055.2(091) } \\
& \text { 305-055.2:2(091) }
\end{aligned}
$$

No está permitida la reproducción total o parcial de este libro, ni su tratamiento informático, ni la transmisión de ninguna forma o por cualquier medio, ya sea electrónico, mecánico, por fotocopia, por registro u otros métodos, ni su préstamo, alquiler o cualquier forma de cesión de uso del ejemplar, sin el permiso previo y por escrito de los titulares del Copyright.

(C) Eudaldo Casanova y M. a Ángeles Larumbe

(C) De la presente edición, Prensas Universitarias de Zaragoza 1. a edición, 2005

La edición de este libro ha sido parcialmente financiada por el Instituto Aragonés de la Mujer

Colección Sagardiana. Estudios Feministas, n. ${ }^{\circ} 6$

Directora de la colección: M. ${ }^{a}$ Dolores Sánchez González

Editado por Prensas Universitarias de Zaragoza

Edificio de Ciencias Geológicas

C/ Pedro Cerbuna, 12

50009 Zaragoza, España

Prensas Universitarias de Zaragoza es la editorial de la Universidad de Zaragoza, que edita e imprime libros desde su fundación en 1542.

Diseño de cubierta: Vicente Villarrocha

Impreso en España

Imprime: Calidad Gráfica, S.L.

D.L.: Z-134-200 
A Javier, que ilumina nuestras vidas 


\section{PRÓLOGO}

Después de todo, lo que denominamos verdad es solamente la hipótesis que nos parece mejor.

James George Frazer, La rama dorada

El libro que este prólogo introduce investiga los orígenes de la misoginia a través de los distintos discursos que han ido perpetuando en nuestra cultura la relación entre la mujer y el Mal. Una relación que ha ido creándose y recreándose con el paso del tiempo, sustentada en abundantes relatos, mitos, símbolos e imágenes que han venido a concretar y a facilitar la comprensión de lo inexplicable. A la par, este libro pretende clarificar diferentes conceptos a los que, en mayor o menor medida, se alude al hablar de cómo se conforma la subjetividad social: representaciones sociales, ideología, imaginario colectivo, mentalidad y pensamiento patriarcal son algunos de ellos.

La obra da buena cuenta del énfasis histórico-cultural por representar a la mujer en una situación de desventaja y desigualdad frente al varón, que tiene su germen en el vínculo que se establece entre las creencias religiosas y la sociedad patriarcal. Nos reconocemos fruto de esa tradición heredada que se ha esforzado por naturalizar la situación histórica de discriminación que han ido sufriendo las mujeres, acuñada en los múltiples mitos que se le han atribuido a través de los diferentes discursos.

Símbolos y mitos están en el origen de todas las literaturas y son formas expresivas del espíritu humano; ofrecen una explicación simbólica de la realidad; revelan lo que está por debajo de lo aparente y contribuyen a explicar el mundo que nos rodea. 
Viejos y nuevos mitos proporcionan formas de comprensión de la cultura, a la vez que participan en construirla. Muchos mitos del presente se reconocen en símbolos dotados de significado en el pasado; por eso, conocer y comprender qué somos hoy obliga a revisar toda una tradición cultural que puso los pilares para construir nuestro tiempo y que sentó las bases del pensamiento contemporáneo.

Ya Panofsky, en sus Estudios de iconología, afirmaba que el pasado es parte de la realidad humana y reclamaba la necesidad de recurrir a él para dar explicación de lo que somos. Me arriesgaré a decir que este mismo empeño por desentrañar parte del ayer para conocer el hoy ha sido para los autores el motor que ha impulsado la escritura de su libro. Es cierto que nuevos discursos, revueltas y revoluciones han propiciado espectaculares cambios, sobre todo -respecto al tema que nos ocupa - en el último siglo; pero todas estas transformaciones fueron posibles tras indagar en una consolidada tradición cultural, aunque fuera para rechazar sus planteamientos y explicaciones, para deconstruirla $y$, si acaso, transgredirla.

Como afirma este estudio, la situación de la mujer en el mundo clásico tuvo su reflejo en la religión griega y romana, donde triunfa el patriarcado. En la vida cotidiana de Grecia y Roma se reproduce para la mujer buena parte de los valores que se le atribuye en la mitología. Así, la cultura clásica admitió que las mujeres eran naturalmente inferiores a los hombres. Griegos y romanos elaboraron teorías filosóficas, mitos y cultos que contribuyeron a relacionar a la mujer con el Mal. A propósito del tema, en este trabajo de investigación se introducen esclarecedoras síntesis en las que se resume e interpreta cómo se configura el pensamiento misógino en nuestra cultura occidental, a través de qué mitos y simbolismos, partiendo de las dos tradiciones que más influencia han tenido: el pensamiento griego (desde el mito de Pandora) y la doctrina cristiana (a partir de la representación de Eva junto al pecado); ambas, causantes de todos los males que en el mundo han sido...

Pero este libro no restringe su estudio a Occidente, y al peso que en nuestra cultura ha tenido la tradición grecolatina y judeocristiana: los autores se aproximan también a la cultura primitiva, a las deidades orientales y a las religiones del Oriente Próximo; exploran 
multitud de personificaciones de la mujer y representaciones que la vinculan no sólo con el Mal sino también con otros símbolos ligados a la fertilidad, a la sexualidad y a su actividad reproductora, que inciden en su carácter ambivalente: el Bien y el Mal, junto al misterio, formarán parte de una representación aceptada en una época por el sentir común; aunque ni idealizaciones ni mitificaciones puntuales (pensemos, por ejemplo, en la literatura renacentista) impiden que las religiones y la sociedad patriarcal intenten, a toda costa, justificar y racionalizar la subordinación femenina y su debida servidumbre al varón.

Los viejos mitos sobre la mujer, pues, no son viejos por encontrarse de manera anacrónica en los discursos más actuales; son viejos porque se asientan y se fundamentan en un pasado lejano que el presente aún reconoce como propio: viejos mitos y símbolos que, con nuevas formas, pueblan todavía los espacios y los discursos más actuales.

El relato bíblico, la explicación mitológica, la filosofía clásica o la idealista, el pensamiento hipocrático, las epístolas de San Pablo, y un largo etcétera, se convierten, así, en discursos que producen y reproducen una concepción del mundo, de todas las posibles, y una consideración de los individuos que lo pueblan, diferente para cada género. Por su difusión y aceptación, se convierten en discursos que construyen y reflejan el sentir de un tiempo; discursos que orientan actitudes y justifican los comportamientos de una época. Pero el lector no sólo apreciará la destreza con la que el profesor Casanova y la profesora Larumbe definen las influencias clave que han consolidado el pensamiento misógino y su implicación en la vida cotidiana; el lector disfrutará también con las lecciones de filosofía que se vierten a lo largo de todo el texto, que transcienden el tema central de su trabajo de investigación.

Este estudio da buena cuenta de cómo lo considerado intrínseco $y$ propio de un sexo no responde sino a una construcción cultural, socialmente aceptada porque se ocultan los argumentos que pudieran justificar la versión contraria; da cuenta de esas ideas sobre la mujer, propagadas durante siglos, para ventaja de unos y sometimiento de otras. Roland Barthes, en sus Mitologías, cuando acusaba 
a la sociedad burguesa de transformar la historia en naturaleza para imponer una visión parcial de la realidad, advertía cómo la mitología es un acuerdo con el mundo, pero no con el mundo como es, sino tal como quiere hacerse. En este sentido, Barthes denunciaba la creación de mitos por la ideología dominante para su beneficio propio. Venía a señalar cómo el poder impone una manera de ver el mundo, inmovilista y alienable, que el mitólogo deberá desvelar y desmitificar. De esta tarea de desmitificación, que se inicia cuando se indaga en el porqué y cómo de las cosas, participa este libro que nos presta una comprensión impagable para desterrar definitivamente la mirada única y adoptar una interpretación del pasado basada en la lectura con sospecha.

Las consecuencias nefastas que para nuestra cultura ha tenido el pensamiento misógino y la creación paulatina de una historia que ha intentado someter y acallar la voz de las mujeres, han sido innumerables, y todavía se padecen hoy en todos los ámbitos sociales. La abundante violencia de género sólo se puede explicar cuando somos conscientes de que, durante siglos, se ha impuesto en el imaginario común una mentalidad de dominio de un género sobre el otro, que fue aceptada como natural; la violencia contra la mujer la ejerce sólo quien ha interiorizado que ésta es un objeto que le pertenece. Sin embargo, admitir que la violencia de hoy tiene su germen en la consideración que sobre las mujeres se fue fraguando en el pasado no resta ni un ápice la culpa y la condena de quien es capaz de utilizar su fuerza contra otra persona.

Para concluir, haremos nuestro el planteamiento de Barthes, para reivindicar, una vez más, que se supriman al fin los conceptos míticos heredados que sustentan una sociedad sexista y desigual, para ser sustituidos por otros conceptos nuevos que, con el compromiso de todas y todos, construyan una sociedad mejor y más justa. Esperemos.

Pilar Vicente SERRANo Profesora titular de Psicología Social Universidad de Zaragoza 
No hay peor veneno que el veneno de la serpiente... Toda maldad es poca junto a la de la mujer.

Eclesiastés 25, 13-26

Elles deviennent le Diable: débiles, timorées, vaillantes à des heures exceptionnelles, sanglantes sans cesse, caressantes... Elles ne valent rien, elles sont faites d'un côté, d'un os courbe, d'une dissimulation rentrée... Elles baisent le serpent...

Jules Bois

En la religión se encuentra, pues, la fuente de violencia sin violencia, el cimiento ideal de una relación social de explotación...

Maurice Godelier

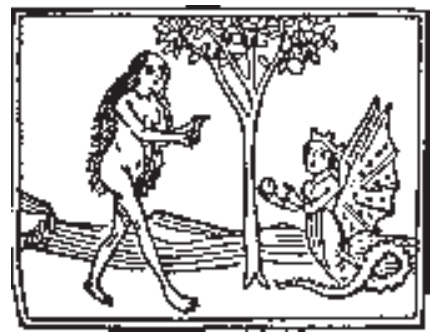




\section{INTRODUCCIÓN}

En febrero de 1948, en la España de la represión, el estraperlo y los boleros, se estrenó una película que fue un auténtico escándalo aun antes de su exhibición. Los carteles anunciadores que pendían del cine Avenida en Madrid fueron manchados con pintura en un intento de ocultar a una explosiva Rita Hayworth que lucía un pronunciado escote, que en castellano terminará por denominarse, caballerosamente, «palabra de honor».

Gilda, que así se titulaba el film, venía precedido por la fama de impúdico con la que lo habían descalificado los sectores más conservadores de la sociedad americana, sin embargo Hollywood consiguió con él uno de los mayores éxitos de la década y en nuestro país, sumido en el marasmo de la dictadura y la posguerra, se convirtió en un auténtico estremecimiento social.

La historia, que giraba en torno a tan exuberante mujer, era confusa y en ella dos protagonistas masculinos completaban un retorcido triángulo amoroso que tenía como telón de fondo un cabaret bonaerense. En ese escenario se desarrolla la secuencia más memorable del film en la que Gilda, mientras canta Put the blame on mamie..., agitando su roja cabellera y sus ardientes caderas, insinúa un striptease que se limita a un negro y largo guante, aunque en España algunos pensaron que iba más allá y que la escena había sido cortada por la censura. La seductora danza ante los ojos de todos despierta en uno de sus oponentes masculinos, interpretado por Glenn Ford, los celos y el paroxismo machista, y termina propinándole a Rita Hayworth la bofetada más famosa del celuloide.

Gilda, y la trama que la envuelve, nos ofrece una imagen de la mujer eróticamente atractiva y sensualmente peligrosa. En distintos momentos del diálogo se deslizan frases en boca de la protago- 
nista como: «hago lo que quiero, con quien quiero y cuando quiero»; «en mis manos los hombres son un juguete» 0 «buscaré mi perdición para perderte a ti».

Los dos componentes fundamentales del film: sexo y pecado, levantaron una auténtica polvareda en la España nacional-católica y un verdadero entusiasmo entre la población masculina. Las colas en los cines de Madrid y Barcelona escandalizaban a los más timoratos, mientras que los soldados que hacían la «mili» viajaban desde sus regimientos para verla, porque su exhibición estaba prohibida en muchas capitales. Hombres y mujeres asistían a su proyección sumidos en un morboso embarazo, y es que el mal siempre es tentador.

La reacción de la Iglesia fue furibunda. La diócesis de Madrid la calificó como «rechazable» y varios obispos maniobraron cerca de las autoridades para conseguir que se retirara de los cines. Acción Católica emprendió una campaña por todo el Estado de rosarios y novenas para conjurar tanta procacidad; y corros de patriotas se juntaban a las puertas de la sala de proyección para cantar el «Cara al sol», mezclando indignación política y religiosa, como muestra de repulsa a la inmoralidad foránea y al aislamiento que padecía el régimen.

Frente a esa mujer descarada y atrevida, sensualmente atractiva hasta la desvergüenza y en suma fascinante, que simbolizaba el pecado y encarnaba al mismo Diablo, las damas cristianas oponían otra figura que pendía en sus escapularios, la de una joven virgen envuelta en una túnica blanca de pureza, cubierta con un soberbio manto azul que, en actitud orante, dirigía su mirada al cielo, rodeada de angelotes y aplastando con su pie la cabeza de una serpiente. Entre estos dos iconos de mujer se extendía una larga historia cultural de dominación masculina.

El propósito de este libro es indagar en los orígenes de la misma para desvelar la estrecha relación que guardaban esas dos imágenes y cómo se gestó toda una visión misógina en el orden de lo sobrenatural dentro de la cultura occidental. Para ello tomaremos como referencia el concepto de representación social como un modelo que revela los mecanismos psicológicos y sociales de su producción, sus operaciones y sus funciones. 

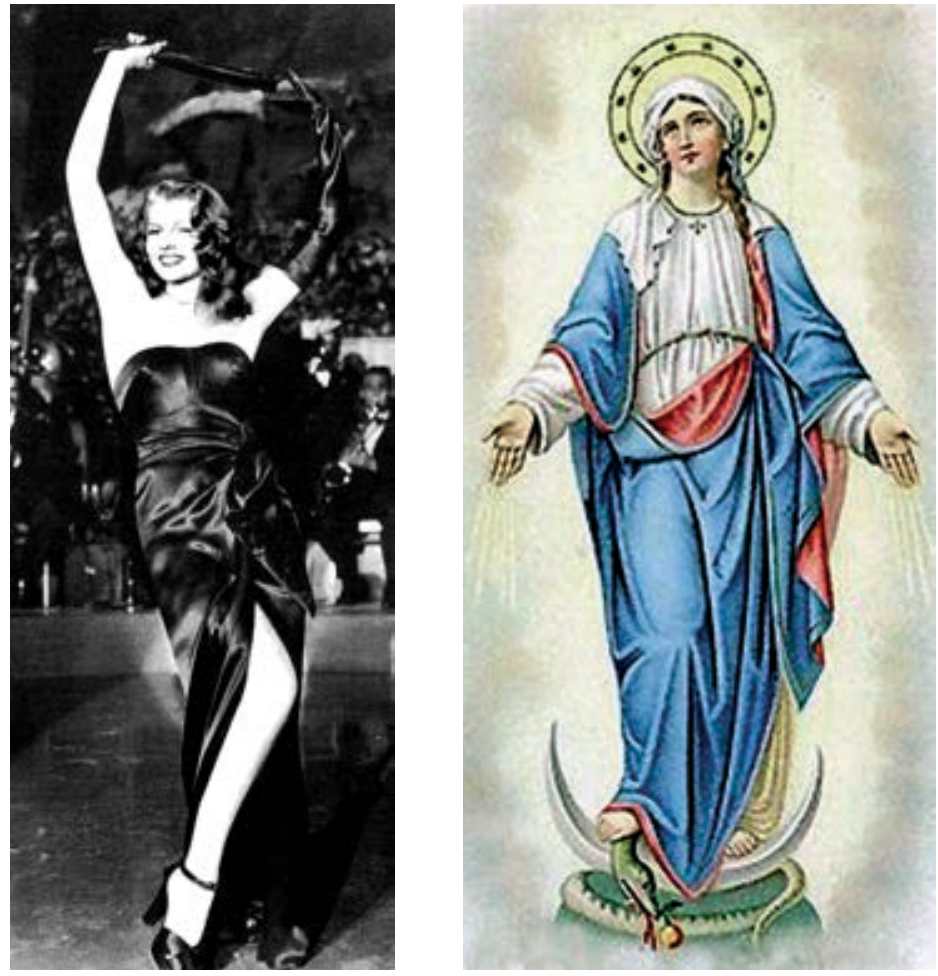

Estos dos iconos están estrechamente relacionados a través de un arquetipo cultural de larga tradición, lo que la moderna psicología social denominaría una representación social, elaborada por la ideología patriarcal en la que se asocia a la mujer con el pecado y con el Mal, encarnado en la serpiente. 


\section{I \\ LA MUJER Y EL MAL}

\section{Algo más que tópicos}

Una de las más importantes características del desarrollo de las ciencias sociales en el siglo Xx es el descubrimiento del simbolismo y de su significado en la vida social, por parte de disciplinas muy distintas como la lingüística, la antropología, el psicoanálisis, la psicología social o la historia. Este «hallazgo» ha colocado en las últimas décadas en un primer plano el concepto de representación social - entendido en sentido amplio, no en el sentido específico que le otorga la psicología social- en la teoría y la investigación, hasta el punto que se ha hecho habitual en estudios de la más diversa índole.

A partir de los años sesenta también se ha convertido en moneda corriente toda una «familia de conceptos» vinculados de manera directa e indirecta con el de representación social. Todos ellos tienen una larga trayectoria en la tradición anterior y comparten el común denominador de explorar dimensiones simbólicas de la vida social: imaginario político, ideología, mentalidad, inconsciente colectivo y otros.

Aunque la formulación de representación social puede encontrarse en diferentes textos, su elaboración conceptual y teórica dentro del campo de la psicología social se debe a Serge Moscovici que, en su investigación sobre la penetración del psicoanálisis en la sociedad francesa a finales de los años cincuenta, partió del interés que le suscitaba lo que se ha denominado pensamiento profano o epistemología popular, y se propuso estudiar la conformación del sentido común confrontado a una teoría científica: el psicoanálisis. 
Para su trabajo empleó cuestionarios estructurados y semiestructurados aplicados en distintas muestras de la población, así como un minucioso análisis de contenido de todos los artículos relacionados con el psicoanálisis aparecidos en periódicos, revistas y diarios entre el 11 de enero de 1952 y el 11 de marzo de 1953. Los resultados de la investigación, que fueron publicados en el libro $L a$ Psychanalyse, son image et son public, el año 1961 y los planteamientos que la animaban están en el origen de su modelo sobre las representaciones sociales.

Con su estudio lograba desvelar cómo se vulgariza una teoría científica y cómo la imagen que de ella se difunde está en constante reelaboración y termina por influir en los comportamientos colectivos. Con posterioridad, contempló la posibilidad de investigar el marxismo en condiciones similares, suponiendo que esas teorías entendidas como económicas y políticas también tenían hondas repercusiones en la manera de ver el mundo en sectores importantes de la población. Con este nuevo trabajo trataba de complementar lo que ya había realizado con una teoría científica ampliando el campo de investigación al ámbito político social; pero, después del derrumbe del llamado «socialismo real», desestimó la publicación de resultados al respecto.

En estos trabajos Moscovici partía de la reformulación del concepto durkheimniano de representación colectiva. Para Durkheim (1898) las representaciones colectivas son formas de conocimiento o ideación construidas socialmente y que no pueden explicarse como epifenómenos de la psicología individual.

Para Moscovici, las representaciones sociales aparecen en las sociedades modernas en donde el conocimiento fluye constantemente a través de una avalancha de información y sirven como guías para la vida cotidiana. A diferencia de los mitos, las representaciones sociales no tienen la posibilidad de asentarse y solidificarse para convertirse en tradiciones ya que la modernidad supone un cambio continuo en los conocimientos. Así mismo, aparece un receptor típico de nuestro tiempo al que Moscovici llama el «sabio aficionado o amateur», o sea un sujeto que demanda información y adopta ante ella una actitud activa. Este aficionado consumidor de ideas 
ya formuladas convierte en sentido común esa información como forma desacralizada y vital del saber moderno.

Según Moscovici, el concepto de representación social difiere del de representación colectiva en que el primero tiene un carácter más dinámico. Para él las representaciones sociales no son sólo productos mentales sino que son construcciones simbólicas que se crean y recrean en el curso de las interacciones sociales; y no tienen por qué determinar inexorablemente las representaciones individuales.

Estas representaciones sociales son definidas como maneras específicas de entender y comunicar la realidad e influyen a la vez que son configuradas por las personas a través de sus relaciones. En resumen, en opinión de Moscovici (1984) las representaciones colectivas son mecanismos explicativos que se refieren a una clase general de ideas y creencias, mientras que las representaciones sociales son fenómenos que necesitan ser descritos y explicados.

Sin embargo, y a pesar de este planteamiento que circunscribiría el modelo de representación social al mundo contemporáneo, el único ámbito de trabajo adecuado a una ciencia planteada como experimental, tal y como sucede con la moderna psicología social, las representaciones sociales pueden ser consideradas en un sentido más amplio, que nos devuelve a un enfoque durkheimniano o más generalizador, como lo han entendido otras ciencias sociales de las que hablábamos en un principio.

Ambos planteamientos parten de imágenes que condensan un conjunto de significados, que funcionan como sistemas de referencia interpretativa y que se construyen a partir de experiencias, informaciones, conocimientos o modelos de pensamiento recibidos y transmitidos a través de la tradición o la educación. En definitiva, y esto es lo importante, son formas de conocimiento socialmente elaborado y compartido. Así pues, la teoría de las representaciones sociales es, esencialmente, una teoría del conocimiento social, en la que ese «conocimiento» se define de una forma amplia no sólo como información factual sino como sistemas de creencias comunes y de prácticas sociales en las que lo simbólico desempeña un papel muy importante. 
Las representaciones sociales pueden considerarse como nódulos sistémicos que sostienen las actitudes. Sin embargo, comparadas con la teoría de las actitudes (Torregrosa, 1968), que también aborda la psicología social, las representaciones sociales van más allá al ofrecer una comprensión más social de las creencias, basada en la perspectiva del construccionismo, que parte de considerar que toda creencia personal está ampliamente determinada por factores históricos, sociales y culturales. El propio Moscovici (1981: 181) las considera equivalentes en nuestro mundo actual «a los mitos y sistemas de creencias de las sociedades tradicionales». Estas formas de pensar y crear la realidad social están constituidas por elementos de carácter referencial, ya que no son sólo formas de adquirir y reproducir el conocimiento, sino que tienen la capacidad de dotar de sentido a la misma realidad social. Su finalidad es la integración, la legitimación, la dominación y la manipulación de la vida práctica.

Estas finalidades de legitimación, dominación y, en última instancia, orientación del comportamiento de los individuos en el marco de la vida cotidiana nos permiten poner en relación el concepto de representación social con el de ideología y con el no menos novedoso de mentalidad.

El término ideología ha alimentado una vasta producción en los más diversos campos desde la teoría política a la filosofía, sin que desde su aparición, a comienzos del siglo XIX, se haya podido consensuar su significado. Podríamos aceptar como válida la definición que nos da Althusser (1968) en La revolución teórica de Marx, donde la define como «un sistema (que posee su lógica y su rigor propios) de representaciones (imágenes, mitos, ideas o conceptos según los casos), dotado de una existencia y un papel históricos en el seno de una sociedad dada», o si se quiere la más sencilla que el mismo autor nos ofrece en «Idéologie et appareils idéologiques d'Etat», artículo aparecido en la revista La Pensée (1970), donde se limita a explicarla como "la relación imaginaria de los individuos con sus condiciones reales de existencia». Conjunto de representaciones, pero también de prácticas y comportamientos conscientes o inconscientes. En este sentido las representaciones sociales se nos presentarían como zonas concretas y definidas del pensamiento común que contribuirían a la trabazón de la estructura ideológica. 
Las representaciones sociales se englobarían, pues, dentro de las ideologías y servirían para enlazar las formulaciones teóricas y conscientes de éstas con la forma de pensamiento vulgar y con la formación de los hábitos cotidianos, permitiendo así la articulación entre el plano consciente con el inconsciente colectivo y el engarce entre la manifestación ideológica con las mentalidades.

El estudio de las mentalidades ha sido especialmente trabajado en los últimos tiempos por la historiografía. Los pioneros en este campo han sido los historiadores franceses de la Escuela de los «Annales» y a ellos se deben magníficos estudios, antes incluso de que se pusiera en circulación el término con un contenido académico.

Para el historiador francés Michel Vovelle (1985: 18) el concepto de mentalidades indaga en el pasado aquello que no está explícitamente formulado, recuperando lo aparentemente insignificante, y cualquier signo o dato enterrado en el nivel de las motivaciones inconscientes. Las mentalidades se revelan en la historia como fenómenos de larga duración y remiten al recuerdo, a la memoria y a formas de resistencia psicosocial frente a los cambios materiales. Serían como fuerzas de inercia en las estructuras de pensamiento intangibles y muy arraigadas que traducirían, si se quiere, a un nivel inferior el imperio de la ideología.

El estudio de las mismas asumiría: «el problema de las mediaciones complejas entre la vida real de los hombres y la imagen - hasta las representaciones fantásticas-que se hacen de ella. Enfoques que desafían toda reducción mecánica, confrontándose con el entrelazamiento de los tiempos de la historia, según la expresión de Althusser (1970), o sea con la difusión de las ideas-fuerza, como con la coexistencia, en planos estratificados, de modelos de comportamiento venidos de diferentes herencias».

La mentalidad, como expresión plebeya de la ideología, requerirá en su despliegue de las representaciones sociales para validar y popularizar el pensamiento dominante. Podríamos decir como resumen que las representaciones sociales desempeñarían una doble función: por un lado, servirían para estructurar el discurso ideológico y, por otro, facilitarían su transmisión a un amplio espectro social. 
En el moderno estudio de las representaciones sociales pueden distinguirse tres grandes campos de interés. El primero es el que caracteriza la perspectiva original de las representaciones como conocimiento vulgar de ideas científicas popularizadas (psicoanálisis, SIDA, capa de ozono, etc.). El segundo es el extenso campo de los objetos culturalmente construidos a través de los siglos y sus equivalentes modernos. El tercero hace referencia a las condiciones y acontecimientos sociales y políticos, donde las representaciones que prevalecen tienen un corto plazo de significación para la vida social. Estos tres campos constituyen lo que podemos denominar la topografía de la mente moderna. De estas tres áreas en las que actualmente se centra la investigación, a nosotros nos interesa la segunda ya que la imaginación cultural proporciona realidad a los objetos que habitan el mundo social y que cuentan con una larga historia, como los roles sexuales, las relaciones materno-filiales, el cuerpo humano, la locura, la discapacidad, entre otros.

Las representaciones de estos objetos hacen inteligible el mundo a los miembros de grupos sociales y culturales, al tiempo que permiten unas interacciones que no sólo los recrean, sino que definen también a los actores como partes complementarias de ellos, proporcionando al sujeto social la impresión de pertenencia a culturas y comunidades específicas. Los trabajos desarrollados en este terreno ya han dado interesantes resultados en lo relativo a la concepción de la mujer que sigue cultivando la sociedad patriarcal y que está frecuentemente relacionada con la sexualidad. Hay un «exceso de sexualidad» en muchas revistas para mujeres —nos dirá Ussher (1997: 80)—, y la imagen que nos transmiten es aparentemente contradictoria. Las mujeres son presentadas bien como virginales, inocentes y puras, o como todo lo contrario, seductoras, sexualmente atractivas e incluso como «peligrosas».

Éste es un ejemplo de cómo las representaciones sociales actuales de la mujer están todavía ancladas en arquetipos históricamente establecidos, en este caso el de la virgen y la prostituta. Sin embargo, mientras las imágenes sexualizadas de la mujer se manifestaban anteriormente de un modo explícito al servicio de la dominación masculina, hoy las representaciones de la sexualidad femenina son más complejas y ambiguas. 
Como ya hemos dicho, con este estudio nos proponemos un trabajo de arqueología cultural en el que vamos a rastrear los orígenes de un arquetipo cultural, de una representación social propia de la ideología patriarcal y de la que aún encontramos reflejo en la posmodernidad, como es la relación entre la mujer y el mal.

\section{La mujer, el Diablo y la serpiente}

El mal y la reflexión sobre el mismo es uno de los problemas más perdurables y una de las indagaciones más interesantes en la historia cultural, como lo pone de relieve el reciente libro de Rüdiger Safranski, El Mal (2000).

La propia contingencia de lo humano, la opresión de las necesidades que padecemos, perenne aunque cambiante; el dolor y el sufrimiento en su más amplia gama de variedades; la misma nimiedad cósmica del individuo enfrentado al otro y a lo otro han convertido el mal, en su concreción física o moral, en una preocupación esencial del ser humano a lo largo de los tiempos, apenas atenuada en el presente, como parece atestiguarlo el siglo que hemos dejado atrás.

Qué es el mal y cómo llegó a existir son preguntas que están entre las más viejas y complicadas de cuantas nos hemos formulado. Podríamos definirlo de modo sencillo como el daño inferido a seres capaces de sentir. Pero la idea del mal va mucho más lejos y abarca las realidades más complejas. Es cierto que el mal puede ser infligido por algo o alguien, pero también es cierto que puede ser sentido como tal aquello que no deriva de una acción natural o consciente. La soledad puede convertirse para algunas personas en el mayor de los males y tras ella no vemos ni las fuerzas naturales ni la acción de nada que desee causar daño.

Deberemos, por tanto, admitir que lo que se entiende como «el mal» es lo que el ser humano ha percibido como tal a lo largo de la historia. Pero esa percepción es tan diversa y cambiante que el concepto no puede ser designado satisfactoriamente. Podemos valernos de definiciones convencionales con fines comunicativos pero éstas son siempre limitadas, ya que el mal es una idea de contornos difu- 
sos y sin coherencia interna, por eso terminaremos por convenir que el mal se percibe existencial y culturalmente; y que resulta imposible traducirlo a una sola categoría. Incluso, en los últimos tiempos esta idea se ha hecho extensiva al daño provocado a otros seres vivos o inertes. La preocupación por la degradación del medio ambiente se ha convertido para un buen número de personas en uno de los principales males que afectan a la moderna civilización.

La modernidad ha intentado objetivar el problema distinguiendo el mal de origen natural, como fatalidad inevitable a la que podemos enfrentarnos, dentro de unos límites, para intentar controlarla o al menos minimizarla, del mal provocado por los humanos, concebido éste como mal moral. El mal natural consistiría en actos destructores debidos a la misma naturaleza, como las catástrofes o las enfermedades e incluso la propia muerte como mal supremo, mientras que el mal moral procedería de la voluntad de los seres humanos. La moderna reflexión centrará su interés en este último, buscando la explicación a esos comportamientos en la residual naturaleza animal del hombre, en el uso de su libertad o en las formas que ha establecido en sus relaciones sociales.

Una explicación muy popular, divulgada fundamentalmente por etólogos, es que el mal perpetrado por los humanos tiene un origen genético-comportamental (Kiss, 1972; Morris, 1972; Lorenz, 1976; Ardrey, 1974). La violencia de la humanidad surgiría no tanto de nuestra naturaleza animal como de nuestra actividad cazadora y gregaria, potenciada por el desarrollo técnico y racional, lo que daría como resultado un comportamiento violento, que no agresivo, ${ }^{1}$ que marcará de modo indeleble nuestra historia.

1 La agresividad parece ser un instinto natural, propio de muchos seres vivos, e íntimamente ligado al de supervivencia; mientras que la agresión es la manifestación extrema del instinto agresivo. La agresividad es, pues, una cualidad o predisposición en un gran número de organismos vivos por la que, en presencia de determinados estímulos, éstos son capaces de generar agresión. Pudiendo definir la agresión, de un modo muy general, como el sometimiento, la vulneración o destrucción del organismo agredido.

Por el contrario, la violencia la vemos como un fenómeno cultural, propio del ser humano, inserto en un sistema de valores que transcienden lo puramente biológico. La violencia implica agresividad y puede implicar agresión vertida en mayor o menor grado, pero supera con mucho la mera pulsión instintual y adquiere manifes- 
El gran adversario del argumento genético es el behaviorismo sociológico. Para los seguidores de esta tendencia, el mal es producto del entorno en el que se operan los procesos de socialización del individuo. Es en la familia, entre los amigos, o en el ámbito institucional y cultural, donde debemos buscar los orígenes del mal (Montagu, 1988). Este enfoque comparte y en cierta medida bebe de algunas premisas del materialismo histórico. Tanto el conductismo como el marxismo, partiendo de análisis muy diferentes y con objetivos bien distintos, ven el mal como resultado último de una deficiente estructuración social y, por tanto, muestran una visión más optimista que los genetistas. Estos enfoques, que podríamos denominar sociológicos, ofrecen explicaciones, en muchas ocasiones plausibles, a la violencia a escala social y también individual.

El existencialismo, para salir al paso de los estrechos límites que marca el sociologismo a la hora de abordar el problema, devuelve al individuo la responsabilidad de obrar de un modo u otro, volviendo a fundamentar en la libertad del ser humano el origen del mal (Sartre, 1947; Camus, 1947/1996). Esa libertad metafísica del existencialismo, medida por el psicoanálisis, constituirá la base explicativa del fenómeno para muchos freudianos como Erich Fromm (1975). Para estos autores la destructividad, con la que identificaríamos el mal, se enraíza en el carácter. Los rasgos genéticos y los problemas ambientales pueden propiciar esa destructividad, pero no bastan para causarla. Arguyen que hay necesidades humanas básicas a las que cada cual es libre de responder de modo positivo o negativo. La necesidad de un objeto de devoción puede llevar a imitar a San Francisco, o a Adolf Hitler; así como la forma de relacionarse puede desembocar en la ternura o en el sadismo, dependiendo del tipo de respuestas que el individuo escoja entre las que le ofrecen sus inclinaciones.

taciones impensables en el mundo animal como pudieran ser la tortura o el insulto. Sólo el miedo consciente a la muerte, al dolor físico o incluso al padecimiento psíquico, sólo el complejo mundo de valores y de signos creados culturalmente hacen de la violencia algo particular del ser humano y distinto a la agresividad o la agresión, a pesar de la dependencia que entre ellas exista. Podríamos decir que la violencia es la forma categorizada y humanizada que ha ido adquiriendo la agresividad en nuestra especie. 
Pero la crueldad, la violencia, la necesidad, son conceptos que tienen una historia y un contexto y, por tanto, frente a ellos podemos abrigar la esperanza de su superación; sin embargo, la sola aceptación de la idea del mal, como fuerza impersonal y autónoma, que ha operado siempre y que alcanza todos los rincones del planeta, nos condena a la desesperanza y al sometimiento a esa misma idea, consiguiendo por la vía de la alienación desempeñar un papel real en las relaciones y el devenir de los humanos. El Maligno, como tal, nunca ha existido nada más que en la mente religiosa, sin embargo la creencia en él ha acarreado numerosos males a la humanidad.

Para el hombre moderno es la experiencia existencial el principal vehículo intuitivo de la percepción del mal, ya que sin excesiva reflexión se siente como un daño sufrido o perpetrado por alguien y sólo, en menor medida, se piensa que esté provocado por «algo» que nos trasciende, por una fuerza inmaterial o un principio que encarne la malignidad. Pero aunque así sea, no hemos podido desembarazarnos totalmente de esa abstracción denominada «el Mal», concebida como agente activo, cuya vigencia se demuestra por sus efectos, que son al mismo tiempo el principal argumento de algunos para seguir validando su existencia.

El Mal no necesita más prueba que la propia realidad que nos rodea. La crueldad y la destructividad son comunes en los sucesos cotidianos de los que nos hablan los periódicos y lo han sido en la historia de la humanidad. El ser humano ha padecido innumerables males a lo largo de toda su existencia y no hace falta mucho más para que esa idea de un poder maligno, de un espíritu del Mal, anide de nuevo en nuestras mentes como lo estuvo, aunque por otra vía, en la de nuestros antepasados.

El Mal se ha sentido frecuentemente y en muchas sociedades como una fuerza consciente, personificándose su percepción. Ese proceso de encarnación ha seguido un camino complejo y ha sido objeto de una lenta y cambiante elaboración en la que se han integrado distintas tramas de valores, dependiendo de los diversos contextos culturales.

La personificación primera del Mal tiene en última instancia el mismo fundamento que la personificación del Bien. El estudio de la 
historia de las religiones nos revela que, en la mayoría de las ocasiones, el Mal ha sido visto como producto de la divinidad e incluso como una parte de la deidad, si se quiere como el lado oscuro de la misma: Sine diabolo nullus deus. En la cultura occidental el apelativo más popular para designarlo será el de Diablo, aunque como tal entidad cultural aparecerá tardíamente, tras un lento proceso de gestación que sólo culminó en la alta Edad Media. ${ }^{2}$

El Diablo simboliza la apoteosis, la objetivación de todas las fuerzas hostiles percibidas como externas a nuestra conciencia. Es la fuente y origen de todo mal, y es la esencia misma del Mal. Cuando se analiza cómo los distintos pueblos han recreado esta idea se puede apreciar cómo cada uno de ellos ha perfilado su propio retrato, cómo han concebido a ese ser maligno de mil formas diferentes. Una de las primeras imágenes elaboradas por la cultura judeo-cristiana representa al Maligno como una serpiente.

La serpiente, símbolo de la fertilidad y de la vida en muchas cosmovisiones antiguas (Cooper, 2000), ha sido relacionada en Occidente con el pecado y el Mal. Su naturaleza inquietante nos ha fascinado desde tiempos remotos y en este reptil hemos visto un ser ambivalente, telúrico y primigenio a la par que misterioso y temible. Su hipnótica mirada, con la que seduce a sus presas antes de convertirlas en víctimas, es la mirada ambigua de la vida, que se renueva a sí misma, pero también de la muerte. Con ella ha contemplado el devenir de los hombres encarnando el misterio de la regeneración hasta quedar asimilada por la religión cristiana con una de las principales epifanías animales del Diablo.

Desde entonces, el ofidio se nos presenta asociado a la mujer, no sólo a través de la figura de Eva, que con su falta acarreó la muerte y el pecado, sino también con María, la madre de Dios, que con su misterioso alumbramiento nos abrió las puertas de la salvación, derrotando así al Mal y aplastándolo bajo su pie. Mujer y serpiente simbolizan la vida pero también el Mal, por eso la serpiente debe ser

2 En la actualidad, la Iglesia católica, que sigue admitiendo la existencia del Diablo, ha procedido a un curioso proceso de «despersonificación» de esta idea. «Cuando se pregunta si el diablo es una persona, se debería justamente responder que es la no persona, la disgregación, la disolución del ser persona» (Ratzinger, 1974: 197). 


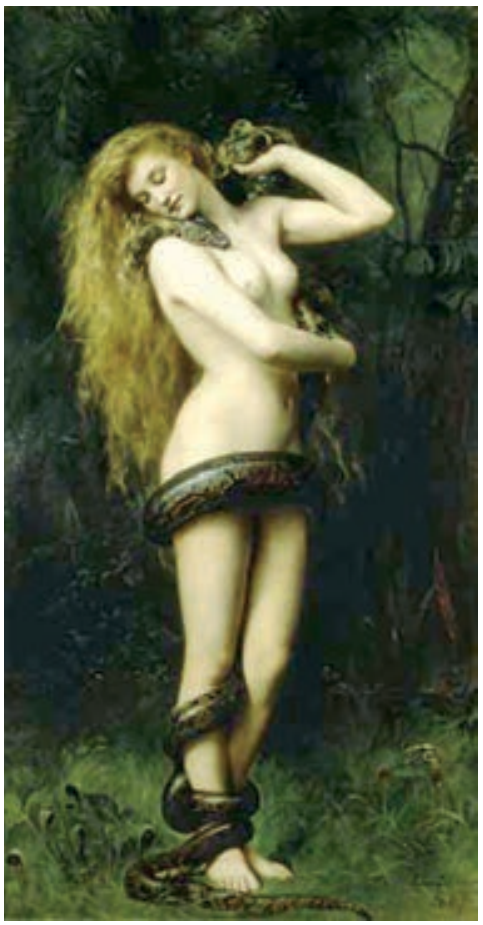

La serpiente, símbolo de la fertilidad y de la vida en muchas religiones antiguas, estuvo asociada a la mujer. Sin embargo, en Occidente ha sido relacionada con el pecado y el Mal. Por eso, debe ser vencida en el mundo de lo sobrenatural y la mujer dominada en la sociedad patriarcal.

vencida en el mundo de lo sobrenatural y la mujer dominada y vigilada por el varón. Este arquetipo cultural, esta representación social ha impregnado de misoginia sagrada y material el pensamiento occidental durante siglos, convirtiendo a la mujer en instrumento eficaz del Diablo.

Pero el Diablo, a pesar de la popularidad que ha alcanzado esta denominación en nuestro medio, limita en exceso su personificación a las creencias cristianas, por eso hemos preferido utilizar, en la mayor parte de este libro, el término Mal, escrito con mayúscula, o el de Maligno, en singular y masculino, para alejarnos de los arquetipos medievalizantes de esta figura propia de nuestra cultura.

La literatura sobre el Diablo se ha multiplicado en los últimos años y en la abundante bibliografía sobre el tema se entremezclan estudios serios con obras de divulgación y con otras sin ningún valor 
científico. La tendencia de casi todos estos trabajos es subrayar la vigencia de este constructo cultural. ${ }^{3}$ No obstante, pensamos que en un mundo profundamente laicizado como es el de las sociedades desarrolladas actuales, esta figura sólo desempeña un papel marginal.

La fijación de las ideas religiosas, incluso la invocación de los poderes políticos, ${ }^{4}$ o la misma proliferación de pequeños grupos de culto satánico, que tanto han atraído la atención del sensacionalismo informativo, no justifican la pretendida actualidad de este fenómeno y sólo sobreviven algunos arquetipos culturales del mismo profundamente reelaborados. No obstante, durante siglos el Mal tuvo carta de naturaleza en la vida social y el Diablo imperó durante casi mil ochocientos años dejando una honda huella en la manera de ver el mundo. Instrumentalizado por la ideología patriarcal hizo a su vez de la mujer una herramienta al servicio de su maldad, legándonos así una de esas representaciones colectivas cuyos vestigios todavía hoy perduran y cuyos orígenes queremos analizar.

3 Un ejemplo lo podemos encontrar en El diablo de Burton Russell (1995: 32) en el que se nos dice: «No es sorprendente, en vista de los horrores del siglo Xx, que, después de una larga pausa, la creencia en el diablo esté reapareciendo rápidamente. Una encuesta completada en 1974 indicaba que en los Estados Unidos la creencia positiva en el diablo había crecido desde 1963 del 37\% al 48\%, con otro $20 \%$ que consideraba probable su existencia».

4 A mediados de la década de los ochenta, personajes tan singulares, pero con una gran influencia, como eran el presidente de los EE.UU., Ronald Reagan, o el líder religioso de la revolución iraní, el ayatolá Jomeini, volvieron a poner de moda al Diablo en el discurso político. Si resulta menos sorprendente que el segundo calificara a EE.UU. de «Gran Satán», que el primero designara a la Unión Soviética como «El imperio del Mal» no se puede explicar nada más que desde el retroceso de la racionalidad en la práctica política occidental. La apoteosis de esa sinrazón premaquiavélica es la reciente acuñación por parte de la Administración americana del inverosímil «Eje del Mal». 


\section{II EVA EN EL PARAÍSO}

Muchos relatos míticos colocan una Edad de Oro, un paraíso terrenal, en el origen de los tiempos. En él habría vivido el hombre feliz hasta la aparición del Mal. Por lo general, esos «paraísos» subsiguen a terribles luchas cosmogónicas que se produjeron en el nacimiento del universo y en las que se enfrentaron, con una violencia devastadora a la par que creadora, fuerzas sobrenaturales. En estos enfrentamientos podemos apreciar cómo la muerte y la destrucción están ya presentes en el inicio y de ello podríamos deducir que el Mal comenzó a existir desde el mismo «Big Bang» mitológico.

Las contradicciones que se dan en este tipo de historias no preocupaban a quienes las elaboraron y esta disposición narrativa tiene su lógica, ya que el Mal que atemoriza a los humanos es el que les afecta directamente. La existencia de un Mal anterior, de un Mal sobrenatural, sólo cobrará importancia en la medida en que su irrupción en ese mundo paradisíaco acarree su desgracia. Pero antes de que eso ocurriera hubo una Edad de Oro y el hombre vivió en un mundo feliz, en un mundo sin Mal, en el que sin embargo existía ya la mujer.

Si definimos el mito primitivo como una historia fantástica que pretende explicar el origen de algo fundamental para los que lo crearon, hemos de admitir que en muchos de estos relatos la idea de la mujer, concebida como distinta, precede a la idea del Mal. Y es que en esa oscura y larga etapa de los orígenes de la humanidad debieron fraguarse consecutivamente los fundamentos del dominio masculino y la conceptualización del Mal. Por tanto, antes de que entrara en el mundo, la mujer vivió en el paraíso, y sólo tras su «caída» real, sólo después de su sometimiento al orden masculino, el Mal hará su irrupción para afligir a los hombres. 


\section{Te trataré como a una reina}

Realmente el pretendido paraíso para el ser humano consistió en un larguísimo período de cientos de miles de años en los que al tiempo que se iba despegando de su condición animal cobraba conciencia de la dureza que suponía la lucha por la supervivencia en un entorno, por natural, hostil y salvaje. Todo lo que podemos saber de esa larga y crucial etapa se reduce, a pesar de los avances en los últimos cien años de la arqueología prehistórica, a muy poco.

Las interpretaciones que se dan sobre cómo fueron apareciendo las diferentes pautas culturales de las que se dotaron los primeros homínidos se limitan a una serie de hechos materialmente comprobados y a un conjunto de hipótesis que están en permanente debate y revisión. No podemos pretender aquí reproducir siquiera aquellas que se han apuntado sobre los orígenes del patriarcado ${ }^{1} \mathrm{y}$ el sometimiento de la mujer. Mencionaremos solamente dos que, consideradas como clásicas, inciden, aunque de un modo distinto, en la idea de que, en el albor de los tiempos, la mujer conoció el «paraíso».

Nos referimos a las tesis de Bachofen con su obra El matriarcado (1861/1987) y a las teorías de Marx y Engels expuestas en $E l$ origen de la familia, de la propiedad privada y del Estado (1884/1981), con las que pretendieron dar una base científica a la hipótesis de un primitivo orden femenino.

1 El patriarcado es un concepto de cuño antropológico profusamente utilizado en el siglo XIX. Tanto las obras de Bachofen como las de Morgan y el mismo Engels lo utilizan con ligeras variaciones. Bachofen en su obra El matriarcado (1861/1987) emplea el término para contraponerlo a esa hipotética Edad de Oro de la mujer en el origen de la humanidad que él defendía. Para Engels, la expresión adquiere connotaciones de dominación y explotación aunque las centra en las clases, que surgirán a la par. La moderna antropología ha querido darle un sentido más ajustado. Goldberg (1976: 31) en su obra La inevitabilidad del patriarcado lo define como: «Toda organización política, económica, religiosa o social, que relaciona la idea de autoridad y liderazgo principalmente con el varón, y en la que el varón desempeña la gran mayoría de los puestos de autoridad y dirección. El patriarcado se refiere solamente a organizaciones supra familiares; la autoridad en las relaciones duales y familiares se designa con el término dominio masculino. El patriarcado es universal». 
Bachofen, historiador suizo de las religiones y del derecho, fue el primero que popularizó a mediados del siglo XIX el término matriarcado para designar un modelo de sociedad arcaica en el que se habría dado una auténtica ginecocracia. A través del examen minucioso de todos los testimonios a su disposición concibió la historia de la antigüedad como una sucesión de fases en la que, primero, habría prevalecido el elemento materno ordenado en torno al derecho natural, la comunidad de bienes, la promiscuidad sexual y los símbolos de la tierra y del agua. A este estadio de la evolución le habría sucedido el patriarcado, que habría impuesto el derecho positivo, la propiedad privada, la monogamia y los símbolos celestes. La obra de Bachofen se considera hoy totalmente superada. La lectura que hizo de determinados datos obtenidos de las sociedades que la antropología denomina matrilineales le llevó a conclusiones que, en general, son apreciadas como erróneas. Sin embargo, algunos de sus planteamientos, envueltos desde el principio en una enorme polémica, ${ }^{2}$ influyeron a través de Morgan (1877/1987) en autores como Marx y Engels. Los padres del materialismo histórico, apoyándose en Bachofen y sobre todo en el evolucionismo antropológico de Morgan, aceptaron una serie de etapas en los orígenes de la humanidad, de las cuales la primera, a la que denominaron «comunismo primitivo», habría sido igualitaria y no habría conocido ningún tipo de distinción de género.

El pionero de esta idea fue, no obstante, el cartesiano Poulain de la Barre, que ya en el siglo XVII imaginó una humanidad en la que hombres y mujeres eran "simples e inocentes» y se ocupaban por igual de la caza y posteriormente del cultivo de la tierra. De esta situación de plena igualdad se habría salido, según el francés, por imperativo natural. Los hombres, más fuertes que las mujeres y des-

2 Una de las críticas más feroces a las tesis sobre el matriarcado de Bachofen, y en general a las ideas evolucionistas basadas en el estudio de las sociedades matrilineales, la realizó a comienzos del siglo xx Robert Lowie, un discípulo de la escuela de Franz Boas que en su obra La sociedad primitiva (1920/1972) señalaba cómo el matriarcado, entendido como lo hacía Bachofen, era un fenómeno que no se daba en las culturas de los primitivos actuales. Pero esta crítica, justificada, iba acompañada de un cuestionamiento de las mismas instituciones matrilineales, llegando a sugerir, desde un punto de vista absolutamente androcéntrico, que la descendencia matrilineal era algo raro e incluso anormal. 
provistos de los inconvenientes del embarazo, habrían terminado por someter a la mujer, sustituyendo las primitivas parejas por la familia extensa, complejizándose así la vida social. Fue el inicio del enclaustramiento de la mujer en el hogar dedicada a las tareas de la crianza, en tanto que los hombres realizaban el resto de las funciones económicas. La familia trajo la propiedad y con ella apareció la herencia. Cuando los hermanos desposeídos, de los que la Biblia nos ofrece varios ejemplos, se sintieron descontentos, se organizaron en bandas de pillaje y, según Poulain de la Barre, es así como sobrevino un estado de guerra que acentuó la subordinación de la mujer al quedar excluida de la organización política y de las prácticas bélicas.

Marx y Engels no conocieron la obra de Poulain de la Barre pero coincidieron con él en algunos aspectos. Su principal preocupación era la opresión de clase y aunque en La ideología alemana, un escrito de su etapa inicial, habían vislumbrado cómo ésta tenía su primera manifestación en la desigualdad de sexos, con posterioridad no profundizaron en esa idea, subsumiendo la opresión de género en la de clase social y no confiriéndoles a las mujeres este estatus. No obstante Engels en 1884, casi cuarenta años más tarde de La ideología alemana, en El origen de la familia, de la propiedad privada y del Estado, aún nos dice:

En un viejo manuscrito inédito, redactado en 1846 por Marx y por mí, encuentro esta frase: «La primera división del trabajo es la que se hizo entre el hombre y la mujer para la procreación de hijos». Y hoy puedo añadir: el primer antagonismo de clases que apareció en la historia coincide con el desarrollo del antagonismo entre el hombre y la mujer en la monogamia; y la primera opresión de clases, con la del sexo femenino por el masculino (OEME, vol. III, 253-254).

En esta obra escrita por Engels, utilizando una abundante documentación dejada por Marx a su muerte, se concretan las tesis del marxismo clásico sobre el tema. Para los padres del materialismo histórico el origen de la desigualdad entre los sexos no se puede achacar a la constitución biológica de la mujer, sino a un orden social con claras raíces económicas. Para ellos la subordinación de la mujer residiría y se fundamentaría en la institución familiar. En la familia, que se centra en la pareja y su prole, se habría impuesto un orden 
patrilineal, en el que la propiedad y la descendencia se trasmitirían por línea masculina, encarnándose en el padre, cabeza de familia, todo el poder y autoridad, convirtiéndose así la mujer, carente de independencia económica, en una propiedad de su marido.

Pero antes de que apareciera la familia, en un estadio primitivo que denominan salvajismo, habría imperado otra forma de organización social mucho más rudimentaria, la horda, en la que no se habría conocido ningún tipo de desigualdad. En una fase posterior, la primera etapa del estadio de barbarie, habrían aparecido otras formas de organización más complejas, como las gens, en las que tampoco podemos apreciar ningún signo de discriminación respecto a la mujer. Por el contrario, para Marx y Engels, que en esto seguían a Bachofen, esta etapa habría coincidido con el paraíso de las mujeres.

En las gens las personas se unían en extensas redes de parentesco por medio de lazos de sangre. Estos lazos se establecían por línea materna, porque el vínculo directo con la madre de un hijo era más fácil de demostrar que el vínculo directo con el padre. Las gens eran, pues, matrilineales. Eran también matriarcales porque la mujer ostentaba un poder considerable y, en las economías primitivas de cazadores y recolectores, cumplían una función económica crucial e independiente como recolectoras, artesanas, almacenadoras y distribuidoras de materias primas. También gozaban de un alto grado de poder, ya que establecían criterios de autoridad en temas cruciales para la colectividad; y de una gran libertad sexual, pudiendo escoger pareja.

Los factores que destruyeron este tipo de sistema social fueron económicos, debido al descubrimiento de la agricultura y la ganadería. Con este cambio, al producirse por primera vez un excedente acumulable, surgió la idea de la propiedad. Ciertos miembros del grupo se proclamaron primero propietarios de los excedentes, procediendo a su distribución arbitraria. No se tardó mucho en hacer extensiva esa idea de propiedad a los recursos esenciales para la producción económica como eran la tierra y el ganado. Como fueron los hombres los que impusieron este nuevo orden debido a su fuerza y al monopolio que ejercían sobre ciertas herramientas, las muje- 
res terminaron por convertirse en parte de esa propiedad, sustituyéndose la matrilinealidad por el linaje masculino que instauró la herencia de las posesiones. A raíz de todos esos cambios las relaciones económico-sociales se complejizaron, desarrollándose estructuras de dominación cada vez más asentadas, que desembocaron en la aparición de clases y en la creación de un orden político.

Las teorías de Engels hoy también se consideran superadas. Los modernos estudios antropológicos han aportado más de un ejemplo de comunidades primitivas actuales en las que apenas existe la propiedad y, sin embargo, ya conocen una clara jerarquización social basada en el sexo.

¿Ha sido pues el patriarcado el modo de organizarse de todas las sociedades humanas desde el origen de la especie? Ésta es una pregunta imposible de contestar, pero a pesar del descrédito en el que se hallan en la actualidad las tesis de Bachofen, Morgan y Engels, nosotros pensamos que no. El patriarcado, como cualquier otra forma de expresión cultural, y ésta lo es sin ningún tipo de duda, surgió en un momento de la historia que no podemos precisar, sucediendo a un estadio natural en el que las distinciones por sexo no se traducían en desigualdades, como así vienen a avalarlo los estudios etológicos y biológicos sobre grupos de animales próximos a nosotros como son los prosimios, monos y antropoides, que con el ser humano forman la especie de los primates (Kay y Voorhies, 1979; Schaller, 1984).

Las modernas tesis antropológicas sobre cómo se pudo producir ese proceso de diferenciación cultural que condujo a un dimorfismo sexual, con la aparición de parejas en las primeras sociedades, siguen marcadas por un fuerte androcentrismo y se apoyan en dos hipótesis. Una apunta, como conclusión de los estudios llevados a cabo con monos macho, que sólo se pudo refrenar la exacerbada competencia sexual que obstaculizaba el desarrollo de los homínidos, creando parejas conyugales, lo que facilitó, en la familia resultante, la división sexual del trabajo necesaria para la subsistencia de esos grupos en su proceso evolutivo. Para algunos autores (Sahlins, 1976), influidos por las teorías freudianas, la regulación cortical y social de la competencia sexual es el principal requisito para la for- 
mación de la sociedad humana. La invención de los tabúes del incesto y del parentesco fueron los elementos que hicieron posible el nacimiento de la cultura.

La otra hipótesis, que se inscribe en la misma tendencia, considera que el factor determinante en ese proceso fue la actividad cazadora. Todas estas teorías androcéntricas sobre la evolución cultural atribuyen al varón los papeles de cabeza de familia y de proveedor económico. Estas funciones sólo las pudo adquirir con la aparición y desarrollo de la caza, actividad para la que consideran al macho dotado de una capacidad innata. Según autores como Tiger y Fox (1973), gracias a la caza cooperativa se desarrolló el intelecto, se perfeccionaron las técnicas líticas, se produjo la división del trabajo e incluso aparecieron las primeras formas de expresión «artística».

Para los defensores de la primera hipótesis, la división de trabajo entre varón y hembra era imprescindible para la subsistencia. La sexualidad como competencia por la obtención de la pareja, entre los primates, puede conducir a luchas tan duras que a veces llegan a ser fatales. Fue este hecho lo que forzó a los homínidos a frenar y reprimir su sexualidad. El ser humano que emergía de entre los animales, forzado a luchar a vida o muerte contra la naturaleza, no podía permitirse el lujo de que hubiera pugnas sociales continuas. Era esencial que la cooperación sustituyese a la competencia. Así, la cultura impuso controles a la sexualidad. A partir de ese momento la sociedad sería la encargada de regularla en pro de la adaptación económica del grupo. De ese proceso surgió la dependencia de la mujer al hombre cazador, que era quien suministraba alimentos. Un mono macho tiene tantas parejas como puede obtener y defender por sí mismo, mientras que un hombre sólo las que puede mantener.

Para los defensores de la «hipótesis del cazador» apenas interesa la actividad recolectora que, sin duda, desarrolló nuestra especie en sus orígenes, ya que se parte del supuesto de que la caza era la técnica más importante para proveerse de alimentos. A esto se suma que eran sólo los varones los que participaban en la actividad depredadora, creando así una visión idealizada del macho como sostén de su pareja y sus crías. Este estereotipo del macho cazador-proveedor suele estar basado en su mayor fuerza física y en su escasa implica- 
ción en la crianza de la prole. A esta adecuación biológica, moldeada por la cultura, se debería la división del trabajo, básica en la familia, creándose grupos de producción cooperativos fuera de esa unidad.

Lo que nos lleva a cuestionar estas tesis que, sin duda, contienen elementos acertados, es más el enfoque general y la categorización de algunos de sus postulados que el fondo de las mismas. Por ejemplo, la premisa de que la competencia sexual entre los primates dificulta la cooperación y por tanto la evolución cultural se basa en estudios que se realizaron en su día tomando como modelo a los mandriles, que son monos de pequeño cerebro y, aunque su adaptación a la vida terrestre ha sido completa, no parecen filogenéticamente el tipo de primates más próximos al hombre. Sin embargo, los antropoides, como los chimpancés y los gorilas, aunque son solamente semiterrestres, muestran más rasgos morfológicos y de conducta comunes con los humanos que los anteriores.

Los estudios sobre antropoides (Schaller, 1984) revelan un tipo de comportamiento adaptativo completamente distinto al mandril. Los chimpancés y gorilas no provocan enfrentamientos agresivos por las hembras, su cortejo está plenamente ritualizado y aunque en él abundan, entre los machos, las embestidas, el lanzamiento de objetos y golpes en el suelo, o al pecho, como ocurre con los gorilas, todas estas muestras no pasan de ser actos de exhibición para atraer la atención de la hembra, más que comportamientos hostiles que pongan en peligro la existencia de la manada.

Así mismo, el desprecio que evidencian los partidarios de la hipótesis del cazador ante la actividad recolectora en los orígenes de la humanidad, tampoco parece concordar con otros datos que poseemos. Los restos arqueológicos confirman la existencia de una prolongada fase social vegetariana entre los primeros homínidos, y algunos autores (Jolly, 1999) han criticado la idea de un temprano desarrollo de la caza en los albores de la humanidad. Para éstos, en ese largo viaje de la animalidad a la humanidad, se podrían detectar dos etapas, en la primera, los homínidos se habrían alimentado fundamentalmente de semillas y bayas, mientras que en la segunda, habrían evolucionado hasta convertirse en omnívoros. En esa 
primera fase la única fuente de sostén del grupo era la actividad recolectora, mientras que en la segunda la caza actuó como factor de aceleración en un rápido proceso de evolución.

Pero esa estructura comunitaria en la que todos los adultos obtenían sus alimentos, sin existir dependencia, habría podido prolongarse durante miles de años. Con la aparición de la actividad cazadora es muy posible que los machos adoptaran la función de proveedores de carne, sin embargo a partir de entonces las hembras y jóvenes pasaron a ser los únicos encargados de la recolección de vegetales, que debió seguir desempeñando un importante papel en la dieta alimenticia (Harris, 1982), como se desprende de estudios efectuados entre primitivos actuales.

Parece evidente que el proceso de estructuración social está determinado por la paulatina división del trabajo, todas las teorías admiten esa premisa. La primera división de la actividad económica que debió establecer el hombre estuvo regida por el criterio sexual, como ya apuntara Engels en su momento. El largo período de gestación y lactancia de las crías entre las hembras humanas pudo servir de pretexto para que, en un momento determinado que no podemos precisar, se apartara a las mujeres de la actividad cazadora 0 , al menos, se las relegara a un papel secundario. Entre los factores que supuestamente frenaban a la mujer, los partidarios de la hipótesis del cazador citan su menor movilidad, la frecuencia cada vez mayor de los abortos y la propensión a los accidentes. Inicialmente esta medida pudo responder a algo tan simple como la necesidad de proteger la supervivencia del grupo. La hembra era la única capaz de garantizar la procreación, y la consciencia de este hecho debió convertir a la mujer en un valor en alza. ${ }^{3}$

3 Debemos tener en cuenta que muy posiblemente durante el todo el Paleolítico e incluso en época posterior la mortalidad debió de ser más elevada entre las hembras que en los machos. Aunque no poseemos ningún dato que pueda avalar esta afirmación todo indica que la mortandad entre las mujeres podía ser mayor debido sobre todo a los efectos del sobreparto. Se ha estimado que la mortalidad entre los cazadores del Paleolítico Superior era muy alta. Más de un tercio de los restos estudiados habían sucumbido antes de los veinte años y en el caso de la raza Neandertal la cifra se elevaba hasta un 55\%. Ya en el Neolítico, donde los hallazgos son más abundantes, no vemos que la tendencia hubiera variado. El hipogeo II de los Mournouards, en 
Querer aislar del potencial peligro de la partida cazadora a un bien tan precioso pudo ser la justificación que llevara a esta primitiva división de funciones. La hembra, inicialmente aceptaría de buen grado esa valorización, máxime cuando la actividad recolectora a la que se debió consagrar desempeñaba también un importante papel en la dieta alimenticia, sin embargo al apartarse de la caza, actividad ligada al uso de la fuerza y a la agresividad, daba los primeros pasos para convertirse en dependiente del macho.

Nada permite indicar que en una fase anterior la mujer no participara plenamente en la caza y muy posiblemente como afirma la antropóloga Linton (1979: 44) «toda la banda viajaba y cazaba junta». En el Paleolítico, la caza de grandes animales se hacía a menudo mediante una técnica muy primaria que consistía en provocar una estampida y conducirlos hacia un cortado para despeñarlos por él. Este procedimiento no sólo posibilitaba, sino que exigía la participación del mayor número de miembros que componían la horda y por supuesto no podemos pensar que quedaran excluidas las mujeres.

Los ejemplos zoológicos también vienen a desmentir que la mujer no fuera capaz de librar combate contra otro igual, es proverbial la agresividad de las hembras entre los depredadores de la familia de los felinos. La leona y no el león es normalmente la cazadora y, aunque se producen enfrentamientos entre leones por cuestiones de jerarquía, también se conocen algunos casos de enfrentamientos entre los dos sexos por razones difíciles de determinar (Ardrey, 1974). Entre los simios con prácticas carnívoras las hembras forman parte del grupo cazador sin ningún tipo de exclusión.

el Mesnil-sur-Oger, que data de fines del tercer milenio, ha proporcionado 33 individuos de edad y sexo determinable. La mortalidad más frecuente para las mujeres se sitúa entre los 15 y los 25 años. Una de las mujeres llevaba un feto próximo al parto, según atestigua la osificación. A partir de los 25 años y hasta los 45, sólo se encuentran esqueletos de hombres, mientras más tarde, de 50 a 70 años, hombres y mujeres aparecen en cantidad notablemente idéntica. En la necrópolis de Saint-Urnel-enPlomeur, en Finisterre (primer milenio), la mayoría de mujeres mueren entre los 20 y los 30 años, mientras que un adulto varón de cada cuatro puede esperar llegar a los 40 ó 50 años de edad. 
Sólo en la conceptualización de las funciones, más allá del instinto, nuestro antepasado inteligente pudo romper el orden natural; fue la meditación sobre la vida, la muerte o la pervivencia del grupo lo que le condujo a un ordenamiento cultural de lo que hasta entonces había sido una práctica natural. Discriminar los efectos del peligro sobre unos u otros miembros de la horda le llevó a prevenirlos atendiendo a lo que podríamos considerar el bien común. Es así como las mujeres, ese precioso valor por su actividad reproductora, fueron protegidas para terminar siendo sometidas.

El monopolio del macho sobre la actividad más valorada por el hombre primitivo debió acabar degenerando en una cierta preeminencia sobre el otro sexo, aunque no pudo quedar claramente establecida hasta que fue consagrada una primera «división de la violencia $»^{4}$ en el conjunto del grupo. Al asumir el varón un papel preponderante en función del control sobre la caza, lo asumía también en el ejercicio de la más importante actividad agresiva. En el ulterior desarrollo del utillaje ofensivo, el adiestramiento, cada vez más necesario, el ejercicio físico que comportaba, quedó reservado a los varones, reforzando así el papel pasivo adjudicado a las mujeres y, tal vez, condicionando su propia estructura tipológica.

Se conocen numerosos casos de primitivos actuales donde queda establecido como tabú el que las mujeres puedan siquiera tocar las armas. Por ejemplo, entre los baruya de Nueva Guinea se admite que fueron las mujeres las que inventaron el $\operatorname{arco}^{5}$ pero, tras

4 Consideramos que este factor se constituye en la génesis de la cultura en algo tan importante como la misma división del trabajo. La violencia, que supera con mucho la agresión animal, se convirtió en un valor cultural presente ya en el mismo proceso de hominización de la especie, guardando desde entonces una estrecha relación con el desarrollo material e ideológico del hombre. En el origen de la cultura actúa como un elemento determinante similar al de la propia división económica basada en la propiedad, vertebrando uno de los ejes fundamentales sobre los que pivota el poder político a través de la ley. En una relación dialéctica entre estos dos factores, la violencia contribuye a estructurar el poder, al tiempo que desde el poder se estructura y se controla la violencia.

5 No resulta casual que el mito haga referencia al arco, ya que este tipo de arma, manejada con una cierta habilidad, podía resultar temible en manos de cualquiera independientemente de su sexo al poder eliminar al contrario sin necesidad de la confrontación cuerpo a cuerpo. Encontraríamos relación entre este relato y el mito clásico de las amazonas cuya arma preferida era también el arco. Las amazonas 
haber hecho un uso desordenado del mismo matando a muchos animales, se les prohibió, bajo tabú, tocarlo.

Por su puesto no compartimos las tesis tan extendidas entre algunos antropólogos ${ }^{6}$ sobre la mayor capacidad bélica de los machos. La mujer debidamente adiestrada en el manejo de las armas, por muy primitivas que fueran, resultaría tan peligrosa frente a un varón como otro varón. No en vano el arma libera al hombre de su servidumbre biológica y lo convierte en superior al resto de las especies. Resulta una falacia admitir esto para el conjunto de los humanos frente a los animales y negarlo en lo referente a los sexos de nuestra propia especie.

Muy pronto los dos factores clave en el proceso de jerarquización de la horda debieron ser absorbidos por los hombres, y si bien es cierto que la estructura biológica de la mujer no justifica el hecho, ésta sirvió de pretexto para imponerlo. El grupo cada vez dependió en mayor medida de machos cazadores y agresivos, las ordalías iniciáticas empezaron a desempeñar una función selectiva en ese sentido. Interiorizada esa realidad por las hembras, pronto colaboraron en la tarea común introduciendo o consintiendo el infanticidio femenino y fomentando la agresividad entre los varones al favorecer sexualmente a aquellos que se mostraban como los mejores guerreros. «La mitad del cielo», como denomina a las mujeres un proverbio persa, fue apartada de las armas naciendo así un rasgo específico de la cultura femenina: su fuerte rechazo a la violencia como impropia del rol que se les había adjudicado.

De ser esto así, y antes de que ocurriera, la mujer debió de vivir en el «paraíso» 0 al menos en una formación social en la que no cono-

que atacaron a Orellana y sus hombres en el siglo XvI lo hicieron arrojándoles flechas, y el mismo término de amazona haría referencia al uso del arco ya que procedería de a-mwzon «las que no tienen pecho» en alusión a la creencia de que entre esas legendarias guerreras sería tradición amputarse un seno para facilitar el manejo de ese arma. Este detalle podría ser interpretado como una referencia a viejos tabúes en la prohibición a las mujeres de usar armamento pretextando su estructura anatómica.

6 Harris aduce que es la mayor fuerza muscular del varón la que ha condicionado de un modo fundamental el rol pacífico de la mujer, no obstante la propia tipología biológica de la mujer podría haberse visto influida por esa temprana división de funciones (1982: 75). 


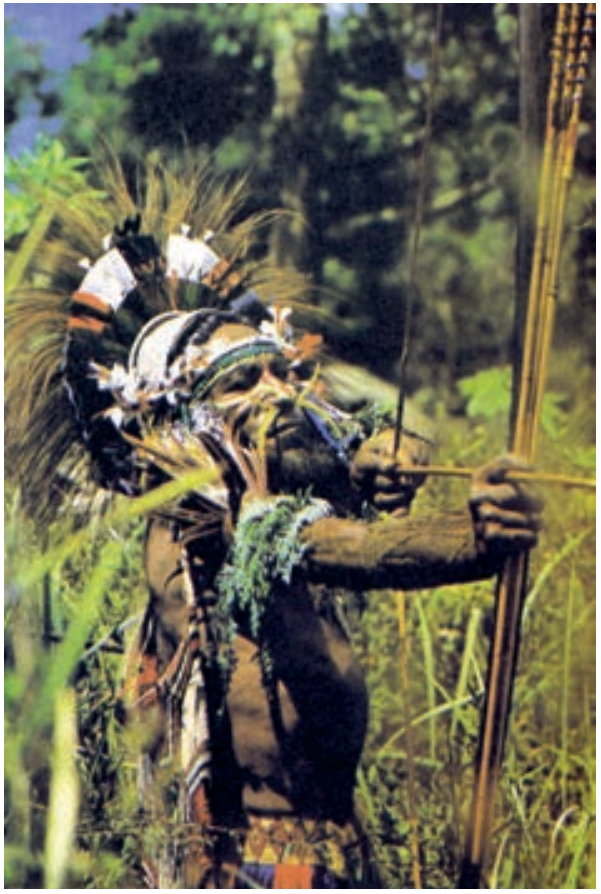

Un factor fundamental en el proceso de asentamiento del patriarcado fue el apartamiento de la mujer de las actividades cazadoras y agresivas. Esta división social de la violencia, para mejor preservar la reproducción de la horda, se convirtió en un elemento de dominio del macho cazador, que apartó a la mujer del uso de las armas por medio del tabú.

ció la discriminación en función de su sexo. Incluso podríamos llegar a admitir la vieja tesis de Bachofen de que durante un tiempo fue la «reina» de ese «paraíso».

Lo que parece evidente es que la actividad reproductora fue especialmente valorada en la comunidad primitiva. Esta valoración, coincidente con una fase del desarrollo intelectivo en el proceso de hominización, se tradujo en una conceptualización sobre la naturaleza reproductora de la mujer que le condujo a ser considerada «diferente». No obstante, en esa fase ambigua, en la que los hombres llegaron a apreciar la importancia social de la mujer en la pervivencia del grupo, es muy posible que recibiera un trato deferente, llegando incluso a desempeñar un papel relevante en el seno de la horda. 
Pero el mecanismo básico de la discriminación estaba en marcha. La «diferencia», en un momento de formación del intelecto abstracto, se tenía que traducir, tarde o temprano, en desigualdad y esa desigualdad pudo jugar a favor y en contra de las mujeres alternativamente. En la mente del hombre primitivo lo distinto al «yo», te domina o debe ser dominado. Ese «yo» que iba emergiendo como característico del ser humano, en un proceso de objetualización de la naturaleza de la que se estaba despegando, apreciaba lo «distinto» como opuesto, en unas formas de vida marcadas por una lucha constante por la supervivencia, y esa oposición debía ser reducida en términos de poder. La diferencia sexual o, mejor dicho, reproductiva no podía sustraerse a ese principio gnoseológico general, comenzando así una larga andadura de veneración y sometimiento que todavía subsiste en nuestros días.

Los enfrentamientos intergrupales por el control del territorio debieron ser cada vez más frecuentes y el ulterior proceso de sedentarización que se dio, a partir de la revolución neolítica, culminó y consolidó la aparición de la sociedad patriarcal, tal y como se ha explicado tantas veces.

El patriarcado no ha existido siempre y la mujer fue expulsada del "paraíso» como resultado de un determinado desarrollo material y de la progresión del pensamiento abstracto. Su pecado era, al mismo tiempo, la que se consideraba su mayor virtud: mantener viva la especie; su condena ser «diferente» al macho que acabó imponiendo su poder. Con esa "diferencia», expresada en términos antagónico-valorativos, hacía su aparición el Mal en el mundo.

\section{Yo te controlo, tú me dominas}

Parejo al desarrollo inicial del poder patriarcal y producto de parecidas realidades debió de nacer el pensamiento religioso, y si querer saber algo sobre aquél es moverse en el terreno de lo hipotético, pretender hacer lo mismo con éste resulta aún mucho más complicado, ya que las condiciones materiales en las que tiene su origen este tipo de creencias son más difíciles de aislar e interpretar. 
El patriarcado ha pervivido como institución cuasi universal a lo largo de toda la historia y, aunque sus formas se han modificado acomodándose a los distintos modos de producción y las diversas formaciones sociales, podemos rastrear su huella en diferentes etapas hasta nuestros días, lo que nos permite reconstruir más fácilmente cuáles fueron sus orígenes.

No ha ocurrido lo mismo con el hecho religioso, que ha sufrido profundas transformaciones, lo que hace mucho más complejo indagar sobre su aparición. La desigualdad entre los sexos sigue viva, aunque atemperada, en la sociedad posmoderna, mientras que el hecho religioso, con claras implicaciones sociales y políticas, sólo muestra su vigencia en la periferia del sistema globalizado.

Sin embargo, la historia reciente de una y otra cuestión ha seguido derroteros parecidos. También, en el caso de los orígenes de la religión se lanzaron, a finales del siglo XIX, toda una serie de teorías, influidas por el evolucionismo en boga, que han sido sistemáticamente cuestionadas a lo largo de la centuria siguiente. Las dos grandes aportaciones decimonónicas son las de Tylor y su discípulo Frazer, que de un modo mucho más sistemático que el marxismo, asentarán los principios para un estudio materialista del fenómeno.

Uno de los padres de la antropología social, el británico Tylor, en su obra Cultura primitiva (1871/1981), introduce para explicar el origen de la religión el concepto de animismo. Para Tylor el animismo, término que toma intencionadamente del latín (animus, anima, 'espíritu, alma'), consistiría en la creencia desarrollada por el hombre primitivo de que todo lo que le envuelve está animado por una fuerza vital similar a la que él posee.

Ese mundo primigenio estaría poblado en su totalidad por seres animados, poseedores de un espíritu que les dotaría de una vida como la del ser humano. En una fase posterior habría surgido la creencia de que esas fuerzas podían desdoblarse de su cuerpo, apareciendo así la representación sobre los espíritus, que no serían otra cosa que «el alma» que abandona a los seres en un momento dado.

En esta personificación de la realidad llegó el hombre a conferir vida y voluntad propias a diversos fenómenos naturales: relámpago, 
sol, luna, planetas, montes, mares, ríos y bosques, dando paso a continuación a representaciones sobre la vida de ultratumba, que al principio se distinguirían muy poco de las representaciones sobre el mundo real.

Para Tylor el animismo supondría la definición mínima de la religión y la fuente de la que, con el tiempo, habría surgido todo un complejo mundo de creencias. Los espíritus de los vientos terminaron por convertirse para los griegos en Eolo, que se comportaba como un ser sobrehumano y todopoderoso gobernando sobre esa parcela de la naturaleza. Por una generalización y una abstracción posteriores se llegó a la idea de un rector y creador supremo. Por tanto, así como del animismo habría surgido el politeísmo, así también de este último surgiría el monoteísmo.

Estas tesis fueron adoptadas y profusamente ilustradas por James Frazer en su monumental obra La rama dorada (1890/1974). En ella, apoyándose en el animismo de Tylor, retoma una vieja idea de Hegel, para establecer una secuenciación en la que diferencia entre una primitiva era de la magia y otra posterior en la que habría aparecido ya la religión, distinguiendo claramente entre ambos principios, el mágico y el religioso.

La magia, a diferencia de la religión, carece de referencia a lo «trascendental» y no tiene por qué reconocer la existencia de unos seres sobrenaturales superiores al hombre y dominadores de la naturaleza. La magia sería equiparable a una "técnica», a una pseudociencia, a través de la cual se pretendería dominar una naturaleza plenamente animada por medio de unas prácticas ritualizadas. Los hombres primitivos creían que se podía influir en cualquier fenómeno natural mediante una determinada actuación simbólica (conjuros, exorcismos, etc.), que respondía a unos principios analógicos muy simples basados en la simpatía o parecido entre las cosas.

Así, Frazer establece, a partir de esa «ley de la simpatía», dos tipos de magia, practicados extensamente y en todas las culturas por el hombre primitivo: la magia homeopática, basada en la ley de la semejanza, y la magia concomitante, que se apoyaría en la ley del contacto. Existen numerosas evidencias de que, entre las poblacio- 
nes primitivas, está muy extendida la creencia de que las cosas semejantes entre sí poseen propiedades y poderes similares. El hombre moderno distingue entre un retrato y la persona retratada, pero no ocurre lo mismo en una mente que ya se ha adentrado por el camino de la abstracción pero que, sin embargo, ha profundizado poco en el pensamiento analítico.

En un mundo plenamente animado lo reproducido se convierte en parte de lo real; es más, podríamos considerar que la reproducción registra la «esencia» de esa realidad. También debemos admitir que no resulta carente de toda lógica pensar que una parte cualquiera de un ser contiene lo sustancial del mismo, así pues lo que hagamos a la imagen o a una parte de ese ser, cabellos, uñas, etc. se lo estaremos haciendo a él mismo.

Los ritos y las fórmulas, el modo en que determinadas cosas son dichas y hechas por quienes poseen el saber y el poder necesarios, buscando una finalidad concreta, perseguirían el objetivo de controlar de alguna forma esa fuerza vital que animaba a las cosas.

Mientras que la religión presupone la existencia de seres espirituales externos al mundo y con capacidad para controlar al individuo y a su realidad circundante, la magia se desenvuelve en el ámbito de lo natural, concretándose en una práctica humana basada en unas técnicas muy estrictas que siempre responden a un proceder meticulosamente ritualizado. De ahí que cuando la magia no surta efecto, el que la practica no pensará que ha fallado el principio general que rige la operación sino que algo se ha ejecutado mal en el rito mágico.

Sin embargo, para Frazer este método terminó por perder su vigencia; fue entonces cuando el hombre se decidió a apelar a seres sobrenaturales superiores a él —espíritus, dioses o antepasados divinizados - para que completaran la eficacia de sus prácticas. Así se habría pasado de la «era de la magia» a la religión, convirtiéndose el chaman en sacerdote y quedando desplazados, con el tiempo, a un segundo plano, los ritos mágicos por otros métodos suasorios como el sacrificio y la oración. El cambio en este sentido habría sido sustancial, puesto que mientras la magia parte de un principio coactivo e igualitario frente a otra fuerza natural, la religión es suplica- 
toria, y el grado de dependencia asimétrica entre el hombre y esa pretendida fuerza sobrenatural es el mayor que se puede llegar a imaginar.

Las tesis de Frazer no tardaron en ser cuestionadas, tachándolas de intelectualistas, excesivamente simplificadoras y lineales. Muy pronto, a través de algunos ejemplos concretos extraídos de estudios antropológicos, toda su teoría sobre el pensamiento mágico, como previo al religioso, quedó rebatida.

Un erudito escocés, Andrew Lang (1901/1969), demostró que entre los pueblos cazadores con culturas muy poco desarrolladas existían dioses superiores. Lang mencionaba que entre pueblos tan atrasados como los aborígenes australianos se reconocía la existencia de seres que no eran ni espíritus, ni fantasmas y que, aunque por lo regular se mantenían al margen de los asuntos cotidianos, desempeñaban el papel de guardianes de las costumbres de la comunidad. Según las leyendas, esos «dioses» serían los que habrían dado a las tribus las leyes por las que se regían, e instaurado los ritos que debían practicar. El escocés concluía que este dato echaba por tierra la teoría de Tylor y Frazer sobre un hipotético desarrollo lineal desde el animismo al politeísmo y finalmente al monoteísmo. También en cierta medida venía a invalidar que las prácticas mágicas antecedieran a las religiosas y que existiera una filiación entre éstas y aquéllas.

A estas objeciones se vino a sumar una aportación antropológica. En una carta del misionero R. H. Codrington, ${ }^{7}$ publicada por el estudioso de las religiones Max Müller en 1878, se mencionaba por primera vez el concepto de mana, término con el que algunas tribus melanesias designaban una especie de fuerza superior que actuaría a través de la naturaleza y de los propios hombres. El mana se haría

7 El pasaje de la carta de Codrington (cit. en Van der Leeuw, 1964: 14) sobre el tema decía: «Es un poder o un influjo no físico y, en cierto sentido, sobrenatural. Pero que se revela en las fuerzas corporales o en cualquier clase de fuerza y capacidad de un hombre. Este mana no está ligado a un objeto, pero puede ser transmitido casi por cualquier objeto; los espíritus [...] lo tienen y pueden comunicarlo [...] Toda la religión melanesia consiste fácticamente en conseguir este mana para uno mismo o en hacer que se emplee en beneficio propio». 
evidente en cualquier objeto, persona o acontecimiento que mostrara un comportamiento, para bien o para mal, insólito.

Esa fuerza sería también conocida por los indios norteamericanos que la denominaban orenda, o wakonda, términos asociados a las ideas de voluntad e inteligencia, aunque a veces se transformaba para ellos en la personificación de un dios llamado Manitu. En Marruecos, esa especie de principio inmanente se designaría como baraka, y sería algo que además podría poseer alguien. También, las cosas o los lugares podían tener baraka, así La Meca facilitaría la adquisición de saber por la baraka del lugar. En Borneo los dayacos conocían el poder de petara, que era concebido también como una fuerza y en ocasiones como un ser indefinido.

Conforme los estudios antropológicos avanzaban, los ejemplos de ese mana como principio único, activo y «sobrenatural» se iban multiplicando, y arrinconaban las tesis de un mundo animado por infinitas fuerzas de orden cuasi natural, como habían sostenido Tylor y Frazer. Por el contrario, parecía afirmarse la existencia de una creencia más o menos generalizada de seres sobrenaturales y todopoderosos investidos de una sacralidad que haría partícipes hasta las culturas más atrasadas de un cierto sentido religioso.

Estas aportaciones fueron de inmediato aprovechadas por la escuela fenomenológica alemana encabezada por Rudolf Otto, que en su obra Lo santo (1917/1991) asimila el concepto de mana al númina de los antiguos agricultores latinos y, apoyándose en él, despliega toda una teoría sobre lo numinoso, entendiendo por esto la sacralidad, no en el sentido moral sino como estado de ánimo y de experiencia espiritual, privativo de la religión. Lo numinoso no es para este autor el mana, ya que se trata de una condición mental exclusiva de la conciencia religiosa y termina por ser explicado como una especie de categoría a priori, es decir, como una predisposición latente que existe hacia lo sagrado. Para Rudolf Otto, el ser humano es un ser religioso; por esta razón, considera inútiles las tentativas de los evolucionistas al querer reconstruir la historia de las religiones, ya que el sentido religioso existe y ha existido en todas las personas y en todos los tiempos. 
De aquí a afirmar que esa fuerza que los melanesios denominaban mana y todas sus manifestaciones eran la expresión primitiva de un monoteísmo primigenio sólo había un paso, que algunos historiadores de las religiones (Schmidt, 1941) y antropólogos dieron.

Por ejemplo Evans-Pritchard (1982) en su estudio sobre los nuer nos dice que este pueblo considera a su dios espíritu puro, y que al ser como el aire o el viento, está en todas partes. Él fue el creador de la tierra y su mantenedor. Todo se le debe porque él formó todo. Creó al hombre pero también fundó las costumbres, todo en la naturaleza es producto de su obra. Aunque es invisible, al estar en todas partes como el aire, oye y ve todo lo que sucede. Atiende sus súplicas y le gustan las oraciones y los sacrificios que los nuer le dirigen para evitar desgracias. Como es recto y justo el dios de ese pueblo africano se enoja y castiga las malas acciones y sólo el arrepentimiento y los reiterados sacrificios pueden aplacar su ira. Son estas interpretaciones las que llevan al historiador de las religiones James (1975: 20) a decir: «Semejante concepción de la deidad, indistinguible del monoteísmo auténtico, constituye una conciencia religiosa de una providencia divina más fundamental que cualquier tránsito gradual de la pluralidad a la unidad».

Las críticas a las viejas teorías decimonónicas se saldan en el caso de la aparición de la religión de modo muy similar a como lo hacen en el tema de los orígenes del patriarcado. Resulta curioso ver cómo sobre una y otra cuestión existe una marcada tendencia por parte de un sector muy nutrido de la investigación por devolver las cosas al orden establecido.

El patriarcado sería para muchos el único sistema de organización social existente desde los más remotos tiempos. Su universalidad y antigüedad lo convertirían en algo casi natural, y ninguna cultura o civilización a lo largo de la historia habría conocido otra forma distinta de vertebración social. Lo mismo ocurriría con el mundo de las creencias religiosas, que estarán presentes desde el alba de los tiempos. Un innato sentido de la sacralidad y una clara distinción entre lo sagrado y lo profano serían también rasgos estructurales y característicos de cualquier cultura independientemente del grado de desarrollo que ésta hubiera alcanzado (Eliade, 1973). 

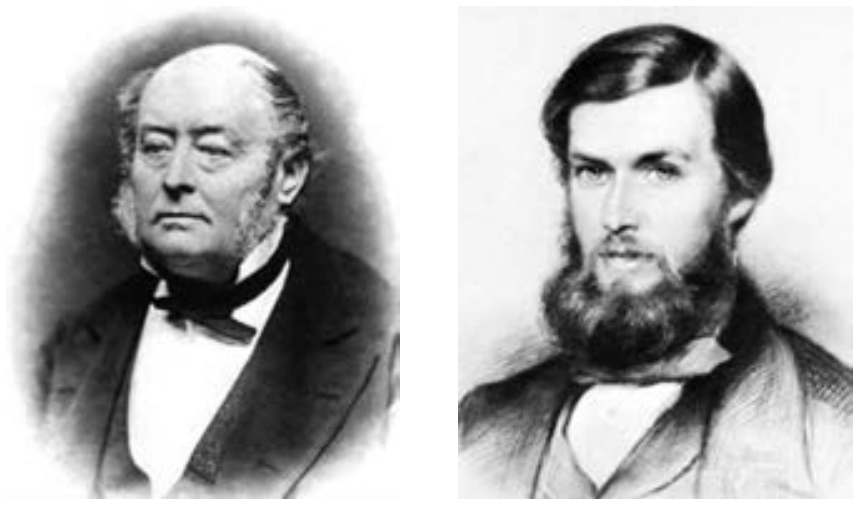

Las teorías de Bachofen (a la izquierda) sobre el matriarcado y las de Tylor (derecha) y Frazer sobre el origen de la religión hoy se consideran superadas $y$, sin embargo, aportan interesantes elementos que permiten vincular en su nacimiento las creencias religiosas y la sociedad patriarcal.

Esta coincidencia, en el sentido de las conclusiones a las que llegan los críticos del matriarcado o del animismo, nos hace sospechar una cierta toma de postura ideológica convenientemente argumentada con abundante documentación factual.

Que las teorías de un Bachofen o un Tylor enunciadas tal y como ellos lo hicieron en su momento pueden estar parcialmente superadas eso nadie lo pone en duda, sin embargo su núcleo central no ha quedado, a nuestro modo de ver, básicamente cuestionado por la crítica moderna que, en ocasiones, ha querido «coger el rábano por las hojas» para rebatir unos análisis que podían adolecer de excesivamente simplistas pero que, a pesar de todo, siguen ofreciendo explicaciones plausibles sobre fenómenos que de ningún modo forman parte de la naturaleza humana y sobre cuyos orígenes apenas tenemos datos. Esto se ha querido subsanar mediante el concurso de la antropología y las aportaciones que ha hecho sobre los pueblos primitivos actuales, pretendiendo que se encontraban, cuando fueron estudiados, en situaciones parecidas a las del hombre cazador-recolector del Paleolítico Superior, pero este procedimiento ha derivado en un cierto abuso del mismo. No podemos olvidar que estos aborígenes de Australia, Tasmania o África, 
supuestamente "primitivos», tienen tras de sí una historia muy larga y se mueven incluso en un medio natural sin duda distinto al de sus ancestros.

Por otra parte, su estudio sólo se ha podido realizar a partir de un contacto previo y en ocasiones mucho después de esos primeros contactos. Hasta qué punto esa relación inicial ha influido en ellos es algo difícil de evaluar. Los procesos de rápida integración de elementos culturales procedentes de otros ámbitos son asombrosos, como lo demuestran los mitos de los indios de la pradera americanos en los que aparece con frecuencia el caballo, animal que sólo conocían pocas generaciones antes de que los antropólogos registraran estas leyendas. ${ }^{8}$ Los mismos cultos «Cargo» ${ }^{9}$ en Melanesia nos demuestran también ese fenómeno que estamos apuntando.

La religión como el patriarcado y como toda ideología está estrechamente relacionada a la historia de la sociedades humanas, y su

8 Encontramos un testimonio de ello en un mito crow (sioux de Montana). En él, Coyote, un héroe civilizador, crea los caballos, antes de la llegada de los españoles: «El Viejo Coyote... del fango hizo nacer los bisontes y los caballos; también creó, a partir de ese fango, los demás animales. A partir de las hojas, hizo las tipis (tiendas), y del fango hizo salir los hombres. Del fango se hizo él mismo una esposa. El Viejo Coyote y su mujer hicieron flechas y todo lo que los hombres tienen costumbre de utilizar. Les dijo que tuvieran relaciones sexuales, y que en diez meses tendrían hijos. Cuando se hicieron numerosos, Coyote los dividió en diferentes tribus y los estableció en círculo. Dejó una tribu en medio e hizo que las demás fueran sus enemigas. La tribu central era la de los crow» (Bouteiller y Monin, 1967: 181).

9 Los cultos «Cargo» (Worsley, 1976) fueron un movimiento milenarista que se desarrolló en Melanesia desde finales del siglo XIX. Tenían como centro la creencia en la llegada de un cargamento de bienes materiales, identificados como productos manufacturados europeos. La implantación del milenio estaba unida al arribo de ese "cargo", que supondría la inversión del orden antiguo y la instauración de una nueva era de prosperidad. El "cargo" representaba para los nativos una clase de bienes de procedencia desconocida cuya elaboración se debía a la eficacia de la magia de los blancos. En la religión melanesia existe una preocupación por los bienes materiales y por la relación entre los espíritus y los seres humanos que se expresa en frecuentes ritos de donación. La llegada del «cargo», que les pertenecería, supondría un éxito de su propia magia que se traduciría en un tiempo de prosperidad inagotable.

Los cultos «Cargo» son un buen ejemplo del poco tiempo que tardan en influir los contactos culturales en las creencias «religiosas» de los primitivos actuales, que integran de modo "sui generis» esos aportes en su mundo de representaciones ancestrales. 
origen y evolución ha sido determinada por la misma evolución social. Como fenómeno de la conciencia que es, evidencia la naturaleza social del pensamiento y las ideas, que sólo pueden darse en un proceso de interacción sobre actividades conjuntas en el seno de una comunidad.

Es así como la religión aparece y se forma en un determinado momento como producto de esa vida social (Levy-Bruhl, 1927/1985). Esas ideas y cultos de los primitivos se fueron elaborando gradualmente a partir de diversas representaciones ilusorias que surgieron en una determinada fase del desarrollo psicocognitivo del ser humano y en estrecha relación con su realidad material.

La religión habría aparecido como consecuencia de la debilidad del hombre primitivo frente a la naturaleza; ${ }^{10}$ pero fue también producto de un determinado grado de desarrollo de la conciencia y está estrechamente vinculada al nacimiento del pensamiento abstracto. Podemos decir que la religión sólo apareció cuando ese fenómeno se hizo inevitable y a la vez posible.

$\mathrm{Su}$ inevitabilidad radicó en las duras condiciones de vida a las que tuvieron que enfrentarse nuestros antepasados, en su desconocimiento sobre el entorno que les rodeaba y los fenómenos que en él se producían, en la tensión emocional que padecían producto de esas condiciones y en el esfuerzo por obtener explicación y consuelo ante esa realidad.

Su posibilidad se concretó cuando la conciencia humana alcanzó un nivel de madurez que permitió que la imaginación pudiera elaborar construcciones fantásticas. Sólo cuando la capacidad de razonamiento abstracto posibilitó la aparición del lenguaje y la elaboración de conceptos se asentaron las bases para unas representaciones ilusorias y deformadas sobre la realidad, que a su vez abrieron las puertas al pensamiento religioso. Los debates sobre cuándo ocurrió eso nos parecen secundarios y, aunque podamos admitir que

10 «... La religión no es más que el reflejo fantástico, en las cabezas de los hombres, de los poderes externos que dominan su existencia cotidiana: un reflejo en el cual las fuerzas terrenas cobran existencia supraterrenal.» (Engels, 1894/1977: OME, t. 35, 326) 
existen posibles indicios de algún tipo de actividad ritual entre los pitecanthropus, sólo poseemos evidencias claras de su aparición durante el Paleolítico Superior. ${ }^{11}$

Hasta el momento en que comenzaron a formarse las primeras creencias en algo sobrenatural debemos pensar que el ser humano primitivo era un materialista espontáneo. Su conciencia registraba las regularidades objetivas del mundo material que él descubría en su actividad cotidiana de un modo puramente empírico, por el procedimiento de "error y ensayo", tal y como ocurre en el mundo animal. Ese método, con todo su primitivismo, le fue permitiendo satisfacer sus necesidades y, tras muchas generaciones, maneras cada vez más perfectas de hacerlo. Con el tiempo, estas maneras se tradujeron en reglas y tradiciones transmitidas también de generación en generación.

La racionalidad de muchos utensilios primitivos, la capacidad extraordinaria de observar, que se manifestaba en el rastreo, la lógi-

11 Los hallazgos realizados en la gruta de Choukuotien, próxima a Pekín, de unos cuarenta cráneos trepanados por la zona del «foramen magnum», parecen evidenciar una práctica caníbal en la que debieron incurrir erectus y neanderthales. Como podemos comprobar por los restos encontrados en Monte Circeo a unos 160 kilómetros de Roma, en Solo, isla de Java, y en otros yacimientos, lo hallado en Choukuotien no debió de ser un caso aislado. Todo indica que ese tipo de perforaciones se hacían con la intención de extraer la masa encefálica de la víctima, posiblemente para ser devorada, y podríamos aventurarnos a establecer que esto debió de ser una práctica habitual a lo largo de miles de años en puntos muy distintos del planeta, pero lo que resulta dudoso es que respondiera a las necesidades alimenticias de aquellos que la ejercieron. Frente a una actividad puramente animal, como es la cazadora, la deglución de cerebros se nos presenta más como un acto ritual que económico. Las interpretaciones realizadas por Métraux (1973) sobre los ritos antropofágicos entre los Tupinambas de Bahía, y también por Harris (1994), coinciden en que el consumo de carne humana no respondía, en primera instancia, a ninguna necesidad material. Las víctimas una vez devoradas eran rápidamente vomitadas por sus consumidores. Hemos de pensar que desde época remota debió de existir veda natural sobre la propia especie, eso no excluye que en casos de extrema necesidad los homínidos se comieran entre sí. En el siglo xx se han detectado numerosos casos de antropofagia alimenticia entre individuos de culturas desarrolladas. La gran hambruna que asoló la URSS en 1921 nos dejó patéticos testimonios que demuestran cómo las barreras culturales no fueron obstáculo frente a este tipo de práctica. Pero también es cierto que el cazador-recolector primitivo sólo en raras ocasiones debió de verse abocado a esa necesidad extrema. Todo parece indicar que la antropofagia ha desempeñado desde los tiempos más remotos, básicamente un papel mágico-ritual. 
ca rigurosa que se desprende de los métodos de caza y las conclusiones que deducían de los hechos observados, nos confirman que el hombre primitivo, en sus primeros estadios de evolución, poco tenía que ver con el pensamiento prelógico con el que quiso caracterizarlo Lucien Levy-Bruhl.

Pero Levy-Bruhl sólo se confundió al juzgar con el criterio predominante en la actualidad formas que se produjeron a partir de un determinado momento. Los estudios antropológicos en los que se apoyó nos ofrecen unas mentalidades ya conformadas, que tienen tras de sí miles de años de evolución cultural y, en muchas ocasiones, de contactos interculturales, no pudiendo extrapolarlas al pasado remoto de la humanidad o valorarlas con los criterios de la modernidad, ya que en una cierta etapa de esa misma sociedad primitiva aparecieron representaciones fantásticas a las que se atribuyeron rasgos y poderes sobrenaturales.

Estas creencias se entrelazaron en un primer momento con la praxis vital y, desde postulados que podríamos considerar materialistas, produjeron un pensamiento mágico cuya finalidad era dominar el entorno para satisfacer mejor esas necesidades, tal y como lo atestigua la funcionalidad de muchos de los ritos que aún subsisten y que anclan su origen en ese pasado remoto. Aunque eso sólo pudo producirse cuando los humanos accedieron a formas de pensamiento abstractas.

El pensamiento abstracto es la unidad más compleja y más contradictoria de un contenido objetivo y de una forma subjetiva. Todo concepto es el resultado de una complicada generalización, ya que el concepto no supone inmediatamente el objeto real. En cierto modo, para que aparezca el concepto es necesario alejarse del objeto. La abstracción se basa en una operación mental que se realiza a partir de la riqueza y multiplicidad de las cosas aisladas e incluso en la generalización más sencilla hay una cierta porción de fantasía, que implica trascender la realidad, ya que el concepto sólo existe en nuestras mentes.

Por medio del lenguaje simbólico, se puede fijar en el concepto lo general y lo sustancial de la pluralidad real. Pero en esa generalización es donde radica precisamente la porción de fantasía que 
abre las puertas a la imaginación. La imaginación, como una forma de fantasía, operará potenciando la cultura, pero también supondrá la apertura a un mundo irreal y a la creación de unas representaciones ilusorias y falsas, que son las que están en la base del pensamiento mágico y religioso.

Estas premisas, necesarias para podernos explicar la aparición de esas formas de pensamiento, debieron de encontrar su cauce a través de las experiencias más comunes en el ser humano. Tylor consideraba que el origen del animismo se hallaba en el fenómeno de los sueños y en la muerte. Hoy todos conocemos la naturaleza de los sueños y, sin embargo, en ellos, nuestro inconsciente nos sigue permitiendo trascender la realidad. Con los sueños nos remontamos a las mayores alturas, conocemos el placer y también experimentamos los acontecimientos más horribles; creamos seres fantásticos, siempre a partir de la realidad que nos es conocida, pero que el sueño es capaz de alterar hasta convertirla en monstruosa; revivimos el pasado y anticipamos el futuro; visitamos lugares ya conocidos y otros en los que nunca hemos puesto los pies; nos reencontramos con seres ya fallecidos y establecemos comunicación con otros vivos que se hallan a gran distancia de nosotros.

Sin embargo durante el sueño o en estado de coma, el cuerpo no abandona el lugar en que reposa. Nos despertamos en el mismo sitio que nos tendimos para descansar. El cuerpo no ha realizado los actos soñados, el resto de los miembros del grupo así lo pueden atestiguar, pero es difícil para el que ha vivido la experiencia soñada no considerar reales todos esos acontecimientos. La conciencia del hombre primitivo tomaba por ciertas todas esas sensaciones e impresiones. A partir de este error sólo se podía llegar a una conclusión: el individuo constaba de dos partes, el cuerpo, que era el que se acostaba y levantaba en el mismo lugar, y otra parte invisible, $\mathrm{u}$ otro cuerpo, que era el que vivía todas las experiencias soñadas. Esa otra parte inmaterial fue bautizada por Tylor como alma y se convirtió en la raíz universal del animismo.

En el lenguaje de muchos pueblos, la palabra que los antropólogos traducen por alma es sinónima de sombra y nos indica el carácter sensualista de estas formas de pensamiento, ya que la som- 
bra es ese otro «yo» que nos acompaña mientras el sol nos ilumina, como nos refiere un mito azteca. Pero el alma para el pensamiento mágico era fundamentalmente fuerza vital. Su presencia daba vida al cuerpo; su ausencia lo deja inerte. Era durante la quietud del sueño cuando el alma se desplazaba. Es así como, tras esta deducción que podríamos considerar lógica, entró la muerte a completar el esquema explicativo de Tylor.

El largo sueño que es la muerte llegaba cuando el alma errante no regresaba al cuerpo. El cuerpo, que era la morada del alma, carecía ya de función cuando el alma lo abandonaba, tras eso no podía venir sino la desintegración, de ahí que muchas culturas terminaran por preservar el cadáver, o los restos del mismo, para un futuro reencuentro con la otra parte del "yo», ya que si esas almas no encontraban su cuerpo podían mostrarse hostiles con los que seguían vivos.

El siguiente paso consistirá nada más que en la constatación de un hecho obvio, los humanos no están solos; los «otros», las bestias de los bosques y los campos, las aves del cielo y los peces del agua, también están provistos de vida. Por medio del razonamiento analógico, los pueblos primitivos terminarán también por atribuirles a todos un alma con la que explicarán la causa de su vitalidad o de su mera existencia.

El hombre primitivo llegó a creer que a través de los rituales mágicos basados en el pensamiento analógico podía controlar el anima de los seres que le rodeaban, sin darse cuenta de que con ese proceder estaba activando un mecanismo que terminaría por dominarlo a él, las creencias religiosas.

Independientemente de todas las críticas que se le hayan podido hacer seguimos considerando esta vieja interpretación sobre el origen del pensamiento religioso como la más válida de las barajadas hasta el momento. La historicidad y materialidad de la misma permiten ponerla en relación con la que apuntábamos más arriba sobre la aparición tardía del patriarcado. Ni el patriarcado ni la religión han acompañado a la humanidad desde sus albores, sino que son producto de un determinado desarrollo material y ambas construcciones sociales se potenciaron mutuamente desde su aparición. 
La religión «fuente de una violencia sin violencia», tal y como la denominó Godelier (1985: 352), terminó de sancionar la división social de la violencia real para someter mejor a la mujer. Fue así como Eva acabó siendo expulsada del Paraíso, aunque quien la expulsó quedó condenado a seguirla si quería sobrevivir. 


\section{III \\ LAS TRES CARAS DE EVA}

Desde la etapa que hemos denominado Paleolítico Superior, hace 35.000 años, hasta el 4000 a. n. e. se abre un largo período en la historia del que seguimos teniendo escasa información. En él, un humano, que tipológicamente ya es muy parecido a nosotros, va a avanzar lentamente superando el estadio animal de la mera depredación hasta convertirse en productor de sus propios alimentos, lo que terminará por distinguirle definitivamente del entorno natural y le permitirá acelerar su desarrollo cultural.

En ese período del Paleolítico nos encontramos con suficientes evidencias como para poder afirmar que los humanos han desarrollado un conjunto de creencias mágico-rituales que forman ya parte de su mentalidad. Toda la pintura rupestre es un testimonio material de estas prácticas y maneras de pensar. Sin embargo, no podemos estar tan seguros respecto a la evolución de la estructura patriarcal que, seguramente, ha dado sus primeros pasos pero aún se encuentra en una fase inicial.

Durante miles de años el hombre continuará siendo cazadorrecolector y sólo hacia el 9000 a. n. e., en la zona del Oriente Próximo, se producirá esa gran revolución, bautizada como Neolítico, que verá el nacimiento de la agricultura y la ganadería. A partir de ese momento y durante los milenios posteriores se perfilarán las creencias religiosas en las zonas afectadas por esos cambios y el patriarcado adquirirá una configuración definitiva. Así, formas de vida y pensamiento distintas, coexistirán durante un dilatado período en un mundo en lenta evolución.

La agricultura o el pastoreo no desplazarán mecánicamente la caza; la sedentarización no vendrá a sustituir el pretendido noma- 
deo anterior, del que nos hablan los libros escolares; tampoco la familia patriarcal se impondrá con facilidad a la comunidad preexistente y las prácticas mágicas se entremezclarán con las primeras creencias religiosas durante mucho tiempo.

El balance inicial de todos estos cambios arroja un resultado ambiguo respecto al sexo femenino; mientras que, por un lado, su naturaleza reproductora le confiere una consideración estimable, por otro, la función que se le ha terminado atribuyendo en las actividades agresivas de la comunidad lo convierte en despreciable. Así, la mujer será la conciencia material de la propia debilidad del hombre ante el medio hostil, enfrentándole a su necesidad y mostrándole el rostro ambivalente de la misma. Su lado más terrible por lo que la necesidad supone de dependencia, pero también su aspecto más codiciable por lo que entraña de deseo.

Convertida en necesidad, la mujer será deseada y estimada a la par que despreciada. Entre estos dos polos la gradación será muy amplia en relación con la importancia que sigan teniendo en cada cultura las actividades productivas de las mujeres. En este sentido la vinculación de su imagen con lo positivo o lo negativo, con el bien y con el mal nos ofrecerá, según los casos, distintas caras de Eva.

\section{La Eva fértil}

El llamado «arte» del Paleolítico Superior nos ha legado un conjunto impresionante de pinturas parietales que han dado pie a las más diversas interpretaciones, desde la clásica que pone en relación su ejecución con ritos de magia mimética para facilitar la caza del animal, hasta las más atrevidas de Leroi-Gourhan (1987), que ve en ellas una polaridad simbólica entre lo masculino y lo femenino que impregnaría todo el arte de ese largo período. En lo que no cabe ningún tipo de duda es que nos encontramos ante manifestaciones que guardan relación con algún modo de actividad ritual. La premeditada y, en ocasiones, recóndita ubicación de estas figuras; la reiteración iconográfica, centrada en la mayor parte de los casos en el mundo animal; la plasmación de extraños signos, como puntos, inci- 
siones y rayas, con un posible significado simbólico, nos indican que la factura de estas pinturas respondía a unas formas de pensamiento muy desarrolladas en las que desempeñaba un importante papel la actividad cazadora.

Junto a estos hallazgos, que testimonian la aparición de un mundo ricamente imaginativo y fantástico, nos hemos encontrado con un impresionante arsenal de útiles y objetos tallados en piedra, asta y marfil, a la mayor parte de los cuales se les ha atribuido una finalidad precisa, relacionada con las actividades cotidianas de la caza, la pesca o el vestido. En medio de todo este cúmulo de restos pertenecientes a las llamadas «industrias líticas» se han encontrado también unas curiosas figurillas de mujer que fueron bautizadas como «venus», siguiendo una vieja tradición en el mundo del arte de designar genéricamente así a las representaciones de desnudos femeninos.

Las estatuillas, cuyos tamaños varían entre los 5 y los $25 \mathrm{~cm}$, están talladas en piedra, marfil y hueso o modeladas en arcilla, y representan a mujeres con los pechos, las caderas y las nalgas muy pronunciadas y sin rostros definidos. En algún caso, como ocurre con la más conocida, la Venus de Willendorf, localizada en el sur de Austria, el rostro está cubierto o ha sido sustituido por un curioso trenzado de cabello o cuerda que envuelve toda la cabeza ocultando las facciones. Las venus no están hechas para ser vistas desde uno solo de sus lados, sino desde todos; esta característica unida a su pequeño tamaño y su portabilidad puede hacernos pensar en amuletos con funciones mágicas (Tabanera, 1977; Giedion, 1981).

Estas originales manifestaciones del «arte mobiliar» se han encontrado por toda Europa hasta alcanzar la zona del lago Baikal en Siberia, y son abundantes los hallazgos en países como Francia, Italia, Alemania, la antigua Checoslovaquia o Ucrania, lo que nos ha proporcionado diversos ejemplares que superan ampliamente el centenar. Las diferencias que podemos establecer entre ellas parecen menos relevantes y significativas que los elementos comunes que las conforman. Así por ejemplo, las veinte estatuillas de Malta (Siberia) son más toscas, pero esto se podría deber a la mayor o menor habilidad de los que las confeccionaron, sin que el grado de 
perfección mermara en absoluto la naturaleza del objeto. Su tipología bien definida nos permite deducir que estamos ante lo que en historia del arte se llama un "género» que siempre cumple y persigue una finalidad concreta. Son, por tanto, unos objetos producto, no del capricho o la casualidad, sino de un propósito que guarda relación con algún aspecto importante en la vida y las creencias de quienes las realizaron.

La mayoría de las estatuillas reproducen mujeres esbeltas, aunque la popularidad alcanzada por la robusta Venus de Willendorf, de forma casi esférica, con cabeza voluminosa, senos enormes, vientre prominente y caderas y nalgas muy desarrolladas, ha generado en muchos la confusión de atribuirles como rasgo común la obesidad, cuando un gran número de piezas se asemejarían más a la estilizada Venus de Lespugue (Francia) que a la Venus de Willendorf. La Venus de Lespugue nos muestra una mujer bien conformada pero que presenta un desarrollo hipertrofiado de senos, caderas y nalgas, como si éstos fueran un añadido premeditado sobre una estructura corpórea normal.

El esquematismo y la geometricidad son las notas predominantes en la representación volumétrica de estas mujeres. Como señalan algunos historiadores del arte (Sureda, 1985), el esquema adoptado sería el de dos hachas de mano o bifaces opuestas, lo que da como resultado un rombo isósceles alargado y perfectamente simétrico, como ocurre con el caso de las halladas en Mezina, que representan unas formas femeninas reducidas a elementos geométricos, además de mostrar otra particularidad: estar decoradas con diversos signos o dibujos, la svástica entre otros. En estas incisiones o presuntos tatuajes entre los pechos, sobre el abdomen o en la espalda, se ha querido ver una marca de familia o de clan, idéntica en todos aquellos grupos que reconocían un antepasado común.

Pero no sólo nos encontramos con esculturas de bulto redondo, el mismo tema de la mujer desnuda quedó registrado, a modo de bajorrelieve, sobre fragmentos de roca con una superficie más o menos plana; es el caso de la Venus de Laussel. En la de Tursac, la figura, que no posee cabeza, ni senos, ni brazos, adopta una posición tan forzada que ha sido interpretada por algunos como propia de un 

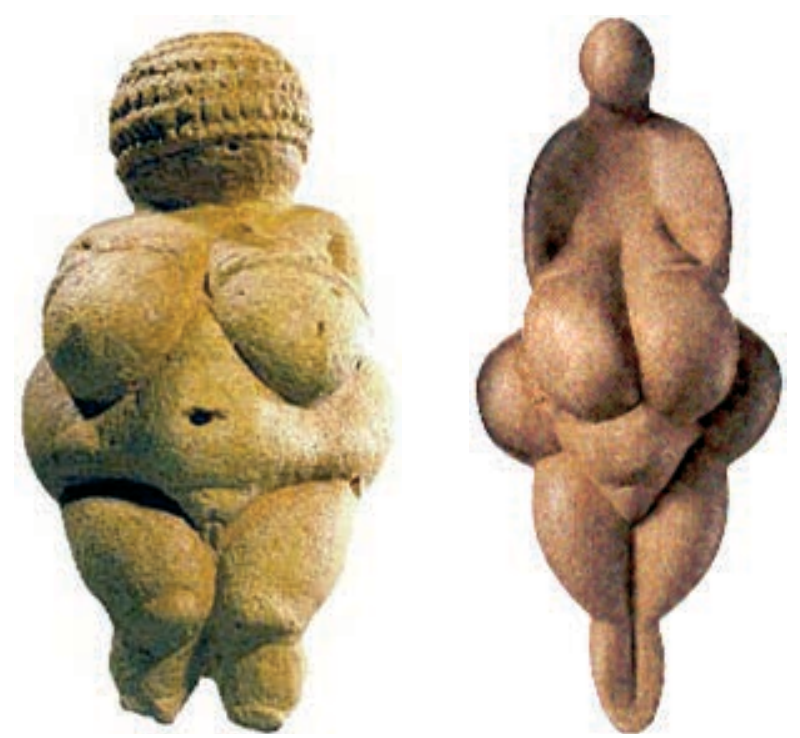

La llamadas «Venus paleolíticas», pequeñas estatuillas como la Venus de Willendorf (izquierda) o la más estilizada Venus de Lespugue (derecha), con sus acusados rasgos sexuales, guardan relación con ritos o cultos de fertilidad en los que la mujer debía de desempeñar un papel fundamental.

parto inminente, y por otros, como una representación andrógina. Esa misma interpretación se habría dado en el caso de la venus hallada en la localidad francesa de Sireuil. La Venus de Brassempouy, también francesa, nos ofrece otra singular característica, no es una imagen de cuerpo entero sino una cabeza que presenta un rostro hierático, sin boca, enmarcado por un tocado o un peinado que llega hasta la base del cuello.

La datación de estas estatuillas se ha podido realizar de un modo más preciso que en el caso de las pinturas parietales, ya que han sido encontradas en diferentes estratos, lo que ha permitido clasificarlas en venus Auriñacienses, Gravetienses o Magdalenienses, aludiendo a los diferentes períodos en los que se divide el Paleolítico Superior, correspondiendo al último ser la etapa más reciente y la que nos ofrece un mayor número de testimonios. También se ha abordado el estudio de su tipología en función de su localización, 
pero esta clasificación, útil en el estudio de las formas, no ha aportado nada que ayude a esclarecer la función o el significado de las imágenes talladas.

La interpretación más corriente es que todas estas figurillas responden a una clara simbología que pone en relación la imagen de la mujer con la fertilidad y que, posiblemente, fueran ejecutadas para desempeñar algún papel en ritos o cultos relacionados con ella (James, 1975). Sin duda nos indican «el papel en alza que por aquellas épocas pudo tener la mujer en la sociedad. No obstante, incluso aceptando que tuvieran carácter mágico, éste llevaría implícito el reconocimiento de una superioridad en el sexo femenino...» (Pericot y Martín, 1973: 39-42).

Lo cierto es que en más de una de estas piezas podemos intuir los rasgos característicos de la gestación y deducir que el artista quiso representar más a la madre que a la mujer. Otros detalles como los senos pesados, los abultados vientres y las marcadas caderas vendrían a abundar en esta tesis de la mujer-madre, bien dotada para la fecundidad. El detalle con el que se trabajan los órganos femeninos contrasta con el descuido e incluso el desprecio con el que el artista aborda el rostro. Este hecho nos indicaría cómo la pretensión de la imagen era representar a una mujer genérica sin ningún rasgo particular, a una mujer fecunda que simbolizaría la fertilidad y la vida en abstracto.

En algún caso esta hipótesis se vería reforzada al haber hallado en la figura restos de almagre u ocre rojo, un color con el que se han encontrado pintados huesos humanos en fosas de enterramiento. La relación entre este color y la sangre parece evidente y, como nos dice Childe (1936/1973), el hombre primitivo ya había establecido la vinculación que existía entre ese fluido y la vida. Su utilización para pintar algunas venus, como ocurre en el célebre bajorrelieve de la Venus de Laussel (Francia), que representa a una mujer con un cuerno de bisonte en la mano, posiblemente fue aplicado para reforzar las cualidades vitalizadoras de la imagen.

Aunque esta teoría es la más difundida, tiene también sus detractores. Chard (1976) opina que este tipo de mujeres no son más fértiles que las delgadas, sino más blandas, más cálidas y mejor ali- 
mentadas, de lo que podríamos deducir que se estaba representando una especie de ideal femenino del Paleolítico Superior. Por otro lado, argumenta que la idea de la fertilidad no preocupaba a estas comunidades de cazadores-recolectores, ya que en estos pueblos la abundancia estaba controlada por fuerzas sobrenaturales y no por la mera reproducción biológica. Si las venus desempeñaron alguna función mágica fue en relación al culto familiar, completando los ritos que se oficiaban en los «santuarios», que eran los lugares donde se han encontrado pinturas rupestres. ${ }^{1}$

La idea de que estas figuras reflejaran un ideal de mujer ha dado pie a su vez a otras interpretaciones, mientras que para algunos, según registra Sanahuja (1982), la esteatopigia (exuberancia adiposa en determinadas partes, en especial las nalgas) constituiría un carácter adaptativo, en situaciones que alternaban períodos de relativa abundancia con períodos de escasez, al igual que se manifiesta aún hoy en los bosquimanos o los hotentotes. Para otros, ese ideal femenino guardaba relación con el erotismo y la sexualidad y no con la fertilidad o la provisión de alimentos. Los que apuestan por esta segunda interpretación sostienen que en esas figurillas queda más destacado el aspecto voluptuoso que el reproductor y citan para corroborar esta opinión los relieves de las paredes de la cueva de Combarelles (Francia), en la que hombres y mujeres bailan vestidos con pieles de animales, con los rostros ocultos y provistos de colas. Podríamos aceptar que el elemento erótico podía acompañar a los ritos de fertilidad (Bataille, 1981) y eso no resultaría extraño, como ocurrirá más adelante en el culto a la diosa madre en alguna religión oriental, si tuviéramos la certeza de que el hombre primitivo conocía los mecanismos de la reproducción, pero no gozamos de esa certeza (Frade, 1996: 14).

En Rusia se han excavado algunos de los yacimientos más ricos en este tipo de imágenes, en especial el de Malta (Siberia), donde

1 La tesis de que estos lugares eran auténticos santuarios ha sido sostenida por diversos autores. Para Leroi-Gourhan (1987) no cabe ningún tipo de duda de que las cavernas desempeñaban esta función y que las plaquetas de piedra o las figurillas venían a ser como santuarios portátiles con la misma estructura simbólica que nos podemos encontrar en las grutas con pinturas parietales. 
aparecieron veinte estatuillas talladas en marfil de mamut y asta, o el de Gagarino (Alto Don), donde se encontraron siete figuras. Lo más importante de estos hallazgos es que gran parte de las imágenes fueron exhumadas en viviendas paleolíticas. En Malta se encontró un campamento con habitaciones estables de planta rectangular que curiosamente estaban divididas en dos mitades, una, a la derecha, reservada a los hombres, ya que en la excavación aparecieron sólo objetos presumiblemente de uso masculino, mientras que la de la izquierda pertenecería las mujeres. Es en estas dependencias donde se encontraron varios ejemplares de venus, mientras que las figurillas localizadas en el sector masculino podrían reproducir pájaros o tal vez falos.

La interpretación que algún autor soviético dio a este original campamento es que las estatuillas femeninas eran dueñas del fuego o del hogar. Esa imagen mitológica de la protectora doméstica ha dejado huella en la cultura de muchos pueblos contemporáneos de Siberia y, en ese caso, las venus serían muestra de un incipiente culto en clanes matrilineales (Tókarev, 1990). Es cierto que en ciertas tribus cazadoras del Asia septentrional se fabrican pequeñas estatuas antropomorfas en madera, llamadas $d z u l i$, que recuerdan a las venus. En las tribus en las que el $d z u l i$ es femenino la figura representa a la abuela mítica, que protege a las familias. Al regreso de las grandes expediciones de caza se les rinde culto ofreciéndoles gachas y grasa. Estos datos vendrían a avalar la función ritual de las imágenes y su vinculación con cultos a los antepasados.

A partir de aquí se formuló la hipótesis de que durante el Paleolítico la mujer-madre se convirtió en pionera de las técnicas de conservación de los recursos cárnicos, del curtido de las pieles, de la ejecución de determinados útiles, siendo a la vez la protectora de la familia y la dueña de la «casa». La interpretación dejaba vislumbrar un culto a la madre protectora y garante de la perpetuidad del clan, lo que permitía enlazar estas teorías con la existencia de un «derecho materno» durante el Paleolítico, que venía a concordar perfectamente con la tesis expuesta por Engels en El origen de la familia, de la propiedad privada y del Estado. 
Esta reivindicación matizada del matriarcado llenó de indignación a un sector del feminismo durante la década de los años setenta del siglo Xx que veía en las viejas formulaciones una trampa tendida a la mujer por la misma ideología patriarcal. Para estas feministas, el mito del matriarcado operaría como anestésico en su lucha por la igualdad. La idealización de una «época dorada» en que la mujer habría sido como una diosa dejaría como saldo un regusto ideológico por esa pretendida divinización. El mito de la mujer adorada por los hombres encontraría su correlato actual en el estereotipo femenino del mundo de la publicidad, el cine o la moda, proyectando sobre el común de las mujeres un espejismo imitativo que las apartaría de una auténtica reflexión crítica sobre su real situación de desigualdad y explotación. ${ }^{2}$

Sin embargo otro sector del movimiento, del que podríamos citar a Françoise d'Eaubonne (1977), basándose en el hecho de que las venus mas antiguas pertenecientes a los períodos Auriñaciense y Gravetiense representan mujeres a punto de dar a luz, afirmaba que fue en aquel momento en el que la especie humana comenzó a tomar conciencia de si misma, buscando perpetuarse más allá del individuo, lo que le llevó a interesarse por el aspecto maternal del nacimiento y por la pervivencia del grupo, coincidiendo en estos planteamientos con los arqueólogos defensores de la teoría de la fecundidad.

Para algunos estudiosos de las religiones resulta imposible precisar el significado de estas figuras (Eliade, 1978), pero como ocurre con casi todo lo que ha llegado hasta nosotros resulta difícil eludir

2 En este sentido la historiadora Sanahuja (1982) hace la siguiente reflexión: «Pero tanto si se considera que «Las Venus» representan mujeres a punto de dar a luz o embarazadas, documentos antropológicos, el canon de belleza del Paleolítico, el sentido erótico de nuestros antepasados o ambas cosas a la vez; incluso si se llega a aceptar que la mujer es convertida en "Gran Madre" por su capacidad reproductora, de ningún modo ello implica que las mujeres gobernaran económica, social y políticamente. Estoy de acuerdo en que la diferencia establecida entre el hombre y la mujer en la reproducción de los hijos suscitara la sorpresa y la admiración del varón paleolítico, el cual probablemente ignorara su intervención en tal tarea, incluso abogo en pro de que la regulación de la descendencia se efectuara según el linaje de la madre (matrilinealidad), pero, en realidad la elevación de la hembra a la categoría de diosa o su degradación a la condición de objeto producen el mismo resultado». 
su interpretación. La hipótesis más lógica parece la más extendida. Esas estatuillas representarían de algún modo ritos o creencias vinculados a la fertilidad (Blázquez, Martínez y Montero, 1993: 77; Durand, 1994).

La fertilidad para el hombre del Paleolítico Superior tendría connotaciones más generales y también más restringidas que para el actual. Podemos suponer que para ellos la fertilidad estaría vinculada a la vida en su sentido más amplio y profundo, y que esta idea abarcaría no sólo a la especie humana sino también, y de un modo particular, a las especies animales. Todo aquello que se moviera y reprodujese de modo similar a como lo hacía el hombre formaría parte de ese tipo de «vida» al que nos referimos. El resto de la naturaleza, el mundo de la vegetación o de los seres inanimados, también tendría para él una forma de vida, pero distinta. En el caso de las especies superiores, que en la mayor parte de las ocasiones eran su fuente alimenticia, la vida se regeneraba a través de las hembras, por tanto la postura ante la hembra del macho cazador forzosamente debía ser ambivalente.

La mujer poseía ese poder que animaba a la naturaleza. En ella residía el misterio de la cantidad, o sea, de la abundancia o de la escasez, era la clave de la pervivencia ya que sin ella todo se acababa y se extinguía el grupo, y la comunidad lo era entonces todo para el hombre. Sin el grupo el cazador aislado no era nada, sólo el grupo protegía, y el grupo dependía de las hembras que resultaban imprescindibles, ya que las hembras poseían esa potencia, esa fuerza maravillosa que permitía reproducirse y sobrevivir: la fertilidad.

La mujer se convirtió así en un símbolo de esa fuerza misteriosa, de esa fertilidad entendida como vida. Como tal símbolo, su poder se extendía a toda la naturaleza animada, a través de ella el hombre se vinculaba con todo lo que le rodeaba, la misma reproducción animal podía quedar asegurada en la medida en que la mujer, por medio del ritual mágico, la garantizara. A través de esa ritualización los atributos sexuales de la mujer se convertían en el símbolo material y visible sobre el que descansaba la reproducción ordenada de la vida. Su naturaleza fértil debió convertirla en muy importante, lo que nos permite presuponer que buena parte de la ordena- 
ción social del grupo debió girar en torno a ella, estructurándose ginocéntricamente, como lo demuestran las sociedades matrilineales, aunque no ginocráticamente como lo pretendieron los defensores del matriarcado.

La Eva fértil de las sociedades de cazadores-recolectores fue una simbolización de lo positivo relacionado con la vida, que debió de estar más cerca del Bien que del Mal en el mundo de creencias del hombre primitivo.

\section{La Eva generatriz}

Entre los años 9000 y 7000 a. n. e. los cazadores, los pescadores y los recolectores de cereales y frutos descubrieron la agricultura y la ganadería. Esto que Childe denominó «revolución neolítica» se produjo gradualmente en diferentes partes del globo, Sudeste asiático, Mesoamérica y Oriente Próximo, y comportó uno de los logros humanos más importantes de toda la historia.

Estos cambios implicaron una serie de transformaciones radicales al convertirse el ser humano en productor de sus alimentos. Por primera vez, pudo acumular de modo regular sus provisiones, lo que le permitió reconvertir su dieta alimenticia al introducir el consumo regular de cereal cultivado; pasando a ser la ingestión de proteínas animales un complemento alimenticio.

Convertida la tierra en la principal fuente de abastecimiento, la tendencia sedentaria, que se había dado ya en época anterior, se hizo mucho más acusada y toda una serie de transformaciones en cadena, tanto en el orden material como en el de la conciencia, cambiaron la vida de los humanos en los milenios siguientes. Las creencias mágico-rituales, de las que nos hemos encontrado diferentes testimonios en época paleolítica, se multiplicaron, pero sobre todo cambiaron su naturaleza y dieron paso a la aparición de la religión.

Tenemos constancia a través de restos humanos hallados en fosas, cubiertos o rodeados de objetos, de que el Neanderthal practicaba algún tipo de enterramiento. En yacimientos descubiertos en Iraq, en Israel, en la Unión Soviética y en Francia podemos apreciar esa 
inquietud por los cadáveres de sus semejantes. En Irak, en Shanidar, se halló el esqueleto de un niño en postura fetal, e incluso se ha dicho que había sido enterrado sobre un lecho de flores. En Qafzeh, en Israel, aparecieron los restos de adulto enterrados en la misma postura y con un niño tendido a sus pies en posición perpendicular. Otro niño, depositado en una fosa, tenía un cuerno de cérvido junto a su mano derecha. En Teshik Tash (antigua URSS), el cadáver de otro niño se hallaba rodeado de cuernos de íbice. En Francia, el hombre de la Chapelle-aux-Saints descansaba encuclillado en una fosa, mientras que en La Ferrassie se encontraron inhumados cinco niños y dos adultos. Éstas son las primeras sepulturas que se conocen y testimonian la existencia de primitivos ritos relacionados con los muertos.

Este tipo de hallazgos aumentan con los Homo Sapiens y las inhumaciones se hacen más complejas y sofisticadas. Los cadáveres son adornados con objetos como pequeñas conchas, colgantes de marfil, dientes de ciervo o de zorro y en ocasiones cubiertos con almagre. Estos muertos tan engalanados son prueba, quizá, de la aceptación de alguna forma de supervivencia, aunque no significan forzosamente esto, ni por supuesto podemos deducir de ellos la creencia en seres superiores. Pero aunque lleguemos a la conclusión de que estas inhumaciones, por el ajuar funerario de armas y útiles que acompaña a los cadáveres, responden a la creencia en otra vida, no podemos afirmar que eso presuponga la existencia de divinidades que controlen ese paso al más allá.

$\mathrm{Ni}$ si quiera el único testimonio hallado de un rito sacrifical en la cueva del Maltravieso (Extremadura) nos puede dar pie a pensar que el hombre de aquella época hubiera avanzado en la construcción de alguna forma de deidad que presidiera sus vidas y sus rituales mágicos.

Para muchos tratadistas de las religiones, incluso con enfoques materialistas, como Kryvelev(1982), el sacrificio es la manifestación más importante ya en las religiones primitivas y es la expresión evidente de la creencia en seres sobrenaturales ante cuyos poderes los humanos deben someterse. Los sacrificios adquirirían el sentido del regalo más generoso a esos seres y constatar la existencia de los mismos presupondría admitir automáticamente la creencia en ciertas formas de divinidad. 
En la cueva de Maltravieso se han hallado huellas correspondientes a una treintena de manos que presentan mutilaciones. A diferencia de otros testimonios arqueológicos de parecida naturaleza, que han sido interpretados como un ejemplo de las duras condiciones de vida, en las que un accidente de cualquier tipo o incluso la amputación involuntaria producto de la congelación podían haber dejado esa marca, en el caso de la cueva mencionada todas las mutilaciones presentan características idénticas y corresponden a las dos falanges del auricular. En esta ocasión no se trata de una pérdida accidental sino de una clara incisión, precisa, rectilínea, sin prolongación del fragmento cutáneo protector. Una amputación tan regular sólo puede explicarse como producto de un sacrificio ritual, ya que resulta difícil imaginar que represente alguna forma de castigo, que podía ser otra posibilidad. En todo caso es casi el único rito sangriento que puede atestiguarse en el conjunto de manifestaciones del Paleolítico ${ }^{3}$ y no podemos establecer por esto de modo concluyente que los hombres de Maltravieso creyeran en seres sobrenaturales o en deidades a las cuales ofrecían ese bárbaro sacrificio.

La ritualización mágica nos ofrece numerosos ejemplos de masoquismo en los ritos de iniciación o de otro tipo. Algunos primitivos australianos acuden a un paraje rocoso que creen habitado por los espíritus de los canguros y se abren las venas de los brazos para que la sangre corra sobre la roca con la intención de fomentar el desarrollo de la especie mediante una renovación de la vida, sin que de este ritual se derive creencia religiosa alguna, entendiendo por ésta la existencia de unos seres superiores con poderes sobre los humanos. Tales tipos de creencias debieron aparecer en época posterior y no fueron ajenos a ellas los cambios materiales experimentados con la revolución neolítica.

$\mathrm{Al}$ convertirse en productor de sus alimentos, en realidad, al convertirse en agricultor, el hombre tuvo que modificar su comportamiento ancestral, y posiblemente una de las modificaciones más

3 En la cueva de Gargas, en Francia, aparecen también siluetas de manos con falanges amputadas y algunos autores (Díez de Velasco, 1998) han sugerido la posibilidad de que se debieran a la práctica de un ritual iniciático en diferentes grados. 
importantes que introdujo con esa nueva forma de vida fue la relativa a su conciencia temporal.

El cultivador neolítico no tuvo más remedio que reconducir su percepción ante determinados cambios que experimenta la naturaleza hasta desembocar en la idea abstracta del tiempo para intentar conceptualizarlo y en definitiva «controlarlo». Sólo por medio de un perfeccionamiento en la técnica de medición del tiempo pudo elaborar planes con mayor o menor anticipación para llevarlos a cabo, pues se veía obligado a realizar en un orden preciso una serie de actividades complejas con vistas a obtener un resultado lejano $\mathrm{y}$, sobre todo al principio, incierto: la cosecha.

Así el agricultor terminó por adecuar su vivencia del tiempo a los ritmos de la tierra, acompasando su propio devenir a los ciclos agrarios. Por otra parte, el cultivo de las plantas imponía una distribución del trabajo orientada conforme a principios completamente distintos a los que habían regido anteriormente, pues la responsabilidad principal en cuanto a asegurar los medios de subsistencia recaía ahora sobre las mujeres.

Se admite generalmente que la agricultura fue un descubrimiento femenino (Hawkes y Woolley, 1977: 227; Girard, 1978: 730; Campbell, 1991: 364). La mujer, ayudada por su espíritu de observación, sacó el máximo partido a esa ocupación ancestral de la recolección de frutos y plantas silvestres. En ella tenía oportunidad de observar el fenómeno de la germinación, y terminó por tratar de reproducirlo controladamente. Así se explica el papel preponderante desempeñado por la mujer en los comienzos de la agricultura; vio cómo su función recolectora pasaba a ser generatriz.

El ciclo agrícola introdujo un profundo cambio en la mentalidad del hombre neolítico; para el cazador sólo era posible concebir dos planos de la realidad cambiante, los que ofrecía la oposición vida/muerte; con la nueva actividad se introdujo un nuevo plano en esa dualidad, el de la regeneración. Este hecho iba a tener enormes implicaciones en la evolución de su pensamiento. Con la conciencia que daba una percepción temporal basada en los ritmos agrícolas, la muerte, como ocurría en el caso de las plantas, se podía superar, no como un mero tránsito locativo a otra vida que continuaba en un 
lugar desconocido, sino como resurrección a partir de ella misma. Este proceso de nacimiento, muerte y resurrección, que se hacía evidente en el año agrícola, terminará por influir en la concepción del propio devenir de los humanos. Si se podía controlar en las plantas, lo mismo se podía hacer con la vida de la comunidad, por la solidaridad vital existente, ya que todo estaba unido bajo un principio cósmico-vital que vinculaba lo telúrico con lo vegetal, lo animal y lo humano.

Por medio de ese principio se establecía la vinculación entre pervivencia de la comunidad y fertilidad de la tierra. Esa relación asumida como un ciclo continuo y unida a la nueva percepción temporal les permitió a nuestros antepasados alumbrar una nueva secuenciación vital. Habría un tiempo originario, un tiempo «sagrado», en el que las cosas aparecieron sobre la tierra, y un tiempo «cíclico», en el que la vida se regenera, repitiendo continuamente el misterio de ese acto primordial, en el que la semilla enterrada se destruye para renacer convertida en otros muchos granos. De ese tránsito misterioso que era la regeneración surgía la abundancia, surgía la continuidad.

En el tiempo primordial, en el origen de las cosas, en el nacimiento de lo sustancial, estaba la clave de ese misterio y el hombre necesitaba poder controlarlo por medio del ritual, para asegurarse la repetición cíclica del acto fundador. Controlar ese proceso era garantizar la vida y la riqueza pero ¿quién podía hacerlo?, ¿quién estaba dotado para dar la vida y familiarizado con los ritmos del mundo vegetal? ¿Quién podía establecer ese vínculo cósmico?

El prestigio simbólico acumulado por la mujer a lo largo del Paleolítico como mediadora de la fertilidad sufrió una profunda mutación a raíz del descubrimiento de la agricultura, al verse potenciado por esta nueva actividad. La mujer no sólo podía garantizar la continuación de la vida a través su propia fertilidad sino que, como lo había demostrado al domesticar las plantas, conocía el secreto del renacimiento. Sólo ella ante la desintegración era capaz de regenerar. Es así como la Eva fértil se convirtió en Eva generatriz y cómo el hombre dio un importante salto en la ideación de lo sobrenatural del que la mujer salió inicialmente beneficiada. 
La fecundidad de la tierra y la fertilidad femenina se asimilaron y, en consecuencia, las mujeres se convirtieron en responsables de la abundancia de las cosechas, pues ellas eran las que conocían el «misterio» de la recreación (Labiosa, 1977: 630).

De esa solidaridad mística entre la fecundidad de la tierra y la fuerza creadora de la mujer, que es, en palabras de Eliade (1975: 301), una de las intuiciones fundamentales de lo que podríamos llamar la «conciencia agrícola», encontramos numerosos testimonios que nos brinda la antropología. Por ejemplo, en Borneo, las mujeres desempeñan el papel principal en las ceremonias y los trabajos referentes a la agricultura del paddy. Sólo se recurre a los hombres para desbrozar y para ayudar en algunas operaciones finales. Son las mujeres las que escogen y conservan las simientes. Parece que se siente en ellas una afinidad natural con los granos, de los que dicen están embarazadas. A veces las mujeres van a pasar la noche a los campos de paddy, en la época en que crece. Su idea es probablemente aumentar la fertilidad de la planta, pero lo que importa es la vinculación que existe entre ambas. En Sumatra, las mujeres se sueltan las trenzas al sembrar el arroz a la espera de que el cereal crezca al menos al tamaño de sus cabellos y las jíbaras de Ecuador cuando plantan la mandioca se sientan sobre el sembrado acariciando y meciendo uno de esos tubérculos, pintado de rojo, como si fuera una criatura.

En un primer momento esta idea de la sexuación femenina de la tierra fue tan naturalmente asumida que era la tierra sola, el principio femenino, el único capaz de generar la vida. Una tierra que sin concurrencia masculina se autofecundaba. Durante siglos, la Tierra Madre concibió la vida sin ayuda alguna. Esta creencia ha dejado abundantes huellas en las mitologías agrícolas; la griega recoge una manifestación de este tipo: «Gea (la Tierra) alumbró primero al estrellado Urano (el Cielo) con sus mismas proporciones, para que la contuviera por todas partes y poder ser así sede siempre segura para los felices dioses...»(Hesíodo, Teogonía 130).

Antes de que fuesen conocidas las causas fisiológicas de la concepción, el padre no podía reconocer a sus hijos y los hombres sólo estaban unidos entre ellos por las madres, este hecho ha servido a los antropólogos para explicar la matrilinealidad. Sin embargo, la pree- 
minencia del varón en estas comunidades neolíticas terminó por imponerse y el elemento masculino hizo su aparición en el relato mítico. Hemos de pensar que a la par que agricultor el hombre se había hecho también pastor y ganadero y los misterios de la reproducción sexual debieron dejar de serlo muy pronto, si no habían sido ya desvelados en época anterior. El conocimiento de su participación en el acto de la fecundación pudo contribuir a que el varón reivindicara un papel en los mitos etiológicos. Lo cierto es que, por las razones que fuera, lo masculino entró en concurrencia con la tierra para dar cumplida explicación del origen de todo. Identificado simbólicamente como uránico, el principio masculino se fundió con lo telúrico para engendrar el cosmos. Estas bodas entre el cielo y la tierra constituyen una de las hierogamias más frecuentes en todas las religiones; por ejemplo, para los maoríes el cielo Rangi y la tierra Papa estaban unidos en un estrecho abrazo. Los hijos que nacieron de ese acoplamiento - Tumata-nenga, Tane-mahuta y otros- se movían a tientas en las tinieblas y decidieron separar a sus padres. Cortaron los tendones que unían al cielo y a la tierra para empujar a su padre hacia arriba hasta que la luz se hizo. Este tipo de relatos los hallamos en todas las latitudes, e historias parecidas se dan entre los indios de la pradera americanos o entre los bosquimanos del centro de África.

La concurrencia de lo masculino registrada en estos mitos nos indica cómo con el desarrollo de la agricultura el hombre fue interesándose cada vez más por esa actividad que se estaba convirtiendo en la principal fuente de subsistencia. Así, la tierra desde el descubrimiento del arado se entendía que era fecundada por el principio viril simbolizado entonces por la reja-falo, asimilando el surco a la mujer y la labranza al acto generador. Los aborígenes australianos practicaban un curiosísimo ritual de fecundación que nos indica lo extendido de estas creencias. Armados de flechas que llevaban a la manera del falo, los hombres danzaban alrededor de una fosa semejante al sexo femenino para, al terminar la danza, plantar estacas en su interior.

Todas estas creencias, que son secuela de la invención de la agricultura, se fueron articulando progresivamente al correr del tiempo. En ellas la tierra comenzó siendo feminizada y la mujer-madre, asimilada a ella, terminó por ser sacralizada, apareciendo así formas de una clara religiosidad en las que el primer dios posiblemente fue mujer. 
Hacia el octavo milenio, los habitantes de Asia Menor, en numerosos emplazamientos, empezaron a fabricar figuritas de piedra o de arcilla que representaban casi en su totalidad a mujeres de caderas muy anchas. Estas representaciones empezaron a extenderse a otros lugares de Oriente Medio. Las figurillas se habían perfeccionado considerablemente aunque tendían a hacerse cada vez más simbólicas y menos parecidas a las formas humanas, exagerando la cabeza, las caderas y los muslos, modelados con gran exuberancia.

Pero son las figuras de Catal Hoyuk, en Turquía, aunque datan de época posterior, las que han dado pie a hablar del nacimiento de la religión. En la aldea de Catal Hoyuk, el yacimiento más importante del período, se han excavado edificios considerados templos en función de su tamaño y por las representaciones descubiertas en su interior: estatuillas, estatuas y pinturas (Díez de Velasco, 1998). Se ha descubierto, pintada a un tamaño enorme, la figura de un gran toro con multitud de hombrecillos a su alrededor. Esa figura, reproducida a escala gigante respecto a las representaciones humanas, ha sido interpretada como la imagen de un ser sobrenatural y temible, cuyo hieratismo nos hablaría de su tremendo poder. Junto a ella, esos hombrecillos diminutos vendrían a subrayar a través de la escala jerárquica la distancia que separaba al hombre de la deidad. También, una de las estatuas encontradas representa a una mujer enorme y obesa. La imagen, que muy bien pudiera ser la de una diosa, aparece dando a luz, sentada sobre panteras, y unos cuernos parecen salir de ella.

De ser cierta, esa hipótesis señalaría un importante acontecimiento, pues estaríamos ante la aparición de la primera manifestación material de la conciencia religiosa en una cultura que está en los orígenes de la nuestra. Por primera vez, quedaría claramente reflejado cómo el hombre había elaborado unas creencias a las que él mismo se vería sometido de modo sumiso, colocándose humildemente ante su fantasía para reverenciarla. A partir de aquel momento la distancia entre ese ser desvalido y el producto de su imaginación no haría sino agrandarse hasta colocar a esas fuerzas superiores en un plano totalmente inalcanzable e ininteligible; dándose la paradoja de que el ser humano habría comenzado a prosternarse ante sus propias representaciones mentales en el momento en que dejaba atrás miles de años de tremenda dependencia material. 


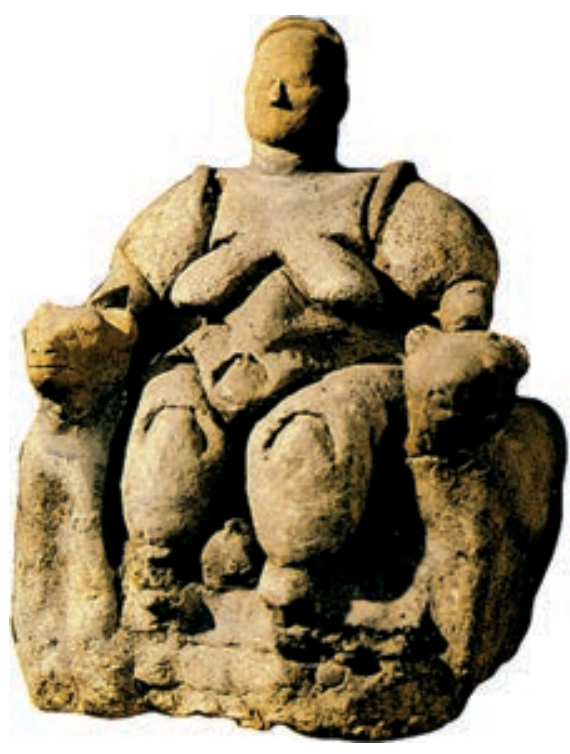

Una de las estatuas encontradas en Catal Hoyuk (Turquía) representa a una mujer enorme y obesa. La imagen, que muy bien pudiera ser la de una diosa, aparece dando a luz sentada sobre panteras. Estos hallazgos han dado pie a los expertos para hablar de la primera manifestación material de la conciencia religiosa en una cultura que está en los orígenes de la nuestra.

$\mathrm{Al}$ menos una de esas deidades, la que representa a una mujer, ha querido ser identificada con la «gran diosa-madre» y el toro como su correlato masculino, presidiendo ambos un culto a la fertilidad y la regeneración. Estas imágenes tan expresivas pueden compararse con otras geográficamente próximas. Aunque la idea de una creencia matriz en una deidad materno-femenina, de la que nos darían noticia las mitologías de Mesopotamia y Grecia, denominada diosa-madre, con una advocación claramente nutricia, se remonta al mundo antiguo. ${ }^{4}$

4 Para algunos historiadores de las religiones (James, 1973) ese culto bajo distintas formas y símbolos sería una continuación del rendido durante el Paleolítico Superior a las «venus» esteatopígicas. La diosa-madre sería señora de la fecundidad y protectora de los muertos y se la habría reverenciado desde Mohenjo-Daro, en el valle del Indo, hasta el Egeo, donde conformó el sustrato de las creencias minoicomicénicas, que están en la base de la religión griega.

Apuleyo a comienzos de nuestra era, ya dice que la diosa-madre había recibido culto bajo distintos nombres en muchas culturas ribereñas del Mediterráneo, pero en todos los casos era la misma divinidad: «Los frigios, primeros habitantes del orbe, me llamaron Diosa de Pessinonte y madre de los Dioses; soy Minerva Cecropia para los atenienses autóctonos; Venus Pafia para los isleños de Chipre; Diana Dictymna 
De lo dicho hasta ahora se desprende que la tierra fue considerada por los primeros agricultores como madre e identificada con la mujer, es decir, ambas engendraban formas vivas sacándolas de su propia sustancia. La tierra estaba «viva» en primer lugar porque era fértil, como la mujer, que era, lo que era, por lo mismo. Todo lo que salía de la tierra estaba dotado de vida y todo lo que regresaba a ella era provisto nuevamente de fuerza vital. La gran diosa-madre invertiría el sentido de la expresión: el hombre es tierra porque es mortal, ya que si el hombre existe es porque proviene de la tierra, porque nació de ella y porque a la terra mater ha de regresar.

La difusión de la religiosidad agraria tuvo como resultado que, al menos, en una fase inicial la mujer alcanzó, a pesar de lo que expondremos más adelante, un alto grado de consideración. Así, el impulso religioso primitivo continuó con la tradición mágico-ritual de época anterior y su finalidad primordial siguió siendo la conservación y el fomento de la vida, de forma que el Bien en estas sociedades agrarias se seguirá identificando con el alimento y la fertilidad, mientras que el hambre y la esterilidad encarnarán el Mal. En este sentido la identificación de lo femenino y de la mujer con lo bueno y lo positivo era más clara que su asimilación al Mal y, en

para los saeteros de Creta; Proserpina Estigia para los sicilianos trilingües; Ceres Actea para la antigua Eleusis; para unos soy Juno, para otros Bellona, para los de más allá Rhamnusia [...] los egipcios poderosos por su antigua sabiduría me honran con un culto propio y me conocen por mi verdadero nombre: soy la reina Isis» (Metamorfosis XI, 2-4).

Esta tesis ha sido muy discutida y, mientras que la profesora Gimbutas (1991) defiende ardientemente que ese culto se dio asociado a un primitivo matriarcado, otros autores (Filoramo, 2000) sostienen que no hay una base sólida que pueda avalar de modo irrefutable la existencia de esa diosa-madre, a la que califican de «mito científico».

Más allá de esta discusión, la antropología nos proporciona algunos ejemplos en los que la creencia en esa figura está entronizada en más de una cultura. Por ejemplo, los indios chamacoco, de América del Sur, colocan en la cumbre de su jerarquía celeste a la diosa Eschetewuarha, que siendo mujer del gran Espíritu le dominaba y reinaba sobre el mundo. Para los chipibo del Ucayali, el mundo era también obra de una mujer celeste. En Australia, los Djanggawul, de la Tierra de Arnhem, rinden culto a la Gran Madre, diosa de la fertilidad y, por último, en una latitud totalmente distinta, y para no prodigarnos en la enumeración, nos encontramos con Sedna la gran diosa del mar entre los esquimales que, a pesar de su aspecto terrible, obra con prudencia y reina sobre la parte más importante del universo habiendo surgido de sus dedos amputados todos los mamíferos marinos. 
algunos casos, como entre los mandanes, la mujer será la única que tenga el poder de conjurarlo cuando el Mal haga su aparición.

Los indios mandanes eran a finales del siglo XVIII, cuando el hombre blanco entró en contacto con ellos, un pueblo no muy numeroso del centro de las Grandes Llanuras de Norteamérica. De lengua siouan, estaban establecidos a las orillas del río Missouri, en una estrecha franja de territorio, en el corazón de la gran nación Sioux. La base de subsistencia de la cultura mandanesa eran la horticultura intensiva basada en el maíz, aunque también cazaban el búfalo y mantenían una intensa actividad comercial con las otras tribus de la pradera, intercambiando los excedentes de maíz y hermosos vestidos de piel por otros productos.

De todos modos, su existencia era precaria; lo atestigua el que sus asentamientos, que eran fijos, estaban fortificados para defenderse de las incursiones de los pueblos nómadas vecinos. El cultivo del maíz en una zona semidesértica era siempre incierto y la introducción del rifle y el caballo había hecho entrar en crisis las formas tradicionales de caza.

$\mathrm{Su}$ organización social estaba basada en clanes matrilineales estructurados de tal modo que una parte de la población pertenecía a los clanes del Cielo mientras que la otra mitad formaban los de la Tierra, una clara simbolización de la doble naturaleza de sus formas de subsistencia. En su mundo de creencias la gente de la Tierra, denominada también la gente del Maíz, habría vivido en tiempos míticos debajo de la tierra, pero habría salido de ella por un agujero llevando la preciosa planta. En este grupo los medicine-men poseían el secreto de las técnicas rituales del cultivo, y sus miembros atesoraban hatillos con las «medicinas» del maíz que permitían el crecimiento de la cosecha. Estos hatillos y los poderes correspondientes eran heredados por el hijo de la hermana del chamán dentro de cada clan. La gente del Cielo (Los de Arriba) se agrupaban en seis clanes, cuyos nombres hacían referencia a animales. También tenían hatillos de «medicinas» y la piel del búfalo desempeñaba un destacado papel en su ceremonial.

Este pueblo llamó poderosamente la atención de viajeros y exploradores durante el siglo XIX por la práctica de un bárbaro ritual 
iniciático denominado okipa. El okipa, como todo ritual, respondía a un ciclo mítico que estaba en la base de las creencias de la cultura mandanesa. El mito refería que en los orígenes del mundo Hombre Solitario, un héroe fundador, vagaba sobre la tierra hasta que se encontró con Coyote, el Primer Creador. Discutieron sobre sus respectivas edades y Coyote ganó, tras lo cual decidieron arreglar la tierra, dejándola como hoy la vemos. Después se separaron siguiendo cada uno su camino.

Hombre Solitario encontró al primer búfalo, de quien recibió el tabaco, la hierba sagrada, que era otro cultivo mandanés, tras lo cual, y harto de su soledad, decidió crear a un hombre y a una mujer con sus propias costillas. Los humanos se multiplicaron reconociendo en Hombre Solitario a su protector, pero le pedían tan a menudo consejo que éste dijo que les enviaría al viento del Sur en vez de aparecer él mismo cada vez que necesitaran ayuda.

Un día Hombre Solitario regresó, y decidió volver a nacer para vivir entre los mandanes. Escogió a una virgen como madre, aunque no consiguió penetrar en su matriz en forma de grano de maíz. Entonces se convirtió en la grasa del riñón de un búfalo, que fue comido por la muchacha, que quedó así embarazada. De ese modo Hombre Solitario se convirtió en el Espíritu del Búfalo.

Otro hombre espíritu, que había nacido de una virgen en otro poblado, era Hoita, el Águila Manchada que se convirtió en un rival de Hombre Solitario. Hoita encerró a todos los animales y pájaros vivientes en Dog Den Butte, que se encuentra al este del río Missouri y los mandanes estuvieron a punto de perecer de hambre, pero Hombre Solitario penetró en la cueva gracias a diversas estratagemas y aprendió la Danza del Búfalo u okipa, gracias a lo cual Hoita liberó al búfalo y dijo que a partir de entonces colaboraría con Hombre Solitario por el bien del pueblo.

Tras otros episodios en el relato aparece Oxinhede, nacido también de una virgen preñada por una sombra. La criatura era un ser negro y superactivo, con el que nadie podía hacer nada. Estaba siempre corriendo y saltando por todos lados, y cuando fue algo mayor, al hacerse con un arco y unas flechas, mató a las serpientes sagradas e hizo otras muchas cosas que molestaban continuamente 
a los espíritus, por lo que se le llamó el Malo. Los Espíritus de las Cosas Sagradas decidieron que debía morir y lo mataron. ${ }^{5}$

Sobre este relato se organizaba el ritual okipa que duraba cinco días y era una ceremonia de iniciación, pero sobre todo un rito generatriz que aseguraba las fuentes de subsistencia del pueblo mandanés. Cada verano y en cada poblado se repetía el okipa. Un hombre perteneciente a una familia rica hacía de director de la ceremonia, junto a él los papeles principales eran desempeñados por las personificaciones de Hombre Solitario, Hoita y el Malo. Los propietarios de los paquetes de medicinas correspondientes actuaban como Búfalos, Castores y otros animales. Dos chamanes enmascarados actuaban practicando las heridas rituales a los jóvenes que iban a ser iniciados, mientras que los principales propietarios de paquetes medicinales pintaban a los actores. Buena parte de la ceremonia se desarrollaba en una enorme tienda preparada al efecto, en ella se reunían en la primera mañana del okipa los jefes y brujos para recibir a Hombre Solitario, que aparecía procedente del Sur.

Hombre Solitario penetraba en la tienda y tras contar su vida a los allí reunidos caminaba por el pueblo durante todo el día, recogiendo los cuchillos de hueso para practicar el ritual; a cambio daba carne de búfalo, y las mujeres, los niños y los perros debían permanecer ocultos. Al anochecer se retiraba a la tienda del okipa, donde esperaba a los iniciados que acudían a ella para comenzar un ayuno preparatorio, mientras Hombre Solitario comía carne de búfalo. Una vez terminada la comida ritual, Hombre Solitario, tras pedir a Hoita que supervisara la Danza del Búfalo, salía de la tienda para regresar al Sur, mientras el baile comenzaba repitiendo el acto mítico realizado en Dog Den Butte.

Durante el segundo día, los ocho bailarines Búfalo salían ocho veces de la tienda para danzar en la plaza, mientras el director del okipa pedía a Hombre Solitario, en medio de grandes lamentos, que ayudara al pueblo. A lo largo de la jornada los jóvenes iniciados eran

5 Oxinhede pertenece a esa categoría de seres sobrenaturales que los antropólogos (Radin, 1960) han denominado trickster, cuyas bromas pesadas provocan la risa o la indignación, pero que en definitiva con su irreverencia simbolizan el Mal que debe ser controlado. 
pintados y preparados cuidadosamente para el rito que se iba a realizar al día siguiente, cubriéndoles los genitales con barro. En el tercer día, que se denominaba «día en que todo vuelve», todas las criaturas que habitaban la tierra, junto con Hombre Solitario, que reaparecía, y Hoita, salían de la tienda para danzar junto con los bailarines Búfalo. Durante este tiempo, en la tienda, los iniciados sufrían una bárbara operación. Hombres de sus clanes paternos con cuchillos de piedra abrían cuatro agujeros en los omóplatos o en el pecho, y deslizaban dos trozos de madera por debajo de la piel, a los que ataban unas correas.

En el cuarto día, y mientras continuaba la danza en el poblado, aparecía una figura loca, que llegaba corriendo en zigzag desde el Oeste, a través de la pradera. Se introducía entre los espectadores mientras las mujeres y los niños chillaban alarmados. Se trataba del Malo, su cuerpo pintado de negro, con círculos blancos, mostraba un falo grotesco. Saltaba sobre los objetos sagrados y parodiaba a un búfalo macho copulando con un hombre disfrazado de mujer. Entonces el director del okipa paralizaba al Malo, mientras la danza continuaba, repitiéndose este episodio hasta tres veces, pero el Malo siempre se recuperaba y volvía a aterrorizar a las mujeres con su obsceno baile sacrílego, pero entonces una mujer le arrojaba ocre amarillo a la cara, mientras las otras le atacaban por todos lados, y la líder de las mujeres le arrebataba su falo burlesco. El Malo se derrumbaba, lloriqueaba y se lanzaba hacia la pradera, seguido por las mujeres que lo abucheaban y le arrojaban estiércol de búfalo.

La mujer que le había arrebatado el miembro ortopédico subía hasta la entrada de la tienda del okipa y tomaba el mando. En un largo recitado hacía saber que ella tenía el poder de la creación, el poder de la vida y la muerte del pueblo, y todo el control sobre los búfalos que vendrían o se alejarían siguiendo sus órdenes. Fuera ya de la tienda, la mujer ordenaba el cese del baile y llamaba a los jefes para presenciar el rito iniciático de los jóvenes. La ceremonia, que continuaba en el interior, consistía en levantar a cada hombre, por medio de las correas de cuero atadas a las maderas del pecho o los omóplatos, que quedaba suspendido del techo de la tienda, mientras se hacia girar vertiginosamente su cuerpo, en medio de los chillidos de los espectadores que gritaban «iMuerto! ¡Muerto!», hasta que per- 
día el sentido. Una vez bajados, los iniciados quedaban tendidos sobre el suelo. Al recobrar el conocimiento se dirigían hacia un cráneo de búfalo para que se les amputara su dedo meñique.

La quinta noche, y una vez terminada la ordalía, varios hombres ancianos deambulaban por el pueblo anunciando que todo el gobierno de los mandanes estaba en manos de una mujer, la que había desarmado al Espíritu Malo, a la que debían pedir, durante el próximo año, los búfalos que les proporcionarían alimento. Los bailarines Búfalo y los brujos eran invitados por la mujer a una Fiesta del Búfalo. Diez mujeres jóvenes la acompañaban mientras que el resto del poblado debía permanecer en sus tiendas. Una a una, las mujeres conducían a los hombres a la pradera para aparearse como búfalos, hasta que cada hombre compraba su libertad a cambio de un pago reducido. ¿Qué significaba todo este ritual con una fuerte carga sadomasoquista?

Los mandanes basaban su subsistencia en la caza del búfalo y la horticultura intensiva. Su estructura social era matrilineal y creían que los hombres nacían sin aptitudes personales. Las capacidades derivaban únicamente de los objetos sagrados contenidos en los paquetes medicinales, pero los paquetes eran heredados dentro del clan materno o adquiridos con ayuda de los compañeros del clan de la esposa. Esto convertía a las mujeres en generadoras de la vida y en la única fuente simbólica de la que los hombres podían obtener su poder.

El masoquismo del ritual okipa nos indica la escasa autoestima que poseía el varón en la sociedad mandanesa. Los iniciados, que eran desexualizados simbólicamente, al cubrirles los genitales con barro, y colgados en el limbo, entre el cielo y la tierra, se sometían a la tortura y la «muerte» como varones inmaduros, para regresar a la tienda de la madre o la esposa convertidos en varones adultos que comprendían y admitían las cosas tal como eran. Eso suponía reconocer que los mandanes eran un pueblo en el que los hombres constituían una parte subordinada al principio femenino que era el centro del poder. La caza del búfalo era importante para la supervivencia de la comunidad, pero se admitía que la hembra del búfalo era el factor principal en la reproducción en los rebaños. 
En toda la ceremonia, el Malo encarnaba el principio masculino sin freno, que podía acarrear numerosos males, y que sólo podía ser vencido por la mujer, la única que, al arrojarle ocre amarillo a la cara simbolizando la harina del maíz, podía conjurar el mal. Y es que la horticultura marcaba de una manera única en las praderas septentrionales el carácter de los mandanes, ya que cualquiera podía cazar búfalos, pero sólo un pueblo muy especial era capaz de cultivar el maíz, y el maíz lo cultivaban las mujeres. Esto debían aprenderlo y aceptarlo todos los varones que se quisieran convertir en hombres. Éste era el mensaje del okipa (Hoebel y Weaver, 1985; Gugel, 2000).

Pero las relaciones de producción y de poder entre los sexos que se daban en los mandanes no fueron idénticas en todas las sociedades agrícolas protohistóricas, ni siquiera en muchas de las de cazadores recolectores que ahora conocemos. El poder patriarcal basado en el monopolio de la violencia se asentaba de modo casi universal mientras que la civilización se desarrollaba, y el Mal, cada vez con una entidad más corpórea, no podía ser conjurado por la mujer, que pasaba a representarlo, de un modo u otro, en los relatos míticos o las prácticas rituales de muchos de esos pueblos, mostrándonos así la otra cara de Eva.

\section{La otra cara de Eva}

Lo dicho en el apartado anterior no debe inducirnos a engaño, ya que con el desarrollo del mundo agrícola comenzó para la mujer una etapa muy dura que culminó con su definitivo sometimiento. Debemos tener presente que en este momento de cambio cultural es cuando se consolidan los fundamentos de la dominación patriarcal, tal y como nos recuerda Lerner. ${ }^{6}$

6 «En algún momento durante la revolución agrícola, unas sociedades relativamente igualitarias, con una división sexual del trabajo basada en las necesidades biológicas, dieron paso a unas sociedades muchísimo más estructuradas en las que tanto la propiedad privada como el intercambio de mujeres basado en el tabú del incesto y la exogamia eran comunes. Las primeras sociedades fueron a menudo matrilineales y matrilocales, mientras que las últimas sociedades sobrevivientes eran predominantemente patrilineales y patrilocales. No existen en ningún lugar pruebas de un 


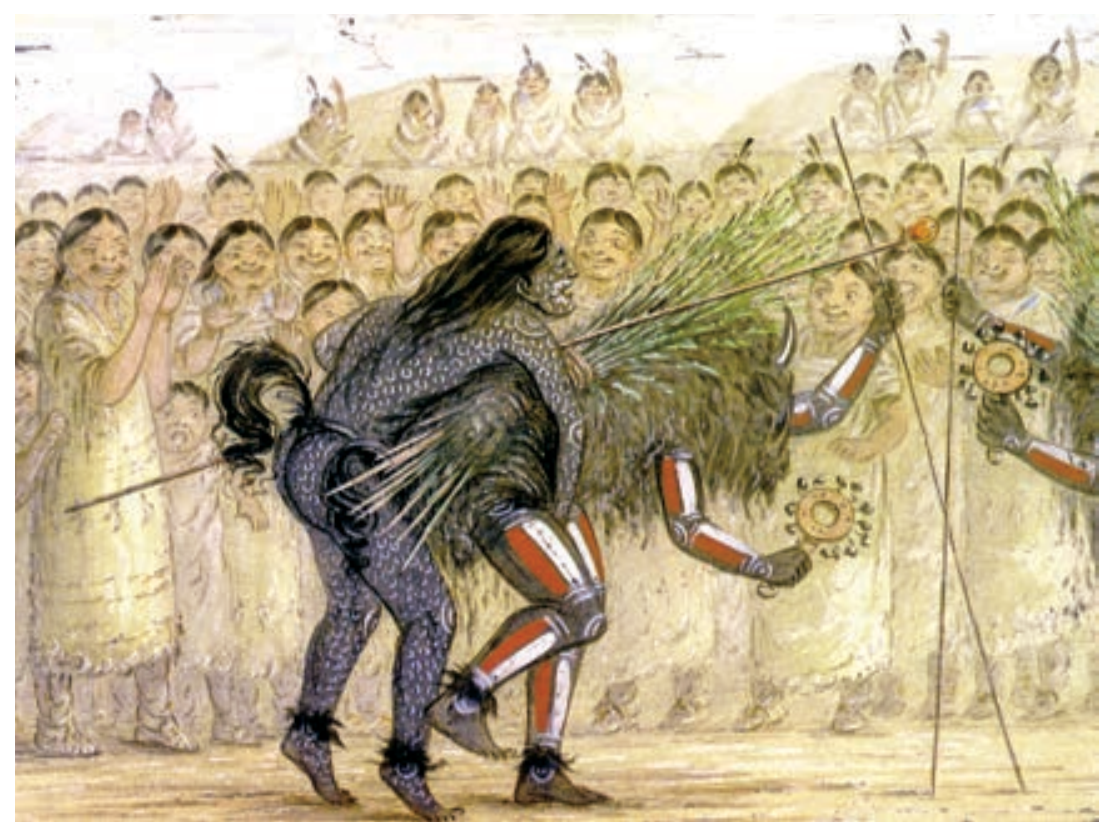

En la ceremonia Okipa, realizada por los mandaneses hasta finales del siglo XIX, el Malo, representado por un personaje pintado de negro, encarnaba el principio masculino sin freno, causante de numerosos males y que sólo podía ser vencido por la mujer, tenida en la más alta consideración por esta cultura indígena.

Es cierto que la mujer aportará, durante este largo período neolítico, más que el hombre en lo relativo a la subsistencia y sobre todo garantizará una cierta estabilidad en la nueva forma de vida. Los recursos del mundo vegetal superan a los del mundo animal e introducen un nuevo tipo de regularidad en la vida de la comunidad. Pero también es verdad que las nuevas actividades económicas complejizarán mucho más las relaciones sociales y que los lazos de dependencia y sometimiento entre los humanos irán parejos a su sumisión ante los seres sobrenaturales que han comenzado a idear.

proceso contrario, que pase de la patrilinealidad a la matrilinealidad. Las sociedades más complejas presentaban una división del trabajo que ya no sólo se basaba en las diferencias biológicas, sino también en las jerárquicas y en el poder de algunos hombres sobre otros hombres y todas las mujeres» (Lerner, 1990: 89). 
En este mecanismo de sometimiento la mujer quedará cada vez más ligada a su función de productora; productora de hijos y productora de granos para alimentarlos, y ese hecho que supuso su valoración en abstracto como vínculo regenerador será también su perdición.

Su trabajo pronto se transformará en servidumbre y su especialización le impedirá acceder a otras formas de poder que no sean las meramente simbólicas. La mujer corriente quedará desvinculada de la creación superestructural de la fertilidad divinizada y sólo su capacidad reproductora y su sexo serán venerados, mientras que ella se verá reducida a tirar del arado y a cumplir con un complejo ritual para hacer viable la cosecha.

Pero no fue sólo la sumisión a la gleba la que esclavizó a la mujer, otros factores contribuyeron a ello. La sedentarización y la agricultura supusieron un crecimiento de la población y una mayor división del trabajo, que se vieron acelerados en algunas zonas del planeta, a partir del momento en que se desarrolla una agricultura de regadío gracias al control del agua en las proximidades de los grandes cursos fluviales. Este hecho aumentó considerablemente el excedente alimenticio, facilitó el salto de la aldea a la ciudad y completó una primera división social, productiva y de poder.

Entre las sociedades agrícolas la defensa del ganado y las cosechas, así como la apropiación de los excedentes de otras comunidades, sería un hecho frecuente, sobre todo conforme fuera aumentando la población y se produjera una cierta presión demográfica que obligará a establecer una competencia por los recursos. En esos enfrentamientos entre poblados estables encontramos los orígenes de la guerra. ${ }^{7}$

7 No podemos considerar guerra a la lucha circunstancial de dos grupos de homínidos en disputa por una charca, ni a los enfrentamientos ritualizados llamados «rotana» que practica anualmente el pueblo africano de los ban-bala en los cuales, tras desbrozar una amplia zona de terreno, se enfrentan dos bandos armados con arcos con la finalidad de disparar flechas, insultarse y realizar todo tipo de maniobras hasta cansarse.

La guerra es una forma de violencia colectiva intraespecífica en la que priman los intereses grupales sobre los individuales. En ella los grupos comprometidos pueden tener, dependiendo de circunstancias culturales o históricas, dimensiones 
La guerra contribuyó de modo poderoso a profundizar aún más la división de funciones entre los sexos y a fundamentar las nuevas formas de poder en la violencia. Podemos apreciar cómo en las primeras culturas urbanas no sólo estaban claramente divididas las tareas, sino que la violencia estaba también estructurada, en el interior de la comunidad y frente a otros grupos, haciendo su aparición el guerrero profesional, apartado de la consecución directa del alimento. El poder, basado en ese control de la violencia, la monopolizaba y la administraba dentro del colectivo por medio de la ley, primero consuetudinaria y luego escrita. Ya no eran sólo las mujeres las segregadas de las prácticas violentas, un buen número de hombres también quedaron relegados de las mismas, y con ello de la dirección de la comunidad.

La vieja tesis de Poulain de la Barre parece llena de sentido. La mujer, socialmente necesaria para mantener la vida, ya que de su fecundidad dependía que el grupo fuera fuerte frente a los otros, resultaba también imprescindible por el trabajo que desempeñaba, que proveía de recursos al poblado. Estas dos razones sumadas a una, ya larga, tradición de apartamiento de las armas la inhabilitaba para la lucha organizada. Aislada en una fase remota de la partida cazadora y ahora de la actividad guerrera, la mujer podía ser la costilla de Adán, pero no la quijada con la que matar al odiado Abel.

variables. En las culturas primitivas unas docenas de guerreros podían ser el equivalente a un ejército moderno.

Esa violencia se ejerce de un modo premeditado, implica una cierta organización y presupone enfrentamiento armado, así como una cierta duración en el tiempo. Los objetivos perseguidos pueden ser muy variados pero guardan una estrecha relación con los intereses del grupo, o al menos de un cierto sector preponderante en el mismo, y están sujetos a factores culturales e históricos (Bouthoul, 1971).

Los primeros testimonios materiales de este tipo de enfrentamientos se localizan en el Mesolítico. En un enterramiento localizado en Wadi Halfa, cerca de Sudán, se han detectado veinticuatro muertes violentas y simultáneas sobre cincuenta y ocho cadáveres hallados, algunos de los cuales conservan incrustados en sus huesos las armas de las que fueron víctimas; también, en las pinturas levantinas vemos imágenes de arqueros que se disparan entre sí, sin que podamos precisar el sentido de la escena. Las impresionantes murallas de la ciudad de Jericó, ya en fase neolítica, puede que sean, por el momento, los primeros vestigios materiales e indiscutibles de que en aquel período se mantenían enfrentamientos prolongados y planificados que encajarían perfectamente con la definición que hemos dado de guerra. 
Esta hipótesis sobre la afirmación del poder patriarcal basado en el papel que desempeña la violencia en las organizaciones sociales primitivas ha sido recientemente rescatada desde un enfoque antropológico por Reeves Sanday (1986) que, tras estudiar este aspecto en ciento cincuenta culturas, plantea cómo en las más antiguas sociedades humanas las mujeres y los hombres habrían conocido una etapa de relativa igualdad. Pero cuando, por el incremento de sus miembros, la escasez de recursos o las migraciones forzosas, la guerra de saqueo contra otros grupos se convirtió en el único medio de supervivencia y los enfrentamientos se multiplicaron, aumentó la tendencia a someter a las mujeres.

Así pues, se apuntarían como causas materiales de la dominación de la mujer su estrecha ligazón con las tareas agrícolas y el papel simbólico que en ellas se le había atribuido, que operó en un doble sentido, de modo despersonalizado sacralizando la feminidad de la tierra y de modo concreto, adjudicándole la vital tarea del cultivo, a la que debía sumar la crianza de la prole. Por otro lado, su desvinculación del poder fáctico, basado en la violencia, la convertía en débil y despreciable para el guerrero.

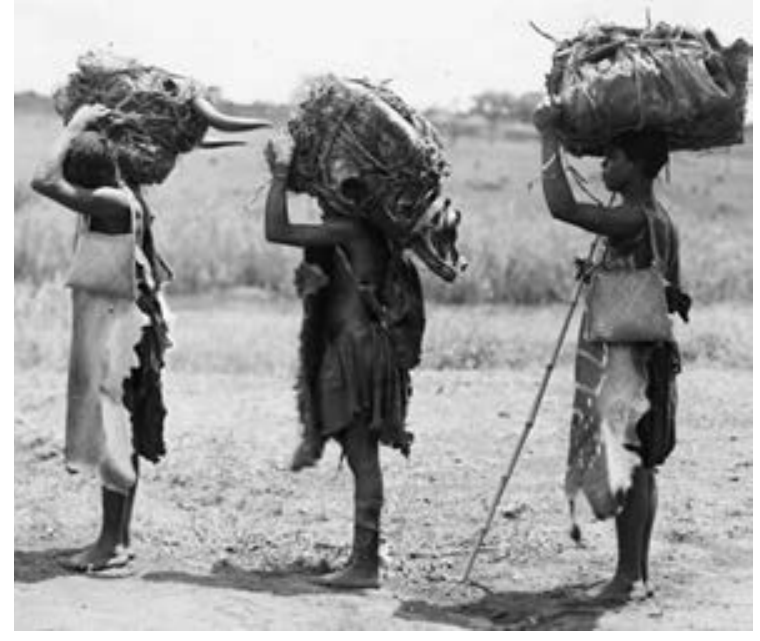

El sometimiento de la mujer está vinculado a su función productora: de hijos y de granos para alimentarlos. Su trabajo pronto se transformará en servidumbre y su especialización le impedirá acceder a otras formas de poder que no sean las meramente simbólicas. 
En este proceso, el patriarcado tendió a justificar y racionalizar la subordinación femenina elaborando una representación de la mujer como un ser inquietante a la par que débil, al que era necesario controlar y tutelar. Así aparecieron los tabúes sexuales destinados principalmente a proteger a los hombres de la «contaminación» de esa fuerza extraña que sólo las mujeres poseían. Por otra parte, sus debilidades y temores y su entrega al cuidado de los niños las presentaban también como especialmente vulnerables.

De esa visión masculina se derivaba un desprecio que se traducía en la atribución genérica a la mujer de una serie de defectos y faltas que, de no ser controlados, podían causar graves daños a la comunidad. Ese control debía estar en manos de los padres, hermanos o maridos, ellos eran responsables de esos seres disminuidos a la par que misteriosos.

En muchos de esos mitos y creencias que han llegado hasta nosotros podemos rastrear ese papel atribuido a la mujer. En ellos se nos cuenta cómo apareció el hombre sobre la tierra, o como se hizo con los principales medios de subsistencia, pero también se nos revelan sus temores y sus miedos a las catástrofes, sufridas en época inmemorial, o a la muerte, que de repente hizo su aparición en el mundo para afligirnos de modo inexorable. En definitiva, para contarnos a través de esos relatos sagrados que el Mal existe junto al Bien y para explicarnos por qué. En esas historias vemos a la mujer acercarse al mal, ella con sus debilidades y con sus impurezas acarrea la desgracia, sirve de vehículo a la maldad o incluso llega a encarnarla.

El tabú, esa prohibición ritual sin aparente fundamento racional, que ya menciona James Cook a finales del siglo XVIII como una creencia polinesia, y que más tarde se ha podido comprobar forma parte constitutiva del mundo de valores en muchos pueblos primitivos, se manifiesta de dos formas distintas; la prohibición ante lo sagrado, que inspira un temor reverente, marcando la distancia que separa al ser humano de lo sobrenatural, y el tabú ante lo impuro, que entraña una clara prevención ante el Mal. La trasgresión, en cualquiera de los dos casos acarrearía la desgracia a quien se atreviera a violarlo, para él y para su grupo. Sin embargo, en el segundo supuesto, la prohibi- 
ción implica el tabú ante lo inmundo, en el doble sentido que tiene este término en nuestro idioma, como algo que está fuera de este mundo pero que a su vez es corrupto, malo en definitiva.

Muchos de los tabúes que afectan a las mujeres en esas comunidades responden a ese significado y guardan estrecha relación con su actividad sexual o reproductora y con las implicaciones simbólicas con las que se las había connotado. El tabú femenino está en la base del rechazo discriminatorio a la mujer que, por su naturaleza 0 su comportamiento sexual, puede traer el Mal. Así en Uganda, una mujer estéril es considerada como peligrosa para el jardín y su marido puede pedir el divorcio invocando este solo motivo.

Pero no es sólo la esterilidad — que podría resultar incluso comprensible si tenemos en cuenta la asociación establecida entre la mujer y el éxito de las cosechas- lo que genera inquietud. Todo lo relativo a la reproducción, como algo misterioso, causa pavor y sirve de pretexto para multiplicar los tabúes prohibitivos con el fin de controlar esas fuerzas.

La menstruación se asocia con la impureza porque se considera un acto fallido de esa fuerza y la mujer menstruante puede contaminar aquello que toque o su sola presencia en un lugar, como los campos de cultivo, puede poner en peligro el resultado de la cosecha. Aunque es cierto que no todas las culturas conciben del mismo modo esta relación entre flujo menstrual y esterilidad. Entre los fineses, las mujeres eran las encargadas de llevar a los campos la semillas en la camisa menstrual. Pero los tabúes sobre la menstruación concebida como algo poluto sirven sobre todo para marcar las diferencias sexuales impidiendo que el hombre se «contamine» de la naturaleza de la mujer y cumplen la función de subrayar una clara división sexual en la que se basa la vida de estas comunidades. Las aborígenes australianas en sus "períodos» tenían prohibido bajo pena de muerte tocar los objetos de uso de los hombres y ni aun caminar por los senderos que ellos frecuentaran. Entre los dene africanos difícilmente se encontraba un ser que produjera tanto miedo como una mujer menstruante, su sola visión constituía un peligro y debía llevar una indumentaria especial que la distinguiera y le cubriera la cara. 
El puerperio también dio pie a similares restricciones. Las razones de esta maculación las debemos buscar en que el acto del nacimiento se veía como sagrado. En él lo sobrenatural actuaba permitiendo aflorar la vida, pero en ese hecho, el contacto entre esas fuerzas misteriosas y lo humano entrañaba un peligro del que se podían derivar males sin cuento. Así, en Tahití, las mujeres tras dar a luz quedaban recogidas en unas chozas especialmente construidas en un lugar sagrado hasta haber superado una cuarentena establecida, y les quedaba prohibido tocar directamente cualquier clase de alimento, debiendo dárselo en la boca las otras mujeres del poblado. En la isla de Kadiak, en Alaska, las parturientas se retiraban del poblado cuando veían acercarse el momento del parto. Ellas mismas se construían una cabaña donde daban a luz y en la que permanecían una serie de días hasta que se consideraba que el peligro que dimanaba ese hecho misterioso había pasado.

Mayor inquietud que la menstruación o el puerperio producía el aborto. Considerado como un fracaso al traer la vida, el miedo que inspiraba era terrible porque indicaba que algo ha salido mal en ese proceso misterioso y vital. No puede extrañarnos, por tanto, que ante el aborto los tabúes fueran los más estrictos y sus violaciones las más terribles. Frazer (1974: 252) nos narra cómo era vivido un aborto entre los bantúes africanos para los que el hecho suponía un mal colectivo:

La sangre de un parto aparece a los ojos de los sudafricanos como inficionada de una corrupción todavía más peligrosa que el líquido menstrual. El marido es excluido de la choza durante los ocho días del sobreparto, principalmente como precaución para evitar que se contamine con las secreciones. No se atreverá el marido a tener su hijito en brazos durante los tres primeros meses de lactancia. Cuando los loquios son particularmente terribles es en el producto de un aborto, en especial el que se ha ocultado. En este caso, no es solamente el hombre el amenazado o muerto, es el país entero, es el mismo cielo el que sufre. Por una curiosa asociación de ideas, un hecho fisiológico causa trastornos cósmicos.

La esterilidad, el puerperio, la menstruación, el aborto, no sólo eran estos aspectos propios de la naturaleza reproductora de la mujer los que suscitaban el tabú, también su conducta, sobre todo 
sexual, podía infligir numerosos males a los hombres. La mujer se vio sometida a una más estrecha vigilancia por parte de los varones directamente vinculados a ella por lazos de sangre. Al hacerse patentes los mecanismos de la reproducción humana y perfilarse una división social en torno a la apropiación de los excedentes de la comunidad, el interés por delimitar la paternidad se convirtió en una de las principales preocupaciones en las sociedades patriarcales. Eso se tradujo en una cadena más para la mujer, que perdió la relativa libertad sexual de la que antes pudo gozar.

Los indios moxos de Bolivia creían que si la mujer de un cazador cometía infidelidad en su ausencia, el hombre sería mordido por una serpiente o un jaguar, y cuando ocurría un percance de este tipo se solía matar a la mujer aunque ella negara haber cometido la falta. En otros casos, el mal que acarreaba la mujer era simplemente económico, así los pescadores aleutianos de nutrias marinas pensaban que no podrían matar un solo animal si durante su ausencia su mujer era infiel o impúdica su hermana. Muchas de las tribus indígenas de Sarawak tenían la firme convicción de que si las mujeres cometían adulterio mientras sus maridos buscaban alcanfor en la selva, se evaporaría el que recogieran.

En ocasiones, el tabú perseguía simplemente un control estricto sobre la actividad sexual de la mujer. Los indios huicholes de México, que siguen practicando este rito, cuando parten a la búsqueda del cactos alucinógeno en expediciones que se prolongan durante cuarenta y tres días, obligan a sus mujeres a que, después de su marcha, se reúnan para confesar al Abuelo-fuego con qué hombres se han acostado desde su niñez, sin omitir ninguno, si no lo hacen no se conseguirá un solo cacto. Para refrescar sus recuerdos, preparan cada cual una cuerda con tantos nudos como amantes ha tenido y situándose frente al fuego, van mencionando en voz alta nombre tras nombre. Una vez concluida su confesión, arrojaban la cuerda al fuego.

Pero el control sexual no era todo. Como nos recuerda Frazer (1974: 47), la mujer, convertida en un apéndice mágico del esposo, podía poner en peligro la actividad que éste desarrollara si no respetaba toda una serie de normas que respondían en más de una oca- 
sión a los principios de la magia mimética. Cuando un cazador de elefantes de Laos salía de caza, prevenía a su mujer para que no se cortase el pelo ni se ungiera el cuerpo durante su ausencia, pues si se cortaba el pelo, el elefante rompería los lazos de las trampas y si ella se engrasaba el cuerpo, el animal se zafaría de ellas.

Si de todos estos males podía ser vehículo la mujer, también aparecía como responsable de alguna de las grandes desgracias que afligían a la humanidad. La muerte, aunque generaba enorme conmoción, por lo general no era considerada exactamente como una desgracia, ni siquiera como un mal, sino más bien como un hecho misterioso que provocaba inquietud y debía explicarse de algún modo.

En muchos casos la muerte había hecho acto de presencia en el mundo por un descuido o por una falta que se podía achacar a un personaje mítico, fuera éste humano o animal. Un fallo en la transmisión de alguna orden divina, un olvido, o una desobediencia eran las explicaciones más frecuentes que se daban para justificar por qué los hombres debían morir. Aunque se asumía lo inexorable del hecho, se podía detectar una responsabilidad en el mismo y esa responsabilidad se atribuía a la mujer, que por su carácter débil, irascible o frívolo había precipitado su aparición.

Los indios de la región de Huarochiri, en el Perú, consideraban que cuando moría un hombre su alma volvía al cabo de cinco días. Por razones no explicadas, un alma volvió a su cadáver con un día de retraso. La mujer del muerto, impaciente, le dirigió vivos reproches e incluso le pegó. El alma, ofuscada, se marchó para siempre y desde entonces la muerte se ha hecho irremediable. Los lolos (leles) del Congo occidental cuentan que el dios ofreció a los primeros hombres dos paquetes, uno conteniendo perlas, cuchillos y joyas, y el otro la inmortalidad. Pero las mujeres, coquetas, se precipitaron en seguida sobre el primer paquete, y se perdió el don de la vida eterna. Para los balubas, los primeros hombres eran inmortales; cuando se hacían viejos, cambiaban de piel como las serpientes y volvían a ser jóvenes; pero esa metamorfosis debía hacerse a escondidas: al ser sorprendida una vieja por una vecina curiosa cuando cambiaba de piel, se introdujo la muerte en el mundo. En Melanesia, aunque con diferentes variantes narrativas según las islas, se creía que 
cuando llegaba la vejez, los hombres abandonaban su piel, como las serpientes, y proseguían su vida con una nueva juventud. Esta posibilidad de regeneración se perdió definitivamente el día en que, al regresar a su casa bajo forma de hermosa muchacha, una madre, no logrando hacerse reconocer por sus hijos, entonces se revistió su vieja piel por desesperación y los hombres perdieron la capacidad de resurrección.

En todos estos relatos nos encontramos a una mujer infravalorada y sobre todo claramente estigmatizada por algunos de los defectos genéricos que le atribuirá la ideología patriarcal en todas las latitudes: la coquetería, la irascibilidad, la curiosidad, la vanidad o el despecho. Pero aunque se le achaca algo tan grave como haber propiciado la entrada de la muerte en el mundo, su vinculación con el Mal o con lo impuro queda más claramente establecida en las prescripciones y tabúes a los que se la somete.

Las creencias religiosas que dejan traslucir estas historias son muy sencillas y en casi ninguna de ellas el relato se plantea la existencia de un Mal personificado, sin embargo encontramos algunas curiosas excepciones, así en un mito que ya hemos mencionado, el de Rangi y Papa, compartido por muchos pueblos de la Polinesia, llegamos a descubrir esa encarnación maligna en un ser que es mujer.

Recordemos que de la unión de Papa y de Rangi, Tierra femenina y Cielo masculino, procede la Vida. Nacido de esta pareja primordial el dios Tane se decidió, con arena y arcilla, a crear la primera mujer, Hine, para luego unirse a ella. Al saber un día que su marido era también su padre, Hine, abrumada de vergüenza, huyó al mundo subterráneo, en que llegará a ser reina bajo el nombre de Hine-Nui-Te-Po (Gran Señora de la Noche). Ese primer incesto, del que había surgido la humanidad, introdujo la muerte en el mundo y, desde entonces, Hine-Nui-Te-Po se ensaña atrayendo a los vivos a su reino. ${ }^{8}$

8 Hine-Nui-Te-Po no es el único personaje sobrenatural que encarna la malignidad en estas culturas preliterarias, podríamos citar también a Gamab, nacido de la elaboración mitológica de los damaras, civilización intermedia entre los bosquimanos y los hotentotes con los que comparten estas creencias ligeramente modificadas. Gamab vive en un cielo superior, que está más allá del cielo de las estrellas, mata con 
En este mito, según Levi-Strauss (1949/1993), nos encontraríamos con una clara advertencia sobre ese tabú universal que es el incesto, pero más allá de ese obvio significado podemos ver cómo la personificación del Mal no acaba de serlo. Ni si quiera Oxinhede, el Malo, de la cultura mandanesa lo encarnaría, al menos como lo vamos a encontrar representado en un momento posterior del pensamiento religioso.

El Mal en esa primera fase del desarrollo de la humanidad no existe. Sí que existen los males, y la vivencia frente a ellos es distinta a como acabará por configurarse en época posterior. El animismo predominante, unido a un ingenuo materialismo, no ha sido capaz de engendrar aún conceptos abstractos como la nada. Lo bueno y lo malo, la bondad y la malignidad se mezclan en los seres superiores como en el mismo hombre. Sus luchas, los castigos que infligen, sus venganzas y sus maldades se inscriben en el orden natural de las cosas. ${ }^{9}$

La estructura patriarcal había avanzado en los albores de la historia de la humanidad mucho más que las maneras simbólicas de representar sus propias limitaciones o, lo que es lo mismo, que las maneras de imaginar fantásticamente el origen de sus desgracias. Fue en la representación imaginada de males que afligían a los humanos donde la contradicción de los sexos afloró para atribuir a

sus flechas a los humanos que elige, los cuales, en lugar de quedar en tierra en forma de espectros, pasan entonces por encima del abismo por un camino difícil para subir junto a Gamab. Habitan a su lado, bajo la forma de viejos y viejas, Gamagu o Gamati, a la sombra del Árbol celeste, alimentándose de carne humana (lo que explica que, cuando se entierra un muerto, pronto no queda más que su osamenta en la tumba), sin tener necesidad de cazar para vivir, ni tampoco de engendrar, pues los espíritus de los niños acuden también a la morada celeste para alegrar a los Gamagu y las Gamati. También podríamos mencionar al Iya de la mitología sioux que devora o mutila a los hombres y los animales, adoptando a veces la forma de huracán y cuyo aliento pestilente propaga enfermedades. Todos estos personajes pertenecen más a una ideación monstruológica que a una auténtica personificación del Mal.

9 Entre los githwans de Alaska nos encontramos con una deidad femenina de difícil clasificación, la Mujer-Rana o Mujer-Volcán (llamada también Mujer de los Metales, porque ella ha dado el cobre, mostrándose en eso bienhechora); destruyó el Mundo por el fuego, poniendo fin a un primer universo mítico. ¿Podemos considerarla por esto una divinidad maligna? La ambivalencia de actitudes, benéficas y maléficas, es una constante en estos panteones primitivos. 
la mujer ese papel ambivalente en el que se resumía todo, ella daba la vida y a causa de ella debíamos morir. Aunque en la memoria se guardara un vago recuerdo de cuando las cosas habían sido diferentes.

En la Tierra de Arnhem (Australia), los Djanggawul, posiblemente una de las culturas más primitivas que hemos encontrado, aún conservan en su memoria mítica cómo se produjo ese cambio. Las Hijas del Sol estuvieron en el origen de todas las cosas. Tras haber traído al mundo a una multitud de seres humanos y haberles enseñado lo fundamental, como el trenzado de plantas para hacer cestas, las Hijas del Sol perdieron para siempre sus objetos sagrados, bandejas y cesterías que les fueron arrebatados por la fuerza, por su hermano y sus propios hijos varones. Después de esta pérdida humillante sufrieron la ablación de sus clítoris, y desde entonces quedó establecida irrevocablemente en la humanidad la separación de los sexos, acompañada de una división del trabajo que reservaba al hombre el privilegio de las actividades religiosas. Iban a ser esas actividades, fundamentalmente masculinas, las que terminarían por elaborar una acabada idea del Mal. Así pues, el Mal no se coló en el Paraíso para tentar a Eva y acarrear la perdición a los hombres, fueron éstos los que al expulsar a Eva precipitaron su propia desgracia y dieron vida al Mal. 


\section{IV \\ LA MUJER \\ EN EL PANDEMONIUM ORIENTAL}

Las mil caras del Mal se dibujaron, algunos milenios antes de nuestra era, sobre las tórridas arenas del Oriente Próximo. En las mismas tierras donde se diera la Revolución Neolítica, donde aparecieran las primeras formas de creencias en seres sobrenaturales, donde surgió la aldea, de la que con el tiempo nacería la primera ciudad, se desarrolló una rica civilización en la que podemos encontrar las raíces de buena parte del pensamiento occidental.

Fueron los egipcios y, sobre todo, ese conjunto de pueblos, mezcla de etnias y culturas distintas, denominados mesopotámicos y, por fin, la antigua cultura persa los que terminaron de dar forma tanto al patriarcado, como sistema de explotación y dominio de la mujer, como a la idea de Mal, concebida como concepto cultural, que ha servido para ulteriores reelaboraciones. Las creencias religiosas alimentaron esa idea y aunque la resolución que le dieron a lo largo de cuatro mil años de historia fue diversa, en su variada teorización encontramos lo básico y fundamental de las concepciones sobre el Mal manejadas muchos siglos después. Oriente no sólo armó intelectualmente esa idea sino que le confirió forma física y la dotó de corporeidad. El Mal fue profusamente personificado y sus caras se multiplicaron por tantas desgracias como se pudieran padecer, surgiendo así un panteón de seres maléficos que hoy vemos como un auténtico pandemonium.

Este proceso se enmarcó en otro mucho más ambicioso: el de ordenar una vida colectiva, dándose una explicación de ella en el marco de su entorno natural. En esta aventura, fueron capaces de 
crear instrumentos fundamentales para el desarrollo de la humanidad, como la escritura y tantos otros, pero también animaron instituciones altamente coactivas destinadas a estructurar una sociedad en gestación. Recurrieron para ello a la observación, a la práctica empírica y a la imaginación que alimentó la especulación sobre aquellas realidades difíciles de entender. La dura necesidad de transformar la naturaleza para sobrevivir o las mismas redes de relaciones que iban estableciendo para quedar atrapados en ellas dieron pie a buscar explicación a tanto sufrimiento, previsible o imprevisto. Fue así como concibieron la presencia de fuerzas externas y malignas que les infligían daño y como nació la idea de un Mal sobrenatural y con ella la de los seres que lo causaban.

Toda esta especulación fue transversalmente recorrida por la división social que fracturó la comunidad primitiva, división de sexos y división de clases. A la mujer se le había adjudicado un lugar en esa sociedad dominada ya totalmente por el principio masculino y éste parecía obligado concederle también un papel en ese complejo sistema explicativo, del que el Mal formaba parte. Su vinculación con él guardará relación con las funciones a las que socialmente se la había condenado, aunque también participará del prestigio del que debió de gozar en época anterior.

\section{Una legión de demonios...}

En Mesopotamia y Egipto nacerán las primeras formas de culto organizado con profundas implicaciones en el seno de la sociedad. La religión servirá para vertebrar un poder político-religioso aparecido con el nuevo modo de producción basado en la explotación de la tierra por medio del control de las aguas.

Un medio natural marcado por la existencia de buenas tierras de cultivo junto a grandes cursos fluviales, acondicionadas con enorme esfuerzo a través del trabajo colectivo y rodeadas de zonas marginales, desérticas o semidesérticas, define la naturaleza eco-económica de esas culturas. Las obras de ordenación del territorio y la gestión de la cosecha fueron las que posibilitaron el desarrollo de un 
poder fuerte en manos de una élite; y la vieja tesis de Wittfogel (1966) sobre la relación existente entre los trabajos de acondicionamiento de la tierra y la merma progresiva de los mecanismos de consenso parece seguir siendo válida. Los despotismos hidráulicos se mostraron operativos en el control de la acumulación y redistribución de los recursos. La existencia de un excedente gestionado de modo centralizado permitió una mayor división del trabajo y la especialización en la elaboración de productos de uso común, como la alfarería, el textil o la metalurgia, fomentó el intercambio con otras comunidades.

La gestión centralizada y eficaz por parte del poder descansaba en una extensa clase funcionarial que fue capaz de desarrollar y atesorar, para sí, sistemas de anotación y control que están en el origen de la escritura, el cálculo o la geometría. Esta burocracia profesional se autojustificó dotando su saber de misteriosos orígenes, ofreciendo de este modo la imagen de una autoridad fuertemente sacralizada, lo que permitió la emergencia de poderosas castas sacerdotales. A ellas se deberán las ricas explicaciones en torno a lo sobrenatural, que conformaron la ideología de esas formas de vida.

Los dioses y el templo se convirtieron en nódulos de articulación de unos sistemas sociales que tuvieron hasta cierto punto características comunes. Nunca en la historia de la humanidad la vinculación entre poder político, administrativo y religioso ha sido tan estrecha. El monarca era el dios o su delegado en la tierra, a su vez los sacerdotes eran sus administradores y el resto de la población estaba sometida y a su merced, porque dependía del templo o del palacio para sobrevivir, sobre todo en épocas de malas cosechas.

Esta nueva y compleja sociedad se apoyaba en una acabada organización patriarcal. La familia se había convertido en el núcleo relacional primigenio y la mujer dentro de ella, y por ende dentro del sistema, ocupaba un lugar subordinado al varón. Todos los textos que han llegado hasta nosotros así lo ratifican y hemos de tener presente que no sólo se trata de textos literarios o religiosos sino también de los primeros textos legales en los que se sanciona, por primera vez en la historia, ese papel dependiente de la mujer. Esos viejos códigos evidencian que sus principales objetivos eran regular 
la propiedad, regular la violencia en el seno de la comunidad y consagrar la asimetría de derechos entre el hombre y la mujer.

Pero el poder, con una legalidad codificada, no podía basarse únicamente en la violencia, sino que debía investirse de autoridad y para ello necesitaba un fundamento ideológico que apuntalara la realidad material. Sólo la autoridad permite que la fuerza resulte un recurso extremo para mantener el orden. Por eso, poder y autoridad pronto se confundieron y el vínculo que se buscó entre ambos fue religioso. Todas las recopilaciones de leyes del mundo antiguo, como son el Código de Esnunna, de Hammurabi o el Levítico, pretenden tener un origen divino, tendente a enmascarar su verdadera naturaleza social para dar a la ley un fundamento sagrado que la haga incuestionable. Así, el imperio de la ley, basado en intereses de clase o de género, devino en época temprana en imperativo moral, o al menos en imperativo sobrenatural. ${ }^{1}$

Los especialistas en la justificación ideológica desempeñaron una intensa labor ya que, no sólo generaron los mecanismos explicativos de su propia existencia, sino que dieron con ellos cohesión social a la comunidad. Los grupos sacerdotales convirtieron el control del tiempo y sus ritmos en una ocupación especializada, que caracteriza a estas culturas. Conocer el tiempo sagrado era poder

1 En el mundo griego es donde podemos estudiar el paso del poder de «facto» al de «iure» en un corto espacio de tiempo, como es el que va de la sociedad descrita por Homero a la obra de Hesíodo, que se hizo eco de esta tendencia en su Teogonía, donde hace desposar a Zeus, dios de los dioses, con Temis, divinización de la justicia, para alumbrar la ley por la que se debían regir los hombres. Las más toscas formas de poder, basadas en la fuerza, se trocaban así, por la gracia de la ley, en autoridad. Esto lo supo ver con gran sagacidad ya en el siglo v a. n. e. Crítias (cit. en Mossé, 1971: 31), que en su obra Sísifo pone en boca de su protagonista la siguiente explicación:

«Hubo un tiempo en que la vida de los hombres era desordenada, controlada por la fuerza bruta como la de los animales salvajes. No había entonces premio para el bueno ni castigo para el malvado. Entonces los hombres concibieron la idea de establecer las leyes como instrumento de castigo a fin de que la justicia fuera la única norma de vida y acabara con la violencia. Si alguien la transgredía era castigado. Pero las leyes castigaban solamente los actos de violencia manifiesta, los hombres continuaron cometiendo sus crímenes a escondidas. Un hombre sabio y astuto descubrió entonces una fuente de temor para los mortales... Así surgió la idea de una divinidad... que puede oír todo lo que se dice y tiene el poder de ver todo lo que hacen... Éste fue pues el origen de las creencias en los dioses así como de la obediencia a las leyes». 
predecir la crecida del Nilo o la llegada de las estaciones, pero también suponía desentrañar los secretos del universo, e incluso prever el futuro, el tiempo que todavía estaba por llegar. Este conocimiento convirtió a los sacerdotes en un grupo social muy poderoso. Si a esto añadimos que monopolizaban otros saberes de tipo médico y científico, nos encontramos con una casta cuya fuerza radicaba en gran medida en las creencias admitidas, en las que las explicaciones religiosas cobraban una importancia fundamental.

Estos sistemas religiosos en gestación tuvieron un rasgo común: la ambivalencia y la ambigüedad en muchos aspectos, especialmente en torno a las ideas de Bien y Mal como fuerzas surgidas a partir de un caos original. Para ellos esa pareja de valores eran dos caras indisolubles del universo, dos manifestaciones casi indistintas del mundo circundante que el hombre debía asumir sin dicotomizar. Los dioses eran poderosos y, como cualquier forma de poder, temibles a la par que benefactores, ya que el control que ejercían sobre la vida les dotaba de esa naturaleza equívoca, por eso todas esas deidades primitivas nos ofrecen una doble faz.

Serán así muy frecuentes las divinidades unidas pero antagónicas. Esa dualidad contrapuesta se expresa a veces por la idea de una confrontación inicial, cosmogónica. Encontramos en estas mitologías luchas terribles siguiendo el patrón de los enfrentamientos humanos. Como resultado, el relato establecerá valoraciones y tomará partido por uno de los bandos contendientes, esto llevará a considerar que algunos de esos seres tienen un carácter más maligno que los otros. A menudo una serie de dioses, depuestos por una generación más joven, son considerados malvados. Los judíos convirtieron en demonios a las divinidades paganas y los dioses olímpicos transformaron a los titanes en seres perversos.

El desdoblamiento de la divinidad en sendos principios, del Bien y del Mal, no se operó ni con rapidez ni con sencillez, y en estas religiones debemos tomar con cautela lo que nuestra perspectiva, educada en la dualidad o el monismo, nos podría llevar a creer, ya que se tardará un tiempo en discernir entre los seres sobrenaturales y los especializados en la comisión del Mal, y en algunas ocasiones la valoración cambiará en función de las circunstancias. 
Pero esta ambivalencia original que vemos en torno a la idea de Bien y Mal no impidió a los hombres de estas culturas buscar explicación concreta e intentar poner remedio eficaz a los males que les podían aquejar, y para poder entender ese proceso debemos tener presentes dos aspectos, uno relativo a las propias concepciones religiosas y el otro en estrecha relación con la manera en la que organizaron su sociedad.

En el primer caso, nos estamos refiriendo a la pervivencia de los mecanismos que regían el pensamiento mágico. La fusión entre unas formas de creencia mágica y otras de tipo religioso se debió de producir con lentitud. La manera en que el hombre durante miles de años se había relacionado con la naturaleza antes de conferirle un poder sobrenatural debió de dejar una honda huella. Así podemos pensar que no hubo realmente una sustitución del rito mágico por la imprecación, sino que ambas fórmulas se combinaron para dar como resultado una síntesis ritual con la que el ser humano se relacionaba con la divinidad. Esa pervivencia se tradujo en toda una serie de prácticas concretas que respondían al viejo fin de controlar o evitar lo imprevisto o perjudicial.

Es evidente que en esa línea de continuidad, lo malo o lo negativo tenía que ser conjurado con ayuda del rito o el hechizo, pero también parece inevitable que por influencia de las nuevas concepciones religiosas, esas fuerzas, que antes eran casi naturales, se elevaran de categoría, personificadas como espíritus o deidades menores, más cercanas a lo material, cotidiano y concreto que los seres «supremos» o las divinidades mayores. Las nuevas castas sacerdotales en su proceso de elaboración teológica no pudieron prescindir de ese imperativo. A las elaboradas mitologías sumaron toda esa herencia mágico-práctica que además acercaba la religión a las clases populares. Mientras que en las justificaciones trascendentes encontraba explicación el nuevo orden político, en la integración de la magia en la vida religiosa se plasmaban las viejas costumbres relacionales del individuo con la naturaleza que le rodeaba y le podía atemorizar.

Es así como la propia forma de organización social terminará de ayudarnos a entender la aparición de una auténtica caterva de 
seres malignos. Uno de los rasgos más sobresalientes de los despotismos hidráulicos fue su jerarquización. La pirámide social en el mundo egipcio o mesopotámico estaba perfectamente reglamentada e incluso legalmente sancionada. Todos, desde el faraón al último de los esclavos, ocupaban su lugar dentro de ese sistema, y la desigualdad, nacida de una suma de factores, estaba perfectamente asumida por el conjunto. Por analogía las divinidades $y$, en general, las fuerzas sobrenaturales también estaban jerarquizadas. Lo cierto es que el animismo y el totemismo iniciales habían poblado ese mundo de multitud de seres que paulatinamente se fueron fusionando y ordenando, introduciéndose la especialización y las categorías. Muy pronto se diferenciaron los dioses supremos de los espíritus inferiores y entre éstos los competentes en distintas funciones, mientras que los primeros se reservaban poderes fundamentales y el patrocinio de las actividades más importantes.

Entre estos seres inferiores nos encontramos de modo más evidente las primeras personificaciones, no tanto del Mal, como de los diferentes y agobiantes males. Mientras que resulta dificultoso atribuir una encarnación del Mal a alguna deidad concreta, aparecerá una legión de espíritus que personificarán males específicos: el calor abrasador del desierto o el frío gélido de la noche, la esterilidad de las hembras o de las huertas, aquellos que estaban detrás de las tormentas devastadoras o los causantes de la enfermedad, del dolor e incluso de la enajenación mental, serán las primeras representaciones del Maligno que elaboraran las religiones originales. Más próximos al mundo de lo mágico que de lo religioso terminarán siendo temidos por sus creadores mucho más que las deidades principales.

Lo cotidiano de su presencia y lo catastrófico de su actividad los convertirá en uno de los principales centros de la actividad cultual y ritual del campesino egipcio o mesopotámico. Especializados en distintos males, aterrorizaban no sólo con sus intervenciones, sino por su apariencia, ya que eran seres monstruosos, en ocasiones, híbridos dotados de los atributos más temibles de la mezcla que los constituía. Su aspecto resultaba repugnante; garras, uñas, picos afilados o aguijones se combinaban con alas, cuernos y cuerpos peludos 
o escamosos para provocar pavor, lo que unido a su merodeo constante con el único objetivo de causar daño o espanto los convertía en temibles.

Casi siempre atacaban de modo directo y brutal y raras veces sus intervenciones guardaban relación con las actitudes morales adoptadas por las gentes, aunque los dioses superiores, a los que podían estar enfrentados o sometidos, los utilizaban para perpetrar daño a los humanos, a modo de castigo o guiados por extraños designios. Tardaremos en ver estos seres al servicio de una justicia divina. En la religión egipcia no será hasta el Imperio Nuevo, con la extensión y democratización del culto a los muertos, cuando aparezca Ammut para devorar el alma de los muertos condenados, por su comportamiento en esta vida, en el juicio osiríaco.

El sistema estatal egipcio era una teocracia estructurada en torno a un monarca divinizado que se identificaba con Horus, el dios halcón. Sin duda, una divinidad totémica local que, según la teología menfita (2700-2200 a. n. e.), aparece como el primer faraón que controló el Alto y el Bajo Egipto, pero tradicionalmente se ha admitido que Egipto tuvo otro dios principal, Seth.

Si Horus era el amo del Alto Egipto, Seth lo había sido del Bajo Egipto, ambos hijos de Osiris y de Isis, terminaron por discutirle el poder. Seth asesinó a Osiris, que era su padre, para luego disputarle la herencia a Horus y dar origen al mito de muerte y resurrección con mayor arraigo en esa religión. En una fase posterior del relato, Horus desafió a su hermano en combate singular y lo venció, con lo que consiguió reinar sobre los dos países finalmente unificados. Este mito, que supuestamente ilustraba la transmisión legítima del poder real y la unificación del imperio, nos presenta a Horus como el hijo bueno y a Seth como el hijo malo, y la verdad es que Seth aparece en otros muchos mitos como un personaje detestable hasta alcanzar en época helenística la consideración de Maligno.

De ese período data una fórmula mágica que ha llegado hasta nosotros, en la que el malvado Seth es invocado para perpetrar el mal a un enemigo. El sortilegio era complicado, ya que resultaba imprescindible proveerse de una cabeza de asno rucio y cubrirse los pies de arcilla, colocándose luego de cara al sol con la testa del ani- 
mal entre los pies. Tras eso venía la parte más desagradable, puesto que el oficiante debía enjuagarse la boca con la sangre del asno y extender una mano hacia delante y la otra hacia detrás para luego pronunciar el conjuro siguiente:

Yo te invoco, oh tú que resides en el aire vacío, tú, el espantoso, el invisible, el todopoderoso, el dios de dioses, el corruptor y el devastador, que odias las cosas donde reina el orden. Cuando fuiste expulsado de Egipto se te llamó «El que lo rompe todo y nunca es vencido». Yo te invoco, Tifón Seth; realizo tu juramento, pues pronuncio tu verdadero nombre, que no puedes rehusar oír: Io-erbeth... ven a mí y acércate, y hiere a aquél o a aquélla con frío y fiebre, me ha hecho daño y ha vertido la sangre de Tifón, ${ }^{2}$ por eso hago esto (Van de Walle, 1967).

Tenemos ahí lo que parece una prefiguración del Maligno, pero no podemos obviar que habían transcurrido muchos siglos desde que se elaboró el mito del enfrentamiento entre Horus y Seth hasta que se registró el maleficio que hemos mencionado. Por otra parte, hoy sabemos que la oposición entre estos dioses sólo se manifestó muy tardíamente, puesto que hasta finales de la quinta dinastía, es decir alrededor del 2245 a. n. e., no se produjo la transferencia del rey difunto en la persona de Osiris, y la del sucesor, el rey vivo, en la de Horus. Entonces y sólo entonces, Horus pasó a ser hijo de Osiris y de Isis. En virtud de lo cual Seth terminó siendo rival y enemigo de Horus, puesto que no podía compartir con éste la realeza.

A esta coyuntura responde también el mito del asesinato de Osiris por su hijo Seth y su personificación como una deidad malvada; y sin embargo en una versión alternativa, Seth y Osiris eran hermanos, y Horus el Menor, hijo de Osiris y de Isis, resultaba ser sobrino de Seth. En mitología, estas deidades hermanas suelen ser interpretadas como pares de un mismo ser, de modo que Seth era la mitad de una personalidad divina cuya otra mitad estaba representada indistintamente como Horus o como Osiris. En definitiva el malvado Seth resultaba ser la otra cara de los benéficos Osiris y Horus, esto avala que tanto Seth como Horus fueran ado-

2 Tifón es un gigante monstruoso, hijo de Tártaro y de Gea, perteneciente a la mitología griega pero que en el Egipto helenístico se asimiló a Seth. 
rados conjuntamente en las primeras dinastías y que sus naturalezas gemelas se representaran a veces en una misma deidad de dos cabezas.

Como alter ego de Horus, Seth defendía al dios supremo frente al Mal y era quien salvaba a Re, el dios solar por excelencia, del ataque de la maligna serpiente Apopi de la que hablaremos más adelante. Como vemos en el caso de Seth se cumple lo dicho, los dioses eran ambivalentes e incluso el malvado asesino de Osiris no podía encarnar enteramente el Mal, ya que para los egipcios lo positivo y lo negativo emanaban del mismo principio cosmogónico.

El universo era para ellos algo vivo y sus manifestaciones no podían ser sino contradictorias como lo son las humanas. Aquello que era fuente de vida lo era también de muerte y sufrimiento, aquello que reverenciaban también les atemorizaba, aquello que decían amar podía ser al mismo tiempo odiado, aquello de lo que dependían para sobrevivir les tiranizaba. Esto se aprecia muy bien en las menciones al faraón que aparecen en algunos textos literarios, como el relato de Sinuhé (cit. en Frankfort, Wilson, Jacobsen, 1974: 99) en el que podemos leer lo que para ellos representaba el teócrata: «Este dios benéfico, cuyo temor se extiende por los campos como [...] en los años de plaga [...] (es) triunfante, destrozador de cráneos, nadie pude estar cerca de él [...] (pero) es enteramente bondadoso y conquista por el amor».

La dualidad entre temor y pleitesía no podía ser expresada y admitida más claramente que en esta imagen que tenían de su dios-rey.

Para ellos la muerte, la enfermedad, la mentira, el engaño no eran sino quebrantamientos del orden cósmico personificado en Maat y, a pesar de su malignidad, formaban parte de esa misma realidad trascendente. Sólo cuando se rompía el equilibrio preponderaban las fuerzas negativas por un tiempo hasta que se volvía al orden primordial. En esas transgresiones fundamentales u ocasionales el hombre podía desempeñar un papel con sus actuaciones, al violar lo prescrito, con sus olvidos o con sus pretensiones. A partir de esa premisa la religión egipcia terminará por integrar códigos morales de conducta y el hombre se verá enfrentado al juicio de los dioses, al premio o al castigo de lo sobrenatural. 
El famoso juicio osiríaco de los egipcios, introducido en época tardía, es un ejemplo de esa derivación hacia una religión moralizante en la que es el individuo quien responde de sus actos ante las deidades. El Mal adquirirá una dimensión si se quiere particular, ya que será el individuo el que una vez muerto rinda cuentas en el Tuat de lo que ha sido su vida en la tierra. No está clara la situación y la naturaleza del Tuat, pero se supone generalmente que era el mundo subterráneo. En ese mundo de ultratumba el alma del finado era pesada en la balanza por el dios negro de cabeza de chacal Anubis. Los que resultaban virtuosos eran recompensados con una vida eterna, mientras que los malvados que habían violado la ley de Maat eran devorados por Ammut o por el fuego de Re, el fuego que daba vida desde el disco solar pero que también abrasaba y quemaba a los inicuos lo mismo que al desierto estéril.

Pero el temor que inspiraba Seth era mucho menor que el producido por la actividad de una legión de espíritus causantes de la enfermedad y la desgracia, a ellos había que temer mucho más, en el día a día, que al mismo dios. Estos seres odiosos y terribles eran nombrados en muchas ocasiones por su aspecto como en el caso de «El de rostro repugnante» 0 «El que vive de los gusanos» e incluso «El que come sus propias deyecciones». Su actividad aumentaba y era más virulenta durante las temporadas de transición, ${ }^{3}$ o cuando el difunto llegaba al Tuat. Se movían de siete en siete o sus múltiplos y difundían las fiebres recurrentes. En época copta se les llamó espíritus $a k h u$, o los que infectan la periferia del mundo organizado, el desierto, la oscuridad, los parajes lejanos, las aguas. Estos agentes del caos revistieron un simbolismo limitado, sin embargo

3 Los egipcios organizaban sus estaciones en función de las crecidas del río Nilo, por eso a diferencia de otras culturas agrarias que establecieron cuatro estaciones, el año egipcio sólo tenía tres, con cuatro meses cada una de treinta días. Akit la inundación, Perit la germinación y Chemu la cosecha. Los tránsitos entre una y otra estación eran momentos delicados, pero no se limitaba sólo a ellos los días que podían ser nefastos. El 26 del primer mes de Akit se consideraba un día especialmente aciago, pues señalaba el enfrentamiento entre Horus y Seth. Durante los días nefastos era preferible no salir de casa y en algunos hasta la administración del Estado quedaba paralizada. El 19 del primer mes de Perit nadie podía acercarse a las mujeres sin ser devorado por la infección. 
parecen formar parte, como servidores, del séquito de algunas divinidades como Sekhmet, de la que haremos más adelante una mención especial.

Las civilizaciones de Mesopotamia y Siria contribuyeron más directamente que la egipcia a dar vida a ese tipo de espíritus malignos, y la persa supondrá un paso adelante al elaborar la idea de un principio único del Mal enfrentado al Bien.

La civilización mesopotámica no presenta los caracteres unitarios que tiene la egipcia; aparece configurada por una mezcla de grupos humanos (sumerios y semitas), sin una unidad permanente y que generaron una diversidad política que se refleja también en la religión. Ésta se nos muestra como una acumulación de tradiciones que, si bien tienen su origen en Sumer, fueron incluyendo materiales de épocas y culturas posteriores (acadia, babilonia, asiria). Pero junto a la diversidad cronocultural encontramos así mismo una enorme variación local debida a la configuración geopolítica que adquirió en su fase inicial, lo que explica que la religión de cada ciudad fuera diferente, incluso en sus dioses principales (Enlil en Nippur, Enki en Eridu, An en Uruk, Nanna en Ur). No obstante, podemos apreciar una cierta unidad de base que tiene su origen en la aceptación consensuada del sistema teológico de Nippur a partir de mediados del segundo milenio y en el prestigio de los antiguos textos religiosos sumerios que fueron traducidos, copiados y venerados hasta el siglo vi a. n. e. y que influyeron en las religiones de una amplia zona del Próximo Oriente.

La continuidad entre la religión sumero-akkadia y la asiriobabilónica es tal que se las puede examinar conjuntamente, teniendo presente además que las civilizaciones de Babilonia y Asiria influyeron tanto a los hebreos como a los canaanitas y que estos últimos dejaron su huella en Israel y en las culturas prehelénicas. Aunque resulta difícil establecer cómo se operó esa difusión, debemos admitir que un conjunto de creencias semíticas comunes está directamente detrás de los orígenes de las civilizaciones griega y judía.

Este flujo dio como resultado una rica realidad teológica y la existencia de multitud de divinidades difíciles de clasificar de modo 
«racional». Los nombres, los atributos y los lugares preferentes del culto, e incluso las identidades de los dioses mesopotámicos, sufrieron continuas variaciones. Se han inventariado no menos de cuarenta nombres para Nintud, Belit llani o «la madre de los dioses», también llamada Makh, Ninkhursag o «reina de la montaña», lo cual significaba «reina de la tierra» para los sumerios y «reina del país de los muertos» para los babilonios. Pero también se llamaba Aruru o «diosa de los partos» y más sencillamente Mama, la que creó al hombre de la arcilla, ancestral ejemplo de principio de creación femenino y huella de una sociedad matriarcal. Y aunque de hecho son siete dioses, o mejor dicho siete arquetipos de divinidad, los que recorren los reinos, las civilizaciones, las lenguas y las religiones de Mesopotamia, se pueden detectar más de cuatro mil deidades y en una clasificación simplificada al menos unas seiscientas.

A esto debemos sumar que el pensamiento mesopotámico registra la historia de una zona de paso, cruce de culturas, que la convierte en escenario de numerosas guerras e invasiones desde el tercer milenio, confiriéndole a su religión un aspecto mucho más espantoso y terrible que en el caso egipcio. Los principales rasgos diferenciadores son una cosmogonía convulsa y la naturaleza caprichosamente cruel de unas divinidades que en muchas ocasiones se ensañan con los hombres. Los inescrutables dioses mesopotámicos podían ayudar, abandonar o simplemente ignorar a una nación, una ciudad o un individuo a los que, sin embargo, se les pedían atenciones constantes y una sumisión total. Por otra parte, la idea de que el rey era un dios que presidía un universo esencialmente inmutable, como ocurría con la religión egipcia, no tenía cabida en sus presupuestos teológicos que no concibieron la existencia de un Maat, como principio del equilibrio universal.

Con este trasfondo podemos explicarnos que la aparición de todos los males del mundo estuviera ya en el origen del terrible relato cosmogónico de Tiamat y Marduk, conocido por Enuma elis ( Cuando en lo alto»), por ser las primeras palabras con las que comienza el mito babilónico, recogido en siete tablillas y cuya recensión más antigua que conservamos es posterior al primer milenio, aunque los especialistas le adjudican una fecha de elaboración muy anterior. 
En el Enuma elis, Tiamat y Apsu (cit. en Messadié, 1994: 130), la pareja primordial reside en la «nada» original, pero los dioses que han engendrado les molestan con sus risas y sus juegos, por lo que sus terribles progenitores deciden eliminarlos. Pero los retoños, sabedores del parricidio que se planea y dignos sucesores de semejante estirpe, se adelantan. Ea da muerte a su padre Apsu y sobre su cadáver engendra a Marduk, dios de Babilonia. Tiamat, la madre primigenia, planea su venganza concibiendo una legión de monstruos de los cuales el de mayor rango es Kingu, al que pone al frente de semejante horda:
Ella forjó armas irresistibles y parió serpientes gigantes
De dientes afilados, de mandíbulas despiadadas;
A manera de sangre, llenó sus cuerpos de veneno
Y revistió de espanto a los dragones furiosos.
Los aureoló de resplandor y los hizo parejos a los dioses
¡Quienquiera que les viese retrocedería presa de espanto!
¡No huyáis, los de las primeras filas!
Ella suscitó la hidra Bashma, el dragón rojo y Lahamu,
Los leones gigantescos, los perros babeantes y el hombre-escorpión,
Los demonios malvados de las tempestades, el hombre-pescado
y el Kusarikku.

Para hacer frente a ese crucial combate Marduk de Babilonia es elegido jefe de los dioses. El héroe derrota a Tiamat y hecho esto se aplica en la creación de la humanidad con el único propósito de que le sirva a él y al resto de las divinidades. Pero el dios la moldeará con la sangre de Kingu, marcando así, en el origen del ser humano, el destino de esta especie nacida de un ser maléfico.

A partir de este mito cosmogónico no resulta extraño que la religiosidad mesopotámica creara un sinfín de monstruos de rango menor especializados en todo tipo de males. A estos demonios se los consideraba retoños de Tiamat, pero más a menudo se los concebía como hijos del gran dios Anu. Los terribles anunnaki eran los carceleros de los muertos en el infierno. Los etimmu eran fantasmas de los que habían muerto en la desdicha. Los utukku habitaban sitios desiertos o cementerios. Otros malos espíritus eran los demonios de pestes, de las pesadillas, de los dolores de cabeza, etc. De entre ellos destacaba Pazuzu, el demonio del viento y la tormenta del desierto 


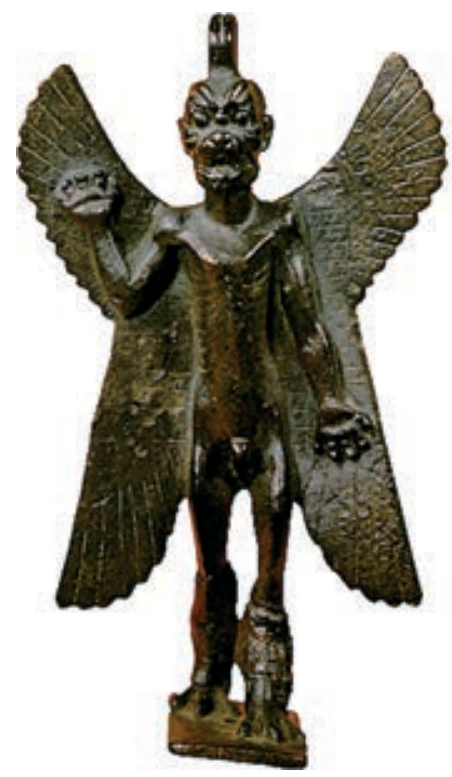

La personificación del Mal apareció en las religiones originales del Oriente Próximo, relacionada de modo ambiguo con algunas divinidades mayores. Pero fue entre los espíritus menores, como el demonio asirio Pazuzu, donde adquirieron sus formas más horribles.

que, con su terrible aspecto, causaba un particular pavor. Un rostro horrible con cabeza crestada, cuatro alas, cola de escorpión, garras de león y patas de pájaro le conferían una apariencia en sí misma maléfica. Era el señor de los espíritus malignos de la atmósfera. No obstante, su imagen era usada también como talismán protector contra otros demonios.

Para combatir a los malos espíritus la magia se convertía en el instrumento más usual. La multitud de fórmulas mágicas, exorcismos y amuletos de los que se dotaron los mesopotámicos les permitía enfrentarse a ellos con más o menos eficacia. En el reverso de una imagen de Pazuzu que ha llegado hasta nosotros figura el siguiente conjuro con un sentido claramente protector (cit. en Koning, 1975: 27): «Yo soy el dios Pazuzu, hijo del dios Hanbu, rey de los demonios de los malos vientos. Soy yo quien sopla con toda la fuerza sobre las tierras, de suerte que éstas se elevan. Y si otros vientos se abaten sobre ellas, será el viento que procede de las regiones donde tengo mi reino el que los destruirá. ¡Oh, que las alas de estos vientos sean destrozadas!». 
Las mismas enfermedades eran concebidas como producto de la actividad de seres maléficos que se instalaban en el organismo afectado. Cada uno de los males se debía a la acción concreta de uno de estos espíritus; así, el alal actuaba sobre el pecho, mientras que el gigim lo hacía sobre el intestino, el idpa sobre la cabeza y el utug sobre la frente. Los desarreglos psíquicos o nerviosos se debían a la acción posesiva de utuk mau. Para curar las dolencias se recurría al hartumim, que sólo utilizaba los exorcismos pertinentes tras haber identificado de qué demonio se trataba. El conjuro se basaba en ocasiones en la magia del nombre, entonces el hartumim utilizaba tablillas de arcilla sobre las que se había grabado el nombre del espíritu junto a la fórmula correspondiente. En otros casos recurría a piedras con un poder benéfico o prescribía abluciones en el agua sagrada del Tigris. Excepcionalmente recetaba la ingestión de sustancias que de modo alguno actuaban por sus propiedades curativas sino por la fuerza mágica de que se las creía compuestas; de entre ellas destacaba la miel, que se consideraba un brebaje de origen divino. Además de estos métodos el hartumim podía practicar la ceremonia de exorcización. Cubierto con un velo azul y blandiendo alguna estatuilla con poderes apotropaicos, en ocasiones con la misma imagen del demonio que se quería expulsar, el médico brujo invocaba por su nombre correcto al espíritu y sobre todo pronunciaba su número mágico o minu, dejándolo así indefenso y obligándole a salir del cuerpo enfermo.

Legiones de demonios convivieron con estos hombres, ayudándoles a explicar sus padecimientos. En ocasiones les favorecían pero, la mayoría de las veces les atormentaban causándoles la desgracia. Esa familiaridad dolorosa con estos seres forzosamente debía reflejar todos los aspectos de la mentalidad dominante, por eso a los demonios y divinidades perversas se les atribuyó un sexo, que en más de una ocasión resultó ser femenino.

\section{... Y algunas diosas terribles}

La ambigüedad que marcó a la religión egipcia y mesopotámica también afectó al sexo de los dioses que crearon a lo largo de su dilatada historia. La coincidencia de contrarios de la que antes hablába- 
mos se expresó sexualmente de formas distintas, y el andrógino divino o la unión en un ser de hermano y hermana resulta frecuente y debemos entenderla como un símbolo de perfección. Esto permitía un campo de variaciones dentro del cual una misma deidad podía ser masculina y femenina, cambiando muchas veces de función según la circunstancia, de tal manera que Amón podía ser padre o madre. Por ejemplo la primitiva diosa Neith, una divinidad increada, a la que se le atribuía la virginal maternidad del dios solar Re, era adorada como diosa de la guerra, siendo representada en forma de una mujer con la corona del Bajo Egipto y llevando en la mano un arco y dos flechas y, sin embargo, era considerada un dios masculino que actuaba como mujer, o bien como una mujer que actuaba como hombre. La bisexualidad no era sino expresión de la androginia de lo increado y el andrógino como la coincidencia de la oposición sexual.

En otros casos se operaban efectos de travestismo o de cambio de sexo. El tránsito del culto en según qué divinidades a través de distintas zonas geográficas o culturales podía comportar la pérdida de identidad sexual. Las frecuentes adopciones de una divinidad por tal o cual Estado o ciudad acarreaban cambios de nombre pero también podían suponer un cambio de sexo. Ishtar, la futura Astarte, luego Afrodita, en árabe Actar, identificada con el planeta Venus, era en su origen un dios masculino que se hizo mujer cuando pasó de Arabia a Mesopotamia. En los procesos de sincretismo ese ser travestido tuvo una particular fortuna, puesto que terminó por asimilar a todas las divinidades femeninas del panteón convirtiéndose prácticamente en la única diosa independiente. Éxito tanto más destacable si tenemos en cuenta que entre los dioses masculinos, incluso los de más acusada personalidad, nunca alcanzaron a absorber por completo a sus rivales, como logrará hacerlo Ishtar.

Estas ambivalencias y metamorfosis sexuales dificultan que podamos establecer con precisión campos de valoraciones bien definidas para los dos sexos, pero no impiden apreciar, aunque sea de modo general, cuál fue el papel que desempeñó el género en las creencias de las religiones originales.

Lo cierto es que tanto en la religión egipcia como en la mesopotámica lo femenino ocupa un lugar destacado en sus respectivos 
panteones. La relación de las divinidades femeninas en Egipto puede parecer muy extensa, desde Nut, diosa del cielo, madre de Re, de Osiris, de Seth, de Isis y de Neftis, hasta Mut, esposa de Amon; Neftis, hermana de Isis; Maat, diosa de la verdad y del equilibrio universal; Uadchet, diosa-serpiente; Bastet la Gata; Seshat, diosa de la escritura; y otras muchas. En cada uno de los cuarenta «nomos» o provincias de Egipto se adoraba a una diosa, fuera divinidad principal o secundaria. Mucho más prolija resulta la relación en el caso mesopotámico, donde las divinidades se multiplicaron sin cesar. Así, el panteón comprendía un gran número de diosas, sobre todo sumerias, pero también semíticas: Annunitu, Antu, Aruru, y muchas más cuyo nombre comenzaba por Ama («madre») o Belit («dama» en acadio). Sarpanitum, Diritu, Delebat, Eru'a, Ereshkigal, Gula, Innin, Innana, Ishtar, Kutusar, Mami, Mammitu, Meme, Nana, Nanse, Nisaba/Nidaba, Shala y Sheru'a son algunas de las más destacadas.

Los principales sistemas teológicos en ambas religiones se apoyaron con frecuencia en la creación, a partir de un dios primordial único, de parejas divinas. Así, en Heliópolis, el dios Atum procrea una primera pareja divina: $\mathrm{Chu}$, el principio masculino, y Tefnet, el principio femenino. Lo mismo ocurre en la religión mesopotámica en donde podemos discernir la existencia de tres parejas relevantes y un regente primigenio que sería Anu, amo del Cielo y padre de las demás divinidades. Los mecanismos de la reproducción humana se trasponían así al mundo sobrenatural y las hierogamias permitían explicar no sólo la constitución de las familias divinas, sino también los procesos de nacimiento y renacimiento de todo lo natural. El acto sexual se convertía en el principio sobre el que descansaba la explicación de buena parte del orden cósmico, sobre todo en la religión mesopotámica, donde la prostitución sagrada se llegó a convertir en una institución sacerdotal, lo que nos indica la importancia que le concedían a este mecanismo en sus teorías cosmogónicas.

A imagen y semejanza del acto de amor que se verificaba en el mundo superior entre el dios y la diosa, el rey o el gran sacerdote (originariamente ambos cargos concurrían en la misma persona) y 
la gran sacerdotisa, una $e n t u^{4}$ o «mujer divina», se unían una vez al año en el templo con motivo de una gran fiesta. En ese rito sexual se exaltaba, de modo plástico y material, sobre todo la fertilidad, sin recurrir a abstractos símbolos de renacimiento o resurrección como ocurría en el caso egipcio. En él podemos ver un vestigio de los antiguos ritos que debieron presidir el culto a la Diosa Madre en las comunidades neolíticas. La presencia del elemento femenino encarnado por la entu nos indicaría así mismo que, a diferencia de los egipcios, la presencia de la mujer en las ceremonias que garantizaban la supervivencia seguía siendo necesaria.

Para explicar el mismo origen de la especie humana, algunos mitos mesopotámicos pensaron también en la maternidad. En los más viejos relatos se invoca a la «sabia» diosa Mami, en otros la diosa Aruru era la encargada junto con Marduk de formar el germen de la humanidad. E incluso cuando recurrieron a otras imágenes creativas como la confección de figurillas de arcilla, era también una diosa la que conservaba la dignidad de alfarera de los hombres.

La abundante presencia de lo femenino en las explicaciones mitológicas podría dar la impresión de un cierto equilibrio de sexos, y sin embargo lo único que revela es la consolidación de la familia patriarcal y su proyección en lo sobrenatural. Los dioses estaban divididos en familias pero siempre siguiendo la línea masculina, y la mayoría de esas diosas eran representadas en su calidad de esposas o parejas de los dioses o bien se las consideraba por ser madres de las principales divinidades. En ningún momento de la jerarquización divina las potencias sobrenaturales más importantes fueron adjudicadas a deidades femeninas, del mismo modo que fue algo extraordinario que la realeza terrestre reconociera a la mujer en Egipto mientras que nunca lo hizo en Mesopotamia. De hecho, las funciones de las divinidades femeninas en la mayor parte de los casos eran esencialmente protectoras y los mitos referidos a ellas las

4 Parece que en Mesopotamia existieron dos clases principales de sacerdotisas: las simples sacerdotisas (shaggitu y ugbabtu) y las grandes sacerdotisas (entu). En el caso de estas últimas su función primordial era representar materialmente a la diosa en el curso de la ceremonia del «matrimonio sagrado». En su mayor parte procedían de familias muy notables, entrando muy jóvenes al servicio de los dioses. 
mostraban cumpliendo los papeles primordiales de la mujer como guardiana por excelencia de la familia y valedora de sus hijos.

En este sentido es muy significativo el mito egipcio de Isis. Isis era la hermana y la esposa de Osiris, rey-dios esencialmente civilizador y enfrentado como ya hemos visto a su hermano Seth quien, con ayuda de sus cómplices, lo mata encerrándolo en un cofre y echándolo al mar. Entonces interviene Isis, que se pone a buscar el cuerpo de su marido con ayuda de su hermana Neftis, la propia esposa del asesino. En el relato más antiguo Isis y Neftis encuentran el cadáver, pero Seth se lo arrebata y lo fragmenta en múltiples pedazos de modo que las diosas han de reemprender la «búsqueda» ahora con el objetivo de reunir todas las partes del cuerpo. Cuando lo han conseguido, inician los ritos funerarios y, gracias a la magia, Isis logra reanimar durante unos instantes el cuerpo de su marido, tiempo suficiente para concebir a su hijo póstumo, Horus, que esconderá y educará a solas en los pantanos del delta con el fin de sustraerlo al odio de su tío. Horus, al ser mayor y con la ayuda de su madre, reivindicará la herencia de su padre.

Como vemos, el modelo representado por Isis no es otro que el de esposa fiel en la adversidad. Su abnegado sacrificio persigue un único fin, preservar la línea sucesoria y conseguir el reconocimiento de los derechos del difunto. Isis se convierte, pues, en la patrona natural de las madres y en la protectora de los hijos, valedora de la estirpe masculina.

La otra divinidad femenina más venerada en Egipto era la diosa Hathor, que ofrecía la otra cara del arquetipo básico de la mujer en la cultura patriarcal como fuente de placeres carnales e imagen y símbolo de la festividad. Como diosa del amor físico, de la danza y de la música se la asociaba a divinidades menores como Bes, enano deforme cuyo tambor espantaba a los genios maléficos, protegiendo a las embarazadas. Su nombre significaba «santuario de Horus» y estaba estrechamente vinculada a ese dios del que tan pronto era la esposa como la madre. En este intercambio de papeles se encierra todo un símbolo freudiano sobre las funciones a las que está destinada la mujer, aunque no se acababa ahí la imagen de esa diosa puesto que, la misma que protegía el amor carnal y era la 
representación divina del placer, se transformaba en un ser terrible que encarnaba la quintaesencia del Mal.

La diosa Hathor también era ambivalente y podía tomar la forma de Sejmet, la diosa de cabeza de león, el Ojo abrasador de su padre el dios solar Re, convirtiéndose así en la vengadora de los dioses. En una conocida leyenda se nos narra esta malvada faceta de Sejmet/Hathor.

Re creó a la humanidad, pero la humanidad se rebeló, conspiró contra el dios y después huyó atemorizada para refugiarse en el desierto. La indignación de Re por la maldad de aquellas criaturas creadas por él fue enorme y decidió castigarlas destruyéndolas sin piedad. Los cortesanos de Re le aconsejaron que se valiera de su Ojo para ejecutar su venganza. El Ojo de Re no era otro que su propia hija Hathor en su encarnación de Sejmet. La terrible diosa cumplió el mandato con auténtico deleite, bebiendo la sangre de los humanos y sembrando la muerte por doquier. La sed de sangre de Sejmet creció tanto al probarla que pronto hubiera acabado con la humanidad. Re, espantado y contrito por su decisión, que iba a suponer el exterminio de sus criaturas, se decide a actuar para detener la matanza. Es entonces cuando idea una treta y manda a sus servidores que se dirijan a la ciudad de Abu para recoger en ella todo el ocre que pudieran encontrar. Tan pronto como regresaron con cestas rebosantes de tierra roja les envió a buscar a su sumo sacerdote en Heliópolis con el fin de que todas las esclavas que trabajaban para el templo mezclaran el ocre con cerveza para elaborar siete mil tinajas de brebaje. Al amanecer el rojo bebedizo que aparentaba ser sangre fue vertido en la tierra. La cruel Sejmet, engañada por el color, se embriagó con el líquido de tal manera que llegó a olvidar su misión. Así se salvó la humanidad de perecer y aprendió que para huir del dolor siempre puede refugiarse en la cerveza que operará como lenitivo de sus males.

El correspondiente mesopotámico de Sejmet también está representado por una deidad femenina, la terrible Ereshkigal diosa del mundo subterráneo babilónico. La reina de las tinieblas originalmente era una diosa celeste llevada a la fuerza por el dragón Kur 
a los infiernos y entronizada en ellos como su señora. Compartía su trono con Nergal, el hijo de Enlil, que también fue en principio una deidad solar.

Las amenazas aparentemente amorosas vertebran la historia de esas oscuras fuerzas subterráneas. Nergal, regente del verano y del calor, había descendido al reino de Ereshkigal por orden de los dioses, para presentar sus excusas a la diosa, por haberla ofendido. Inexplicablemente seducido por la belleza del cuerpo infernal, cede al deseo y se acuesta con el monstruo que tenía, según nos lo describe un texto (cit. en Izzi, 1996: 163): «Un cuerno como el de un cabritillo en la frente, puntiagudo [...] orejas de oveja y manos humanas [...] cuerpo de un pez curvado por la espalda [...] de la cintura a los pies era un perro [...] y estaba cubierto de escamas como una serpiente». A pesar de esto Nergal se funde con ella en un apasionado abrazo al punto de que cuando llega el momento de la partida, Ereshkigal se deshace en lamentaciones. Loca de amor, la diosa envía a los cielos un mensajero, Namtar, para que se apodere de Nergal y lo devuelva a los infiernos para poseerlo nuevamente:

Corre, Namtar, y habla con Anu, Ellil y Ea.

Pega tu rostro a la puerta de Anu, Ellil y Ea para decirles que cuando fui niña nunca conocí los placeres de las demás niñas, nunca conocí los juegos infantiles.

El dios que me enviásteis y que me ha dejado encinta, que venga a dormir otra vez conmigo.

¿Que vuelva ese dios y pase la noche conmigo como amante!

La súplica de la diosa va acompañada de una amenaza, ya que si los dioses no obligan a Nergal a descender de nuevo al infierno para compartir el lecho de Ereshkigal, ésta anuncia:

¡Haré que suban los muertos y que devoren a los vivos, y haré que habiten más muertos que vivos en la tierra! (cit. en Messadié, 1994: 132).

A Nergal no le quedó más remedio que plegarse a las exigencias de esa furia, por lo que baja de nuevo al mundo de las sombras y, tras mantener una violenta escena de amor y maltrato, accede a convertirse en el compañero de la diosa monstruo. 
Ereshkigal pervivió durante siglos como una poderosa fuerza oscura transformándose con el paso del tiempo en una mediadora entre los mortales y el mundo infernal. Incorporada a los rituales mágicos, vemos cómo siguió siendo invocada por los hechiceros de finales del mundo antiguo mucho tiempo después de que la cultura que le había dado vida hubiese desparecido.

Estas deidades se nos manifiestan como diosas de destrucción, peste, guerra y muerte y, en cierta medida, como las encarnaciones más acabadas del Mal concebido como forma superior. Pero Sejmet o Ereshkigal no son las únicas personificaciones femeninas de la maldad que aparecen en el Oriente Próximo. En la religión cananea, término con el que la Biblia designa a una cultura que se desarrolló en la costa de lo que hoy es Siria, el Líbano e Israel, nos encontramos con Anath.

Anath era la hermana del gran dios Baal y reproduce con él el paradigma fundamental de los mitos de fertilidad. Cuando el malvado Mot devasta el mundo, Baal sale a combatirlo y se enfrenta con él, pero desgraciadamente es derrotado y muere en el combate. La desaparición de Baal acarrea la esterilidad de la tierra durante siete largos años hasta que Anath lo encuentra y lo entierra adecuadamente, pero esto no es suficiente, puesto que debe vengar la muerte de su hermano. La diosa, tras apoderarse de Mot lo mata, lo abre en canal y con fuego aventa sus entrañas.

Esta imagen de la venganza terrible se encarna en una diosa virgen que lo era también del amor, a la par que de la guerra. En esa ambivalencia podía adoptar un comportamiento que la convertía en cruel e inhumana, personificando así el Mal en esa cultura, tal y como nos la muestra un texto cananeo de la época (cit. en Rusell, 1995: 98):

\footnotetext{
¡Mirad!, Anath combate con violencia, da muerte a los hijos de dos ciudades, combate a la gente de la orilla del mar, aniquila a la humanidad del amanecer [...]

Se hunde hasta las rodillas en sangre de héroes y hasta el cuello en la sangre de la tropa...
}

Entre la legión de demonios menores también encontramos una abundante muestra asimilada al género femenino, desde Ammut, el 
horripilante híbrido que devora el alma del egipcio poco virtuoso en el juicio osiríaco, hasta la Lilith hebrea que trataremos en otro capítulo. Especialmente terrible resultaba Lamashtu, hija de Anu, un espíritu maligno que se cebaba precisamente en las mujeres, ya que era responsable de la fiebre puerperal y de la muerte de los recién nacidos, convirtiendo en desdichado a su propio sexo al privar a muchas madres de la descendencia que daba significado a sus vidas. Lamashtu se representaba, según nos la muestra un amuleto, como una mujer desnuda con cabeza de león. En el talismán este monstruo se encuentra arrodillado sobre el lomo de un asno dando de mamar a dos animales encima de una barca que flota sobre un río. La ausencia de la fórmula mágica que debió completar la pieza tal vez nos hubiera aclarado el sentido de tan singular escena.

Lo cierto es que la vinculación de la mujer, o el sexo femenino, con esas fuerzas malignas se evidencia en otros datos. Por ejemplo, el destacado papel que desempeñaban en el ejercicio de múltiples exorcismos, o bien dedicadas a la nigromancia (shaílutu) practicando la evocación e interrogatorio de los etimmu (espíritus de los muertos). Se las menciona bajo diferentes denominaciones: kashshaptu, mushtepishtu, eshshebutu, agugillatu, narshinnatu, mushlahhatu (ésta última, a juzgar por su nombre de origen sumerio, se servía de «serpientes» para efectuar sus conjuros...), siempre asociadas a prácticas maléficas. Es en Babilonia donde nacerá el concepto de bruja como aquella mujer que ejerce todo lo opuesto a los procedimientos religiosos, es decir, una especie de «magia negra», y a la que se consideraba persona muy peligrosa. De hecho el código de Hammurabi establecía que a las acusadas de este delito «se las arrojará al río».

Pero no debemos confundir este pandemonium, con su imaginativa variedad de personificaciones y representaciones, con un progreso intelectual de la idea del Mal. Por el contrario, la conceptualización de un principio maligno dotado de voluntad precisa, enorme poder y con un rango divino opuesto en todo al Bien supremo no surgirá de esta variopinta cohorte de seres diabólicos cada uno con su esfera de influencia bien delimitada. La idea del Mal tendrá su origen en el zoroastrismo persa y servirá para complementar teóricamente la rica imaginería que había adquirido en la cultura egipcia y mesopotámica. 

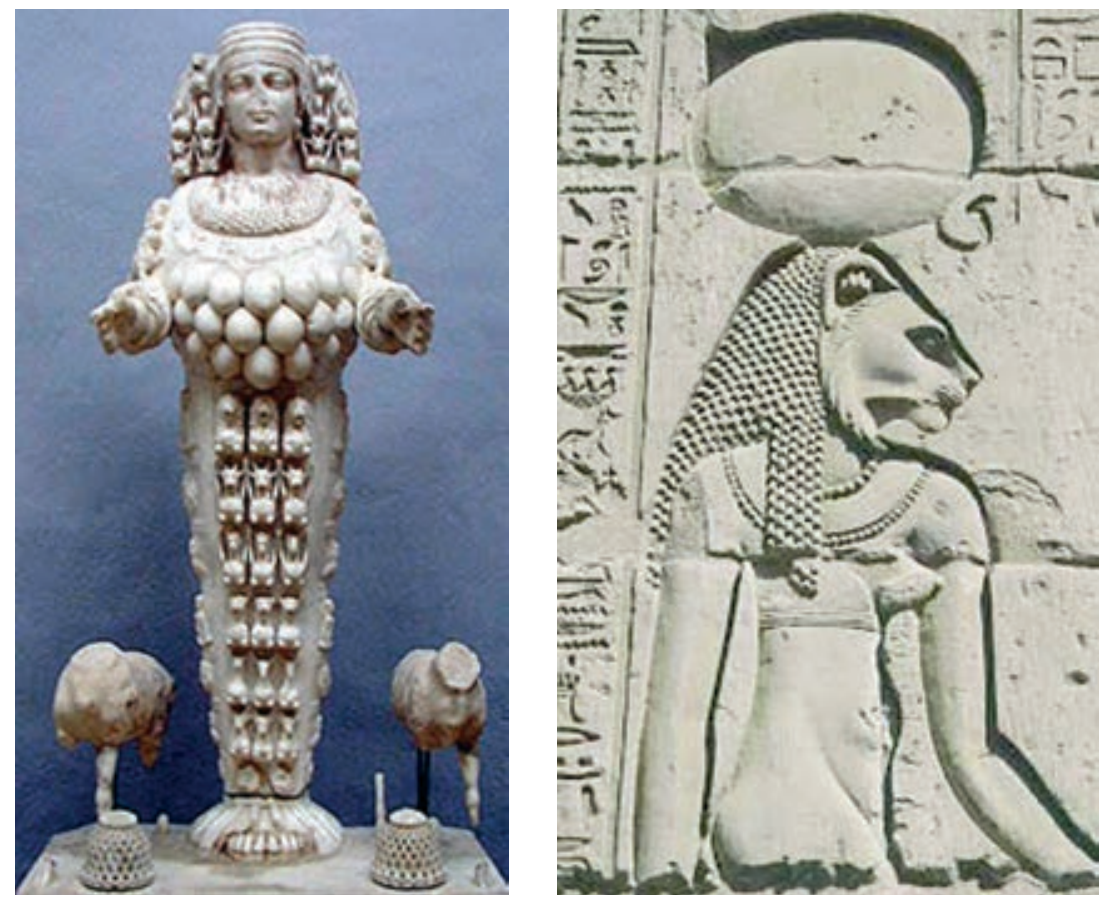

En las religiones del Oriente Próximo, la mujer siguió ocupando un destacado papel en sus panteones. Valorada como mediadora de la fertilidad, como ocurría con la diosa babilónica Isthar, a la que los efesios representaban como madre nutricia con numerosos pechos (izquierda), pero también encarnando las fuerzas más terribles y malvadas, como era el caso de la diosa león egipcia, Sejmet.

Aunque su aparición es muy posterior y tiene otras raíces culturales, el zoroastrismo es la primera religión que define un principio del Mal tal y como será posteriormente adoptado por las religiones monoteístas. Así, las imágenes y el concepto del Mal tienen una factura oriental y se complementarán a la perfección para influir en la ulterior categoría cultural del Diablo que tanto arraigo tendrá en la cultura occidental durante siglos.

El mazdeísmo o zoroastrismo parece ser una elaboración religiosa que descansa en la figura de un profeta, Zaratustra, al que podemos ver como el primer fundador de una la religión revelada. 
Aunque no existe consenso se considera que la parte más antigua del Avesta, el texto sagrado del mazdeísmo, consistente en diecisiete himnos llamados los gatha, es obra directamente suya. Uno de los principales rasgos de esta religión es su nula predisposición al compromiso sincrético que había estado presente en todas las formulaciones anteriores. Zaratustra plantea una doctrina que hay que aceptar como verdad revelada tal y como sale de sus labios, sin ningún margen al compromiso, y que divide a los hombres entre los que la aceptan o la rechazan. En esta actitud podemos ver una clara superación de las religiones funcionalmente políticas y socialmente estructurantes que buscaban en todo momento integrar los cambios que se iban produciendo en el devenir de las comunidades que las alentaban. Por el contrario, el zoroastrismo adquiere una pretensión trascendente y universalizadora que desborda a las viejas creencias.

Zaratustra plantea como divinidad suprema a Ahura Mazda (Sabio Señor), pero no genera un monoteísmo estricto. Por una parte, opta por un dualismo y por la otra admite una serie de emanaciones divinas que se relacionan con Ahura Mazda por lazos de filiación. Ahura Mazda ha generado dos seres que han elegido caminos diferentes: Spenta Mainyu (Espíritu Santo) optó por asha (la verdad), Angra Mainyu (Espíritu Destructor) por druj (la mentira). No queda claro si el Mal es fruto del error o de la libre lección de Angra Mainyu; en textos posteriores y en la medida en que Angra Mainyu se confirma como un espíritu maligno podríamos pensar en esta segunda posibilidad, ya que Spenta Mainyu termina por identificarse con Ahura Mazda como señor del Bien y Angra Mainyu con Ahriman, como señor del Mal, desembocando en un dualismo sistemático en el que desde el origen del mundo éste se divide en dos polos opuestos y en lucha. Las emanaciones malignas que aparecen como hijos de Angra Mainyu, los Daeva, que se definen como servidores de $d r u j$, están formados por buena parte de los dioses antiguos previos a la revelación y por toda una caterva de demonios y seres maléficos como son Aeshma, el furor; Azi, la codicia; Apaosha, el abrasador; y otros.

El dualismo formulado por Zaratustra fue un paso revolucionario en el desarrollo de la idea del Mal. Por primera vez se presenta- 
ba como un principio absoluto y su personificación, Angra Mainyu o Ahriman es el primer ser que lo encarnó de modo radical. Esto permite identificar claramente a una figura precisa con la malignidad. Aunque se produce la paradoja de que, en las representaciones iconógráficas de Ahriman, el Mal no adquiere las formas terribles que tomó en las antiguas culturas mesopotámicas.

En esta primera teorización del principio del Mal también aparece el género, aunque lo hace de modo más evidente en las desviaciones heréticas del zoroastrismo, como el zervanismo o el maniqueísmo. Para los zervanitas del período sasánida había un único principio, Zurvan, una coincidencia de contrarios que contenía en sí el Bien y el Mal, lo masculino y lo femenino, la luz y las tinieblas, la bienaventuranza y la miseria, el orden y el desorden. Zurvan era eterno pero en su soledad quiso un hijo y su mitad femenina dio a luz no una sino dos criaturas, una de ellas producto del amor y el deseo, y la otra de un momento de duda.

El hijo del deseo de Zurvan fue Ormuz, dios de la bondad, la luz y la vida. El hijo de su duda fue Ahriman, señor de las tinieblas y el Mal. Zurvan pensó no dar nada a Ahriman, el desamado, pero Ahriman reclamó el gobierno del mundo, ante el horror de su padre que se vio obligado a reducir a la fuerza maligna expulsándola a las tinieblas exteriores. Pero Ahriman, que durante tres mil años estuvo alejado del mundo, se despertó de su sueño por la intervención de la prostituta Jeh y reanudó su ataque contra Ormuz.

Así empezó el tercer período de tres mil años, que presencia un enfrentamiento prácticamente igualado en el cosmos entre las fuerzas del Bien y del Mal. Ahriman creó todas las cosas aborrecibles, tales como los escorpiones, los sapos y las víboras, la fealdad, la tormenta, la sequía, la enfermedad y la muerte. Él mismo podía adoptar la apariencia de cualquier ser que le conviniera, puesto que sus numerosos disfraces eran un signo más de su naturaleza embustera y engañosa. Los demonios vivían en los animales inmundos, o vagaban por el aire, y podían entrar en los cuerpos de seres humanos, poseyéndolos y causándoles la enfermedad, la locura o la muerte. Con la intervención de Ahriman se introdujo por primera vez la violencia y el desorden en el cosmos. 
Algunos de estos demonios estaban asociados primordialmente con lo femenino. Los textos hablan de la insatisfacción de Ormuz por tener que crear a una hembra con objeto de propagar la raza humana; y aunque Spandarmat, la buena tierra, es una figura positiva de Gran Madre, son más frecuentes las manifestaciones de la Madre Terrible y negativa.

Druj, originalmente la abstracción de la mentira, se convierte en el período Pahlavi en una líder hembra de la hueste de los demonios. Az, el espíritu de la concupiscencia, el engaño y el desorden es masculino en el Avesta, pero en el maniqueísmo y en el zervanismo se transforma en el espíritu femenino de la codicia, la avaricia y el error. Jeh (Jahi), la Gran Prostituta, es un demonio femenino de la disipación y la lujuria, pero es más que eso: es uno de los principios colaboradores de Ahriman, una fuerza que desde el comienzo le ayuda a destruir el cosmos y es responsable de sacarle del estado de inconsciencia en que estaba. Un mito presenta a Jeh como la amante de Ahriman. Después de copular con el Príncipe de las Tinieblas, Jeh ensucia a Gayomart, el hombre perfecto. En el zoroastrismo, la mujer como vil seductora es más prominente que la mujer como madre nodriza.

Como podemos apreciar, las religiones del Oriente Próximo nos ofrecen una imagen acabada de cómo el predominio de lo masculino se había impuesto en el mundo de las creencias, desplazando a los valores vinculados a la feminidad dominantes en épocas anteriores. Este hecho respondía a los cambios sociales y económicos, que situaron a la mujer en una posición secundaria, tanto dentro del sistema productivo, como en el de poder. Sin embargo, la herencia milenaria de prestigio, basada en el control real y simbólico de los procesos reproductivos que atesoraba, no pudo ser ignorada. Lo femenino siguió estando significativamente representado tanto en las cosmogonías como en los panteones de las religiones originales, siempre relacionado con su faceta fértil. En ese sentido la importancia que se le daba no era menor que el misterio que entrañaba el origen de la vida tras el que se encontraba la mujer.

Los indicios más claros que señalan ese tránsito en el predominio de lo femenino a lo masculino, en el mundo de los valores, los 
hallamos, tal vez, en la gestación de la rica simbología que elaboraron esas religiones. Las asociaciones que se establecieron entonces entre la mujer y una serie de elementos han llegado hasta nosotros, y nos revelan el lugar de lo femenino en el campo de las mentalidades.

Data de esta época la relación de lo masculino con lo solar, impuesta por las castas sacerdotales en economías agrarias, lo que implicó, casi por exclusión, la asociación de lo femenino con lo lunar. Los principales dioses, Amon o Schnuna, eran solares, mientras que las divinidades lunares fueron casi siempre femeninas. La naturaleza cambiante de nuestro satélite le confería un aspecto inestable que abría un amplio campo de interpretaciones no todas positivas. La luna se regeneraba continuadamente y parece lógico que se la relacionase con la fertilidad y la vida. La desaparición del satélite en la oscuridad no era nunca definitiva y según un himno babilónico dedicado a la diosa Sin, la luna es «un fruto que crece por sí mismo». Algunas diosas lunares, como sucede con Hathor o Ishtar, patrocinaban a su vez la fertilidad. Pero también se veía en el astro un cuerpo celeste sujeto a la ley universal del devenir, del nacimiento y por ende de la muerte. Por eso, en contraposición al sol, significaba el mundo de las tinieblas, ya que su imperio era la noche. En este sentido su influencia aparecía como negativa, rigiendo el desorden —sólo tenemos que recordar cómo la asociación establecida entre la luna y la locura data de época remota-. Así mismo, frente al principio activo solar, a la luna se le atribuyó como rasgo la pasividad, ya que como espejo se limita a reflejar la luz del sol. Todo esto sirvió para asentar que la relación de lo femenino con lo lunar supusiera considerar a la mujer como voluble e inestable, pero también como pasiva $\mathrm{y}$, a pesar de esto, como temible.

La otra gran asociación simbólica con lo femenino se establece con la serpiente vinculada a su vez con la luna. Alguna de las características que el hombre de la antigüedad apreciaba en el ofidio permitía establecer una analogía con lo lunar y, a través de esto, con lo femenino; nos referimos a la muda de la piel en los reptiles, que les hacía pensar en una regeneración constante, como ocurría en el caso del astro. Por tanto la serpiente era un animal que proyectaba su influencia sobre la fertilidad como ocurría con la mujer, y que esta- 
ba, como ésta, en el origen de la vida, en lo primordial. En El Libro de los muertos los reptiles son los primeros en aclamar a Ra cuando aparece sobre la superficie de Nou.

Esa relación entre la luna, la serpiente y la fertilidad tanto femenina como telúrica ha sido claramente expresada por Mircea Eliade (1973: 163): «El mismo simbolismo central de fecundidad y de regeneración sometidas a la luna y distribuidas por el astro mismo o por formas consustanciales (magna mater, terra mater) explica la presencia de la serpiente en la iconografía o los ritos de las grandes diosas de la fertilidad universal. En cuanto al atributo de la gran diosa, la serpiente conserva su carácter lunar (de regeneración cíclica) unido al carácter telúrico. En un momento dado, la luna es identificada con la tierra, considerada a su vez como la matriz de todas las formas vivas».

En Egipto, el prestigio del reptil fue muy grande. Los nombres de las diosas aparecen en los textos con un signo determinativo que es el de la serpiente y su imagen servía para representar, entre otras divinidades, al mismo dios creador Atum. En El Libro de los muertos, Men, dios identificado con Horus, se cubría con una diadema adornada por dos plumas o dos víboras, y en la doble corona que portaba el faraón figuraba la cobra, el ureus, como signo de poder.

Pero la serpiente, símbolo de la fertilidad, presentaba una gran ambivalencia, podía ser valorado muy positivamente, pero también poseía numerosas connotaciones negativas. Por su hábitat más frecuente entre las rocas y su peculiar sistema de locomoción, reptando sobre su vientre, se le consideraba un animal telúrico. La «diosa cobra» de los egipcios vigilaba el crecimiento de las plantas, mientras que en la cultura mesopotámica estaba asociada a Ea, el dios de las regiones inferiores. Esto hacía que se la viera como un ser abismal que dominaba sobre lo subterráneo y sobre las profundidades marinas. Su picadura venenosa en algunas especies y su sigilo en el ataque la convertían en terrible, mientras que su frialdad y su hipnótica mirada la asociaban con lo inhumano e inmundo como ocurría entre los hebreos. En este sentido son numerosos los mitos en los que el ofidio es causa u origen de la pérdida de la inmortalidad en los hombres, como ocurre en el relato de Eva, que abordaremos más adelante, pero también en el de Gilgamesh. 
Para Diel (cit. en Cirlot, 1978: 407), la serpiente no es el símbolo de la culpa personal, sino del principio del Mal inherente a todo lo terreno, y la Gran Serpiente de la mitología sumeria es concebida como la expresión más acabada del Mal. La relación de muchos seres malignos con este reptil o con derivaciones fantásticas del mismo (hidra, medusa, dragón, etc.) es muy habitual. Cuando la diosa madre Tiamat planea su venganza, los primeros monstruos que crea son terroríficas serpientes con dientes afilados, mientras que en la mitología egipcia los genios maléficos que pueblan el Tuat cobraban la forma de este animal, aunque para los egipcios la relación más clara entre el reptil y el Mal se personificó en la serpiente Apopi, que todos los días pretendía obstaculizar la aparición de Re, el dios solar. Ese monstruo gigante, demonio de la lluvia, del temporal, del rayo y del trueno, atacaba todas las mañanas y todas las noches la barca del sol para detener su curso, convirtiéndose así en su eterno adversario al repetirse cada jornada ese drama cósmico de enfrentamiento entre la luz y las tinieblas.

La encarnación de la hostilidad frente al orden en la figura de Apopi se perfiló sobre todo a partir del Imperio Medio. El Libro de los muertos y la literatura mágica de las épocas más recientes consagraron esta serpiente como un ser lleno de agresividad y de perfidia. En el punto de partida, Apopi, nacida de un escupitajo del demiurgo Neith, se rebeló y eso selló su destino como genio de las sombras. Constantemente amenazaba con dejar seco el Nilo celeste por el que bogaba la barca del Sol. Sin embargo el dios Re, ayudado por la tripulación divina y por los conjuros de los sacerdotes, algunos de los cuales han llegado hasta nosotros en una obra titulada Libro de la destrucción de Apopi, siempre conseguía superar las maniobras de su enemiga y proseguir su marcha victoriosamente, logrando imponer el imperio de Maat.

La figura de Apopi tiende a confundirse o a superponerse con la de otras serpientes o dragones cósmicos. Ante todo con la del guardián del Dat, esto es, del lugar subterráneo por el que viaja el Sol durante la noche. Esta serpiente, llamada Nehaher (Rostro Espantoso) o Ur (Antiquísima), rodeaba con su enorme cuerpo el «refugio» nocturno del Sol, pero cada mañana el monstruo aflojaba sus anillos, y el astro (representado por Osiris en este mito, y ya no 
por Re) quedaba libre. Otras veces, Apopi se confundía con Nehebkau que, en el inicio del mundo, también constreñía con su cuerpo toda la creación. Pero aunque la identificación más importante se produce con el malvado Seth, sin embargo en un mito anterior ambos eran adversarios. Cuando la serpiente sembraba sus desastres, hambrunas, inundaciones y nubes de langosta, se decía que la barca de Re había encallado en el banco de arena de Apopi, y era Seth, por orden del mismo dios solar, el encargado de reducir a la cautividad al monstruo y restablecer el orden de las cosas. Sólo será a partir de la caída en desgracia de Seth cuando comience su complicidad con el terrible reptil.

Es cierto que los símbolos de lo femenino que elaboraron las culturas del Oriente Próximo fueron muchos, pero éstos nos parecen los más relevantes para subrayar el aspecto que nos interesa: el declive de lo femenino/lunar frente a lo masculino/solar y la relación que se puede establecer entre esa simbología astral con el Mal a través de la serpiente. Esta asociación negativa va a sobrevivir hasta el presente, aunque sólo sea a modo de superstición o de ofidiofobia tan extendida en el mundo occidental, como un arquetipo del inconsciente colectivo que nos lleva a manifestar nuestro rechazo a esos reptiles relacionados a su vez con la mujer.

A pesar de todo esto, no podemos vincular tajantemente el Mal a lo femenino ni en la religión egipcia ni en la mesopotámica. Sejmet o Hereskigal son divinidades ambivalentes que sólo en una de sus facetas encarnan lo diabólico; tal vez, porque ya la usurpación de las principales funciones por el patriarcado había colocado al frente de las más importantes atribuciones en el panteón a dioses masculinos. Los señores de las tinieblas eran siempre e incuestionablemente masculinos, como lo eran también los dioses de la luz. Parece que la masculinidad quedó reservada para los dos principios activos fundamentales simplemente porque desde la ideología patriarcal lo masculino era ontológicamente superior. El mazdeísmo será la religión que de modo más acabado establecerá ese patrón. Con ella el Mal, como gran principio universal, se masculiniza. No era concebible para la mentalidad dominante que pudiera ser de otro modo. 

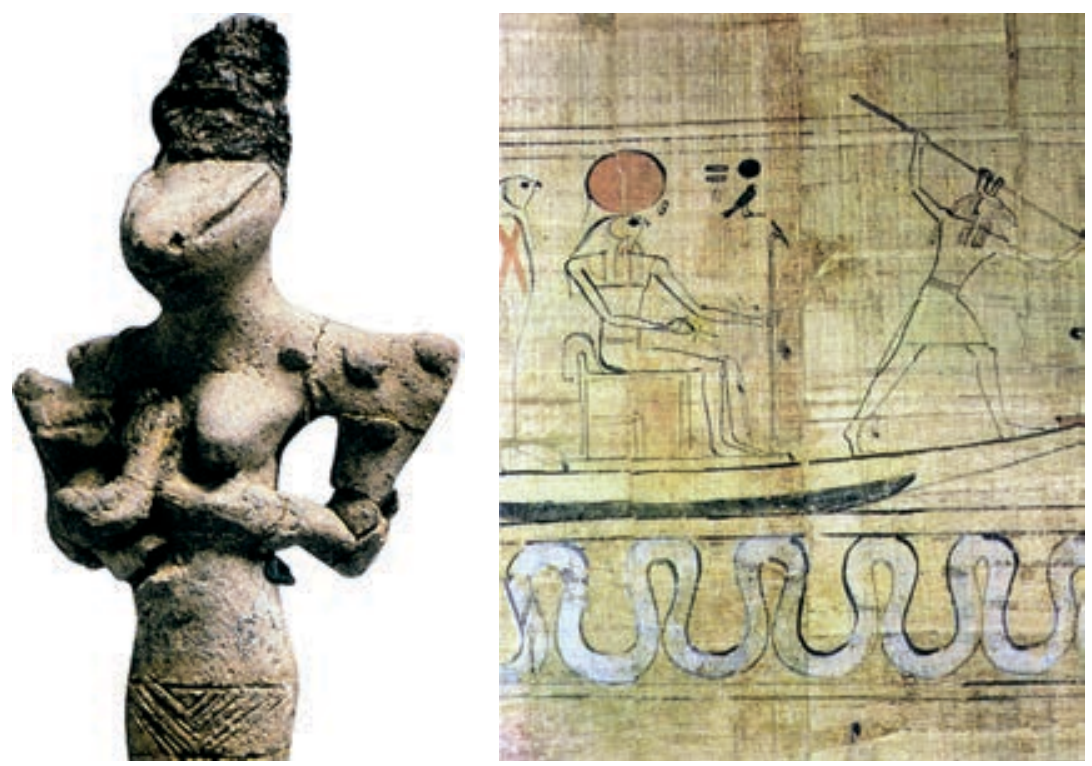

La serpiente, asimilada a lo femenino, simbolizó en el caso de la diosa egipcia Uadchet (izquierda) una fuerza positiva como es la fertilidad, mientras que la serpiente cósmica Apopi encarnaba la maldad de las tinieblas frente a la luz e intentaba impedir todos los días la navegación de la barca solar de Re.

En una cosmovisión dualista las dos fuerzas en lucha, con similares potencias, tenían que ser masculinas, aunque la misoginia tenía reservada a la mujer la función de ser causa eficaz del Mal. Lo femenino no podía desempeñar un destacado papel en ese sentido, pero podía ser mediador o introductor del Mal y lo que, quizá, resultaba más perjudicial, por medio de su naturaleza fecunda y material, lo femenino se manifestaba como el más importante sostén activo de la presencia permanente del Mal como el obstáculo principal para trascender la contingencia de la perversa realidad material. Pero para que quede perfectamente establecida esta relación que vincula el Mal con la trilogía mujer-pecado-materia será necesario que otras formas explicativas conocidas como filosóficas y otras concepciones de la culpa religiosa arraiguen en nuestra mentalidad. Para ello resultará imprescindible el aporte cultural del mundo griego y judío. 


\section{$\mathrm{V}$ \\ UNA GRAN CALAMIDAD \\ PARA LOS MORTALES}

En el primer milenio a. n. e., en las orillas del Mediterráneo se desarrollaron las civilizaciones griega y latina de cuya herencia son deudores buena parte del pensamiento y creencias del mundo occidental. Pequeñas comunidades políticamente independientes en la península helena y una ciudad-estado, Roma, en el corazón de la península itálica están en el origen de esa cultura que se ha considerado clásica.

Inicialmente, los griegos y los romanos practicaron una economía agrícola y ganadera, perfectamente adaptada al medio natural y basada en la pequeña propiedad y en la utilización de la mano de obra esclava, pero muy pronto se integraron en las rutas comerciales que surcaban el Mediterráneo, lo que les llevó a desarrollar una política expansiva y colonizadora que desembocó en la constitución de sendos imperios con los que culmina el mundo antiguo.

En la base de esas culturas nos encontramos por primera vez con la definición de hombre libre como sujeto de derechos civiles y políticos en el marco de una sociedad. Es así como nació el concepto de ciudadano, no sólo como opuesto al de súbdito, propio de los imperios orientales, sino también al de extranjero, esclavo o mujer, privados de ese derecho por su condición legal.

En la primera etapa de estas comunidades, los ciudadanos —un número muy reducido de la población- diseñaron formas de consenso pseudodemocráticas que, con el tiempo, han llegado a considerarse modélicas, al convertirse el gobierno de la Atenas del 
siglo v a. n. e. o el de la República Romana en paradigmas de la democracia antigua. Pero la misma idea de ciudadanía sólo era definible por oposición a aquellos que carecían de ella y la ciudadanía se convirtió en una prerrogativa de los varones libres. En este esquema de poder, consensuado por un sector de la población, la familia patriarcal se convertía en una pieza clave, pues sólo la línea paterna podía transmitir ese derecho fundamental. De este modo, el patriarcado no sólo encontró su justificación moral en el mundo clásico, sino que, de manera meticulosa, logró sancionar legalmente su preeminencia como modelo hegemónico en el seno de la sociedad.

No obstante, en el marco de relación política que fueron las democracias esclavistas y patriarcales, basado en un alto grado de libertad y responsabilidad entre los que eran ciudadanos, se pudo desarrollar toda una nueva cosmovisión distinta a la engendrada por las opresivas estructuras de poder teocrático características del Oriente Próximo. De esa nueva cosmovisión, no sólo surgirán unas creencias en lo sobrenatural muy humanizadas, sino que también aflorarán por primera vez novedosas teorías explicativas, que no entroncaban directamente ni con el mito, ni con la religiosidad. Nos estamos refiriendo a la filosofía, que hará su aparición en el mundo griego para arraigar profundamente en el pensamiento occidental.

De esa nueva mentalidad, alejada de la aplastante omnipotencia de los dioses, no emergerá ninguna imagen perfilada del Mal, aunque por primera vez se planteará su problema en otros términos -filosóficos y racionales - a partir de la pregunta que ya se hicie-

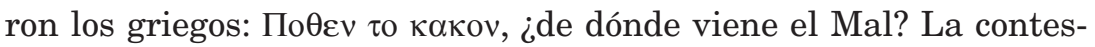
tación, que nos ofrecerá una amplia gama de respuestas a lo largo de más de mil años de historia del pensamiento grecolatino, no eliminará la pervivencia, sobre todo en el sustrato popular, de toda una serie de creencias en seres fantásticos y monstruosos vinculados a valores y fuerzas negativas. Pero será, sobre todo, en el campo de la religiosidad trascendente y mistérica y en las asociaciones simbólicas de algunas divinidades donde podremos apreciar el peso del patriarcado en las creencias clásicas. 


\section{Fatalismo y razón}

La visión del mundo y del hombre que tenían los griegos de la antigüedad, y que hasta cierto punto compartieron con los latinos, era tremendamente fatalista. Más allá de las explicaciones que los mitos pudieran dar de cómo entró el Mal en el mundo y sobre quién recaía esa responsabilidad, nos encontramos con que la cultura griega contempló el sufrimiento y el dolor como parte impredecible de la misma naturaleza, enfrentándose a ello con enorme resignación. Por eso junto al estereotipo que nos presenta a este pueblo amante de la vida como ningún otro, debemos contemplar esa otra faceta que lo muestra como pesimista respecto a la condición humana, escéptico frente al amparo divino, y armado con su sola razón, no para conjurar el Mal, sino para asumirlo con dignidad.

Para los griegos, el Mal, bajo sus distintas manifestaciones, se abate sobre los humanos de modo imprevisto para afligirlos y los dioses parecen ser los responsables. Homero, en su Ilíada (VI, 145) compara la extrema fragilidad de los hombres con las «hojas que el viento hace caer»; y en el canto XXIV (525), es Aquiles el que, conmovido por las lágrimas de Príamo y por su propio dolor, pronuncia una solemne frase condenatoria: «Lo que los dioses han hilado para los míseros mortales es vivir entre congojas mientras que ellos están exentos de cuitas». El mismo amargo resentimiento contra la divinidad podemos apreciar en el poeta Mimnermo de Colofón (D 2) cuando concluye su lamento sobre la vida con esta dolorida e impía observación: "No hay hombre alguno al que Zeus no envíe mil males».

Pero es sobre todo en el teatro, en las obras tanto de Esquilo como de Sófocles, donde más claramente se afirma que es la voluntad divina la que acarrea la trágica ruina del héroe o de su familia, puesto que la culpa se hereda con la sangre, y se ceba en los descendientes hasta la última generación. Como nos dice Sófocles en Antígona (585): «Felices aquellos cuya vida no ha probado las desgracias! Porque, para quienes su casa ha sido estremecida por los dioses, ningún infortunio deja de venir sobre toda su raza...». 
Para Esquilo o para Sófocles, que se dejan llevar por una piedad política frente a las primeras manifestaciones críticas a la religión por parte de los filósofos, la suerte es equivalente a la voluntad de Zeus, y éste es responsable de lo que ocurre en todas partes. En Los Persas (93), Esquilo llega a afirmar que ningún mortal puede escapar a las insidias de los dioses, y en Las Coéforas nos cuenta una historia en la que podemos apreciar de modo aún más explícito cómo los humanos no son sino meros juguetes de la divinidad.

Orestes es inducido por las Erinias, fuerzas que personifican las furias, a hacer pagar a los asesinos la muerte de su padre pero, cuando ha consumado su venganza matando a Egisto y Clitemnestra, las mismas Erinias persiguen a Orestes en nombre de su madre. Ante las quejas del héroe, lamentándose de su injusto sufrimiento, se le contesta que los dioses nos obligan a una acción necesaria y después nos castigan por ella. Para Esquilo los lamentos del héroe no son legítimos porque cuando Clitemnestra le pidió misericordia el hijo vengador le replicó que era el destino el que exigía su muerte. Esa ley, que tan cruelmente él aplicó, era la misma a la que Orestes se veía sometido.

A pesar de esta tendencia dramática a responsabilizar a los dioses de los males que padecemos, tanto en Esquilo como en Sófocles, encontramos un fondo moralizante. La divinidad no obra así por capricho. Persigue un fin que es siempre justo: educar al ciudadano en la heroicidad por medio del sufrimiento (Antígona, 176). Sin embargo, en la mayoría de los autores, para liberar a los dioses de esa terrible tarea pedagógica y, en última instancia de toda responsabilidad, se recurre al destino como el causante de los males.

En Eurípides, el último gran trágico del período clásico, presa ya del escepticismo religioso, resulta evidente que no son las deidades olímpicas las que obran el Mal. Es la Moira la que no establece distinción entre buenos y malos, tratándolos a todos por igual. El destino no es moral y no entiende de premios o castigos. Cuando Hecuba (625) apela a la ley y la justicia, su alegato fracasa, y la troyana acaba con la dura afirmación de que «el más feliz es aquel a quien de día en día no le ocurre ningún mal». Por eso el destino, los griegos lo saben, es siempre cruel y tarde o temprano el hombre se 
encuentra sumido en la desgracia. Para ellos, la felicidad resultaba peligrosa y como muy bien observó Murrey (cit. en Dodds, 1999: 61): «en la poesía griega es un presagio siniestro para cualquiera ser calificado de... feliz».

Son las Moiras las que actúan de forma autónoma, imponiéndose al mismo Zeus, que se ve obligado a ejecutar las determinaciones de esa ley inmarcesible. En Homero, la Moira aparece en singular y es ella la que distribuye a cada uno su parte de años, de días y de horas. Es ella la que determina que la suerte de Aquiles sea morir glorioso y joven; y la diosa Tetis, su madre, aunque lo sabe, no puede hacer nada por evitarlo. El propio Zeus, ansioso por salvar a su hijo Sarpedon, que va a caer bajo los golpes de Patroclo, renuncia a cambiar su destino; no podría perturbar el orden establecido por la Moira. Su papel debe limitarse a sostener la balanza en que se pesa la suerte de los humanos y leer el fallo que ésta pronuncia al inclinarse. Eso es lo que hacen los dioses cuando llega la hora de la muerte para Héctor, y en la Odisea (III, 230-238) será Atenea, a través de Mentor, la que explicará a Telémaco esa ley inquebrantable: "Fácil es para un dios, si lo quiere, aunque sea desde lejos socorrer a un mortal... Mas la muerte es común para todos, ni pueden los dioses evitarla al amado varón una vez que le toma el destino fatal del morir...».

En las obras de Hesíodo, las Moiras se multiplican; así, aparecen tres que son hijas de la Noche, aunque también se las convertirá en hijas de Zeus y de Themis. Cloto, la hiladora del hilo de la vida; Laquesis, la que da la felicidad; y Atropos, la insobornable, que determina el fin para los mortales. Ellas rigen, desde el nacimiento, la suerte de los humanos. El arte las representó, de acuerdo con su función, llevando el huso y el hilo; a veces también, como su madre Themis, portando un rollo, donde estaba inscrito el porvenir de los hombres; y una balanza, con la cual pesaban sus actos, o unas tijeras, con las que cortaban el hilo de la vida. Los romanos las equipararon a sus Parcas, curiosamente también personajes femeninos. Ellas serán las encargadas de sembrar, inopinadamente, el Mal, salpicando la existencia de sufrimientos hasta que deciden su inexorable final. 


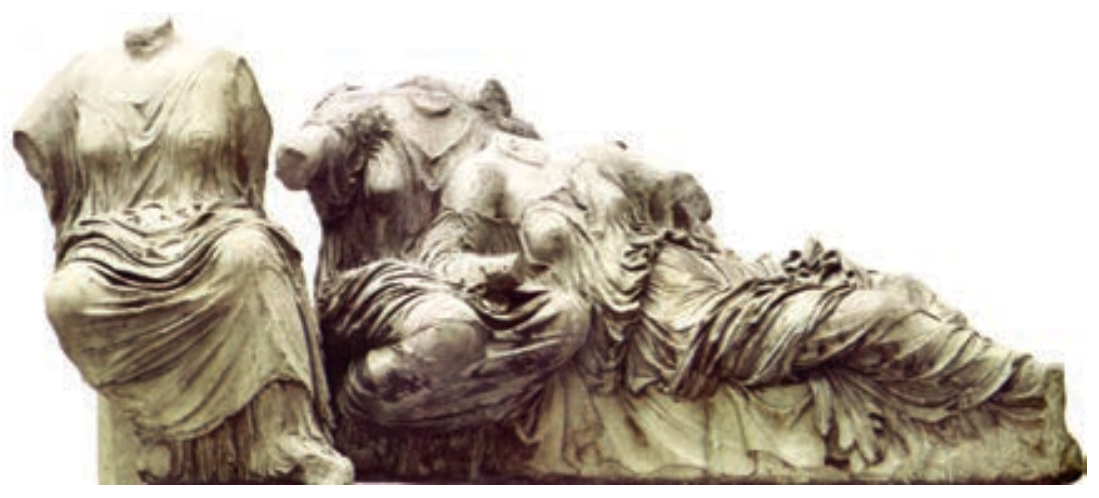

Los griegos y los romanos, tremendamente fatalistas, concibieron el mal como un aspecto inexorable del trágico destino de los humanos, regido por las Moiras o las Parcas, personificadas por tres figuras de mujer: Cloto, Laquesis y Atropos.

No puede extrañarnos, pues, que Herodoto (Historias, I, 31) narre la historia de una madre que imploró a Hera que otorgase el mayor bien a sus hijos en premio a su piedad. La diosa accedió a sus súplicas, y los muchachos fueran liberados de la vida sin sufrimientos. En Edipo en Colona (1224), el piadoso Sófocles supo resumir este sentimiento trágico en una frase terrible, que no era sino una sentencia común entre los griegos: «El no haber nacido triunfa siempre sobre cualquier razón. Pero ya que se ha venido a la luz lo que en segundo lugar es mejor, con mucho, es volver cuanto antes allí de donde se viene». Frente a esta concepción fatalista de la vida, frente al amoral desamparo en el que los sumía la divinidad, la cultura griega sólo podía recurrir a la razón para intentar explicar el imperio de ese orden natural y para ayudar al hombre a convivir con él.

Las soluciones que sugieren los filósofos ante la pregunta «¿de dónde viene el Mal?» dan como resultado diferentes respuestas que a la larga tendieron a favorecer el escepticismo. Los presocráticos, en general, no fueron capaces de trascender el fatalismo mitológicoliterario al abordar el problema. Así, para Heráclito el Mal forma parte del conjunto de la armonía universal a la cual contribuye, lo que puede implicar la idea de una «justicia» inmanente. Leucipo y Demócrito se limitaron a vincular las nociones de Bien y de Mal al 
azar. Los pitagóricos profundizaron más en el tema e hicieron una curiosa aportación que va a conocer un notable éxito. Pero el pitagorismo fue una escuela de pensamiento que estableció una estrecha relación con un sustrato de creencias religiosas de procedencia oriental: el orfismo. Fue de estas influencias de donde surgió la teoría del Mal desarrollada por los pitagóricos.

El orfismo era un culto religioso muy primitivo que tenía su origen en Tracia y que llegó a Grecia en torno al siglo vi a. n. e., extendido por sacerdotes vagabundos. Los «orfeotelestes», que así se denominaban estos curiosos personajes, iban de aldea en aldea predicando determinado tipo de ritos purificadores e iniciáticos con los que prometían la dicha en una vida futura a quienes los siguieran. Estas creencias presentaban un marcado carácter sectario y aparecían como un desafío al culto predominante impuesto por las polis.

Estos orfeotelestes eran los herederos refinados de viejos ritos chamánicos que se negaban a adaptarse a las nuevas estructuras políticas de la Grecia urbana, marginándose voluntariamente del sistema religioso en auge. Por eso el pensamiento oficial encarnado por Platón o Teofrasto, únicas fuentes de información que tenemos sobre los órficos, los despreciaba y los tachaba de farsantes. No obstante, tuvieron cierto predicamento entre el pueblo y ejercieron una gran influencia entre los pitagóricos, quienes integraron las doctrinas órficas dentro del sistema, adaptándolas a las nuevas corrientes de pensamiento.

El mito central del orfismo guarda estrecha relación con Dionisos, otra curiosa manifestación religiosa de la que hablaremos después. Según este mito, conocido como el de Dionisos y los titanes, al comienzo del mundo sólo existía Fanes, el andrógino que da a luz todas las cosas. Pero Fanes engendró a Urano y éste a Cronos, el padre de Zeus. Como podemos apreciar en esta parte del relato se incorporan elementos de la cosmogonía olímpica, puesto que se nos cuenta la lucha de Zeus con los titanes. La originalidad órfica aflora cuando se nos dice que Zeus, tras vencer a los titanes, se tragó a Fanes, asimilando así en su interior el principio original. 
Convertido de este modo en un dios creador, Zeus generó de nuevo todas las cosas, incluyendo a los mismos titanes que él había destruido. En ese nuevo momento primordial se decidió también a engendrar un hijo, Dionisos. En su odio a Zeus, y envidiosos de la felicidad de Dionisos niño, los titanes distrajeron al pequeño con un espejo y se apoderaron de él para despedazarlo y devorarlo. Pero Atenea logró rescatar el corazón del niño dios y lo entregó a su padre, que lo ingirió con la finalidad de devolverle la vida. Para ello, el dios celeste copuló con la mortal Semele, la cual dio a luz de nuevo a Dionisos. Complacido con la resurrección de su hijo, Zeus procedió a castigar a sus asesinos destruyéndolos de nuevo por medio del rayo. De las cenizas de estos seres impíos y abominables nacerán los humanos.

El mito introduce de forma imaginativa el dualismo en el pensamiento griego, pero también la idea de una posible reencarnación cuyas raíces se hunden sin duda en el chamanismo tracio. La humanidad, nacida de los restos de los titanes, tiene una naturaleza doble: espiritual y material. La parte material deriva de estos seres terribles de los que procedemos y la parte espiritual de Dionisos que, al haber sido devorado por ellos, también se integra en cada uno de nosotros.

Pitágoras supo darles a estas ideas un alcance general trasformando el mito en logos e incorporando lo básico de la leyenda a una doctrina que se convirtió en respetable en la medida en la que adoptó el lenguaje de los filósofos. Según él, el alma es un principio inmortal de origen astral que, como consecuencia de una caída, está obligada a encarnarse. El pitagórico Filolao afirmará que el alma está asociada al cuerpo y se encuentra en él sepultada como en una tumba, lo que guarda un gran parecido con lo que nos dirá Platón en el Cratilo (400 c).

Para los pitagóricos, al término de la vida humana, el alma liberada va a purificarse a las regiones bajas de la atmósfera, después regresa a la zona astral antes de sufrir una nueva reencarnación. La doctrina de que el cuerpo era la cárcel del alma les llevó a creer en la metempsicosis, la trasmigración de las almas. Sólo se puede escapar a la materia corporal por medio de una serie de encarnaciones 
que podremos ir superando en la medida en que nos entreguemos a las prácticas rituales destinadas a alcanzar la pureza. El proceso de reencarnación sólo cesará cuando se logre esa pureza perfecta, y se retrasará en la medida en que se produzcan recaídas en la materialidad. Por eso los pitagóricos se abstenían de comer habas, que consideraban como la semilla por excelencia y por tanto como la raíz de la carne.

Con estas doctrinas vemos aparecer en el mundo griego el dualismo que ya nos hemos encontrado en la religión mazdeísta, pero el dualismo pitagórico es diferente al de Irán. El dualismo persa planteaba un conflicto entre dos poderes espirituales, uno de luz y el otro de tinieblas. El dualismo órfico nos propone un conflicto que se dirime en el seno del propio individuo en función de su doble naturaleza espiritual y material. En el pitagorismo queda enunciada claramente, y por primera vez, la oposición de materia y espíritu, de cuerpo y alma, que tanta influencia tendrá sobre el pensamiento cristiano y que tanto contribuirá a asimilar el Mal a la naturaleza material de los hombres. Esta interpretación ganó terreno en el período helenístico al sumarse a ella la influencia directa del dualismo iranio. Fue entonces cuando la materia y el cuerpo se asignaron al reino de la maldad y el alma quedó consagrada como el símbolo de la bondad espiritual.

Pero antes de que esto ocurriera, las ideas pitagóricas ya habían prendido en los medios aristocráticos de Italia meridional. Se constituyeron sectas en Crotona, Locres, Metaponto y Tarento que, incluso, llegaron a hacerse con el poder en algunas de estas polis durante un tiempo. Así, curiosamente, el chamanismo, fenómeno primitivo y extraño a la ciudad y, en cierta medida, ajeno también a lo que tradicionalmente hemos considerado como mentalidad helena, consiguió ser aceptado por la élite pensante gracias a la elaboración pitagórica, llegando a influir de modo poderoso en uno de los más acerados críticos del orfismo, el mismísimo Platón.

La elaboración de Platón en torno al Mal es más rica y compleja que la de su maestro Sócrates y en ella podemos apreciar la influencia pitagórica. Platón parte de la idea socrática de que el Mal surge del desconocimiento o la ignorancia que el individuo tiene 
sobre lo bueno y el Bien, pero Platón profundizó en el problema al planteárselo en un sentido inverso. Para poder determinar qué es el Mal y dónde radica era necesario, y mucho más importante, saber y conocer qué era el Bien. Con este propósito tan ambicioso, Platón se enfrentaba a las pretensiones relativistas de la escuela sofista que consideraba que el Bien, como tal, carecía de naturaleza propia y específica; y que tanto el bien como el mal eran convencionales y relativos.

Los sofistas, influidos por el sistema democrático, reducían a términos de correlación de fuerzas los conceptos trascendentes y defendían que el poder o la operatividad eran las únicas medidas del bien y el mal, de lo bueno y lo malo. Platón que defendía ideas más elitistas y aristocráticas combatió siempre esas teorías, desarrollando un pensamiento de base monista en el que, sin embargo, tuvo que integrar la dualidad.

Los platónicos sostenían la creencia de que todo es producto o emanación de un solo principio que identificaban con la idea de Bien supremo, pero se veían obligados a admitir que en el cosmos existía un elemento refractario cuyo origen no quedaba claramente establecido. De la mayoría de los textos platónicos parece desprenderse que ese elemento era la emanación más baja de ese principio único y primero, pero en su teoría también quedaba abierto un portillo por el que se deslizaba el dualismo, al no rechazar de plano que pudiera existir un elemento enteramente independiente en el que se encarnaría el Mal. ${ }^{1}$ Ese elemento más bajo se identificaba con la

1 Existe un conocido pasaje en el libro x de Las Leyes (896 e) en que parece reconocerse una dualidad original. Todo el planteamiento parte de la idea que Platón tiene sobre la causa última del movimiento. Para el filósofo, la materia no puede engendrar movimiento de modo autónomo, sólo el alma es la que puede imprimir movimiento a los cuerpos. Un animal se mueve porque lo mueve su alma y los objetos son movidos por cuerpos animados. Esto le lleva a sostener que: «En consecuencia ¿no habremos de afirmar necesariamente que el alma es la causa del bien, del mal, de lo bello, de lo feo, de lo justo de lo injusto y de todos los contrarios, ya que la hemos admitido como causa de todo?...».

«¿Será un alma sola o varias?»—se pregunta el filósofo—. «Varias es lo que yo responderé por vosotros. En todo caso no hemos de poner menos de dos: la que no puede hacer más que el bien y la que es capaz de hacer lo contrario».

La opción dualista tan claramente expresada no vuelve a aparecer en la obra de Platón, rica por otra parte en contradicciones y ambigüedades. 
materia, pudiéndose apreciar aquí la influencia que el orfismo ejerció en el pensamiento de Platón.

Lo básico para el filósofo es la oposición que establece entre el mundo ideal o espiritual y el mundo material, confiriéndole al primero un estatus de preeminencia que lo hace más real y mejor que el material. La tradición occidental subsiguiente quedó profundamente marcada por estas ideas. El cristianismo, producto en parte de la herencia helenística, se impregnará de platonismo, consagrando la superioridad del espíritu sobre la materia y la existencia de un principio bondadoso y único, lo que no le impedirá aceptar la presencia de otro inferior y maligno.

Platón no excluyó tampoco de su obra una cierta faceta moralizante. El filósofo, consciente de que sus planteamientos metafísicos no terminaban de justificar la existencia de los muchos males que aquejan al mundo, incorporó a sus teorías - recurriendo a los viejos mitos griegos sobre la vida de ultratumba - toda una concepción sobre el premio o los castigos que el alma del individuo disfrutaría o padecería en función de su comportamiento en esta vida.

La idea de un juicio post mortem no era nueva, ya la hemos encontrado en la religión egipcia, pero con Platón se enriquece al ponerse en relación con el resto de su filosofía para ejercer una enorme influencia en el pensamiento posterior. No obstante, no vamos a encontrar en su obra una visión coherente al respecto, sino algunas reflexiones que guardan relación tanto con sus concepciones idealistas como con su preocupación por establecer los principios de una moral práctica.

En esta elaboración parte de creencias anteriores sobre el más allá establecidas por la mitología griega en la que, a diferencia de lo que ocurría con la egipcia, el alma del inicuo era condenada a castigos y penas eternas. Para los egipcios un fallo desfavorable en el juicio osiríaco suponía simplemente la muerte, el no poder trascender a la vida del más allá; sin embargo en los mitos griegos el condenado debía padecer determinado tipo de sufrimientos por toda la eternidad. Platón, partiendo de estas creencias, establecerá un sistema de redención de penas para la mayor parte de los casos, pero, sobre todo, asentará la idea de que a través del sufrimiento se podía alcan- 
zar la purificación. Esta vinculación entre sufrimiento y salvación también será adoptada por el cristianismo primitivo que la convertirá en uno de sus paradigmas fundamentales. ${ }^{2}$

Para los griegos, tan pronto como el muerto entraba en el reino de Hades era conducido ante el tribunal que tenía que decidir en cuál de las tres regiones de este reino, previamente señaladas, tendría que permanecer. Homero cita solamente a un juez, Radamante, hijo de Zeus y de Europa. Versiones posteriores añaden otros dos jueces y el tribunal aparece ya formado por Minos, Radamante y Eaco. Los tres se habían hecho acreedores, durante su vida, a la equidad, imparcialidad y sentido de rectitud. En los casos de discrepancia en el seno del tribunal solía decidir Minos. Su juicio determinaba si el alma del difunto iba al Erebo, al Tártaro o a los Campos Elíseos.

Los condenados al Erebo eran conducidos antes al palacio de la Noche, delante de las Erinias, que velaban para que los dioses ejercieran su recta justicia. A veces, eran ellas mismas las encargadas de acusar al espíritu del difunto o de perseguir a los vivos, como hemos visto en el caso de la tragedia. Las Erinias eran tres: Megere, Alecto y Tisifon. Se las representaba con cabellera de serpientes y aspecto feroz. Su mirada era espantosa, por lo que se las suele confundir con las gorgonas, especialmente con Medusa.

En el mismo palacio de la Noche residía también su hijo, Tanatos, dios de la muerte; su imagen respondía a la del propio Erebo: un paisaje desolado, de pantanos pestíferos y áridas llanuras

2 La idea de sufrimiento/muerte igual a resurrección, por otras razones relacionadas con las mitologías escatológicas de tipo vegetal, ya la encontramos en la palingenesia egipcia. Es necesario que aquello que simboliza la vida muera para poder renacer pero, en ocasiones, esta muerte adquiere la forma de un sacrificio, o de una muerte violenta. Osiris es asesinado y despedazado por Seth y Dionisos por los titanes en el mito órfico. En este tipo de creencias encontraríamos ya la raíz del sufrimiento redentor.

En el caso de Platón se parte de la idea de castigo. Las faltas o las culpas contra los dioses deben ser purgadas por medio de una pena. Esa pena puede ser eterna o, a través del sufrimiento, puede terminar redimiendo al que la padece. Este planteamiento se mezclará con la purificación del alma del individuo mediante la mortificación de la materia para dar como resultado la ecuación cristiana de sufrimiento igual a salvación. 
llenas de lagos sulfurosos, donde las sombras de los muertos erraban sin reposo entre espantosos monstruos, expiando de ese modo sus culpas.

Al Tártaro eran precipitados los enemigos de los dioses, ya fueran dioses o descendientes de ellos, o las almas de los mortales que habían cometido terribles crímenes. Todos sufrían allí castigos eternos, sin posibilidad alguna de perdón. Allí moraba por toda la eternidad Titios, uno de los gigantes, que le había faltado el respeto a Letona, la madre de Apolo y de Artemisa. Su castigo era horrendo: vivía, pero constantemente era devorado por dos buitres. También penaba allí Tántalo, que había robado el néctar y la ambrosía del Olimpo, con el fin de darlo a probar a los mortales. O, según otra versión, porque había traicionado a los dioses. Castigadas allí eternamente, estaban asimismo las Danaides, hijas del rey Danaos, que habían asesinado a sus maridos en la noche de bodas. Su castigo era desesperante: llenar un tonel sin fondo con sucesivos acarreos de ánforas de agua. La mitología griega es rica en ejemplos de esta índole, en los que se mezclan los castigos más originales con los tormentos más refinados. Las almas condenadas sabían que debían cumplir su condena y la aceptaban resignadamente.

Por último, los Campos Elíseos eran la morada de los que habían sido juzgados como dignos de recibir una recompensa. Allí los espíritus permanecían eternamente jóvenes y gozaban de una primavera sin fin.

¿Cómo pudo Platón integrar esas creencias fabulosas en su sistema de pensamiento? Cuando el filósofo elaboró sus teorías era consciente del escepticismo que ya existía entre un sector de la población griega sobre ese tipo de relatos, precisamente aquel segmento más culto y urbanita al que él pretendía dirigirse. Pero Platón también se percataba de que la masa de la población seguía creyendo en esos mitos y que, cada vez más, fomentado por los cultos mistéricos de los que hablaremos más adelante, las gentes sencillas demandaban seguridades respecto a la otra vida; por eso no dudó en avalar el mito para, a través del mismo, introducir lo fundamental de su sistema de pensamiento. Por eso al final del Gorgias (524 b) pone en boca de Sócrates, que habla con Calicles sobre la vida del más allá, la 
siguiente afirmación: «Escucha... un relato muy bello que tu considerarás una fábula... pero que yo tengo por narración verídica. Lo que voy a contarte, en efecto, vas a oírlo de quien lo juzga verdadero».

Lo fundamental para Platón era concienciar a las gentes de dos cosas: la primacía de lo espiritual sobre lo material y la necesidad de un comportamiento ético en esta vida para ganar la felicidad en la otra. Todos aquellos que cometieran faltas atroces como actos de pillaje en los templos u homicidios deberían pagar por sus culpas. ${ }^{3}$ Como puede apreciarse, lo que queda claro para Platón es que a la muerte le sigue un juicio y esta idea la hallamos en el Gorgias, el Fedón y La República, en las que nos habla del Hades.

La visión infernal que en ellas nos da le sirve al filósofo para ratificar las teorías pitagóricas de la reencarnación asumidas por él, puesto que después de un viaje de mil años en el más allá, parece ser que las almas terminan por reencarnarse y, olvidando su pasado, renacen en un cuerpo. Las almas de quienes durante la vida anterior fueron esclavos de sus deseos corporales se reencarnarán en animales que representan su vicio dominante, arrastradas hacia el fondo por el elemento corporal sin poder levantar el vuelo y alcanzar la purificación.

En todas estas creencias parece quedar clara la preeminencia de lo espiritual sobre lo material, pero no se establece de modo nítido que sea la materia la causa eficiente del mal, eso corresponderá al platonismo posterior.

3 El escenario del sufrimiento que deben padecer las almas malvadas es otra de las aportaciones fundamentales del infierno platónico. El castigo o la purificación sólo se consigue mediante el padecimiento material, contrasentido incomprensible ya que esas penas las sufre la parte espiritual del individuo condenado. Pero en el infierno platónico así queda establecido y los castigos que en él se mencionan se van a incorporar, ampliados y refinados, en infiernos posteriores.

En La República (616 c), Platón cita el caso de Ardieo, un tirano de Panfilia, asesino de su padre y de su hermano y autor de innumerables fechorías, quien cada vez que intentaba salir del Tártaro, se veía arrastrado a él de nuevo por «unos hombres salvajes y que aparecían envueltos en fuego". Al tirano Ardieo y otras almas en pena que pretendían huir «les ataban los pies, las manos y la cabeza, los echaban por tierra y los desollaban, y luego, llevándolos a la orilla del camino los desgarraban sobre retamas espinosas, declarando a la vez a cuantos pasaban por allí por qué trataban de ese modo a aquellos hombres y se empeñaban en arrojarlos al Tártaro». 
En el pensamiento de Aristóteles, el otro gran filósofo de la antigüedad, no tiene cabida un principio del Mal. Para él todo movimiento viene de la Primera Causa y se orienta hacia la Causa Final; en ese sentido, el Bien y el Mal no son formas separadas. No hay nada que sea bueno o malo en sí mismo; el Bien y el Mal pueden aplicarse a toda categoría de la naturaleza. El mal es simplemente un fallo en los seres en cuanto a estar imperfectamente orientados hacia la Causa Última; este fallo puede ser una imperfección material o moral. Si es moral, se debe a un alejamiento del justo medio, ya hacia el exceso, ya hacia la insuficiencia. En el pensamiento de Aristóteles, nada alentaba el concepto de un principio del Mal o su personificación. La materia puede entorpecer el progreso hacia el fin último, pero no se la puede considerar un principio del Mal.

Como vemos, las creencias religiosas terminaban en el mundo antiguo por revestirse de pensamiento filosófico. Ya hemos señalado cómo el orfismo fue adoptado por el pitagorismo para acabar influyendo en el platonismo. Lo mismo sucederá con los planteamientos dualistas neoplatónicos que terminarán dando cobertura filosófica a las creencias mazdeístas, aunque introduciendo un elemento añadido, procedente del desarrollo de las corrientes moralizantes posaristotélicas, como es el del libre albedrío.

Para Plutarco, pero también para Máximo de Tiro o para Celso, la existencia del Mal en el mundo se debería, en primer lugar, a la creación de la materia y, en segundo, a la acción del libre albedrío del hombre, no tanto en su comportamiento ético para con los demás, como en su inclinación por los placeres materiales por encima de los espirituales. Plutarco retomaba así el argumento de Platón en el Libro $X$ de Las Leyes. La materia no puede ser la causa de sí misma; por tanto hemos de deducir que fue producida por el espíritu. Como el espíritu del Bien no puede ser el origen del Mal, tenemos que llegar a la conclusión de que existen, al menos, dos espíritus que deben ser contrarios y contrapuestos. El espíritu creador de la materia sería a su vez responsable del origen del Mal.

Las escuelas posaristotélicas aún ahondaron mucho más en una visión humanista del mal. Para los estoicos, cuya influencia sobre el 
pensamiento moral cristiano fue inmensa, el núcleo de sus ideas sobre el tema descansaba en una actitud radical de la voluntad: la decisión de aceptar el dolor, de anular el mal y sus causas, como parte del orden (cosmos), y de insertarse volitivamente en la totalidad universal: «Es decir, de negar el dolor asumiéndolo, de rechazar el mundo hostil incorporándolo, de invertir, en suma, la relación dialéctica sujeto-mundo» (Puente, 1974: 85). Para los estoicos los seres humanos tienen libre albedrío, pero la libertad consiste en aceptar la realidad distanciándose de ella. El error y el mal proceden de la no asunción de los designios de la naturaleza en una resistencia inútil, porque de todos modos estamos forzados a desempeñar nuestro papel y si nos oponemos a ello sólo conseguimos garantizarnos la infelicidad. Evitemos los excesos y aceptemos libre y felizmente nuestra función en el universo ordenado.

En la misma línea que los estoicos discurrieron los epicúreos. Según Epicuro, el fundador de esta escuela, el universo es el resultado del azar que ha combinado de forma plural los átomos que lo componen. Los dioses, de existir, son injustos y egoístas, no les interesan en modo alguno las acciones de los hombres que, en consecuencia, no pueden esperar nada de ellos, aunque, como contrapartida, tampoco los deben temer, ni en este mundo ni después de la muerte. Para estos materialistas, el Bien y el Mal son construcciones humanas enteramente relativas. Obrar mal es preocuparse en exceso por las cosas de este mundo que, en última instancia, carecen de significado. Por eso, el modo de pensar correcto será evitar el dolor evitando las preocupaciones, mientras que el Mal será todo lo que amenaza la paz social y el equilibrio del individuo.

El epicureismo, a través de la obra de Lucrecio, nos ha dejado algunas de las reflexiones más audaces y modernas que se escribieran en el mundo antiguo sobre el Mal. Este escritor latino del siglo I a. n. e., autor del poema moral De la naturaleza de las cosas, le dice a la humanidad que no debe temerse nada más que a sí misma. Todo mal que pueda sufrir descansa en las acciones humanas y en las actitudes que se adoptan frente a la vida y a la misma naturaleza. Tampoco nada se debe temer tras la muerte porque no existe un mundo del más allá. 
Lucrecio es el primero en reprochar a todas las religiones haber fomentado el Mal al sembrar en la conciencia de la humanidad temores y angustias a propósito de castigos infernales, cuando han sido las religiones las que en muchos casos han propiciado actos que el poeta considera criminales. Las creencias en seres sobrenaturales no han servido ni como paliativo, ni como consuelo de los males que los propios humanos producen o padecen; por el contrario, las religiones, han excitado sus pasiones y actuado como un velo que les ha impedido ver la realidad.

Para este existencialista avant la lettre el verdadero infierno es la vida o, más bien, la angustia que se apodera de nosotros ante amenazas imaginarias o ante males reales. El miedo a la muerte, el miedo a los dioses, el miedo a los castigos divinos, pero también el miedo a asumir nuestra naturaleza vulnerable y contingente, el mismo miedo a la conciencia, poblada de fantasmas y de creencias absurdas que nos han imbuido, son los verdaderos males que aquejan al ser humano. Para librarse de ellos debe enfrentarse a esos temores, conocerse a sí mismo, moderar sus instintos y aceptarse. Mientras no sea capaz de enfrentarse a esas tareas padecerá en esta vida los peores castigos del infierno. Lucrecio, mucho antes que Sartre, nos descubrió que el infierno, el Mal en definitiva, está en nosotros mismos y en los demás.

Y hallamos en la vida ciertamente cualquier horror que en Aquerón profundo haber dicen...

La incertidumbre de futura suerte no puede en tanto ver, ni sabe cuándo tendrán por fin un término sus males, y temen que se agraven en la muerte: la vida es el infierno de los necios. De la naturaleza de las cosas (III, 978-1024).

Tanto los epicúreos como los estoicos rechazaron la idea de un Bien y un Mal sobrenaturales y buscaron en los humanos y sus acciones su explicación, considerando que ambos conceptos eran meras construcciones culturales destinadas a justificar ilusoriamente la misma naturaleza o la propia condición humana. No obstante, las aportaciones hechas por la filosofía clásica sirvieron para establecer unos principios morales al margen de los imperativos de la religión. Había pautas generales de comportamiento a las que 
supuestamente todos debían atenerse para poder llevar una vida digna en sociedad. Determinadas acciones podían considerarse intrínsecamente malas independientemente de lo que establecieran las leyes humanas o divinas. Una ley racional y universal regía el cosmos, y el Mal consistía en no atenerse a esa ley. El Mal era, pues, o un defecto o insuficiencia de la naturaleza, o bien una trasgresión o un exceso frente a los límites marcados por esa ley cósmica.

Pero frente a esta elaboración intelectual de las élites cultas del mundo grecorromano, las clases populares buscaban explicaciones al mal más sencillas y menos racionales. Las especulaciones filosóficas no podían servir para comprender un mundo en que el desorden y la destructividad, mas allá del control del individuo, parecían acechar por todos lados. Por eso, las viejas creencias que personificaban el Mal y las antiguas prácticas para conjurarlo siguieron vigentes en el mundo clásico tanto como lo habían estado en épocas anteriores.

\section{Sobre daimones y maleficios}

Las religiones griega y romana fueron elaboraciones complejas; por un lado, hunden sus raíces en las creencias más primitivas pero, por otro, pretenden responder a modelos sociales y políticos más evolucionados que los que se habían dado en el Próximo Oriente antiguo. Por eso no encontramos en ellas un clero todopoderoso o una confusión entre el orden político y el sobrenatural, lo que no evita que mantuvieran rasgos arcaicos, producto en ocasiones de su naturaleza sincrética, hasta épocas muy avanzadas. Por ejemplo, cuesta imaginar a los desenfadados dioses de la mitología olímpica reclamando sacrificios humanos y, sin embargo, ésa debió de ser una práctica que se mantuvo viva durante largo tiempo.

En el mundo griego nos encontramos con el testimonio literario que avala este tipo de sacrificios mencionados en la Ilíada (XXIII, 175) y en numerosas tragedias. La Ifigenia de Eurípides nos plantea la necesidad de que la hija de Agamenón perezca bajo el cuchillo de Calcas, para que la flota griega pueda partir hacia Troya, otras víctimas humanas son inmoladas en Las troyanas, en Hecuba, 
o en Las heraclidas. Pero más allá de las referencias literarias, hallamos testimonios históricos. El adivino Eufrantides, que asistió a Temístocles en Salamina, ordenó sacrificios humanos a Dionisos Omestes y el rito se mantuvo hasta época avanzada, porque Plutarco, promovido a la dignidad de primer magistrado de su ciudad natal, Queronea, nos cuenta cómo le tocó presidir la ceremonia de «expulsión del hambre», que consistía en golpear a un esclavo con las ramas de determinado árbol, dotado de ciertas propiedades, para echarlo luego de la ciudad entre el griterío ritual de los celebrantes: «Fuera el hambre y dejemos que entren la prosperidad y la salud».

Esta ceremonia guardaría relación con otras que conocemos como las celebradas cuando un brote de la peste azotaba a Marsella, una de las colonias griegas más ricas y esplendorosas, y en las que se practicaba como ofrenda el sacrificio de un hombre de humilde condición que era mantenido a costa de la ciudad para tal fin. En el ritual se le investía con un hábito especial y se le ceñía una corona de ramos benditos paseándolo por las calles, mientras los habitantes pedían a su paso que recayesen sobre la cabeza del «chivo expiatorio» todos los males que afligían a la urbe. Por último, lo lapidaban fuera del recinto amurallado.

El festival de la Targelia, que se celebraba en Atenas el mes de mayo, comprendía una ceremonia en que un hombre y una mujer eran conducidos a las afueras de la ciudad y lapidados hasta morir. En Abdera, ciudad de Tracia, incluso era un ciudadano significado el que se ofrecía como víctima propiciatoria. También en Roma encontramos manifestaciones parecidas. Todos los años, el día 14 de marzo, era llevado en procesión un hombre, al que llamaban Mamurius Veturius, o sea el Viejo Marte, cubierto con pieles, al que pegaban con cayados largos y blancos para terminar echándolo fuera de la urbe.

En ocasiones, los sacrificios no respondían a prácticas de exorcización, sino a ritos propiciatorios o de fundación. En las excavaciones llevadas a cabo en un templo del Janículo, en Roma, se encontró parte de un cráneo en una cavidad abierta bajo la estatua de Astarte; y Tito Livio (Historia de Roma desde su fundación, XXII, 57) relata que un griego y una griega de la Galia fueron enterrados 
vivos en el foro boario, para proteger el lugar. Plinio (Historia Natural, I, 30) cita un senado-consulto del año 657-97 a. n. e., prohibiendo inmolar un hombre, lo que demuestra, señala él, que hasta esta época se hacían horribles sacrificios.

Estos terribles procedimientos para conjurar el Mal nos hablan, como muy bien supo apreciar en su obra Dodds (1999), de la pervivencia de toda una serie de ritos y creencias primitivas alimentados por sentimientos irracionales que también estuvieron presentes en la cultura clásica.

Si bien las religiones oficiales se elaboraron en torno a panteones y cultos que perseguían una integración ordenada de la comunidad, sobre la base de las nuevas formas de organización política y de una sensibilidad fundamentalmente antropocéntrica, los griegos y los romanos no pudieron evitar la proliferación de prácticas mágicas y cultos mistéricos que respondían a los temores y las inquietudes del pueblo llano.

Entre las divinidades mayores resulta difícil encontrar alguna que se pueda identificar como una encarnación del Mal. Los dioses olímpicos pueden presentar una cierta ambigüedad, como ocurría con las divinidades orientales, pero ni siquiera aquellos más terribles, como el mismo Hades, muestran los rasgos de una deidad maléfica.

Tampoco entre los dioses menores encontramos claras representaciones de la maldad, como lo demuestra la religión romana que fue pródiga en este tipo de divinidades. Los romanos que casi tenían un dios para cada función y cuyo panteón llegó a albergar a Crépito, dios de la ventosidad, no concibieron entre esta abigarrada multitud nada más que media docena de divinidades menores, meras personificaciones de males concretos, como Robigo, el demonio que causaba la roya del trigo, o entidades secundarias a quienes se atribuían jugarretas desagradables, como Cacus, el demonio del fuego, o Vejovis, el «Júpiter malvado».

Si hemos de buscar algo equivalente a seres sobrenaturales encargados de propiciar la desgracia de los humanos, habremos de hacerlo entre los espíritus inferiores, llamados por los griegos demo- 
nios, ya que las divinidades oficiales, aunque arbitrarias, caprichosas e inmorales, siempre tenían un carácter benefactor para aquellos que las respetaban y seguían sus mandatos.

La palabra demonio deriva del griego, daimon, espíritu, y en Homero nos la encontramos utilizada como sinónimo de dios, o también como el poder desconocido del que depende un destino. Como personificación del destino aparece en la tragedia griega el Alastor, un daimon que persigue la expiación de un crimen abatiéndose sobre el culpable y sus descendientes. Cuando el crimen era especialmente execrable, como podía ser el parricidio, las encargadas de este cometido eran las Erinias. Como éstas, Alastor presentaba una doble imagen como servidor de la justicia pero también como un ser terrible, auténtica encarnación del Mal. Desempeñando este papel maléfico es como aparece en las comedias de Eurípides. Pero el término daimon, en época posterior, pasará a denominar a todas las entidades sobrenaturales de rango inferior que podían ejercer una actividad benéfica o maléfica sobre la vida de los humanos. Sólo más tarde, en la forma latina daemon, terminará por significar espíritu maligno o perverso.

La creencia en los daimones era común a la filosofia y a la fe popular, hasta el punto de que los daimones aparecen en $E l$ Banquete de Platón como seres intermedios entre dioses y hombres, fundamentalmente buenos y que moran en el aire alrededor de nosotros. Xenócrates siguiendo algunas de las ideas de Platón, que fue su maestro, parece ser que redactó el que podríamos considerar como el primer tratado de «demonología», que desgraciadamente no se conserva, y en el que establecía una verdadera sistematización de este tipo de seres. Para él los daimones eran almas flotantes que existían antes de encarnarse en los cuerpos, y que sobrevivían cuando éstos habían muerto. Además, Xenócrates es el primero en distinguir entre daimones buenos y malos.

En el siglo II también Plutarco se ocupó de los demonios en su tratado Sobre la decadencia de los oráculos. Asumiendo parte de las ideas de Xenócrates, describió los daimones como almas intermediarias que pueden llegar a ser dioses o recaer en el rango de los hombres. También estableció la pertinente distinción entre los dai- 
mones buenos, que fomentarían las acciones generosas en los dioses y en los hombres, y los daimones malos, que serían quienes inspirarán las malas acciones en las divinidades o en los humanos.

$\mathrm{Su}$ naturaleza fue objeto de las más variadas interpretaciones. Para Máximo de Tiro poseían una cierta corporeidad, pero ésta era más fina que la del resto de los seres materiales; para Jámblico y Apuleyo pertenecían al género de los animales y su cuerpo estaba formado por el aire. No carecían de racionalidad, eran eternos y podían manifestar los mismos defectos y pasiones que los humanos.

Dos principios filosóficos apuntalaban las creencias en estos espíritus, tan populares y próximos a las gentes sencillas: las teorías dinamistas y el dualismo. El pensamiento antiguo no podía imaginarse una fuerza abstracta sin punto de partida. La idea de un principio único o de una causa primera está en la base de la especulación filosófica desde los presocráticos. Esa preocupación fundamental en los orígenes del pensamiento racional guardaba una estrecha relación con las ideas animistas que alimentaron el pensamiento mágico-religioso. La fuerza, el principio o la esencia, que subyacía en todos los seres, según la especulación filosófica, era equiparable al espíritu que les daba vida, según las viejas creencias. Por otro lado, el dualismo que hemos visto aflorar en Platón también contribuía a nutrir la antigua idea dicotómica de los opuestos enfrentados. Nada era más sencillo de admitir para el hombre de la antigüedad que la existencia de unos espíritus malignos y otros benefactores que operaban, incluso, por encima o al margen de la voluntad de los dioses.

Así las divinidades olímpicas oficiales, por efecto de las Moiras y los daimones, terminaron por quedar a salvo en la responsabilidad de las desgracias y de los males, pero también perdieron terreno en la fe popular, con la excepción de la diosa de la brujería, Hécate, y del dios médico, Asclepio. Como contrapartida, la importancia de los daimones creció y era a ellos a quienes se les atribuía, cada vez más, una intervención sobrenatural en la vida humana. Ellos poseían precisamente esa fuerza, esa «dinamis», esa vida activa, de la que muchos seguían creyendo dotados a todos los seres. 


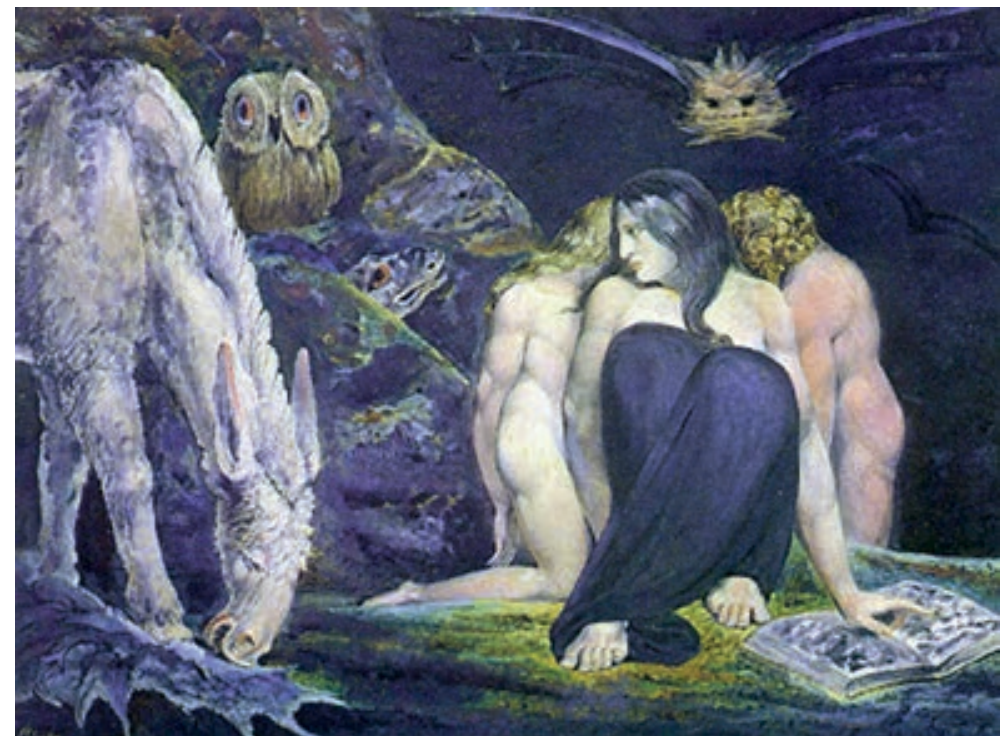

Hécate trifronte fue por excelencia, en el mundo clásico, la diosa del conjuro y el maleficio, invocada con frecuencia como mediadora en hechizos y encantamientos. Aunque no personificaba el Mal, esta divinidad femenina inspiraba temor al convertirse en vehículo del resentimiento humano y simbolizar el poder de las fuerzas oscuras.

Entre los romanos, para los que el vaticinio y la predicción desempeñaban un importante papel en sus creencias, los daimones actuaban como intermediarios de los augures y arúspices; ellos estaban detrás de los sueños cargados de significado y ellos eran quienes hacían posible los prodigios operados por la magia. Los nombres y representaciones de los daimones se hicieron abundantísimas en los papiros mágicos y en los amuletos, llegando a producirse el fenómeno sorprendente de que la religión, en los últimos tiempos de la antigüedad, se «demonizara» cada vez más, como muy bien apuntó en su día Nilsson (1969).

Pero la palabra daimon terminó por asociarse a destinos desgraciados y ya en el siglo IV a. n. e. se empleaba más para designar a los espíritus maléficos que para referirse a sus congéneres benefactores. Muy pronto, también se les achacó ser responsables de la 
locura entre los hombres e incluso en los animales. En época arcaica la locura era atribuida a que la persona había sido poseída por un dios o, aún más frecuentemente, por ninfas. La epilepsia, la paranoia, e incluso el sonambulismo o el delirio febril eran atribuidos a los dioses (Starobinski, 1976: 11-51). La diosa Hécate o los espíritus de los muertos producían el sonambulismo cuando tomaban posesión del cuerpo del vivo y lo dejaban desocupado durante el sueño; y, en Roma, el culto propiciatorio a Febris, el dios de la fiebre, llevó a la construcción de un templo del que nos da noticia Plinio (II, XVI). Con posterioridad, la posesión terminó asignándose a los daimones que adquirieron así una facultad que luego sería característica de su sucesor más desarrollado, el Demonio.

Un tipo de daimon eran los keres, espíritus de los muertos representados como pequeños seres provistos de alas, con terribles dientes, uñas afiladas, un cuerpo grosero y azulado, y el mentón cubierto de sangre humana que bebían insaciables de los moribundos. A ellos se debían las pesadillas, pero también podían provocar la ceguera o la demencia.

Una popular celebración ateniense, las Anthesterias, que se celebraban a finales de febrero, se cerraba con un rito de exorcización de estos seres. En la tercera jornada de la fiesta, tras diversos ritos de purificación en los que una panspermia cocida era derramada en una grieta como ofrenda para Hermes psicopompo en recuerdo de los muertos, los participantes terminaban las ceremoias con el grito ritual «iTodos los keres a la puerta! iSe acabaron las Anthesterias!», con lo que se consideraban expulsados estos espíritus horripilantes.

Con los keres, de espantosa faz, podemos enlazar la creencia en los daimones con la fantástica imaginación del pensamiento mítico que, desde época remota, alumbró una rica galería de monstruos y fantasmas que sirvieron para alimentar los temores de griegos y romanos y para asustar a los niños.

Híbridos como las sirenas, las tres arpías o el minotauro, personajes monstruosos como las gorgonas, Scila, Caribdis, el león de Nemea, la hidra de Lerna, los pájaros de Stimfalo y otros de menor importancia, aunque no fueron identificados como daimones, contri- 
buyeron a cimentar un supersticioso temor y ayudaron a personificar el Mal; aunque bien es cierto que no se puede establecer una verdadera identidad entre estos seres y el Mal, ya que estos monstruos tenían unos poderes muy limitados. Vivían confinados en ciertos lugares, en regiones más o menos lejanas, careciendo por tanto de libertad de movimientos y de la omnipotencia que, por ejemplo, los persas atribuyeron a Arhiman.

Los romanos también recrearon sus propios daimones malvados: los lemures y los larvos que eran espíritus perversos de los que se debían guardar. Los primeros volvían a la tierra periódicamente, tratando en vano de recuperar su envoltura carnal. Los larvos eran espíritus errantes que, en vida, habían sido criminales, o no habían recibido sepultura. Solían manifestarse como espectros, o bien bajo apariencia animal.

En esta pendiente degenerativa, los daimones terminaron por ser la personificación de los atributos perversos previamente asociados a los dioses y adquirieron algunas de las características asignadas a los monstruos. Esos rasgos y características pasaron después a la iconografía y la leyenda del demonio cristiano.

La creencia en los daimones surgió de la profundidad del alma popular griega y romana como una reacción contra una religión oficial que velaba sobre todo por el buen funcionamiento social, distanciando las formas de poder del mundo de las creencias. Este proceso de laicización de las estructuras de dominio, bajo la tutela de unas divinidades que sancionaban el orden y anatemizaban el «éxtasis», no fue aceptado por el común de las capas populares que buscaron refugio a sus pretensiones y anhelos en otro tipo de cultos y ritos más satisfactorios para ellos; y hasta cierto punto inquietantes para el Estado, que intentó en todo momento desprestigiarlos o integrarlos como parte de la religión oficial.

El pueblo, no conforme con la resignación filosófica que practicaban las élites e insatisfecho con los dioses estatales, meros apéndices de la autoridad, se apropió con avidez de las creencias orientalizantes, resucitó lo más primitivo de sus propias religiones y terminó encontrando consuelo en la hechicería como método para conjurar a los demonios que, como nos indican algunos autores 
(Frankfort Wilson, Jacobsen, 1973: 31): «no son otra cosa que el mal concebido de modo substancial y dotado de voluntad». Por eso los griegos, y más tarde el mundo romano, se entregaron a toda clase de prácticas tenebrosas y no fueron ajenas a ellas ni la deisidaimonia ni la superstitio.

La palabra deisidaimonia designa, no el temor necio e ilógico a cualquier cosa que nos salga al paso, sino el excesivo temor a los dioses o si se prefiere a los daimones; más a estos últimos que a los primeros. La idea de que los daimones eran espíritus maléficos, que rondaban por todos los sitios y especialmente junto a las tumbas, se asoció, en la mente popular, con otra antigua creencia sobre el alma de los difuntos que no habían tenido honrosa sepultura o habían sido víctimas de una muerte en circunstancias violentas, dolorosas o desgraciadas. Estas almas vagarían errantes por la tierra en busca de un cuerpo o reclamando justicia y se convertirían, en su triste penar, en instrumentos dóciles al servicio del Mal. Y aquí es donde entra en juego el phtonos ( $\phi \theta 0 v o \varsigma$ ) griego, como el otro elemento compositivo de la deisidaimonia.

El phtonos para el griego era algo más que la envidia y lo debemos traducir por malquerencia; ese sentimiento que, naciendo de la envidia, se traduce en el deseo de que aquél, más afortunado que nosotros, conozca la desgracia. La raíz $\phi \theta \imath v \omega$ significa: consumirse, debilitarse, venir a menos, perecer, y nos indica bien a las claras cuáles eran las intenciones de aquellos que proyectaban su phtonos sobre otro. El phtonos no era un sentimiento privativo de los humanos, los dioses podían proyectar su phtonos sobre los pobres mortales. Cuando éstos, embriagados por el éxito o la felicidad, se vanaglorian de ello, corrían el peligro de acarrear los celos divinos. Los dioses griegos, tan cercanos a los humanos, no podían consentir que la jactancia de un mortal ensombreciera su propia majestad, era entonces cuando sentían el phtonos hacia ellos y procuraban su perdición.

El phtonos para el griego se podía materializar en la mirada y entonces producía el mal de ojo, pero también podía cifrarse en un encantamiento y era ahí donde desempeñaban un papel los daimon malignos, puesto que eran los intermediarios invocados para pro- 
yectar el mal por medio del conjuro. Nadie estaba libre en Grecia del phtonos del vecino, del rival amoroso o político, del enemigo declarado o encubierto, puesto que la envidia acecha sinuosa en cualquier parte sobre todo cuando la dicha o la fortuna te sonreían. Por eso, era muy importante resguardarse contra el phtonos y todos los medios que se pudieran adoptar contra el maleficio de los espíritus invocados por los que te envidiaban serían insuficientes.

La superstitio romana no tiene una raíz etimológica tan clara como la deisidaimonia griega, ya que deriva del verbo latino superstare (estar sobre), que designa la condición del testigo (superstes), o sea de aquel que puede dar fe de algo porque ha estado allí o porque ha sobrevivido al hecho. Por tanto, en su origen, el término no poseía un significado propiamente religioso, pero entre los romanos se impuso rápidamente una acepción, digamos, mixta. Según Cicerón (Sobre la naturaleza de los dioses, II, 28) «se llama supersticiosos a quienes rezan u ofrecen sacrificios todos los días para que sus hijos les sobrevivan». Como vemos, la acepción ciceroniana supone que el super-viviente no es otro que el supersticioso, que termina por definir al que muestra una extrema devoción a los dioses.

En el término latino está ausente, en principio, la connotación de temor que tiene la palabra griega equivalente, pero ambas adquirieron un sentido desfavorable. Entre los romanos se llegó a oponer la superstitio a religio, que designaba la preocupación por realizar los rituales según las normas y de un modo adecuado, o sea, del modo oficial que las autoridades determinaban. No podemos olvidar que religión, según Cicerón viene de re-legere, religar o unir, y esto en el caso de las religiones oficiales del mundo antiguo no sólo hacía referencia a la unión de los hombres con las divinidades sino sobre todo a la cohesión social que producían este tipo de prácticas, una de las principales finalidades buscadas por el poder estatal. Así la superstitio era concebida como una forma pervertida de la religio $\mathrm{y}$, a menudo, tachada de exageración absurda, basándose para ello en el otro sentido del prefijo super, como lo que es superfluo o vano.

Las supersticiones tanto en Grecia como en Roma fueron numerosísimas, como en cualquier cultura antigua y, a pesar del rechazo que despertaban entre las élites cultas, estuvieron muy extendidas 
en todas las capas sociales. Era presagio de desgracia el que un perro negro entrase en casa, o una serpiente cayese del techo al patio, o que una viga se rajase, o se vertiese vino, aceite o agua. $\mathrm{Si}$ una rata hacía un agujero en un saco de harina o al salir se tropezaba en el umbral, era mala señal: aquel día era mejor quedarse en casa. Mentar el incendio durante un banquete era una imprudencia pero se remediaba con darse prisa a echar agua sobre la mesa. $\mathrm{Si}$ cantaba un gallo durante un convite, mejor abstenerse de comer. Si uno se levantaba con el pie izquierdo en Grecia significaba lo mismo que todavía hoy sigue significando para nosotros, sin embargo ocurría al revés en Roma, donde la marcha militar se iniciaba con el pie izquierdo como señal de buen augurio en la campaña.

La deisidaimonia y la superstitio nos interesan porque son el fundamento de las prácticas mágicas, sin esas creencias desarrolladas al margen de las oficiales no podríamos explicarnos el florecimiento de cultos y ritos que ayudaron al hombre clásico a prevenir el mal o a invocarlo para infligir daño a sus adversarios.

Pero la magia, como expresión ritual de esta forma anárquica de concebir la religión, contó con numerosos adversarios. Platón la critica en Las Leyes, aunque bien es cierto que lo hace de modo poco convincente y su alegato parece más retórico que sincero. ${ }^{4}$

4 «En cuanto a aquellos semejantes a bestias feroces, no contentos con negar la existencia de los dioses o de creerlos, bien negligentes o bien corruptibles, menosprecian a los seres humanos hasta el punto de ganarse un buen número de adeptos entre los vivos, con la pretensión de que ellos puedan evocar los espíritus de los muertos y puedan incluso seducir a los dioses a los que embrujarían con sacrificios, plegarias y encantamientos, y que por afán de dinero se esfuerzan en arruinar enteramente a los particulares, a familias enteras y a la ciudad, en cuanto a todo aquel, digo, que haya sido fundadamente culpado de estos crímenes, el tribunal lo condenará, según la ley, a ser encarcelado en la prisión central donde ningún hombre libre podrá visitarlo» (909 e).

La incongruencia del párrafo salta a la vista sobre todo viniendo de un hábil razonador. Llama la atención que considere a los que caen en estas prácticas como incrédulos que niegan la existencia de los dioses, para luego afirmar que los invocan, les ofrecen sacrificios y pretenden manipularlos. Por otra parte, la alusión a «las bestias feroces» parece apuntar más a los celebrantes de los cultos dionisíacos que a los brujos o los magos. En las bacanales en honor a Dionisos, los celebrantes se envolvían en pieles de pantera, o de macho cabrío y contra estas manifestaciones, por otra parte integradas en el culto oficial pero en competencia con las divinidades olímpicas, parece ir dirigida la crítica. 
Aristóteles, que prestó mucha atención a la hechicería, dice acertadamente que la phtonos alimenta a los hechiceros y como se trata de un sentimiento que trastorna la armonía de la polis, resulta peligrosa. Por eso se practica clandestinamente a diferencia de la religión, que se celebra solemnemente y sirve para unir a todos los buenos ciudadanos. Bernand (1991) ha demostrado de manera concluyente que la phtonos era tenida por numerosos pensadores griegos como una de las causas principales de la discordia.

En época posterior se destacó en estas críticas Plutarco, quien en una obra de juventud — Sobre la superstición — arremetió contra la superstición y los supersticiosos a los que consideraba más culpables de impiedad (asebeia) que al mismo Anaxágoras, que había sido desterrado de Atenas por afirmar que el Sol era una masa de piedra incandescente. Unos y otros cometían, a los ojos del escritor, el peor de los pecados: cuestionar la religión oficial en la que se asentaba el orden político.

También en el mundo romano la superstitio y la magia encontraron detractores, de hecho su práctica se prohibía explícitamente en la Ley de las XII Tablas. Por ejemplo, Horacio señala como un rasgo de la firmeza de carácter no preocuparse por los lemures y Séneca dedicó a la superstición todo un tratado: Sobre la superstición, en el cual censura ciertos cultos romanos en los que intuye un exceso, pero sobre todo arremete contra los ritos orientales que, por aquel entonces, empezaban a infestar Roma.

La religión romana era extremadamente tolerante y abierta. Roma siempre acogió a las divinidades foráneas mientras éstas no manifestaran una actitud excluyente o su culto no implicara ritos incivilizados. En el panteón se podían encontrar a partir del siglo II representaciones de muchos dioses extranjeros e, incluso, se reservaba un lugar a in deo ignoto, a un dios desconocido, para que aquellos visitantes cuya religión fuera desconocida a los romanos le pudieran rendir culto. Pero esta tolerancia con cualquier fuerza que se pudiera considerar como sobrenatural y propiciatoria respondía a un planteamiento social y político que buscaba reafirmar el poderío de la ciudad y cohesionar a los súbditos del imperio bajo la tutela de Roma. 
Este enfoque esencialmente utilitario llevaba a los romanos a sacrificar ofrendas a los dioses de sus enemigos antes de una confrontación, con el ánimo de ganárselos para su causa. Eso no implicaba que se olvidaran de los propios, con los que mantenían una relación de estrecha familiaridad que descansaba en una especie de contrato espiritual a la vez que social. Por esta razón, el recurso individual y directo a la divinidad suponía la apropiación ilícita del poder de las divinidades en provecho de un particular frente a la colectividad, fuera ésta la familia, la gens, la curia, el collegium o el propio Estado. Por este motivo, todo ciudadano romano que hubiese sido testigo de algún fenómeno sobrenatural o extraordinario debía dar parte de ello a la autoridad religiosa, la única facultada para interpretarlo.

El segundo peligro que comportaban estos cultos era el debilitamiento del Estado, aspecto este que afectaba a la misma estructura de poder. Durante la etapa republicana, el poder se ejercía en nombre de los dioses sin recurrir como en Oriente a investirse de divinidad. En época imperial, la misma figura del poder, encarnada por el emperador, terminó divinizándose, siguiendo el modelo oriental. Por eso el culto al Genio del emperador, que era la única garantía de acatamiento al sistema que tenían las autoridades romanas, se convirtió en algo tan importante. Cualquier actividad al margen de estos esquemas se le antojaba al Estado romano cuando menos sospechosa, y las prácticas mágicas o la superstitio, aunque toleradas, eran mal vistas por la clase dirigente. Aunque libre frente a los dioses tutelares, el romano debía abstenerse de querer establecer una relación personal con ellos.

Las críticas de un Platón o de un Séneca a la magia y la superstición se fundan en las razones del orden establecido, pero nos encontramos con otras que nacen de la libertad de espíritu y el buen sentido de los que las formulan, como las más jocosas e hirientes críticas de Teofrasto que, en su obra los Caracteres (XVI), nos ofrece un retrato satírico del que ha caído en la deisidaimonia. Pero sería un error creer que todos los supersticiosos eran hombres del pueblo carentes de cultura. Un rico hombre de Estado como Nicias; un escritor, discípulo de Sócrates, como Jenofonte; o emperadores como Tiberio, Vespasiano o Marco Aurelio, el emperador filósofo, se rodea- 
ron de adivinos y astrólogos y practicaban ritos casi tan minuciosos como el supersticioso de Teofrasto.

Los artífices o mediadores en estos ritos eran magos, brujos, taumaturgos y encantadores, en griego magoi o pharmakoi, administradores de recetas y sortilegios que actuaban como nuestros curanderos, sin estatuto oficial, para aliviar dolencias reales, satisfacer deseos, conjurar posibles males o provocarlos en otros por encargo del cliente. Estaban también los goetoi, o magos de la clase baja, especialistas en el hechizo. Los más instruidos usaban letras milesias y efesias o palabras sacramentales tomadas de la lengua de Frigia para realizar sus encantamientos. Aunque despreciados por muchos como meros charlatanes, intervenían con asombrosa frecuencia en la vida privada de los ciudadanos. Porque la cotidianidad de los griegos, sobre todo en el período helenístico y de los romanos en la época del Imperio, estuvo llena de imprecaciones, de sortilegios y de brujerías. Gozaban de una consideración especial los hechiceros babilonios y egipcios, quienes estaban reputados como hábiles especialistas en las artes negras y los encantamientos. Dondequiera que iban llevaban sus dioses y sus daimones, valorados como especialmente poderosos.

Pero mucho antes de poseer magos extranjeros, duchos en las prácticas egipcias y caldeas, Grecia tenía sus propios brujos. Hay numerosas muestras de prácticas mágicas en la Ilíada y sobre todo en la Odisea, y las magas de Tesalia desde muy antiguo eran célebres en toda la Hélade por sus dotes en la predicción del porvenir. Acudían a consultarlas desde muy lejos y se les atribuía el poder de hacer bajar la luna de los cielos, gracias a la magia de sus cantos. Sin embargo, este tipo de ritos eran considerados de origen foráneo e importados de Oriente, como queda claro en los relatos mitológicos. La mayor maga de la mitología griega, Medea, era una bárbara de Colcida, aunque establecida en Tesalia, desde donde pudo transmitir su arte aprendido de Circe, otra extranjera con poderes sobrenaturales.

Circe, de linaje divino por su nacimiento - su padre fue el Sol y su madre, Persea, era hija del Océano-, se inició muy pronto en el arte de los filtros ponzoñosos, envenenando a su esposo, para asen- 
tar su morada después en la Isla de Ea. El canto X de la Odisea alude a ella como envenenadora pero también como una diosa rubia, utilizando por primera vez en la historia de la cultura occidental esa mezcla de belleza y maldad propia del arquetipo de la mujer fatal, atractiva y seductora pero mortal y destructiva para el hombre. Como reina de la isla, Circe habitaba en un soberbio palacio de piedra en torno al cual pululaban lobos y leones, aunque realmente se trataba de animales encantados por los brebajes de la bruja, que no atacaban a los hombres y que se acercaban a ellos meneando su larga cola y dejándose acariciar.

Su sobrina Medea, hija del prudente Eetes, rey de Colcida, fue como ella experta en el arte de elaborar y administrar los filtros más ponzoñosos o más saludables. Con sus artes encantó al dragón que custodiaba el vellocino de oro, ayudando de este modo a Jasón en su empresa. Rejuveneció también a Esón, padre del jefe de los argonautas. Pero, nublada por los celos, destruyó a su rival Creusa, con una bola de fuego. Tanto fue su despecho por la traición de Jasón que, llevada por su odio, llegó a dar muerte a los hijos que había tenido con él.

También, la literatura nos ofrece testimonios de cómo eran y operaban magos y brujas, aunque hemos de constatar que las principales referencias hacen mención a estas últimas y no a los primeros. El mismo Tácito (Germania VIII) afirmaba que la hechicería y la adivinación eran propias de mujeres y los personajes que aparecen ejecutando ritos mágicos casi siempre lo son, como ocurre con las terribles Canidia y Sagana, de Horacio (Sátiras, I, 8). El poeta nos presenta a dos sórdidas viejas que están realizando una ceremonia nigromántica en el Esquilino bajo la luz de la luna. Con los pies desnudos, con los cabellos sueltos y una palidez de muerte, envueltas en negros ropajes, pronuncian con lúgubres gritos sus conjuros; evocan las sombras de los muertos, escarban con las uñas la tierra y la llenan de sangre de una cordera negra que desgarran a mordiscos. Mientras que perras infernales y serpientes acuden al ruido para completar la escena. En el relato vemos cómo llegan a sacrificar a un niño para utilizar su médula disecada en la fabricación de filtros ponzoñosos. Cuando se ven obligadas a huir, porque algo las asusta, a Sagana se le cae la peluca, y a Canidia, la denta- 
dura postiza. La iconografía posterior sobre las brujas deberá mucho a este relato.

El origen de otro tópico relacionado con las prácticas brujeriles lo encontramos en el Asno de oro de Apuleyo (III, 4-6) en el que se nos narra cómo la protagonista, Panfilia, se embadurna todo el cuerpo con ungüentos mágicos, desde las uñas a los cabellos y, tras pronunciar un conjuro, se transforma en lechuza y sale volando. El rito de la metamorfosis en pájaro por efecto de la pomada lo encontraremos referido a las brujas medievales que también se untaban antes de trasladarse por los aires, aunque la bruja conservaba su forma humana y el vuelo se efectuaba a caballo de una escoba o a las espaldas del mismo Diablo.

Más inocentes parecen Las Magas del poema escrito por Teócrito en el siglo III, donde nos presenta a una mujer joven que, abandonada por su amante, ha decidido encadenarlo a ella mediante ritos eficaces. Con ayuda de su sirviente, utilizando ramas de laurel y filtros, invoca, entre otras divinidades, a la Luna, a Hécate y a Medea.

No sólo tenemos referencias mitológicas de brujas como Circe o literarias como las que acabamos de referir. En medio del anonimato que presidió la labor de estos personajes, nos encontramos con la mención de algún nombre propio correspondiente a una persona real, como ocurre con Apolonio de Thiana, que vivió en la segunda mitad del siglo I a. n. e. y cuyas destrezas le han hecho pasar a la historia, aunque envuelto en la leyenda, como uno de los grandes magos griegos de todos los tiempos.

El mago o el brujo en esta época ya es sólo un mero intermediario y para realizar su labor se ve obligado a invocar fuerzas sobrenaturales. Serán los daimones o las divinidades invocadas las encargadas de realizar el deseo. El ritual mágico ha perdido así parte de su naturaleza primitiva, la fuerza del brujo ya no descansa en conocer y ejecutar con precisión el rito, sino que ahora, la contaminación de las ideas religiosas ha modificado la esencia del ritual. Externamente se apoya en los mismos principios, la «simpatía», el poder de la palabra, la meticulosidad y precisión escrupulosa que debe presidir el acto, pero el hecho de la invocación nos indi- 
ca que las creencias sobre las que se fundamentaban las prácticas mágicas en el pasado se han alterado.

Según los textos encontrados, los brujos no solían solicitar la ayuda de los dioses principales del Olimpo, sino la de divinidades menores y subterráneas, o bien la de los espíritus de los difuntos, y más significativo, la de deidades extranjeras. La principal divinidad invocada por brujos griegos y romanos en este tipo de cultos fue Hécate.

Esta inquietante deidad femenina a quien podríamos considerar como la patrona de los órficos y de los magos, también parece proceder de Tracia, como Bendis ${ }^{5}$ y Sabazio. ${ }^{6}$ Era una diosa lunar y ctónica a la vez, afín a Artemisa. Hesíodo nos la presenta como engendrada por Asteria y Perses y descendiente directa de los perversos titanes. La creencia popular la consideraba como un poder temible, infernal en el peor sentido de la palabra, que se encargaba de comisionar espectros que atormentaban a los humanos y de engendrar los terrores nocturnos. Estaba presente cuando un alma se unía al cuerpo y también cuando se separaba de él en el momento de la muerte. Vivía entre las tumbas, pero también en los hogares, como reminiscencia de la vieja tradición de inhumar los cuerpos cerca del lugar donde se solía encender el fuego.

Maga por excelencia, se aparecía ante quienes la invocaban en las noches de luna clara con una antorcha en la mano o en forma de distintos animales: loba, yegua, pero sobre todo como perra, que era su animal preferido, encarnación de un alma errante. Presidía las encrucijadas, los lugares por excelencia de la magia; en ellas se levantaban sus estatuas, en forma de mujer con triple cuerpo, adosado por la espalda, o bien tricéfala, recordando las distintas caras de la luna; a sus pies se depositaban al final del mes ofrendas alimenticias que, según la tradición, debían permanecer allí hasta que se descompusieran, como señal de que habían sido bien recibidas por la diosa. A Hécate se la invocaba para combatir la locura

5 Diosa tracia de la luna, venerada especialmente en Atenas, fue identificada con Artemisa y su culto era orgiástico.

6 Advocación tracia de Dionisos. 
puesto que, al ser producida por los daimones y la diosa tener poder sobre ellos, podía evitarla. Conocía todos los conjuros amorosos y su culto estaba difundido sobre todo entre las mujeres. Una de las fórmulas para su invocación era como sigue (cit. en GérinRicard, 1975: 79):

Ven, infernal, celeste y terrestre Bomba, ${ }^{7}$ diosa de los grandes caminos, de las encrucijadas, tú que traes la luz, andas por la noche, enemiga de la luz, amiga y compañera de la noche, a ti a quien regocija el aullido de los perros y la sangre derramada, que vagas en medio de las sombras a través de las tumbas, tú que deseas la sangre y traes el terror a los mortales, Gorgo, ${ }^{8}$ Mormo, ${ }^{9}$ luna de mil formas, asiste con ojo propicio a los sacrificios.

También se han hallado imprecaciones dirigidas a Plutón, a Proserpina, a Hermes y otros. E incluso, en la época tardía, tuvieron en cuenta al dios de los hebreos, rebautizado como Iavoth, que era el encargado de llevar la discordia a los hogares, pues era muy frecuente que los daimones invocados fueran extranjeros o, al menos, tuvieran nombres tan complicados que lo pudieran parecer. Se han hallado referencias a seres de apelativos tan exóticos o extravagantes como Baruchambra, Barbaramchelumbra, Abrathabrasax, Sesengenbarfages, Pakeptoh y otras por el estilo, de origen posiblemente cilicio o fenicio, o simplemente inventados por el hechicero y en los que siempre suelen predominar las siete vocales del alfabeto griego consideradas como especialmente mágicas. Aunque entre los dioses extranjeros gozaron de especial reputación las divinidades egipcias de Thoth, Anubis y el malvado Seth, por el contrario fueron

7 Sobrenombre de origen onomatopéyico que se daba a la diosa muy frecuentemente en este tipo de conjuros y que hacía referencia al estruendo con el que se pre-

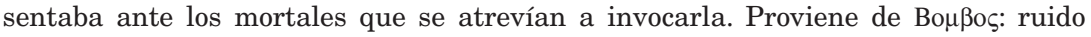
sordo, estampido.

8 Diminutivo de Gorgona, monstruoso ser femenino cuya mirada bastaba para convertir en piedra a quien la contemplaba. Con el tiempo aparecieron tres gorgonas: Medusa, Euriale y Esteneo, hijas de Forquino y de Ceto, y que vivían en los confines de Occidente. En este caso, está usado como sinónimo de Hécate, como ser pavoroso o monstruoso.

9 Era un genio femenino con el que se asustaba a los niños diciéndoles que mordía a los malos y los dejaba cojos. Sin duda, está utilizado en este caso con poca precisión como sinónimo de Hécate. 
más raras las apelaciones a otras divinidades orientales, sólo con menos frecuencia se menciona a Mitra o a la diosa babilonia Ereshkigal.

Los procedimientos podían ser muy distintos según la naturaleza del rito. Una de las primeras referencias en el campo literario alude a un rito nigromántico, de invocación a los muertos para dilucidar el porvenir, y la hallamos en la Odisea (XI), cuando siguiendo las prescripciones de Circe Ulises evoca el alma de Tiresias. Ésta no es la única obra clásica en donde se desarrolla un rito de necromancia, en Los Persas de Esquilo el coro de fieles, en una escena alucinante, consigue con sus invocaciones hacer salir de su tumba al viejo rey Darío. En la ceremonia para evocar a un difunto parecía natural alimentarlo primero, tal vez para hacerlo favorable, por eso se sacrificaba un cordero, un gallo o una cabra, preferiblemente negros, ya que este color se asemejaba a las tinieblas con las que casi todos los pueblos habían inundado la estancia de los muertos.

En la misma Odisea, Homero nos narra otro episodio en donde aparecen nuevos elementos en el ritual mágico, nos referimos al encantamiento llevado a cabo por Circe que convierte a los compañeros de Ulises en cerdos. En este caso intervienen los filtros que la maga les da a beber en un banquete, después de lo cual toca a los veintidós marinos con una varita para completar el hechizo. Los desgraciados pierden la memoria pero son conscientes de su triste situación, por eso lloran amargamente. Ulises al enterarse de lo ocurrido parte al rescate de sus compañeros y asesorado por Hermes, que le entrega la raíz y el tallo de una planta llamada «moly», sin duda un antídoto, logra destruir el encantamiento.

En este relato no sólo encontramos la varita de Circe, otro elemento que se convertirá en muy frecuente en este tipo de prácticas, sino que también aparecen las pócimas mágicas elaboradas a base de plantas. Los síntomas que aquejan a los compañeros de Ulises presentan similitudes con los del envenenamiento por solanáceas ponzoñosas como el estramonio, la mandrágora o el cannabis. De todo ello, cabe deducir que en la época en que fueron compilados y fijados por escrito los textos de la Iliada y la Odisea, los griegos ya conocían las propiedades de estas plantas y las utilizaban para ela- 
borar filtros con la finalidad de pervertir, estimular o debilitar las facultades. La terapéutica con bebedizos y ungüentos formaba parte de la farmacopea en uso, tanto para dañar como para curar. ${ }^{10}$

Pero además de las plantas existían innumerables agentes mágicos, algunos de ellos extraños y repugnantes como por ejemplo, los excrementos de los ratones. Si se los frotaba sobre la piel de un hombre, éste se volvía impotente. Se conseguía el mismo efecto con las cenizas de brezo, mezcladas con orina de buey. Un feto de liebre, comido crudo, podía devolver la fecundidad a la mujer. Sin embargo, otros eran mucho más normales y se pensaba que la leche de vaca poseía una acción estimulante sobre la concepción.

Con algunos de estos agentes se podían fabricar amuletos en los que el poder mágico residía en llevarlos constantemente en contacto con el cuerpo. El testículo derecho de un asno en un brazalete, reforzaba la virilidad, mientras que la mujer veía estimulado su deseo si se ataba tres raíces de malva en el brazo. En otras ocasiones el amuleto debía ser confeccionado por un experto y contenía inscripciones mágicas de la más variada índole y en muchos casos sin un significado lógico, como el ARSERVERSE, que escribían los romanos en el dintel de sus puertas para conjurar el fuego.

En los ritos apotropaicos era fácil prescindir del concurso del brujo y el mismo particular podía ejecutar el conjuro siempre que fuera lo suficientemente escrupuloso para reproducir fielmente el ritual. Así se operaba en una festividad religiosa romana, las lemurias, que se celebraba el 9, el 11 y el 13 de mayo. Como estos espíritus buscaban sobre todo la morada familiar para asustar a los vivos o atormentarlos, se necesitaba una fuerte protección contra ellos. Por

10 La familia de las solanáceas ha sido conocida desde la antigüedad en Occidente por sus propiedades alucinógenas. Parece que el beleño, y especialmente el beleño blanco, era utilizado con finalidades adivinatorias o proféticas como lo atestiguan los nombres que recibía de Pythonio y Apollinaris, que son una clara alusión a la serpiente pitón y al culto de Apolo al cual iban asociados los ritos mánticos en el santuario de Delfos. Debido a su poder estimulante o inhibitorio sobre el organismo, algunas de estas plantas eran muy apreciadas en la práctica de la magia. A la hierba artemisa se le atribuían propiedades estimulantes del apetito sexual. Las hojas del pimiento (agnus castus) esparcidas sobre el lecho poseían una acción tónica infalible sobre la líbido de las mujeres y similar efecto provocaba el jugo de la malva. 
eso, durante estas fechas, el dueño de la casa se levantaba a medianoche, hacía unas abluciones y se llenaba la boca de habas negras. Entonces empezaba a dar vueltas por su morada, al tiempo que hacía con las manos ciertos signos para ahuyentar a los espíritus. Mientras caminaba, iba escupiendo habas, al tiempo que repetía hasta nueve veces las siguientes palabras: «Me rescato con estas habas y rescato a los míos». Después de esto se lavaba; otra vez, cogía dos vasijas y las golpeaba entre sí, con el fin de espantar a los malos espíritus domésticos. Recordemos cómo las habas para los pitagóricos eran la semilla de la vida, mientras que los lemures eran los espíritus de los muertos.

Eran muy frecuentes los hechizos y encantamientos amorosos, en ellos intervenía un curioso instrumento en forma de rueda a la que los griegos llamaban rombos y los romanos turbo. Parece que era un método infalible para atraer al hombre y consistía en una ruedecita que tenía cuatro radios a los que se ataba un pajarillo, el cuclillo, según parece, o el torcecuello, en griego $v \gamma \xi$ (iygx), y se hacía girar velozmente con un cordel o a golpes de varilla; entonces, como si un hilo invisible ligase la rueda al amante, objeto del hechizo, éste se sentía atraído irresistiblemente por la muchacha que lo ejecutaba o lo había encargado. En la obra de Teócrito, Las Magas, que antes mencionábamos, la protagonista, como parte del encantamiento, hace girar la rueda mientras entona el estribillo: «Ingx, atrae hacia mí a ese hombre, a mi amante». ${ }^{11}$

11 Mucho más contundente resulta la fórmula que aparece en la famosa colección PGM (papiros mágicos en griego) que recoge toda una serie de textos de procedencia diversa, escritos o copiados en época helenística. El conjuro al que nos referimos persigue que la mujer deseada no sea de ningún otro hombre y dice así: «Yo deposito cerca de vosotros esta atadura, dioses de la tierra Uesemigadon (?) y Core Perséfone Ereshkigal y Adonis el Barbarita, Hermes subterráneo, Tout phokentazepseu aerchathau mi sonktai kalbanachmbre (palabras mágicas) y el poderoso Anubis psirinth (?), el que tiene las llaves de los que están en el Hades, dioses y démones de la tierra, los que han muerto demasiado pronto, hombres, mujeres, muchachos y muchachas, por los años de los años, los meses de los meses, los días de los días, las horas de las horas. Conjuro a todos los démones de este lugar para que ayuden a este demon.

Levántate para servirme a mí, quienquiera que seas, varón o mujer y dirígete a todo lugar, a todo camino a toda casa y tráela y átala; induce a fulana, cuya entidad posees a que me ame a mí, fulano, hijo de mengano; que no tenga relaciones sexuales por delante ni por detrás, ni busque placer con otro varón, sino únicamente conmigo...» (P. IV, 335-355). 
La lectura de las invocaciones nos informa sobre los motivos de los supersticiosos, y podemos apreciar que en la mayoría de los casos estaban movidas por la frustración y la malquerencia personales. Desgraciadamente la phtonos era una realidad en el mundo griego y en el romano, de ahí que la mayor parte de los conjuros que hemos encontrado sean defixiones dictadas por el odio hacia el otro. La defixión es el término latino que designa el soporte material donde figura el conjuro mágico, aunque las maldiciones son tan abundantes entre ellas que ha terminado por asimilarse a este tipo de encantamientos maléficos. Las primeras que hemos hallado son griegas y se remontan al siglo IV a. n. e.; desde Grecia esta práctica pasó a Roma y, posteriormente, se extendió por todo el Imperio. Con la defixión se consagraba a un enemigo a la maldad de las divinidades invocadas. Cualquier motivo era válido para mandar confeccionar una defixión, y nadie estaba a salvo de ser víctima ignorante de la defixión de otro. Esta circunstancia favorecía el conjuro apotropaico y la multiplicación de defixiones de respuesta, «aquel que me ha maldecido será maldito por mí».

La defixión se efectuaba de este modo. En una lámina de plomo -éste es al menos el tipo de soporte que ha llegado hasta nosotrosse escribía el nombre execrado con una fórmula de maldición con la que se dedicaba la víctima a las divinidades infernales. Luego se debía introducir la placa con la inscripción en un sepulcro, en donde se clavaba mediante un clavo largo, aunque se han encontrado algunas en otros lugares. Las maldiciones podían ser colectivas y los nombres siempre estaban escritos con cuidado por el temor a que una indicación poco exacta hiciera ineficaz la práctica. En el texto se intercalaban signos mágicos de carácter alfabético y en alguna plancha se halla trazado un tosco dibujo. Con las fórmulas imprecatorias se alternaban palabras mágicas, por ejemplo, en las griegas, $\alpha \beta \rho \alpha \xi \alpha \varsigma^{12}$ (abraxas), aunque las fórmulas de la maldición no tenían

12 Abraxas es un extraño ser híbrido presente como símbolo en religiones y cultos mistéricos de la antigüedad. Entre los mazdeístas representaba al mediador entre el Bien y el Mal, mientras que los seguidores de Mitra lo consideraban como intermediario entre Mitra y la humanidad.

Tiene cabeza de gallo y su cuerpo, revestido con una armadura, termina en dos serpientes curvadas hacia arriba, cada una con su cabeza. Frecuentemente porta 
por qué ser complicadas, a veces simplemente se escribía la palabra Consagro; en otras, por el contrario, el odio del autor se hacía evidente y se pedía para la víctima enfermedades o la ruina económica. ${ }^{13}$

En la magia no encontramos una figura central del Mal, concebido de forma abstracta y omnipotente, pero sí que hallamos una expresión de la maldad humana, en la que las fuerzas sobrenaturales se ponen al servicio de los intereses y las pasiones particulares, enfrentándose así a las religiones oficiales que pretendían una integración de la comunidad como premisa para un mejor control social. Sin embargo, en las prácticas mágicas y de brujería se van a fraguar muchos de los elementos y arquetipos de los que se acabará valiendo el poder para ejercer ese control. El miedo y el odio que estas manifestaciones alimentaban en las clases populares podrán ser fácilmente manipulados cuando la situación lo requiera; entre tanto, la malignidad y el Mal irán encontrando asociaciones simbólicas que terminarán por tener un enorme arraigo en nuestra cultura y a ellas no será ajena la ideología patriarcal.

\section{Pandora, la esfinge}

¿Qué papel jugaba el género en todo este tipo de creencias y manifestaciones? Algo podemos entrever en lo que hemos venido

un escudo en el que aparecen las letras IAO. Las siete letras del nombre tienen el valor numérico de los días del año: $365(\mathrm{a}=1, \mathrm{~b}=2, \mathrm{r}=100, \mathrm{x}=60, \mathrm{~s}=200)$ y coinciden con los 7 planetas conocidos en el mundo antiguo. Se considera que la palabra mágica por excelencia, ABRACADABRA, procede de este nombre cuyo origen etimológico puede estar en los términos egipcios abrak sax que significan "palabra sagrada».

13 Un tipo de defixión original era aquella destinada a eliminar al competidor deportivo. Se han encontrado hojas de metal hechizadas enterradas en los circos, para provocar la caída de los caballos durante las carreras de carros. Uno de estos conjuros que fue hallado en África, en la tumba de un niño, reproduce sobre una tablilla de plomo del siglo III a un demonio barbudo de pie en una barca, tal vez, la chalupa de Caronte, en una mano lleva una vasija y en la otra una lámpara encendida, símbolos fúnebres. En su pecho, está escrito BAITMO ARBITTO. Sobre la barca, tres nombres de caballos: Noctivagus, Tiberis y Oceanus. Alrededor, palabras mágicas desconocidas. La inscripción del reverso consagra al demonio a cuatro cocheros, Aarus, Félix, Primulus y Romanus: «pueden volcar y perecer aplastados, ellos y sus caballos» (Bouisson, 1976: 179). 
exponiendo. No es casual que el destino, siempre fatal para los griegos, fuera encarnado por tres personajes terribles que estaban personificados por mujeres, o que las horrendas hechiceras Canidia y Sagana fueran unas viejas repelentes o, incluso, que la divinidad de la magia y la brujería, practicada indistintamente por hombres y mujeres, fuera Hécate, una deidad femenina.

Esta adjudicación genérica en el pensamiento clásico a las fuerzas sobrenaturales que podían encarnar lo más terrible no parece en absoluto casual. En realidad respondía a factores de naturaleza diversa, materiales e ideológicos. De entre los primeros resulta fundamental la situación social que se adjudicó a la mujer en el mundo griego y romano; los segundos, reflejo de los anteriores, suponían la reafirmación y el desquite del orden patriarcal en el terreno de las creencias.

La dependencia de valores generatrices vinculados a lo femenino que se había conocido durante una larguísima etapa en el período de formación del pensamiento religioso, se saldaba a finales del mundo antiguo con una reacción androcrática que terminaría por relacionar el Bien y lo positivo con lo masculino y el Mal, y lo negativo con lo femenino; aunque es cierto que este proceso no fue lineal y el prestigio de la fecundidad siguió pesando en algunos aspectos de las nuevas religiones universales.

En el orden material conviene recordar cuál era la situación de la mujer griega y romana, ya que sólo teniendo presente esa realidad podremos comprender cómo la elaboración ideológica pudo proyectar de modo tan nítido esa visión patriarcal en unas culturas inspiradas por la razón.

En la antigua sociedad griega las mujeres estaban privadas, como ya hemos dicho, de derechos políticos y civiles, y, por consiguiente, su posición era de una neta inferioridad respecto al hombre. Los griegos adjudicaron a las mujeres los papeles de madre, sierva y cortesana y se puede decir que ser madre era la finalidad primordial para la mujer, la única meta de su vida.

Todo su mundo se reducía a su casa y su familia. En su casa era la oicourema, la vigilante del hogar, pero realmente su casa era su 
cárcel, ya que en ella permanecía recluida la mayor parte del tiempo, relegada a unas habitaciones especiales, las gynaekonites, normalmente situadas en el piso superior. A las mujeres no se les consentía aparecer en público, a menos que fuera una reunión religiosa o familiar, e incluso para hacer sus compras personales debían ir siempre acompañadas por sus tutores o por una esclava.

Las niñas no recibían ningún tipo de educación escolar, pero se las aleccionaba por parte de la madre en los cuidados de la casa y aprendían a gestionar el oikos, así como a tejer. Sólo en muy raras ocasiones, las muchachas de buena familia recibían alguna formación y deberemos esperar al período helenístico para que las jóvenes comiencen a ir a la escuela. Aunque esta situación no era igual en toda Grecia, ya que las espartanas se ejercitaban junto con los chicos en la palestra, siguiendo los principios de la eugenesia que caracterizaban al régimen lacedemonio. Esto sorprendía a los atenienses, quienes las llamaban phainomirides, puesto que durante los ejercicios exponían sus muslos (Eurípides, Andrómaca, 597). Sabemos también, que en la isla de Lesbos, al principio del siglo VI a. n. e. se estableció un instituto pedagógico para chicas, bajo la dirección de la poetisa Safo.

Como madre, la mujer griega contaba con el respeto de su marido y de sus hijos, y el esposo la honraba como progenitora que era de sus descendientes legítimos. Pero con ese respeto que se rendía a las madres, fácilmente detectable en los testimonios literarios, se terminaba toda su consideración, ya que las mujeres no estaban autorizadas para llevar a cabo transacciones legales de ningún tipo; en particular, no podían poseer ni comprar o vender propiedades. En éste y otros casos, las mujeres estaban representadas por su tutor, a saber: su padre, marido o hermano o, en su defecto, por el familiar más próximo. En cualquier caso siempre estaban bajo la tutela de un hombre.

Tampoco constaban en los registros oficiales del demos o de la fratría y sus únicos derechos eran poder contraer matrimonio legal y el derecho de la epikleria. La epikleria era una institución que permitía a la hija sin hermanos hacerse cargo de la herencia sin poder realmente poseerla, gestionarla o venderla. La única salida a esta 
situación era el matrimonio precipitado con el pariente más cercano por la línea paterna, de modo que la propiedad se conservara dentro de la familia.

A las jóvenes se les impedía cualquier tipo de relación con el sexo opuesto, y era fundamental que preservaran su virginidad, tal y como manifiesta en la Odisea (VI, 2885) la princesa Nausica que le dice a Ulises: «Yo también despreciaría a aquella que a despecho de su querido padre y de su madre fuera sola entre hombres antes del día de sus nupcias». Por eso el matrimonio era siempre fruto de un acuerdo entre los padres. Eran éstos, o su tutor legal, quienes escogían el futuro marido a la joven, puesto que su consentimiento no era necesario. El matrimonio siempre respondía a intereses económicos o sociales y era la forma legal de preservar o acrecentar el patrimonio o de estrechar lazos de sangre.

La posición de la mujer casada no cambiaba, el tutor era ahora su marido y, aunque residiera en otro domicilio, la casa, como antes, seguía siendo su lugar de reclusión, con la diferencia de que era ella quien la gestionaba, debiendo ocuparse del cuidado de los hijos, supervisando el trabajo de los esclavos y velando por el aprovisionamiento del hogar. Así mismo custodiaba las llaves, mientras su marido lo considerara oportuno. También se ocupaba de hilar y tejer para satisfacer las necesidades del vestuario. Esta actividad que practicaban hasta las reinas, como ocurre con Helena en la Ilíada o Penélope en la Odisea, estaba tan estrechamente unida al quehacer de las mujeres en todas las culturas de la antigüedad que, en el mundo romano, el epitafio más frecuente que nos encontramos en las lápidas mortuorias de las esposas es: «cuidó la casa y trabajó la lana».

Este rígido estatus no afectaba a las mujeres de clases sociales más bajas, que se veían obligadas a trabajar fuera del hogar, realizando faenas agrícolas, vendiendo sus productos en el mercado, o ganándose un salario en otros oficios como tejedoras, costureras o comadronas, como ocurría con la madre de Sócrates. Hesíodo en Los trabajos y los días (604 a) aconseja a un granjero que para ahorrar dinero contrate a muchachas sin hijos.

Pero éste no era el caso de las mujeres respetables, que no debían ser vistas en público si no era por una razón seria. «Una 
mujer honorable debe permanecer en su propia casa. Las calles son para las indignas» (Menandro, Sentencias, 546). Incluso la compra diaria, era hecha por hombres o por esclavos. Cuando se recibían huéspedes en la casa, las mujeres de la familia no aparecían, ya que era tarea de los sirvientes ocuparse de los invitados, eso sí, bajo la supervisión de la señora de la casa.

Por norma, el hombre salía siempre solo, para trabajar o para participar en acontecimientos públicos, pero también para encontrarse con sus amigos y entretenerse en la palestra, en los juegos y en los symposia. ${ }^{14}$ Sólo el espectáculo teatral estaba abierto a las mujeres, siempre que acudieran a él debidamente acompañadas, aunque a la comedia, dada su procacidad, era impensable que asistiese ninguna mujer ateniense que se preciase, así al menos parece desprenderse de un fragmento de Las Leyes de Platón (658b).

Demóstenes (Contra Neera, 122) nos resume magistralmente en uno de sus discursos no sólo cuál era la posición de las mujeres atenienses durante el período clásico, sino la curiosa clasificación que de éstas se hacía en virtud de los papeles sexuales que se les habían adjudicado: «Las hetairas ${ }^{15}$ las tenemos por placer, las concubinas ${ }^{16}$ por el cuidado cotidiano del cuerpo, y las mujeres para procrear legítimamente y tener un fiel guardián de los bienes de la casa».

14 Los symposia eran banquetes exclusivamente masculinos en los que los comensales bebían más que comían, enfrascándose en la conversación sobre los más diversos temas mientras gozaban de la música y la danza que ejecutaban las hetairas.

15 Las hetairas eran prostitutas de rango superior. La palabra significa "amiga» y como compañeras de los hombres aparecían en los symposia y en otros acontecimientos sociales en los cuales las esposas legítimas, las hermanas o las hijas estaban excluidas, no sólo por cuestiones de moral, sino por la pobre educación que éstas tenían frente a las hetairas que eran valoradas por poder mantener una conversación inteligente con los hombres.

Eran, por lo general, metoixoi, extranjeras, y provenían de ciudades más desarrolladas donde la mujer gozaba de una mayor libertad, en muchos casos su origen era jonio. En otros, se trataba de hijas de prostitutas afortunadas, que daban una formación a las muchachas de la que ellas habían carecido.

16 La concubina era una institución muy extendida en el mundo antiguo. El objetivo principal del concubinato era la procreación en el caso de que la mujer legítima fuese estéril o hubiese procreado solamente hijas. El mismo Sócrates, aparte de su esposa legítima, Jantipa, tenía a la concubina Mirto. En el texto mencionado de Demóstenes, el término puede entenderse como prostituta, que era la mujer con la que se mantenían relaciones sexuales esporádicas a cambio de dinero. 
Por otro lado, el hombre era polígamo y dueño indiscutible en una sociedad patriarcal en la que no sólo gozaba de plenos derechos políticos y civiles, sino que también tenía poder absoluto sobre la mujer, a quien podía expulsar en cualquier momento, ya que el pretendido divorcio se reducía al repudio que él podía ejercer previa devolución de la dote. En el caso de la mujer sólo en circunstancias muy excepcionales y por mediación de la autoridad podía instar la separación, aunque nunca era motivo para ello el adulterio del marido, que estaba no sólo consentido sino institucionalizado. El varón podía mantener una o más concubinas y además podía distraerse con las hetairas y las prostitutas, donde y cuando gustase, mientras que la mujer sorprendida en adulterio era inmediatamente expulsada del domicilio conyugal.

Resumiendo, podemos decir con Flacelière (1973) que la mujer en la antigua Grecia no sólo perdió la posición que había mantenido en la lejana sociedad matriarcal, sino también, la relativa libertad y consideración que disfrutaba en la época minoica.

La situación de la mujer romana no varió sustancialmente respecto a la griega, aunque sí hemos de admitir una cierta evolución que se produjo a lo largo de los más de mil años de historia de esta cultura. La vieja ley de las Doce Tablas y las leyes sagradas de época monárquica otorgaban al padre un poder omnímodo sobre su familia, consagrando legalmente la patria potestas, que suponía la autoridad absoluta del cabeza de familia sobre sus hijos, y del marido sobre la mujer que tenía a su cargo (in manu), como si se tratara de una de sus hijas (loco filiae).

Estas leyes le conferían al padre el derecho de vida y muerte sobre sus descendientes. Podía abandonar impunemente a los recién nacidos en los vertederos públicos, donde perecían de hambre y de frío si alguien nos los recogía. Esta práctica que se mantuvo vigente hasta bien entrado el siglo IV de nuestra era se cebaba particularmente con las niñas que seguían siendo consideradas como una carga por el pater familias. Los censos del Imperio Romano de los siglos II al IV revelan que el número de varones era mucho más elevado que el de mujeres. Este dato sólo se puede explicar por la práctica del infanticidio femenino y por una mayor 
mortandad infantil entre las niñas, debida a unas peores condiciones de vida. ${ }^{17}$

El derecho gentilicio de la Roma antigua, sobre el que reposaba la familia patriarcal, se basaba por un lado en ese poder ilimitado del pater familias y por otro en el vínculo agnaticio que sólo reconocía como único parentesco legítimo el que creaba la descendencia masculina, o agnatio. Esta última prerrogativa se modificó con el Imperio cuando se reconoció la cognatio, o parentesco por la rama de la mujer. También a finales de la República, la mujer romana consiguió que se le reconociera el derecho formal sobre sus hijos, y las fórmulas legales del pretorado le otorgaron la posibilidad de acceder a la custodia de su progenitura, tanto en caso de tutela como en el de mala conducta del cónyuge.

En el ámbito de las costumbres, el romano parece algo más tolerante que el griego. Las matronas romanas no padecían un régimen de clausura como las griegas y podían salir de sus casas para intercambiar visitas con familiares y amigos o ir por las tiendas a hacer sus compras. A la mujer se le consentía también asistir a las recepciones y banquetes, aunque durante toda la época republicana tenía prohibido beber vino, bajo pena de muerte, o mostrarse reclinada, debiendo permanecer sentada durante el banquete, mientras que los varones, siguiendo la tradición, comían recostados en sus triclinios.

Los criterios educativos fueron también más liberales y en la edad infantil los niños y niñas de las buenas familias romanas recibían instrucción conjunta en escuelas elementales, donde se apren-

17 Hoy resulta especialmente estremecedor leer un testimonio sobre la exposición de las niñas como el que aparece en el papiro Oxirrinco, citado por Crossan (1996: 79). El obrero Hilarión escribe a su esposa Alis, utilizando para dirigirse a ella el título de hermana, como era habitual en Egipto.

«Hilarión a su hermana Alis, salve; y también a mi señora Berous [¿su suegra?] y a Apolonarion [su primogénito]. Sepas que seguimos en Alejandría. No te preocupes si ves que todos vuelven menos yo, que me quedo en Alejandría. Te ruego encarecidamente que te ocupes de nuestro hijito [Apolonarion], que yo, en cuanto reciba la paga, os la enviaré. Si por ventura llegaras a dar a luz, caso de ser un niño, deja que viva; pero si es una niña, exponla [para que muera]. Le has dicho a Afrodisias «Que no me olvide». ¿Cómo iba a olvidarte? Por tanto te recomiendo que no te preocupes. [Año] 29 de César [Augusto], [en el día] 23 [del mes] Pauni». 
día a leer, escribir y los rudimentos de la aritmética. Por lo demás, la formación de la joven romana se orientaba, como la griega, a ser una esposa fiel y una buena ama de casa, aunque una vez casada gozaba de una mayor consideración como dueña de su hogar.

Las críticas que nos encontramos en algunos autores romanos sobre una pretendida emancipación de las mujeres en la época del Imperio responden más a su talante misógino que a la realidad. Por otra parte, estas críticas no hacen sino recrear un viejo tópico de la literatura latina desde sus orígenes, como es el lamento por la pérdida de los viejos valores morales y las antiguas costumbres. Los casos que Juvenal (Sátiras, VI) menciona de mujeres con una buena formación cultural, que el escritor minimiza y desprecia, y los de aquellas que «cubiertas con un casco abdican de su sexo» practicando en la palestra esgrima como los varones, debieron de ser casos aislados que se dieron entre las élites, pero que en ningún momento representaron al conjunto de las mujeres romanas, ni supusieron un cambio real en la consideración social.

La situación de la mujer en el mundo clásico y las valoraciones que de ella se hacían tuvieron su reflejo en la religión griega y romana, cuyas divinidades más importantes fueron masculinas. También la jerarquía de estos dioses fue patriarcal. A la cabeza de los panteones figuraba un dios, Zeus/Júpiter, cuyo rasgo más destacado era actuar como un auténtico pater familias.

Esta patriarcalización religiosa en Grecia data de la invasión aquea en torno al año 1400 a. n. e. La llegada de los aqueos a la Península Griega supuso una profunda modificación de la religión que antes se practicaba, y una de sus aportaciones más sobresalientes fue la transformación de las principales divinidades en dioses masculinos, enterrando definitivamente la prioridad que se concedía a las deidades femeninas. Sin embargo no fue Zeus, ese dios uránico de segunda generación, quien inicialmente desplazó lo femenino en la primacía del panteón. En un primer momento, los aqueos prefirieron a Poseidón, que se convirtió en el dios masculino más importante hasta el final de la época aquea, momento en el que Zeus impuso su hegemonía indiscutida, desterrando a su antecesor al dominio marino. 
El mito del enfrentamiento entre Poseidón y Atenea refleja muy bien cómo ese desplazamiento de la feminidad en la primitiva religión griega adecuaba en el terreno de las creencias la realidad material. Cecrops, el primer rey del Ática, que tenía una naturaleza doble mitad humana y mitad serpiente - en lo que podríamos ver el trasunto de una antigua diosa de la fertilidad travestida - vivió bajo su reinado la disputa entre Atenea y Poseidón por la hegemonía sobre la región. La pugna se resolvió por medio de un juicio en el que el tribunal, arbitrado por el mismo Cecrops, debía decidir sobre cuál era la aportación más útil a los hombres hecha por cada una de las dos divinidades. Atenea presentó el cultivo del olivo mientras que el dios, con un golpe de tridente en el suelo, hizo brotar un mar de agua salada en la acrópolis. La ganadora fue Atenea porque Cecrops atestiguó que la diosa había sido la primera en enseñar el cultivo del árbol, tan preciado, a los humanos. La furia que esta decisión desató en Poseidón le llevó a inundar todo el Ática lo que arredró al mismo Cecrops, que para calmar al dios condenó a las mujeres atenienses quitándoles el derecho a votar; prohibiendo que en adelante los hijos llevaran el nombre de sus madres y despojándolas del título de ciudadanas.

Más explícito respecto a la transferencia del poder femenino al patriarcal resulta otro mito en el que se narra la lucha entre Apolo y Pitón. Pitón, la diosa serpiente, era la guardiana del santuario de Delfos hasta que Apolo la mató disparando sus flechas contra ella. Esta victoria de la divinidad masculina suponía en términos religiosos y socioculturales la desaparición de un culto telúrico representado por la serpiente, imagen de la tierra divinizada, y de la mujer, y su sustitución por un culto solar.

No obstante, el triunfo del patriarcado no podía suponer la eliminación total de las divinidades femeninas, cosa que hubiera resultado absurda e incomprensible, pero sí que supuso una profunda adaptación de las diosas tradicionales al nuevo orden. La antigua Diosa Madre, que simbolizaba tanto la fertilidad como la sexualidad, vio disociadas sus funciones de género. La nueva cultura patriarcal necesitaba, por un lado esposas fieles, madres legítimas y fecundas pero también mujeres placenteras. Razón por la que Hera pasará a representar, casi exclusivamente, el matrimonio, la unión 
legal; Demeter la maternidad y fecundidad de la tierra y Afrodita, una divinidad oriental, el amor carnal, legítimo o no.

Pero ninguna de estas diosas encarnaba a la mujer intocada, la virgen que custodia el misterio del sexo, vinculado al orden familiar y a la fertilidad, por eso los griegos adoptaron a Artemisa, transposición de la antigua Diosa Madre que no podía ser poseída por ningún varón fuera éste divino o mortal. Paradójicamente, esta misma divinidad podía personificar también la fertilidad asexuada, cuando ésta se asociaba a la mujer-madre, creadora de vida, pero no a la reproducción sexual. Por eso nos podemos encontrar a la Artemisa de muchos pechos de los efesios, estrechamente relacionada con Cibeles, Ma y la Gran Madre de los dioses, que protegía a los humanos desde su etapa cazadora y, a veces, como la valedora de los animales salvajes y como diosa cinegética.

Para completar el panteón en este sentido quedaba por recoger la idea del andrógino primordial, el símbolo de aquel tiempo pretérito en el que la humanidad aún no conocía el desgarrón de los sexos. Para ello, los griegos recurrieron a Atenea, una diosa virilizada hasta tal punto que siempre aparecía armada, haciendo suya la función negada a las mujeres por el tabú ancestral: el ejercicio de la violencia. Las armas habían fundado el orden en un tiempo primordial, dando ventaja a los hombres sobre los animales y aportando prosperidad y protección. Por este motivo, Atenea tenía también un carácter fundador y aparecía como una divinidad civilizadora entre cuyas funciones estaba el auspicio de las artes y la tutela de la propia polis ateniense.

Simplificando en extremo podríamos decir que este panteón primordial pasó al mundo romano —en el que ya existía por influencia indoeuropea otra tríada masculina: Júpiter, Marte y Quirino- que terminó por adaptarlo a su peculiar concepción religiosa, enfatizando, no obstante, alguna otra divinidad femenina a la que le dieron una importancia fundamental, como es el caso de la diosa Vesta, la Hestia de los griegos.

El nombre de Vesta tiene raíz indoeuropea, significa «arder» y con él se quería simbolizar el fuego sagrado del hogar, el fuego sagrado de Roma misma. El templo de esta diosa, a diferencia del 
resto de los templos romanos, de planta cuadrangular y perfectamente orientados, era circular y no necesitaba de ninguna orientación celeste puesto que toda su potencia radicaba en la tierra. En él ardía perpetuamente la llama divina y la diosa no era representada con ninguna imagen. Para mantener encendido el fuego sagrado estaba atendido por seis vestales vinculadas al colegio de los pontífices. Estas mujeres, elegidas por el Pontífice Máximo cuando tenían entre seis y diez años, quedaban consagradas a la divinidad durante los treinta años siguientes. Su poder simbólico era enorme y estaba vinculado a la conservación de su virginidad. Cuando un reo se cruzaba con una vestal camino del suplicio, era inmediatamente indultado. En las luchas del anfiteatro, ellas tenían, también, poder de vida o muerte sobre los gladiadores vencidos, pero si una vestal faltaba a su voto de castidad se le castigaba enterrándola viva.

Todas estas representaciones divinizadas de género femenino pueden llevarnos a pensar que su poder en el plano de las creencias sobrenaturales era mucho mayor que en el mundo material y que la feminidad desempeñaba, al menos en esa esfera, un importante papel en la sociedad patriarcal, encarnando fuerzas fundamentales (Anderson y Zinsser, 1992: 176). Un examen más atento nos descubre que esta suposición sólo es una verdad a medias. Parece una obviedad afirmar que el hombre del mundo clásico tuvo que adjudicar dentro de su cosmovisión un lugar para la mujer en el orden espiritual. Lo fundamental, no obstante, es la posición que éste ocupa respecto al conjunto, así como las valoraciones que se desprendían de esta ubicación. Lo que podemos apreciar es que ese lugar respondía a las funciones adjudicadas a la mujer en la sociedad androcrática.

Las principales divinidades femeninas del mundo antiguo encarnan los valores de la mujer sometida. Ninguna de estas diosas, excepto Gea, una divinidad pasiva, es relevante en la cosmogonía griega o romana; no están, por tanto, presentes en el origen del universo. Ninguna asume, excepto las andróginas Atenea/Minerva o Artemisa/Diana, funciones del varón. Su autoridad siempre está limitada o subordinada a la jerarquía masculina y sus principales «armas» son las propias del arquetipo femenino elaborado por la 
ideología patriarcal: la seducción, el engaño, los celos, etc. Sus virtudes o defectos son típicamente femeninos, en un sentido peyorativo e, incluso, sus mismas atribuciones sólo cobran significado en un mundo sagrado ordenado en torno a la familia, al poder del padre y a la patrilinealidad.

Podemos decir que el mundo sobrenatural de los griegos y los romanos no se separa un ápice del mundo material, del que no deja de ser nada más que una proyección. Pero este mecanismo también funcionará a la inversa: a determinados valores o constructos culturales se les buscará una personificación genérica, y es aquí donde nos encontramos con que el mundo antiguo tuvo una particular inclinación por asociar el Mal, lo monstruoso o lo terrible con lo femenino.

La mitología y la literatura se encargaron de difundir esa imagen de la mujer como vehículo o encarnación del Mal. Los poemas homéricos, que son el pilar fundamental sobre el que se asienta la cultura griega, se inscriben en el épico ciclo troyano en el que, en la mayor parte de los casos, la desgracia, el dolor y la muerte vienen de manos de una mujer o de deidades femeninas menores.

La leyenda de la guerra de Troya se inicia cuando la diosa Eride, ofendida por no haber sido invitada al banquete nupcial de Tetis y Peleas, arroja una manzana sobre la mesa de los comensales y pronuncia la terrible frase de la discordia: «para la más bella». La disputa que se genera entre las diosas, y sobre todo entre Hera, Afrodita y Atenea, tiene todos los rasgos del enfrentamiento banal entre mujeres desde una perspectiva androcéntrica. La querella termina por dirimirla Paris, al entregar la manzana a Afrodita, que encarna el misterioso poder de seducción; trampa fatal por la que se desliza el Mal, turbando la razón de los hombres que se ven desbordados por el deseo.

Es ese deseo fatal el que llevará a Paris a «raptar» a Helena, infligiendo una grave ofensa a Menelao. La cómplice sumisión de la secuestrada se entrecruza con el derecho de posesión del esposo desairado, para dar como resultado una guerra terrible que llenará de gloria a los héroes pero que acarreará numerosos males y desgracias y terminará con la destrucción de la majestuosa Ilión. 
La infidelidad y el crimen están también en el origen de la tragedia de Orestes y en la de Electra. Los celos criminales en Medea, o el desafío al orden establecido por parte de una mujer en la de Antígona, y así en otras muchas obras. Parece como si la literatura griega se hubiera propuesto acuñar el tópico universal de que ellas son la desgracia de los hombres. En los casos mencionados se entremezclan otros muchos presupuestos y valores, pero en todos ellos aparece la mujer o lo femenino como instrumento del Mal.

Esa inconsciencia con la que opera el género femenino en la literatura griega no es sino una sobredeterminación con la que se abunda en el tópico patriarcal. La mujer por sí misma no tiene posibilidad de ejercer el mal porque carece de capacidad para ello. Aunque eso nos podía conducir al engaño, ya que, si conscientemente era «incapaz», inconscientemente, por su propia condición inferior, podía acarrear numerosos males a los hombres. La mejor justificación del opresor es culpabilizar a la víctima y este mecanismo primario de la autoexoneración, como tantos otros, también nos fue descubierto por los griegos.

El Mal había aparecido en el mundo ordenado del cosmos por culpa de la mujer. Fueron defectos intrínsecos en ella, como la irresponsabilidad y la curiosidad, las que precipitaron a los humanos al caos, obligándoles a conocer la muerte. Eso es lo que intenta enseñarnos Hesíodo con el mito de Pandora.

Pandora es la primera mujer en la cosmogonía griega. En su creación intervinieron todos los dioses y cada uno la dotó de una cualidad, aunque Hermes le inspiró la falsedad y la mentira al concederle el don de la palabra; él fue también quien le puso nombre y la llamó «mujer». Pero esta obra divina había sido premeditada por Zeus para castigar a los humanos a los que Prometeo acababa de entregar el fuego sagrado que había robado a los dioses.

El padre Zeus envió la mujer a Epimeteo que, seducido de inmediato por sus encantos, la aceptó como compañera, junto con una jarra que Pandora había bajado del Olimpo. Pero en esa jarra se encerraban todos los males y nada más llegar a la tierra, la mujer, picada por la curiosidad, la abrió para ver qué contenía, con lo que desparramó todas las desgracias entre los humanos. Sólo la esperanza, curiosamente considerada también como un mal por el fata- 


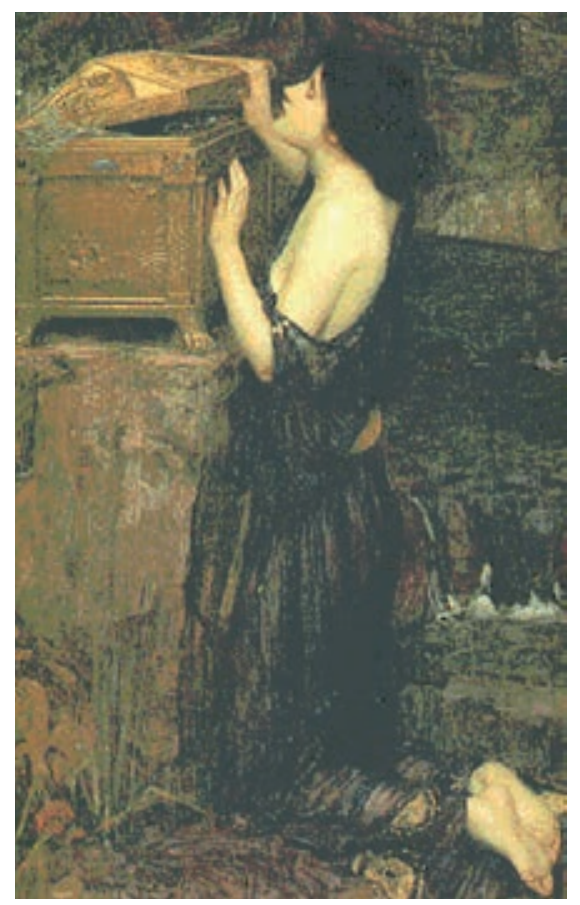

Para los griegos, el mal se instauró en el mundo por la falta cometida por Pandora, la primera mujer. En las diferentes versiones del mito la desdichada no obra conscientemente sino que es víctima de la curiosidad o la negligencia, defectos intrínsecos a su sexo, según la ideología patriarcal, lo que no evita que el hombre esté condenado al sufrimiento por su culpa.

lismo griego, permaneció en el fondo del recipiente antes de que Pandora pudiera volver a cerrarlo, pero el Mal ya existía en el mundo por obra de la mujer.

Otra tradición nos cuenta que el hecho fatal se produjo no por curiosidad sino por descuido. En esta versión la jarra, o la caja, tal y como ha quedado fijado en la imaginación popular, contenía todos los bienes; al abrirla, Pandora provocó que la dicha, la bienaventuranza o la inmortalidad se esfumaran de la tierra subiendo otra vez a los cielos olímpicos. El resultado fue el mismo y el Mal se instauró en el mundo. En ambos casos, la mujer no obró conscientemente sino que fue víctima de la curiosidad o la negligencia, defectos intrínsecos atribuidos a su sexo.

Para el mito griego quedaba claro que la mujer no era el Mal, pero también se establecía sin ninguna duda que éste llegaba a los 
hombres a través de ella. Hesíodo (Teogonía, 592) se muestra groseramente explícito al respecto cuando considera a la mujer como «espinoso engaño irresistible para los hombres... gran calamidad para los mortales».

Estos relatos que asociaban a la mujer con el Mal se complementaban en el mundo de creencias clásico con el rico bestiario monstruológico de naturaleza femenina que compartieron griegos y romanos: Circe, la terrible y al mismo tiempo atractiva maga, que convertía a los hombres en cerdos y de la que ya hemos hablado. Escila, la ninfa que habitaba en el estrecho de Mesina, con cuerpo de mujer, que a partir de las ingles se convertía en seis feroces perros que devoraban todo lo que hallaban a su alcance y que tenía el poder de transformarse en una roca amenazadora para todas las naves que se acercaban a ella. Caribdis, compañera inseparable de la anterior, un remolino mortal que tres veces al día absorbía el agua del mar tragándose todo lo que flotaba para escupirlo después.

Las sirenas, que en un principio tenían cuerpo de ave y cabeza de mujer y sólo posteriormente alcanzaron la fisonomía con la que actualmente las reconocemos, mujeres de cintura para arriba y peces en su parte inferior, que con sus melodiosos cantos atraían a los marinos a la muerte con la finalidad de devorarlos.

Equidna, la víbora de la que nos habla Hesíodo, mitad mujer, mitad serpiente, que vivía en una caverna en Cilicia desde la que hacía expediciones para alimentarse con los viajeros que por allí se atrevían a pasar. Sus apareamientos con Tifón dieron como frutos numerosos monstruos como Cerbero, el perro del infierno.

También estaba Quimera, hija de la anterior, que se manifestaba como una mezcla de animales feroces como el león y la serpiente. Sus correrías y pillajes en la comarca de Licia, escupiendo fuego por la boca, terminaron cuando le dio muerte Belerofonte.

La Hidra, que era otro vástago de Equidna, era una gran serpiente que tenía de cinco a cien cabezas y cuyo aliento era mortal. Con ella se vio obligado a enfrentarse Hércules, que aprovechó su sangre, tras haberle dado muerte, para envenenar sus flechas. 
Los mitos griegos también incorporaron a las Arpías, inmundas aves rapaces con cabeza de mujer. Las arpías, las «raptadoras», que Virgilio coloca a la entrada del Hades, eran seres alados con cuerpo de buitre y garras y orejas de oso, que barrían el mundo como el viento de tormenta, y se dedicaban a molestar a los humanos arrojándoles sus excrementos.

Y no podemos olvidar a las gorgonas, horribles mujeres con cabellera de serpientes, cuya mirada convertía a los hombres en piedra. Medusa, la más terrible de todas, que fue muerta por Teseo, aparece representada en la escultura griega con un rostro grotesco y una lengua que le cuelga hasta la barbilla. Diodoro y Plinio las identificaron con un pueblo formado únicamente por mujeres feroces con el cuerpo totalmente cubierto de pelo.

Los romanos sintieron una especial predilección por Lamia, una adaptación latina de la Mormó griega, que actuaba como el «cocón» de los niños pequeños según Horacio (Ars poética, 340). Lamia era oriunda de Libia y sus padres habían sido Belo y la misma Libia. Joven y hermosa había sido seducida, como tantas otras, por Zeus, el padre adúltero por excelencia. Hera, la esposa oficial de Zeus, celosa por estas relaciones se las arregló para matar al hijo de Lamia y siempre que la muchacha se quedaba embarazada hacía perecer a la criatura. No contenta con esta venganza terrible, convirtió a su infeliz rival en una insomne perpetua, que de ninguna manera podía conciliar el sueño.

Presa de la desesperación, la joven se ocultó en una cueva donde, sumida en la soledad y la amargura, terminó por metamorfosearse en un monstruo envidioso de las otras madres, cuyos hijos se dedicaba a secuestrar, en sus largas e interminables noches, para devorarlos. Zeus, el causante de todos sus males, al fin se apiadó de ella y le concedió la horripilante gracia de poder quitarse los ojos a voluntad. Merced a tan singular don, Lamia podía descansar, sacándose los ojos de las órbitas, y depositándolos en una vasija junto a ella. La imaginación popular terminó por multiplicar a Lamia, que se convirtió así en una legión de monstruos femeninos que rondaban por las noches para convertir en presas a los jóvenes que sorprendían, sorbiéndoles la sangre. 
De todas estas historias podemos extraer alguna conclusión. Estos monstruos guardan estrecha relación con las religiones orientales, especialmente con la egipcia que, como ya sabemos, tendía a concebir a los seres sobrenaturales con formas zooantropomorfas. La innegable influencia oriental en las antiguas creencias griegas y en la formación de su religión es indiscutible y ha sido puesta de relieve en más de una ocasión (Vian, 1977), aunque el espejismo de una cultura helena racionalista y humanizada ha llevado a negarla con la misma frecuencia (Hamilton, 1976: 12).

En estos seres horripilantes sólo encontraríamos la pervivencia de esas influencias, alimentadas por una imaginación popular temerosa, amiga de la fantasía y proclive a las emociones fuertes. Pero, en general, estas creencias se habrían ido desgastando con el paso del tiempo y por efecto de la crítica ejercida por las élites cultas, que las habría rebajado de mitos a cuentos, deslizándose del terreno de lo religioso al campo de lo literario. Sin embargo, como parte del mito, o como producto de la ignorancia y la fantasía, estos relatos habían cumplido y seguían cumpliendo una clara función al servicio de la ideología patriarcal, al transmitir un doble mensaje.

En primer lugar lo que estos personajes feminizados nos muestran es el carácter maligno de esa parte de la realidad circundante. Lo «otro», lo femenino, cuestiona peligrosamente el orden superior masculino. En la oposición existente, el que detenta el poder no puede engañarse sobre la debilidad del contrario, que siempre acecha para arrebatárselo o para destruirlo. Lo que se afirma como positivo y preponderante lo hace en función de esa oposición entre el Bien y el Mal. Por tanto, el héroe varón no sólo debe medirse con sus iguales antagónicos, sino que también debe enfrentarse a sus opuestos inferiores.

De este planteamiento se deriva la otra lección que estas historias pretenden transmitir. Lo masculino termina siempre por triunfar sobre lo femenino, haciendo valer aquello que le ha permitido ser más poderoso, la inteligencia y la razón. Frente a lo brutal y lo monstruoso femenino, el héroe mitológico siempre sale como vencedor, al oponer su propia inteligencia a lo animal e irracional de la bestia. 


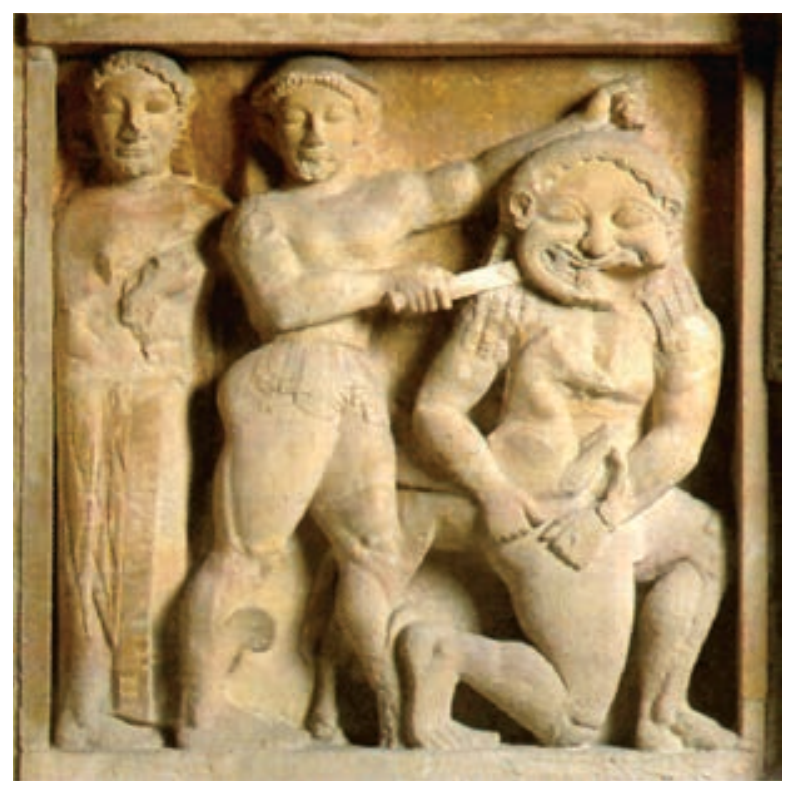

Muchos de los horribles monstruos que idearon los griegos eran de naturaleza femenina y estaban relacionados con las serpientes, como en el caso de la Medusa. No obstante todos ellos terminaban siendo destruidos por el héroe que imponía así el imperio de la razón sobre la bestialidad.

Todos los monstruos feminizados acaban por ser destruidos o engañados por el héroe. El arquetipo de éste es Hércules, que liquida a la Hidra, pero que también es capaz de capturar a la cierva de Artemisa, símbolo de la virginidad, o de apoderarse del ceñidor de Hipólita, reina de las amazonas. Ulises, utilizando la inteligencia y la seducción, consigue engañar a Circe, se escapa de Escila y Caribdis y logra sustraerse al fatídico encanto de las sirenas. Perseo acaba por matar a Medusa, valiéndose de las propias armas del monstruo, ya que es la mirada de la gorgona la que termina por petrificarla, cuando se ve reflejada en el espejo-escudo tras el que se protege el héroe.

Pero el triste destino de todos estos monstruos femeninos en la mitología patriarcal no tiene parangón con el de Lamia, una mujer castigada por otra - aunque ésta sea una diosa- por desempeñar el rol impuesto por el hombre. En la leyenda de Lamia se resume la tragedia del género sometido, ya que se convierte en víctima de sí misma, al asumir como fundamental aquello a lo que ha sido reducida. 
Lamia no es tanto víctima de la seducción de Zeus como de los celos de Hera. Si tomamos como referencia un caso de adulterio en que el engañado es el marido, como ocurre con Hefaistos cuando es burlado por Afrodita y Ares, encontramos una reacción distinta, propia del que se siente dominador y seguro. Hefaistos se limita a sorprender a los amantes, a capturarlos y a exponerlos al ridículo. En última instancia, el varón vive las ofensas a su honor como un episodio desagradable pero no trascendente. Su posición dominante le permitirá castigar a la adúltera sin que se vea mermada su consideración social, pero no ocurre lo mismo con la mujer convertida en esposa y madre, sobre todo cuando se cuestiona esta segunda función.

La mujer sólo sirve para dar hijos legítimos al varón y la esterilidad era la peor maldición que podía sufrir. No sólo era motivo de repudio, sino que invalidaba lo fundamental de su ser social. Defender la maternidad era defender su identidad como sujeto. Por tanto, los celos más terribles en el mundo clásico no los encarnará Otelo, sino Medea, cuya venganza ante el desamor de Jasón le llevará al terrible suicidio social de asesinar a sus propios hijos.

En el caso de Hera, poco fecunda y madre de criaturas desgraciadas, como el cojo Hefaistos y el sanguinario Ares, los engaños de su esposo provocan unos celos horribles que se descargan no contra el adúltero, sino contra la rival y sobre todo contra los frutos de estas relaciones. La mujer, impotente para poder escapar o subvertir esta relación de dominio, termina por convertirse en su principal sostén. El adversario no es el hombre, con el que no puede medirse y al que no puede desafiar, el adversario real es la otra mujer que atenta contra su ser social, como esposa o como madre.

Por eso la venganza de Hera sobre la desdichada Lamia no puede ser más terrible, le priva de la maternidad y la convierte así en un ser insomne, que no puede conocer el descanso, ya que ansía vanamente una realización imposible. Esta condena fatal sólo puede engendrar envidia y resentimiento y, así como los celos llevan a Hera a destruir a Lamia, su frustración le llevará a buscar la desgracia de las otras mujeres, privándolas de aquello que las hace ser: sus hijos. 
Sin embargo, hemos de admitir que la mujer y lo femenino, reducido en una cosmovisión patriarcal a la procreación legal o al disfrute del varón, aparecía como poco temible, al menos en esas personificaciones monstruosas que eran rápidamente sometidas por el héroe o devaluadas por el filósofo. Nos encontraríamos, por tanto, con que la vinculación entre el Mal y lo femenino se nos mostraría como muy frágil si no fuera porque el verdadero Mal para el pensamiento griego lo encarnaba el destino.

Es en la tríada Pandora-Moira-Erinias donde descubrimos el núcleo básico de la inculpación genérica con la que la ideología patriarcal griega liga el Mal a la mujer. Fue Pandora la que introdujo los males en el mundo, sobre todo la muerte que, a pesar de ser fatalmente deseada para poner fin a las otras desgracias que padecemos, es siempre temida. Sólo cuando el hombre se vio condenado a morir por culpa de la mujer, la Moira se puso a trabajar en esa tarea tan femenina como es el tejer para atar nuestras vidas a su voluntad. Si pretendemos desafiar esa voluntad nos encontramos con las Erinias, que se encargan de castigar nuestra soberbia llenándonos de sufrimiento para, al final, percatarnos de que estamos en el camino de Damasco y que nuestro destino se va a cumplir de todos modos inexorablemente. Sólo queda que la Moira decida cuándo cortar ese hilo, para descubrir que si venimos de mujer, en manos de mujeres estamos todo el tiempo y es su representación también la que pone fin a nuestra existencia, sin llegar a comprender muy bien si eso es una liberación o una condena a un mundo de sombras que, con sufrimientos o no, es lo más parecido a la espantosa nada.

Nos podemos legítimamente preguntar por qué ese empeño por vincular el Mal a la mujer. Al fin y al cabo en el mundo antiguo ésta era un ser inferior, absolutamente sometido y del que nada había que temer y, sin embargo, el Mal y la desgracia aparecen personificados en su género. Podríamos pensar en un acto de prepotencia exculpatoria del poderoso frente al débil, como ya hemos apuntado, pero creemos que es una explicación cuando menos incompleta. En el fondo de esa relación culpabilizante, feminidad/Mal se esconde en principio el temor. Para Delumeau (1989: 473), ese temor es ancestral y se debe a ese profundo «misterio» que es la maternidad: «El miedo que la mujer inspira en el otro sexo se basa sobre todo, en ese 
misterio, fuente de tantos tabúes, de terrores y de ritos, que la une mucho más estrechamente que a su compañero a la obra de la naturaleza y hace de ella el santuario de lo extraño».

Cuando hemos mencionado a los principales monstruos feminizados en la mitología griega, intencionadamente hemos excluido uno para ilustrar esta argumentación. Nos referimos a la Esfinge, un ser inquietante nacido de la fantasía oriental, que en Grecia acechaba a los humanos camino de Tebas para plantearles un doble enigma sobre la naturaleza cambiante del hombre y sobre la oposición de los contrarios en mutua dependencia. Cuando el viajero era incapaz de adivinar el acertijo lo devoraba.

«¿Cuál es el animal que primero camina a cuatro patas, después a dos y luego a tres? ¿Cuáles son las hermanas que se engendran mutuamente?» El hombre en el tiempo, el día y la noche. Interrogantes que se abrieron paso con la propia conciencia humana y que aún hoy siguen inquietando. Ese ser enfrentado a su propio devenir y a una naturaleza mudable, siempre igual y distinta, a la que él pertenece pero que no puede comprender, seguía temeroso ante el misterio de la vida.

La Esfinge, símbolo del enigma por excelencia en la cultura occidental, no podía ser sino un monstruo femenino porque representaba ese misterio universal: lo incomprensible de la conciencia escindida ante el mundo circundante. Desde esa condición interrogaba a los hombres sobre ellos mismos y ninguno era capaz de responder ante el dilema de la feminidad. El hombre se reconocía ante ella como un ser incompleto, transitorio e incapaz de entender su propia condición.

Sólo Edipo adivina en parte el enigma y descubre que ese ser cambiante con el tiempo, uno y distinto, que desconoce su origen y no puede evitar su final, es el hombre, y que el día necesita de la noche para ser, aunque sea su opuesta. Respuesta suficiente para que la Esfinge le deje seguir su camino, en él deberá enfrentarse a la vida, a su propio destino y entonces comprenderá que sus respuestas han sido insuficientes, porque sigue sin entender lo que está en el principio y en el fin, como opuesto y complementario. La mujer y la vida, la Moira y la muerte marcan el trágico periplo vital del desdichado Edipo que es el hombre mismo. 
En la fábula, la Esfinge, llena de desesperación ante la astucia de Edipo, se suicidará. La enigmática, inquietante y monstruosa feminidad no podía tener otro final en una cultura patriarcal. Pero su misión estaba cumplida al enfrentar a los hombres a su naturaleza escindida e incomprensible. Expulsados del paraíso animal estaban muy lejos de ser dioses y seguían sin controlar el origen de la vida, que continuaba siendo potestad de la mujer. El prestigio que su función fecundadora había tenido en época ancestral, cuando el hombre vivía inmerso en la naturaleza, se había metamorfoseado en esa cultura netamente masculina que caminaba hacia la racionalidad en un profundo temor que había que controlar o al menos conjurar.

La mujer seguía siendo necesaria a la par que incomprensible y esa combinación limitaba la autoridad y el poder del hombre. Una dominación completa hubiera pasado por poder prescindir de la mujer y comprender el misterio de la vida que ella atesoraba, y ambas cosas resultaban imposibles. La primera se podía controlar, sometiéndola y diversificando sus funciones sexuales y afectivas, la segunda sólo inspiraba inseguridad, y esa inseguridad en el hombre racional se vinculaba necesariamente con el temor y éste con el Mal.

Para los hombres, la mujer resultaba una extraña combinación, mezcla de deseo, necesidad y misterio. Un poderoso motivo de crítica a las mujeres era el empleo de su atractivo sexual para influir en ellos. Son abundantísimas las referencias literarias en este sentido. La solución parcial al problema consistió en reducirlas a categorías particulares y distintas: la esposa, la prostituta, la compañera, la concubina. Pero ese sometimiento no ponía fin a la dependencia y al poder de dar la vida que poseían. Había que minimizar y estigmatizar ese poder misterioso para terminar arrebatándoselo. La ciencia de la época y también la filosofía contribuyeron a ello.

En el Corpus hipocrático, la mujer aparece como un ser diferente e inferior al hombre. La manera en la que Hipócrates distingue el cuerpo del hombre y de la mujer, comparando al primero con un tejido compacto y el segundo con la lana lacia, nos indica cómo la diferencia para él no sólo es orgánica, sino constitutiva y esencial. 
Por otra parte, la medicina griega y romana, aunque redujeron a la mujer a su función reproductora, pretendieron hacer bascular el mérito de la concepción a favor del varón, mientras que la responsabilizaban de la esterilidad.

Por un lado, el hecho de considerar el útero como un repulsivo «animal dentro de un animal ${ }^{18}$ contribuyó a denigrar el cometido de las mujeres en la concepción y, por otro, se intentó minimizar su función por medio de la curiosa teoría de los espermas. Tanto para Aristóteles como para el Corpus hipocrático, el esperma del hombre es fuerte y con él se conciben los niños, mientras que el débil esperma femenino sólo posibilitará engendrar niñas. El proceso de gestación tampoco será el mismo para los embriones varones que para las hembras: «El embrión femenino se solidificará más tarde: la razón es que el esperma de la mujer es más débil y más húmedo que el del macho... y por esta razón los loquios son más prolongados en el parto de una niña que en el de un chico» (De la generación, XVIII, 8).

La idea de que el hombre era el principal responsable de la concepción positiva, o sea de la concepción de varones, contribuía a conjurar en parte ese poder misterioso de las mujeres sobre el origen de la vida. Al arrebatarles ese privilegio esencial no lograban, no obstante, acabar con el temor que seguían inspirando, pero sí se les privaba del prestigio simbólico que habían gozado en una época anterior. En la medida en que era rebajada por su propia naturaleza se aproximaba a la materialidad y aquí los filósofos idealistas completaban la explicación de por qué la mujer y el Mal estaban relacionados.

Platón al final de su obra Timeo (91 e) acepta la teoría sobre el «vientre errante»: «un animal deseoso de procreación en ellas [las mujeres], que se irrita y enfurece cuando no es fertilizado a tiempo durante un largo período y, errante por todo el cuerpo, obstruye los conductos de aire sin dejar respirar ocasionándoles las peores caren-

18 Vieja teoría procedente de la cultura egipcia por la cual se creía que los desarreglos de la mujer tenían su origen en una mala posición de la matriz. El útero se desplazaba en su cuerpo buscando una correcta ubicación. Estos «úteros errantes» fueron aceptados por la medicina griega, que les confirió la misma valoración misteriosa que la egipcia, asimilándolos a un animal. 
cias...». Esto es así para el filósofo porque en realidad las mujeres son la reencarnación de «todos lo varones cobardes y que llevaron una vida injusta...», manifestándose como un símbolo de la degeneración de la raza humana. Una mujer era una mujer debido a su incapacidad para fabricar semen, incapacidad que, según Aristóteles, procedía de su fría constitución: «Hay que considerar su naturaleza como un defecto", nos llega a decir el estagirita (La generación de los animales, 775 a, 14-16). Así pues, el fluido menstrual no era sino un semen deficiente y la mujer un hombre inacabado o imperfecto, capaz de proveer sólo la materia del feto, al que el varón, superior, aportaba la forma y el alma.

Estas teorías llevaban en la cultura clásica a identificar al varón con la civilización, la razón y el orden y a la mujer con la naturaleza y la emoción, pero también con el caos y el Mal. El hombre podía llevar una vida presidida por la razón y la lógica, mientras que en la mujer primaba lo instintual y se veía arrastrada a satisfacer sus pasiones más primarias.

En esa tendencia natural e impulsiva de la mujer hacia la materialidad, la filosofía idealista sólo podía considerarla estrechamente relacionada con el Mal. Eudoxio de Cnido, que intentó explícitamente conciliar las doctrinas de Platón con las del mazdeísmo, tuvo un continuador en Xenócrates, que exponía un conflicto entre dos principios universales: Mónada y Díada. Mónada era el principio masculino, el Dios original, la inteligencia racional y Díada era el principio femenino, la irracionalidad y el Mal. Este dualismo se reflejaba, en un nivel más bajo, en la oposición entre los dioses olímpicos, generados por la Mónada, y los titanes, hijos del principio femenino. En un nivel todavía más bajo, estaba el conflicto entre los demonios del Bien y el Mal.

La filosofía y la ciencia habían dado su respuesta a algo que, en el terreno de las creencias, la sociedad patriarcal ya había anticipado y, sin embargo, en este ámbito del pensamiento religioso la ambigüedad aún permanecía arraigada con fuerza. Lo femenino todavía era alabado por lo misterioso de su poder fecundador, aunque también aquí las antiguas creencias en la diosa madre terminarían por retroceder. 


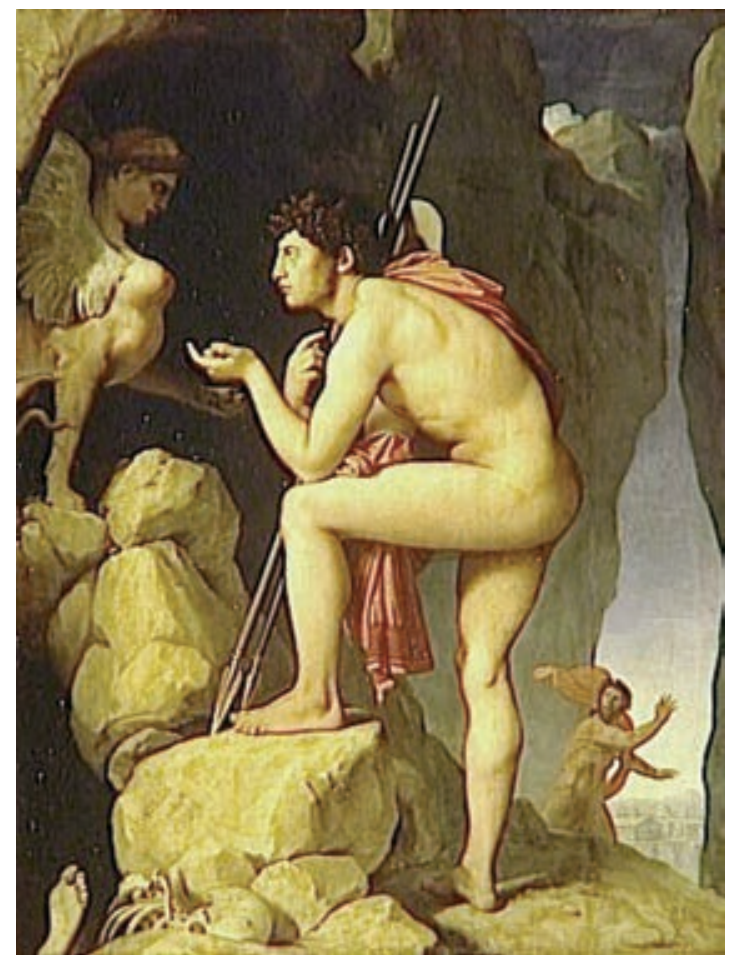

La esfinge, símbolo del enigma por excelencia, no podía ser sino un monstruo femenino porque representaba ese misterio universal: lo incomprensible del dilema de la feminidad. El hombre se reconocía ante ella como un ser incompleto, transitorio e incapaz de entender su propia condición.

\section{Falocracia y palingenesia}

La religión olímpica griega, con su carga de escepticismo y resignación heroica, sirvió a una clase guerrera que se educó en esos valores con Homero. También fue útil al desarrollo de una conciencia política que desembocó en la constitución de las polis. La escasa intervención de los dioses en la nueva organización social contribuyó al asentamiento de una cultura urbana bajo el imperio de unas leyes elaboradas por los hombres y sólo avaladas por la divinidad. Pero ese tipo de vivencia religiosa implicaba en menor medida a las clases populares que buscaban un consuelo y unas seguridades que las creencias oficiales no proporcionaban. 
Las élites podían adoptar una postura displicente respecto al más allá, su posición privilegiada les permitía enfrentarse a la dureza de la vida con una despreocupación que no podía ser la misma que la del pobre campesino del Ática, que buscaba encontrar una protección más eficaz en los trabajos y los días de su dura existencia y algún tipo de compensación, aunque fuera en otra vida. Por eso, desde época temprana, y apoyándose en un sustrato arcaico, aparecieron en Grecia toda una serie de prácticas cultuales destinadas a satisfacer esas necesidades espirituales que demandaban los estratos más bajos de la población. Fue así como se desarrollaron, hasta alcanzar una enorme importancia, los llamados misterios, de los cuales el más importante fue el celebrado en torno a Deméter en Eleusis.

En el origen de estos misterios, que se dieron en la pequeña población de Eleusis, próxima a Atenas, nos encontramos con toda probabilidad con un primitivo rito iniciático tribal, que transformaba a los jóvenes en miembros adultos de la colectividad. Esta práctica, no obstante, perdió su sentido con los cambios sociales y políticos que experimentó el mundo heleno hacia el siglo viI a. n. e. y dejó de ser funcional en una sociedad en la que carecía de significado transformar al iniciado en miembro de una comunidad que se fundaba ya en otros principios.

El rasgo esencial de los viejos ritos iniciáticos, en este caso como en el de todas las culturas primitivas que los practicaron, era su naturaleza democrática; al ser igual para todos, el rito convertía a los participantes en iguales. Todos los adolescentes que lo superaban pasaban a ser considerados como guerreros y las diferencias se establecían en función de la familia o del clan de pertenencia. Esta práctica resultaba ya inadecuada en un sistema basado precisamente en la desigualdad legal, consagrada por el derecho de ciudadanía que, precisamente, suponía la superación del viejo orden fundado en el parentesco de sangre.

Si el rito sobrevivió es porque se transformó reorientando su función y pasando a ser un rito de fecundidad generatriz que pivotaba sobre la divinidad femenina de Deméter, diosa de la fertilidad de la tierra, en la línea de los cultos agrarios en los que la mujer y 
lo femenino desempeñaban un papel esencial. Pero en Eleusis podemos estudiar cómo esas arcaicas creencias experimentaron una nueva transformación para adaptarse a un desarrollo social y cultural cada vez más complejo. Inicialmente, los cultos agrarios no perseguían otro objetivo que garantizar la fecundidad de la tierra y los mitos de que se acompañaban solían explicar la alternancia y regularidad del ciclo agrícola, como era caso del mito de Perséfone o Core, vinculado al culto de Deméter en Eleusis.

Según la leyenda, Deméter tendría una hija, Perséfone o simplemente Core - muchacha en griego-, que habría despertado, por su gracia y belleza, el deseo de Hades, el dios subterráneo del mundo de las sombras. Hades se habría apoderado de Perséfone haciéndola suya y llevándola a su reino. Su madre, desesperada por el rapto de la joven, abandonó el Olimpo y comenzó un doloroso peregrinaje por la tierra en busca de su hija. Tal era su tristeza que descuidó sus funciones, ocasionando la esterilidad de los campos hasta tal punto que los humanos, aterrados, pensaron que iban a perecer y suplicaron a Zeus que interviniera. El Dios padre obligó a Hades a que restituyera a Perséfone junto a su madre, pero éste le hizo comer a la joven una granada, fruta sagrada, que le obligaba a volver junto a él al menos parte del año. Así, Deméter podía gozar de la compañía de su hija durante algunos meses, momento en que la diosa, dichosa por la presencia de la muchacha, hacía reverdecer la tierra, mientras que Hades la reclamaba la estación restante, y Deméter, entristecida, sumía a la naturaleza vegetal en el letargo.

Una parte no sustancial del mito permitió vincular las prácticas rituales con la población de Eleusis y metamorfosear su función agraria, en otra de naturaleza trascendente. En su vagar por la tierra, Deméter había encontrado refugio en Eleusis, en casa del rey Celeo, donde se le acogió amablemente e, incluso, se le hizo sonreir de nuevo, por eso fue ella misma la que mandó que allí se erigiera un templo en el que se le rendiría culto. Así quedó establecido su santuario en Eleusis, aunque su influjo se extendió por toda Grecia y por todo el mundo antiguo hasta que terminó por desaparecer en el siglo IV de nuestra era. En esa misma casa ocurrió algo que posibilita explicar cómo el rito agrario de fertilidad terminó por convertirse en un misterio de bienaventuranza tras la muerte. La divina 
viajera no fue reconocida de inmediato por sus anfitriones que, aunque la consideraron de noble origen, no vieron en ella a la diosa Deméter, por lo que le pidieron que se hiciera cargo como nodriza de la educación de los hijos del rey Celeo.

Agradecida, la diosa aceptó el trabajo con el secreto propósito de conceder la inmortalidad al pequeño Demofón, que acababa de nacer. Por eso Deméter no amamantaba al niño, sino que lo untaba con ambrosía y por las noches lo bañaba en fuego con la finalidad de convertirlo en inmortal. Una noche, cuando se hallaba en plena tarea, la reina Metaneira la sorprendió metiendo a la criatura en la lumbre, y asustada lanzó un grito. Entonces, la diosa, renunciando a su propósito, exclamó: «iHombres ignorantes y sin juicio para prever el bien o el mal que el Hado nos ha de traer!» (Himno homérico a Deméter, 256). Demofón ya no podría ser inmortal, pero Deméter proclamó su auténtica identidad y prometió que si se le rendía culto en aquel lugar enseñaría a los humanos los misterios mediante los cuales los iniciados gozarían de un nuevo nacimiento a una inmortalidad dichosa.

Podemos deducir que los rituales con los que estaba originalmente vinculado este mito se orientarían al mantenimiento de la vida y de la fecundidad. Serían mitos generatrices relacionados con una Diosa Madre, como los que ya se practicaban en Oriente y muy posiblemente en Creta. El papel secundario que en el relato se le concede al personaje masculino así nos lo indica, y su trasformación en algo distinto y más profundo como la inmortalidad del alma humana, habría aparecido más tarde.

$\mathrm{Al}$ igual que en Creta, parece que los ritos se celebraban en un principio al aire libre y en beneficio de toda la comunidad y no de unos pocos iniciados. No hay vestigios arqueológicos de un Telesterion o santuario mistérico antes de la ocupación ateniense de Eleusis. Sólo con Pisístrato, a mediados del siglo vi a. n. e., se puede constatar un incremento del culto y una asunción por parte de los atenienses de estas prácticas rituales. Debieron de ser los aldeanos que emigraban a la ciudad los que inicialmente llevaron consigo el culto agrario, pero en el marco de la polis y con la quiebra del viejo orden social los misterios sufrieron una profunda modificación y 
perdieron su naturaleza comunitaria y su primitiva función, convirtiéndose en un rito de redención sólo para iniciados.

Mucho se ha escrito y poco se sabe sobre los misterios eleusíacos, el secreto al que se veían obligados los participantes nunca fue vulnerado y los escasos indicios que han llegado hasta nosotros no nos permiten afirmar con certeza en qué consistían, y lo que ocurría realmente en el interior del Telesterion permanece en la oscuridad. Conocemos las prácticas previas en las que podemos distinguir los pequeños Misterios y los ritos preliminares de los grandes Misterios (telete) de la experiencia final (epopteia). Los verdaderos secretos de la telete y la epopteia jamás fueron divulgados, pues sobre los que lo hicieran pesaba la amenaza de muerte.

Los pequeños Misterios se celebraban, durante el mes de anthesterion (febrero), en Agras, un suburbio de Atenas, y comprendían un conjunto de ceremonias de purificación, basadas en el ayuno, los sacrificios y los baños lustrales, que se realizaban bajo la supervisión de un mistagogo o conductor de los mystae o neófitos. En el mes de boedromion (septiembre-octubre), ${ }^{19}$ se celebraban los grandes Misterios. Las ceremonias duraban ocho días y todos los que hablaban el griego, mujeres y esclavos incluidos, tenían derecho a participar en ellas si habían superado los «pequeños Misterios».

El primer día se celebraba la fiesta en Atenas, a donde se transportaban a tal efecto en procesión solemne los objetos sagrados (hiera) desde Eleusis. El segundo día, 14 de boedromion, se organizaba una procesión hacia el mar. Cada uno de los aspirantes llevaba en brazos un lechón al que purificaba con agua marina antes de practicar su sacrificio. Los dos días siguientes los mystae los pasaban en retiro. El quinto día marcaba la culminación de las ceremonias públicas. Al alba se formaba una gran procesión que iba desde el Eleusinium ateniense hasta el Iaccheum. La estatua del hermoso dios joven Iacchos, portando una antorcha en la mano, era adornada con mirto e incorporada al cortejo, iniciándose el camino hacia

19 El año ático era de 12 meses de 29 ó 30 días y comenzaba en el solsticio de verano hacia finales de junio, por eso el tercer mes del año, boedromion, se correspondía con parte de nuestro mes de septiembre y comienzos de octubre. 
Eleusis. Al atardecer la comitiva debía llegar a un puente que atravesaba el Kefisio; en aquel punto, unos hombres disfrazados prorrumpían en exclamaciones obscenas e insultantes. Por fin, la procesión llegaba al santuario cuando declinaba el día. De inmediato se instalaba el campamento y una parte de la noche se dedicaba a las danzas y canciones en honor de la diosa. Al día siguiente los aspirantes ayunaban y ofrecían sacrificios antes de penetrar en el templo para dar comienzo a la parte más importante de la iniciación, los ritos secretos o telete.

Alguna de las ceremonias podían incluir legomena, breves fórmulas litúrgicas o invocaciones, de ahí que la iniciación estuviese vedada a los que no supieran hablar griego; y es muy probable que durante la noche tuviera lugar el acto culminante de la iniciación, o epopteia. El día siguiente se dedicaba sobre todo a ritos fúnebres y libaciones por los muertos, y el último día los mystae regresaban a Atenas.

Las especulaciones sobre lo que podía ocurrir en el interior del Telesterion han sido muchas pero el impenetrable secreto en el que estaba envuelta la ceremonia hace honor al nombre misteria con la que fue bautizada. Lo que sí nos queda claro es el sentido del rito. Ya en el Himno homérico a Deméter (480-482) se dice: «Dichoso, entre los hombres terrestres, el que los ha contemplado; pues el no iniciado en estos misterios, el que de ellos no participa, no alcanza jamás una suerte como la de aquél, ni aun, después de muerto, en la oscuridad tenebrosa». Parece evidente que el significado del rito, cuando fueron escritos estos versos a finales del siglo vII a. n. e. era ya claramente palingenésico. El antiguo rito de iniciación tribal había dado paso a otro agrario y generatriz, bajo el patrocinio de la doble personalidad femenina Deméter/Perséfone, y éste, por último, había terminado por transformarse en un ritual iniciático de resurrección.

La raíz de la creencia en la supervivencia tras la muerte, como una elaboración ideológico-cultural, está sin duda asociada a los ritos de fertilidad vinculados a la tierra. De este modo aparece en las religiones orientales y es lógico pensar que así debió de ser también en la cultura occidental. Pero el concepto que entrañaba la creencia eleusíaca comportaba algunas diferencias respecto a sus equiva- 
lentes egipcio o mesopotámico, adquiriendo un carácter más humano e implicativo. La supervivencia que se obtenía en Eleusis era cualitativamente superior a la egipcia y entrañaba la idea de una vida placentera en el otro mundo: «Tres veces dichosos los mortales que, después de contemplar los misterios, marcharán al hades. Sólo ellos podrán vivir allí, mientras que todo será dolor para los restantes», nos dice Sófocles (Fragmentos, 719).

Para el egipcio era suficiente con sobrevivir a la muerte. Conjurar la nada o la destrucción era ya una aspiración suficiente para el fellah del Nilo que, a partir de un momento determinado, procuraba por todos los medios un decente proceso de conservación de su cadáver para, al menos, poder enfrentarse al juicio osiríaco. En este avatar, el egipcio sólo se valía de una serie de prácticas y fórmulas mágicas que le garantizaban por medio de su correcta ejecución ese tránsito a una vida que no pensaba muy distinta a la que había vivido en este mundo. En el caso de la iniciación eleusíaca se requería de una participación voluntaria en el rito, podríamos decir que era necesaria una cierta adhesión a la creencia y una implicación personal en una ceremonia que practicaba el vivo para seguir viviendo. También se diferenciaba de las palingenesias ${ }^{20}$ orientales en que se le revelaba al iniciado un misterio, el misterio de la vida eterna, haciéndole partícipe de algo trascendente y no mero sujeto pasivo de fórmulas mágicas. Este involucrar al iniciado en el conocimiento sagrado lo ratifica Píndaro (Trenos, 137), que nos dice: «jFeliz el que después de haberlos visto, desciende a la tierra; feliz el que conoce el fin de la vida, y conoce el comienzo que otorgan los dioses!».

El enriquecimiento que suponen estas creencias respecto a otras más primitivas y menos evolucionadas señala la distancia que

20 Aunque es un término utilizado por la corriente estoica para designar la reconstrucción del universo después de que el fuego lo haya destruido, nosotros lo utilizamos aquí como lo hace el Evangelio de $\operatorname{Mateo}(19,28)$ en el sentido de aquella creencia que asegura una vida mejor en el más allá. Lo preferimos al término «salvación» porque éste lo consideramos más apropiado para las religiones de naturaleza específicamente salvífica, como es el cristianismo, cosa que no ocurre en el caso que nos ocupa. Así mismo pensamos que es más adecuado que el de «escatología», reservado a aquellos cultos o creencias religiosas que anuncian el próximo final de los tiempos y una salvación colectiva. 
separa el mundo oriental del segundo milenio del vertido cultural del mundo grecomeditarráneo del siglo vi a. n. e. Podemos decir que Eleusis fue el auténtico nacimiento de la resurrección intelectualizada que heredará el mundo occidental. La importancia del hecho no pasó desapercibida a Platón, que se mostraba favorable al rito, ni tampoco a otros ilustres pensadores del mundo antiguo, como el mismo Cicerón, que se convirtió en iniciado. Ellos contribuyeron a que el rito acabe adquiriendo un tinte moralizante y una dimensión esperanzadamente existencial.

Cicerón (Leyes, II, 14), que se esforzó en forjar nuevos valores y creencias superadores de los viejos mitos, nos dejó un claro testimonio de lo que estamos diciendo: «Entre los muchos dones excelentes y divinos de Atenas, a los hombres, nada hay mejor que estos Misterios por los que somos llevados de la barbarie a la civilización. Con razón reciben el nombre de iniciación, porque así es como hemos aprendido los primeros principios de la vida; y no sólo hemos recibido la manera de vivir con alegría, sino también de morir con una esperanza mejor».

Ya hemos señalado que en principio podía ser iniciada cualquier persona que cumpliera unos requisitos mínimos, hasta los esclavos y las mujeres, cosa que no deja de llamar la atención, tenían derecho a un mundo feliz en el más allá. No se requería nada más que ajustarse a lo diseñado por los oficiantes, vestigio sin duda de la naturaleza mágica del rito. Pero pronto apareció de manos de pensadores y literatos la idea de que un renacer dichoso en el otro mundo sólo podía estar al alcance de aquellos que hubieran llevado una vida digna y correcta.

La universalidad de la salvación para los mystes, independientemente de su catadura moral, es algo que señala cínicamente Diógenes cuando comenta que el ladrón Patakios, como había sido iniciado, viajaría más a gusto después de su muerte que el mismo Epaminondas. Esta idea no podía sino repugnar a toda la corriente filosófica nacida del pensamiento socrático con una fuerte carga moralizante. Por eso Platón, en el Fedón, se muestra explícito: sólo los puros, los virtuosos, los que ansían conocer el Bien pueden aspirar al moderno renacer que ofrece la palingenesia eleusíaca. Para 


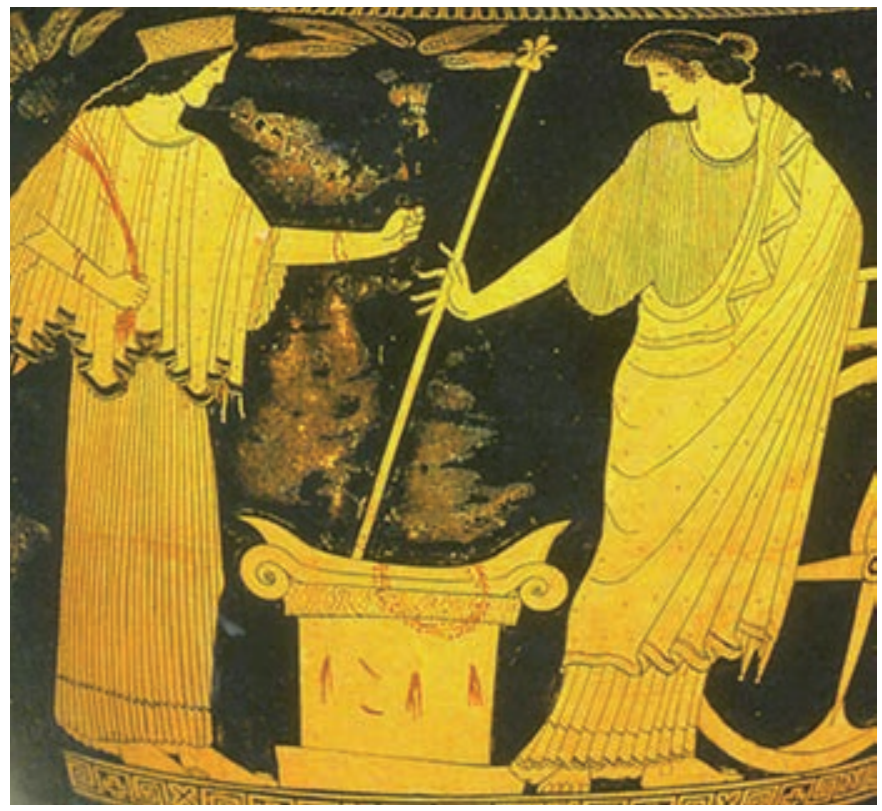

En el santuario de Eleusis se desarrollaban unos ritos mistéricos que comenzaron siendo agrarios y evolucionaron hasta convertirse en palingenésicos, presididos por la diosa Deméter, lo que nos indica el enorme prestigio de lo femenino en este tipo de creencias.

Platón no basta con iniciarse, es necesario acceder al rito debidamente purificado, y la purificación no es meramente ritual, sino moral, y comporta la moderación, la justicia, la valentía y la misma sabiduría.

Muchos de los elementos de la resurrección de la carne que siglos después el cristianismo pondrá en circulación están ya aquí formulados. El misterio, la revelación, la conducta correcta y la iniciación obligada, si se quiere acceder a la salvación, aparecen en el mensaje eleusíaco de factura platónica, lo que hace exclamar a Vian (1977: 323) que la fórmula «fuera de la iglesia no hay salvación» está ya comprendida en esta interpretación del rito.

La conclusión precipitada que podríamos sacar de lo que estamos diciendo es que la moderna palingenesia salvífica, predomi- 
nante con posterioridad en Occidente, tiene su origen en Grecia, y que nació bajo el signo de la feminidad de Deméter; pero esto resultaba inadmisible para una sociedad patriarcal, de ahí que aparezca Dionisos a disputar ese privilegio a la mujer.

Al hablar de Dionisos resulta ineludible caer en el tópico de considerarlo un dios enigmático. Durante mucho tiempo se le creyó oriundo de Asia y se pensó que era una divinidad tardía en el panteón griego (Rohde, 1918/1994). Lo cierto es que no forma parte de los dioses olímpicos y que su presencia entre los griegos y su reconocimiento es posterior y más dificultoso que el de otras divinidades, aunque Homero lo menciona ya como un dios perfectamente admitido entre los helenos.

Interpretaciones recientes sobre un fragmento de escritura micénica en la que aparece el nombre di-wo-un-so-jo han querido ver en él una antigua denominación de Dionisos. De ser cierta esta suposición las tesis sobre su modernidad y origen extranjero se desmoronarían para mostrarnos a una de las divinidades prehelénicas más arcaicas de la religión griega. Lo que parece innegable es que su consolidación como tal debió de ser tardía y este hecho se pudo deber a la naturaleza de lo que Dionisos representaba.

Con esto entramos en otro de los temas más debatidos sobre el dios, al que se le conocen y atribuyen distintas funciones y patrocinios. Lo que nadie discute es que desde sus más remotos orígenes estuvo vinculado con cultos de carácter estático en los que las mujeres desempeñaban un papel primordial y posiblemente exclusivo, de lo que podemos deducir que era una divinidad masculina especialmente reconocida por lo femenino, lo que no resulta tan común como en principio se pudiera suponer, ya que las griegas y las romanas solían invocar a diosas como Afrodita/Venus o Hera/Juno.

Las noticias que tenemos sobre esos primitivos ritos son escasas y fragmentarias. La aportación fundamental la sigue constituyendo la obra de Eurípides Las bacantes y de ella no podemos deducir con certeza qué era lo que representaba el rito orgiástico en honor de Dionisos. En la tragedia de Eurípides, el mismo Dionisos, acompañado por un cortejo de ménades o bacantes, regresa a Tebas, lugar de nacimiento de su madre, ofendido porque su culto es igno- 
rado todavía en Grecia. Pero sus tías, Agave, Ino y Autonoe, se niegan a aceptar su origen sagrado. Dionisos, aún más enfurecido por ese desplante, las hace enloquecer. Las tres hermanas, presas de la «manía» dionisíaca, se lanzan, junto con las demás mujeres de Tebas, hacia la montaña del Citerón. Penteo, el hijo de Agave que es rey en Tebas, desconfía de aquel charlatán, embaucador de mujeres, y quiere restaurar el orden. Manda apresar al dios pero éste consigue librarse y logra persuadir al propio Penteo de que vaya a espiar a las mujeres durante sus ceremonias.

Mientras tanto, se extiende la noticia de los prodigios que se están produciendo en el monte: las tebanas amamantan cervatos y lobeznos; hacen brotar fuentes de leche, miel y vino con sólo golpear con sus tirsos el suelo y las rocas. Su poder parece ser irrefrenable; despedazan toros sin necesidad de cuchillos; tienen los cabellos flameantes, y los soldados de Penteo nada pueden contra ellas. El desgraciado Penteo, cuando llega al escenario de semejantes maravillas, nada puede contemplar pues las tebanas, encabezadas por la propia madre del rey, se lanzan sobre él confundiéndolo con un león y lo despedazan vivo, blandiendo su cabeza como trofeo.

Eurípides, sin duda, se inspiró no sólo en la leyenda sino en prácticas cultuales que se debieron dar en la Grecia arcaica y que de algún modo aún sobrevivían en tiempos del autor en algunas zonas de la Hélade. En ellas, la ceremonia debía comportar la oribasia nocturna, es decir, el retiro a la montaña de las mujeres, a fin de celebrar orgías sagradas en torno a una víctima sacrificial o diasparagmos. En el momento culminante del éxtasis orgiástico el animal sería despedazado por las participantes y devorado crudo. Esta práctica homofágica vendría avalada por el epíteto Omestes, con el que en algunas ocasiones se denomina a Dionisos y que significa el «comedor de carne cruda». Por medio de este rito las participantes no sólo conocerían una epifanía total del dios sino que, a través de la ingestión de la víctima sacrificada, comulgarían con él, ya que en este tipo de ceremonias es en la carne cruda de los animales despedazados donde se encarna la propia divinidad.

¿Cuál podía ser el sentido de este salvaje ritual? En parte está contestado. Comulgar, confundirse con la divinidad, para experi- 
mentar por medio del éxtasis su propio poder. El «entusiasmo» dionisíaco permitiría a quienes a él se entregaran, identificarse con su dios en la existencia terrena. La bacante recibía, al igual que Dionisos, el nombre de Bacchos (o Bacche en femenino), mientras que algunas veces se designa a Dionisos con el adjetivo Bacchios, «aquel que hace de bacante», lo que viene a avalar esta hipótesis. En principio nada nos podría hacer sospechar que tuviera un sentido más profundo y palingenésico como los misterios eleusíacos. Parecería estar más relacionado con prácticas chamánicas primitivas y orientales que con un mensaje de revelación y salvación mucho más elaborado y, sin embargo, siguen planeando interrogantes tales como: ¿qué representaban las mujeres en una ceremonia de estas características, en una sociedad patriarcal y machista? Esto nos obliga a volver sobre la naturaleza del dios.

Dionisos, es una obviedad, está relacionado con la vid y con el vino, y en ese patrocinio detectamos una vocación vegetal de la divinidad que, cada vez más, se apunta como su auténtica naturaleza primigenia. Todo parece indicarnos que en sus representaciones más primitivas el dios era identificado como un simple tronco de árbol con una máscara en su parte superior (Martín y Metzger, 1978: 149). El árbol es una de las más ricas representaciones simbólicas que conocemos, ya que se pueden encontrar múltiples significados tanto por su forma como por su especie, por sus hojas o por su misma estructura tripartita de raíz, tronco y copa. Su simbología abarca desde lo religioso a lo político, y Mircea Eliade (1975: 244-296) nos habla de hasta siete interpretaciones diferentes aunque orientadas todas ellas hacia el cosmos vivo en consonancia con la regeneración. Pero el tronco de árbol, en las culturas agrarias, guarda relación con la fertilidad masculinizada, ya que no sería otra cosa que un símbolo del falo erecto (Oestereicher, 1983: 22).

En algunos lugares de la India, el matrimonio se celebra junto a un árbol con la esperanza de que la unión sea fértil, y se ha podido constatar como muy extendida, en distintas culturas, la creencia entre las mujeres estériles de que al frotar sus cuerpos con un árbol plantado pueden conseguir la fecundidad. Esta vinculación del simple tronco despojado de sus ramas con el miembro viril estaría también estrechamente relacionada con las antiguas festividades del 
«mayo», que se han practicado por toda Europa y que aún perviven en algunos rincones. El «mayo» es un tronco de árbol que la comunidad clava en un lugar determinado al comenzar la primavera, de ahí el nombre que recibe la festividad, pues en muchos casos la fecha señalada suele coincidir con este mes del año. En los Vosgos, la ceremonia se celebraba el primer domingo de mayo y en Suecia el mástil de mayo se erguía durante el solsticio veraniego con troncos de pino despojados de sus ramas. La celebración se completa con el adorno del tronco con motivos florales e incluso premios, que se colocan en el extremo del mástil y daban origen a concursos de cucaña. Por ejemplo, en Inglaterra la jornada comenzaba cuando grupos de jóvenes se paseaban el día señalado por las casas, coronados de flores y pidiendo regalos, para terminar con una danza en torno al tronco. Como en otros ritos de fertilidad y regeneración, el sexo desempeñaba en el «mayo» un importante papel y esas danzas podían tener un carácter orgiástico. Frazer (1974: 157) nos ofrece un curioso testimonio de este tipo de fiestas a través de la pluma de un puritano inglés del siglo XVI que en una obra titulada Anatomía de las ofensas relata cómo al final de estas celebraciones, «de cuarenta, sesenta o un centenar de doncellas que van al bosque esa noche, escasamente la tercera parte de ellas vuelven inmaculadas a sus casas».

No sería aventurado admitir que si las primeras representaciones de Dionisos nos lo muestran como un mero tronco de árbol, a lo sumo con una cabeza o careta, el dios fuese, en época arcaica, una primitiva personificación del falo erecto en el que el bálano sería su propio rostro.

El culto al falo como símbolo masculino de la regeneración lo encontramos en el origen de la cultura indoeuropea. El linga hindú es posiblemente la plasmación más abundante de este tipo de representación, aunque en la base del linga aparece un sexo femenino en forma triangular que apuntaría todavía una relación de dependencia hierogámica en su función generatriz. Pero en la cultura griega el falo, bien sea a través del tronco de árbol o de otras manifestaciones, ya se ha desprendido de esa raíz, al menos en su plasmación material, aunque como veremos más adelante el valor de la hierogamia podía pervivir de otro modo. 
Esta manifestación de Dionisos, tronco de árbol, que aparece claramente representada en más de una cerámica griega en la que se muestra al dios como un maniquí, en torno al que danzan frenéticamente unas mujeres que consumen vino, no es la única que avala la estrecha relación existente entre esta divinidad y el falo generador. Otras numerosas pistas terminan por asociarlo a él y a sus ritos con el culto al miembro viril.

El tirso, instrumento de veneración propio del culto dionisíaco, es en sí mismo un símbolo fálico. El bordón adornado con hidra y mirto, plantas de la vida perenne, y rematado por una piña, no es sino la expresión portátil del mismo tronco o falo al que se rinde adoración como fuente de vida. Recordemos que en las Bacantes de Eurípides las mujeres al golpear el suelo con sus tirsos hacían brotar leche, miel y vino, y el poder del tirso resultaba invencible frente a las armas de los soldados del rey Penteo.

Una de las festividades en honor del dios, que aún se celebraban en época clásica y que siguieron vivas hasta la aplastante victoria del cristianismo, era la Dionisia de los campos, que tenía lugar en el mes de Poseidón, o sea en diciembre-enero. En ella participaba todo el mundo, incluso los esclavos. Se practicaba, entre otros, el juego del askoliasmos, que consistía en saltar a la pata coja sobre unos odres hinchados y engrasados. Grupos alegres y ruidosos de los comoi, coros cómicos, se repartían por los caminos y callejuelas del pueblo bailando, cantando y lanzando bromas obscenas a todos los que encontraban a su paso. A partir del siglo $\mathrm{v}$ a. n. e., los pueblos más ricos añadieron representaciones dramáticas a estas fiestas. Pero el momento culminante de la fiesta era la procesión que paseaba un falo de grandes dimensiones, acompañándolo con cánticos y realizando finalmente un sacrificio. El cortejo tenía sin duda la función de promover la fertilidad de los campos y la fecundidad de los hogares. Una copa ática de figuras negras del museo de Florencia recoge la escena en imágenes. En cada cara de la copa está representado un ídolo en forma de falo colocado sobre unas andas que llevan a hombros un grupo de hombres itifálicos. La vara de madera, que conserva incluso sus nudos, remata en una especie de cabeza de animal, hecha con gran pobreza y en la que se ve pintado a un lado un gran ojo (Martín y Metzger, 1977: 166). 
Los testimonios literarios, a través de Aristófanes, y los gráficos, como la decoración cerámica que acabamos de mencionar, atestiguan la importancia del falo en la fiesta de las Dionisias del campo, que tenían lugar no sólo en el Ática, sino en otros muchos puntos del Mediterráneo, ya que sobrevivieron largo tiempo. Un decreto ateniense que se ha conservado, relativo a la colonia de Brea (en Tracia), y fechado hacia el año 445 a. n. e., estipulaba que los habitantes de esta ciudad deberían enviar una vaca y una panoplia a Atenas para las Grandes Panateneas y, para las Dionisiacas, un falo. Una mención tardía que nos habla de la pervivencia de esta celebración nos la ofrece Agustín de Hipona (La ciudad de Dios, VII, 21) refiriéndose a ritos similares practicados en el Lacio. Allí la divinidad era Liber, un trasunto romano de Príapo, personaje del que hablaremos más tarde.

Otro dato que avala la tesis del carácter fálico de Dionisos y sus cultos es la estrecha relación que mantiene con Hermes, quien, a diferencia de Dionisos, sí es un dios olímpico y su origen parece ser más pecuario que vegetal, aunque normalmente está asociado a distintas funciones. Se le considera un experto en robos y avezado en el arte del engaño, razón por la que es el protector de los ladrones. Estas habilidades le convierten también en el patrón de los comerciantes. Como el engaño, en una sociedad penetrada ya por la actividad comercial, se basa en la palabra, Hermes es el dios de la elocuencia, inventor de las lenguas y la escritura. Acostumbrado a trabajar en los caminos, es el que vela por los viajeros y se convierte así en el mensajero de los dioses, y el que acompaña también a las almas en su último viaje; entonces nos aparece como el Hermes psicopompo, que se comunica tanto con el Hades como con el Olimpo.

Toda esta variada gama de actividades, que lo convierten en el dios más pluriempleado del panteón, oculta otra que posiblemente estuvo en el origen de esta divinidad antes de que se impusiera el culto dionisiaco, nos referimos al Hermes fálico, símbolo de la fertilidad masculina. Hermes fue sin duda en época remota una divinidad que pasó de velar por el ganado en su Arcadia natal a significar toda fuente de riqueza natural, compenetrándose con la tierra y transformándose en una deidad ctónica. Como tal, su símbolo predilecto terminó siendo el falo. Con Dionisos compartía el tirso, trans- 
formado en caduceo en el que aparecen serpientes enroscadas relacionadas inicialmente, como ya sabemos, con la fertilidad femenina y en época posterior, también con el falo. Una forma muy común de representación del dios era en un pilar cuadrangular por cuerpo - lo que nos remitiría al tronco de árbol dionisíaco - rematado por la cabeza de Hermes y con un falo en erección. Atenas estaba llena de estos Hermes, en los cruces de las calles y en las salidas a los caminos. Fueron estas estatuas las que mutiló Alcibíades costándole el destierro.

También eran comunes entre las dos divinidades otros rasgos, como el escaso respeto a las normas establecidas y su gusto por alterar el orden. En ese sentido, los dos participaban de una naturaleza que nos recuerda a los trickster primitivos. Ya en la cuna Hermes se las apañó para robar a Apolo el ganado del sol, también es cierto que en medio de la fechoría inventó la lira, instrumento que encantó tanto a su hermano que terminó por cambiárselo por los bueyes robados. Esa doble condición de dios revoltoso y fundador le confiere enormes potencialidades tanto para la creación como para el desorden. Por eso no puede llamarnos la atención que Pan, la divinidad que habita en los bosques, fuera hijo suyo. Esta criatura que con su aspecto dio origen al término pánico, tal era el pavor que causaba entre aquellos que se lo topaban en su camino, nació peludo y con aire cabruno, con cuernos y pezuñas y, como su padre, era también una deidad fálica. Siempre rijoso, Pan perseguía incansable a las ninfas y su apetito sexual no se saciaba nunca, siendo fuente de placer pero también de destrucción. Por el contrario, el otro hijo de Hermes, nacido de su unión con Afrodita, no pudo conocer el desasosiego del deseo, pues Hermafrodito volvía a soldar en su persona la división de los sexos.

Hermes y Dionisos también estuvieron vinculados desde el accidentado nacimiento del segundo, ya que, destruida su madre Semele, por los celos y engaños de Hera, Dionisos, tras su nuevo alumbramiento, surgiendo del mismo costado de Zeus, fue encomendado por éste a Hermes para que lo condujera junto a Ino y Atamante, que debían criar al niño. Al entregar la criatura a sus tutores, nuestro dios embaucador, formuló una curiosa recomendación: que fuera educado como una niña. Las ambigüedades sexuales 
que aparecen en estos descendientes de Hermes, entre el agresivo Pan y el indefinido Hermafrodito, así como las instrucciones pedagógicas que imparte respecto a Dionisos, unido al posterior decantamiento de éste como una divinidad fálica, nos permiten extraer algunas conclusiones.

La primera sería que las dos divinidades tuvieron una raíz común de tipo agrario y ganadero, propiciatoria de la fecundidad y la vida. Este paradigma común se diversificaría en un momento que no podemos precisar, adquiriendo cada uno de ellos perfiles propios y asumiendo distintas funciones. Es muy posible, y no se puede descartar, que si el origen de Dionisos es extranjero, como durante tanto tiempo se ha creído, fue sólo con la presencia del joven dios foráneo cuando parte de la naturaleza de Hermes se desgajó de su antigua personalidad, para adquirir la condición que nos resulta más familiar como dios olímpico. Debemos tener presente cómo la leyenda hace más viejo a Hermes que a Dionisos.

Podríamos también deducir que Hermes habría asumido en época remota el curioso papel de dios falocrático, aunque perfectamente integrado en el orden divino de los dioses operantes y que sólo después de aparecer Dionisos éste habría cargado con esa responsabilidad, que cada vez parecía a la sociedad urbana griega como más primitiva. Liberado en parte de esa naturaleza fálica inicial, Hermes se hizo cargo de otros cometidos más respetables y en consonancia con el desarrollo económico y cultural de las polis, pasó de proteger los campos a proteger el comercio y articuló su acción más en torno a la palabra que en torno al falo. Pero lo que más nos puede interesar desde nuestro punto de vista es que en su función original Hermes encarnaría un propósito claramente patriarcal, el imponer un nuevo modelo de fecundidad no vinculado con lo femenino, arrebatando así el principal atributo de prestigio simbólico al otro sexo, que lo había ostentado durante milenios.

En ese proceso, que no debió de ser sencillo, la elaboración ideológica tuvo que sortear los obstáculos de la costumbre y el temor a lo ancestral. En la descendencia de Hermes vemos la ambigüedad en la que se debió de mover el propósito durante mucho tiempo. Mientras que Hermafrodito sería un producto del 

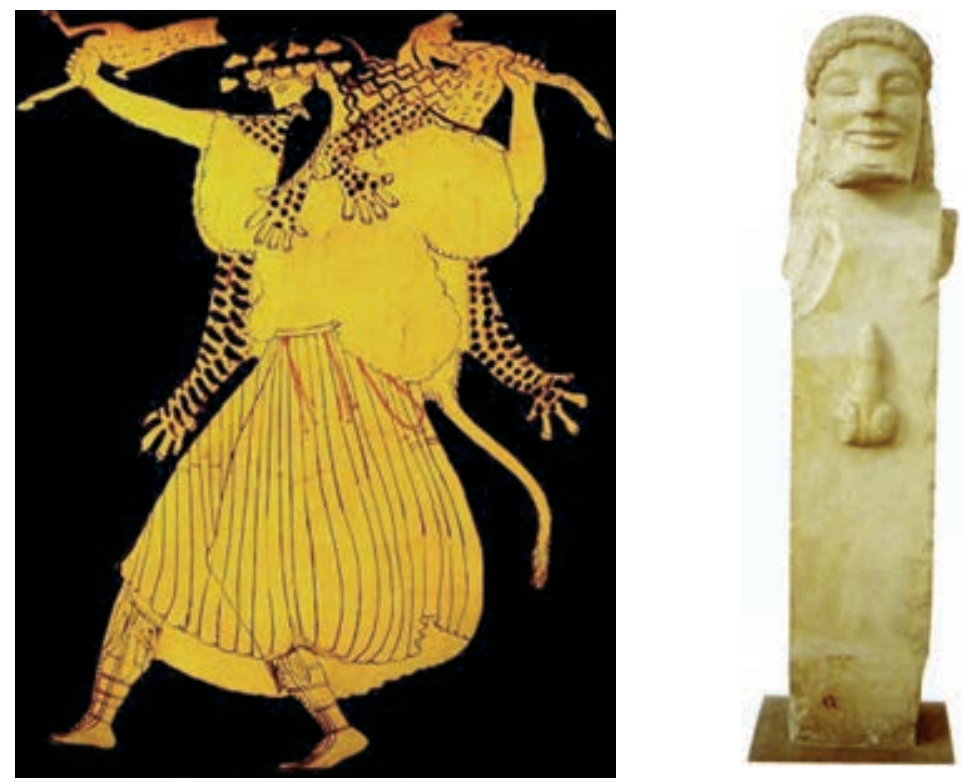

Tanto Dionisos, a la izquierda, como Hermes, son dioses asociados a los cultos fálicos que la sociedad patriarcal impuso para restar poder a la asociación simbólica mujer/fertilidad.

pacto o de la nostalgia, Pan era una afirmación salvaje y brutal del macho. La misma recomendación hecha a los tutores de Dionisos de que el joven dios fuera educado como una niña nos indica que la duda en la pugna con el principio de la fertilidad feminizado debió de estar presente durante largo tiempo hasta que por fin pudo imponerse. En época arcaica, cuando la lucha ya había concluido, sólo a través de una divinidad ligada a la alteración del orden y al vino pudo aceptarse la sustitución del poder fecundador femenino por la falocracia, viéndose obligadas las propias mujeres a ser las primeras en asumirlo, convirtiéndose en las «maniáticas» adoradoras del dios.

Aún queda, no obstante, recordar otro dato para reafirmar este aspecto fálico, muchas veces olvidado e incluso negado, del primitivo Dionisos; nos referimos a la comitiva y los acompañantes del dios. Además de las ménades o las bacantes, siempre hipnóticamente 
sumisas a la par que exaltadas, nos encontramos con un cortejo de seres cuya naturaleza no ofrece dudas. Los sátiros y faunos, correspondientes del Pan hermético, son personajes a los que se les distingue por encarnar la falocracia más salvaje. La animalidad se refleja en sus cuerpos y sus escarceos, pretendidamente amorosos, que tienen todas las connotaciones de la violación, en la que se mezcla la pasión cinegética con el deseo de total dominio y sumisión de la víctima, concretado en la penetración.

Esta visión de un Dionisos fálico, tan sorpresivo y rico en sus dones, antaño, y tan prestigiado por Nietzsche, en el presente, terminó por no gustar ni a los griegos de aquella época ni a los estudiosos actuales. Los primeros crearon un hijo para él, Príapo, que asumió los aspectos más groseros del padre; y los segundos, desde los estudios académicos, no se han cansado de negarla.

Príapo, a pesar de ser estimado como la encarnación de la potencia viril, la fecundidad de los huertos y, sobre todo, de la prosperidad y la riqueza, no deja de mostrársenos como producto de una aberración. Según una variación de la leyenda no fue concebido por Dioniosos y Afrodita, sino por ésta y Zeus, y la enorme desproporción de su miembro viril se debería a un maleficio de Hera que, celosa como siempre, habría condenado a la criatura dotándolo con esa deformidad. En esta versión podemos apreciar un arreglo en torno a la paternidad para poder explicar la exageración priápica, pero sobre todo en ella vemos el rechazo de una sociedad más culta y refinada ante los excesos de unos ritos que ya eran vistos por muchos como rústicos y primitivos.

Los mitógrafos modernos también se han espantado ante tan vulgar representación de la potencia viril y han hecho todo lo posible por disociar al hijo, heredero de esos atributos, del padre, negando que Dionisos hubiera tenido nunca ese carácter tan salvaje y arcaico. Se ha rechazado durante mucho tiempo la confusión del dios con el falo. Éste fue particularmente el punto de vista de Nilsson (1954), que distinguía taxativamente el falo/símbolo de las dionisíacas del propio dios. Para él, aunque Dionisos se rodease de demonios fálicos, y aunque el falo tuviese gran importancia en sus cultos, el dios no habría figurado nunca bajo los rasgos de una divi- 
nidad fálica. Hoy se plantea el problema en términos diferentes y algunos testimonios cerámicos han sido interpretados por Martín y Metzger (1978: 167) como una prueba de que Dionisos no sólo estuvo rodeado de atribuciones fálicas, que debían de guardar alguna relación con sus funciones, sino que el mismo dios fue reconocido bajo ese aspecto.

Por tanto nos encontramos con que la doble unión de Hermes y Dionisos con Afrodita dan como resultado a Pan y a Príapo, lo que nos permite aventurar que todas esas divinidades tienen un común denominador funcional relacionado con la fertilidad viril, lo que viene a apuntalar la hipótesis de que bajo diferentes manifestaciones, en función de la propia evolución religiosa, la sociedad patriarcal griega se propuso sacralizar una nueva imagen/símbolo de la fecundidad desligada de lo femenino. Esta virilización de la primordial función de la antigua y todo poderosa diosa-madre sólo pretendería adecuar en el plano superestructural la realidad material de la mujer en Grecia, usurpando así en el terreno de las creencias las parcelas de poder simbólico de las que aún gozaba en un panteón totalmente patriarcalizado. El poder generatriz, con todas sus implicaciones, no podía ser patrimonio único y exclusivo de las mujeres, es más, no podía ostentarlo en el plano sobrenatural y divino un sexo que era manifiestamente inferior. La propia concepción de las relaciones sexuales entre los griegos forzosamente les debía conducir a la revisión de sus viejas creencias. Ya hemos apuntado cómo teorizaban en el plano social la realidad poligámica de la que gozaban los varones, pero para comprender la hipótesis que barajamos es necesario acercarnos a cómo entendían el propio acto sexual, y para ello deberemos dar un rodeo.

Aunque los griegos no conocieron las cortapisas morales con las que el cristianismo cargará la ideología occidental respecto al sexo, tampoco fueron excesivamente explícitos en el asunto. Las invectivas misóginas contra la mujer se movieron siempre en el terreno social y filosófico. Los textos con los que nos encontramos devalúan a la mujer como ser social, como sujeto pensante e, incluso, como persona física. Tal y como hemos podido apreciar en el corpus hipocrático, la fecundación positiva ya era entendida como obra del 
varón, pero nos falta aproximarnos a cómo concebían el coito y, sobre todo, qué implicaciones ideológicas tenía tal visión. Para ello es necesario recurrir a esa curiosa institución que fue la pederastia, ${ }^{21}$ que tanta tinta ha hecho correr.

A pesar del particular empeño que ha habido en insistir en que la pederastia formaba parte de la paideia griega, y que no era una relación homosexual sino homoerótica, parece evidente que se admitía alguna forma de contacto sexual entre el erestes y el eromenos. Por lo que concierne a este aspecto de las relaciones, las fuentes parecen reticentes a mencionarlo, pero poseemos evidencias pictóricas en varios vasos (Vrissimtzis, 1997). Frecuentemente, observamos a adultos tocando los genitales de muchachos, nunca lo contrario, pero lo que más nos interesa es que, cuando se realizaba el acto sexual, ocurría exclusivamente entre los muslos del joven, y ambos participantes estaban uno frente al otro. Todos los vasos que representan escenas sexuales de pederastia concuerdan. No hay ninguno que represente una relación anal. Representaciones que impliquen un acto sexual de este tipo se refieren exclusivamente $o$ a figuras mitológicas (sátiros y faunos) o son escenas de symposia que incluyen prostitución masculina homosexual entre adultos, nunca una relación de pederastia. El acto, entre los muslos del eromenos, era el único permitido de acuerdo con las reglas no escritas de la pederastia.

21 La pederastia era un institución educativa en la que un adulto estaba encargado de transmitir su conocimiento y su experiencia a un adolescente y de ayudarlo convertirse en un ciudadano, a cambio el adulto gozaba de la belleza, de la fuerza y del vigor del joven, era por ello un intercambio creado en beneficio de ambos.

La pederastia seguía una serie de reglas concretas. En esta relación al adulto se le llamaba erastes (aquel que ama) y al joven eromenos (el amado). El eromenos debía tener entre doce y dieciocho años. La relación con un muchacho de edad inferior resultaba inconcebible; era a los doce años cuando los niños entraban en la pubertad y empezaba a formarse su personalidad, por lo que necesitaban de un instructor.

Por otro lado, la continuación de esta relación después de los dieciocho años era considerada inaceptable y generalmente desaprobada. El erastes debía tener más de veinte años, lo que significaba que él mismo había pasado por el estadio de eromenos, y había adquirido una adecuada cultura y experiencia social que, a su vez, podía transmitir. Las relaciones se establecían en el gimnasio y en la palestra. Allí los hombres adultos podían mirar a los jóvenes, entrenarse desnudos y admirar sus cuerpos armoniosos, sus habilidades y su rendimiento. 
Las razones para ello son fáciles y simples de entender. El contacto a través del ano, relegaría al joven aspirante a ciudadano, al papel de la mujer, al papel de sujeto pasivo y sometido. De acuerdo con los principios que prevalecían en la época, la penetración del pene, tanto por la vagina, por el ano, como por la boca, era un acto agresivo que implicaba poder y por tanto estaba reservado única y exclusivamente a los hombres; mientras que, por otro lado, significaba la sumisión de la persona penetrada. Sumisión y pasividad concordaban sólo con mujeres y esclavos. Por tanto, en la relación pederástica era inconcebible que un futuro ciudadano ateniense fuera expuesto a tal humillación. No era una cuestión moral, sino de honor. En ningún caso se permitía la penetración de órganos sexuales a muchachos que más tarde se convertirían en sujetos responsables, tendrían cargos públicos y administrarían la fortuna del Estado; puesto que tal cosa les reduciría al papel deshonroso de objeto, contrario al que, más tarde, serían llamados a ejercer en la sociedad. Por lo que, el contacto entre los muslos salvaguardaba la dignidad y virtud del eromenos.

De lo dicho se puede deducir que la aparición del falo como símbolo virilizado de la fecundidad no sólo suponía disputar al género femenino esa fuente de poder sino que predeterminaba en sí misma un tipo de relación generatriz en la que lo masculino era el elemento dominador y prepotente, mientras que lo femenino se consideraba inferior y sometido. Así concebida la falocracia no sólo era una actitud ideológico-social, sino que extendía su poder a lo mágicosimbólico, a todas las esferas de la actividad ritual y a todo el conjunto de creencias religiosas. Entre las funciones que asumía el falo destacaba la apotropaica. El símbolo de la potencia y de la fuerza masculina se convertía en el mejor valladar frente al Mal, por eso son tan abundantes en el mundo clásico los amuletos que representan el falo. En más de una ocasión aparecen relacionados con el ojo, órgano al que se le atribuían los mismos poderes. La mejor prevención frente al phtonos del vecino era el falo ocular. A veces, especialmente si quería dársele cierto valor ornamental, aparecía bajo aspectos zoomórficos: con garras de león alado o con garras y alas de águila. También nos los encontramos con campanillas que sumaban la protección del metal contra el encantamiento mientras que el tintineo ahuyentaba a los malos espíritus. 

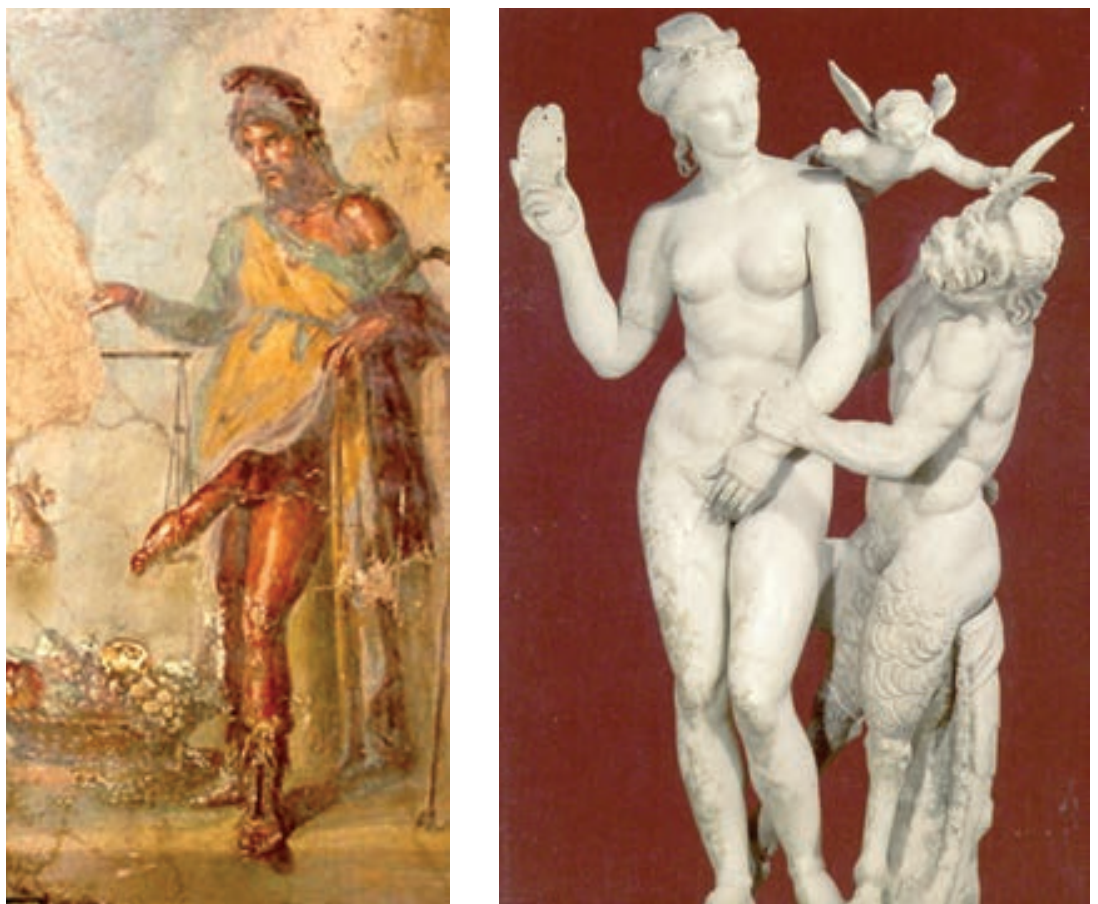

Príapo, a la izquierda y Pan, dos de los hijos de Hermes asociados también al culto a Dionisos, son manifestaciones exageradas de la falocracia que en el mundo clásico terminó representando la riqueza y la fertilidad.

Ahora ya estamos en disposición de retomar el hilo sobre la palingenesia eleusíaca que, lejos de estar patrocinada por los antiguos principios de la fertilidad femenina, terminó por suponer la apoteosis, aunque sofisticada, de lo contrario, puesto que Deméter, la madre, era seducida por Dionisos, el antiguo dios-falo, en un rito que, inicialmente, pretendía afirmar el poder generatriz masculino sobre el femenino y que, posteriormente, derivó en una ceremonia iniciática que otorgaba la salvación eterna a quienes la seguían.

La presencia de Dionisos en Eleusis no ha sido probada pero, aunque muy debatida, tampoco ha sido explícitamente refutada. El dios no aparece para nada en el Himno homérico que nos detalla 
minuciosamente el origen del rito, pero podríamos pensar que tal vez la vinculación de Dionisos con los misterios fuera de época más tardía. Lo cierto es que en un coro de la Helena de Eurípides y un pasaje del Pean délfico de Filodamo de Skarfea asocian a Dionisos con las divinidades eleusinas, lo que vendría a avalar que en una fase ya madura de los ritos, los intelectuales del momento admitían al dios como un personaje más del drama eleusíaco.

Donde sí encontramos pruebas irrefutables de la presencia del dios en Eleusis es en los testimonios cerámicos, sobre todo a partir del siglo IV a. n. e. Se han hallado numerosos vasos pintados y vasos en relieve que conceden un espacio preferente a Dionisos junto con Deméter y Perséfone. Como muy bien apuntan Martín y Metzger (1977: 181): «los artesanos del Cerámico no eran... buscadores de asociaciones eruditas. Si no han vacilado en acercar a Dionisos al mundo eleusino, es porque esta cercanía era admitida por todos». Sin embargo, las opiniones académicas están divididas en este sentido. El gran estudioso Nilsson (1954) cree que de poderse demostrar la presencia efectiva de Dionisos en los cultos, ésta se debería más a una respuesta de los artistas ante la enorme aceptación del dios en los medios populares, que a un replanteamiento esencial del culto. Otros, como Mylonas (1961), han intentado reducir el papel de Dionisos, señalando la excesiva importancia que se ha dado a la arqueología figurativa en los intentos por explicar por qué el dios aparece en muchas representaciones cerámicas.

Por el contrario, el viejo Foucart (1900/1999) aseguraba que Dionisos era tan antiguo en Eleusis como Deméter y que, junto con la diosa, participaría en todo el rito, figurando en un plano de igualdad. Aunque consideraba que el Dionisos eleusíaco era ya una divinidad «civilizada» que no respondería a la primigenia figura, primitiva y salvaje, que él suponía de origen tracio. Lo cierto es que estas afirmaciones se apoyaban en fuentes escritas más bien tardías, como el retórico Arístides, el historiador latino Apelio o el mismo Plutarco, y en algunas otras referencias que datan de época bizantina, lo que podría reforzar la idea de que la entronización del dios fue posterior, cosa con la que tampoco estaría de acuerdo Foucart. 

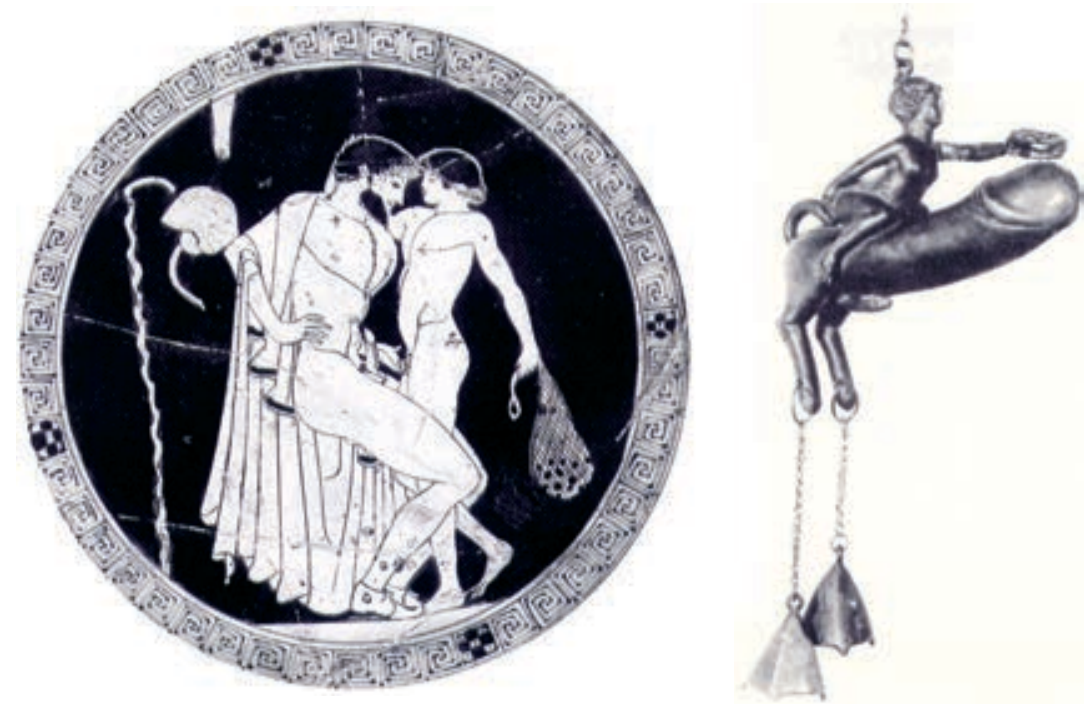

En la pederastia griega, el acto sexual ocurría exclusivamente entre los muslos del joven, ya que la penetración implicaba sumisión de la persona penetrada. Sumisión y pasividad concordaban sólo con mujeres y esclavos.

La cultura patriarcal terminó atribuyendo al falo poderes apotropaicos para conjurar el Mal. Por eso son tan abundantes en el mundo clásico estos amuletos.

Pero más allá de algunas dispersas referencias literarias y de una abundante iconografía cerámica en la que el dios siempre aparece acompañado de otros personajes y divinidades, no determinantes en el sentido del culto, ¿cómo podemos relacionar la figura de Dionisos con Eleusis y cuál era el sentido de su presencia allí? Forzosamente debemos recurrir a interpretar la personalidad de un actor perfectamente integrado en los ritos y sin embargo, a nuestro juicio, insuficientemente explicado. Nos referimos a Iacchos, esa joven divinidad que partiendo de Atenas se dirigía el 20 de boedromion a Eleusis para, sin duda, representar algún papel que nunca ha sido aclarado.

Las opiniones concuerdan en general en ver en él al dios que personifica el cántico de los mystes y el grito exultante «iIacche!» que lanzaban durante su procesión. No obstante, Sófocles en un coro de 
su Antígona identifica a esta apuesta divinidad con Dionisos, cosa que no hace Aristófanes en su comedia Las Ranas, donde establece una clara distinción. Tampoco las representaciones gráficas ayudan, al menos eso es lo que parece, ya que Iacchos se nos muestra como un personaje de aspecto juvenil, vestido con una suntuosa túnica corta, calzado con altos borceguíes y sin ningún atributo característico de Dionisos como pudieran ser el tirso o la piel de cervato. Pero ante esta objeción hemos de tener en cuenta dos cosas: la naturaleza polimórfica de la divinidad y la evolución que su imagen experimentó con el paso del tiempo, que terminó por mostrárnoslo, en época tardía, como un apuesto joven.

El nombre Iacchos recuerda a Bacos, uno de los apelativos de Dionisos, y Grimal (1993: 538) admite que algunos consideran a este personaje como un mediador entre las diosas eleusinas y el dios fálico y vegetal. Pero con más frecuencia pasa por ser hijo de Perséfone y en este caso sería la reencarnación de Zagreo, la primera manifestación de Dionisos. Zagreo, hijo de Perséfone y de Zeus, habría sido aquel niño que, víctima de los celos de Hera, fue despedazado por los perversos titanes y sólo salvado in extremis por su propio padre que lo volvió a engendrar, según el mito órfico que mencionamos con anterioridad. De aceptar esta versión, Iacchos no sería sino la primera encarnación de Dionisos y, por tanto, manifiestamente diferente a la segunda. Esto podría ayudarnos a explicar su aspecto tan distinto al tradicionalmente difundido, aunque seguiría dejando en el misterio cuál era la función que tenía asignada en el Telesterion eleusíaco.

A nosotros sólo se nos ocurre una que podía encajar perfectamente en la primitiva naturaleza del rito agrario. Iacchos sería la personificación de la masculinidad en una hierogamia ritual. Es más, al encarnarse en Dionisos joven, lo que se habría pretendido, en un intento de arrebatar el misterio de la vida a la mujer, era poner de relieve el poder fecundador del macho frente a la pasiva fertilidad femenina. La hipótesis no es nueva, al menos en parte Chochod (1975) ya quiso ver en el misterio impenetrable de la telete una pantomima sagrada de este tipo. Para este historiador de las religiones, durante la iniciación se desarrollaba un espectáculo que se componía de diferentes escenificaciones en las que se representa- 
ban la gesta de Deméter y de su hija y los esponsales de Zeus y Core. Como vemos, los protagonistas de la unión sagrada no son los que nosotros proponemos, que creemos en una hierogamia incestuosa entre la misma Deméter (abuela) y Iacchos/Dionisos (nieto), como máximos exponentes de la fertilidad agraria femenina, que representaría el pasado, y de la falocracia patriarcal, que supondría la implantación de las nuevas creencias.

De ser ciertas estas suposiciones, según Chochod, el hierofante asumiría el papel de Zeus y la sacerdotisa de Deméter el de Core y se produciría una unión natural que se consumaría en la oscuridad. Zeus, o mejor, el hierofante que desempeñaba su papel arrastraría a la sacerdotisa a una oquedad subterránea, momento en que se apagarían las antorchas y la concurrencia guardaría un recogido silencio mientras se consumaba el acto. Recordemos, a propósito de este instante imaginado, que la representación de Iacchos lo mostraba siempre portando una antorcha, posiblemente para iluminar su camino hacia la unión sagrada o como símbolo del falo en el que se encarna el fuego de la vida; en este sentido, las antorchas simbólicas se apagarían en el momento en que entrara en acción el falo mismo.

Pero esta versión de los hechos se le antoja a Chochod excesivamente timorata y producto de una tardía relaboración cristiana. Para él, la hierogamia daría paso entre los iniciados a una orgía sexual semejante en todo a las saktis del culto de Siva y a los grandes sacrificios Petro del Vudú haitiano, sin que faltara ningún ingrediente, ni tan siquiera el brebaje ritual: el toddy en la India; la tafía (aguardiente de caña) en las Antillas; y el misterioso cyceon en Eleusis, del que algunos textos nos hablan como un bebedizo que, según el historiador, estaría compuesto a base de agua, vino, miel y harina, a todo lo cual se añadiría una hierba fundamentalmente afrodisiaca, del tipo del Corynante Yohimbe. Lo cierto es que Tertuliano al hablar de los misterios eleusíacos nos dice que todo lo que ocurría en ellos ofendía al pudor, aunque afirmaciones de este tipo deben ser consideradas con el mismo cuidado que las versiones hipotéticamente edulcoradas por otros cristianos sobre lo que pasaba realmente en Eleusis que, por otra parte, nunca sabremos con certidumbre qué era. 
El principal reparo que se podría oponer a estas posibles versiones del culto es precisamente su primitivismo. Resulta difícil creer que personas de la talla intelectual de un Cicerón se dejaran encandilar por una tosca y vulgar representación de una hierogamia o que participaran con entusiasmo en un rito de naturaleza estática, valorándolo como un consuelo para sobrellevar esta vida y como esperanza prometedora para la futura. Sin embargo, frente a esto, podemos decir que la naturaleza de los ritos sagrados no radica tanto en su materialidad como en el profundo significado que se les quiera dar y en la representación con la que se envuelven. Los grandes ritos cristianos son de una manifiesta simplicidad y no por eso han dejado de impresionar incluso a las mentalidades más modernas. Por otra parte, no podemos creer que, a lo largo de los más de mil años de historia del culto en Eleusis, las formas de los misterios no evolucionaran. Como se ha reconocido, el sentido del rito experimentó una mutación, en línea, si se quiere, con su primitivo significado, pero varió su naturaleza para dejar de ser un rito agrario y transformarse en un culto palingenésico. Otro tanto pudo suceder con su representación. Tal vez, cuando Cicerón fue iniciado, la veterana casta sacerdotal de Eleusis ya había introducido modificaciones en la morfología del acto adecuándola al paso del tiempo, a sus nuevas funciones y a una sensibilidad más refinada. Cualquier cosa que podamos especular en ese sentido no pasará de ser una mera suposición.

La interpretación que apuntamos resulta coherente con la tesis central de este capítulo y con la tendencia impositiva de la ideología patriarcal en el mundo de las creencias religiosas. Un Dionisos sofisticado, pero en definitiva generatriz y estático, explicaría mejor que una dolorida madre que busca a su hija perdida el sentido del misterio palingenésico de Eleusis. Deméter seguiría presidiendo los ritos pero todos los iniciados terminaban sabiendo que sólo al ser poseída era el dios y no ella la que transmitía la vida que estaba en la base de su propia salvación eterna. La diosa madre de la fertilidad había sido definitivamente desplazada por una masculinidad agresiva como única fuente de una fecundidad positiva que ya no sólo velaba por la regeneración del grano, sino por el renacer de nuestras almas en una vida mejor. Las mujeres conscientes de su derrota asumieron 
el nuevo rol en el plano sobrenatural y buscaron el refugio de la diferencia en otros ritos en los que se consagraba su apartamiento y su sumisión, por eso el epígono del culto eleusíaco a Deméter lo debemos buscar en Roma en los misterios de Bona Dea.

La leyenda de esta diosa es bastante simple y podemos decir que en ella se resume la realidad de la mujer en la sociedad patriarcal. En una primera versión nos encontramos a la diosa como hija de Fauno, una de las encarnaciones fálicas más claras. Su padre intentó poseerla pero la diosa lo rechazó siendo, primero, embriagada y después brutalmente golpeada con ramas de mirto para vencer su resistencia. Como no lo consiguió, Fauno se convirtió en una serpiente y pudo por fin consumar la incestuosa violación. La polimórfica serpiente, símbolo durante milenios de la fecundidad femenina, se transformaba aquí en una imagen del falo afirmando de esta manera la prepotencia del macho.

En otra versión, Fauno, en una altereidad lógica en la sociedad patriarcal, ya no es el padre sino el marido de Bona Dea y la diosa se transforma en la mujer fiel y la sumisa esposa, entregada en cuerpo y alma al cuidado del hogar. Pero un día encontró una jarra de vino y se la bebió, fue entonces cuando su marido le pegó tal paliza que acabó con ella; después, acosado por los remordimientos, le tributó honores divinos.

Si el mito es una historia fantástica que pretende enseñarnos el origen de un hecho o un fenómeno real, el de Bona Dea sigue conformando la mentalidad y los actos de muchos hombres en el presente, puesto que las historias de la diosa parecen arrancadas de las hojas de sucesos de cualquier diario actual. $\mathrm{Al}$ rendirle culto mistérico, las romanas no hacían sino aceptar el papel al que habían sido reducidas en el mundo material. Abusos, maltrato y sumisión eran el triste destino de la mujer, y la fábula daba una explicación sobrenatural de esa terrible condición.

Las fiestas de Bona Dea, en las cuales participaban todas las matronas, así como sus sirvientas y las vestales, se celebraban cada año en Roma en una fecha variable aunque seguramente próxima al mes de diciembre. Las mujeres se reunían en la casa de un magistrado revestido del imperium (en principio el cónsul en ejercicio), 
bajo la presidencia de su mujer y, esa noche, todos los hombres debían salir de la casa. No conocemos muy bien los ritos que tenían lugar, aunque parece que se bebía vino, se cantaba, bailaba y no podemos descartar actos orgiásticos de naturaleza erótica. Sólo subrayaremos que, a pesar del carácter excepcionalmente liberador, el consumo del vino, prohibido como hemos dicho durante mucho tiempo a las mujeres romanas, nos indica otro sentido en la ceremonia.

La fiesta del vino, la Vinalia, se celebraba curiosamente el día en que se festejaba también a Venus, que había terminado por ser la diosa femenina por antonomasia, resumiendo en su persona todas las atribuciones de la mujer, aunque se la seguía adorando en especial como diosa del amor y del placer. Por otra parte, en Roma se había aceptado, tras una resistencia inicial, ${ }^{22}$ el culto a Dionisos como dios del vino, pero también como el que poseía los misterios relativos a la generación, por lo que se terminó asociando esta divinidad griega al Liber itálico, cuyo emblema, curiosamente, era el falo, la misma identificación primitiva del Dionisos arcaico. Como los misterios de Bona Dea, parece ser, tenían un carácter orgiástico y sólo podían participar mujeres, podemos ver en ellos un vestigio de los ritos báquicos e interpretar el consumo del vino prohibido como un acto de reconocimiento y sumisión de la mujer ante el dios que realmente daba la vida al fecundarlas y convertirlas en madres. La expropiación simbólica de la diferencia se había consumado y a la mujer no le restaba nada más que ser Bona Dea a merced de Fauno en el cortejo de Dionisos.

La cultura griega y romana no establecieron una vinculación directa de la mujer con el Mal. Como en el Oriente Próximo, la cul-

22 En el año 186 a. n. e. se abatió una implacable persecución en Roma sobre los practicantes de cultos dionisíacos. El hecho es absolutamente excepcional y sólo encuentra paralelo con las ulteriores persecuciones cristianas. Una denuncia acusó a las bacantes de crímenes y libertinaje y el Senado actuó de inmediato. Tenemos una detallada relación del asunto a través de Tito Livio (XXXIX, 8-18) e incluso conocemos el senadoconsulto que desató la persecución que, a pesar de ser llevada a cabo con todo rigor, no pudo evitar el arraigo del culto en Roma. El motivo de esta intolerancia excepcional entre los romanos se debía al carácter mistérico de las ceremonias fuera de la religión oficial y, lo que era más preocupante para las autoridades, fuera del control del Estado. 
tura clásica admitió que las mujeres eran naturalmente inferiores a los hombres y, por tanto, no se les podía elevar a la condición de principio del Mal; pero, precisamente debido a esta inferioridad, los griegos y los romanos sí que asentaron teorías filosóficas, mitos, cultos y asociaciones que contribuyeron a relacionarlas eficazmente con él. El platonismo, al confundir la materialidad con lo femenino, las ideas hipocráticas con sus tesis sobre la fecundación positiva o el culto a Hécate, la diosa del maleficio, son un buen ejemplo de ello. Así Lamia se fundió con Sagana para contribuir a forjar la imagen del perverso espíritu femenino que por la noche encarna o invoca al Mal para seducir a hombres o matar a niños. Este estereotipo se desplazó gradualmente a lo largo de los siglos para fijarse finalmente en la bruja medieval.

También la vieja ligazón del mundo subterráneo con la fertilidad cobró una nueva dimensión al relacionar aquél con la muerte. La conjunción de sexo y Hades quedó establecida a través del mito y de los cultos mistéricos que debieron de tener carácter orgiástico. Estos ritos relacionados con Dionisos o Bona Dea terminaron siendo considerados como lascivos, pero antes de que se produjera una criminalización del sexo por parte del cristianismo, que terminó por verlo como el principal instrumento del Maligno, fue necesario que Occidente incorporara a su cultura el aporte judío. 


\section{VI \\ LAS HIJAS DE LOS HOMBRES}

En un algún momento del segundo milenio a. n. e., difícil de precisar, grupos de origen semita abandonaron sus asentamientos en la zona del Fértil Creciente y comenzaron una vida de nomadeo que terminaría por llevarles a las tierras de Canaán, donde desde tiempos remotos habitaban como sedentarias otras tribus de la misma raza.

Muchos siglos después, los hebreos, que tienen su origen como pueblo en estos desplazamientos, escribieron sobre sus antepasados y atribuyeron a la estirpe de Abraham el haber salido de la ciudad de Ur para emprender este largo peregrinaje. La historia, recogida en el Génesis y basada sin duda en la tradición oral, quedaría justificada por el propio nombre de $I b r i$, que adoptaron estas comunidades y que significa "pueblo de más allá», esto es, del otro lado del Éufrates.

El relato cuenta que el clan de Abraham residió largo tiempo en el país de Arran, al este de Karkemish, prosiguiendo luego su viaje, a lo largo del Creciente Fértil, hacia el país de Canaán. Los usos religiosos y jurídicos que aparecen en la Biblia y que hacen referencia a esta época quedan avalados y, en cierta medida, justificados por los documentos hurritas de la Alta Mesopotamia, en especial por los de la localidad llamada Nazi, encontrados y descifrados por la arqueología moderna.

De la misma narración bíblica a través del relato de José y sus hermanos podemos deducir que algunos descendientes de Abraham emigraron a Egipto durante una hambruna, aunque las causas de este nuevo desplazamiento no están suficientemente aclaradas, per- 
maneciendo en el valle del Nilo desde el período de los reyes hicsos hasta el éxodo definitivo, poco antes o durante el reinado de Meneptah. Durante varias generaciones los hebreos sirvieron a los egipcios como siervos o como esclavos hasta que a finales del siglo XIII a. n. e. acaudillados por el semilegendario Moisés, emprendieron de nuevo su andadura hacia la tierra prometida por su dios.

Ningún documento egipcio deja testimonio de este éxodo, aunque se ha intentado relacionar a los hebreos con los esclavos y prisioneros llamados hapiru, de los que se habla en las tablillas de Amarna sin que exista mucho fundamento para esa asociación. Lo más probable es que este grupo insignificante pasara desapercibido a los cronistas del Imperio Nuevo. Lo cierto es que, más allá del fantástico relato de la huida de Egipto que nos ofrece la Biblia, ese nuevo movimiento entre las tribus nómadas de la zona desértica de Palestina supuso un acontecimiento fundamental y señaló el comienzo de la historia de Israel.

\section{Un dios patriarcal}

Los descendientes de Abraham habían venerado a un dios concebido según la costumbre de los nómadas como un espíritu tribal; pero Moisés, el nuevo caudillo de los hebreos, de origen egipcio como indica su nombre, les convenció de que eran el pueblo escogido por ese dios y que estaban vinculados a él por una alianza que suponía conducirles a una nueva tierra de promisión.

Desde entonces la influencia de esa idea se fue abriendo paso lenta y contradictoriamente entre los hebreos, que elaboraron una serie de normas y creencias cada vez más definidas para sellar su especial unión con esa divinidad a la que comenzaron a denominar YHWH. Dado que en la antigua escritura semítica las vocales no se escribían, debemos admitir la tradicional hipótesis de que esta palabra se pronunciara Yahweh.

El mismo término de «hebreo» que sólo servía para aludir al perteneciente a un grupo étnico, se fue devaluando entre el pueblo escogido, que pasó a utilizar la palabra Israel, con el sentido de 
nación, para denominarse a sí mismo. La primera mención a Israel se encuentra en las estelas de la victoria del faraón Merenptah (1224 a. n. e.). Por fin, tras muchos años de peregrinaje, este pueblo de nómadas a la búsqueda de territorio creyó identificar la tierra prometida en el país de Canaán, fértil en la llanura del río Jordán, pero pobre y montañoso en la Samaria del norte y en Judá al sur.

Su penetración en ese país destinado a ser su patria se efectuó en medio de largas y cruentas luchas, contra los propios cananeos, pero también frente a los molestos vecinos del norte, los arameos. Antes de su definitivo asentamiento aún se vieron obligados a defenderse de los peligrosos invasores procedentes del mar: los filisteos, y tuvieron que luchar también por mantener su independencia con poderosas potencias como la egipcia y la hitita. Los hebreos, constituidos en doce tribus autónomas, pudieron superar estos desafíos unidos por la ley de Moisés y amparados por la protección de Yahweh, simbolizada por el Arca de la Alianza.

Una vez establecidos en las colinas de Palestina, estos pastores procedentes del desierto comenzaron un largo y difícil proceso de adaptación a los sistemas de vida sedentarios y agrícolas en los que la influencia cananea se dejó sentir. El sustrato religioso de los antiguos habitantes de la tierra prometida era politeísta e Israel tuvo que luchar contra esas creencias, mientras que el deseo de convertirse en un pueblo respetado les arrastraba hacia formas de gobierno monárquicas, a semejanza de las realezas de sus vecinos fenicios y arameos.

Con Saúl, David y Salomón, estos dos últimos entre los años 1010 y 932 a. n. e. aproximadamente, Israel conoció la monarquía y llegó a su apogeo político como lo atestiguan las ambiciosas obras emprendidas en Jerusalén, Gezer o Megiddo. Adaptado a la propiedad privada de la tierra y con una organización social fuertemente patriarcal, este pequeño reino fue capaz de sobrevivir durante más de cien años a los turbulentos embates políticos del Oriente Próximo, pero a la muerte de Salomón el país se fragmentó debilitándose considerablemente. Israel al norte, con Samaria como capital, y Judá al sur, en torno a Jerusalén, se convirtieron en dos pequeños Estados que no pudieron resistir mucho tiempo y terminaron 
siendo sometidos por los grandes imperios de la zona. Los asirios conquistaron pronto Israel, y Samaria fue ocupada en 721. Años después, Nabucodonosor destruyó el reino de Judá y Jerusalén fue tomada en 586, viéndose los jefes judíos arrastrados a un doloroso exilio en Babilonia hasta que Ciro, en el año 539 a. n. e. conquistó Mesopotamia y permitió el retorno de los desterrados a su patria.

Todas estas vicisitudes experimentadas por los hebreos y su misma decadencia como Estado sólo pudieron ser superadas gracias a la firmeza y originalidad de sus creencias. La desgracia, y no la grandeza, cimentó la religión judía y esta religiosidad, basada en el sufrimiento y la tensa espera en un supremo momento de apoteosis triunfal, será el principal legado de este pueblo a la cultura humana.

La seña de identidad más destacada de la religión judía y la que más iba a influir en ulteriores elaboraciones ideológicas es sin duda el monoteísmo. Ninguna cultura hasta entonces había sido capaz partiendo del animismo primitivo de desarrollar una formulación tan acabada de lo sobrenatural. El breve intento del faraón Amenofis IV de introducir el culto a Aton como único dios en el panteón egipcio no fue sino un paréntesis en la historia de la religiosidad politeísta de este pueblo, que no sobrevivió a su fundador. Los hebreos, por el contrario, partiendo de una monolatría original, que nos resulta difícil de vislumbrar, y en la que se daba culto a la divinidad tribal con carácter exclusivo como elemento de cohesión, fueron capaces, a lo largo de un dilatado período de tiempo, de crear en una contradictoria lucha con las influencias idólatras del entorno una bien trabada concepción de un dios único.

En la fase inicial de la historia de Israel los demás dioses no eran negados en su calidad de tales, sino que no se les daba culto porque resultaban extraños al grupo, aunque hubo momentos en que la tentación de los becerros de oro asedió a la religiosidad hebrea, que supo vencer las dificultades para afirmarse en la ley de Moisés.

El Yahweh bíblico fue con toda probabilidad el dios de alguna tribu meridional que terminó imponiéndose cuando se consolidó la identidad «nacional» israelita como consecuencia del mestizaje con las poblaciones cananeas. Por el relieve que le da el relato tampoco 
podemos menospreciar el papel que pudo desempeñar un caudillo como Moisés, cuyo origen egipcio ha hecho sospechar a algunos autores, como el mismo Freud (1937/1974), de la pervivencia y la influencia del monoteísmo de Aton en la religión judía.

Fue sin duda en la fase premonárquica y en lucha con las divinidades cananeas y palestinas cuando se gestaron las bases del monoteísmo judío. Sin embargo, el control del nuevo territorio y los intentos de asimilación de las poblaciones de origen, a las que se quiso aglutinar en un culto nacional centrado en la ciudad sagrada de Jerusalén y en el templo, supusieron la aparición de tendencias sincréticas y contemporizadoras contra las que se levantaron las voces de numerosos profetas.

Tras el exilio en Babilonia, vivido como un castigo divino, se consolidó de modo pleno el monoteísmo excluyente. Solamente Yahweh era el dios verdadero, uno y único, el resto de las divinidades no eran en realidad más que espejismos y falsedad. Esta original elaboración se puede explicar desde la debilidad y la frustración de una pequeña comunidad que se obstina en sobrevivir con una identidad propia. El monoteísmo de los judíos que tanta influencia va a ejercer no es una supervivencia de una religiosidad fundamental de los antiguos semitas o de una religión primitiva de la humanidad. Es, ni más ni menos, la transposición en el plano de la ideología de la unidad de un grupo que afirma su existencia autónoma apartándose y segregándose conscientemente del resto de las naciones, convencidos firmemente de que son el pueblo destinado a cumplir los designios de Yahweh.

Pero el monoteísmo judío no es sólo eso, es también la más acabada expresión ideológica del patriarcado en lo sobrenatural. El pueblo hebreo tenía ya, mucho antes de su definición nacional, una cultura patriarcal fuertemente arraigada en su estructura social. El patriarcado se había impuesto desde hacía siglos en toda la zona del Oriente Próximo y se puede decir que era entre las comunidades nómadas y pastoriles donde se encarnaba más crudamente. Los mismos textos bíblicos, aunque escritos mucho después, se refieren a los primitivos conductores como patriarcas, y la organización tribal quedaba estructurada en forma de clanes 
(mishpahah) presididos por esos patriarcas que ejercían su poder omnímodo sobre la familia extensa que los componían. Ellos serán el germen de los oikodespotes (déspotas domésticos) que es como el Evangelio denominará en griego a los cabezas de familia judíos.

La mujer estaba totalmente sometida al varón. Se la valoraba sobre todo por la descendencia legítima que le pudiera dar y por el trabajo con el que contribuía a la colectividad, pero estaba totalmente al margen de la toma de decisiones, careciendo de relevancia social. Para un hombre, casarse era convertirse en "propietario de una mujer» (Dt. 21, 13) y el término esposa significaba literalmente «propiedad de un marido» (Éx. 20, 17). Absolutamente cosificada en el contrato matrimonial, no desempeñaba sino un papel pasivo, y eran el pretendiente y su padre quienes cerraban su compra con el padre o la familia de la mujer. Dentro del clan se la consideraba una posesión familiar y el Deuteronomio $(25,5)$ consagraba la ley del levirato por la que una viuda sin hijos debía ser tomada como esposa por el hermano del desaparecido, siendo el primer hijo nacido de esa unión un descendiente directo del difunto.

Sin embargo, el trabajo de la mujer era imprescindible en la vida comunitaria. A las faenas domésticas se sumaba la elaboración de tejidos (Prov. 31, 16) y de otras tareas más duras si su condición social le obligaba a ello (Rut. 2, 2). A diferencia de otras lenguas semíticas, en hebreo el femenino de melek, rey, no existía para designar a su esposa. La mujer tampoco tenía ningún derecho legal, no heredaba ni de su padre ni de su esposo si existían herederos varones $(\mathrm{Nm} .27,8)$ y ni siquiera podía hacer un voto religioso sin el consentimiento del varón que la tutelaba (Nm. 30, 4).

Se admitía el concubinato e imperaba la poligamia aunque la monogamia encubierta a través de los descendientes de la esposa primera $(\mathrm{Gn} .2,24)$ tendía a afirmar los derechos de herencia materiales y de prestigio que el patriarca pudiera legar a su sucesor $(\mathrm{Gn}$. 27). El repudio era un derecho casi exclusivo del marido, que lo podía ejercitar como dice el Deuteronomio «con sólo que le hallara (a la mujer) una tara» $(24,1)$. La esterilidad era un castigo divino ( $\mathrm{Gn}$. $20,18)$ y el adulterio se pagaba con la vida (Dn. 22, 2). 
La consideración que se tenía de la mujer era degradante. En esto no difería de otras culturas, aunque en la judía se prodigaban los dicterios más misóginos incluso en los textos sagrados, en especial en los libros proféticos. Así, para Isaías (3, 16; 47, 1-8) las mujeres eran ridículamente vanidosas, voluptuosas y perversas. Amós $(4,1)$ las consideraba crueles y Jeremías $(3,1)$ y Ezequiel $(16,1)$ las veían como la quinta esencia de la falsedad.

Sobre esta forma de explotación, dominio y desprecio la religión judía erigió una superestructura teológica que iba a sancionar como ninguna otra hasta entonces esa situación de opresión. El politeísmo antiguo se había visto obligado en sus múltiples cosmovisiones a dar cabida a lo femenino en el mundo de las creencias sobrenaturales. El principio vital del origen necesitaba de una génesis en la que forzosamente debía participar, si no la mujer, sí al menos el principio generatriz que representaba su sexo. Esto explica que en las diferentes mitologías se multiplicaran las hierogamias cosmogónicas y que las distintas religiones integraran, en mayor o menor medida, a divinidades femeninas en sus respectivos panteones.

Hemos tenido la oportunidad de ver cómo esas divinidades fueron sufriendo ulteriores procesos de adaptación a la estructura patriarcal dominante y cómo en muchos casos fueron perdiendo importancia y poder a favor de las divinidades masculinas. Pero, en cualquier caso, el politeísmo era un sistema religioso que permitía mantener viva la dialéctica de los sexos, sin embargo el monoteísmo en su formulación última acabó con todo esto.

Dos aspectos fundamentales venían a romper con todas las visiones anteriores: el dios increado y atemporal, y su identificación por parte de los creyentes como padre omnipotente.

El Yahweh de la Biblia no es eterno, será muchos siglos después cuando la teología medieval cristiana podrá introducir ese concepto, pero el dios judío trasciende la temporalidad. Sólo él está al comienzo del tiempo, «en el principio...» nos dice el Génesis $(1,1)$. Esa condición de preexistencia suprema, más que su univocidad, es lo que lo convierte en singular y preeminente sobre el sexo femenino, al negar radicalmente su rasgo fundamental: el generatriz. La fuente 
de sumisión y prestigio de la mujer en el mundo antiguo, la capacidad de dar y renovar la vida, quedará anulada de raíz en la cosmogonía judía. Sólo Yahweh, el increado, será generador de todo, sólo él será capaz de dar la vida en el origen (Heb. 11,3) y de su sola voluntad dependerá que se renueve.

Lo femenino no tiene cabida en esa cosmovisión unisexual porque no podemos obviar que el Yahweh judío tiene sexo. Ese único dios no se manifiesta como un resumen de contrarios en el que se confunden los opuestos de género, sino como la suprema expresión de la masculinidad madura. ${ }^{1}$ Es cierto que no hay en el Antiguo Testamento una expresión explícita sobre la naturaleza de género de Yahweh, lo que ha llevado a algunos autores a jugar con la ambigüedad (Ochshorn, 1981), pero es que la afirmación resulta innecesaria habida cuenta de los numerosos indicios sobre el asunto, empezando por el fragmento del Génesis en el que se nos relata cómo Dios hizo al hombre a su imagen y semejanza (Gn. 1, 26).

Esta imagen masculinizada de la divinidad única se completa con una serie de rasgos característicos que lo convierten en padre de aquellos que le rinden culto y es este aspecto el que termina de completar la visión patriarcal del monoteísmo hebreo. Las deidades supremas de los diferentes panteones politeístas se presentaban a las culturas que las habían creado como poderes terribles, más de

1 La prohibición en la religión judía de representar la imagen del dios y su misma inmensidad nos impide saber cómo imaginaba su apariencia el pueblo escogido. Sus esporádicas manifestaciones directas nunca están personificadas como ocurre con la zarza ardiente que se dirige a Moisés en el Éxodo $(3,6)$ y la prohibición a ser visto por el pueblo se hace explícita cuando los hebreos se hallan a los pies del monte Sinaí (Éx. 19, 21); romper esta prescripción suponía la muerte (Éx. 33, 20). En la mayoría de los casos se presenta a través de intermediarios celestes y en las raras ocasiones en las que parece ser él mismo quien interviene en el relato, como ocurre cuando lucha contra Jacob (Gn. 32, 31), nada se nos dice de su aspecto, aunque podemos deducir que estamos no ante una divinidad juvenil sino madura. Lo mismo podemos colegir de la ulterior elaboración cristiana en la que al trimorfizarse la divinidad, el Padre terminará adoptando en la iconografía, por influencia apocalíptica, la imagen de un anciano venerable como plasmación de la autoridad y la sabiduría, mientras que Jesús tampoco se nos presentará como un joven, sino más bien, y teniendo en cuenta las edades humanas en el mundo antiguo, como un hombre maduro. 


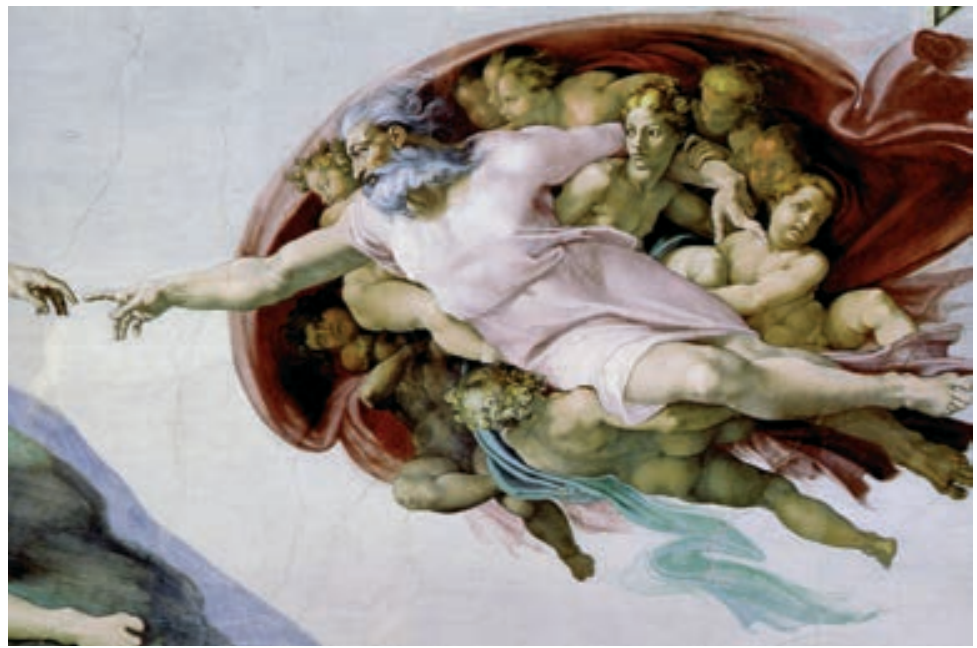

El monoteísmo judío consagró como única divinidad a un dios masculino a imagen de los patriarcas del pueblo escogido. Desaparecían así las diosas fecundas que poblaron el mundo de creencias en la antigüedad.

naturaleza política que familiar. La imagen a la que podríamos asimilar a Zeus o Amón es la de la realeza. Un poder ordenador basado en la fuerza y completado por la corte funcional del resto de las divinidades. Prueba de ello era cómo estas deidades majestuosas se habían enfrentado con dioses más antiguos resultando vencedores e imponiendo su autoridad, que era reconocida por el resto de los seres sobrenaturales y por ende por los mismos mortales.

Los hombres que las adoraban estaban simplemente sometidos a su voluntad a través de diferentes mecanismos y eran meros y fieles súbditos de la divinidad, a la que intentaban propiciar o atraer por medio del culto, como una reminiscencia de las creencias mágicas. Pero, a pesar de esta aparente sumisión, no estaban vinculados al dios nada más que por su condición de inferioridad. Sabían lo que tenían que hacer y lo hacían confiando en la justicia divina, sin que en ningún momento se sintieran parte de un plan sobrenatural ni sujetos de un particular destino. La original aportación de la religión judía es introducir el concepto de alianza con la divinidad y 
saberse pueblo elegido destinado a ejecutar los designios del Ser Supremo. Esta vinculación, esta alianza, sólo podía ser entendida desde una relación familiar. Yahweh se convertía en el patriarca del grupo que iba a recibir su herencia y como tal actuaba imponiendo su voluntad, en ocasiones desconcertantemente arbitraria, de modo terrible; pero, también, demostrando una predilección que sólo el padre manifiesta a su prole.

$\mathrm{Al}$ concebir así la relación con la divinidad, la religión judía expresaba la formulación más elaborada de la dialéctica sexual, que está en la base de la cultura según Freud. ${ }^{2}$ La mujer, el principio de lo femenino, desaparecía quedando soslayada la contradicción y la disputa con y por las mujeres, fuentes de placer y generadoras de vida. La ordenación de todo el universo se establecía en torno a un principio masculino y eran los hombres quienes interpretaban la voluntad sobrenatural en clave de relación paternofilial. El patriarca había escalado a la divinidad, y lo que Freud consideraba «cultura» sin más, bien podría entenderse como cultura patriarcal.

2 Freud en su obra Totem y Tabú publicada en el año 1912 intentaba, apoyándose en sus doctrinas y en los últimos trabajos de antropología, dar una explicación coherente sobre el origen y la pervivencia de las religiones. En 1925 (1925/1974) resumía así la última versión de las tesis expuestas en su libro:

«El asesinato del padre es el nódulo del totemismo y el punto de partida de la formación de las religiones.

El padre de la horda primitiva habría monopolizado despóticamente a todas las mujeres, expulsando o matando a sus hijos, peligrosos como rivales. Pero un día se reunieron estos hijos, asesinando al padre, que había sido su enemigo, pero también su ideal, y comiéndose el cadáver. Después de este hecho, no pudieron, sin embargo, apoderarse de su herencia, pues surgió entre ellos la rivalidad. Bajo la influencia de este fracaso y del remordimiento, aprendieron a soportarse unos a otros, uniéndose en un clan fraternal, regido por los principios del totemismo, que tendían a excluir la repetición del crimen, y renunciaron todos a la posesión de las mujeres, motivo del asesinato del padre. De este modo, surgió la exogamia, íntimamente enlazada con el totemismo. La comida totémica sería la fiesta conmemorativa del monstruoso asesinato, del cual procedería la conciencia humana de la culpabilidad (pecado original), punto de partida de la organización social, la religión y la restricción moral.

Una vez abandonada la sustitución del padre por el animal totémico, el padre primitivo, temido, odiado, adorado y envidiado, se convirtió en el prototipo de la divinidad». 
Este perfil del patriarcado sobrenatural, esta elevación a la categoría metafísico-religiosa de una institución social sólidamente arraigada desde hacía siglos en las culturas antiguas no la impusieron los hebreos sin resistencias, ya que tuvieron que librar una enconada batalla, que duró largo tiempo, con el principio femenino.

En la Biblia nos encontramos con indicios contradictorios que hacen referencia a esa pugna que también es corroborada por datos arqueológicos. En Tell Beit Mirsim, una localidad del antiguo reino de Judea, se han hallado figurillas de una mujer desnuda, que representan a una diosa o símbolo mágico de la fecundidad. Estas imágenes sabemos que eran muy frecuentes en la Palestina de la Edad del Bronce, pero las descubiertas en Tell Beit Mirsim se han encontrado en un estrato arqueológico perteneciente a la Edad del Hierro cuando esa localidad era ya israelita, lo que viene a ratificar la supervivencia del «paganismo». Un paganismo en el que el poder simbólico de lo femenino aún no había sido ahogado por Yahweh. La arqueología permite de este modo entrever todo el trasfondo religioso y cultural del judaísmo primitivo, dubitativo y en lucha con la influencia cananea.

Sabemos que entre los cananeos estaban profundamente arraigados los cultos a la vegetación relacionados con lo femenino y la renovación de la vida. La misma serpiente del Génesis (Gn. 3) se nos presenta como un animal ambiguo al que no podemos identificar mecánicamente con la encarnación del Mal, como apuntaremos más adelante. Es muy probable que la serpiente del Edén representase la versión remitologizada de lo que en su origen fue este animal tan significativo en las creencias del mundo antiguo.

La serpiente, ya lo hemos dicho, fue muy venerada en Egipto y en todo el Oriente Próximo, incluido Canaán. Yahweh la utiliza para castigar a Israel, pero cuando Moisés intercede por su pueblo es Dios mismo quien le ordena que construya una imagen de ese animal en bronce y la suspenda de un asta para que todo aquel que haya sido mordido pueda mirarla y así sanar (Nm. 21, 6-9). También la vara de Aarón se convierte en una serpiente para confundir a los magos egipcios y se le llegó a rendir culto en el mismo 
templo de Jerusalén hasta que su figura de bronce fue destruida por el rey Ezequías (2 Re. 18, 4).

Asociada a la renovación de la vida y a la inmortalidad la encontramos en el relato mesopotámico de Gilgamesh, y como imagen de la fertilidad la descubrimos con mucha frecuencia en todo el área del Mediterráneo, acompañando a las diosas de la fecundidad, lo que unido al término arum, que significa astuta, aplicado a la serpiente del Génesis nos puede llevar a deducir que Eva y el reptil eran un trasunto reelaborado de esa deidad, ya que la misma palabra significa también «desnuda», que era como se solían representar a esas divinidades y como se hallaba Eva antes de su caída.

Así mismo se ha podido comprobar que el Yahweh de antes del destierro se veía todavía obligado a compartir culto con la diosa Astarté, tal y como lo demuestra el descubrimiento de sendos templos erigidos uno junto a otro al lado del muro israelita de Mispá. Un ejemplo de la tesis que estamos apuntando es el hallazgo de papiros arameos en Yeb, a comienzos del siglo xx, en los que hemos podido leer cómo todavía en el siglo v a. n. e. se atribuían a Yahweh consortes femeninas en esta colonia militar judía del Alto Egipto en una clara evolución del sometimiento de lo femenino al dios patriarca, que ya no tendría que compartir culto con la feminidad, sino que en ese proceso de dominio habría llegado a someterla, integrándola en su harén para terminar definitivamente anulándola. ${ }^{3}$

3 La prueba de esta pervivencia de lo femenino en la religión judía la hallamos en el Talmud. En estos tratados interpretativos de los textos sagrados judíos, aparece una hipóstasis femenina del dios denominada Shekinah. Esta figura, que puede ser entendida como una denominación de la sabiduría divina, moraba en el Templo de Jerusalén al tiempo que deambulaba con las tribus y encarnaba a Israel proporcionando al pueblo curación y consuelo.

Pero según una interpretación gnóstica judía Shekinah era algo más, ya que personificaba el lado femenino del dios. Esa parte de la divinidad habría sido la que creó el mundo y al primer hombre. En este relato vemos cómo se le devolvía a lo femenino su poder fecundador, mientras que el lado masculino del dios se limitaba a un papel pasivo.

La Cábala (doctrina mística que juega con el valor numérico de las letras en el alfabeto hebreo para interpretar los textos sagrados) recogió también la presencia de Shekhina desarrollando un curioso mito. Los cabalistas representaron a Adonai, un trasunto del dios masculino, como un rey y a Shekinah como la encarnación del mismo Israel. Esta pareja se uniría en una hierogamia sagrada en el Templo de 
Las ideas y valores, sobre todo en el terreno de lo sobrenatural, son los factores culturales que más lentamente evolucionan y cambian. El enorme prestigio de lo femenino tardó en ser destruido en el mundo de creencias judío, que lo mantuvo vivo durante un largo período de tiempo a la par que iba dibujando el perfil del dios único. En ese proceso de gestación de la divinidad desempeñaron una tarea fundamental los llamados profetas bíblicos, moralistas y predicadores adeptos del monoteísmo que con sus soflamas abocetaron los rasgos del dios. Así el Yahweh de Amós, antes de la caída de Samaria, fue sobre todo un dios justo y justiciero. El profeta Oseas puso el énfasis en su amor paciente e inagotable, e Isaías, desde el reino del sur, hizo hincapié en su santidad esencial. Pero será a raíz del destierro babilónico cuando surjan con las prédicas de Ezequiel y del Deutero-Isaías las aportaciones más contundentes respecto al poder omnipotente de Yahweh. A ellos se debe la imagen de un dios creador, omnisciente y todopoderoso que controla todos los acontecimientos en el devenir del universo, domina los fenómenos naturales y destruye a todos sus enemigos. Ese poder sobrenatural habría escogido al pueblo de Israel como elegido para materializar su designio en el mundo y su voluntad se revelaba en los escritos sagrados que, por aquellas fechas, se afanaban en redactar los judíos de la primera diáspora.

El proceso de configuración de la divinidad no se vio completado, según algunos autores (James, 1973), hasta el siglo II a. n. e., pero lo esencial del mismo se había llevado a cabo mucho antes y podemos decir que con el redactado definitivo del Pentateuco ${ }^{4}$ en

Salomón una vez al año. Pero tras la destrucción del Templo, Adonai se habría retirado del mundo rehusando encontrarse con Shekinah de una manera impura, y la misma Shekinah habría sido capturada por los extranjeros y sometida a todo tipo de humillaciones y violencias. Su destino se convertía así en símbolo de la triste suerte corrida por el Pueblo Escogido (Zohar, I, 203 a).

4 Los cinco primeros libros de la Biblia son conocidos en el mundo cristiano como Pentateuco, pero para la religión judía son la Torá lo que literalmente significa «enseñanza». La tradición religiosa atribuye su redactado a Moisés pero la crítica actual ha establecido que se trata de una obra elaborada a partir de fuentes distintas y escrita en épocas diversas. Parece ser que la primera y más antigua de las fuentes fue la denominada yahvista (o «J», de Jahwe, variante alemana de Yahweh) y se suele fechar en los siglos X o IX a. n. e. Este nombre se debe a que el autor utiliza la denominación "Yahweh», para designar al dios, mientras que la fuente denominada 
torno al siglo vi o v a. n. e. alcanzó su madurez. En esas fechas la creencia mayoritaria apuntaba ya a la existencia de un solo dios verdadero, viéndose enfrentados los teólogos judíos, desde esa novedosa concepción, a explicar el origen del Mal.

\section{Satán: de funcionario a rebelde integrado}

El monoteísmo consecuente entraña para los que lo profesan el problema de explicarse por qué existe el Mal en el mundo. Para las religiones y creencias politeístas o dualistas como la zoroástrica la respuesta resulta más sencilla ya que el Mal se encarna en una o algunas de las divinidades del panteón. Los pueblos que contemplan la existencia de «dioses ociosos» tienen también una fácil explicación de por qué los dioses, después de realizada su obra, dejan que ésta se mueva en la imperfección, al haberla abandonado a su suerte olvidándose de los hombres.

No obstante, en casi todas las mitologías encontramos un extraño sentimiento de culpa del que Freud nos da cuenta en sus teorías, que termina por convertir a los humanos en corresponsables de sus desgracias. Un descuido, una falta cometida en el tiempo original por el hombre y en muchos casos, como ya hemos visto, por la mujer ayudan a conciliar la idea de poderosas aunque temibles fuerzas benefactoras con la dura realidad de la vida y de la muerte.

En la religión judía el problema se complica porque concibe al único dios como un padre protector, pero se resuelve gracias a la propia naturaleza de la institución patriarcal y a que durante siglos la monolatría judía se vio contaminada por las creencias politeístas del entorno en el que se desarrolló. Por eso, cuando nos enfrentamos a la explicación del Mal en los hebreos, el problema deja de ser teoló-

«E», de elohim (señor en hebreo), emplea esta otra palabra para nombrar a la divinidad siendo su factura posterior (siglo VIII a. n. e.). El libro del Deuteronomio o fuente «D» se redactó en el reino de Judá un siglo después. Por último, tendríamos la fuente «P», también llamada sacerdotal, escrita tras el exilio en Babilonia, en los siglos VI o v a. n. e. Por las mismas fechas se habría acometido un redactado definitivo que se debió de llevar a cabo en Jerusalén. 
gico para convertirse en exegético, ya que en los escritos religiosos producidos por esa cultura se entrelazan y superponen explicaciones distintas, elaboradas a lo largo del tiempo, que hacen imposible una respuesta sencilla; aunque lo que descubrimos al final es una elaboración sincrética en la que se integran las tres grandes interpretaciones: el Mal sólo puede provenir del Bien; el Mal es producto de una falta cometida por el hombre en su fase original lo que engendra el castigo divino como acto de justicia, o el Mal es el resultado de la acción consentida de una poderosa fuerza maligna que se enfrenta a la divinidad desde los mismos orígenes del cosmos.

La respuesta primera y más contundente en orden a asentar la creencia en un solo dios es la que nos da la Biblia en sus textos proféticos, Yahweh es el único autor del Bien y del Mal:

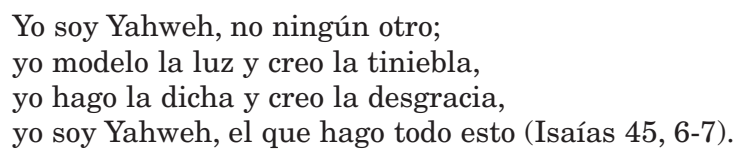

En otros pasajes son sus cultores los que afirman la singularidad y omnímodo poder del dios a través de sus terribles manifestaciones (Lm. 3, 38 y Am. 3, 6); y en un contrasentido de su omnisciencia el Yahweh del Génesis (Gn. 6, 7) llega a arrepentirse de su obra y piensa en destruirla. Incluso en una ocasión es él mismo quien actúa contra Moisés sin ningún tipo de mediación e intenta matarlo (Ex. 4, 24). ${ }^{5}$

¿Cómo conciliar a este dios terrible, con la bondad o con la elección del pueblo hebreo como escogido? Las explicaciones que se han dado desde hace mucho tiempo siguen siendo válidas. Su propia naturaleza paternal lo convierte en autoritario y en inopinadamente irascible. Solicita una obediencia ciega a sus mejores hijos, desconfiando de ellos, como ocurre en el caso de Abraham cuando le manda sacrificar a Isaac.

5 Este extraño pasaje, del que la mayoría de los exegetas judíos o cristianos no han sabido dar una explicación, ha sido interpretado por Freud (1937/1974, op. cit., tomo IX) en Moisés y la religión judía. Lo cierto es que resulta tan desconcertante que la tradición posterior atribuyó el hecho a Mastema (Jubileos, 48, 2, 3), exonerando así a Yahweh de tan criminal acción. 
Los prueba constantemente por medio del dolor y el sufrimiento como si tuviera que cerciorarse de que son acreedores de la herencia que les tiene reservada, como sucede en el caso de Job, y sobre todo los educa en la crueldad frente a aquellos que no creen en él.

El Yahweh del Pentateuco es un dios guerrero y despótico que acaudilla a un pueblo inseguro a la conquista de una tierra propia poblada por enemigos idólatras. En definitiva podemos decir que es un dios recreado a la medida de las necesidades de las tribus hebreas en su etapa inicial de formación como nación. No ahorrará la sangre y la desgracia ni a sus hijos ni a los enemigos de éstos, a los que mandará exterminar sin ningún tipo de contemplación, y sobre los que ejercerá una justicia mucho más cruel que la basada en la ley del «ojo por ojo». El episodio de la conquista de la ciudad de Jasor que nos narra el Libro de Josué $(11,16)$ es bastante explícito en este sentido. Tras la toma de la ciudadela el mismo Josué mata al rey de los cananeos con su propia espada y, siguiendo lo que era costumbre en la guerra del mundo antiguo, los israelitas «mataron toda cosa viva en ella, y la arrasaron entera; no perdonaron nada que tuviese aliento, y la destruyeron por el fuego [...] y tomaron para sí el ganado y todo el resto del botín».

Esa crueldad también se proyectaba sobre el propio pueblo de Israel para el que la culpa individual se tornaba rápidamente en castigo colectivo. Los gentiles que se interponían en su camino debían ser destruidos implacablemente pero, también, cualquier israelita que desobedeciese a Yahweh era un posible reo de muerte. En el mismo Libro de Josué $(8,25)$ se nos cuenta la ira de Yahweh cuando un hebreo se guardó parte del botín sin entregarlo a su dios. La divinidad, celosa de las ofrendas debidas, castigó a todo el pueblo con la derrota. Josué, alarmado, preguntó a Yahweh qué debía hacerse, y el dios le contestó que el culpable tenía que pagar su culpa. Se echaron suertes, por medio de las cuales se iba a manifestar el juicio de dios y se descubrió que Acán era el infractor. Tras lapidarlo en el Valle de Ator, la ira del Señor se aplacó y como recompensa entregó la ciudad de Hai a la furia de los israelitas que mataron también aquí a todos sus habitantes: «El número de los muertos de esa jornada, hombres y mujeres, fue de doce mil, la población entera». 
El comportamiento del dios de los judíos no se diferencia en mucho del de otros dioses del Oriente Próximo en aquellos tiempos. Sus acciones despiadadas y la imagen que de sí mismo trasmite en el Deuteronomio $(32,41-42)$ nos recuerdan a la diosa egipcia Sejmet:

Cuando haya mojado mi espada llameante, cuanto tome en mi mano el juicio, castigaré a mis adversarios y tomaré venganza de mis enemigos. Embriagaré de sangre mis dardos, mi espada devorará carne, sangre de muertos y cautivos, las cabezas de los príncipes enemigos.

La naturaleza de Yahweh en la religión hebrea preprofética no es sino un trasunto de las costumbres salvajes de esos nómadas errantes y conquistadores.

Un dios que tan abiertamente se nos presenta como único y por tanto como paradigma del mal que aflige a los hombres no necesitaría de ningún otro ser que actuara en su nombre. Sin embargo, y aquí es donde podemos apreciar la influencia politeísta del entorno, el Yahweh del primer período de la historia de Israel ya recurre a espíritus mediadores que, en ocasiones, no son sino la propia proyección de su lado oscuro. Es así como entran en la historia de la religión judía otras fuerzas que personifican el Mal. Como nos dice Maggi (2000: 25), «aquellos seres que en los pueblos vecinos de Israel eran representados como rivales de la divinidad, en la Biblia son reclutados por Dios mismo y se convierten en instrumentos suyos». Estas fuerzas terribles van desde espíritus puros en los que podemos entrever la mera plasmación de ese «lado oscuro» de Yahweh hasta la personificación de las desgracias naturales o las enfermedades. A través de todos ellos es como se manifestará el Mal en el Antiguo Testamento.

Algunos eran simples representaciones de males concretos, como la peste, Reshef, mera derivación del nombre de la enfermedad en cananneo. Entre ellos ocupaba un lugar preferente Mevet, la muerte. Este rey de los terrores cotidianos actuaba, más allá de la figura literaria, como un espectro que organizaba a sus huestes: las plagas y el hambre para asolar con ellas a los hombres. La muerte es una potencia en sí misma con la que se puede tratar y los impíos 
sellan pactos con ella (Is. 28, 15 y Sap. 1, 16). En otras ocasiones, son los animales impuros del Levítico $(11,13-18)$ que pueblan el desierto los que adquieren una categoría superior y llegan a personificar la desgracia (Job 30, 29). Pero por encima de éstos actúan los espíritus y es en esa esfera inmaterial donde debemos indagar para rastrear el Mal en esencia. En primer lugar mencionaremos al «Espíritu de discordia», que parece tener una naturaleza autónoma pero que sin embargo sólo actúa por mandato divino. Con su mediación Yahweh proyecta la división y la traición entre su pueblo (Jue. 9, 22-23). Esta entidad sirvió en algún caso a los redactores del texto para justificar los enfrentamientos internos en Israel.

Otra figura del Mal, verdaderamente terrible y con una gran proyección posterior, es «El Exterminador». Este ser responde a una tradición beduina que conjuraba la funesta acción de ese espíritu sanguinario sobre sus rebaños sacrificándole un cordero durante el plenilunio de primavera y untando con su sangre las tiendas de la tribu. La tradición judía lo presenta como un ángel sometido también a la voluntad de Yahweh. Su intervención en el crucial pasaje del Éxodo (11, 4-5) cuando extermina a los primogénitos egipcios es verdaderamente terrorífica y a ella se debe su ulterior fama, aunque su hálito mortal se deja sentir en otros versículos bíblicos (Nm. 17; 1 Crónicas). En el Libro de la Sabiduría (18, 14-16), el mortal espectro se convierte en "palabra» del dios para sembrar parecida devastación. Con el paso del tiempo esta siniestra figura llegó a resultar incompatible con la voluntad de Yahweh y la tradición judía terminó por asignarle un nombre propio: Mastema. Este apelativo no era sino una creación nominativa para distanciar esas crueles actuaciones de la figura de un dios que se había ido humanizando.

Mastema aparece en el Libro de los Jubileos, un apócrifo ${ }^{6}$ del siglo I a. n. e., y sirve para cargar sobre él la culpa en algunos episodios especialmente conflictivos, como la orden que recibe Abraham de sacrificar a su hijo, o el intento de asesinato de Moisés, y para personificar al Exterminador de los jóvenes egipcios en el Libro del Éxodo.

6 Los apócrifos son un conjunto de libros judíos de ambiente bíblico, escritos entre el año 200 a. n. e. y el siglo II, y no considerados canónicos, por lo que no han sido integrados en la Biblia. Estos escritos suelen ser explicaciones de textos sagra- 
Con la traducción de la Biblia del hebreo al griego efectuada entre los siglos III y II a. n. e. entran en ella los demonios. Los traductores se encontraron con la dificultad de verter al griego el apelativo de algunos seres fantásticos que aparecían en el relato por influencia babilónica, sobre todo en el texto redactado después del exilio. El término escogido por los setenta míticos sabios que acometieron esta tarea de traducción fue el de daimonia, en su sentido más peyorativo y les sirvió tanto para designar a sátiros, los ceirin hebreos, peludos y barbados que vagan por el desierto, como para denominar a todos los dioses paganos que aparecen en las Escrituras con una excepción: Beelzebub, dios de Ecrón (2 Re, 1, 2) que conserva su propio nombre, un compuesto de Bel (Señor) y Zebub (moscas), el Señor de las moscas. Se trataba de una divinidad filistea que protegía contra las enfermedades transmitidas por estos animales que los hebreos consideraban seres impuros. En el Nuevo Testamento, sobre todo en el Evangelio de Marcos, su nombre aparece intencionadamente deformado por los fariseos, que lo transforman Beelzebul, el Señor del estiércol, para designar una manifestación del demonio que pervivirá durante siglos.

Algunos otros de estos seres preservaron también sus nombres. Así Seoel, ${ }^{7}$ la personificación del reino de los muertos, y Abaddón, el

dos anteriores, por ejemplo El testamento de Moisés; pretenden revelar ocultos misterios o simplemente buscan poner el énfasis en un dogma determinado y servir a las creencias de alguna secta, y pueden tener un acusado carácter fantástico. Los apócrifos anteriores al siglo I son conocidos como Apócrifos del Antiguo Testamento, mientras que los de inspiración cristiana los conocemos como Evangelios Apócrifos o Apócrifos del Nuevo Testamento. Algunos de los más importantes son La vida de Adán y Eva, Libro de Henoc, Jubileos, Evangelio de la juventud de Jesús, Correspondencia entre Jesús y el rey Abgar, varios Apocalipsis (de María, de Pedro, etc.) y Hechos (p. ej. Los Hechos de Pedro). Todos ellos sirven para indagar en la evolución del pensamiento religioso tanto judío como cristiano primitivo.

7 En su origen la religión judía no contemplaba ningún tipo de resurrección. El espíritu del hombre tras su muerte descendía al Seoel y allí permanecía llevando una existencia lánguida. A partir del siglo II a. n. e. se introduce la idea de la resurrección reservada a aquellos cuya vida hubiera estado presidida por la observancia de la Ley y la rectitud moral. Es entonces cuando el Seoel comienza a asimilarse con el Gehena, un valle próximo a Jerusalén, lugar asociado con el culto a Moloc y maldito por los profetas, en el que sufrirían castigos por el fuego los judíos impuros. Sólo es a partir de esta construcción cuando el Seoel puede equipararse con el ulterior infierno cristiano. 
señor que manda sobre él, figuran como tales en Proverbios $(27,20)$ y en otros pasajes bíblicos. Lo mismo sucede con Asmodeo, al que se le califica de demonio y que aparece en el Libro de Tobías $(3,8)$ enamorado de Sara, a la que le mata todos los maridos en la noche de bodas antes de que pueda consumar su matrimonio. Azazel es otro de estos espíritus impuros tomado de las tradiciones beduinas y al que los caravaneros del desierto le enviaban cada año el 10 de tishiri (septiembre-octubre) un macho cabrío cargado con las culpas colectivas como ofrenda expiatoria. Se le menciona en el Levítico $(16,10,22)$ como tal, pero más tarde nos lo volvemos a encontrar en el apócrifo Libro de Enoch como uno de los ángeles rebeldes a Dios. Por último recordaremos a Belial, «El que engulle», una especie de personificación de la nada absoluta, del vacío metafísico (2, Sal. 22, $5 ;$ y 18,5$)$ que volverá a reaparecer, con la grafía algo modificada, como Beliar en el Nuevo Testamento y en los apócrifos, transformado ya en una personificación del Mal.

También conservan su denominación algunos monstruos que se deslizan en las páginas del Viejo Testamento y que la posterior tradición cristiana terminará por identificar con el Mal absoluto, como es el caso de Leviatán o Behemot.

Leviatán es un monstruo marino de origen cananeo que guarda relación con otras bestias mitológicas al ser una serpiente que posee varias cabezas y un aspecto aterrador. Su nombre puede significar «gran pez» o «serpiente retorcida». También en este caso el imaginario reptil es obra de Yahweh (Job 3, 8; Sal. 104, 26), que parece haberlo creado para jugar con él y luego destruirlo manifestando así su poder (Sal. 74, 14; Is. 27, 1). Los textos rabínicos posteriores situarán su nacimiento el quinto día del Génesis y lo harán perecer a manos del arcángel Gabriel que lo derrotará con ayuda de la divinidad. Tras darle muerte, según se nos narra, el vencedor confeccionó con la piel de este ser monstruoso un enorme palio con el que cubrió Jerusalén, siendo tal el resplandor que desprendía que se podía percibir desde cualquier rincón del mundo.

Menos claro parece el origen de Behemot, y aunque algunos apuntan una posible etimología egipcia a partir de $p$-ehe-moú, «buey de agua», lo más probable es que su nombre sea el plural de behe- 
$m a$, que en hebreo significa simplemente «cuadrúpedo». No obstante, la tradición judía lo convirtió en un ser de unas dimensiones desmesuradas y de un aspecto indefinido, capaz de beber en un solo día el agua del Jordán y de comer la hierba de mil montañas. El apócrifo Libro de Henoch le atribuye el sexo masculino y le hace residir en el desierto mientras que a Leviatán lo imagina hembra y le adjudica el mar como dominio. Behemont es considerado en el Libro de Job como «primacía de las obras de Dios» invencible por los hombres pero sometido a la divinidad.

Otro ser de parecidas características a la famosa pareja de monstruos es Rahab, que aparece citado al menos tres veces en el Antiguo Testamento (Job 26, 12; Is. 51, 9; Sal. 89, 11) pero siempre como derrotado por Yahweh. Su origen parece ser babilónico y su nombre significa «violencia». Su figura no excitó tanto la imaginación judía, aunque algunas leyendas lo presentan intentando impedir la separación de las aguas en el Mar Rojo durante la huída de Egipto o, por el contrario, ayudando a Noé a rescatar un libro de medicina mágica el Sefer Raziel.

Pero de todos estos espíritus, demonios y monstruos, el que estaba destinado a imperar sobre ellos y a adquirir una cierta independencia de su creador careció inicialmente de nombre propio, ya que en su origen era simplemente ha-satán: el fiscal. Así aparece por primera vez en Zacarías $(3,1)$ sentado a la diestra de la divinidad ejerciendo esa labor de acusador. Solamente en una ocasión figura la palabra Satán en la Biblia como nombre y no como función acompañada del artículo (1 Cr. 21, 1); y lo hace en un texto de época tardía (siglo IV a. n. e.) para sustituir a un Yahweh injusto que busca la perdición de David y de su pueblo.

El ha-satán en el Antiguo Testamento también está al servicio de Yahweh y desempeña diversas funciones por encargo de la divinidad. Así opera como obstáculo oponiéndose a algunas acciones de los hombres (Nm. 22, 4, 6), aunque también se utiliza el mismo término para designar a los adversarios terrenales: "Yahweh suscitó a Salomón un satán, Hadad el edomita, de la estirpe real de Edom» (1 Re. 11, 14). Cuando se le menciona personificado se nos presenta entre los «hijos de dios», especie de corte celestial, como un discipli- 
nado funcionario que tiene la misión de vigilar todo el reino y dar cuenta a su señor. «Dijo entonces Yahweh al satán: ¿De dónde vienes? El satán respondió: De dar vueltas por la tierra y pasearme por ella» (Job 1, 7, 8). Las pruebas o «tentaciones» a las que ha-satán somete al paciente Job se las impone con el consentimiento divino y a través de él sólo obra la voluntad de Yahweh para probar al fiel y abnegado creyente.

Este personaje-función que es ha-satán será traducido en la versión griega de la Biblia como diabolos, palabra que significa «el que divide o separa» y esos dos términos, sinónimos desde entonces, estarán destinados a nombrar de modo preferente el Mal personificado en la religión cristiana.

Pero mientras que es Yahweh quien ejerce o consiente el Mal de modo directo o a través de sus emisarios y a los hombres no les queda sino sufrir ese aspecto terrible de la deidad y aceptarlo como aceptan los beneficios que ésta les depara (Job 2, 10), los redactores de las escrituras intentaban ir más allá y buscar una explicación a ese terrible comportamiento. Desde la mentalidad religiosa, que contempla abrumada el absoluto poder del único dios al que adora, la primera justificación al hecho no podía ser otra que el hombre mismo, que con sus acciones desagradaba a la divinidad e infringía sus mandatos.

Esta otra teoría justificativa del Mal que culpabiliza directamente a la humanidad aparece en muchas religiones y en la judía se vale para su exposición de recursos mitológicos del medio en el que se movió el pueblo escogido. La existencia de una Edad de Oro expresada en el Génesis por medio del Jardín del Edén es un tópico que se repite en más de una de las construcciones sobrenaturales del Mundo Antiguo. La pérdida de esta idílica situación se habría debido a una falta cometida por la pareja primordial al desobedecer un mandato divino y, aunque la expulsión del Paraíso Terrenal de Adán y Eva estaría muy lejos de ser motivada por la comisión de un «pecado original» en el que luego lo transformará la teología cristiana, esta impostura humana en el origen servía a los judíos para explicarse las primeras y naturales desgracias que aquejaban a los hombres: el trabajo, el dolor y la muerte. 
No obstante, el texto sagrado no se detiene aquí, ya que el hecho no se presenta como un mito aislado que sirva para que los hombres entiendan la génesis de aspectos concretos de su realidad, sino que, en el caso judío, se busca un hilo de continuidad, convirtiendo la explicación mitológica en relato histórico. Este aspecto novedoso respecto a otras religiones en las que no se manifiesta, o lo hace de modo menos consistente, obliga a los autores bíblicos a profundizar en la dialéctica de la falta, el castigo y la expiación, que tan profunda huella dejará en esa religión. Así, en la primera parte del relato sagrado y con menor intensidad en el resto, vamos a ver a Yahweh constantemente enfurecido maldiciendo y castigando a los humanos que con su inicuo obrar desafían sus mandatos y se hacen acreedores de los males que ellos mismos se procuran.

En el Génesis los episodios que se suceden sobre este tema de la falta y el Mal son abundantes y algunos sirven para clarificar la presencia constante de males sobre la tierra. El crimen de Caín permite explicar el asesinato, la violencia, el fratricidio y la envidia. El diluvio, relato tomado directamente de la mitología babilónica, permite relacionar la catástrofe con el comportamiento colectivo, así como poner de manifiesto la clemencia divina con aquellos que le son fieles. La torre de Babel ilustra la soberbia del hombre, y el castigo tiene como misión resaltar su humilde condición al verse sumido en el caos de la diversidad. Sodoma y Gomorra nos advierte por primera vez de la gravedad de las faltas relacionadas con la infracción de los tabúes sexuales, que tanta importancia terminarán por cobrar en la religión judía.

Conforme avanzamos en la «historia» del pueblo escogido la dinámica de falta y castigo se hace más concreta y menos universal, puesto que termina por servir de ilustración a los avatares externos e internos de Israel. Sólo sobrevive a lo largo de toda la narración un reiterado ejemplo destinado a fundamentar el monoteísmo: los que se oponen a Yahweh y a su reconocimiento como el único dios verdadero son o terminarán siendo destruidos.

Esta teología de preferencias y poder absoluto hubo de conjugarse con la triste realidad política de ese pequeño e insignificante pueblo. La decadencia, la derrota y el exilio eran difíciles de explicar 
desde los pretendidos designios divinos y, tras el destierro, la idea de que el Mal era sólo producto de los pecados de Israel comenzó a parecer insuficiente a los redactores más jóvenes de los textos bíblicos que, ansiosos por ver cumplida la voluntad de Yahweh, desarrollaron un nuevo género profético: el apocalíptico.

Apocalipsis en griego significa «revelación» y el género apocalíptico se extendió entre los tratadistas religiosos durante un largo período de tiempo que abarca del siglo II a. n. e. al II. Su raíz se encuentra en la profética de época anterior centrada en vaticinar las desgracias de Israel, pero también, la felicidad y la libertad prometidas (Is. 24, 27).

Mientras que el mensaje de los profetas giraba sobre la llamada a la obediencia y el respeto a la Ley del único dios, los escritores apocalípticos ponían el énfasis en el final de los tiempos y el triunfo de la divinidad. Estos nuevos profetas dejaban de ser intérpretes del sueño de los demás y eran ellos mismos los que experimentaban la revelación onírica que les desvela el sentido de la historia del mundo, presentada como predicciones anteriores ya cumplidas. Por eso, así como los acontecimientos del pasado se habían hecho realidad, la veracidad de lo que ellos vaticinaban, y que estaba por venir en un futuro no muy lejano, también se cumpliría.

Sus pronósticos no se limitaban al triunfo del pueblo elegido sobre el resto de las naciones de la tierra, ya que esa victoria no era sino el preludio del final de la historia humana y de toda una renovación cósmica. En ese momento supremo, equivalente al tiempo original, el mundo recuperaría el estado de pureza primigenio, el Mal quedaría definitivamente erradicado para toda la eternidad y los justos ya muertos resucitarían para disfrutar de una felicidad también eterna.

Estilísticamente este género utilizaba un lenguaje simbólico y en él abundaban esotéricas imágenes de difícil o ambigua interpretación. Este recurso no era sólo poético, ya que permitía al autor abrir diferentes vías de lectura en el texto, lo que garantizaba una determinada perennidad y veracidad hermenéutica de lo profetizado. No obstante, estas imágenes, muchas veces confusas y bestiales, se ha podido comprobar que se inspiraban en los mitos e iconos de las otras religiones del antiguo Oriente Próximo. 
Tradicionalmente se ha aceptado que el primer libro apocalíptico del Antiguo Testamento es la segunda parte del atribuido a Daniel, que alude a la época de la persecución de los judíos por parte del rey seleúcida Antíoco IV Epífanes, a mediados del siglo II a. n. e., fecha en la que se redactó en su versión actual. La creencia en la resurrección del cuerpo en la religión judía aparece por primera vez en este libro (Daniel 12,2) y cabe la posibilidad de que esta doctrina tuviese mucho que ver con la idea de que un dios justo recompensaría a aquellos que, como los mártires Macabeos, ${ }^{8}$ habían muerto defendiendo a Israel y su Ley.

Sin embargo son pocos los libros apocalípticos que se integran en los textos canónicos, mientras que nos encontramos una mayor abundancia entre los apócrifos, y en todos estos autores detectamos la impaciencia por el cumplimiento de la promesa divina. En el siglo II a. n. e. la historia del pueblo escogido era ya larga y tortuosa, y de tan prolongada espera y tanto sufrimiento se podía, pero sobre todo se deseaba, intuir un pronto y feliz final. No obstante, todos los indicios materiales señalaban en sentido contrario lo que disparaba una pregunta inevitable: ¿por qué Yahweh probaba tan duramente a sus hijos?

La imagen terrible del dios de los primeros tiempos se había ido humanizando y responder al dilema achacándolo sólo a su tiránica voluntad resultaba entonces casi impío. Quedaba como explicación el pecaminoso comportamiento de Israel pero, aun aceptando esta inculpación, la contestación parecía insuficiente y suscitaba otra pregunta, también de difícil respuesta: ¿por qué los elegidos se mostraban tan inconstantes y proclives a la ofensa? Sólo la actuación de un poder maligno, de un ha-satán, de un terrible adversario del pueblo y su dios, podía explicar tanto extravío, tanta impiedad, tanto retraso en alcanzar lo prometido por el padre. Sólo esa fuerza, casi igual a la del dios, permitía comprender la dura realidad en la que se venía debatiendo el pueblo de Israel desde la muerte de Salomón.

8 Recordemos que reciben este nombre los caudillos judíos que se rebelaron contra los sirios seléucidas, que pretendían la asimilación religiosa del pueblo de Israel, en el año 167 a. n. e. La revuelta se produjo cuando Antíoco IV profanó el Templo de Jerusalén. La lucha, de guerrillas en sus inicios, se hizo para rescatar la Ley «del poder de los gentiles y de los reyes» (1 Mac. 2, 48). 
Este tipo de justificaciones subjetivas daban cuerpo teórico a las influencias experimentadas por la religión judía a raíz del exilio en las que el dualismo de origen persa se había filtrado en unas creencias constantemente puestas a prueba. A lo largo del tiempo se fueron desechando las tentaciones idólatras de los dioses vecinos que se sustentaban en planteamientos poco sutiles y muy primitivos, pero formulaciones más elaboradas como las del dualismo iranio debieron de dejar una profunda huella que terminó por cobrar carta de naturaleza debidamente corregida en la etapa de los escritos apocalípticos.

La idea de una poderosa fuerza del Mal enfrentada al único dios podía contribuir a explicar las desgracias de Israel de un modo más convincente que las vías exploradas hasta entonces por los escritos sagrados, aunque tenía que adaptarse a un monoteísmo cada día más fuertemente anclado en la conciencia del pueblo. Ese proceso de adaptación corrió por cuenta de las profecías apocalípticas que en ningún momento cuestionaron lo esencial: la preeminencia del único dios verdadero. El Maligno, que podía adoptar diferentes manifestaciones en función de su poder, no debería ser sino una desdichada criatura de la divinidad, desde luego de rango superior, pero en última instancia sometida a Yahweh, que terminaría por destruirlo totalmente al final de los tiempos. Entre tanto, ese ser polimorfo que representaba el Mal serviría al único dios para probar a su pueblo, aunque en la historia de su avatar existencial podría haber alcanzado cierta autonomía en su impura labor, convirtiéndose en un peligroso adversario de los designios divinos.

$\mathrm{Su}$ actitud de desacato y rebeldía sería la misma que tantas veces habían adoptado ingratamente los humanos frente a su creador, y su origen podía radicar en una o varias faltas catalogadas como impías. Ambición, soberbia, envidia del creador o de su obra; cualquiera de estas imposturas podía servir para explicar cómo algunas criaturas, en su origen celestiales, habían desatado la cólera de dios y precipitado su caída de la posición de colaboradores de la divinidad a fuerzas que sólo procuraban el mal. Este relato, que no vulneraba la esencia del monoteísmo, introducía coherencia y sentido tanto a la desgraciada historia de Israel como esperanza en un desenlace próximo en el que ese adversario de dios, encarnado en mil males diferentes, terminaría por ser definitivamente sometido. 


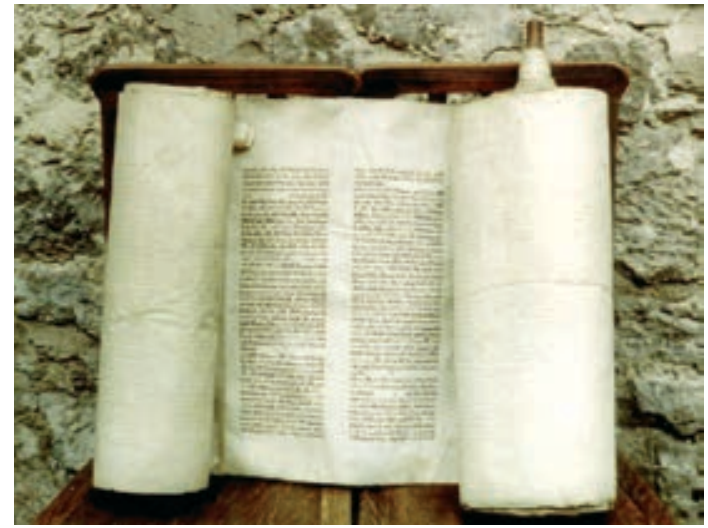

Cuando la Tora se vertió al griego, el término Satán, que en hebreo significa «fiscal» o «adversario», fue traducido por la palabra diabolos: "el que divide o separa». Así, estas dos populares denominaciones del Maligno tienen su origen en la religión judía.

Elaborada la matriz inicial, fue obra de autores apocalípticos terminar de darle forma valiéndose de material mitológico propio o foráneo, lo que produjo diferentes variantes sobre el origen, la personificación y la perversa labor de ese poderoso enemigo antagonista del dios. En La vida de Adán y Eva, un apócrifo del siglo I escrito sin duda por un judío, aparece ese «adversario» mencionado como nombre propio y sin artículo: es Satán, quien tienta con éxito a Adán y Eva para que caigan en la desobediencia, apareciéndose a Eva en forma de un hermoso ángel. Cuando Satán ha conseguido perderla, Eva llora y dice: «Malhaya contigo, diablo. ¿Por qué nos atacas sin motivo? [...] ¿Por qué nos acosas, enemigo [y nos empujas] a la muerte en la perversidad y la envidia».

Entonces Satán revela sus motivos dirigiéndose, como es natural, al varón:

«Adán, toda mi hostilidad, envidia y dolor, vienen por ti, ya que por tu culpa fui expulsado de mi gloria y separado del esplendor que tuve en medio de los ángeles; por tu culpa fui arrojado a la tierra». [...] dijo Dios: «He aquí que hice a Adán a nuestra imagen y semejanza». 


\begin{abstract}
Entonces salió Miguel, convocó a todos los ángeles y dijo: «Adorad la imagen del Señor Dios». Yo respondí: «No, yo no tengo por qué adorar a Adán. [...] No voy a adorar a uno peor que yo, puesto que soy anterior a cualquier criatura, y antes de que él fuese hecho ya había sido hecho yo. Él debe adorarme a mí, y no al revés». Al oír esto, el resto de los ángeles que estaban conmigo se negaron a adorarte. Miguel me insistió: "Adora la imagen de Dios». Y contesté: «Si se irrita conmigo pondré mi trono por encima de los astros de los cielos y seré semejante al Altísimo» (AAT, dir. Díez Macho, 1982-87: vol. II, 340-341).
\end{abstract}

Los angeloi, en griego, o emisarios divinos ya aparecen en Isaías y se les suponía un alto rango en la corte celestial. Según el autor apocalíptico algunos de estos ángeles acaudillados por uno principal, al que nombra como Satán, se habrían rebelado contra su dios guiados por la envidia a Adán y por la soberbia ante el Todopoderoso, aunque existen otras versiones como luego veremos sobre la falta cometida, por lo que la divinidad los habría castigado arrojándolos al vacío. En el relato queda claro que el Mal se encarna en una entidad particularizada que trabaja contra el hombre y contra Dios y cuyo poder es casi tan grande como el de éste. Para el pueblo escogido se despejaban muchas dudas sobre la inescrutable voluntad divina ya que Satán venía a explicarla, a la par que servía para comprender también, por qué el Mal prosperaba en el mundo.

La historia se repite en otros apócrifos, ya hemos hablado del Libro de los Jubileos en el que el Adversario, o sea Satán, adquiere el nombre de Mastema y personifica ese lado oscuro y terrible de Yahweh en algunos pasajes bíblicos. En otras obras del mismo género el Mal adopta nombres diferentes, así en Los Testamentos de los Doce Patriarcas, en el Testamento de los judíos o en el Testamento de Isaías se le denomina como Belial. Pero el apelativo de Satán tendrá una particular fortuna a la hora de nominar ese poder maligno, aunque todos los demás también servirán para designar el mismo concepto.

Poco a poco su naturaleza se irá dibujando como una potencia asociada al pecado y servida por los espíritus de la ira, el odio y la mentira. Se le verá como el señor de la guerra, del derramamiento de sangre, del exilio, la muerte, el pánico y la destrucción. 
Su principal cometido consistirá en tentar a la humanidad y bajo su imperio servirán los inicuos. Pero al final de los tiempos, el Mesías, el enviado del Señor, liberará a la humanidad del cautiverio del Mal.

Realmente la historia de Satán no es una historia de degradación y decadencia como pudiera parecer a simple vista, sino que por el contrario refleja el brillante ascenso de una figura oscura y subalterna, de un simple funcionario de la corte celestial encargado de las tareas más desagradables, a la de un personaje que ve ennoblecidos sus orígenes y que llega a tener casi tanto poder como su creador, aunque su trágico final esté escrito de antemano. El Mal —en un humano y legítimo deseo - terminará desapareciendo, pero mientras se aguarda a ese final anunciado, su imperio podrá rivalizar con el de la divinidad. Ese dualismo de origen mazdeísta en el seno de una religión fundamentalmente monoteísta lo acabarán de desarrollar algunas comunidades religiosas como las del Qumran.

En los escritos de esta secta, recuperados a través de los famosos Rollos del Mar Muerto, ${ }^{9}$ nos encontramos con una cuidadosa elaboración en la que el enfrentamiento moral entre el Bien y el Mal se encarna en el hombre mismo, devolviéndole así, aparentemente, la responsabilidad de sus actos. Por eso los justos seguirán los dictados del Bien mientras que los injustos se convertirán en siervos del Mal: «En mano del príncipe de las luces está el dominio sobre todos los hijos de la justicia, ellos marchan por el camino de la luz. Y en mano del Ángel de las tinieblas está todo el dominio sobre los hijos de la falsedad; ellos marchan por caminos de tinieblas. A causa del Ángel de las tinieblas se extravían todos los hijos de la justicia...", nos dice un escrito del Qumran, conocido como La Regla de la Comunidad (1QS, III).

Sin embargo, los dos principios no están completamente divorciados ni son simétricos como ocurría en la religión iraní, y se impo-

9 Los Rollos del Mar Muerto son una serie de manuscritos guardados en vasijas de barro y hallados casualmente en 1947 por un pastor beduino en unas grutas próximas a Khibert Qumran. Están escritos en hebreo o arameo y recogen textos elaborados por una comunidad de vida de inspiración apocalíptica que se regía por medio de una Regla escrita. Su datación los sitúa en el siglo I a. n. e. 
ne, en buena lógica monoteísta, la preeminencia del dios sobre su criatura maléfica, porque «del Dios del conocimiento viene todo lo que es y será». Así, aunque sea sólo por permisividad, Satán, a pesar de aparecer como un rebelde cosmogónico, sigue trabajando por cuenta ajena para su Señor.

\section{Pondré enemistad entre ti y la mujer...}

En una sociedad patriarcal como la judía, entregada al culto monoteísta de un dios todopoderoso, invisible y masculino, pudiera parecer que no quedaba resquicio para atribuir a la mujer o a lo femenino ninguna función ni para procurar el Bien ni para engendrar el Mal y, sin embargo, no es así.

Ya hemos mencionado la pervivencia de esa faceta femenina de la divinidad en el culto y posteriormente en los mitos cabalísticos, pero más allá de estos vestigios y reinterpretaciones populares sobre la androginia o la hierogamia del dios con su pueblo, la mujer juega un destacado papel en la arquitectura de las creencias judías, convirtiéndose en piedra angular para poder entender por qué el Mal aqueja a los humanos y, tal vez lo que sea más importante para la evolución del pensamiento occidental, frente a qué deben estar prevenidos para ser menos vulnerables a él.

Es cierto que la mujer apenas tiene relevancia en las prácticas religiosas y en el culto, quedando reducida a ser una mera espectadora de segundo rango en las ceremonias y en los ritos. No obstante, la encontramos a ella o a lo femenino manifestándose desde las creencias populares más simples y folclóricas hasta las teorías teológicas más complejas. Veamos a continuación algunas de estas manifestaciones menos trascendentes en las que se dejan sentir las influencias del medio cananeo en las creencias judías.

El pueblo hebreo, como otros pueblos semitas, también creía que la mujer, a diferencia del hombre al que le estaban reservadas experiencias religiosas trascendentes, gozaba de una particular 
predisposición para entrar en contacto con lo mistérico de modo mucho más sencillo y natural. De hecho en el Antiguo Testamento aparecen al menos cinco mujeres: Débora, María, Julda, Noadias y Maher, ${ }^{10}$ a las que se les reconoce la capacidad de profetizar, lo que para una sociedad y una religión como la judía no resulta nada despreciable. Sin duda el reconocimiento de esa misteriosa capacidad se apoyaba en los numerosos ejemplos que le ofrecía el entorno a través de las sacerdotisas y adivinas de sus vecinos. Con todo, desde época temprana, se censurará cualquiera de estas prácticas que no estén avaladas por Yahweh por considerarlas mágicas, ya que la magia sólo podía ser entendida como una violación del poder absoluto de Dios.

Esta condena sin paliativos aparece en el Éxodo $(22,17)$ como un mandato divino y allí podemos leer: «A la hechicera no la dejarás con vida». En el Levítico $(20,6)$, teniendo en cuenta lo que podía ser un proceder habitual en el medio cananeo, se prohibía explícitamente consultar a cualquier clase de magos o adivinos, so pena de ser exterminado por el mismo Yahweh. No obstante, para asegurarse el castigo de los infractores, unos versículos más abajo (Lv. 20, 27), se estipula que: «El hombre o la mujer en que haya espíritu de nigromante o adivino, morirá sin remedio: los lapidarán. Caerá su sangre sobre ellos» y la prohibición vuelve a aparecer en el Deuteronomio (18, 10-12).

Como puede apreciarse, en estos versículos no se alude exclusivamente a la mujer, ya que el exigente monopolio del único dios tenía que asegurarse de que nadie, fuera cual fuese su sexo, pudiera entablar relaciones con lo sobrenatural a no ser que estuviera facultado o hubiera sido escogido por la divinidad. Sin embargo la primera prohibición que registra el Éxodo, y posiblemente la más antigua, se formula en femenino, y la única mención que se hace en el Antiguo Testamento a este tipo de rituales de modo claro y directo se le atribuye a una mujer, lo que viene a ratificar la creencia y el temor que los judíos tenían ante sus pretendidos dones.

10 Jue. 4, 4; Éx. 15, 20; 2 Re. 22, 15; Neh. 6, 14; Is. 8, 3. 
La llamada «bruja» de Endor, que aparece en Samuel (1, 28, 13-14), es un pasaje muy debatido ${ }^{11}$ en el que se nos cuenta cómo el rey Saúl, preocupado por el inminente ataque del ejército filisteo, consultó a una nigromante que habitaba en Endor, nombre por el que se la conoce. La mujer, tras alguna reticencia y temiendo una trampa, accedió a evocar al espíritu para que le aconsejara al rey antes de la batalla. Parece ser que entonces Saúl oyó la voz de Samuel que le anunciaba la derrota, la muerte y el futuro reino de David. El relato no especifica de dónde surgía la voz, aunque en la traducción griega de Los Setenta se designa a la maga como heggustramythos, que significa ventrílocua, lo que nos puede hacer pensar que operaba como un médium y que el espíritu invocado hablaba por su boca. En la Vulgata se la denomina simplemente como pythonissa o mulier pythonem habeos, es decir, mujer que adivina el futuro.

Lo cierto es que la magia y la adivinación se toleraban si estaban oficializadas, se practicaban de modo discreto entre las clases populares y formaban parte de la vida cotidiana de los israelitas, pese a las reiteradas prohibiciones. La misma naturaleza de su dios les hacía concebirlo como muy distante y alejado de sus problemas más cotidianos, por eso muchos judíos echaban mano de los amuletos y acudía a las invocaciones que aprendían de los pueblos vecinos para paliar esta carencia. Así las creencias oficiales consentían llevar filacterias en el brazo derecho o bien ciñendo la frente de los hombres. Estas pequeñas cintas de pergamino con un texto escrito del Éxodo (13, 1-10 ó 13, 11-16) o del Deuteronomio (6, 4-9 ó 9, 13-21) podían ser consideradas como vulgares talismanes; pero junto a éstos, que estaban permitidos, se usaban otros, como los brazaletes en forma de serpiente de los que la arqueología ha dado abundantes testimonios. También nos encontramos con los tarafims, unas estatuillas, parece ser, encargadas de proteger la morada del poseedor, bastante generalizadas, aunque no se sabe exactamente su verda-

11 Los cristianos de los primeros siglos como Agustín de Hipona y en la actualidad las iglesias protestantes, más apegadas al texto bíblico que el resto de las confesiones, no han admitido nunca que fuera el espíritu de Samuel quien se apareciera, sino que fue el demonio quien se manifestó adoptando la forma del rey ya muerto. Este tipo de conclusiones han llevado a considerar a la que era una simple adivina que realizaba discretamente su oficio como una bruja hechicera. 
dera significación y en Zacarías $(10,2)$ se les atribuye poderes oraculares. La misma tolerancia podemos apreciar respecto a la adivinación. Saúl antes de recurrir a la pitonisa de Endor había consultado a los videntes de la corte pero no habían sabido ofrecerle consejo. ${ }^{12}$

En el mundo de los espíritus menores y los seres espantosos que atemorizaban a los judíos, la femenina Lilith, que cita Isaías (34, 14), ocupa un lugar destacado. Parece ser que su origen era babilónico y que sintetizaba a una tríada de demonios: Lila, Lilitu y Ardat Lili. Los dos primeros eran una pareja macho-hembra; mientras que el tercero, adoptado por el mundo hebreo, era un demonio femenino que se dedicaba a atormentar a los seres humanos causándoles enfermedades y todo tipo de desgracias.

La literatura rabínica la describe con alas y pelos fluctuantes (Eruvim 100b, Nida 24b) y en una tablilla sumeria de terracota se nos muestra como una mujer desnuda y alada, con los cabellos rizados, adornada con collares y brazaletes y cuyos pies son garras de ave rapaz. Se yergue sobre una pareja de leones postrados en tierra y se encuentra flanqueada por dos inquietantes lechuzas.

El nombre Lilith parece derivar de la palabra hebrea lailâh, que significa «noche», ${ }^{13}$ aunque en sumerio, la palabra lil significa «aire». Enlil, por ejemplo, fue el Señor (En) del Aire (Lil). Por tanto el término sumerio lili (plural lilitu) podía simplemente hacer alusión a un «espíritu». En el primer caso su nombre evocaría el reino

12 Los adivinos judíos a los que aluden algunos escritos eran los llamados meonim que conocían el futuro mediante la interpretación de las nubes y los menaquéch que utilizaban serpientes para predecir el porvenir, siguiendo ambos el modelo caldeo. Aunque la adivinación sagrada se realizaba por medio de el efod, una vestimenta sacerdotal, cuya descripción detallada aparece en el Éxodo (28, 6-14). En ese pasaje se nos dice cómo formaban parte del traje ceremonial dos piedras de ónice talladas en forma de dado, el urim y el tummim, en cuyas caras se grababan los nombres de las doce tribus de Israel, seis en cada dado. Estas piezas engastadas en oro iban sobre los hombros del sacerdote y, posteriormente, terminaron utilizándose para predecir el futuro mediante el procedimiento de formular una pregunta y echar las suertes que, según una convención establecida, contestaban afirmativa o negativamente a lo consultado.

13 También se ha asociado este nombre al chillido del búho, ya que el nombre de estos pájaros deriva de la raíz lwly. 
de las tinieblas que asustan al hombre y que están asociadas al Mal, mientras que en el segundo haría referencia al inquietante mundo de los seres etéreos y podríamos entender que se trataba de un espectro maligno.

La información que aparece en el Talmud ${ }^{14}$ sobre Lilith es escasa, sin embargo, se puede reconstruir a partir de ella la imagen que los hebreos tenían de este espíritu femenino. En el tratado del Shabbath (151 b), el Rabí Hanina sentencia: «está prohibido a los hombres dormir solos durante la noche porque el que contradice este mandato cae víctima de Lilith». Y en el tratado de Ghittin (69 b) se llega a advertir a los varones de los males que pueden correr si hablan con mujeres de cabellos largos en lugares altos, ya que sin duda éstas son encarnaciones de Lilith que los convertirá en sus víctimas.

Lo que se puede deducir de estos pasajes es que Lilith representaba el Eros perverso y era la personificación de los peligros que entraña el atractivo femenino que, como más adelante veremos, era una pieza clave en la concepción del Mal. Su figura por un lado sugiere una desbordante sexualidad pero, por otro, se nos manifiesta como un vehículo de perdición. Su cuerpo desnudo y deseable se presenta armado de garras con las que atrapa a sus presas masculinas convirtiéndose en una imagen fascinante y a la vez peligrosa. Ella provoca, al dormir el hombre solo, las poluciones nocturnas y su evocación incita a la masturbación. A partir de esta imagen se construirá una leyenda que la convertirá en un monstruo originario enemigo también de recién nacidos y parturientas, ya que la sexualidad incontrolada se opone a la normalidad familiar y a la legítima descendencia.

14 El Talmud es un conjunto de escritos religiosos de enorme importancia en la religión judía. Está dividido en dos partes, la primera se llama Mishna (ley oral hebrea), escrita alrededor del año 200, y la Guemarah, que es un comentario a la Mishna recopilado entre los siglos III y VI. Existen dos versiones, el Talmud palestino o de Jerusalén y el Talmud babilónico. El primero de influencia helenística contiene sesenta y tres tratados de la Mishna. El segundo, considerado el más importante de estos documentos, se escribió hacia el siglo VI aun cuando sólo contiene treinta y siete tratados o comentarios a la Mishna.

En este documento se reglamentan los ritos, oraciones, diezmos, ofrendas, fiestas y relaciones conyugales, principios morales, discusiones eruditas y tiene sus propios métodos de razonamiento y argumentación. 
Los textos extrabíblicos más antiguos que asocian a Lilith con el Génesis son los Rollos del Mar Muerto, en los que la encontramos mencionada en plural, lo que nos permite deducir que en su origen era la manifestación de un tipo de espíritu maligno sin más: «Y yo, el Instructor, proclamo la majestad de su resplandor a fin de asustar y aterrorizar a todos los espíritus de los ángeles destructores y los espíritus bastardos, demonios, Liliths, búhos y chacales y los que golpean de improviso para desviar al espíritu de conocimiento...» (4Q510, 1-2).

Las investigaciones arqueológicas llevadas a cabo por la Universidad de Pennsylvania en lo que fue la ciudad de Nippur, al sudeste de Irak, descubrieron objetos de cerámica que contenían conjuros mágicos escritos en arameo para protegerse de la influencia del espíritu malvado. Estos cacharros, que datan del siglo VI a. n. e., reflejan la existencia de una colonia judía en Nippur por esas fechas y, según Patai (1988), son anteriores en cien años al Talmud babilónico. En las escudillas se encuentra ratificado lo arraigado de esta creencia popular y en una de ellas aparece dibujada la imagen de Lilith desnuda, con el pelo largo y desatado, los senos delineados, sin alas, los genitales fuertemente marcados y los tobillos encadenados.

Pero la elaboración de un relato mitológico que asocie literariamente esta imagen con los orígenes del Mal es posterior y data ya de época medieval. Es en el manuscrito llamado Alfabeto de Ben Sira donde se describe ampliamente la historia de Lilith que ha dado pie al moderno mito feminista. Este texto del que existen dos versiones, una en arameo y otra en hebreo, fue redactado en un momento impreciso entre los siglos VII y $\mathrm{x}$, aunque muy posiblemente recoja una leyenda oral de época mucho más antigua. En él se basarán los cabalistas judeohispanos como Moisés de León, que en el libro El Zohar, escrito en lengua castellana a finales del siglo XIII, convierte a Lilith en la reina de los demonios.

Según el Alfabeto de Ben Sira reseñado por Patai, Lilith fue la primera esposa de Adán antes de que apareciera Eva. Aunque creada a la vez que el hombre para ser su ayudante, Adán quiso tratarla como a cualquier otro animal del Paraíso puesto bajo su tutela, 
pero Lilith se rebeló y lo hizo ante la postura que Adán quería imponerle para realizar el acto sexual. Él quería copular sobre ella pero Lilith se negó alegando que habían sido creados iguales, y que las posiciones a adoptar tenían que reflejar esa igualdad. En este punto el relato no termina de especificar por qué la desavenencia desembocó en la fuga de Lilith pero podríamos imaginar que la disputa sexual terminó en violencia. Lo cierto es que Lilith quería huir del Edén pero para conseguirlo debía burlar a su guardián. Fue entonces cuando pensó en seducir al mismo Yahweh utilizando sus encantos femeninos. Así finalmente logró que éste le revelara su nombre sagrado, Lilith lo pronunció y voló lejos del Jardín y de Adán para siempre.

La rebelde buscó refugio en una cueva en las costas del Mar Rojo, y tomó como amantes a los demonios del mundo con los que tuvo miles de diabólicos descendientes, los lilim. Por eso se la llamará más tarde Madre de los Demonios y se convertirá en esposa de Samael o de Asmodeo, el demonio lujurioso de la Biblia. Pero Adán echaba en falta a Lilith y fue a lamentarse de su abandono ante Yahweh suplicándole que la obligara a retornar. Yahweh accedió, más por despecho a que una de sus criaturas hubiera huido del Paraíso que por complacer a Adán, por lo que ordenó a tres de sus ángeles que trajeran de vuelta a tan díscola criatura. Senoy, Sansenoy y Semangelof, que así se llamaban los celestes emisarios, pronto encontraron a Lilith en su refugio y le exigieron retornar con Adán por orden de Yahweh. Ante la negativa de Lilith la amenazaron con exterminar a cien de sus hijos cada día hasta que se decidiera a obedecer, pero la mujer les contestó que incluso esa suerte era mejor que volver a la situación anterior para quedar sometida al varón. Como los ángeles cumplieron su amenaza, Lilith, desesperada y enfurecida, juró vengarse por el dolor que le estaban infligiendo y proclamó que ella también mataría a los hijos de los hombres. Fue así como se convirtió desde entonces en un peligro para los pequeños e incluso para sus padres.

Los recién nacidos estarían desde ese momento expuestos a su venganza; durante veinte días las niñas, y los niños durante ocho. También atacaría a los varones en su sueño, robándoles el semen para engendrar nuevos demonios; y las madres parturientas debían así 
mismo guardarse de su ira. Sólo ante un amuleto que llevara el nombre de los tres ángeles enemigos su maleficio se detendría.

La finalidad ideológica del relato es clara. La mala esposa que no se somete a la voluntad de su marido sólo puede esperar convertirse en un monstruo sanguinario enemigo de la descendencia legítima. Pero su libertad sexual, al optar voluntariamente por renunciar al vínculo conyugal, también la transforma en un ser atractivo, objeto de deseo para todos los hombres, sin percatarse que el sexo desordenado acarrea el Mal e incluso la muerte. El Zohar cabalístico resalta este aspecto artero y taimado de la seductora Lilith:

Ella se llena de adornos, como una abominable prostituta, y espera en las esquinas de calles y avenidas para atraer a los hombres.

Cuando un tonto se le acerca, lo abraza y lo besa, y mezcla su vino con veneno de serpiente para él. Cuando él ha bebido se desvía hacia ella, y cuando ella ve que él se ha desviado del camino de la verdad se quita todos los adornos que se había puesto por este tonto (I, $202 \mathrm{~b})$.

Estas creencias permitieron a Lilith ocupar un lugar destacado en el folclore religioso y en la tradición popular hebraica. Así cuando un niño dormía solo y reía en sueños se interpretaba que Lilith estaba presente. Para conjurar el peligro se debía depositar un cuchillo bajo su almohada o bien contar con un amuleto con los nombres de Senoy, Sansenoy y Semangelof o simplemente pintar en alguna de las paredes de la habitación: «Adán y Eva, fuera Lilith».

De este demonio, que actuaba sobre todo las noches de los viernes con luna menguante, también debían guardarse las mujeres gestantes o las que iban a contraer matrimonio, y todas las demás durante su menstruación, ya que eran vulnerables a sus actos maléficos con los que era capaz de impedir el nacimiento de los niños, causar problemas durante el parto, provocar abortos y hasta la esterilidad.

Los rincones de la casa, los arcos y los umbrales eran sitios donde se escondían los lilim, esperando la oscuridad para atacar a 
todos aquellos que no estuvieran protegidos. Estos seres terribles que chupaban la sangre de sus víctimas son un claro antecedente del vampirismo. La misma Lilith copulaba en sueños con los hombres, a modo de los súcubos medievales, y podía estrangular a los desgraciados a los que había poseído.

En la actualidad este curioso ser, producto de los miedos del patriarcado antiguo, ha cobrado una inesperada actualidad de manos del movimiento feminista que lo ha adoptado como un símbolo de rebeldía y como el arquetipo original de la lucha de la mujer. Curiosamente, mientras el mundo de los terrores infernales atraviesa por la contradictoria situación del olvido más absoluto o de la aberrante reivindicación de la cultura morbosa, Lilith ha experimentado un nuevo proceso de transformación en su larga historia convirtiéndose en espíritu positivo al servicio de la emancipación femenina.

Esta tardía redención ha rescatado a la que fue la primera mujer en el pensamiento esotérico hebreo de la situación en la que la había sumido la cultura patriarcal, para terminar siendo considerada la protofeminista de la historia, imagen mítica de libertad y rebeldía frente al varón. De su utilización como emblema mágico de esas aspiraciones tenemos muestra cercana en la obra de Carmen Alcalde Cartas a Lilith, pero el fenómeno es global. En Estados Unidos existe una revista feminista que lleva su nombre y se realiza una gira musical denominada "Lilith Fair Tour» que agrupa a muchas de las mejores cantantes del momento con la finalidad de abrirles las puertas de la música pop.

Cierto es que la Lilith mítica cumple el perfil de mujer emancipada al vivir desprejuiciadamente su sexualidad en un plano de equidad, al no aceptar las imposiciones violentas del varón, al abandonarlo a su suerte y sustraer a sus criaturas de la tutela de un padre impuesto. Es por tanto la antítesis de la madre y la esposa sumisa moldeada por el hombre, pasiva, entregada a la maternidad y al cuidado de los hijos, con enormes sacrificios. Por esto Lilith se convirtió, en el represivo y patriarcal mundo judío, en un ser monstruoso, aunque dominado por la fuerza de los hechos, de la religión y de la magia. 

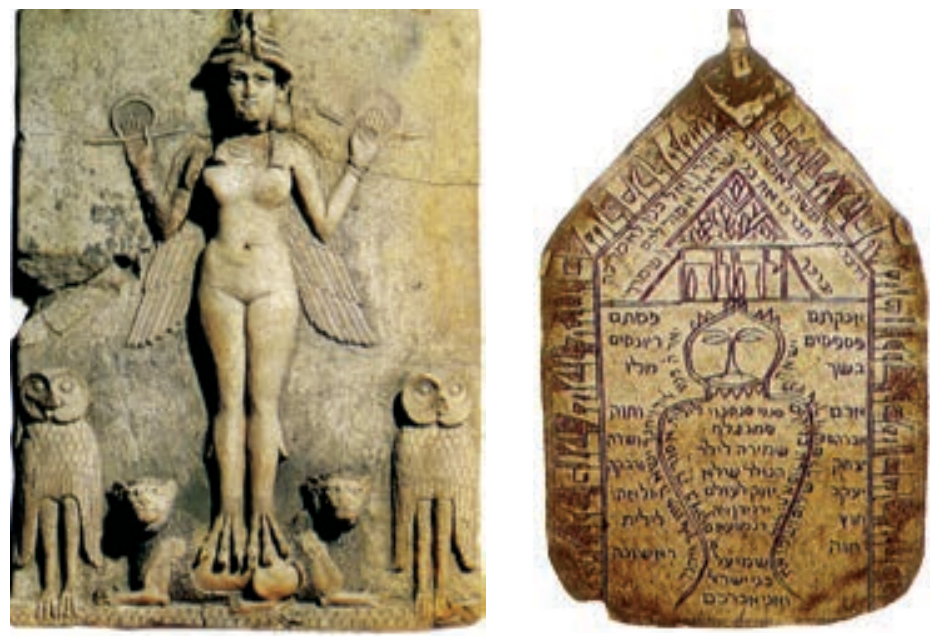

Lilith es un monstruo femenino, nacido en el Oriente Próximo y antecedente del moderno vampiro. La mitología judía la convirtió en la primera mujer de Adán, pero se rebeló ante sus deseos de dominio, por lo que fue condenada a hacer el mal. Para protegerse de ella se usaban amuletos como el que vemos a la derecha.

No podemos, sin embargo, extrapolar la figura de Lilith del momento y el medio cultural que le dio vida. Las creencias en torno a ella desde la óptica de una historia de la ideología patriarcal resultan secundarias, mientras que la imagen de su rival Eva tiene mucho más peso e influencia en la arquitectura de la misoginia sobrenatural.

El mito de Eva es una de las más claras y conocidas historias sobre cómo la mujer fue responsable de que males fundamentales, incluida la muerte, afligieran al hombre. Desgracias a las que el cristianismo sumará la idea de un «pecado original» o falta primigenia que lastrará a la humanidad desde su mismo origen. Ya hemos dicho que este tipo de relatos de factura patriarcal está presente en muchas religiones y en el caso de la judía, todo el pasaje del Génesis relativo a la creación de Adán y Eva hasta su caída no es sino una reelaboración de distintos mitos mesopotámicos, que sirvieron de base para las dos historias que configuran ese texto sagrado, ya que en él podemos leer dos versiones sobre el origen de la primera mujer. 
En la primera (Gn. 1, 27-28) se nos dice: «Creó, pues Dios al ser humano a imagen suya, a imagen de Dios le creó, macho y hembra los creó. Y bendíjolos Dios, y díjoles Dios: "Sed fecundos y multiplicaos..." La segunda versión se lee unos versículos después (Gn. 2, 18 y 25): "Dijo luego Yahweh Dios: "No es bueno que el hombre esté solo. Voy a hacerle una ayuda adecuada". Y Yahweh Dios formó del suelo todos los animales del campo... mas para el hombre no encontró una ayuda adecuada. Entonces Yahweh Dios hizo caer un profundo sueño sobre el hombre, el cual se durmió. Y le quitó una de las costillas rellenando el vacío con carne. De la costilla que Yahweh Dios había tomado del hombre formó una mujer...».

Hoy, sabemos que ambas versiones fueron redactadas en momentos distintos. El primer relato es obra de un escritor sacerdotal ( $\left(\mathrm{P}_{»)}\right)$ anónimo del siglo VI a. n. e.; mientras que el segundo sería el más antiguo y generalmente se atribuye a la fuente denominada yahvista ( «J»). Al mito, o al texto religioso, no se le debe pedir una lógica rigurosa y el Génesis no es una excepción. Salta a la vista la incongruencia de las dos historias superpuestas. Resulta contradictorio que una vez creados los primeros seres humanos, macho y hembra, la divinidad piense que no es bueno que el varón esté solo y se decida a formar a la mujer a partir de una costilla o costado de Adán. Por eso sobre estas pocas líneas se ha escrito hasta la saciedad. Se ha pretendido decir que la versión sacerdotal es menos despectiva que la yahvista (Russell, 1995) más primitiva y menos sutil respecto al origen de la mujer, sin embargo la estructura del mito responde a los mismos presupuestos. Es cierto que en la primera, hombre y mujer aparecen al unísono y en aparente pie de igualdad, pero no es menos cierto que la fuerza narrativa de la segunda se impuso al reflejar de modo más plástico la realidad ideológica y social que se pretendía describir.

De admitir la hipótesis de un doble sentido en el relato es muy posible que el más antiguo recogiera de forma más burda la realidad de un pueblo nómada y agresivo en el que la mujer sufriría todos los excesos de la opresión de género, mientras que el segundo traduciría las inquietudes de una sociedad más estructurada y de una especulación religiosa mucho más sofisticada. De ahí la extraña redacción que utiliza el autor para describir la creación del hom- 
bre y la mujer: «a imagen de Dios le creó, macho y hembra los creó», que hace pensar en un ser casi andrógino como luego interpretaría la Cábala judía. ${ }^{15}$

Independientemente de estas consideraciones podemos decir que todos los rasgos del patriarcado están presentes ya en el mismo origen de la mujer, que es creada después que el hombre, a partir de una parte del varón y pensada como una ayuda para éste. Es Adán quien le da nombre tal y como hace con los animales del Edén, y aunque el texto manifiesta que por ella el hombre abandonará a su padre y a su madre para ser una sola carne, lo que realmente quiere transmitir es que sólo así podrá contar con descendencia y ser él mismo un patriarca familiar.

Debemos tener presente a la hora de enjuiciar el sentido del relato que la creación de la mujer no es sino una parte necesaria pero no suficiente del mito, que sólo cobra sentido con la «falta» y la expulsión del Paraíso. En ese momento nodular de la historia es cuando se define de modo preciso la «naturaleza» que le tiene reservada la religión judía a la mujer.

Eva es tentada por una serpiente parlante, «el más astuto de todos los animales del campo» nos dice la Biblia. En ese ser no podemos ver una encarnación del Mal, será en época posterior cuando se produzca esa identificación. En una lectura desprejuiciada la serpiente queda reducida a un trickster que con su juego fatal precipita la desgracia sobre la pareja primigenia, pero en esa catástrofe la mediadora será realmente la mujer. Ella es la que prueba la fruta prohibida y como le resulta apetecible se la da al que el texto ya llama «su marido» que la prueba también. En ese mismo instante descubren su desnudez.

15 Según la Cábala, Adán fue creado a imagen y semejanza de Elohim (El Señor), que no sería un ser masculino o femenino, sino ambos a la vez. Así, si Dios es hombre y mujer, padre y madre, entonces Adán (término que se traduce como «humanidad») tuvo que ser hombre y mujer en uno, de otra manera hubiera sido un ser imperfecto.

Por todo esto consideran que la perfección de Adán es superior a la de los ángeles, ya que Adán es visto como un ser cósmico al que denominan Adán Kadmon, arquetipo del resto de los humanos. Pero este arquetipo sería separado por Elohim Yahweh en sus dos mitades, hombre y mujer, convirtiéndose en una criatura imperfecta. Esta imperfección finalmente le llevó a la caída (Zohar, III, 91 b). 
Yahweh les había prohibido que comieran de dos árboles que se encontraban en el centro del jardín, uno proporcionaba el discernimiento entre el Bien y el Mal, el otro la vida eterna. Adán y Eva sólo pudieron probar del primero antes de ser descubiertos por su creador. Cuando éste se dirige al hombre para preguntarle si habían violado su mandato la acusación exculpatoria de Adán resulta contundente: «La mujer que me diste por compañera me dio del árbol y comí». El mismo mecanismo, algo infantil, de remitir la culpa al otro que ha hecho de inductor es el que utiliza Eva con la serpiente.

Pero las excusas no sirven ante la indignación del padre que condena a los tres a penas que terminan por definir la naturaleza de los infractores. La serpiente se arrastrará y quedará desvinculada del linaje femenino; el hombre, por haber sido débil y «haber escuchado la voz de (la) mujer», dice Yahweh, deberá trabajar con esfuerzo la tierra hasta que a ella vuelva; y a Eva la condena a parir con dolor y a ser dominada por su marido (Gn. 3, 16). Es la consagración divina de la división sexual del trabajo y del sometimiento de la mujer. Tras esto, Yahweh hizo túnicas de piel para cubrir la desnudez de sus cuerpos y luego, temeroso de que probaran del árbol de la vida eterna y fueran tanto como él, pues ya conocían el Bien y el Mal, los expulsó del Edén.

La culpa de la mujer es manifiesta. Ella, con su inconsciencia, viola la norma y precipita que lo haga el hombre. Las motivaciones de éste no quedan claras, no parece que fuera la soberbia de ser igual a su creador, ni que hubiera premeditación en el acto. En el caso de Eva aún parece más evidente que simplemente se deja llevar por una curiosidad voluptuosa, la fruta le parecía apetecible. La indignación de Yahweh también se nos antoja más la respuesta de un padre airado porque no se ha respetado su autoridad que la de un dios enfurecido frente a un acto de rebeldía que pone en peligro su poder. El castigo no viene sino a explicar la naturaleza, trabajo-muerte, y a sancionar las formas más primitivas del sometimiento patriarcal: «Hacia tu marido irá tu penitencia, y él te dominará».

Estamos frente a una estructura mítica repetida en numerosas ocasiones. La falta no pasa de ser un descuido nacido del 
voluble carácter femenino. ${ }^{16}$ La curiosidad, la inconsciencia, la debilidad de Adán ante las insinuaciones de la mujer suponen la violación de una norma, si se quiere más o menos arbitraria, y eso precipita el castigo, que no es sino una constatación de lo evidente y la pérdida de un estado idílico nacido del deseo de los hombres.

El mito del Paraíso bíblico aparece como una variante más de una estructura sencilla y se apoya en otros relatos muy similares que el pueblo hebreo conocía por el contacto con las culturas mesopotámicas. En el mito sumerio de Dilmun se nos cuenta que el dios Enki y su mujer «la Virgen pura» eran la única pareja dormida en el mundo paradisíaco del país de Dilmun cuando todavía no existía nada más. En este lugar primordial no se había formado la vida y será precisamente la «Virgen» quien pedirá al dios que haga aparecer las aguas vivificantes antes de unirse a él en un matrimonio sagrado. Las diferencias son tantas como las similitudes, cabría destacar en este caso cómo la «Virgen» desempeña un papel inverso al de Eva al ser ella la que insta al dios a crear la vida y no precipita la muerte con su falta, como hace la hebrea.

El relato de los orígenes de Eva a partir de la costilla de Adán probablemente es también la corrupción de otro mito mesopotámico, según el cual la diosa madre Ninhursag, nombre que tomó la «Virgen» tras su matrimonio sagrado, curó la costilla del dios primordial Enki y en el proceso creó a la diosa Nintur, que significa «dama de la costilla» y también «dama que da la vida». Nintur se convirtió en la protectora de los partos, encargada de formar niños en el útero a partir de las costillas de sus madres. En el nombre de Eva — que Adán le impone y que quiere decir «madre de todo lo que está vivo»— también detectamos restos del primitivo poder de lo femenino, pero en el caso judío la mujer es degradada como causante del mal y corruptora del hombre.

16 En el Zohar la serpiente paradisíaca, convertida ya en el demonio Samael, razona patriarcalmente de la siguiente forma: «Si hablo con el hombre, éste no me escuchará, porque es difícil influir en la mente de un hombre. Por eso es preferible que hable primero con la mujer, que es de mentalidad más superficial. Sé que ella me va a escuchar, porque la mujer escucha a cualquiera» (II, 243a-244b). 
Pero más allá de las similitudes aparece un dato de difícil interpretación, nos referimos al enfrentamiento al que la divinidad condena a la mujer y la serpiente. Los cristianos, muchos siglos después, verán en este animal al mismo demonio; será en el Apocalipsis de Juan (Ap. 12, 9) donde «la antigua serpiente» se identifique con el Diablo o Satanás. Sólo a partir de esa asimilación podrá entenderse el pasaje como una profecía en la que la Virgen termina por vencer al Mal, al ser ella la mediadora privilegiada entre el pecado de los hombres y su salvación. Pero cuando fue escrita la historia, y para el pueblo judío, nada de esto tenía sentido, por eso hemos de recurrir a otra explicación para que resulte inteligible.

Esa «enemistad» entre la mujer y la serpiente tiene sin duda un sentido metafórico y en el conjunto del castigo es la única pena de la que no se puede hacer una lectura directa. Morir, sufrir, trabajar son males naturales que no requieren de otra justificación que la que nos da la misma realidad, sin embargo ¿por qué la serpiente ha de ser maldita entre todas las bestias y entre todos los animales del campo?

A este reptil se le consideraba en las creencias populares un animal astuto e inteligente, aunque es cierto que era tenido por una bestia inquietante. Siguiendo la línea de razonamiento anterior, en la que veíamos la influencia de otros mitos en el Génesis, se ha querido apuntar que es el mismo animal que en el poema de Gilgamesh engaña al héroe mesopotámico y le arrebata la planta de la vida eterna, instituyendo así la muerte en el mundo. Esto serviría para explicarnos por qué es la serpiente la encargada de tentar a Eva, pero quedaría sin respuesta el interrogante de su enfrentamiento con la mujer. Parece mucho más convincente considerar, como ya hemos insinuado más arriba, que el ofidio es un trasunto de la propia Eva, o sea de la mujer misma y sobre todo de su poder vivificador. Las diosas de la fecundidad eran representadas acompañadas de serpientes. Pudiera ser que Eva, originalmente, fuese la diosa serpiente de la vida y con la maldición bíblica se la quisiera despojar de esos restos de prestigio simbólico que otras culturas le seguían rindiendo. Culturas vecinas pero sacrílegas para los judíos. 
En una concepción patriarcal del poder absoluto la representación de la fertilidad debía ser aplastada por la propia mujer para que la ejerciera en monopolio la única divinidad masculina. Ésa era la auténtica falta y ése era el verdadero castigo de la «madre de todo lo que está vivo»: la autorrenuncia de su sexo a ser lo que había sido y el sometimiento al orden del varón en la figura del esposo.

Nos queda otro aspecto que dilucidar sobre Eva y su caída. Ya hemos dicho que el «pecado» de soberbia es difícil de admitir en una historia más bien ingenua y primitiva. La culpa de la mujer era la frivolidad, y los males que había provocado parecían todos ellos naturales a la triste condición humana, por tanto su responsabilidad en la historia del Mal podía quedar minimizada. Sin embargo, en el relato se apuntan algunos indicios que permitirán a la religión judía establecer una versión más elaborada sobre la implicación femenina en los orígenes de la desgracia humana.

Llama la atención que la primera reacción de la pareja tras la falta sea darse cuenta de que están desnudos, lo que nos hace pensar en el acusado sentido del pudor que tenía el pueblo judío. De hecho, en el Levítico se utiliza la expresión «descubrir la desnudez» para hacer referencia al acto sexual, lo que ha llevado a algunos autores (Messadie, 1994: 311) a considerar que el pecado cometido por «nuestros primeros padres» fue el conocimiento carnal, tal vez inspirándose en el relato mesopotámico de Enkidu. ${ }^{17}$

17 La historia de Enkidu figura en el famoso relato de Gilgamesh, de hecho este personaje se convertirá en el gran amigo del protagonista del poema. En su origen, Enkidu es el hombre salvaje y primigenio que vive en plena armonía con la naturaleza, en medio de los animales, como si de un Adán paradisíaco se tratara. Pero Enkidu conoce el sexo gracias a una ramera, que en un prolongado abrazo de siete días le descubre los placeres del amor. Al despertar de esa ardorosa pasión, el «buen salvaje» se da cuenta de que las cosas ya no son iguales, los animales le rehuyen y él se siente distinto. En el poema es la mujer la encargada de desvelarle lo que ha ocurrido: «iTú eres (sabio), Enkidu, eres como un dios! ¿Por qué con las criaturas silvestres vagas por el llano?» (Tablilla I, V, 34-35).

El sexo le ha conferido el conocimiento al personaje apartándolo de la mera naturaleza y acercándolo a la divinidad. Pero en ningún momento la experiencia sexual se presenta como una falta ni mucho menos acarrea un castigo, por el contrario Enkidu empieza a vivir una vida más plena gracias a la mujer que, sin embargo, se nos muestra como una ramera conocedora del placer carnal, distinta a la esposa a la que le competían otros menesteres en la sociedad mesopotámica. 


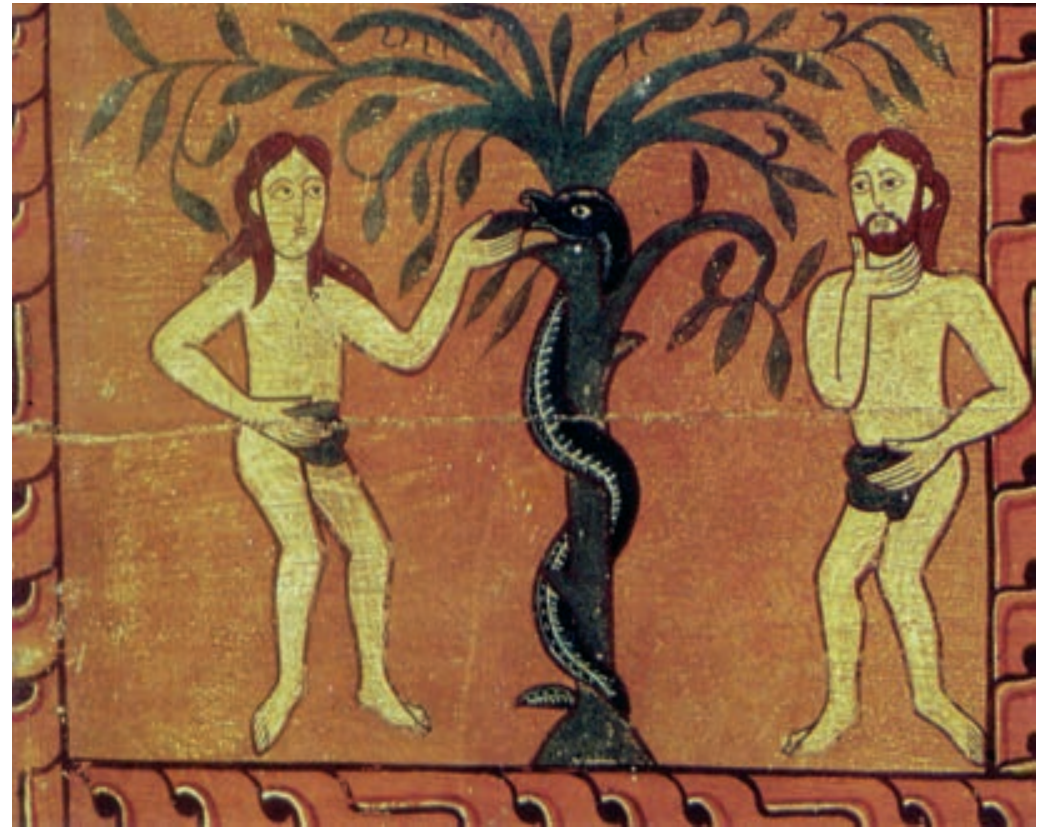

El Génesis establece una ambigua relación entre la mujer y la serpiente, sobre la que fundamenta la falta, convertida por el cristianismo en Pecado Original. De ese modo, mujer y serpiente, como personificación del Mal, quedarán vinculadas de manera muy distinta a como lo estuvieron en los antiguos cultos de fertilidad.

Pero en el núcleo de la historia paradisíaca faltan aspectos determinantes para articular de modo suficiente la hipótesis del «pecado sexual»; aunque es cierto que nos pone sobre la pista de cuál puede ser el origen del Mal y quién su responsable, tal y como lo vemos confirmado algunos versículos más adelante en un oscuro pasaje del Génesis $(6,1-7)$ en el que se puede leer:

Cuando los hombres comenzaron a multiplicarse en la tierra y les nacieron hijas, los hijos de Dios vieron que las hijas de los hombres eran hermosas y tomaron para sí como mujeres las que más les gustaron. Dijo entonces el Señor:

-Mi aliento no permanecerá por siempre en el hombre, porque es mortal; la duración de su vida será de ciento veinte años. 
Por aquel entonces había gigantes en la tierra, y también después de que los hijos de Dios se unieran a las hijas de los hombres y ellas les dieran hijos. Éstos son los famosos héroes de antaño.

$\mathrm{Al}$ ver el señor que crecía en la tierra la maldad del hombre y que todos sus proyectos tendían siempre al mal, se arrepintió de haber creado al hombre en la tierra. Y, profundamente afligido, dijo: creado...

-Borraré de la superficie de la tierra a los hombres que he

La historia, que prologa el relato del Diluvio, también se inspira en otras similares presentes en distintas mitologías y sin duda su redacción reúne dos textos escritos en épocas diferentes, uno de los cuales, al menos, data del exilio babilónico.

Las hierogamias en las que seres sobrenaturales se unen con humanos para procrear héroes o monstruos quedan recogidas desde la mitología sumeria hasta la griega y resulta difícil determinar de qué fuente bebieron los redactores bíblicos, aunque, independientemente de ese hecho, lo que nos interesa en este caso es la aparición de tres elementos fundamentales para comprender cómo fueron progresando las ideas religiosas sobre el Mal en el pensamiento judío. Estos tres elementos son: la presencia de unos seres superiores que se rebajan a sí mismos, la aparición de nuevo de la mujer como causante de la falta y, esta vez sí, el sexo como motivo de la degradación.

Los seres superiores, «los hijos de Dios», miembros de una corte celeste o ángeles, como los entendieron los persas, resultaban imprescindibles en esta teología monoteísta para justificar la presencia de fuerzas sobrenaturales distintas a la misma divinidad que pudieran influir en los hombres. Su existencia, pero sobre todo su perversión o rebeldía, permitirá la aparición de un poder enfrentado al Bien y con capacidad de arrastrar a los humanos al Mal. Los mecanismos para llegar a esta situación pueden ser diferentes en las distintas religiones y varían según el relato, aunque respetan siempre la estructura profunda del mito.

Podemos encontrarnos con que los seres sobrenaturales ofrezcan a los hombres bienes como el fuego o enseñanzas como las artes o las prácticas agrícolas sin el permiso de los dioses, desatando así su furia y el consiguiente castigo, como ocurre con el Prometeo de la mitología griega. También ellos o sus hijos podían, en un acto de 
rebeldía, enfrentarse directamente con la divinidad o las divinidades más antiguas, es la historia de los titanes o, simplemente, como se nos sugiere en los versículos del Génesis, pueden degradarse al sentirse atraídos por la materialidad encarnada en las «hijas de los hombres».

El sentido del pasaje, posiblemente intercalado en una redacción tardía, tiene como finalidad introducir y justificar el terrible castigo del Diluvio, pero va más allá. El redactor quiere darnos cuenta de la permanente inclinación del hombre al Mal y la sola naturaleza humana, obra de Dios, le parece insuficiente para explicar esta decadencia, por eso recurre a la intervención de un elemento sobrenatural distinto a la misma divinidad, en esta ocasión personificado en los «hijos de Dios». Con él consigue justificar la presencia y duración de los males en el mundo, librando, por un lado, de su responsabilidad a Yahweh, y explicando, por otro, por qué el hombre se ve constantemente seducido por la maldad en un desafío permanente y temerario a la ley impuesta por su creador.

La degradación de un aspecto de lo sobrenatural resultaba necesaria y, en una religión que se afirmaba como monoteísta, podríamos decir que imprescindible, para urdir esa trama explicativa, como ya hemos apuntado más arriba. Por eso la unión aberrante de esos «hijos de Dios» con las «hijas de los hombres» dará como resultado a unas criaturas que el texto denomina nefilim. Este término, que muchos traductores de la Biblia han trasladado al redactado moderno con la palabra «gigantes» puede traducirse realmente, y sin traicionar su etimología, como «caídos» (Porter, 1995: 32). Los nefilim o sus padres aún no encarnan el Mal e incluso los vemos desempeñando el papel de héroes, pero cuando rompen las barreras entre lo sobrenatural y lo humano alteran irreversiblemente el orden divino. Por lo que podemos intuir terminarán personificándolo y en ese proceso la mujer y el sexo resultarán fundamentales.

Si admitimos que el Mal encarnado no estaba presente en el Paraíso y que la falta cometida por Eva no permite deducir su aparición, el primer indicio de responsabilidad de la mujer en este sentido lo debemos buscar justamente en el pasaje que estamos tratan- 
do, ya que en él las «hijas de los hombres» se convierten en vehículo necesario y causa eficaz para que aparezca, aunque en el relato todavía no se haga evidente. En los inicios de ese proceso, a las mujeres se les atribuye una posición de sumisión instrumental y resulta significativo cómo se formula su participación en esa hierogamia, aludiéndolas como «hijas de los hombres».

«Cuando los hombres comenzaron a multiplicarse sobre la tierra...» es un recurso narrativo que va mucho más allá de la mera fórmula expresiva de parentesco en una sociedad patrilineal. Parece lógico que con esa estructura familiar asentada se recurriera a esa expresión, que es la que prevalece en todo el Antiguo Testamento y penetra incluso en los Evangelios. En el mismo Génesis vemos cómo Dios llama a Isaac «el hijo de Abraham» y en las sucesivas cronologías se repite la misma alocución.

Pero más allá de esa forma metafórica de nombrar el parentesco que hoy nos parece habitual, descubrimos un profundo giro en la consideración de la mujer respecto a otras culturas del entorno, al no concederle el único atributo de prestigio que era el de la procreación, convertido, a través de la palabra revelada, en un acto masculino.

Este tipo de pensamiento encajaba perfectamente con la concepción patriarcal y monoteísta de la religión judía. Con él se invertía el rol que la mujer había desempeñado y seguía desempeñando en el resto de las religiones del Oriente Próximo y el Mediterráneo como fuerza vivificadora. La mujer quedaba reducida a ser un mero eslabón en la reproducción de la vida en la que el varón y el mismo Dios se convertían en los principales protagonistas.

Así los «hijos de Dios» tuvieron hijos con las «hijas de los hombres» y a ellas sólo les restó parirlos con dolor, aunque antes de experimentar esos sufrimientos propios de su condición sedujeron a aquellos atrayéndolos por medio del sexo a su degradación. Es en el sexo en su doble vertiente reproductiva y placentera, donde la moral judía va a instituir una clara dicotomía entre el Bien y el Mal, haciendo gravitar sobre ella el peso de la «falta», y es a través del sexo cómo la mujer se va a convertir en la causa por la que el 
Mal terminará cobrando carta de naturaleza entre los hombres. No es su capacidad reproductora, que el hombre acabará por usurpar, sino su capacidad seductora la que la convertirá en fuente de perdición.

La ordenación de la actividad sexual estaba ya regulada por medio del tabú, e incluso por la ley escrita, en todas las culturas cuando Abraham salió de Ur. Esa regulación estricta, que se puede apreciar en el Levítico en el caso de la religión judía, tenía en otras sociedades unas claras funciones estructurantes de la familia, el patriarcado y la jerarquía social. Comenzando por la prohibición del incesto, como paradigma base del desarrollo cultural del que nos habla Lévi-Strauss (1949/1993), hasta la penalización del adulterio, todos los pueblos del mundo antiguo conocían reglas de comportamiento sexual. Lo verdaderamente original que aporta la religión judía a este orden de cosas es, por un lado, la separación tajante entre placer sexual y procreación y, por otro, la estigmatización moral del gozo carnal.

En las disposiciones que registra el Antiguo Testamento se puede apreciar claramente lo que estamos diciendo. Las prohibiciones en las prácticas y tipos de relación sexual perseguían lo mismo que en otras sociedades, pero en el caso de la judía eran mucho más amplias y estrictas y adquirían una valoración moral mucho más profunda que las del mero uso social, para derivar en falta contra la ley divina. Si comparamos el Código de Hammurabi (siglo XVIII a. n. e.) con el Levítico (siglo x a.n. e.?) podemos apreciar algunas de estas diferencias. En la ley babilónica se prohíbe, por supuesto, el incesto y el adulterio, al tiempo que se contempla otra serie de infracciones o regulaciones relativas al matrimonio: la dote, la responsabilidad respecto a los hijos, el divorcio y la herencia. Como reflejo de una sociedad más evolucionada, el código babilónico recoge hasta 67 disposiciones sobre el tema, que abarcan una amplia casuística, sobre las 282 que lo componen. Sin embargo en ninguna de ellas, ni siquiera aquellas que afectan a miembros del clero, son entendidas como falta moral, sino que quedan registradas como delitos o violaciones de la ley social. 
Por el contrario en el Levítico todo incumplimiento en este sentido era entendido como un acto contra Yahweh, y el castigo humano sólo venía a sancionar de modo material la condena divina. A esto hay que sumar una visión mucho más pudibunda y restrictiva de las relaciones sexuales, que no sólo pretendía preservar el patriarcado y la familia, sino coartar cualquier forma de actividad que no tuviera como finalidad la procreación. Hasta tal punto el sexo estaba orientado a la reproducción que en el Levítico $(15,16-17)$ el simple derrame seminal se consideraba como una pérdida de vitalidad y se catalogaba entre los actos impuros que maculaban al individuo. Por medio de ciertos ritos debía restablecerse la integridad y con ello, «la unión con Dios (única) fuente de vida». Como es lógico desde esta perspectiva quedaba explícitamente prohibida la masturbación y por su puesto la homosexualidad (Lv., 18, 22), que era castigada con la muerte, y a la que el relato le dedica todo un pasaje con la destrucción de Sodoma y Gomorra, ejemplo de la terrible ira divina. Siendo condenada también, como impura e infamante, cualquier práctica zoofílica (Lv., 18, 23).

En muchas de las culturas contemporáneas a la judía las prácticas sexuales no estaban connotadas moral y prejuiciosamente, por el contrario se entendían como algo natural, como un disfrute gozoso que culminaba en una fecunda regeneración de la vida. En Egipto la masturbación del dios Ra permitía explicar la aparición de Shu y Tefnut, la primera pareja, y ya hemos comentado cómo en Babilonia se practicaba la prostitución sagrada y la diosa Inanna entonaba cánticos a su vulva, a la que comparaba con un cuerno y con «el creciente de la luna nueva», mientras que el dios Enki equiparaba el coito a la verdad, y el renacimiento: «A mi hija Inanna daré la verdad! ¡Desciende a los Infiernos! ¡Asciende del mundo de los muertos! ¡El arte de copular! ¡El beso del falo!» (Husain, 2001: 77). La alusión de Enki a la felación demuestra que el sexo no se limitaba a la procreación, y en otros versos en que se menciona el dulce sabor de la vulva y la cara del dios Dumuzi entre los muslos de Inanna se alude claramente al cunilingus.

También los griegos, entre los que la desnudez del cuerpo no causaba ningún tipo de vergüenza - aunque los usos prescribieran el recato-, reivindicaban sin ningún pudor el sexo en manifestaciones 
tan ostentosas como la exaltación priápica del falo. En sus casas nos podemos encontrar con la inscripción en mosaico de la frase «H $\mathrm{H}$ KOITO $\Sigma$ (feliz coito); mientras que en la romana, como en Pompeya, nos hallamos con la representación de unos genitales masculinos acompañada de la leyenda: «Hic habitas felicitas». La cultura clásica exaltó el sexo, toleró todo tipo de contactos y sólo aquellos que atentaban contra las estructuras sociales quedaron sancionados.

Los pretendidos escándalos sexuales que sacudieron al Imperio Romano, sobre todo en su primer siglo de existencia, y a los que son tan aficionados los historiadores de la época, siempre ocultaban intrigas de naturaleza política. Cuando Augusto destierra a su hija Julia a la isla de Pandataria no lo hace sólo porque se haya acostado con decenas de hombres y violado las reglas del pudor propias de una mujer patricia, sino porque se halla involucrada en una conspiración encabezada por el hijo de Antonio. Las numerosas referencias que tenemos sobre salaces orgías entre las élites servían a los escritores para criticar al poder y a las clases altas como se desprende de lo que nos apunta Juvenal: «El juego y el adulterio no son cosas vergonzantes salvo en las casas humildes». De hecho sólo se condenaban aquellas uniones que cuestionaban la imagen tradicional del vir y de la virtus. "En cuanto a los emperadores, no eran tanto sus excesos como los actos que ultrajaban su dignidad de hombres — nos apunta Robert (1999: 209)—. Especialmente el hecho de abusar de jóvenes de nacimiento libre y también desempeñar un papel pasivo en una relación homosexual». Por lo demás cualquier práctica erótica era normalmente admitida como la obra del mismo Ovidio; y las pinturas, cerámicas y objetos que han llegado hasta nosotros, y que recatadamente siguen poblando los almacenes de los museos, nos lo demuestran.

Por el contrario, el pueblo judío fue tremendamente pudibundo y condenó cualquier actividad sexual que no estuviese directamente encaminada a la procreación. Desde la desnudez hasta la sodomía todo era censurable en una cultura que hizo del sexo una pieza clave en su alianza con Dios como pueblo escogido, al mismo tiempo que convertía el placer carnal en una de las principales causas de su debilidad y desgracia. 
El primer mandato divino de «creced y multiplicaos, llenad la tierra» (Gn. 1, 28) y las promesas hechas por Yahweh a los patriarcas de convertirlos en padres de un gran pueblo $(\mathrm{Gn} .22,17)$ van orientadas en ese sentido y responden a una lógica elemental. No podemos olvidar que las comunidades judías tenían un origen nómada y que como tales su supervivencia dependía de la reproducción de sus rebaños. Por otra parte, en el contexto político en el que se movían no pasaban de ser una pequeña nación belicosa y aguerrida a la búsqueda de una tierra que tenían que conquistar y luego defender. Su debilidad en este empeño estribaba en su número, por lo que su potencial militar y su poder terminaban por depender de sus recursos demográficos.

Se podría alegar que no fueron el único pueblo con estas características, pero sí fueron los únicos en creer que estaban embarcados en una misión asignada por la divinidad y que contaban con su singular protección frente al resto de los hombres. A diferencia de otras sociedades antiguas, sus ideas de grandeza imperialista se fundaron en creencias transcendentes y no en prácticas militares o políticas con una clara orientación posibilista. En ese aspecto fueron los primeros en desarrollar una ideología teleológica capaz de modelar sus hábitos y costumbres morales. Esas costumbres en el terreno del sexo estuvieron dirigidas a fomentar una política natalista y a abominar de prácticas sexuales de los otros.

Durante generaciones, los maestros judíos predicaron que la finalidad fundamental de la unión carnal era tener hijos. En el Talmud (Yeb. $61 \mathrm{~b}$ ) se llega a decir que «todo ayuntamiento que no produce multiplicación, no es más que prostitución» y se consideraba el celibato como una anomalía y casi como una vergüenza. La ley judía ordenaba que un hombre unido durante diez años a un matrimonio sin hijos debía divorciarse de su esposa y casarse con otra, o si no mantener a su cónyuge estéril y tomar nueva mujer para engendrar descendencia; mientras que las leyes de impureza prohibían incluso las relaciones maritales excepto en las épocas más aptas para que se produjese la concepción.

A pesar de las diferencias existentes entre los diversos grupos de judíos (los fariseos, por ejemplo, no censuraban abiertamente el 
sexo dentro de los límites del matrimonio, mientras que los esenios ${ }^{18}$ practicaban la continencia sexual), todo lo que no condujera a convertirles en un pueblo numeroso estaba prohibido o condenado y el placer parecía proscrito.

Cabe preguntarse el porqué de esta actitud tan restrictiva y la primera explicación ya está dada: los judíos querían multiplicarse siguiendo el mandato de Yahweh y querían hacerlo sin mezclarse con los gentiles, lo que suponía rechazar abiertamente cualquier tipo de promiscuidad. La segregación voluntaria como pueblo escogido está en la base de su identidad y también en el origen de su temor al intercambio sexual. Entre los judíos ortodoxos sólo la adoración de dioses paganos levantaba más indignación que el comportamiento sexual de los gentiles. Los rabinos o intérpretes de la Ley repetían machaconamente que el resto de las naciones carecían de opinión sobre la pederastia, la sodomía o el incesto, y advertían de los peligros que se corrían al mantener trato carnal con ellas. ${ }^{19}$

El profeta Malaquías atacaba furiosamente los matrimonios mixtos, y sobre todo en la diáspora, los judíos no intercambiaban mujeres con los gentiles, propiciando su propio aislamiento y violando así una norma fundamental de la convivencia intercul-

18 Era una secta religiosa judía de la que tenemos escasas referencias por los textos de la época, aunque los hallazgos arqueológicos de Qumran nos permiten saber algo más sobre ella, ya que se cree que este asentamiento comunitario en el desierto correspondía a una facción escindida del movimiento. Los esenios vivían al margen de la vida religiosa oficial que se desarrollaba en torno al Templo en Jerusalén. Se consideraban un grupo de elegidos preparados para la inminente llegada del Reino. $\mathrm{Su}$ vida era comunitaria, entregada al trabajo y a lectura de los textos sagrados, bajo una rígida jerarquía a la cabeza de la cual se encontraba el Maestro de la Justicia, e imbuida de una meticulosa disciplina ritual.

19 Mary Douglas (cit. en Crossan, 1996: 95) sostiene una curiosa teoría al respecto: «Cuando un rito pone de manifiesto algún tipo de inquietud por los orificios del cuerpo, el equivalente sociológico de esta inquietud supone el afán exagerado por proteger la unidad política y cultural de una minoría. Los israelitas fueron siempre a lo largo de su historia una minoría sometida a fuertes presiones... Los peligros que pudieran amenazar las líneas divisorias de su cuerpo político se reflejarían perfectamente en su preocupación por la integridad, unidad, y pureza de su cuerpo físico». En el siglo I a. n. e. ese sentimiento se debió de agudizar bajo la presión imperialista romana, acrecentando la sensación de desasosiego ante el placer carnal con el que se deleitaban los invasores. 
tural. Esta actitud provocó un similar desprecio por las costumbres sexuales judías. Los gentiles criticaban como bárbaras y excéntricas prácticas como la circuncisión o la misma poligamia, como podemos apreciar en la explicaciones que da el historiador judío Flavio Josefo al tratar de justificar ante sus lectores romanos las diez esposas del rey Herodes el Grande: «Entre nosotros es costumbre tener varias esposas a la vez» (Antigüedades de los judios 17, 2,15).

Precisamente uno de estos ritos, la circuncisión, era capital en el conjunto de sus creencias ya que se consideraba uno de los requisitos fundamentales en los que se basaba su alianza con Yahweh. «Circuncidaréis la carne de vuestro prepucio y ésa será la señal de mi alianza con vosotros» (Gn. 17, 12). La circuncisión se detecta entre numerosos pueblos primitivos de África, América y Australia pero no entre los indoeuropeos y los mongoles aunque, en la mayoría de los casos es concebida como un rito de iniciación del adolescente, que pasa así a formar parte de la sociedad de los adultos. Reviste la ceremonia una gran importancia y constituye una prueba del valor y resistencia del iniciado. En la antigüedad los egipcios la practicaban también y es muy probable que éste fuera el origen del rito entre los israelitas, que instituyeron que todos los niños varones al octavo día de su nacimiento debían ser circuncidados, perdiendo así el carácter de ceremonia iniciática y adquiriendo otro significado.

En este sentido, la naturaleza de la circuncisión en el caso judío puede interpretarse como una ofrenda pars pro toto por la que el hombre ofrecería a su dios una parte de donde reside la vida como símbolo de su especial vinculación con aquél, que es su única fuente. Lo significativo de aceptar esta hipótesis es que para la patriarcal cultura judía el sexo sobre el que gravitaría la fertilidad sería el masculino, relegando a la mujer a un segundo plano en la responsabilidad de engrandecer al pueblo escogido. Ellos consideraban esta ofrenda como un acto de vasallaje hacia su Señor y aunque la práctica era individual, en su significado profundo se veía implicada toda la comunidad. La naturaleza sexual del precepto fomentaba la segregación con los gentiles como muy acertadamente apreció Tácito (Historias, V), que llegó a afirmar que los judíos 
habían instituido este rito "para ser conocidos por esta diversidad» y así mantenerse distantes de las mujeres extranjeras.

La circuncisión operaba como una considerable barrera genética, porque en la medida en que se mantenía en vigor esa diferencia cultural y religiosa con los pueblos del entorno, hacía poco probables los matrimonios exógamos y muy difíciles las relaciones sexuales esporádicas. De este modo contribuía poderosamente a mantener separados a los israelitas de los demás pueblos, justo en la circunstancia en que la mezcla adquiere carácter irreversible, en el acto de engendrar.

Todo esto ayuda a entender las prevenciones y prohibiciones que regían la vida sexual de los judíos y nos permite explicar la precaución con la que afrontaban el sexo, aunque no arroja luz sobre por qué llegaron a cuestionar su aspecto placentero; para ello deberemos ahondar en una moral religiosa y teleológica que devino en frustración colectiva configurando el carácter de toda una comunidad. Hasta ahora hemos visto cómo el sexo era entendido desde una óptica funcional tendente a la reproducción, a lo que debemos sumar la tensión colectiva ante la promesa reiteradamente incumplida por el único dios verdadero que no terminaba de colocar a Israel sobre el resto de las naciones de la Tierra.

La cultura judía era la cultura de las expectativas largamente defraudadas, y el sentir de Israel se podía resumir en el Salmo 22 «iDios mío, ¿por qué me has abandonado?!». Con el transcurso del tiempo, Yahweh no sólo no había satisfecho sus anhelos como pueblo, sino que había consentido que los judíos fueran invadidos y humillados constantemente. Es cierto que el relato de Job indicaba cómo se debían soportar resignadamente todas las calamidades con las que la divinidad quisiera probarles, sin perder la fe en la sagrada promesa. También era cierto que el Mesías que iba a salvarles había sido anunciado por los profetas, pero esto no impedía que en el día a día los judíos sintieran, de un modo mucho más acuciante que otros pueblos también sojuzgados, su triste condición. La firmeza en sus convicciones aún contribuía a vivir más angustiosamente esa contradicción. Aceptar los designios divinos sin dudar ni tambalearse en su fe les llevaba a cuestionar su propia 
integridad en la observancia de la Ley. Es aquí donde debemos buscar la explicación del nacimiento de tantas sectas distintas que interpretaban la verdad revelada al tiempo que introducían un mayor desconcierto en el conjunto de las gentes sencillas.

En medio de este sentir colectivo se fueron abriendo paso con fuerza dos ideas. Una, señalada más arriba, apelaba a la existencia de un ser superior maligno y enfrentado a Yahweh que continuamente tentaba al pueblo. La otra, en íntima relación con ésta, era la creencia en una culpa colectiva como única explicación posible de la postración de Israel.

La idea de culpa así entendida era extraña al resto de las religiones del área. La manera de relacionarse con la divinidad descansaba en las demás culturas politeístas en la imprecación propiciatoria o exculpatoria en el caso de una falta cometida. La primera basada en el «jDo, ut des!» (¡Dame para que te dé!) concebía el ritual, la ofrenda, la oración o la ceremonia como una manera de regalar al dios para ganarse sus favores, en una gama de supuestos tremendamente diversa que podía abarcar desde el deseo personal hasta los propósitos políticos del Estado, pasando por las necesidades colectivas. La segunda partía de admitir que las faltas cometidas por los hombres desagradaban a las divinidades fueran aquellas individuales o colectivas. En esos casos era necesario aplacar su furia con rituales especiales que podían llegar al sacrificio humano según las épocas y lugares.

En este sentido todas las religiones conocían el concepto de falta cometida voluntaria o involuntariamente por los creyentes. Estas faltas contra el orden natural o la ley divina solían ser rituales, acarreaban castigos y servían para explicar los males coyunturales, pero en todos los casos respondían a realidades puntuales y en ningún supuesto tenían un carácter atemporal o duradero.

Los judíos frente a la idea de falta, que también conocían, desarrollaron con el tiempo la de culpa y prepararon el terreno para la de pecado original que introducirán los cristianos como estigma originario de la especie. La culpa es ante todo un sentimiento y como tal hay que entenderlo. Su naturaleza es difusa y se puede concre- 
tar en una o varias faltas pero va más allá de ese concepto. No nace de un desacato al poder divino que desencadena una reacción, ni de la violación de los tabúes. No se trata del incumplimiento de un uso, un mandamiento o una ley, no procede de ninguna parte. No tiene que ver, al menos en su gestación, ni con la piedad ni con las debilidades humanas. Lo que provoca la culpa está tan profundamente escondido que su naturaleza queda oculta; sólo Dios lo conoce (Sal. $69,6 ; 90,7)$ y sin embargo el ser humano es culpable sin llegar a entender qué ha hecho para serlo.

La culpa atormenta a los humanos que sienten el abandono de Dios, el más profundo desamparo y un temor vertiginoso. La culpa pesa sobre el individuo o el colectivo provocando cuando menos desasosiego y minando la autoestima del que la sufre. La culpa puede traducirse en pesadumbre o remordimiento y es difícil expiarla porque el acto reparador parece insuficiente, no ante la magnitud de los hechos, sino ante la propia naturaleza ambigua y subjetiva de la culpa. La falta se puede conjurar, la culpa no. Frente a ella no basta con el arrepentimiento. Por eso es difícil librarse de la culpa aunque se ritualice el perdón, porque su fundamento no es la trasgresión sino la oposición entre la realidad y el deseo que genera frustración; y ese sentimiento de culpa suele provocar el autocastigo, el desequilibrio e incluso la inmolación.

La cultura judía en vísperas de la aparición de Jesús, con todos sus matices y diversidades, era una cultura culpable. No centraba la culpa en ninguna falta en concreto pero ésta se hacía evidente en el incumplimiento de la promesa divina, de ahí que la multitud de profetas que poblaban las tierras de Palestina llamaran a la expiación y el arrepentimiento individual y colectivo, proclamando que cualquier sacrificio reparador era poco para obtener el perdón.

Ese sentimiento inconcreto llegó a impregnar la mentalidad y la vida de los judíos de tal forma que cualquier placer les podía llegar a parecer afrentoso a los ojos de Yahweh, aumentando así su culpa y alimentando aún más su desasosiego. Y de todos los placeres —que sin embargo seguían disfrutando—, el del sexo era el más deleznable. Quedaba muy atrás el erotismo sensual del Cantar de los Cantares que los judíos cultivaron en sus momentos de gloria y 
esplendor. ${ }^{20}$ En ese disfrute, concebido como falta, la mujer se convertía en el instrumento de la lujuria y de ella se había valido el Mal para encarnarse en el mundo.

Esta idea en principio dubitativa, que responsabilizaba a la mujer directamente en la materialización de Satán, se fue abriendo paso hasta afirmarse de modo contundente en el período apocalíptico. De modo contradictorio se admitía que la mujer contribuía a fortalecer al pueblo escogido, los hijos que nacían de ella eran judíos, pero también se la veía como la principal causante de que el Mal retrasase el triunfo esperado. El sexo no podía ser concebido sólo como fuente de vida, ya que era también causa de pecado, y como culpables que eran no podían admitir que fuera fuente de placer como lo consideraban los abominables paganos. La mujer había traído la desgracia a Israel, no por la inconsciente frivolidad de Eva al no cumplir la norma impuesta, sino al haber prestado su cuerpo fecundo para engendrar el Mal.

Una de las primeras y más influyentes narraciones apocalípticas que recoge esta idea es el Primer Libro de Henoc. Según Henoc, que se apoya en el pasaje del Génesis que antes hemos comentado, «los ángeles, los hijos del cielo, vieron y desearon» a las hijas de los hombres. Estos ángeles tenían un jefe llamado Semyaza que alimentó entre ellos su concupiscencia por las mujeres mortales. Estos seres, no de naturaleza divina pero sí sobrenatural, descendieron del cielo y tomaron esposas humanas a las que enseñaron las artes de la magia y la agricultura. Otro de ellos, llamado Azazel, casi igual en rango a Semyaza, adiestró a los hombres en la fabricación de armas que les condujeron a la violencia y a las mujeres les desveló los secretos del adorno para que con ellos pudieran tentar a los varones incitando su lujuria.

20 Este libro amoroso, que la tradición atribuye al mismo rey Salomón y del que la crítica actual no acierta a precisar su fecha de redacción, fue objeto de polémica en el siglo I cuando un sector del judaísmo quiso expurgarlo del conjunto de libros sagrados. Si permaneció como tal fue porque se impuso la tradición, aunque hubo autoridades como Rabí Aqiba que prohibieron su lectura. Esto nos da idea de cómo había cambiado la vivencia del sexo en la mentalidad judía en vísperas de nuestra era. El Cantar de los Cantares fue acogido entre los libros cristianos porque se hizo de él una lectura alegórica, poco verosímil, en la que el amado era Cristo y la amada su Iglesia. 
De tales uniones y enseñanzas no podía sino salir el Mal. Los hijos de las mujeres y los ángeles fueron gigantes que se volvieron contra los hombres llegando incluso a caer en la antropofagia. Entonces la humanidad desesperada dirigió sus súplicas hacia Dios como único remedio a tanta desgracia. Yahweh, misericordioso, envió a los ángeles justicieros para que restauraran el orden. En el relato, el protector arcángel Rafael ataca al mismo Azazel y lo despeña a los abismos tenebrosos por una grieta abierta en el desierto; mientras que sus otros secuaces son arrojados a los profundos valles de la tierra donde quedan condenados a permanecer allí hasta el día del juicio.

El Libro de Henoc atribuye el pecado a la lujuria, personifica el Mal en seres sobrenaturales de extraordinario poder y convierte a la mujer en instrumento eficaz de la desgracia humana. Pero el autor o mejor dicho los diferentes autores que a lo largo de siglo y medio elaboraron este mito se muestran prudentes con la tradición y con la Ley; por eso en la redacción que ha llegado hasta nosotros se afirma que «el pecado no ha sido enviado sobre la tierra, sino que el hombre mismo lo ha creado», lo que nos indica cómo en el período apocalíptico la formulación sobre el origen del Mal era aún muy vacilante.

Mucho más contundente se muestra el Libro de los Jubileos que nos cuenta cómo en tiempos de Jared, quinientos años después de la creación, algunos ángeles descendieron a la tierra. En este caso su presencia no estaba animada por el deseo carnal, sino que sólo pretendían instruir a los hombres para que aprendieran a obrar rectamente. Pero después de su llegada al mundo caen presas de la lujuria por las hijas de los hombres, lo que acarrea su corrupción. Aquí, la formulación es más clara: la bondad sobrenatural cede al pecado de la carne ante la incitación de la mujer y es en su atractivo sexual donde radica la caída.

Los jefes de estos ángeles perdidos por la mujer son Belial y Mastema; y sus hijos son también gigantes que destruyen e incitan al Mal. De nuevo el Señor castiga a estas desgraciadas criaturas haciéndoles batallar entre sí hasta su completa desaparición, mientras que sus padres son encadenados en las profundidades de la tierra. No obstante, una décima parte de los espíritus de los gigantes muertos permanecerán en el mundo con el consentimiento de 
Yahweh, y bajo las órdenes de Satán, para seguir haciendo el mal $\mathrm{y}$ tentando a la humanidad a pecar.

Será en el Testamento de Rubén en el que se termine de dar forma definitiva al mito y se introduzcan detalles que reciclará la brujería medieval. En este escrito seudoepigráfico se nos cuenta cómo fueron las mujeres, siguiendo los pasos de Eva, las que sedujeron a los ángeles guardianes con maquillajes y peinados. Cualquier tipo de ambigüedad desaparece en este caso y el peso del pecado se carga sobre la mujer, que poseerá la capacidad de perder a los hombres como perdió a los ángeles guardianes.

Lo novedoso es cómo resuelve el relato la encarnación maléfica. $\mathrm{El}$ autor, más sofisticado que los de versiones anteriores, se plantea el problema de cómo los ángeles siendo seres espirituales y por tanto inmateriales pueden engendrar hijos directamente en un cuerpo mortal. La solución que propone guarda relación con la posesión demoníaca que tanta repercusión tendrá en los siglos posteriores. Para Rubén, los espíritus maléficos se presentan a las mujeres mientras éstas tienen trato carnal con sus maridos. Este planteamiento que podría resultar exculpatorio se retuerce para aclarar al lector que son las mujeres las que sienten lujuria por los guardianes, consiguiendo así concebir formas ajenas a la simiente de los hombres. La brujería medieval retomará este argumento para dar origen al mito de los íncubos. La bruja invocará al Maligno y se entregará con él a todos los excesos mientras hace el amor con un humano.

En el Testamento de Rubén, todos los elementos se han hecho presentes: mujer, sexo y encarnación del Mal están ya perfectamente elaborados y trabados y se llega a afirmar: «si la lujuria no se apodera de vuestra mente ni siquiera Beliar os vencerá» (AAT, vol. v, 33). La misma fórmula nos encontramos en el Testamento de Simeón en el que se advierte a los hombres: «Guardaos de la fornicación, porque ella es la madre de todos los males, aparta de Dios y acerca a Beliar» (AAT, vol. v, 40).

Por eso cuando surjan en el siglo II a. n. e. las comunidades esenias en el medio judío, su prevención misógina frente a la mujer como causante de las desgracias que atormentan al pueblo escogido 
no será sino una manifestación, si se quiere extrema, de una representación social perfectamente asentada en la cultura de Israel.

Para los esenios, como para Rubén, la mujer es la aliada de ese poderoso enemigo de Dios y del hombre, que se ha ido perfilando en el pensamiento religioso judío y que ya entonces recibe diferentes nombres: Mastema, Beliar, Azazel o Satán. Sabemos que los esenios eran hostiles al matrimonio, y consideraban como una de las mayores virtudes la castidad (Antigüedades de los Judios 18, 1, 5). Estos ascetas impacientes con la llegada del Mesías y con los que, según algunos autores, tuvo contactos Jesús, no se recataban en predicar contra la «mujer demoníaca». Inspirándose en el Eclesiastés y en los Proverbios escribían en un texto de los famosos Rollos del Mar Muerto:

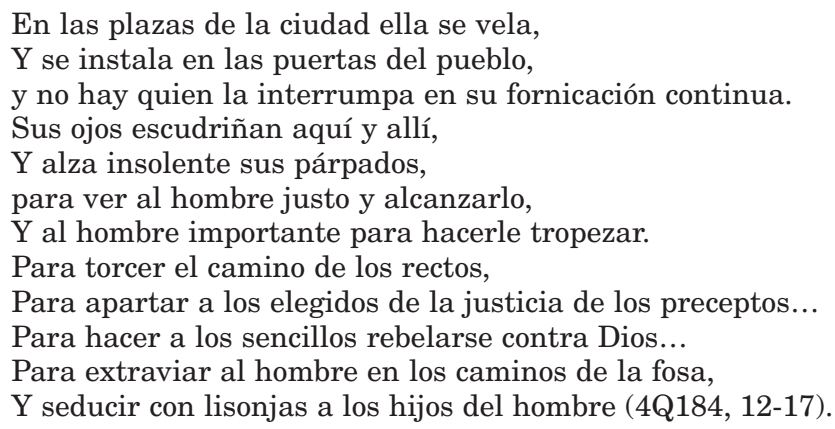

En el momento de la aparición del cristianismo la figura del Maligno y la condena sobre el sexo y la mujer están perfectamente asentadas. Por supuesto el Satán, el adversario de Dios, era masculino pero sólo a través de lo femenino había llegado a atormentarnos y lo había logrado por medio del sexo, uno de los valores más apreciados de lo femenino en las culturas del mundo antiguo. Estigmatizándolo daban una vuelta de tuerca más en la opresión patriarcal al reducir el papel de la mujer a una sola función que ni siquiera era la maternidad, sino la de soporte biológico para que los hombres pudieran multiplicarse y hacer así grande a Israel. Sólo a través de la encarnación en mujer virgen de un dios vivo que viniera a redimirnos de la culpa vieron los cristianos, secta escindida del judaísmo, la posible salvación, la rehabilitación parcial de la mujer y la derrota definitiva del Mal. 


\section{VII \\ LA PUERTA DE SATANÁS}

Los cristianos en sus orígenes no fueron sino una secta judía seguidora de un «nabi» o profeta de origen galileo ejecutado por los romanos, bajo el reinado de Tiberio, por la naturaleza sediciosa de sus prédicas. Será a lo largo del primer siglo de su existencia como grupo cuando se definirán y asentarán las bases fundamentales de lo que hoy entendemos por religión cristiana y en su elaboración desempeñará un papel fundamental Saulo de Tarso. Su condición de judío, su formación helenística y su ciudadanía romana le permitieron reorientar a ese grupúsculo mesiánico hacia una religión de salvación con proyección universal.

El proceso de nacimiento del cristianismo se desarrollará en medio de fricciones entre los primitivos seguidores de Jesús, gentes sencillas salidas del medio popular, y posteriores incorporaciones, como la del mismo Saulo/Pablo, procedentes del mundo urbano y helenizado, más sofisticado, de la diáspora. El momento culminante de este enfrentamiento, del que sólo poseemos una información escasa y sesgada, se produjo en el llamado «Concilio» de Jerusalén. En este crucial encuentro para el futuro de la nueva religión Pablo y sus partidarios lograron imponer sus tesis a Simón Pedro, según se desprende de la Carta a los Gálatas, y a Santiago, hermano de Jesús y dirigente de la comunidad de Jerusalén (Hch. 15, 1-29), levantando así acta de nacimiento del cristianismo, como religión distinta a la judía, de la que había surgido.

Si hemos de creer el relato bíblico, las diferencias se saldaron con un acuerdo por el que los primeros discípulos aceptaban abrir sus creencias a la gentilidad y renunciaban a imponer a los nuevos adeptos muchos de los preceptos mosaicos de los que ellos eran fie- 
les observantes, como debemos suponer lo había sido el mismo Jesús. No obstante, los seguidores de la «primera hora» lograron que se respetaran algunos principios como abstenerse de consumir alimentos consagrados a los ídolos, respetar la prohibición sobre ingestión de carne que no hubiera sido desangrada y, curiosamente, no practicar la fornicación, que diferentes versiones traducen por: matrimonios ilegales, impureza o inmoralidad sexual, lo que nos indica cómo el cristianismo naciente asumió desde sus albores mismos la restrictiva moral sexual profesada por el judaísmo.

Sin embargo, este pacto permitirá la estructuración y difusión de las nuevas ideas. En primer lugar supondrá la apertura del «evangelio» cristiano, del mensaje de la recién nacida doctrina, a los gentiles, convirtiéndose así en una religión universal y sustrayéndose, en cuanto a sus fines, al medio judío. Los extranjeros ignorantes de la ley de Moisés, desde aquel momento, se convertían también en coherederos del pueblo escogido por Yahweh.

Como conclusión lógica de esta premisa paulina numerosos ritos hebreos, como la circuncisión, que obstaculizaban su difusión entre los extranjeros debían ser abandonados. Las leyes judías serían sustituidas por las enseñanzas de Jesús/Cristo, fundando así una nueva alianza entre Dios y todos los hombres. La finalidad de este contrato divino con la humanidad no podía ya basarse en el mesianismo entendido como la esperanza nacionalista del pueblo de Israel, sino que será sustituida, por influencia de los ritos mistéricos, por un mensaje de redención que prometía la salvación en la otra vida, en la que el alma de los adeptos gozaría de la plenitud.

Esta promesa descansaba en la figura de un héroe cultual, Jesús, que poco tenía que ver con el «nabi» judío. El Jesús de Pablo era una encarnación del Espíritu de Dios. Un Cristo o Ungido, venido a la tierra para dar origen a una nueva humanidad. Ese héroe cultual se presentaba —entonces todavía metafóricamente- como el Hijo de Dios, como el Señor que llegaba para sustituir al Mesías en el que habían creído sus discípulos. Ese nuevo Mesías cristiano se habría encarnado no para conducir al pueblo elegido a la victoria, sino para cargar con los pecados de los hombres y redimirlos con su 
propio sacrificio al morir en la cruz. A su ejemplo de sufrimiento debían unirse los redimidos por medio del amor para obtener la salvación.

Sobre este sustrato básico de creencias se impondrán así mismo algunos ritos. Por influencia paulina, los primitivos cristianos comenzaron a consagrar sencillas ceremonias de las cuales la primera fue de iniciación, concebida como bautismo. Relacionada con la idea de purificación del pecado, el agua bautismal lavaba al neófito y lo integraba en la iglesia o comunidad de fieles. Pero más importante que la purificación era el sacrificio imitativo. Por eso los cristianos, cuando se reunían en casa de alguno de los hermanos, «partían el pan juntos» y comían de él, «comulgando» con el Señor, uniéndose de este modo, simbólicamente, al Sacrificado en la cruz, siguiendo en esto los principios de los cultos mistéricos de otras religiones.

Al principio este conjunto de creencias y prácticas se transmitieron oralmente entre las diferentes comunidades, pero a medida que la nueva fe se iba propagando, se consideró necesario fijar por escrito los dogmas más importantes. Fue así como aparecieron los Evangelios, relatos pretendidamente inspirados por la misma divinidad, que presentaban a los nuevos creyentes la figura de Jesús. La finalidad de estas historias sagradas no era tanto rememorar la vida del maestro como incidir en determinados aspectos de la nueva doctrina. De hecho, la redacción de estos primeros textos se distancia en el tiempo de los acontecimientos en ellos narrados, en ocasiones - como ocurre con el Evangelio de Juan-, más de setenta años, lo que resta fiabilidad a la historicidad del relato. Sin embargo, independientemente de lo que pudiera haber hecho o dicho en vida el profeta, es en estos escritos donde va a gravitar lo esencial de la nueva religión.

Junto a estas «historias de vida» o mejor dicho de muerte y resurrección, que es lo fundamental del mensaje cristiano, aparecieron a lo largo de los primeros siglos de nuestra era, otros escritos de la más variada índole, sobre las vicisitudes de los apóstoles en la difusión de la Buena Nueva. Cartas atribuidas a alguno de ellos y dirigidas a distintas comunidades, apologías, obras de naturaleza 
didáctica o incluso apocalíptica, y hasta textos refundidos como La armonía de los evangelios, escrita por Taciano a mediados del siglo II. Toda esa literatura se convertirá en el sostén teórico de la primitiva iglesia cristiana.

Con el paso del tiempo la jerarquía de la que se dotará la incipiente organización religiosa establecerá una criba de esos textos en función de las disputas teológicas que irán surgiendo en su seno. Así aparecerá un corpus canónico compuesto por veintisiete escritos que desde Tertuliano conocemos como Nuevo Testamento. Atanasio, obispo de Alejandría, será el primero, en el año 367, en declararlos como los únicos válidos e inspirados por Dios. Serán, como decía Ireneo de Lyon de los cuatro evangelios cien años antes, «regla de la verdad», pero aún se tardará más de un siglo hasta que el Papa Gelasio I (492-496) los ratifique oficialmente.

Fuera de este canon quedaban otros muchos escritos de inspiración cristiana, aunque la iglesia no los considerará de inspiración divina y en algunos casos los tachará de claramente heréticos. Estos escritos conocidos como «Apócrifos» tienen origen y cronología diversa, que abarca desde el siglo II hasta finales del siglo V. Esta abundante literatura, unida a la producción de los Padres de la Iglesia, constituye un complejo y rico entramado teológico sobre la naciente doctrina que sabrá recoger las viejas ideas del Mal y acomodar los ancestrales prejuicios sobre la mujer procedentes del mundo judío para integrarlos en esa nueva cosmovisión, no sin someterlos, en algunos de sus extremos, a un profundo proceso de reelaboración.

\section{Y vosotros, ¿quién decís que soy?}

Satán, el Diablo, Belcebú, Beliar... La herencia judía se deja sentir en el cristianismo, y el Mal, bajo muchas de las advocaciones con las que ha sido nombrado en la religión judía, reaparece en el Nuevo Testamento y en los primeros escritos de la recién nacida iglesia del Señor. Podríamos decir que su presencia se intensifica en los textos cristianos y según Morton Kelsey (cit. en Rusell, 1995: 223) las alusiones a demonios o al Diablo, directas o indirectas, en 
el Nuevo Testamento suman quinientas sesenta y ocho, frente, por ejemplo, a las trescientas cuarenta que se hacen del Espíritu Santo. Los evangelistas se refieren al demonio o a la posesión demoníaca en más de un centenar de ocasiones, lo que no es poco si tenemos en cuenta que se trata de unos escritos relativamente breves en relación con el corpus bíblico.

Las apelaciones preferidas son Satán o el Diablo, más la primera, que va ganando terreno en la nueva doctrina, que la segunda, citada, no obstante también, en numerosas ocasiones. Satán aparece como tal treinta y tres veces en el Nuevo Testamento y el Diablo veintinueve, aunque las referencias más abundantes son a los demonios y a sus víctimas. El cristianismo inicial no se puede despegar de la creencia en un mundo poblado de espíritus malignos que procuran el mal moral, causan enfermedades o arrastran a la locura. Según Máximo de Tiro, escritor pagano que vivió en el siglo II, los demonios que rondaban la tierra por aquel entonces eran treinta mil, pero para el cristiano Atanasio, dos siglos después, el aire ya estaba lleno de ellos y Macario los consideraba «tan numerosos como las abejas».

Por lo general toda esta impresionante hueste es nombrada en singular, refiriéndose a esa fuerza perversa que la encabeza como: «el Enemigo», «el Tentador», «el Malo» 0 «el Maligno», «el Acusador», «el Príncipe de este mundo», o «el Príncipe del imperio del aire». Lo cierto es que el cristianismo fue menos imaginativo en este extremo de lo que lo habían sido otras religiones, y son escasas las aportaciones que hace en cuanto a nuevas denominaciones o personificaciones del Mal. Una muy significativa que aparece en el apócrifo Hechos de Juan es la de Mamon, el demonio de la riqueza.

Mamon es el término arameo que sirve para designar el oro o las posesiones materiales. Aparece en el Eclesiastés $(31,8)$ y en Mateo $(6,24)$ en un sentido muy distinto al apócrifo, en el que sirve para designar a un demonio. En él podemos leer una condena explícita a los ricos, que nos revela las aspiraciones igualitarias de los primeros cristianos. En textos judíos del siglo I a. n. e. ya nos encontramos con la atribución sistemática de vicios o faltas a espíritus impuros, lo que señala una evolución en la concepción de esos seres. 
Mientras que en el pasado eran las enfermedades o desastres los que prestaban su nombre para personificar a un demonio, en vísperas de la aparición del cristianismo estas denominaciones se habían desplazado en su uso para designar desviaciones morales o, incluso, para condenar categorías sociales, como en el caso de Mamon.

Conviene recordar para entender esto la composición social y el talante nivelador del cristianismo primitivo, inspirado por la ideología comunitaria de los esenios y compuesto, en su mayor parte, por las clases más bajas de la sociedad. Como nos recuerda Jerónimo: «la comunidad de Cristo no se recluta ni en el Liceo ni en la Academia, sino en el más bajo populacho», que se sentía atraído a la nueva doctrina por sus promesas en la pronta implantación - con la segunda venida de Cristo - de un reino de los pobres y los humildes.

Esas aspiraciones, que terminaron siendo reorientadas por la naciente iglesia, se mantuvieron vivas durante algún tiempo y encontramos clara huella de ellas en el Nuevo Testamento, donde podemos leer la historia de Lázaro o la acrimoniosa diatriba contra los ricos que aparece en la Epistola de Santiago (5, 1-6). Por eso la aparición del demonio Mamon, más que la expresión de un poder sobrenatural, sería la manifestación del odio de clase latente entre la masa de los primeros cristianos.

Tampoco nos encontramos en los evangelios a Lucifer, que será una de las aportaciones más importantes de la nueva doctrina a la personificación e ideación del Mal. El nacimiento de este ser, dramáticamente sugestivo, fue largo y complejo y en él podemos rastrear el proceso de elaboración de un mito con una enorme repercusión y un profundo arraigo en nuestra cultura, que desborda con mucho el ámbito religioso para dejar una profunda huella en la literatura, el arte o las costumbres populares. El punto de partida debemos buscarlo en algunos escritos apócrifos como el Libro de los secretos de Henoc, también conocido como el Henoc eslavo, cuya datación es incierta, pero que muy bien podía haber sido redactado antes del siglo I. En esa obra y en otras del mismo estilo, queda recogida la idea del «ángel caído» tras un gesto de rebeldía contra su creador. En este caso el autor del fragmento achaca la caída de ese arcángel innominado a un pecado de soberbia: 
Pero uno del orden de los arcángeles, apartándose juntamente con la formación que estaba a sus órdenes, concibió el pensamiento inaudito de colocar su trono por encima de las nubes que están sobre la tierra para así poder equipararse con mi fuerza. Yo entonces lo lancé desde la altura juntamente con sus ángeles, y él se mantuvo volando en el aire continuamente sobre el abismo (AAT, vol. IV, 177).

En el capítulo anterior hemos visto cómo en otro apócrifo, $L a$ vida de Adán y Eva, probablemente posterior al Henoc eslavo, ya se asimila ese ángel a Satanás. Es muy posible que Lucas el evangelista conociera alguno de estos textos o que al menos estuviera al corriente de esa «historia» que circulaba entre los exegetas del siglo I, lo que pudo influir en un versículo de su evangelio en el que dice: "Yo veía a Satanás caer del cielo como un rayo». Con esta expresión, que Lucas pone en relación con el resultado favorable de la misión llevada a cabo por los discípulos, habría querido subrayar el triunfo de Dios sobre el Mal y el poder del que Jesús dotaba a sus seguidores para vencerlo: «Señor hasta los demonios se nos someten en tu nombre... Os he dado el poder de pisar sobre serpientes y escorpiones... y nada os podrá hacer daño» (Lc. 10, 17-20). De nuevo en este caso volvemos a encontrarnos con la imagen de la serpiente, como animal impuro, para representar las asechanzas del Maligno.

Será años después cuando entre los círculos ilustrados de los Padres de la Iglesia se establezca definitivamente la relación entre la idea de una caída angélica con el versículo de Lucas y se busquen referencias proféticas anteriores para explicar el origen del Mal en el mundo que darán lugar a la aparición de Lucifer. En su pugna contra la herejía maniquea muchos comentaristas se aplicaban en resaltar en sus escritos que el origen y la misma existencia de los demonios no podía provenir de un principio del Mal ajeno a Dios. Satán y toda su cohorte estaban en el mismo plano que los ángeles y el resto de las criaturas como obra del Creador.

«Sabemos, dice el eremita Antonio por boca de Atanasio, que los demonios no han sido creados por demonios... Ellos también fueron creados buenos» — como los demás ángeles-y si se han vuelto malos «caídos de la sabiduría celeste», es por culpa suya, por el mal uso que han hecho de su libertad (Vida de Antón, 22). Tertuliano abundaba 
en la misma tesis al afirmar con toda energía que Dios no había creado al Diablo sino a un ángel que al alejarse de él, por un acto libre, se había transformado a sí mismo en demonio. Y Gregorio Magno establecía la relación entre el mito del ángel caído y la aparición del ha satan del Antiguo Testamento al comentar el prólogo de Job. Si Satán estaba presente en la corte celestial entre los ángeles elegidos, sólo era posible porque, aunque hubiera perdido su beatitud, había conservado la naturaleza que tenía en común con los demás ángeles, naturam tamen eis similen non amisit (Morales, II, 4).

Por tanto, podemos decir que entre el cristianismo ortodoxo estaba universalmente admitida la idea de que el Mal procedía de la rebeldía y castigo de unos ángeles que por un pecado se habían convertido en demonios. Con esta premisa firmemente establecida, es Orígenes, en el siglo III, quien buscando una genealogía profética al mito se encuentra con dos referencias en Isaías y Ezequiel que van a dar vida a Lucifer. Por un lado, utiliza un pasaje en que Isaías (Is. 14, 12-13) satiriza la grandeza y soberbia de Nabucodonosor, a la par que vaticina su caída. Por otro lado, recurre a otro fragmento de Ezequiel (Ez. 28, 119) dirigido contra EtBaal II, rey de Tiro, escrito en el mismo sentido. Ambos párrafos hacen referencia a personajes históricos y en ningún momento lo que se dice de ellos puede atribuirse a ningún ser sobrenatural, pero esto no le importa demasiado a Orígenes, que se limita a tomar prestado para ilustrar su propia historia del ángel caído el fondo del relato y un apelativo que Isaías aplica a Nabucodonosor.

Ezequiel al referirse a Et-Baal II dice:

Querubín protector de alas desplegadas

te había hecho yo,

estabas en el monte santo de Dios,

caminabas entre piedras de fuego.

Fuiste perfecto en tu conducta

desde el día de tu creación, hasta el día en que se halló

en ti iniquidad. [...]

$\mathrm{Y}$ yo te he degradado del monte de Dios, y te he eliminado, querubín protector, de en medio de las piedras de fuego.

Tu corazón se ha pagado de tu belleza, has corrompido tu sabiduría 
por causa de tu esplendor.

Yo te he precipitado en tierra [...]

$\mathrm{Y}$ yo he sacado de ti mismo

el fuego que te ha devorado;

te he reducido a ceniza [...]

Eres un objeto de espanto,

y has desaparecido para siempre (Ez. 28, 1-5 y 12-19).

Ciertamente las alusiones que el profeta hace al monarca de Tiro nos pueden llevar a pensar con toda facilidad lo que Orígenes quiso ver, es decir, que estos versículos se referían a un ángel del orden de los querubines que henchido de soberbia había sido castigado por su creador siendo precipitado a la tierra desde las alturas celestiales. Aquí el Padre de la Iglesia tenía bellamente expresada, por una pluma de autoridad, la historia de la "caída», sólo le faltaba un nombre a tono para bautizar al protagonista de ese drama cósmico. Ese nombre lo obtuvo del fragmento de Isaías:

¡Cómo has caído de los cielos,

Lucero, hijo de la Aurora!

¡Has sido abatido a tierra, dominador de naciones!

Tú que habías dicho en tu corazón:

«Al cielo voy a subir,

por encima de las estrellas de Dios

alzaré mi trono,

y me sentaré en el Monte de la Reunión,

en el extremo norte.

Subiré a las alturas del nublado, me asemejaré al Altísimo.

¡Ya!: al Seoel has sido precipitado, a lo más hondo del pozo» (Is. 14, 12-15).

Este otro texto utilizaba para referirse a Nabucodonosor la expresión de «Lucero, hijo de la aurora» lo que llevó a Jerónimo, traductor del Antiguo Testamento, a verter este apelativo al latín con el término Lucifer, «el que porta la luz», sólo entonces nacerá esta nueva denominación cristiana del Mal.

Así pues, Lucifer, hijo de muchos padres, vino al mundo de las ideas en época tardía y le costó imponerse como tal, puesto que el mismo nombre que le designaba se había utilizado también en el Apocalipsis latino para referirse a Cristo (Ap. 22, 16), y aunque en las 


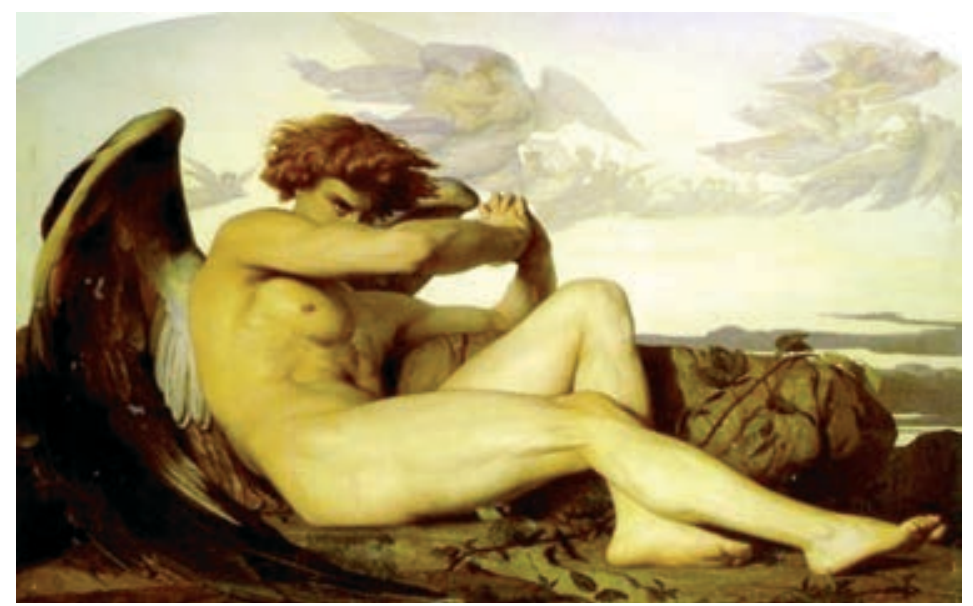

La principal aportación del cristianismo a la personificación del Mal radica en la figura de Lucifer, que tiene su origen en un sugestivo mito sobre la rebeldía de unos ángeles, identificados tradicionalmente como masculinos.

traducciones actuales se recupera la expresión de Lucero del alba en ese versículo, la existencia de la denominación aplicada a Jesús en las Sagradas Escrituras hizo que el nombre de Lucifer se utilizara de modo habitual entre los primeros cristianos, llegando incluso a existir un San Lucifer, obispo de Cagliari en el siglo IV. No obstante, el gran éxito de la leyenda del ángel caído entre las gentes sencillas terminó con el triunfo del Mal y así los nombres más extendidos en el cristianismo para designarlo se fundieron en uno solo, el de Lucifer, el demonio que pasó a ser Satán, el Diablo por excelencia.

La otra gran imagen del Mal elaborada por el cristianismo sí que tiene presencia bíblica, pero carece de presencia actual, ya que se trata del Anticristo: el Mal por venir. La leyenda del Anticristo nace de la conjunción entre la literatura apocalíptica judía y lo que Guignebert (1966) denominó «el fracaso de Jesús». Para las primeras comunidades de cristianos la identificación de Jesús con el Mesías y su triste destino resultaban incomprensibles, de ahí que la única reacción posible entre unos hombres impregnados de fe en sus propias creencias fuera sostener, desde el primer momento, que el Mesías Jesús no había muerto. Ése fue el punto de partida del mila- 
gro de la Resurrección y lo que compartían los discípulos era la profunda convicción en el próximo retorno de Cristo a la tierra para instaurar definitivamente su Reino, tal y como él mismo les había prometido. Por tanto, los primeros cristianos vivían en una tensa espera, en griego parousia, la vuelta triunfante de un Mesías justiciero. Esa segunda venida supondría, y aquí entran en juego las ideas apocalípticas tan extendidas en el medio judío, el final de los tiempos y el inicio de un segundo Paraíso del que disfrutarían los fieles seguidores, mientras que el Mal sería definitivamente destruido.

En la tradición apocalíptica ese momento iría precedido de una enorme convulsión en la que las fuerzas del Bien se enfrentarían a las del Mal en un último y definitivo combate, que no era sino la versión epigónica e imitativa de las grandes luchas cosmogónicas presentes en muchas mitologías antiguas y ausentes en la judía. En ese enfrentamiento último haría su aparición una figura que, bajo el influjo de Satán, sembraría el caos y la destrucción durante un tiempo antes de ser definitivamente vencida.

La apocalíptica del siglo I entendía a ese personaje como un poder terrenal y perverso, encarnación y resumen del Mal. Alguien que, como Antíoco IV Epifanes en la profecía de Daniel $(7,23)$, «devorará toda la tierra, la aplastará y la pulverizará». La influencia de Daniel y las descripciones que éste había hecho de esa figura, inspirada en el tirano rey helenístico que pretendió erradicar el culto del Templo, son determinantes en la aparición del Anticristo neotestamentario. De su profecía beberán muchos relatos apocalípticos posteriores para ilustrar el final de los tiempos y diseñar el perfil de ese enemigo de Dios. Los autores del Nuevo Testamento sabrán recoger lo básico de esa historia y nos irán desvelando su imagen en diferentes pasajes.

La primera aparición en los textos canónicos del mito del fin del mundo cristiano se registra en el llamado «Apocalipsis sinóptico» ${ }^{1}$

1 Se utiliza la denominación de Evangelios sinópticos para designar a los de Marco, Mateo y Lucas dado su tremendo parecido y la similitud en muchos de sus pasajes que permitirían una lectura simultánea (sinóptica) de los mismos. Por el contrario, el Evangelio de Juan muestra profundas diferencias con éstos e incluso su contenido teológico es sustancialmente distinto. 
(Mc. 13, 1-37; Mt. 24, 1-25; Lc. 21, 5-38), unos fragmentos de contenido similar que figuran en los evangelios de Marcos, Mateo y Lucas y en los que se hace referencia al desconcierto que acaecerá antes de la llegada del Reino. En estos pasajes no hay, todavía, alusiones a una figura concreta que encarne al Anticristo, pero ya se nos previene que en ese tiempo de tribulación surgirán «falsos cristos y falsos profetas» (Mc. 13, 22; Mt. 24, 24; Lc. 21, 8). Entonces reinará la confusión, se levantará nación contra nación y reino contra reino, habrá terremotos y hambre e imperará «la abominación de la desolación», anunciada por el profeta Daniel $(11,31 ; 12,11)$. En esta alusión podemos intuir la aparición de un sujeto singularizado que a modo de caudillo encabezaría las fuerzas del Mal, así al menos la interpretará el cristianismo posevangélico a partir de que Ireneo de Lyon, a finales del siglo II, en su obra Contra las herejías considere esta expresión como una imagen simbólica de «El hombre Impío», el «Hijo de perdición». El Padre de la Iglesia se apoyaba para hacer esta afirmación en otro texto del Nuevo Testamento, la Segunda carta a los Tesalonicenses.

Esta Carta, que muchos exegetas no consideran obra del apóstol Pablo, es un eslabón más en la elaboración de la leyenda del Anticristo pudiéndose estimar como cruciales sus aportaciones en este sentido. El texto donde se utiliza por primera vez el singular se refiere a esa temida figura. Para su autor, el tirano final no lo representa una amalgama confusa de falsos cristos o falsos profetas, sino un solo sujeto al que denomina como «El hombre Impío», el «Hijo de perdición» y también como «El Adversario». Este personaje, «bajo el influjo de Satanás» (2 Tes. 2, 9), vendrá para oponerse a Cristo, por lo que podemos deducir que el texto lo concibe como un mero servidor en la tierra a las órdenes del Maligno, sin producirse una identificación entre él y Satán, que será quien lo envíe y al que estará en todo momento sometido.

Esto, inevitablemente, nos lleva a pensar que la Carta imagina el enfrentamiento último entre potencias simétricas, tal y como ya lo habían apuntado los esenios. Dios enviaría a Cristo para encabezar las fuerzas del Bien mientras que Satán encomendaría las huestes del Mal al "Adversario». La interpretación, que raya la herejía, respondía a la doctrina de la subordinación, muy difundida en la tradi- 
ción cristiana temprana, que sostenía que el Hijo no era igual al Padre en poder, por eso en el combate apocalíptico la contrapartida de Cristo no podía ser Satán mismo sino una figura inferior, de naturaleza terrenal, como había sido Antioco IV Epifanes para Daniel.

La idea de un «Adversario» concebido como poder terrenal daba pie a que autores apocalípticos apreciaran signos de su presencia en distintos personajes coetáneos a estos escritos. Un ejemplo de lo que estamos diciendo lo encontramos en un fragmento del Libro III de los Oráculos Sibilinos, ${ }^{2}$ en el que el redactor, posiblemente un cristiano de finales del siglo I, identifica a un personaje que no nombra - pero en el que podemos reconocer fácilmente a Nerón, por los crímenes que le atribuye - con Belial, el demonio Beliar del Antiguo Testamento. Para los primeros cristianos, la figura de este emperador se antojaba como más terrible que la de otros, ya que con él habían comenzado las persecuciones a los seguidores de la nueva doctrina. Resulta pues lógico que en este tipo de escritos se terminara por equiparar a Nerón con el Diablo, antes incluso que al mismo Tito, hijo del emperador Vespasiano y destructor de Jerusalén en el año 70. Y es que por aquellas fechas el cristianismo cosmopolita había alcanzado la suficiente autonomía como para desentenderse de la suerte real que pudiera correr el pueblo de Israel.

Esa asimilación del Adversario final con el emperador parricida tuvo un enorme éxito, máxime cuando se extendió la leyenda por todo el Imperio de que Nerón no había muerto tras su caída y que iba a volver desde donde se hallaba oculto para arrasar Roma. Este bulo, que queda recogido por Tácito (Historias, lib. II) y Suetonio (Vida de los doce césares, lib. vi), alimentaba la fantasía de los autores apocalípticos como el Juan del Nuevo Testamento, que en su

2 Los Oráculos Sibilinos constituyen un género dentro de los Apócrifos. Son libros de naturaleza apocalíptica escritos por judíos de la diáspora a imitación de los Oráculos paganos. Su intención era poner de manifiesto la superioridad del judaísmo y predecir el triunfo definitivo de Israel, aunque desde el siglo II nos encontramos también con Oráculos Cristianos. En el caso al que hacemos mención, la obra es de factura judía y posiblemente date del siglo II a. n. e., pero el fragmento de Nerón/ Belial es una interpolación posterior hecha por mano cristiana. 
obra cifra en el nombre de César Nerón el número de la Bestia, ${ }^{3}$ término con el que designa al postrero enemigo del Bien.

El Apocalipsis de Juan es la última gran aportación en la génesis del Anticristo, y aunque en ella sigue sin aparecer esa denominación en concreto, las aportaciones que hace sobre cómo será esa definitiva encarnación del Mal o el cataclismo que acompañará el final de los tiempos van a tener una honda repercusión posterior, entre otras razones porque es el único libro de naturaleza escatológica admitido entre los canónicos del Nuevo Testamento. Sus espantosas imágenes, llenas de una fuerza terrible, nutrirán durante siglos la especulación y fantasía de teólogos y artistas en el mundo cristiano. Sin embargo, las dos únicas menciones que nos encontramos en la Biblia en las que figura explícitamente el apelativo de Anticristo carecen de ese colorido que nos brinda Juan en su obra, aunque, curiosamente, también se le atribuyen a él.

El nombre de Anticristo se nos desvela en sendas Cartas de Juan, en ellas ya no se espera la llegada de ese ser monstruoso y terrible que alimentaba los temores del cristiano de primera hora, tampoco se desprende de las mismas que tenga que ser un poder terrenal y mucho menos Nerón redivivo. Lo que nos transmiten ambos escritos es que el Anticristo ya está entre nosotros manifestando su perversidad al sembrar la confusión en los fieles, al inducirles al error sobre la verdad revelada. Ésa es su labor, propagar la herejía. Esta visión teológica sobre la ortodoxia de la fe y sus adversarios se combinará con las otras más plásticas del Anticristo, como una fuerza destructora y bestial. Aunque la versión de las Cartas estará llamada a desempeñar un importante papel en la historia de la Iglesia, que entenderá como la más peligrosa Bestia la que se encarna en quien discrepa. «¿Quién es el mentiroso, sino el que niega que Jesús es el Mesías? Ése es el Anticristo» (1 Jn. 2, 22) nos dirá el autor del texto, embarcado ya en las luchas teológicas frente a la disidencia, luchas que si no provocó el Mal sí que estuvieron llenas de humana maldad.

3 Juan en el Apocalipsis (13, 18) nos dice que la misteriosa Bestia tiene un número, el 666. En esta cifra podrían ser leídas, si se aplica la gematría, tan popular en la antigüedad, y por medio de la cual se puede hacer una sustitución por letras de un valor numérico o a la inversa, las palabras en hebreo nrwn qsr, que significarían, con las correspondientes vocales añadidas, Nerón César. 


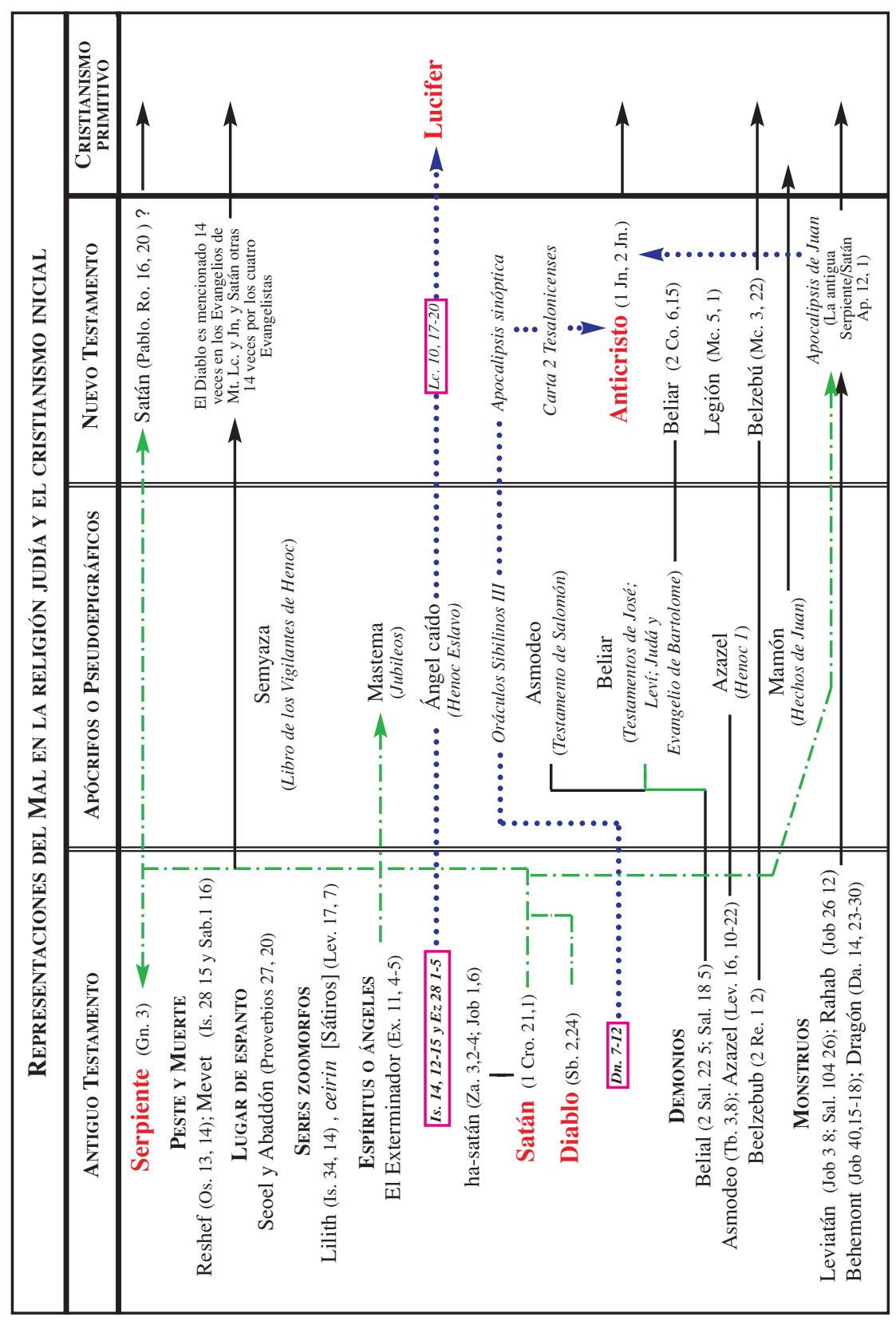




\section{No nos dejes caer en la tentación}

Cabe preguntarnos cómo era y cómo actuaba esa fuerza perversa, fuera cual fuese el nombre con el que la designaran los primeros cristianos. La imagen de Satán permanecerá difusa durante mucho tiempo. El mundo judío, reacio a crear formas que pudieran suponer un acto de blasfema imitación a la obra de Dios, no nos legará ninguna representación. Por otra parte la naturaleza espiritual y evanescente del Maligno, unida a su enorme poder de adaptación, le permitirá cobrar cualquier apariencia, y serán los tradicionales animales impuros o los endemoniados quienes le prestarán sus cuerpos para manifestarse. Basilio, Padre de la Iglesia que escribió en el siglo IV, será el primero en sostener que cuando un demonio deseaba materializarse hacía condensar vapores y los reunía hasta constituir un cuerpo, ya de ser humano o de animal, del que tomaba posesión; sin embargo en el Evangelio sólo vemos a demonios que se apoderan de cuerpos ya formados sin ningún tipo de dificultad.

Los cristianos, cuando comiencen a plasmar en iconos sus dogmas, tampoco mostrarán ningún interés en representar al Diablo, y las formas que utilicen para recrear la comunidad de fieles o al Cristo pastor de almas imitarán las del arte romano, alejándose así de la fantástica imaginería oriental. Estamos por tanto muy lejos del Satán cornudo y repugnante de los siglos posteriores. Es más, podemos pensar que la corporeidad demoníaca, si atendemos a su origen, debía responder en la imaginación de las primeras comunidades, a la de un ángel perverso en su ser aunque no necesariamente en su imagen ( 2 Corintios 11,14 ).

Si bien la tradición apocalíptica tuvo que influir con sus descripciones monstruosas, en los ulteriores retratos del Diablo, sólo algunas características como el color rojo de la Bestia $(12,3)$ quedarán recogidas siglos después. Los escasos rasgos que se le atribuyen en los textos del primer cristianismo se resumen en el color negro, por el que se inclina La Epístola de Bernabé, que lo imagina así, como Señor de las tinieblas que es. Otro apócrifo, Los Hechos de Felipe, lo dota de alas, como pudiera parecer lógico por su origen 
angelical, y de un olor a humo que terminará transformándose en el medioevo en olor a azufre. La síntesis primera de esta imagen la establecerá el Monje Rufino en el siglo IV cuando en una de sus obras afirme que Macario el Menor había visto volar una serie de pequeños demonios parecidos a «etíopes sucios».

Lo cierto es que, a pesar de ser tan abundante la presencia del Maligno, los primeros cristianos no tenían una idea clara de cómo era, e incluso lo imaginaban con un aspecto que hasta cierto punto pudiera parecer normal, si no fuera por algunas exageraciones en cuanto al tamaño, y porque recurrían a tatuar su nombre sobre el cuerpo para reconocerlo mejor, como podemos leer en El Apocalipsis del Santo Teólogo Juan cuando se describe al Adversario final de este modo:

El aspecto de su rostro es triste; sus cabellos, como puntas de flechas; sus cejas son ásperas; su ojo derecho es como la estrella de la mañana y el izquierdo como el de un león. Su boca tiene medio metro de anchura; sus dientes tienen una cuarta de longitud; los dedos de sus manos son como hoces. Las huellas de sus pies tienen un metro de largo y en su frente está escrito: «El Anticristo» (cit. en McGinn, 1997: 87).

Las formas del Diablo en aquella época eran tan imprecisas que cuando en un relato aparezcan descritas las que hoy nos resultan familiares se producirá la paradoja de que quien las posee sólo haga que alabar al Señor. Jerónimo relata en su Vida de San Pablo, el primer ermitaño (cita en Koning, 1979: 139) que yendo Antonio a visitar al anacoreta se encontró en el camino con una especie de pequeño sátiro, de cuya imagen iba a beber la imaginería demoníaca medieval. Se trataba de un ser de escasa estatura, cuyas manos recordaban garras, con piernas velludas, con pezuñas de cabra y dos pequeños cuernos en la frente. Antonio se detuvo espantado por la visión, pero el personaje se aproximó respetuosamente y le ofreció algunos dátiles diciéndole: «Soy un ser mortal, uno de los habitantes del desierto que los paganos, en su ceguera, adoran bajo los nombres de fauno o sátiro, o íncubo. Mi viaje es un encargo de mi pueblo: te pedimos que ruegues por nosotros al Dios de todos, pues sabemos que ha venido para salvar al mundo y cuyas alabanzas suenan por toda la tierra». Como vemos en esta ingenua historia de glorificación de la nueva doctrina las viejas formas del Mal se inclinaban para alabar al Cristo redentor. 
Si el perfil icónico del Maligno resultaba impreciso no ocurría lo mismo con el moral. El Diablo ya era entonces la esencia del Mal, la mentira misma, la causa de la muerte espiritual de los hombres que lo siguieran. Era el enemigo permanente del Reino de Dios, su adversario más pertinaz. Señor de este mundo material hasta el definitivo retorno de Cristo, aunque también gobernaba en las tinieblas profundas y en los abismos. Su poder era inmenso y costaba rechazarlo o vencerlo, pero su destino estaba sellado, pues sería definitivamente derrotado al final de los tiempos.

$\mathrm{Su}$ principal actividad era actuar de mil maneras distintas contra el hombre, la obra suprema del Creador. Su presencia y su nefasta labor eran constantes. Pablo (1 Tes. 2,18$)$ llega a justificar un viaje que no pudo efectuar alegando que Satán se lo había impedido, aunque no aclara de qué manera. La frase nos da una idea muy precisa de cómo cualquier adversidad podía ser interpretada por los cristianos como obra del Diablo, en línea de continuidad con lo que habían sido este tipo de creencias en el Oriente Antiguo. Aunque es cierto que en algunos escritos de la nueva religión se intenta desdramatizar esa vivencia recordando a los fieles que la llegada del Mesías había supuesto el triunfo sobre el Mal, como afirma el autor del Pastor de Hermas: «El diablo sólo infunde miedo; pero este miedo no tiene eficacia alguna. No lo temáis pues, y él huirá de vosotros». Pero resultaba difícil aceptar este mensaje cuando se conocían los textos sagrados.

En los Evangelios no sólo se insiste en la presencia del Mal sino que se nos aclara cómo actúa. Tienta al mismo Jesús y podemos, por tanto, suponer que hace lo propio con los hombres, poniéndolos a prueba con intención de reclutarlos para su lucha contra el Señor. Castiga a los pecadores en su reino (Mc. 9, 47; Mt. 25, 46; Lc. 13, 23-29), ${ }^{4}$ y por medio de los demonios, que son su expresión o sus ser-

4 En los Evangelios se insinúa un lugar de castigo impreciso en donde arde el fuego, aunque en ningún momento se relaciona con Satán, pero muy pronto la tradición cristiana vinculará ambas creencias. Las primeras alusiones precisas a un infierno cristiano, castigo para pecadores, las encontramos en un escrito del siglo II titulado El Apocalipsis de Pedro. El apóstol tiene la oportunidad, como Virgilio, en el que sin duda se inspira el texto, de viajar por el imperio de Satán. En el curso de su horroroso periplo ve árboles de cuyas ramas penden, colgados por la lengua, los blasfemos, mientras que sus pies arden abrasados por el fuego. En un lago de fango ardiente los 
vidores, se apodera de los cuerpos humanos o animales y los posee. La posesión es la forma de actuación más habitual de Satán en el Nuevo Testamento y como contrapartida el exorcismo es una de las actividades más frecuentes de Jesús, al punto de que él mismo llega a definir su misión diciendo: «Sabed que expulso demonios y realizo curaciones hoy y mañana, y al tercer día acabaré» (Lc. 13, 32).

Además de las referencias sumarias los evangelios sinópticos enumeran seis casos concretos de exorcismo en los que no se puede distinguir muy bien si se trata realmente de posesos o de enfermos, aunque el tratamiento que les aplica el profeta es como si estuvieran poseídos. El número de este tipo de intervenciones no es muy elevado pero contrasta con la total ausencia de esta práctica en el Antiguo Testamento.

Pareciera al enfrentarnos a los textos como si por aquellas fechas todo Israel se viera afectada por una auténtica epidemia de posesión demoníaca que se cebase en un amplio sector de la población (Mc. 1, 32; Mt. 8, 16; Lu. 4, 40) y algo así podría estar sucediendo si atendemos a la curiosa tesis que sostiene Crossan (1996) apoyándose en estudios de arqueología cultural comparada. Según este autor, los trastornos múltiples de la personalidad, que pueden estar tras el fenómeno del endemoniamiento, se multiplican en aquellos pueblos o comunidades que viven situaciones excepcionales como pudiera ser la de una ocupación colonial. En esos casos el choque de una cultura tenida como superior, al menos en los aspectos militares, con otra que sufre la erosión de sus propios valores provocaría, como una curiosa forma de resistencia, el aumento de este tipo de fenómenos. La tesis es sugestiva y en parte al menos acertada, si además tenemos en cuenta que la posesión por parte de espíritus malignos en personas o animales pertenecía de antiguo al bagaje cultural de los pueblos del Oriente Próximo.

penados permanecen sumergidos, «mientras que los ángeles encargados de atormentarlos estaban por encima de ellos» (reparemos en el término que utiliza para designar a los «demonios infernales»). Un poco más allá se encuentra con mujeres colgadas por los cabellos como castigo por su adulterio y así continúa narrando diversos tipos de sufrimientos, distintos en cada caso según la falta (Minois, 1994: 105).

Antes de perfilar la imagen de Satán el cristianismo temprano ya recreó cómo era su reino para advertir a los hombres cuál sería su triste destino de no seguir el recto camino de la Iglesia. 
Los judíos, más allá de la presencia romana, estaban sumidos en un medio en el que esos estados de alteración de la personalidad eran considerados como habituales al margen de creerlos como causa u origen de muchas enfermedades. Egipcios, mesopotámicos y otros pueblos del Mediterráneo oriental, durante milenios habían padecido y combatido la acción maléfica de los espíritus cuando se apoderaban de una persona. En el siglo I a. n. e. el pensamiento judío admitía, como hicieron los primeros cristianos, que el mundo estaba poblado de demonios. El Talmud (Ber. 6a) nos dice: «Si el ojo humano tuviera la facultad de verlos, ningún hombre podría vivir a causa de los espíritus malignos. Son mucho más numerosos que los hombres. Cada uno de nosotros tiene mil a su izquierda y miríadas a su derecha». Frente a esta realidad, y sin renunciar a lo básico de sus creencias, los judíos asimilaron los métodos de sus vecinos para combatir esta abrumadora invasión.

Existían exorcistas que en el nombre de Dios intentaban expulsar a los demonios, como lo atestiguan los mismos textos evangélicos. Cuando los fariseos acusan a Jesús de practicar exorcismo en nombre de Belcebú, Jesús les contesta: «vuestros hijos, ¿con qué poder los expulsan?» (Mt. 12, 27). En los Hechos de los Apóstoles $(19,11-16)$ se narra un jocoso episodio en el que unos exorcistas judíos, hijos de un sacerdote, intentan arrojar un demonio en nombre de Jesús, el espíritu se revela diciéndoles que quiénes son ellos para conjurarle y luego, a través del endemoniado, les propina una paliza. El mismo Flavio Josefo nos relata cómo contempló una expulsión llevada a cabo con éxito por un tal Eleazar, que la realizó ante el mismo emperador Vespasiano:

La forma de curar era la siguiente: acercaba a las fosas nasales del endemoniado un anillo que tenía en el sello una raíz de una de las clases mencionadas por Salomón, lo hacía aspirar y le sacaba el demonio por la nariz. El hombre caía inmediatamente al suelo y él adjuraba al demonio a que no volviera nunca más, siempre mencionando a Salomón y recitando el encantamiento que había compuesto (Antigüedades de los judíos, vIII).

En ese marco es donde debemos encuadrar los pasajes neotestamentarios de Jesús y sus discípulos conjurando directamente el Mal. Nada de esas historias es extraño al mundo judío de aquella 
época y sólo en algunos matices se diferenciará el proceder de los cristianos, en ese combate del que seguían sus contemporáneos de otras religiones. Por eso, las intervenciones que nos revelan los textos responden a un módulo, un tipo de narración común y repetitivo, que encontramos en otras culturas.

El relato, en primer lugar, describe los síntomas y la gravedad del afectado por la posesión. Su comportamiento siempre supone una alteración física o de actitud que se hace visible a los que le rodean. Puede consistir en la privación de una o más facultades, o en una actividad desordenada e incluso violenta en estos sujetos -que la demonología medieval terminará denominando como «energúmenos»— la persona parece dotada de una fuerza extraordinaria, manifiesta convulsiones y todo tipo de anomalías.

A renglón seguido la narración suele resaltar cómo ya entonces otros exorcistas intentaron la sanción sin conseguirlo y tras poner de relieve la dificultad del caso deja que actúe el taumaturgo que va a llevar a cabo la curación. El proceder del exorcista podía ser muy distinto y es aquí donde el cristianismo se diferenciará de las prácticas anteriores.

Lo habitual era que el exorcismo consistiera en un complicado ritual mágico como algunos de los que hemos encontrado descritos en el mundo mesopotámico, ${ }^{5}$ pero, con la evolución del pensamiento religioso y en el marco de una creencia monoteísta como la judía, lo normal era considerar al sanador imbuido de un poder dimanante de Dios para vencer al espíritu impuro, lo que conllevaba una simplificación del ritual. No obstante, siempre iba acompañado de manipulaciones, tocamientos de las partes afectadas del cuerpo $u$

5 Koning (1979: 22) nos relata uno de estos exorcismos babilónicos donde se pretendía expulsar al demonio femenino Lamashtu causante de una enfermedad. «Es preciso bendecir la casa. Hay que tomar arcilla y fabricar una imagen de Lamashtu. Luego colocarla sobre la cabeza del enfermo. Llenar un infiernillo con cenizas y colocar dentro un puñal. Durante tres días se sitúa cerca de la cabeza del enfermo. En la noche del tercer día se toma la imagen de la cabeza del enfermo y se la mata con el puñal para enterrarla luego en un rincón de la pared.» Como podemos apreciar el ritual no era sencillo, requería de diferentes adminículos y no se desarrollaba en una sola sesión. 
otros signos que, junto con órdenes dadas al demonio o conjuros específicos, le obligaban a salir. En esta fase era habitual que el taumaturgo intentase conocer el nombre del espíritu ocupante; ya que conocer su nombre, por los viejos principios de la magia de la palabra, era poder controlarlo o dominarlo con mayor facilidad.

Realizada la expulsión, el sujeto manifestaba ostensiblemente su curación, dando muestras de haber recuperado sus facultades o de poder desenvolverse con total normalidad. Por último, los que habían contemplado el hecho expresaban su admiración por el exorcista y alababan lo milagroso de sus poderes.

Con este proceder, que nos encontramos descrito en medios religiosos muy alejados del judío, actúa Jesús en los Evangelios frente a los demonios, aunque los autores de los textos pretenden reducir al mínimo la ritualización del acto. Éste es el original matiz que introduce el cristianismo que pretende subrayar cómo la sola palabra, la orden divina sin más, basta para realizar la expulsión con éxito. La palabra desempeña un papel muy importante en el nuevo mensaje, «la Palabra era Dios» (Jn. 1), nos dirá el más espiritual de los evangelistas. Por medio de este recurso se pretende enfatizar la distancia que separa al Hijo de Dios de los espíritus inmundos. Al Señor, todo poderoso, le basta con una simple orden para imponer su autoridad sobre esa desdichada criatura, obra suya, que es el Diablo.

No obstante, en el relato evangélico se deslizan algunos indicios de que Jesús y sus discípulos debieron de actuar de modo muy parecido a como lo hacían otros taumaturgos de su tiempo. En el evangelio de Marcos $(8,22)$ Jesús recurre a la saliva para sanar a un ciego y en los Hechos de los Apóstoles (19, 11-16) los demonios salen expulsados con el simple contacto del poseso con algunas de las prendas que había llevado Pablo, lo que pone en entredicho la originalidad cristiana de la simple orden en nombre de Dios, que por lo demás prevalece en el resto de los casos.

El exorcismo más detallado que registran los sinópticos es el que Jesús ejerce sobre un poseso de la región de los gerasenos (Mc. $5,1-13)$. En este pasaje se cumplen todas las fases del módulo narrativo que hemos descrito excepto una, que es la clave para entender el sentido profundo del relato. Nos referimos a que una vez que el 


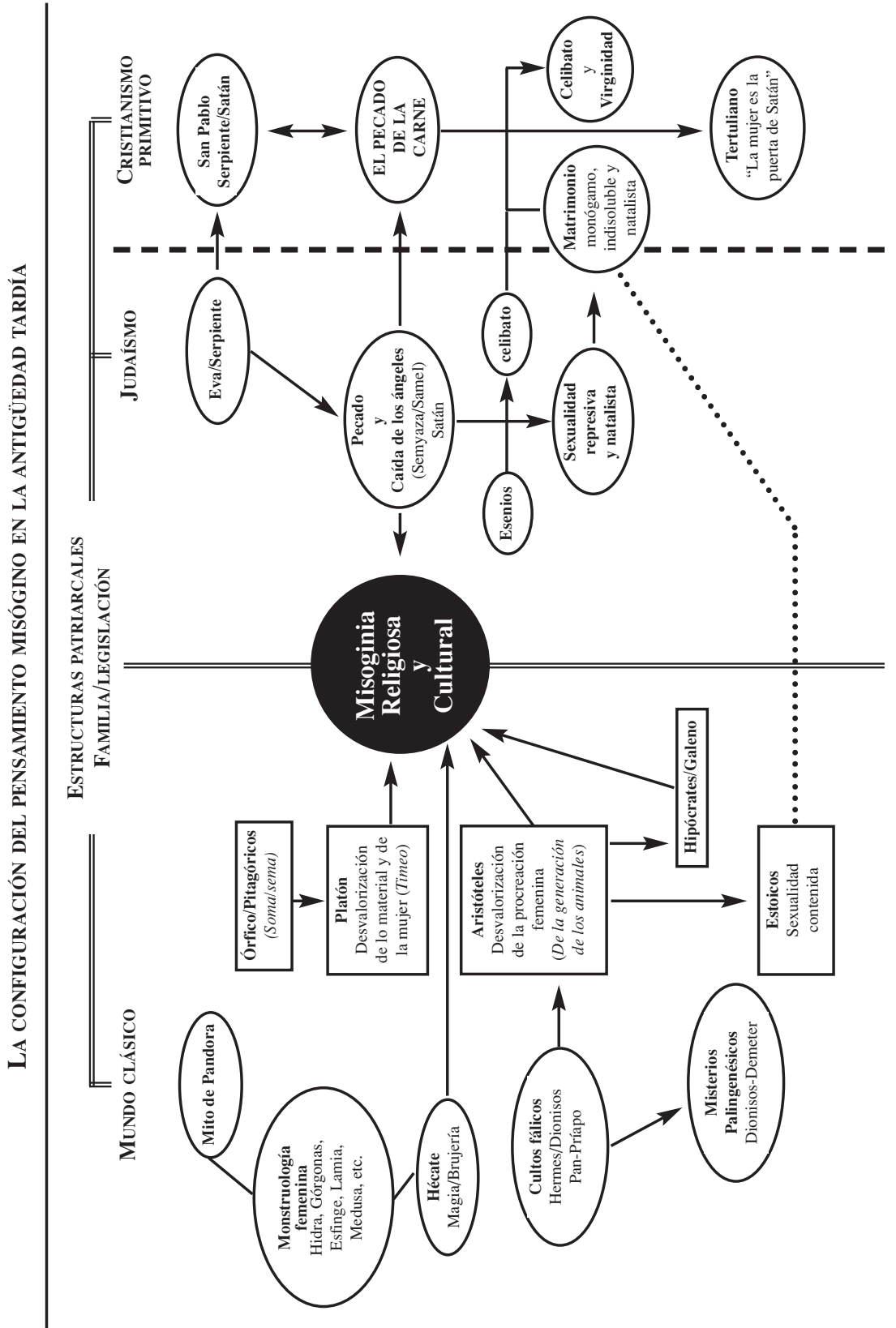


hombre ha sido curado, los testigos, en vez de glorificar a Jesús, le piden que se aleje de aquellos lugares, ¿por qué? Según Crossan porque el milagro estaba cargado de un simbolismo político que resultaba peligroso incluso para los que sólo lo habían contemplado.

Recordemos que Jesús expulsa a un demonio del geraseno —que daba muestras de ser un auténtico «energúmeno»-, cuyo nombre es Legión, una clara alusión al ocupante romano que había «poseído» el cuerpo de Israel convirtiéndolo en impuro. La expulsión no se produce sin más, ya que Legión, con el permiso de Jesús, va a refugiarse en una piara de cerdos, animales inmundos para los judíos, para terminar precipitándose por un acantilado al mar. Cuesta no interpretar este relato como la proyección de los deseos mesiánicos del sector más rebelde del pueblo judío en el que se debían de encontrar el propio Jesús y sus partidarios. Así como Mamón era el odiado demonio de la insultante riqueza, Legión no sería otra cosa que la expresión de la maldad del imperialismo romano.

La posesión como forma de intervención del Diablo dejará una profunda huella en el cristianismo posterior, pero su carácter excepcional hará que, a la larga, influya en menor medida que la otra forma de actuación diabólica que es la tentación, mucho más frecuente y con implicaciones más profundas que la primera.

En los evangelios sólo encontramos un pasaje en el que el Maligno, bajo el nombre de Diablo, tienta a alguien y lo intenta nada menos que con el mismo hijo de Dios (Mt. 4, 1-11). En ningún otro momento se nos dice que Satán o demonio alguno tienten a ninguna persona, lo que podría llevarnos a relativizar la importancia de este tipo de actuación. De hecho esa secuencia evangélica apenas es tenida en cuenta en muchas de las biografías históricas de Jesús (Crossan, 1996; Vermes, 1984; Trilling, 1970...). La misma forma de la narración es típicamente legendaria y, según Bultman (2000), responde a un modelo de discusiones rabínicas consistente en plantear a un hombre considerado justo un dilema moral que éste debía resolver recurriendo a una cita bíblica. De hecho la estructura del relato es muy similar a las tentaciones de Job que aparecen en el Antiguo Testamento o a las experimentadas por hombres «santos» en otras religiones como Buda, Zaratustra, etc. 
Realmente hemos de interpretar todo el pasaje como alegórico. Por un lado, debemos entender que en la historia del personaje, antes de lanzarse a la que será llamada su «vida pública», se produzca un período de retiro en soledad para entregarse a la meditación sobre la tarea que va a emprender. Los cuarenta días que permanece alejado del mundo han sido sacados de la estancia de Moisés en el desierto (Éx. 34, 28) y las «tentaciones» no serían sino las dudas que asaltaron a Jesús ante la magnitud de su misión. Pero la alegoría podría ir más lejos al prevenir a todos los humanos sobre el poder y atrevimiento del Diablo, que no se arredra en poner a prueba al mismo Dios vivo.

Así fue como lo terminaron comprendiendo los primeros cristianos que aprendían con la historia a temer las asechanzas del Maligno al tiempo que se les facilitaba un modelo de cómo derrotarlo. En la literalidad, para los más simples, o en lo alegórico del relato, lo que se podía apreciar era el enorme peligro que experimentaba cada hombre. De ahí que, Jesús mismo, les enseñase a pedir al Padre que no les dejara "caer en la tentación", cosa a la que eran proclives dada su extraordinaria fragilidad. Fragilidad que ya no era la del individuo corriente ante su dios, como en cualquier otra religión, sino la del cristiano creyente ante la falta moral que suponía el incumplimiento de la ley sagrada impuesta por el Dios verdadero.

La labor cotidiana y silente del Mal nos permite, mejor que cualquier otro tipo de manifestación diabólica, acercarnos a la nueva moral que pondrá en circulación la recién nacida doctrina. Los principios morales del cristianismo en los primeros siglos de su existencia los podemos encontrar aisladamente en otras creencias 0 en el pensamiento filosófico de la época, como dice Meeks (1994: 12): «es extrañamente difícil, sin duda, decir con exactitud qué tenía de nuevo la moralidad cristiana, o trazar en torno a ella fronteras precisas. El lenguaje de la virtud que hablaban los cristianos era una adaptación de tradiciones de discurso moral más antiguas, no era algo que partiese de la nada».

Será la decantación de esos principios a la luz del misterio sobre la muerte y resurrección de las almas en función del cumplimiento de leyes sagradas las que conferirán una dimensión distinta a esos 
conceptos morales comunes a otras formas de pensamiento. La reorganización y reorientación de esos principios propiciará una nueva sensibilidad que terminará por configurar una manera de ver el mundo totalmente distinta. No es nuestra intención adentrarnos aquí en tan complejo problema, pero resulta imprescindible para entender lo que sigue que hagamos al menos una breve mención a los principales fundamentos que orientaron ese giro cultural. Y para ello partiremos de la tentación, que es la expresión «material» de cómo una fuerza maligna, lo que Mateo denomina un «Espíritu inmundo» (Mt. 12, 43-45) nos induce a pecar.

El Mal ya no se presentaba como un ser concreto que podía imaginarse fantasiosamente de diferentes formas — nada más alejado de la monstruología oriental—, sino que se percibía como una presencia que se movía entre los hombres sin que lo pudieran siquiera intuir. «Numerosa es su turba en el aire que nos rodea, no están lejos de nosotros...» nos dice Atanasio en su biografía de San Antonio. Pero lo peor era que esos espíritus impuros, manifestaciones del Mal, podían habitar en los humanos induciéndolos a obrar, sin que esa posesión de la que eran objeto se hiciese perceptible, como en el caso de los endemoniados.

El espíritu, el daimon griego, según los filósofos, animaba la vida de los hombres e inspiraba sus actos. Para el cristiano, si estaba lleno del espíritu del Bien, idea suprema en la teoría platónica, se hallaba poseído por el Espíritu Santo, pero si, por el contrario, un espíritu impuro se apoderaba de él, sus actos eran perversos y lo alejaban de la salvación. La impureza adquiría así también un nuevo significado; ya no se trataba de un estado transitorio sobrevenido por una circunstancia vital, como la menstruación, o por un incumplimiento ritual, la impureza unida a lo espiritual se presentaba como una mácula moral que nos apartaba de Dios.

El cristianismo por influencia helenística, ya presente en el mundo judío, reorientó la naturaleza y actividad del Mal desde la materialidad a la espiritualidad, y desde la desgracia o el terror irracional a la falta moral. Eso no quiere decir que siguiera pesando en él toda la abigarrada herencia de la demonología anterior y que el Mal, del que Dios debía librarnos al rezar el padrenuestro, 
continuase interviniendo de la manera más inopinada en la vida de los primeros cristianos; sin embargo se había comenzado a dar un giro en ese sentido en los medios judíos helenizados que el cristianismo supo apreciar e integrar en sus creencias. Por eso, junto al Espíritu Inmundo, Mateo y Lucas (Mt. 12, 43-45; Lc. 11, 24-26) nos hablan de «siete espíritus peores» que no son sino meras denominaciones de vicios o pecados que ya aparecían en el Testamento de Rubén, un apócrifo del siglo I a. n. e. ${ }^{6}$

Las maneras de defenderse de estas continuas asechanzas tampoco podían ser las de siempre. La magia quedaba proscrita y, tras el triunfo del cristianismo, Constantino prohibió las prácticas adivinatorias y esotéricas. En algunos de los primeros escritos cristianos, como La epístola de Bernabé o el Didaché, se las consideraba diabólicas, condenando a sus adeptos al reino de las tinieblas; y aunque los cristianos continuaron utilizando fórmulas muy parecidas a las de los paganos, poco a poco el pensamiento oficial de la Iglesia fue arrinconándolas por innecesarias ya que, como aseguraba Ignacio de Antioquía en su Carta a los Efesios, con la aparición de la estrella que había anunciado el nacimiento del Redentor «se destruyó toda magia, se desvaneció todo encantamiento; se abolió la ignorancia del mal, pereció el viejo reino...». Sólo la nueva señal de la cruz, a partir del siglo III, ${ }^{7}$ se utilizaba como signo apotropai-

6 Realmente en el Testamento de Rubén se les denomina «Espíritus del error», aunque podemos deducir que se tratan de la misma entidad. Esos «Espíritus del error» son: «El espíritu de la fornicación, el de la insaciabilidad, el de la guerra, el espíritu del agrado y el encanto, el del orgullo, el espíritu del engaño, y por último el de la injusticia» (3, 2-7. AAT, vol. v). Podemos observar cómo la obsesión por la pureza sexual tan arraigada en el pensamiento judío de la época les llevaba a colocar como el primer «error» la fornicación.

7 La formación de un monograma universal de la nueva doctrina fue una tarea lenta. Una de las primeras imágenes simbólicas del cristianismo fue el pez. Clemente de Alejandría (fallecido antes del año 215) recomendaba en su Pedagogo utilizar esta forma ya que «Si vemos un pescado recordaremos al apóstol (se refiere a Simón Pedro pescador) y a los neófitos que sacamos del agua». Debemos recordar que el bautismo por inmersión era una ceremonia de iniciación de la religión cristiana. Así mismo, el

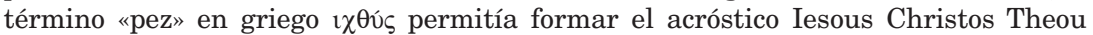
(H)Yos Soter (Jesucristo Hijo de Dios el Salvador).

Otra de las primeras imágenes símbolo fue la del crismón, que consistía en la simple yuxtaposición de las dos iniciales en griego de la palabra Cristo, que eran la X y la P. Sobre esta base se superpuso, a partir del siglo IV, la cruz, completándose el 
co frente a los demonios o el mal de ojo, sobre todo si soplabas en las manos antes de hacerla, pues la humedad del aliento, que recordaba el bautismo, redoblaba sus efectos.

Vivida así la constante presencia del Mal y con tan exiguos recursos materiales para enfrentarse a él, la lucha a la que se veía obligado el cristiano para vencerle terminaba por librarse en su interior. La nueva religión planteaba una radical oposición entre el Bien y el Mal, ya que dejando atrás ambigüedades se decantaba por un mazdeísmo encubierto en el que, sin embargo, el Mal obraba apoyándose en el libre albedrío de los seres, como lo demostraban la caída de los ángeles o el pecado de Adán. Dios sólo hizo el Bien, fueron los ángeles los que se rebelaron y corrompieron, lo mismo sucedió con los humanos; por tanto el mal, o los males, que padecían eran producto de sus decisiones, trasladándose así el sentimiento culpable del pueblo judío como colectivo al cristiano creyente como individuo.

$\mathrm{Al}$ interiorizar intensamente la relación con la divinidad la culpa cobraba un relieve especial, resultando ese modelo de relación con lo sobrenatural especialmente tenso, mucho más que el del éxtasis alcanzado en cualquier ceremonia ritual, ya que se transformaba en una vivencia cotidiana en la que el hombre se enfrentaba a la divinidad, no sólo desde la infinita nimiedad ante su creador, sino con la conciencia culpable, sabedor de que sobre él pesaba una falta, un pecado original ${ }^{8}$ cuya secuela se traducía en una innata tenden-

monograma con las letras alfa y omega, primera y última del alfabeto griego y resumen gráfico del principio y final de los tiempos.

Sin embargo, la cruz, que terminó por imponerse como signo universal, no apareció hasta el siglo III y debió de esperar hasta que, a instancias del emperador Constantino, comenzara a utilizarse de modo generalizado. En principio la cruz era tenida como infamante, ya que se veía en ella un instrumento de suplicio pero, según la leyenda, el emperador Constantino antes de la batalla contra su rival Magencio en el puente Milvio tuvo un sueño en el que se le apareció el instrumento del sagrado martirio al tiempo que oía una voz que le decía «In hoc signo vinces» (Lactancio, Sobre la muerte de los perseguidores, 44, 5). Tras su victoria el emperador mandó erigir una gran cruz en Gólgota y consiguió que se fuera imponiendo una lectura teológica de este signo como símbolo de la pasión y de la salvación.

8 La idea de un pecado original fue inicialmente expuesta por Pablo (Rom. 5, 12) y desarrollada por los Padres de la Iglesia, que se apoyaron para ello en dos pasajes del Antiguo Testamento, Job $(14,4)$ y Salmos $(50,7)$ a los que apelan Clemente de Alejandría, Orígenes, Atanasio y otros. También aparece en el apócrifo Libro de 
cia al mal, contra la que siempre debía estar alerta. La salvación prometida dependía de su fidelidad; sus actos y hasta sus pensamientos ponían constantemente en peligro su resurrección.

La psicologización y moralización de la vivencia religiosa llevará al cristianismo a reorientar el sentido de la ceremonia colectiva o del viejo ritual que pasarán a ser un mero signo sensible de la creencia convertida en paradigma. Lo que cuenta es la adhesión personal del converso a la fe, aunque sea contra viento y marea, sobre todo en los primeros siglos. Además, las aspiraciones ecuménicas de la nueva religión obligarán al cristiano a romper con las viejas prácticas del país o los cultos locales, para identificarse única y exclusivamente con su Iglesia. Una nueva hermandad universal, materializada en la comunidad de pertenencia, vendrá a sustituir los antiguos vínculos entre religión y etnia.

Así, la nueva fe buscará convertir al creyente en unidimensional con una sola tarea: su salvación. Se diluye la distinción entre las actividades habituales y la práctica cultual y ya no basta ser como los fariseos, estrictos cumplidores de la ley ritual, porque es en el interior de cada uno donde se libra la decisiva batalla contra el Mal. Como nos dicen los sinópticos: «...Lo que sale de la boca viene del corazón, y eso es lo que mancha al hombre. Porque del corazón vienen los malos pensamientos, los homicidios, los adulterios, las fornicaciones, los robos, los falsos testimonios y las injurias. Eso es lo que mancha al hombre; comer sin lavarse las manos (como era preceptivo en el estricto cumplimiento de la Ley) no mancha a nadie» (Mt. 15, 18-20; Mc. 7, 15, 20-23).

El cristiano como soldado de esa fe, que es la verdadera, debe enfrentarse con valor a los que la nieguen o tergiversen. El componente de intolerancia de la nueva doctrina donde primero se dejará sentir es en las luchas internas que se producen entre las diferentes tendencias por la afirmación de unas teorías frente a otras que

Esdras del siglo I. En esta obra se presenta a Adán como el autor de la caída del género humano (VII, 48), y como el transmisor a toda su descendencia de la mala semilla del pecado (III, 21-22; IV, 30). Aunque será Agustín de Hipona quien, en su lucha contra la herejía pelagista, termine de darle su forma teológica definitiva. 
serán consideradas heréticas. «Primogénito de Satanás» —nos dice Meeks (1994: 125)— pasará a ser un epíteto corriente para calificar al tachado de hereje; mientras que el interlocutor cristiano del Octavio, obra de Minucio Felix, llegará a declarar orgulloso: «vosotros los paganos no castigáis mas que los crímenes cometidos; para nosotros los cristianos, el mismo pensamiento es un pecado». La intransigencia inicial es de tal calibre que deja estrecho margen para el arrepentimiento ya que como dice Juan (1 Jn. 3, 8): «El que peca es hijo del diablo». Por eso todos los actos del cristiano estarán orientados por esa visión y en ellos los más íntimos ocuparán un lugar destacado. Es aquí donde la mujer y el sexo reaparecen para desempeñar su papel decisivo en esta nueva moral.

\section{No fue Adán el que se dejó engañar...}

La imagen de la mujer que nos brindan los Evangelios no es muy distinta a la que existía en Palestina cuando apareció Jesús. A pesar de los esfuerzos del feminismo creyente por encontrar en la figura del profeta un cambio en este sentido, la literalidad del texto y una interpretación histórica - y no teológica- del mismo dejan poco margen para la duda. Por el contrario, podríamos sospechar que se produjo un empeoramiento en esa situación que queda ratificado con los progresos iniciales de la nueva doctrina, suponiendo el cristianismo un cierto retroceso del estatus de la mujer respecto a la condición de la que llegó a disfrutar en el Imperio Romano.

Las mujeres apenas aparecen en los Evangelios y cuando lo hacen es siempre en un segundo plano. Nada, excepto el deseo de igualdad que mueve a algunas exegetas contemporáneas, nos permite aseverar que realmente fuera distinto a lo que el relato nos cuenta. Es verdad que en la comitiva de seguidores de Jesús figuraban mujeres, lo que no puede asombrarnos, como a Jean-Marie Aubert (1975: 21), que aprecia en esto un signo del talante innovador del mensaje evangélico; por el contrario, debemos interpretar el hecho como normal. Las mujeres, bien acompañando a sus maridos o simplemente como seguidoras del profeta, debieron de formar 
parte de ese cortejo o comunidad itinerante, cuyo núcleo central estaba, sin embargo, compuesto por hombres. El trasiego de gentes de ambos sexos por los caminos de Israel, en grupos más o menos numerosos, viajando por motivos económicos, religiosos o personales, era frecuente y nada nos hace suponer que no participaran en estos desplazamientos las mujeres e incluso los niños, como se desprende de algún pasaje del Evangelio (Lc. 2, 41).

En este sentido parece lógico que las mujeres estuvieran presentes en momentos cruciales de la vida de Jesús. Hemos de pensar que algunas de ellas se beneficiaron con sus curaciones y exorcismos y se convirtieron en adeptas entusiastas de su prédica. Es muy posible, como sostiene Tunc (1999), que llegaran a participar incluso en acontecimientos que a posteriori cobraron una enorme importancia, como la última cena, aunque lo significativo no es que lo hicieran, sino el silencio que guardan los evangelios sobre ese extremo.

Las menciones que nos encontramos sobre el tema las sitúan siempre en una posición de sumisión y servicio frente al varón, como por otra parte resulta lógico si atendemos a la mentalidad dominante. Mateo $(27,55-56)$ nos dice que acompañaron al Maestro en su muerte. «Estaban allí, mirando desde lejos, muchas mujeres que habían seguido a Jesús desde los tiempos de Galilea sirviéndolo». La frase resulta reveladora. Es muy probable que los romanos no les impidieran estar presentes en el lugar del suplicio, mientras que se debieron de mostrar mucho más recelosos con los amigos o partidarios varones del reo de sedición. Eso explicaría la presencia femenina en esos momentos terribles, no obstante el evangelista las coloca lejos del escenario de la tragedia, mirando a distancia la agonía del Maestro al que habían «servido» desde Galilea.

$\mathrm{Su}$ función queda explicitada en esta frase: las mujeres servían a Jesús y a sus seguidores varones, y en algunos casos, como tal vez ocurría con Juana mujer de Cusa, intendente de Herodes, «le ayudaban con sus bienes» (Lc. 8, 1-3) en función de su disponibilidad económica. Los nombres que aparecen en la narración son contados y de entre ellos destaca uno, el de María Magdalena, a la que el profeta habría exorcizado de siete demonios que la poseían 
(Lc. 8, 1-3). Este personaje, que parece tener un particular relieve en la historia - lo que justifica que en los apócrifos aparezca despertando los celos de los apóstoles-,${ }^{9}$ será confundido por la tradición cristiana con otras dos mujeres que protagonizan sendos encuentros con Jesús.

Una de éstas es la pecadora que cita Lucas (7, 36-49), la cual, arrepentida por sus faltas, se humilla ante Jesús con la máxima sumisión, lavándole los pies y secándoselos con sus propios cabellos. Una escena similar se repite con María de Betania, hermana de Lázaro. También ella unge al maestro con perfume que derrama sobre su cabeza, según Mateo $(26,6)$, y Marcos $(14,1)$, mientras que Juan le hace adoptar de nuevo la postura de rendida a sus plantas. Estos personajes terminaron por fundirse en la figura de la Magdalena por obra de Gregorio Magno que, en el siglo vi, en sus Homilias confundirá a las tres para hacer de María Magdalena el arquetipo de la pecadora contrita, creando así una imagen tremendamente atractiva de la seducción erótica vencida a los pies de la virtud, que tendrá un notable éxito en el imaginario cristiano posterior.

La actitud de comprensión, indulgencia y acercamiento, que en otras secuencias evangélicas adopta Jesús respecto a la mujer, y en la que se ha querido reconocer un giro copernicano del cristianismo sobre el tema, se correspondería con toda una corriente del pensa-

9 En algunos evangelios apócrifos como Los Hechos de Felipe, El Evangelio de María: Myriam de Magdala y, sobre todo, en el Evangelio de Tomás la importancia que se le atribuye a esta mujer es tan grande que en ellos se insinúa una pugna con los discípulos varones por las preferencias del Maestro. En esta competencia por el amor del profeta el más afectado sería el propio Pedro, al que se le hará exclamar en un arrebato: «Que María nos deje porque las mujeres no son dignas de la vida». Pero más allá de estos roces y de las preferencias que Jesús pudiera sentir por Magdalena, lo que queda muy claro en el Evangelio de Tomás es la visión que tiene el cristianismo inicial sobre la mujer y su papel a desempeñar en la nueva religión. El propio Mesías le contesta a Pedro: "Yo la guiaré para convertirla en varón de manera que también ella se convierta en un espíritu viviente semejante a vosotros los varones. Porque toda mujer que se haga varón entra en el reino del cielo».

Sobre la teoría de la equivalencia y subordinación, que fundamenta esta frase, hablaremos más adelante; ahora nos basta con apreciar cómo para gozar del reino de Dios hasta la misma Magdalena, a la que tanta importancia se le ha dado últimamente (Drewermann, 1996; Haldas, 1997), debía transformarse en hombre, ya que para la mujer como tal, el apócrifo no deja margen. 
miento moral judío de la época que, influido por el humanismo helenístico, buscaría suavizar la conciencia que en general se tenía sobre las mujeres en una sociedad despóticamente patriarcal. Nos encontramos con vestigios de esta postura en un libro tan misógino como el Talmud en el que, sin embargo, se atribuye al rabino Gamaliel - maestro de Pablo antes de su conversión- una anécdota en este sentido, ${ }^{10}$ aunque no sería ésta la única muestra de lo que estamos diciendo, ya que las mismas discusiones rabínicas, que tan apasionadamente se estaban produciendo por aquellas fechas, sobre los motivos moralmente válidos para ejercer el derecho de repudio, nos indicarían que un sector del clero judío buscaba reorientar la moralidad de las relaciones conyugales en un sentido aparentemente favorable a la mujer, impidiendo que el varón pudiera librarse de ella caprichosamente.

Es justamente en el marco de estas discusiones donde debemos encajar el pasaje evangélico en el que se pregunta a Jesús su opinión en la controversia, y que servirá al cristianismo posterior para justificar su rechazo al divorcio. Los fariseos inquirieron a Jesús: «¿Le está permitido a uno repudiar a su mujer por cualquier motivo?» (Mt. 19, 3; Mc. 10, 2; Lc. 16, 18). La contestación que da el profeta refleja la misma postura que sostenía el maestro Shammai, la única ofensa que puede justificarlo es la impudicia de la mujer, que algunas traducciones entienden como adulterio o unión ilegal. Con esta respuesta Jesús se oponía a las tesis de maestros rabínicos, como Hilell, para el que el repudio resultaba admisible hasta por quemar la sopa, o la aún más extrema del famoso maestro Akiba, que lo consideraba oportuno: «incluso si (el hombre) encuentra a una mujer más joven y más hermosa que ella» (Git. 9, 10).

10 Se atribuía a Gamaliel el siguiente cuento moral: «Dijo el césar... "vuestro Dios es un ladrón, pues está escrito: el Señor hizo caer un sueño profundo sobre Adán... y mientras dormía le tomó una costilla”. Entonces su hija (la de Gamaliel) le dijo "permíteme que le conteste yo"... Unos ladrones nos asaltaron anoche, nos arrebataron un jarro de plata y dejaron en su lugar un jarro de oro, a lo que el césar le dijo: “OOjála vengan contra nosotros todos los días ladrones como éstos!”. Y ella le indicó: “¿No fue también buena cosa para Adán que le tomaran una costilla y le dieran a cambio una mujer para servirle?"» (Guemará, Sanh. 39 a). 


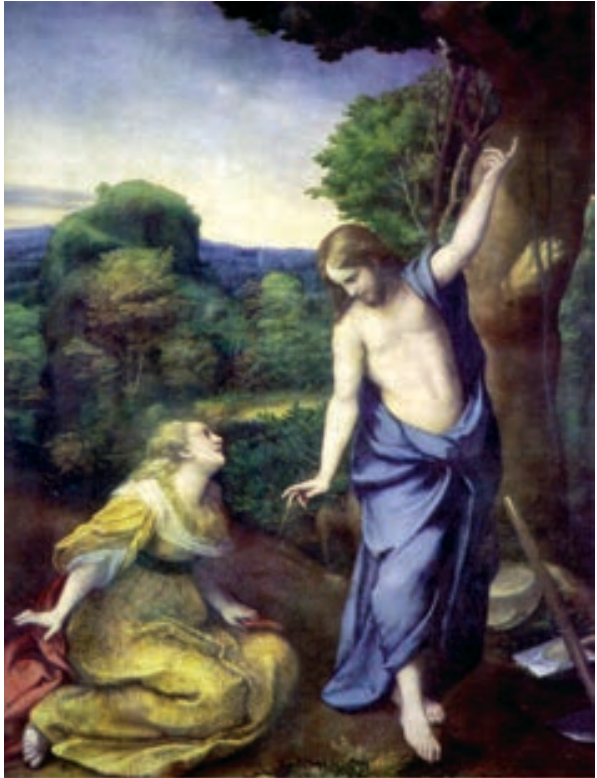

La mujer apenas aparece en el relato evangélico, solamente María Magdalena adquiere algún relieve. Sin embargo, en el Evangelio de Juan le cuesta reconocer a Jesús resucitado y éste le impide que se acerque a Él, como recoge el famoso cuadro de Correggio, titulado Noli me tangere (1518-1519).

La actitud de Jesús respecto al asunto no es distinta a la de toda esa corriente que, obsesionada más por la pureza sexual que por la justeza de la decisión, ${ }^{11}$ no rechazaban el repudio, pero sólo lo creían justificado en los casos de impudicia, por entender que actitudes más tolerantes daban pie a una cierta liberalidad sexual, mucho más abominable aún que el abandono de la mujer. Es en esta posición —en la que podríamos identificar rasgos del pensamiento esenio- donde los evangelistas colocan a Jesús, al que presentan con un talante extremadamente puritano, como se desprende de la sentencia que Mateo $(5,27)$ pone en su boca: «Oíste que fue dicho: No cometerás adulterio. Pero yo os digo que cualquiera que mira a una mujer para codiciarla, ya adulteró con ella en su corazón».

11 Mucho más explícito se muestra por las mismas fechas Filón de Alejandría, un judío helenizado, que en su obra Sobre la leyes especiales se manifiesta contrario a la disolución del matrimonio y al aborto, reinterpretando así en un sentido restrictivo tanto la institución del repudio como las alusiones sobre el aborto que aparecían en Éxodo (21, 22-23). 
La frase se inscribe en esa línea de moral que hallamos así mismo en el Talmud (Lv. R., 23, 12), donde aparece un aforismo similar que reza: "No solamente al que peca con su cuerpo se le llama adúltero, sino también al que peca con su ojo se le llamará así». Ésta era la principal preocupación evangélica, no la situación de la mujer, sino el pecado de la concupiscencia. No se trataba tanto de impedir el repudio, cosa que Jesús no hace explícitamente, sino de limitar las relaciones sexuales oponiéndose a las uniones múltiples y de condenar la atracción carnal. Aquel que tuviera contacto con una mujer repudiada o con un hombre separado cometería adulterio, ${ }^{12}$ e incluso aquel que pensara en ello lo cometería también.

Sólo cuando el sexo impúdico se interpusiera, el hombre podría rechazar a su mujer, negándole esta posibilidad a ella en caso contrario. Es cierto que en la mayor parte de las ocasiones era el varón quien ejercía el derecho, aunque el Éxodo $(21,7)$ establecía que la primera mujer podía hacerlo valer si el marido se casaba con otra y no le proporcionaba alimento o no cumplía con sus deberes conyugales. En este sentido la pretendida prohibición del divorcio establecida por Jesús - tan poco clara en el texto evangélico- supondría un cierto retroceso en los derechos teóricos de la mujer judía y terminaría, con el tiempo, cercenando claramente los de la mujer romana al imponerse el cristianismo en el Imperio. Como nos confirmará Pablo, el matrimonio indisoluble se admitía como un mal menor frente a la tentación del sexo del que el paradigma evangélico era María Magdalena, la pecadora arrepentida; y es que como dice Tunc (1999: 34), para los primeros cristianos «iEva se perfila siempre tras cada mujer!» y detrás de Eva aparece la serpiente, que es Satán mismo.

Pablo de Tarso al final de la Epístola a los Romanos $(16,20)$ nos dice: «El Dios de la paz pondrá en breve a Satanás bajo vuestros pies». Russell (1995: 233) interpreta que el apóstol identifica metafóricamente a Satán con la serpiente del Paraíso, estableciendo así un vínculo entre el origen del Mal en el mundo y la batalla final que

12 Así lo entiende un siglo después Clemente de Alejandría, que en su obra Stromata $(3,49)$ afirma: «Lo que Jesús quería decir es que un hombre casado que se haya divorciado de su esposa por su infidelidad no debe volverse a casar». 
contra él estaban librando los cristianos. Sea o no apropiada esta lectura, un tanto forzada del pasaje, lo cierto es que para Pablo la llegada del Cristo resucitado estaba próxima y que el Mal, aunque vencido por el sacrificio en la cruz, no había sido erradicado. Por eso, los cristianos tenían que estar alerta en ese momento crucial para no dejarse arrastrar por el Enemigo, manteniéndose en guardia frente a los ardides que éste había utilizado desde el principio de los tiempos. Lo que lleva al apóstol a recordar «que no fue Adán el que se dejó engañar sino la mujer, que seducida, incurrió en la trasgresión» (I Tim. 2, 11-14).

Su postura misógina y la de sus seguidores está fuera de toda duda ${ }^{13}$ y a pesar de que en la Epístola a los Gálatas $(3,28)$ nos dice que «ya no hay distinción entre judío y no judío, entre esclavo o libre, entre varón o mujer...» porque todos han sido redimidos sin distinción por Cristo Jesús, la realidad es que en los escritos que se le atribuyen juzga a la mujer como un ser inferior, que en todo momento debe estar sometida al hombre y apartada de los ministerios del culto.

En este sentido uno de sus pasajes más conocidos es el relativo al velo de las mujeres. Pablo, que luchó denodadamente por abolir las prescripciones de la Ley mosaica, transige y le parece oportuno que las mujeres asistan cubiertas a los actos religiosos. «Todo varón que ora o habla con Dios con la cabeza cubierta deshonra a Cristo, que es su cabeza. Y toda mujer que ora o habla con Dios con la cabeza descubierta deshonra al marido que es su cabeza... El varón no debe cubrirse la cabeza, porque es imagen y reflejo de la gloria de Dios. Pero la mujer es la gloria del varón, pues no procede el varón de la mujer, sino la mujer del varón; ni fue creado el varón por causa de la mujer, sino la mujer por causa del varón. Por eso y por respeto a los ángeles debe llevar la mujer sobre su cabeza una señal de sujeción» (I Cor. 11, 4-11). Lo largo de la cita abrevia el comentario, y aunque se ha intentado excusar la postura de Pablo alegando la

13 Los autores cristianos como Aubert (1975: 29-56) se muestran reticentes ante esta realidad y prefieren calificar la postura del apóstol como ambigua, achacándola a la misoginia imperante en la sociedad patriarcal y a las «influencias» judías de Pablo. 
influencia del medio, este argumento desmiente la actitud desafiante que el apóstol y el cristianismo en su conjunto adoptaron frente a otras prescripciones y costumbres, imperantes tanto en el mundo judío como en el pagano.

Pero si el uso obligatorio del velo, a pesar de la justificación mucho más profunda y patriarcal que el mismo Pablo nos da, podía interpretarse como una imposición ritual de poca importancia, en la misma Epístola (I Cor. 14, 34-36) reincide mandando callar a las mujeres en el seno de las comunidades cristianas, ya que bajo cualquier circunstancia debían estar sometidas a sus esposos: «Que las mujeres guarden silencio en las reuniones; no les está, pues, permitido hablar, sino que deben mostrarse recatadas, como manda la ley. $\mathrm{Y}$ si quieren aprender algo, que pregunten en casa a sus maridos...».

La justificación teórica a esta contradictoria actitud entre el mensaje de igualdad universal que postulaba el cristianismo, tal y como queda reflejado en la Epístola a los Gálatas, y la discriminación de género que realmente predicaba Pablo y que terminará adoptando la Iglesia, comenzó a elaborarse siglos más tarde con Agustín de Hipona, aunque fue Tomás de Aquino quien le dio forma definitiva con la doctrina de la «equivalencia y subordinación». Esta teoría (Borrensen, 1968), de factura helenística, que se fundamenta en la separación de alma y cuerpo, viene a decir que los varones y las mujeres son iguales en el plano del «alma», pero no en el plano «corporal», ya que son seres subordinados, dada su manifiesta inferioridad. Así pues, sólo el varón es un reflejo de la imagen de Dios, mientras que la mujer sólo lo es por su alma, por eso el varón se considera el principio y el fin de la mujer, como Dios es el principio y el fin de la creación.

Lo esencial de esta idea estaba ya presente en los líderes del movimiento desde sus inicios, como lo deja bien claro el mensaje paulino y, a pesar de que hay signos de una cierta resistencia inicial por parte de algunas mujeres, terminará por imponerse en la religión cristiana. Es cierto que la tradición nos habla de mujeres que en los primeros momentos llevaron una activa vida de apostolado, como Tecla, seguidora entusiasta de Pablo a la que el apóstol no se digna en mencionar una sola vez. También se puede constatar la existencia 
de diaconisas que ayudaban a los obispos en el bautismo de las mujeres e incluso en la prédica dentro de los gineceos donde tenían prohibida la entrada los varones, pero el bautismo de los niños hizo superflua su presencia y en el segundo Concilio de Orleans del año 553, se prohibió su ordenación por la «fragilidad de su sexo» (Canon 18).

Pero el recelo de Pablo ante la mujer no sólo venía dado por su naturaleza manifiestamente inferior, que ya habían teorizado los conductores religiosos y los grandes pensadores del pasado, sino, y sobre todo, porque la mujer era un instrumento eficaz en manos del Diablo y lo era por su poder de seducción, para atraer al hombre al pecado de impureza (porneia), el peor de los vicios en el que el humano podía caer.

Esta postura determinará las actitudes sexuales del cristianismo en los primeros siglos de su existencia. El apostol de los gentiles será el primero en exaltar las virtudes de la abstinencia y el celibato dentro de la nueva Iglesia, antes incluso de que aparecieran los pasajes evangélicos en este sentido, ya que la obra escrita de Pablo es anterior a la redacción del Evangelio de Marcos. ${ }^{14}$ Él mismo parece ser que era soltero y sus ideas sobre las relaciones sexuales, lejos de haber sido influidas por la tolerancia de su maestro Gamaliel, se alineaban en el entorno del ascetismo judío más estricto.

La impureza que tradicionalmente había acompañado a la mujer, aunque sólo fuera episódica, la alejaba de aquellos que ansiosamente buscaban el acercamiento a la divinidad a través de un camino de perfección. Estas ideas es muy posible que se vieran apuntaladas por las influencias del medio helenizado en el que se había educado Pablo, a través del cual debió de conocer la aversión platónica a la materialidad y la necesidad de una norma de vida basada en una espiritualidad catártica. Lo que vendría a sumarse a la negación del placer como vía del sufrimiento imitativo y purifica-

14 Tanto en Mateo como en Lucas aparecen desconcertantes declaraciones en boca de Jesús que avalarían las posturas más extremas de abstinencia sexual y en las que podemos apreciar influencias esenias. Mateo $(19,12)$ nos cuenta cómo Jesús elogia a los «que eligen no casarse por causa del reino de los cielos» y Lucas aún le hace decir algo más desconcertante frente a la tradición natalista judía, puesto que en el pasaje veintitrés, versículo veintidós, llega a afirmar: «Dichosos los estériles, los vientres que no engendraron y los pechos que no amamantaron». 
dor, dentro del esquema del sacrificio regenerador que el cristianismo terminará poniendo en circulación. ${ }^{15}$

Pero tal vez el factor de mayor peso para poder explicar la actitud de Pablo ante el tema fuera la profunda convicción que tenía ante la inminente llegada del Reino. En la Epístola a los Tesalonicenses (1 Tes. 4, 16-18) llega a decir: «Cuando se dé la orden, cuando se oiga la voz del arcángel, y resuene la trompeta divina, el Señor mismo bajará del cielo, y los que murieron unidos a Cristo resucitarán en primer lugar. Después, nosotros, los que aún quedamos vivos, seremos arrebatados junto a ellos entre nubes...». Su convicción de que llegaría a ver el final de los tiempos aún en vida era tan profunda que cualquier otra idea que no estuviera orientada a la salvación de su alma y a la preparación espiritual para ese momento se convertía en absolutamente secundaria. La familia, las obligaciones sociales y sobre todo el sexo pasaban a un segundo plano ante la inminente vuelta del Mesías Glorificado (Cor. 7, 32-37). Para el de Tarso todo aquello que distrajera o desviase la atención del cristiano de la tarea de prepararse para ese momento era nocivo para su salvación, por eso en la Primera Epístola a los Corintios insta claramente al celibato $(7,7-8)$ y llega a pedir que: «los que tienen mujer vivan como si no la tuvieran» (I Cor. 7, 29). Aunque consciente de la realidad en la que está sumido acepta como mal menor el matrimonio indisoluble: «Es mejor casarse que abrasarse» (I Cor. 7, 9) que es lo que les esperaba a los que se dejasen tentar por Satán y cayesen en la fornicación.

La idea de una absoluta castidad prendió en todo un sector del cristianismo inicial, que la convirtió en una seña de identidad de la nueva doctrina como muestra de renuncia total al mundo y de

15 El sufrimiento como expiación está ya presente en el pensamiento judío y se manifiesta desde los primeros balbuceos del cristianismo. Trocme (1972: 246), hablando de los primeros cristianos helenizados de la iglesia de Jerusalén nos dice que estaban movidos: «por una cierta sed de martirio que se expresa claramente en diversos pasajes del Evangelio según Marcos (especialmente los capítulos 8 al 10), documento que en su primera forma debió de surgir del grupo... Los helenistas hacían una exigencia fundamental: no se podía ser cristiano si no se sufría por Cristo y por el Evangelio. Esta idea tuvo un éxito, a veces inquietante, en la posterior historia del cristianismo antiguo». 
ardiente entrega a su fe. Apologistas y Padres de la Iglesia como Taciano el Sirio, Julio Casiano, Gregorio de Nisa o Jerónimo hicieron del rechazo total del sexo un baluarte de la lucha contra el Mal. Convencidos de la inminencia del final de los tiempos y de la naturaleza perversa de la relación, predicaron que la mejor manera de preparar el alma era la renuncia a todo lo material y especialmente al contacto carnal.

Muchos hombres de entre los primeros cristianos siguieron ese camino e incluso hubo mujeres que, a pesar de su enorme grado de dependencia respecto a los varones de la familia, optaron por él. No podemos descartar, como apunta Elizabeth Clarck (cit. en Pagels, 1990: 132), que entre damas de buena posición ésta fuera una salida para sus aspiraciones mucho más airosa que el matrimonio arreglado por los padres. En nombre de Cristo, estas mujeres al abrazar el celibato voluntario, podían «conservar el control de su propia riqueza (herencia), viajar libremente a través del mundo como "peregrinas santas", dedicarse a ocupaciones intelectuales y espirituales, y fundar instituciones que podían dirigir personalmente».

Sin embargo, otro sector más escéptico respecto a la parousia apreciaba que, aunque la batalla final contra el Mal había ya comenzado, el desenlace del conflicto estaba aún lejano, por tanto lo que había que hacer era mantenerse firmes y serenos en ese combate crucial. Por eso era necesario encauzar los instintos humanos de los fieles, orientándolos de modo conducente sin pretender negarlos de raíz. Para Clemente de Alejandría, uno de los defensores de esta postura, el matrimonio y la misma procreación no sólo no eran rechazables, sino que le parecían una manera de servir a Dios cumpliendo su mandamiento expresado en el Génesis (Sobre el matrimonio 7,57 ), por eso se oponían al aborto o el infanticidio - por medio de la exposición pública del recién nacido-, que admitían y practicaban los paganos.

Lo mismo defendía Ireneo, obispo de Lyon, que aseguraba que rechazar el matrimonio era alejarse de la obra de Dios. Ignacio de Antioquía acusaba de orgullo desmedido a aquellos que hacían de la castidad exagerada una seña de identidad de la perfección cristiana y Justino sostenía que de extenderse esa actitud, contraria a la 
voluntad divina, pronto no habría hombres en el mundo para servir a Dios. No obstante, todos transigían en que una minoría de hombres y mujeres, ansiosos de un mayor grado de perfección, abrazaran la abstinencia total y prefirieran la virginidad al contacto, aunque no toleraban que intentaran imponer sus tesis como más santas que las que ellos mismos postulaban, o que llegaran a considerar el matrimonio como «hierba amarga", tal y como aparece calificado en el Evangelio de los egipcios, ${ }^{16}$ equiparándolo a la misma muerte. Aunque también los moderados seguían manifestando profunda reticencia al placer derivado del sexo, ya que el mal no radicaba tanto en la unión de los cuerpos, sino en el deseo concupiscente que la acompañaba. Lactancio se pronunciaba contra todo "placer estéril y vano» (De Opificio Dei, XIII) y Orígenes consideraba que unirse sin buscar la procreación de los hijos era ultrajar la naturaleza, por tanto el matrimonio cristiano terminará por definirse como monógamo, indisoluble y exclusivamente orientado a la reproducción.

Así pues, antes de que el cristianismo triunfara convirtiéndose en religión oficial estaban ya apuntadas dos tendencias sobre el sexo en la nueva doctrina. Con el tiempo la realidad terminó prevaleciendo y triunfó una sin negar totalmente la otra. Los partidarios del matrimonio casto y natalista hicieron de sus opiniones las dominantes en el seno de la Iglesia y para ello se valieron de la figura del mismo Pablo.

Hoy se considera que del conjunto de escritos paulinos que aparecen en el Nuevo Testamento sólo algunos salieron realmente de la pluma del apóstol, mientras que otros como las Epístolas a Timoteo (I y II), la dirigida a Tito y, muy posiblemente, Efesios, Colonenses y la Segunda a los Tesalonicenses son escritos «deuteropaulinos» escritos por sus seguidores y atribuidos al de Tarso. Esto nos ayudaría a explicar las contradicciones que sobre el matrimonio figuran

16 Con el Evangelio de los egipcios ocurre lo mismo que con Los Hechos de Tomás, que no debe confundirse con el homónimo encontrado en Nag Hammadi, una obra totalmente gnóstica. El que mencionamos aquí es obra de comunidades heterodoxas egipcias de Tebaida y Libia, escrito en la segunda mitad del siglo II, y del que sólo nos han llegado fragmentos recogidos por otros autores. 
en unas Epístolas y en otras. Mientras que en algunas se vislumbra al Pablo auténtico, clamando por la abstinencia, en otras nos encontramos con un Pablo «doméstico» que teoriza sobre la familia cristiana (Ef. 5, 25-30).

El primero dejaría su huella en textos como los Hechos de Pablo y Tecla, un apócrifo, posiblemente del siglo II, en el que se puede leer (cit. en Pagels, 1990: 47): «Bienaventurados quienes preservan su carne pura, porque ellos se convertirán en el templo de Dios. (2 Cor. 6, 16). Bienaventurados los célibes, porque a ellos hablará Dios. Bienaventurados los que tienen mujer pero viven como si no la tuvieran, porque ellos heredarán a Dios (1 Cor. 7, 29). Bienaventurados los cuerpos de las Vírgenes, porque ellos complacerán a Dios, y no perderán la recompensa de su pureza (Mt. 10, 42)». Escritos de este tenor se difundieron entre las iglesias cristianas tanto de Occidente como de Oriente, donde se produjo un auténtico movimiento eremítico en el que muchos hombres y mujeres buscaron la pureza de sus cuerpos y la perfección de sus almas retirándose al desierto.

La tendencia más moderada contó, sobre todo, con el realismo y viabilidad de las ideas que defendían. Dionisio de Alejandría escribía al obispo de Cnossos para «exhortarle a no imponer a los fieles la pesada carga de la continencia como obligación, teniendo más bien en cuenta la debilidad de la mayoría» (cit. en Danielou, 1965: 162). Pero también encontró poderosos aliados teóricos entre los pensadores paganos.

Los filósofos y literatos del mundo antiguo nos dan testimonio de un giro en la moral sexual del Imperio, que comenzó a producirse a partir de la segunda mitad del siglo I. El estudioso francés Viene (cit. en Robert, 1999: 235) ha sintetizado muy acertadamente esa evolución cuando escribe que los romanos pasaron de una sexualidad exótica, inspirada en la «bisexualidad de la violación", heredada de época republicana, a la moral de pareja y la alabanza de la conyugalidad. Si bien las distintas corrientes de pensamiento diferían en cuanto a la postura a adoptar frente al matrimonio, todas coincidían, en mayor o menor medida, en defender la misma conducta sexual basada en la templanza, el dominio de uno mismo, el desprecio por las pasiones, y la exaltación de la virtud. 
Los filósofos, sobre todo los neoplatónicos, reactualizaban la contradicción existente entre la «carne», como plasmación de la materia en los humanos, y el espíritu; entre la materialidad del cuerpo, con sus pasiones irrefrenables y la inmaterialidad del alma, que debía domeñarlas; y todos coincidían en despreciar el placer físico a la vez que ponderaban el espiritual derivado de la meditación. Incluso los epicúreos, desde postulados hedonistas, se sumaban a esa idea que Lucrecio resumía al escribir: «Gozan siempre las almas racionales de un deleite purísimo y seguro, mejor que los amantes desgraciados...» (De la naturaleza de las cosas, IV, 1460).

Pero sobre todo eran los estoicos los que a través de conceptos como virtus, askesis y decorum propagaban esa nueva moral de la continencia y el ascetismo. Séneca le llega a decir a Lucilio que «el verdadero placer es el desprecio de los placeres» (Cartas a Lucilio $110,10)$, y criticando los vicios que hacen débiles a los hombres convirtiéndolos en malos ciudadanos, el cordobés escribe: «En primer lugar pongo a aquellos que jamás están desocupados sino para el vino y Venus, porque éstos son los más torpemente entretenidos; que los demás que pecan engañados con apariencia de gloria vana, yerran con cubierta de bien. Ora me hables de los avarientos, ora de los airados, ora de los guerreros, todos éstos pecan más varonilmente; pero la mancha de los inclinados a la sensualidad y deleites es torpe» (De la brevedad de la vida, VI).

Como único contrapeso a esa llamada a la temperancia el estoicismo esgrimía el principio del deber para con el Estado. Los buenos romanos tenían que seguir procreando para engrandecer el Imperio, por eso abundan las declaraciones favorables al matrimonio y a la natalidad, e incluso nos encontramos en Musonio Rufo, u otros, alegatos en contra del aborto y el infanticidio. Epicteto se anticipará en la argumentación a Justino cuando en defensa del matrimonio reproductivo critique a aquellos que sólo piensan en el placer extraconyugal o en el goce carnal, rechazando la unión legal, fecunda y responsable. «¿Qué pasaría? - les dice- ¿De dónde vendrían los ciudadanos? ¿Quién les instruiría?... No hay que ver la belleza en ninguna otra mujer nada más que en la propia.» 
Podemos decir que frente a la imagen estereotipada de una sexualidad romana como una perpetua bacanal, entregada a todo tipo de excesos -imagen que se encargó de fomentar la nueva religión- lo cierto es que el modelo de matrimonio cristiano, que se impondrá en la cultura occidental, nació a la par entre los pensadores estoicos del mundo romano. El mismo Epicteto (Pláticas, III, VII) lo resume con una frase que podría ser suscrita por la mayoría del cristianismo militante: «casarse, tener hijos, venerar a los dioses, cuidar a los padres...».

Las afinidades entre la moral estoica y la ideología cristiana, que han sido señaladas en numerosas ocasiones (Noonan, 1969; Puente, 1974; Robert, 1999), llegan a unos extremos insospechados, puesto que la aspiración ecuménica de la corriente filosófica unida a la humanitas que defendían, como una auténtica dignificación de la persona, le llevan a Marco Aurelio a decir: «el amor al prójimo es cualidad del alma razonable» $\mathrm{y}$ «es propio del hombre amar incluso a quienes le ofenden» (Meditaciones XI, 1; VII, 22). Pero más allá de estas formulaciones genéricas de amor universal los estoicos se van a encontrar con los cristianos en otros aspectos de la moral sexual. Convencidos de la existencia de un orden natural a través del que se manifestaba el Destino, fueron ellos los que acuñaron el término «contra natura» para condenar algunas prácticas que ya habían proscrito los judíos, como la homosexualidad que, lógicamente, también fue condenada por el cristianismo desde sus inicios (Ro. 1, 26-27).

No obstante, una diferencia fundamental entre estas posturas paganas y la moral cristiana era la motivación. Mientras que los filósofos romanos rechazaban ciertas actuaciones o modelos de relación en función de una serie de principios nacidos de la reflexión sobre el funcionamiento social, en el caso de los cristianos pesaba de un modo determinante, aunque no fuera el único motivo, el temor al pecado y al Mal. Partidarios de un matrimonio regulado o de una castidad extrema, todos los cristianos recelaban del sexo en general, y los varones, que construían la nueva creencia, del género femenino en particular, ya que al fin y a la postre eran las mujeres las que atraían a los hombres arrastrándolos a la concupiscencia. Esta diferencia resulta crucial para entender cabalmente la distancia que separa una ética filosófica de una moral religiosa, e incluso para poder comprender cómo la idea del Mal influye en la configuración de la sexualidad cristiana frente a otras religiones de la antigüedad. 
La castidad ya existía como valor religioso cuando apareció el cristianismo. Numerosos cultos paganos exigían a sus sacerdotes o adeptos algún tipo de abstinencia sexual. Ya hemos mencionado la virginidad necesaria durante sus años de servicio para las vestales. Los sacerdotes de Ceres, en África, debían abrazar el celibato y lo mismo sucedía con los que servían en el santuario de Delfos. Casi todos los ritos mistéricos prescribían períodos de abstinencia sexual como fórmula de purificación, dándose el caso más extremo entre los sacerdotes de Cibeles, que se emasculaban al considerarse casados con la diosa. Pero mientras que para todos éstos la sexualidad alejaba de la divinidad o suponía una cierta impureza transitoria, para los cristianos, la castidad, además, venía impuesta porque el sexo y la mujer acercaban al Mal.

Toda la literatura cristiana en sus inicios está plagada de alusiones de ese tipo. El demonio, el Diablo, o como se le quiera llamar, es una poderosa entidad masculina, pero siempre se había valido y se seguía valiendo del pecado de la carne para llevar a cabo su obra. El esquema ya establecido, mucho tiempo atrás, de la mujer como colaboradora eficaz del Mal volvía a ser recreado por el cristianismo que, sin embargo, lo envuelve en sexualidad por ser este placer el peor de los pecados. Así, mujer, sexo y Satán se revelan continuamente en una mezcolanza promiscua en el sentido más literal de la expresión para probar la fe de los Santos desde los primeros tiempos.

Tanto en los escritos ortodoxos como en los apócrifos de diferente signo aparecen relatos que recogen este arquetipo. Por ejemplo, en los Hechos de Tomás (cit. en Koning, 1979: 117), ${ }^{17}$ posible-

17 No debemos confundir los Hechos de Tomás con el llamado Evangelio de Tomás, que ya hemos mencionado. Los «Hechos» (S. Juan, S. Pablo, S. Pedro o S. Andrés) constituyen todo un ciclo dentro de los apócrifos cristianos, caracterizados por su ingenua fantasía y por la defensa de una extrema castidad. Focio considera todo el conjunto como una sola obra, atribuyéndola a Leucio Carino.

Por el contrario, el Evangelio de Tomás es uno de los primeros escritos cristianos, anterior incluso a los evangelios canónicos, y forma parte de la colección de manuscritos de Nag Hammadi, encontrados dentro de un recipiente cerámico a finales de 1945. Compuesta por más de 45 escrituras religiosas cristianas y paganas, se dispone en 13 códices escritos en copto, con un total de aproximadamente de 1100 páginas. El «Evangelio» recopilaba una serie de proverbios atribuidos a Cristo. 
mente del siglo II, una mujer se confía al apóstol diciendo estar poseída por un demonio lujurioso que despierta en ella voluptuosos deseos. Tras ser exorcizada por Tomás, recibe el bautismo e ingresa en la comunidad cristiana. El tema de la posesión, que tan frecuentemente recogen los evangelios canónicos, se sexualiza en este caso anunciándonos lo que va a ser un tema recurrente en la literatura de esta naturaleza. Pero mientras que en ningún momento dentro del canon evangélico se establece la relación entre posesión y sexo, en la producción cristiana se convertirá en un lugar común. El mismo error de Gregorio Magno al confundir a María Magdalena con la mujer adúltera vendría a confirmar lo extendido de este recurso literario-moral tan abundante en la patrística.

El punto de arranque lo encontramos en los tópicos sobre el origen del Mal elaborados por los judíos para arremeter contra la mujer, que recogerán los Santos Padres. Así, Justino Mártir, Lactancio o el mismo Tertuliano (Apologético) rescatan la historia de la voluptuosa unión entre los ángeles y las «hijas de los hombres». $\mathrm{Al}$ primero le servirá como explicación de la enorme abundancia de demonios que infestaban la tierra. Sostenía que los ángeles copulaban con las mujeres y así nacían estos espíritus malignos para tentar a los varones, no sólo con el pecado de la lujuria, sino con todos los vicios imaginables (Apología de Antonino Pío). Lactancio pondrá el énfasis en la responsabilidad de la mujer en el origen del Mal, siguiendo el Génesis $(6,1-7)$ sostendrá que los ángeles que «conocieron» a las mujeres realmente habían sido enviados por Dios a la tierra para protegerlas frente a Satán, pero que ellas terminaron por seducirles con sus encantos y los convirtieron así en servidores de aquél (Instituciones divinas, II, 8).

Estos antinaturales contactos en el origen de los tiempos se vulgarizarán en la pluma de los escritores cristianos al transformarlos en una procaz manera de intervención del Diablo en lo cotidiano. Ya no se trataba de la posesión de un cuerpo por un espíritu maligno para causar la enfermedad o la perversión moral, sino que, inspirándose en leyendas como la de Lilith, se invertían los términos y era el demonio masculino el que copulaba directamente con la mujer. Estas singulares coyundas entre carne y espíritu, que por 
otra parte estaban en la base del cristianismo al admitir la milagrosa concepción de Jesús, generaban curiosos problemas teológicomorales a los tratadistas.

Basilio, padre de la Iglesia, en su obra La verdadera virginidad especula sobre la violación de una virgen por un demonio y se pregunta si su castidad física operaría como una auténtica barrera contra la posesión satánica o si por el contrario podía suceder que una mujer virgen consintiera mantener contacto con el demonio perdiendo así su alma pero conservando su himen intacto. También se planteaba una variante del problema: ¿Qué podía suceder cuando la violación hubiera sido efectuada por un hombre contra la voluntad de su víctima? Ese supuesto, desgraciadamente mucho más corriente que el anterior, llevaba a los cristianos a cuestionarse si esa mujer seguía siendo virgen a pesar de todo. Basilio se inclina por considerarlo así, haciendo de la virginidad una virtud del alma que no guarda relación con el hecho físico de la desfloración.

Pero la manera más habitual del Diablo de valerse de la mujer en su actividad era aprovechar la sensualidad de su cuerpo para ejercer la tentación sobre el varón. Hipólito fue uno de los primeros que sufrió estos asedios eróticos en forma de demonios femeninos que, desnudos, se le aparecían por las noches para seducirle y atraerle al pecado. Antonio el ermitaño padeció el mismo tipo de asaltos en un sin número de ocasiones en las que el Diablo, con atractivas formas de mujer, le sometía a visiones lujuriosas para perderlo, tal y como nos cuenta Atanasio en la biografía que escribió sobre él: «El perverso demonio entonces se atrevió a disfrazarse de mujer y hacerse pasar por ella en todas sus formas posibles durante la noche, sólo para engañar a Antonio. Pero él llenó sus pensamientos de Cristo, reflexionó sobre la nobleza del alma creada por Él, y sobre la espiritualidad, y así apagó el carbón ardiente de la tentación» (Vida de Antón).

Hilarión, otro eremita que desde su adolescencia vivió en el desierto, padeció las mismas tentaciones, según nos narra Jerónimo: "Muchas y variadas fueron las tentaciones y las insidias del demonio, tanto de día como de noche; si quisiera narrarlas todas excedería los límites de este libro. ¡Cuántas veces, mientras estaba acosta- 
do, se le aparecieron mujeres desnudas; cuántas veces, estando hambriento, vio suculentas comidas!» (Jerónimo, Vida de Hilarión).

El mismo Jerónimo sufrió parecidas experiencias a las que hace mención en una carta escrita a Eustaquio, aunque en este caso el demonio actúa a través de la imaginación del santo: «Pues bien; a pesar de que no tenía más compañía que la de escorpiones y fieras, mi imaginación frecuentemente se me escapaba y forjaba en mi fantasía escenas de bailes con jóvenes hermosas. ¡Qué cosa! Mi cuerpo estaba helado, mi carne prácticamente muerta, y, sin embargo, así y todo, sentía en mis miembros arder la llama de la concupiscencia» (Santiago de la Vorágine, La leyenda dorada).

Rufo, otro ermitaño, cuenta cómo un monje, eremita como él, sucumbió a la tentación y cuando iba a consumar el acto la hermosa mujer que le incitaba se esfumó lanzando una carcajada y dejándolo sumido en el tormento de la culpa. La leyenda dorada, escrita muchos siglos después, recoge de la tradición y de escritos de esta primera época numerosos relatos de semejante naturaleza.

Como vemos Satán y la mujer tienen una estrecha vinculación que, en ocasiones, es deseada e inducida por medio del maleficio que ésta utiliza para invocar a aquél. En Agustín de Hipona va a aparecer por primera vez la idea de un pacto diabólico, que tanta repercusión tendrá en época posterior. En La ciudad de Dios (VIII, XIX), condena en general cualquier tipo de práctica mágica, como ya habían hecho las religiones anteriores, pero introduce un matiz especial, consustancial a la nueva doctrina. Si el mago o la bruja se ven obligados a solicitar para sus prácticas la intervención de alguna fuerza o divinidad, que forzosamente no puede ser la de Dios al que se le reza o se le pide por medio de la oración en el seno de la Iglesia, esa potencia oscura deberá ser de naturaleza maligna. La deducción de lo que estos contactos implicaban la establece en De doctrina cristiana $(11,20)$, donde llega a la conclusión de que entre esos demonios y quien los invoca se establece un pacto de obligación mutua. Con esta formulación, el núcleo del contrato satánico, que tan presente estará en la caza de brujas siglos después, aparece ya apuntado (Dexmüller, 1997: 89; Schmitt, 1992: 25). 
Las tradicionales prácticas mágicas ya no sólo suponían una competencia frente a la nueva divinidad del cristianismo, sino que implicaban necesariamente la concurrencia del Diablo en esas artes. Clemente de Alejandría ( $E l$ Pedagogo III, 4) recoge esta interpretación al hablarnos de aquellas criaturas que: «alimentan las habladurías de las viejas, escuchan la buenaventura de los hechizos y encantamientos con el fin de arruinar las relaciones conyugales». Cesario de Arlés lo secunda al condenar el uso por parte de los galos de hierbas, amuletos y «signos diabólicos» utilizados en una «medicina sacrílega» con el fin de curar la esterilidad y de regular la natalidad (McLaren, 1996: 136).

La mayor parte de la carga misógina apreciable en estos escritos está vinculada al pecado y al sexo, más que a las tradicionales argumentaciones referidas a las carencias o debilidades propias de la naturaleza femenina. Es cierto que nos podemos encontrar con manifestaciones despreciativas en ese sentido, como las que vierte Juan Crisóstomo (cit. en Koning, 1974: 289) cuando, en línea con el Eclesiastés, ataca a las mujeres diciendo: «Qué es la mujer, más que una enemiga de la amistad, un castigo inevitable, un mal necesario, una seducción elemental, una desdicha rebuscada, un peligro doméstico, un daño delicioso, un perjuicio natural y pintado con atractivos colores...». Pero incluso en este caso, en que la retahíla de improperios podría ser suscrita por muchos autores paganos - que el mismo Crisóstomo cita como fuentes de autoridad sobre la materia-, al final de la argumentación aparece el pecado: «...en las invectivas que leemos contra las mujeres, la palabra hembra indica el placer de la carne».

Tal vez, la descalificación que mejor recoge la naturaleza sobrenatural de la misoginia cristiana la formula Tertuliano ( $E l$ adorno de las mujeres, I, 12) cuando dice: "Vosotras sois la puerta de Satanás... tú (mujer) eres la que le convenció a él a quien el diablo no se atrevió a atacar... ¿No sabéis que cada una de vosotras es una Eva? La sentencia de Dios sobre vuestro sexo persiste en esta época, la culpa, por necesidad, persiste también».

Es cierto que Tertuliano se muestra groseramente explícito respecto a la postura del cristianismo inicial frente a la mujer, pero no 
es menos cierto que su exabrupto sólo peca de ser contundentemente explícito. Su misoginia, apreciable en toda su obra, no traiciona en lo más mínimo lo que era una creencia generalizada incluso entre las mujeres cristianas, atormentadas por su triste condición. Fuera cual fuese la actitud que adoptaran los creyentes frente a la sexualidad, tanto los moderados partidarios del casto matrimonio para procrear servidores de Dios, como los que clamaban en defensa de la virginidad, todos pensaban que la mujer resultaba un peligro para la salvación.

Aunque Justino consideraba a la serpiente «príncipe de los demonios malos» lo cierto es que durante todo este largo período de gestación del cristianismo la asociación del pecado con la serpiente, como antiguo símbolo de la fertilidad de la mujer, desaparece de modo explícito y sólo se puede establecer por vía indirecta. Sólo se alude a la serpiente como encarnación del Diablo, como hace Jerónimo por influencia del Apocalipsis de Juan, o como un animal taimado, repugnante y tal vez mortal. Y es que la mujer ya no representa para la inmensa mayoría del cristianismo lo que antaño representó, una fuerza vivificadora aunque inquietante, sino que simplemente aparece como un peligro: el de la tentación de la carne.

Esta condena del sexo, y por ende del género, abarcaba todos los aspectos de la misoginia preexistente, con la diferencia de que involucraba al hombre contaminándolo con una culpa moral que podía suponer su perdición eterna. Nunca hasta entonces la relación entre el Mal y la mujer se había establecido de forma más acabada y nunca hasta entonces había acarreado riesgos de tal orden.

El único reducto aparente en el que se refugiará durante un tiempo la antigua imagen enaltecida de la feminidad será el de la herejía. Las desviaciones heréticas se multiplicaron en los primeros siglos como síntoma evidente del proceso de construcción del dogma. De entre las muchas que afloraron, tal vez, una de las más atrayentes sea la gnóstica. La gnosis recuperaba muchos de los elementos de los viejos cultos y creencias del pasado, reciclando para el cristianismo toda una carga mistérica que la nueva religión se esforzaba en disolver en el mensaje revelado. 
Los gnósticos, por el contrario, se empeñaban no tanto en creer como en conocer, ya que frente a la fe oponían el conocimiento. Según sus creencias ellos eran los seguidores de unos pocos iniciados a los que Cristo habría revelado los secretos más profundos, orientándolos de ese modo en el camino de la verdadera salvación a través de la redención interior del hombre. Éste era el punto de partida para una enorme variedad de interpretaciones sobre esos misterios, por eso la gnosis nunca actuó como una doctrina unificada frente a la Iglesia ortodoxa. Por el contrario, se manifestó tremendamente rica y fecunda, desplegándose en numerosas corrientes como los valentinianos, los basilidianos, los cainitas y otras.

Todas ellas creían en una serie de mitos fuertemente impregnados de mazdeísmo y platonismo en los que se solía distinguir entre alma y espíritu. La primera, en terminología moderna, se podría equiparar con el sistema psicocognoscente entendido como mente y sensación, mientras que el espíritu sería aquella potencia que nos permitiría trascender a las esferas más elevadas del conocimiento perfecto. En esta curiosa dualidad cognoscente, los gnósticos reservarían a la naturaleza femenina el dominio del espíritu por considerarla, todavía, como el principio de la vida que une a los humanos con su misma trascendencia. Esta interpretación será el canto del cisne, antes del fin del mundo antiguo, de ese viejo arquetipo cultural presente desde los orígenes de la humanidad. Lo femenino, como paradigma de la vida, se transformará en las teorías gnósticas en la fuente del espíritu, en el principio del auténtico conocimiento, de la verdadera redención humana, y lo hará valiéndose en algunos casos del antiquísimo símbolo de la serpiente.

En el apócrifo gnóstico titulado La hipostasis de los arcontes y recogido por Pagels (1990: 105-106) nos encontramos con este bello relato del Génesis:

Entonces el Principio Espiritual femenino llegó (en) la Serpiente, la Instructora; y les enseñó diciendo, «¿Qué es lo que (os) dijo?». ¿Fue esto: «De todos los árboles comerás; pero del (árbol) del conocimiento del mal y del bien no comerás»?

La mujer carnal dijo «No sólo dijo: "No comáis" sino "No lo toquéis; porque el día en que comáis de él, de muerte moriréis"». 
Y la Serpiente, la Instructora, dijo: «de muerte no moriréis; pues por celos os dijo eso. En cambio vuestros ojos se abrirán y seréis como dioses, conocedores del mal y del bien». Y el Principio Instructor Femenino abandonó la serpiente...

En este mito gnóstico es la feminidad la que insta a la rebeldía no para hacer caer a los humanos en la desgracia y en la muerte sino para brindarles el conocimiento que les permita, al menos, asumirlas y, en la línea de sus creencias, trascenderlas. Y lo hace desde la perspectiva precisamente de la superación de la fractura de género, ya que algunas escuelas gnósticas se verán influidas por la idea de un andrógino primitivo, que también contempla Platón en el Banquete (189d - 191e), y en la que el hombre y la mujer, en pie de igualdad, se concebían creados como humanos a imagen de Dios, resumen de ambos sexos. Sólo a ese «ser humano» completo le estaba reservado el auténtico conocimiento si era capaz de seguir el camino marcado por el espíritu. No pensemos que todo el movimiento gnóstico participó de la misma visión sobre lo femenino. El Evangelio de Tomás, con claras influencias gnósticas, nos ha servido más arriba para ilustrar la tesis contraria, en la que la mujer debía masculinizarse para entrar en el Reino, olvidando así la confluencia de género.

No obstante, ambas interpretaciones estaban condenadas con el triunfo del cristianismo. Convertida la Iglesia en Imperio Católico, la herejía, junto con la serpiente, encarnación del demonio e imagen antigua de la feminidad divinizada, serán vencidas, como pronosticara Pablo, aunque se deberá seguir esperando para verla definitivamente aplastada. 


\section{UN LARGO EPÍLOGO}

A finales del mundo antiguo lo esencial estaba dicho y el medioevo sólo introducirá variaciones complementarias sobre el discurso misógino y el Mal. Incluso se puede afirmar que frente a la creencia tan generalizada sobre estos siglos oscuros como los de la apoteosis de Satán y el sometimiento de la mujer a su imperio, durante un largo período de tiempo no fue así. Por el contrario, lo que detectamos es un cierto retroceso en el poder Diablo y una recuperación de la feminidad cristianizada a través de la figura de la Virgen.

El culto a la mujer en el cristianismo sólo era cuestión de tiempo. En los albores de la nueva religión todo giró en torno a la definición de su figura central, Jesús el Cristo, pero resulta difícil imaginar cómo esa doctrina, con vocación totalizadora, podía prescindir de la mujer y no conferirle un espacio adecuado en el conjunto de sus creencias, haciendo abstracción evidente de la misma realidad material. Lo femenino en el cristianismo no podía limitarse a esa mirada suspicaz sobre la mujer como causante de las desdichas humanas e instrumento en manos del Mal. Tarde o temprano debía abrirse un espacio que permitiera reciclar, al menos en parte, el viejo arquetipo de lo femenino como raíz de la vida. Y aunque desde sus inicios María ocupa un lugar importante, en función de la naturaleza milagrosa de su maternidad, le costará alcanzar un reconocimiento más profundo, y no meramente instrumental.

Es cierto que en el Evangelio de Lucas nos encontramos con un pasaje, denominado tradicionalmente como el "Magnificat» (Lc. 1, 32-43), en el que se exalta la figura de María designándola como Madre del Altísimo y Bendita entre todas las mujeres, sin embargo la misma Iglesia católica reconoce que las escuetas ocho menciones en todo el texto evangélico en las que se hace referencia a la Virgen 
podrían parecer escasas, dada la importancia que posteriormente ha tenido. Un signo evidente de esta inquietud es la abundante exégesis desarrollada más tarde para relacionarla con otros pasajes bíblicos. Pero lo cierto es que, excepto Lucas, el Nuevo Testamento no le presta apenas atención, llegando a desaparecer casi totalmente en Los Hechos, en los que se la nombra de pasada en una sola ocasión (Hch. 1, 14), dejando así que sean los apócrifos los que nos fabulen algunos avatares de su vida, como ocurre en el Protoevagelio de Santiago. ${ }^{1}$

Podemos decir que sólo es a partir del siglo IV cuando surgirá un culto específico y diferenciado a María, a pesar de encontrar indicios apologéticos anteriores en Justino, Tertuliano, Irineo, etc. Pero si el culto popular se afirma a finales de esa centuria con el triunfo del cristianismo, sus primeras señales se podrían remontar al siglo III en el que ya se le dirigían a María oraciones como el Sub tuum praesidium, del que se encontró, en 1938, una copia papiracea cuya datación se remontaría a aquellas fechas. También tenemos noticias de la que sería su primera aparición milagrosa a Gregorio el Taumaturgo, que murió en el año 270, aunque el dato lo conocemos tiempo después a través de la vida de este santo escrita realmente en el siglo IV por Gregorio de Nisa. Y respecto a la iconografía, tan importante para el cristianismo, sólo se recogerá su figura, de modo nítido desde el siglo VI, sobre todo a través del arte oriental, aunque han llegado hasta nosotros algunas representaciones (sarcófago de la catedral de Tolentino) correspondientes al siglo III.

Realmente es tiempo después cuando María cobra la suficiente entidad como para convertirse en problema teológico, al negarle Nestorio el título de «Madre de Dios», lo que obligará al Concilio de Efeso (431) a proclamar que la Virgen era Theotokos en el verdadero sentido de la palabra, o sea la que había dado a luz a Dios mismo. Éste es el momento culminante de su consagración y todas las

1 El Protoevangelio de Santiago es un apócrifo de mediados o finales del siglo II, que pretende llenar los vacíos de los Evangelios canónicos con relación a María. Con un marcado carácter fantástico incide sobre todo en el misterio de la virginidad, cayendo incluso en lo grosero, con el fin de afirmar mejor este dato clave en el cristianismo a través del que se cumplía la profecía de Isaías $(7,14)$ sobre el nacimiento del esperado Mesías. 
demás gracias que la Iglesia le irá sumando no podrán compararse con ésta, que la elevaba de humilde madre de un mesías para algunos judíos, a madre de Dios para toda la catolicidad.

Muchos siglos antes de nuestra era, ese prototipo mítico consagrado en Éfeso había arraigado en Oriente Próximo. Al igual que tantas diosas madres como Deméter, Isis, Astarté o Cibeles, María dio a luz un dios hecho hombre, que murió por la salvación de la humanidad, resucitó a los tres días para luego retornar al final de los tiempos. Sin embargo, el cristianismo monoteísta y patriarcal tardó siglos en recuperar el mito. Tradicionalmente se han aducido razones diversas para explicar esa tardía incorporación, como los prejuicios evidentes del medio patriarcal, la focalización en la figura de Cristo y el necesario esclarecimiento sobre su misma naturaleza, el rechazo a los cultos femeninos paganos... Todos estos argumentos sin duda tienen validez pero no terminan de aclarar por qué a partir de un momento impreciso se comenzó de nuevo a tolerar el culto a la mujer para terminar institucionalizándolo. Deberemos, una vez más, remitirnos a la realidad material para poder entenderlo.

A partir del siglo III el Imperio Romano se sumió en una profunda crisis en todos los campos que le conducirá a una lenta agonía antes de su definitiva disolución a causa de las invasiones bárbaras, doscientos años después. Los bárbaros no se abatieron sobre Roma destruyéndola, sino sobre un Imperio que se desmoronaba e intentaba evitar el derrumbe valiéndose, precisamente, de tropas bárbaras.

Desplazada su capital primero a Milán y luego a Rávena, el Imperio sólo tenía de romano el nombre. Los gastos para hacer frente a la defensa de las fronteras hacía mucho tiempo que se habían revelado exorbitantes. A partir del siglo III la hacienda del Estado se vio obligada a arrancar a los ciudadanos impuestos y cargas fiscales cada vez más onerosas. La élite civil, exangüe, fue reemplazada en el poder por el ejército y los grandes terratenientes provinciales. El paso de la toga republicana, distintivo de la clase gobernante, o los emblemas heráldicos de la nueva sociedad, organizados jerárquicamente, sirven para simbolizar esos cambios. 
Al desaparecer la clase media de hombres libres, las masas rurales antes que someterse al yugo de los bárbaros o a la arbitrariedad de los bandidos, buscaron protección cerca de los hacendados, quedando, no obstante, reducidas a la pobreza y a la servidumbre en los grandes latifundios. Porque entre otros efectos, uno de los más profundos de esta crisis será el lento pero imparable proceso de ruralización de la economía, que terminará por configurar un nuevo modo de producción que marcará la vida de los hombres en los siglos siguientes.

La ruralización constituyó un factor muy importante en la vida material y espiritual de las gentes en los últimos siglos del Imperio. La falta de mano de obra acompañada del declive de la esclavitud y la interrupción del comercio debido a la inseguridad reinante, junto con la presión ejercida sobre las fronteras por germanos y persas, paralizaron casi totalmente la antes floreciente actividad económica, supusieron la decadencia de la vida urbana, el retroceso de la población, y el éxodo de muchos de los habitantes de la ciudad al agro, donde resultaba más fácil la supervivencia.

Los intentos por parte de las autoridades para frenar esa tendencia quedan reflejados en las numerosas medidas que adoptaron en ese sentido. Ya desde el siglo IV se decretaron disposiciones severas, que llenan varios títulos del Código Teodosiano, en las que se advertía a los curiales de las ciudades que el abandono de su «patria» era un acto impío y se les amenazaba con la confiscación de las tierras que fueran a ocupar en el campo. Pero la tendencia al colonato y a la concentración de la propiedad agraria era imparable $\mathrm{y}$, un siglo después del inicio de la crisis, el dominatus, como forma de grandes posesiones dispersas, llenaba todos los rincones del Imperio imponiendo un tipo de economía autárquica.

En el Tratado de Agricultura de Paladio, escrito a finales del siglo IV, se recomienda la utilización en las fincas de artesanos especializados a fin de que los campesinos no tuvieran pretextos para trasladarse a la ciudad. El consejo resulta significativo en la medida que viene a ratificar esa tendencia a la autosuficiencia basada en la unidad de producción agrícola. Como nos dice el historiador italiano Bernardi (1975: 57): «La economía feudal o del señorío, de la 
Edad Media, se hallaba a la vuelta de la esquina»; y en esas nuevas relaciones que se estaban imponiendo, la familia, como célula de trabajo y mantenimiento, iba a cobrar una mayor importancia que en la época anterior.

Anderson y Zinsser (1992: 144, vol. I) nos recuerdan que: «A través de los siglos una mujer y un hombre sobrevivían en el campo, y podían albergar esperanzas de futuro viviendo en el seno de una familia. Sólo con la ayuda de los otros podían los campesinos terminar las labores perpetuas que aseguraban la subsistencia y armonizar los desafíos y el caos periódico en sus vidas». La frase no puede resumir mejor un hecho social milenario. La unidad familiar campesina es, en primer lugar, y ante todo, una unidad de producción y en la medida en que esa unidad se mueve en un grado de autarquía económica mayor, el papel de la mujer se acrecienta. El aporte del trabajo femenino en numerosas tareas domésticas y agrarias la convierte en un elemento imprescindible para la supervivencia del grupo y de los varones que lo componen.

No se puede negar que la mujer encontraba en este modelo un determinado grado de protección frente a la violencia o agresión exterior, pero no es menos cierto que aportaba en mayor medida que recibía, sobre todo en forma de trabajo comunitario vertido en las más diversas ocupaciones para las que había sido adiestrada desde hacía siglos. La preparación de los alimentos, el tejido de los vestidos, el cuidado de la prole y los ancianos se complementaban con las labores en el huerto o las faenas más penosas en los momentos cruciales del año agrícola. La crisis en la mano de obra esclava y la semiparalización del intercambio a finales del mundo antiguo sirvió, en el marco de la economía campesina, para revalorizar la función de la mujer en el seno de la familia. La artesa de amasar y la rueca sirvieron más en la recuperación de su imagen por el cristianismo que el mismo mensaje evangélico.

La figura de la Virgen María se beneficiará de estos cambios, así como de otros de orden muy distinto. Nos referimos al culto a los mártires que la Iglesia primitiva comenzó a tolerar a la par que crecía la devoción por la Madre del Creador. Esta manifestación de religiosidad, que no alcanzará una cierta entidad hasta la oficialización 
de la Iglesia, veneraba a aquellos cristianos que por su fidelidad habían entregado sus vidas antes que renegar de su fe, encontrándose por tanto ya junto al Señor.

Algunos aspectos de este tipo de devoción inquietaban con razón a las autoridades eclesiásticas, ya que en ellos veían rebrotar formas y creencias paganas. Las historias de los santos mártires recordaban en ocasiones a los viejos mitos grecorromanos y el entusiasmo que despertaban entre la masa las pretendidas reliquias de estos héroes de la fe, podía guardar relación con prácticas rituales próximas a la superstitio antigua. Sin embargo la Iglesia triunfante las consintió, aunque intentó encauzarlas. El mismo Agustín de Hipona se mostró inicialmente en contra, y con él se alzaron otras voces autorizadas anunciando los peligros que entrañaban, pero acabó transigiendo a raíz del traslado a su diócesis de las reliquias del santificado Esteban y de los milagros que operaron.

La razón de esta postura hemos de buscarla en la resistencia que encontraba la nueva doctrina en el medio campesino. ${ }^{2}$ Las masas rurales se aferraban a sus creencias, y su vida religiosa seguía alimentándose de prácticas ancestrales relacionadas con fuerzas de la naturaleza, con lugares sagrados y con celebraciones cuyo origen y significado se perdía en un pasado remoto.

En el marco de esa resistencia se operó un fenómeno de inversión. El cristianismo terminó por aceptar esas prácticas siempre que los campesinos transigieran en su conversión y modificaran algunos de sus aspectos cristianizándolos. Como nos dice Guignebert (1966: 178), «En muchos casos (el cristianismo) termina por imponerse por la lenta penetración de la presión diaria; en otros, hace el milagro de convertir de golpe un pueblo y hasta una región más extensa. Lo más frecuente es que proceda por sustitución; traspone en su provecho leyendas y supersticiones, y el culto de los santos le hace esta operación sumamente fácil».

2 Recordemos que el término «pagano» deriva directamente de pagus, «campo» en latín. La asimilación de las dos voces, hoy está probado que se operó en la primera mitad del siglo IV, generalizándose poco a poco en la segunda. 
La veneración de los santos mártires, y sobre todo la creencia en su autoridad e intercesión para conseguir lo que se les pedía, facilitó el bautismo de los campesinos. Se atesoraban sus reliquias y se tenía fe en los milagros que aquellos a las que habían pertenecido operaron en vida, así como los que podían obrar, a través de ellas, una vez desaparecidos.

Se les consagraron iglesias en los antiguos emplazamientos de los templos paganos o en los primitivos lugares de culto; los días de su muerte se convirtieron en fiestas que vinieron a sustituir los ritos de antaño. La importancia de los obispados empezó a guardar una relación directa con estos cultos, lo que permitió que primitivos localismos religiosos quedaran a salvo. Así, desde los espacios materiales hasta la cristianización del tiempo sagrado, todo contribuyó a esa paganización de la nueva religión que dio como resultado la pervivencia del politeísmo entre las gentes sencillas.

En medio de estas manifestaciones de fe, las mujeres se convirtieron en los principales agentes cristianizadores y la tradición nos lega numerosas historias en las que son ellas, ya bautizadas, las que consiguen convertir a sus esposos con toda su familia. Los nombres que nos llegan corresponden a las clases altas, como no podía ser de otro modo, sin embargo el fenómeno puede resultar indicativo de esa cierta revalorización de lo femenino de la que hablamos. La princesa burgundia Clotilde convirtió a su esposo Clodoveo; Igunda consiguió que el visigodo Hermenegildo abandonara el arrianismo; Berta, casada con Adalberto, rey de Kent, logró abrir las puertas a los misioneros que evangelizaron a los anglosajones; los lombardos fueron definitivamente captados para el cristianismo por Gundeberga, esposa del rey Rotari. La relación podría continuar ya que con las invasiones bárbaras las mujeres parecen convertirse en las más eficaces propagadoras del mensaje evangélico.

El nacimiento del culto mariano debe encuadrarse en ese contexto general en el que, en medio de la convulsión que supone el desmoronamiento del mundo antiguo, la mujer sale beneficiada, convirtiéndose en una aliada de la Iglesia. La imagen de la Virgen muy pronto vendrá a sustituir las devociones de las antiguas diosas y su figura desempeñará una función primordial como mediadora entre 
lo sobrenatural y lo femenino. En este proceso de recuperación de valores ancestrales que la feminidad volvía a representar, el cristianismo se verá obligado a revisar la relación de la mujer con el pecado y con el Mal.

Con Agustín de Hipona la idea de un pecado original iba a quedar firmemente establecida en la religión cristiana. Reconsiderar la relación de la mujer con esa falta primordial suponía recuperar la figura de Eva, y la Virgen iba a servir en ese propósito. Para ello, la Iglesia se valdrá de una antigua contraposición simbólica presente ya desde los primeros tiempos, la de María enfrentada a la primera mujer; enfrentamiento que terminará convirtiéndose en una transformación en la que la Virgen aparecerá como la nueva Eva.

El primer indicio de esto lo encontramos al final de la Epistola a Diogneto (XII), un texto cristiano del siglo I en el que se menciona cómo el amor de Cristo ha operado una reversión en el drama del Paraíso. Todos los que crean en Él se beneficiarán de esa redención, porque, como nos dice la epístola, la fe es el auténtico árbol de la vida: «si te allegas (a él) y tomas el fruto, recogerás la cosecha que Dios espera, que ninguna serpiente toca, ni engaño infecta, ni Eva es entonces corrompida, sino que es creída como una virgen, y la salvación es establecida».

La relación entre Eva y una virgen imprecisa parece poco significativa, no obstante contempla la posibilidad de una transformación radical de la mujer al haber quedado redimido el pecado cometido por la primera.

La idea terminará por fructificar dando paso a una elaboración más refinada. Por eso, mucho antes de que se reivindicara a María como objeto de culto, su figura ya era utilizada por los escritores cristianos para establecer un paralelismo con Eva. Por medio de ese recurso, más formal que teológico, Justino, Ireneo de Lyon e incluso el mismo Tertuliano conseguían una equilibrada ejemplificación en la que contraponían, a través del mismo sexo, pecado y virtud, demostrando así el orden perfecto que reinaba en el misterio de la salvación. 
No es paradójico, aunque lo parezca, que sea el misógino Tertuliano (De carne Christi, 6, 17) el que mejor exprese esa contraposición entre una mujer y otra: «Porque la palabra del diablo, artífice de la muerte, se metió dentro de Eva cuando ésta era todavía virgen —nos dice el escritor latino-, paralelamente la palabra de Dios, constructora de vida, tenía que meterse dentro de la Virgen, para que se restableciera la salud del hombre por el mismo sexo por el cual había venido al hombre la perdición. Eva creyó a la serpiente, María creyó a Gabriel. Lo que aquélla pecó creyendo, creyendo lo corrigió ésta».

Con la comparación, subraya netamente la terrible falta de Eva, de la que consideraba herederas a todas las mujeres, contraponiéndolas así a la figura de María como espejo de virtudes. Es precisamente en ese aspecto en el que incidirán todas las aportaciones posteriores que se encargarán de resaltar, sobre todas las demás, dos de esas virtudes: la virginidad y la obediencia.

Cuando el segundo Concilio de Nicea en 787 estipule el culto obligado a María y prohíba la entrada al cielo de todo aquel «que no confiesa que la santa siempre virgen María, propia y verdaderamente madre de Dios, es más excelsa que toda criatura visible e invisible, y con toda su fe no pida sus intercesiones...» (Doctrina Pontificia IV, 1954: 33), María se habrá convertido definitivamente en la mediadora de la redención humana y todos deberán volver sus ojos hacia esa nueva Eva que ha hecho posible el milagro de la salvación.

Así, la vieja idea de la mujer como fuente de vida reaparece en el cristianismo de modo más sutil que en formulaciones anteriores, ya que María se presenta como madre de la vida espiritual. Pero si todos los cristianos debían venerar otra vez el principio vivificador de la feminidad, las mujeres debían hacerlo imitativamente, teniendo siempre a la Virgen como referente moral en su castidad, en su sumisión, en su silencio, en su resignación, en su dolor... Sólo así podrían escapar de ser utilizadas por el Diablo en su perversa labor, aunque en los siglos siguientes el ángel caído iba a mostrar una cierta indolencia en su actividad.

Estamos de acuerdo con Delumeau (1989: 263) cuando afirma que la presencia de Satán durante la alta Edad Media es poco sig- 
nificativa. Por supuesto las creencias en el Diablo siguieron vigentes tanto en la Iglesia como entre el vulgo. El arte del período recoge su imagen en la literatura y en la plástica. Gregorio de Tours o Sulpicio Severo en sus inocentes historias de santos nos presentan un Diablo que siempre es derrotado por la virtud del biografiado, mientras que nuestro Berceo lo imagina como un auténtico monarca feudal rodeado de su corte, y al que Teófilo ${ }^{3}$ está dispuesto a rendir vasallaje al acudir a él para vender su alma. No obstante, la intervención de Nuestra Señora logrará rescatar el infernal contrato cuando el sacerdote, lleno de arrepentimiento, la invoque como mediadora ante Dios, para anular el acuerdo, derrotando así, una vez más, a tan vulnerable enemigo (Milagros de Nuestra Señora, $\mathrm{XXV}, 735-742$ ).

Más feroz lo reflejará el cincel del escultor que labró el pórtico de Sainte-Foy de Conques (siglo XII), aunque también lo concibe como un rey flanqueado por un séquito de demonios a sus órdenes y sentado en su trono en medio de su imperio subterráneo. Su cabello erizado, casi flameante, sus ojos desmesurados, su gran boca entreabierta mostrando sus colmillos, en un gesto que intenta, inocentemente, trasmitir espanto, componen una figura básicamente antropomorfa que cuenta, sin embargo, con pies como garras y con una serpiente que se enrosca a sus plantas.

A pesar de su constante presencia, imaginada de una forma $u$ otra, o precisamente debido a esto, su figura se integra de tal modo en la vida cotidiana de las instituciones y de las gentes que llega a trivializarse. Los grandes teólogos de estos siglos, como Gregorio Magno o Isidoro de Sevilla, no aportan novedades sustanciales ni

3 La historia de Teófilo tiene su origen en Pablo Diácono, un consejero de Carlomagno (siglos VIII-IX) que la tradujo de un relato griego, posiblemente del siglo vi. En ella se nos narra a modo de exemplum, cómo el sacerdote Teófilo, apartado arbitrariamente del servicio que prestaba cerca de su obispo, lleno de despecho, decide pactar con el Diablo para recuperar su puesto. Su importancia radica en que por primera vez aparece de modo explícito el tema del «pacto satánico». La historia tuvo un enorme éxito, sirvió para construir muchos sermones, fue acomodada a otros relatos introduciendo variaciones, e incluso terminó por ser objeto de representaciones gráficas, como se puede apreciar, por ejemplo, en la vidriera de la catedral de Mans de época gótica, y de ella se sirvió Berceo para este milagro de Nuestra Señora. 
sobre su origen ni sobre su naturaleza, ya que se limitan a recrear los viejos tópicos sobre su actividad. ${ }^{4}$ Es entre el pueblo llano donde mejor apreciamos ese fenómeno de coexistencia con el Diablo que se produjo en los orígenes de Europa.

Los sencillos campesinos que constituían el grueso de la población incorporaron la figura de los demonios, de Satán o del Diablo, a sus primitivas creencias y ritos paganos, relacionándose con él con una soltura de la que el folclore popular, que ha subsistido hasta el siglo XIX, nos deja numerosos testimonios como lo demuestran las investigaciones de Claude Seignolle (1995: 241-281) y los rastros que aún perviven en el lenguaje popular. Ejemplo elocuente de esto último es la expresión de "pobre diablo», utilizada para designar a una persona inofensiva aunque pretenciosa. El Diablo altomedieval es un pillo que quiere engañar al ingenuo campesino pero que, la mayor parte de las veces, termina siendo chasqueado, o bien es una fuerza adversa a la que se puede dominar por medio de amuletos, conjuros y ritos que el labriego lleva utilizando desde hace siglos. Parecido proceder se adoptará en las historias ejemplares que el cristianismo ponga en circulación en las que, cuando el demonio actúa, casi siempre sus intentos terminan en fracaso gracias a la intervención de la Virgen o de los santos.

La misma pervivencia del paganismo obligaba a la Iglesia a ser transigente y a desdramatizar estas creencias en las que el Mal formaba parte, perfectamente integrado, de la vida de las gentes. En

4 Tal vez una de las pocas aportaciones novedosas es la relativa a la idea del «rescate». Con el pecado original la humanidad había quedado en manos del Mal, por eso, como hemos visto, al Diablo se le consideraba Señor de este mundo. Eso suponía que Dios le había otorgado alguna clase de derecho sobre los hombres y para redimirnos, siendo totalmente justo, debía pagar un rescate a Lucifer, lo que explicaría el enorme sacrificio de la cruz. El Diablo se habría aferrado impacientemente al rescate ofrecido, queriendo apoderarse de una persona sin pecado, pero ignorante de la divinidad de Jesús perdió sus derechos sobre Cristo y sobre toda la humanidad (Alcuino, Libri carolini 2, 28; Beda, Homilía 2, 1, cit. en Rusell, 1995: 116-117).

Esta curiosa teoría, en la que se deja sentir la influencia del derecho romano que la Iglesia ya estaba experimentando, se barajaba junto con la idea del sacrificio, por la que Jesús se habría ofrecido voluntariamente como víctima propiciatoria pura para expiar nuestros pecados. Será esta última interpretación del drama de la cruz, en la que el Diablo no desempeña sino un papel secundario, la que terminará imponiéndose. 
muchos casos, las historias de hechos milagrosos llevados a cabo por santos frente a monstruos locales como dragones o serpientes gigantes reflejan esa actitud conciliadora, ya que la bestia terminaba siendo dominada sin necesidad de acabar con ella, como ocurre con el relato hagiográfico de Silvestre o el de Marta (Vorágine, 1990: 84 y 419), que domaron sendos dragones sin matarlos, demostrando así el poder divino, al tiempo que respetaban los antiguos mitos que concebían a estos seres fantásticos como tiránicos protectores a los que se podía propiciar favorablemente por medio de ritos $\mathrm{u}$ ofrendas.

En cierta medida el Diablo era considerado por la mayor parte de la población como esos dragones terribles, una fuerza extraña a la realidad circundante encargada de sembrar el mal, pero a la que se podía hacer frente debidamente pertrechado con las jaculatorias y los signos pertinentes. En definitiva, una manifestación maligna de lo sobrenatural con escasa trascendencia en la sencilla vida de los humildes excepto en los momentos de desgracia. Esa actitud, percibida por el poder, resultaba suficiente para el mantenimiento del orden y de la fe. Los mismos castigos que la Iglesia imponía ante prácticas mágicas o supersticiosas eran muy moderados, excluían cualquier tipo de pena física, recurriendo única y exclusivamente a la penitencia. La justicia civil podía tomar medidas contra aquellas personas que pudieran causar daños por medio de la hechicería o el maleficio, pero el hecho debía ser demostrado, lo que habitualmente resultaba muy difícil, por lo que las autoridades consideraban ese tipo de acusaciones como meras tonterías propias del pueblo bajo.

En los sínodos de Tours (567), Berghampstead (697) y París (829) se condenó la brujería pero por considerarla una práctica pagana, y la Lex Baiuvariorum, del siglo vIII, castigaba con una multa no muy elevada a los que por medio de artes mágicas dañaran las cosechas de su vecinos. Sin embargo, Agobardo, arzobispo de Lyon desde 816 hasta 840, en su tratado La loca opinión del pueblo respecto al granizo y el trueno (cit. en Schmitt, 1992: 59), se burla de los crédulos campesinos que achacan las desgracias que sufren sus campos a los hechizos lanzados por los tempestarii, nombre que se les daba a los brujos que provocaban las tormentas. «Hemos visto y oído a muchos, tan embrutecidos por su locura, tan alienados por su 
necedad, que creen y dicen que existe una región, a la que ellos llaman Magonia, de donde vienen naves a través de las nubes, dichas naves transportan a ese país los frutos que el granizo hace caer y perecer, y los nautas aéreos hacen regalos a los tempestarii a cambio de los frutos».

Esta postura del poder, tanto eclesiástico como civil, frente al peligro que el Mal y sus mediadores pudieran causar a los buenos cristianos, nos habla de un clima de seguridad en la fe en un mundo socialmente ordenado. Pero las cosas iban a cambiar a partir del siglo XIII, momento en el que empezamos a percibir cómo las relaciones entre el Diablo y los humanos se dramatizan de modo trágico.

La explicación a este cambio en la mentalidad occidental debemos buscarla en las crispadas transformaciones que estaban alterando el, hasta cierto punto, estable sistema feudal. Desde el siglo XI nuevas técnicas de cultivo permitieron un crecimiento en la producción que se tradujo en un aumento de los intercambios. Esta revitalización de la actividad comercial supondrá, también, el resurgimiento de la vida urbana. En las ciudades aparecerá una nueva clase social de hombres libres, dedicados a actividades artesanales o al comercio, que desarrollarán una nueva mentalidad, más realista y pragmática. Todo esto implicó una mayor dinamicidad social que afectó a todos los órdenes de la vida, incluido el espiritual, e hicieron su aparición en Occidente las herejías.

Aunque los primeros movimientos heréticos son perceptibles en esta parte del continente desde mediados del siglo XI, es sobre todo en la centuria siguiente, con la herejía albigense o cátara, cuando éstas manifestaciones de piedad extraviada empezarán a inquietar seriamente a las autoridades eclesiásticas. La razón de esa inquietud era triple; por un lado les preocupaba la desviación teológica, en la que veían renacer las turbulentas confrontaciones dogmáticas de los primeros siglos de la Iglesia, pero sobre todo les atemorizaba la doble naturaleza sedicente de la herejía, ya que todos estos movimientos, como nos dice Morghen (1987: 91), aun dentro de la variedad de sus proposiciones, tenían un punto de partida y de llegada común: «la actitud de polémica y de lucha que todas adoptaron hacia 
la Iglesia Romana y la jerarquía...». El problema eclesiológico en la herejía de la Edad Media prevalece pues sobre el problema puramente teológico.

A esto hay que añadir que muy pronto las herejías sumaron a la actitud antirromana otra, si cabe, mucho más terrible para el orden establecido: su naturaleza social. Ésta es la otra vertiente sediciosa de ese tipo de disidencia, que enmascaró las reivindicaciones materiales tanto de la burguesía emergente como del campesinado más pobre; y es que como dice Macek (1967: 21): «todo el movimiento antifeudal tuvo que revestirse entonces de una forma religiosa... El púlpito jugaba un papel esencial en la difusión y en la fortaleza de las ideas llamadas revolucionarias. Solamente, desde lo alto del púlpito, el clero y el orador podían hablar a las grandes masas populares, explicarles las causas de las iniquidades de la época, educarles y conducirles. Al pie del púlpito, en efecto, se acumulaban las personas más humildes... Cada palabra del predicador del pueblo podía encender en el corazón de su auditorio llamas de fe y de consuelo, pero también podía avivar la resolución de poner en juego su vida para hacer triunfar la verdad de Dios».

Cuando en el siglo XIV se manifieste con toda su crudeza la crisis derivada del impacto de la peste negra, de la eterna guerra entre Inglaterra y Francia, y del hambre, producto de las malas cosechas, la lucha de clases se agudizará y, en ocasiones, los rebeldes buscarán justificación a sus posturas en la discrepancia religiosa frente al viejo sistema imperante, como en el caso del dulcinismo ${ }^{5}$ que sacudió la región de Novara, en el norte de Italia, a comienzos de siglo, o en el de tantos otros.

5 Dulcino se convirtió en el dirigente de la secta Hermandad Apostólica a la muerte de su fundador, Gerardo Segarelli, que fue quemado en la hoguera por hereje en 1300. Los miembros de este movimiento pretendían devolver a la Iglesia a la pobreza primitiva de época de los apóstoles. Predicaban con el ejemplo llevando una vida de absoluto desprendimiento, que superaba a la de los franciscanos y esperaban la pronta venida del Reino. Esa esperanza milenarista les empujó a preparar el terreno. En 1304, Dulcino y sus partidarios se refugiaron en las montañas próximas a Novara emprendiendo expediciones de saqueo contra las posesiones eclesiásticas en las que se vieron secundados por los campesinos de la zona, Sin duda, como dice Lambert (1986: 214), «la pobreza de los campesinos cercanos a su refugio montañoso les haría receptivos a su doctrina». 
El movimiento de Wiclef en Inglaterra, el de Jan Hus en la Bohemia del siglo Xv, o el mismo de Thomas Münzer en Alemania, ya en plena Reforma, están vinculados a rebeliones campesinas y son la antesala o la caja de resonancia de la ruptura protestante que sacudirá a toda Europa en siglo XVI, precipitando unas guerras de religión cuyas estribaciones serán perceptibles hasta mediados de la centuria siguiente. Las tensiones inherentes a esa profunda mutación, de la que nacerá la modernidad, se irán retroalimentando en medio de una convulsión que sacudirá de arriba abajo el viejo orden feudal. Durante ese prolongado período de tiempo toda la estructura de poder político, social y de creencias quedará en entredicho. De los temores que se deriven de eso saldrá fortalecido el Diablo y pagará por ello la mujer.

El papa Gregorio IX, apoyándose en las órdenes mendicantes, franciscanos y dominicos, sobre todo en esta última, decidió en 1233 crear la Inquisición para combatir la herejía bajo la dirección episcopal. Durante mucho tiempo esa institución no se preocupó por la hechicería y cuando en 1258 solicite autorización del papa Alejandro IV para incluir la brujería como delito que cayera bajo su competencia, la petición será denegada. La razón de esto hemos de buscarla en la pervivencia en el seno de la Iglesia de la opinión existente sobre esas creencias como meras supersticiones, tal y como quedaba recogido en el famoso Canon Episcopi.

Ese curioso documento, que a través de Graciano terminó por integrarse en el Derecho Canónico, era realmente una falsificación, no sabemos si intencionada o inocente de su autor. A principios del siglo x el arzobispo de Trier le había pedido a Regino, antiguo Abad de Prüm, que escribiese una guía disciplinaria para uso de sus obispos, en la que éste incluyó un canon procedente de un capitulario del siglo IX, ya perdido, que comenzaba con la frase Episcopi episcoparum ministri... y al que le atribuyó una antigüedad que no tenía, considerándolo un documento del siglo IV, producto del Concilio de Ancira, lo que daba al texto una autoridad que más tarde será discutida por la propia Iglesia.

El Canon (cit. en Robbins, 1992: 173) recogía una condena genérica de las supersticiones existentes sobre las personas que practi- 
caban pretendidos maleficios y descalificaba la creencia de que hubiera mujeres que pudieran volar por medio de conjuros:

También hemos de señalar — nos dice el Canon- que ciertas mujeres desgraciadas, pervertidas por Satán, seducidas por ilusiones y fantasmas de demonios, creen y declaran abiertamente que, en mitad de la noche, cabalgan a lomos de ciertas bestias con la diosa pagana Diana, junto a una horda de mujeres, y en el silencio de la noche vuelan sobre enormes extensiones de tierra y obedecen sus órdenes como si fuera su ama y son llamadas a su servicio otras noches. Pero no importaría si se limitaran a su propia infidelidad y no arrastraran a tantos otros al abismo de su perfidia. Pues una inmensa multitud, engañada por esta idea falsa, cree que es cierto, y en esta creencia abandona la verdadera fe y cae en errores paganos al pensar que existe otra divinidad u otro poder que no sea el de Dios único.

Como vemos, el Canon ya refleja la idea de mujeres embarcadas en noctámbulos vuelos al servicio de un poder sobrenatural. Los tres elementos que aparecen en esta superstición - existente ya a comienzos del siglo $\mathrm{x}$ - terminarán quedando integrados en la imagen de la bruja posterior. Serán mujeres, y no hombres, las que volaran por las noches para dirigirse, junto con otras compañeras, a reuniones presididas por el mismo Satán, que les otorga poderes para ello en función de un pacto sellado con sus adoradoras.

Pero lo que hace el Canon Episcopi es tachar de superchería todas esas estupideces y condenar a quienes las crean. Ésta será la postura de la Iglesia durante siglos, considerar que los actos de brujería eran ilusiones o fantasías producto de los sueños, como ya había apuntado Agustín. Por tanto, lo censurable para la Iglesia de entonces era creer en ellos. Sin embargo esta actitud irá cambiando conforme la crisis bajomedieval se agudice y las herejías se multipliquen tornándose más peligrosas.

En 1326, bajo el impacto de una serie de años de malas cosechas y de hambre entre el campesinado, el papa Juan XXII a través de la bula Super illius specula establece que las prácticas maléficas deben ser castigadas como las heréticas sin llegar todavía a equipararlas. A esta progresiva identificación entre desviación herética y hechicería contribuyó la peste negra que asoló toda Europa a partir de 1348. 
Entre las gentes sencillas el origen de la desgracia se buscaba en los elementos no asimilados más próximos al pueblo, así surgió la especie, en muchos lugares, de que eran los judíos los causantes de la epidemia al haber envenenado las fuentes y los manantiales. Pero podían ser también los leprosos, impuros en sí mismos, o los extranjeros, extraños a la comunidad. Además, como señala Delumeau (1989: 203), los teólogos enseñaban qué demonios y brujos se convertían, llegado el caso, en los «verdugos» del Altísimo y en agentes de su justicia. Nada había de sorprendente, por tanto, en que unos seres malhechores, actuando, sin saberlo, como ejecutores de los designios de Dios, difundieran voluntariamente gérmenes letales. En la misma línea, los inquisidores, también, achacaban a las acciones del Diablo y de sus seguidores el origen de tanto mal que aquejaba a la cristiandad y a su santa institución.

En los años posteriores a la plaga se hacen perceptibles dos fenómenos: las tendencias misóginas experimentan un fuerte crecimiento, sólo tenemos que recordar nuestro Libro del Buen Amor, y la persecución contra la herejía se recrudece, llegándose a quemar en la hoguera, en la localidad francesa de Carcasonne y solamente durante el año 1357 a treinta y una personas. En 1376 Nicolau Eymeric, inquisidor general de Aragón en su «Directorium inquisitorum» afirmaba ya que la mayor parte de las prácticas de hechicería eran heréticas puesto que presuponían un culto de latría o dulía rendido al demonio.

Dos famosos procesos también contribuyeron a preparar el camino para que finalmente la Inquisición se terminara haciendo cargo de los casos de hechicería. Nos referimos al juicio y muerte en la hoguera de Juana de Arco en 1431 y al posterior procesamiento y ejecución de su colaborador Gilles de Rays en 1440. En el primero la intencionalidad política de la condena está fuera de toda duda, los ingleses eliminaron a la Doncella de Orleáns por su belicosa actitud, pero no hemos de olvidar que justificaron el veredicto acusando a Juana de hechicería, lo que hasta cierto punto sentaba un precedente de lo que luego iba a ser una práctica frecuente de la Inquisición, utilizada por el poder para desembarazarse de opositores o elementos molestos. 
En el caso de Gilles de Rays se adujo que este antiguo mariscal de Francia se había entregado a todo tipo de excesos que habían costado la vida a muchos niños a los que había asesinado en ceremonias de extraña naturaleza en las que se quiso ver un pacto satánico. También aquí pudieron jugar un papel los intereses espurios para hacerse con la fortuna de Rays, pero la notoriedad del personaje hizo que el proceso tuviera una notable repercusión.

Aún habrá de pasar un tiempo antes de que el papado se decida a bendecir la caza indiscriminada de brujas desechando la vieja doctrina del Canon Episcopi, y será Inocencio VIII el que finalmente en 1484 con su bula Summis desiderantes affectibus dé oficialmente ese paso.

El documento papal es una advertencia dirigida a los obispos del norte de Alemania para que presten todo su apoyo a dos inquisidores, Heinrich Kramer y Jacob Sprenger, en su labor procesal. Estos dos dominicos muy pronto se harían tristemente famosos por ser los autores de un manual para uso de sus colegas que se convirtió rápidamente en el texto más difundido sobre el tema, al conocer treinta y cuatro reediciones en los siglos siguientes, con más de 35.000 copias. El Malleus Maleficarum, que así se llamaba la obra, estuvo prologado por la bula papal, lo que, con ayuda de la recién nacida imprenta, le garantizó al decreto pontificio una difusión hasta entonces desconocida.

La bula de Inocencio VIII condenaba explícitamente toda práctica maléfica que acarreara perjuicios del más diverso tipo a personas, ganado y tierras. La enumeración en el texto de posibles daños a la propiedad cuando habla de la destrucción de «los frutos de la tierra, las uvas de la vida, y las frutas de los árboles... las bestias de carga, rebaños, así como animales de otras clases; también viñedos, huertos, prados, praderas, maíz, trigo y otros cereales de la tierra...", anteponiéndolos al "peligro del alma de sus habitantes», nos señala las intenciones que, en parte, pudieron mover al Sumo Pontífice a promulgar ese documento. Al final, cuando alude a que «ningún hombre se oponga a esta declaración de extensión de nuestra autoridad y jurisdicción so pena de que caiga sobre él la ira de Dios Todopoderoso», también nos da alguna pista en torno a los móviles que pudieron motivar el redactado de la bula (Robbins, 1991: 323). 
Como nos dicen Guy y Jean Testas (1970: 66), la violencia y la inquietud agitaban los ánimos de los campesinos, que por la noche celebraban conciliábulos que podían acabar, muy a menudo, en verdaderas expediciones destinadas a atemorizar a los ricos, víctimas con frecuencia del bandidaje. En 1476, un pastor de Niklashausen llamado Hans Böhn dijo que se le había aparecido la Virgen para decirle que los pobres ya no debían pagar impuestos ni diezmos porque la llegada del Reino estaba próxima, causando una auténtica conmoción popular. Sabemos que toda una serie de pequeños levantamientos campesinos en Alemania salpicaron el final del siglo XV y precedieron a la gran sublevación de 1524 . Por otra parte, las amenazas que emite el papa en el documento, para que sus órdenes sean respetadas, nos indican hasta qué punto era cuestionada su autoridad en tierras alemanas en las décadas inmediatamente previas al inicio de la Reforma protestante.

Todo esto debió de influir en Inocencio VIII cuando redactó la bula, aunque para Hale (1993: 281) la Summis desiderantes affectibus sólo respondía al interés de proveer de chivos expiatorios al pueblo frente a una amplia gama de desgracias. Así la brujería y la herejía, dos caras de la misma moneda a partir de entonces, se convertían en los instrumentos materiales de los que se servía Satán para sembrar el mal entre los buenos cristianos; y contra herejes y brujas cargará con todo su rigor el atemorizado orden existente.

Sujeto de castigo por prácticas maléficas podía serlo tanto un hombre como una mujer, pero desde los inicios de la persecución los mismos promotores reconocieron que había más brujas que brujos. Eso es por lo menos lo que sostenía el dominico Nider, profesor de Teología en Viena y uno de los primeros tratadistas sobre el tema en su obra Formicarius, publicada en 1435 y en la que se inspirarían los autores del Malleus Maleficarum. La razón que aducía el sacerdote era que las mujeres tenían la lengua más larga y les contaban a otras lo que habían aprendido. La lógica de este manido argumento misógino brilla por su ausencia pues no se explica por qué la mayor locuacidad atribuida a la mujer desde tiempo inmemorial puede justificar la práctica de la hechicería. Sin embargo, y a pesar de ser absurdo el argumento, prosperó y Geiler von Kaysersberg lo 
asumió, a comienzos del siglo XVI, añadiendo que las mujeres eran también más crédulas e impresionables que los hombres $\mathrm{y}$, por tanto, más proclives a las alucinaciones. En este caso el razonamiento tendría que llevarnos a pensar lo contrario de lo que su autor se proponía, o sea que las pretendidas brujas no eran sino pobres mujeres presas de sus fantasías, pero la lógica no era una de las cualidades de las que gozaban los inquisidores.

Un tratadista local como es nuestro Martín Castañega, que escribió en 1529 , se sumaba a los mismos tópicos, aunque los vestía de una mayor seriedad al retomar la vieja idea de la naturaleza perversa de la mujer. Fray Martín (cit. en Blázquez, 1989: 21) opinaba que Cristo la había apartado de sus sacramentos, lo que posibilitó que el Diablo le abriera las puertas de sus «execramentos» conquistándola con más facilidad. A esto añadía que por su naturaleza más simple las mujeres eran más fáciles de engañar, por su curiosidad se veían inclinadas a conocer las cosas ocultas, por su debilidad eran más propensas a la venganza artera y, por último, que al llegar a la vejez desarrollaban o avivaban apetitos carnales que no pudiendo satisfacer las llevaban a pedir ayuda al demonio.

Sin duda, quienes dieron más pábulo a este ataque indiscriminado de género fueron Kramer y Sprenger que, gracias a la enorme difusión de su libro, lograron que se admitiera como verdad evidente por toda Europa que había que llamar a esa herejía, «no "de los brujos", sino "de las brujas", para que la denominación resulte aún más justificada». A lo que añadían que siendo hombres no había que olvidar dar gracias al Altísimo puesto que «hasta ahora ha preservado al sexo masculino de una plaga grande. Porque quiso nacer y sufrir por nosotros en este sexo y eso lo ha privilegiado» (Quest. VI, 95).

Este tipo de dicterios, que la mujer venía padeciendo desde hacía siglos, no habrían revestido más importancia que la psicosocial propia de una grosera cultura patriarcal si no fuera porque terminaron costando la vida a miles de mujeres, ya que se calcula que de las imprecisas cifras que se barajan sobre el número de víctimas de esta persecución, solamente el 15\% fueron hombres. 


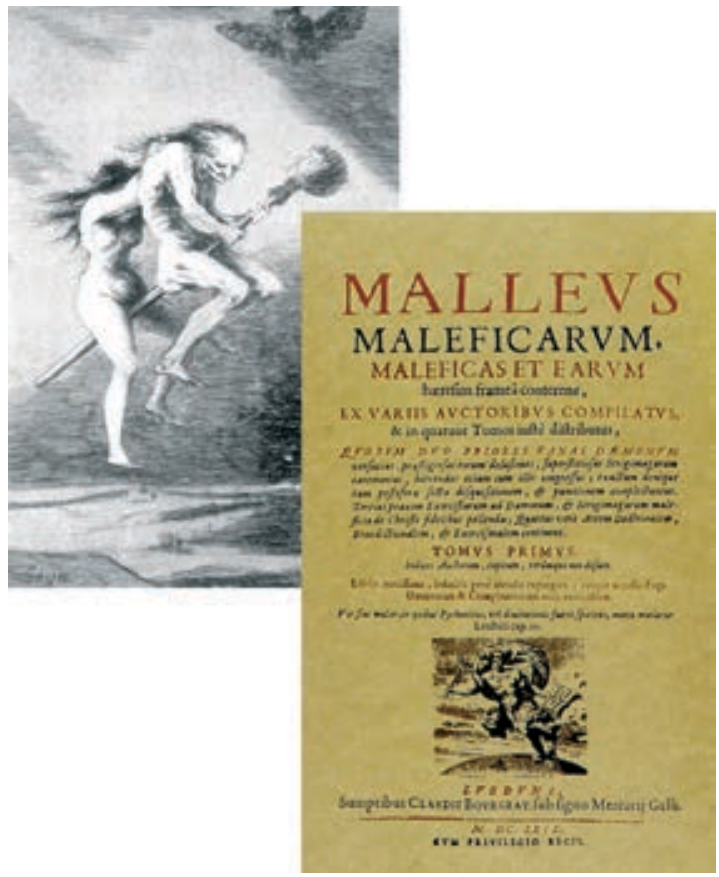

El epítome de la misoginia en el plano de lo sobrenatural se dio con la caza de brujas que se desató en Europa y América en el tránsito a la Modernidad. Miles de mujeres fueron víctimas de los prejuicios de género, del temor al Diablo y de la intolerancia religiosa.

La bruja, que quedará definida como un arquetipo social que ha llegado hasta los dibujos animados en la actualidad, era vista por inquisidores y tratadistas como una mujer casi siempre vieja y fea, que sellaba pactos con el Diablo. La teoría del pacto satánico era clave en el mecanismo de inculpación ante los tribunales y había evolucionado desde que la apuntara Agustín de Hipona. A esa elaboración contribuyó la Universidad de París, que aceptó en 1398 que la brujería descansaba sobre esos pactos, argumento del que se valió la Inquisición para entender que ese acuerdo diabólico era herejía. Una vez sellado el pacto con sangre humana, detalle efectista que sólo aparece a partir del siglo XIV, la bruja procurará la desgracia de 
los buenos cristianos por diversos procedimientos. Echará el mal de ojo o practicará conjuros y maleficios con los que arruinará las cosechas de sus vecinos, matará su ganado, hará enfermar a hombres, mujeres y niños, o les provocará la impotencia a los varones y la esterilidad a las hembras.

También sabrá fabricar pociones —antiguos filtros de amor o venenos tradicionales para eliminar enemigos - de ingredientes repugnantes con las que podrá controlar la voluntad de las personas a su antojo. Esas pociones o ungüentos también le servirán a la bruja para volar por las noches en dirección a reuniones con otras iguales, presididas por el mismo Satán, que adoptará diferentes formas para presentarse, aunque es muy frecuente que lo haga como macho cabrío. En esas reuniones, denominadas aquelarres, se entregarán a todo tipo de excesos y ofensas contra la fe para terminar rindiendo culto a su diabólico señor. $\mathrm{Y}$ por último, y esto no podía faltar, las brujas comerciarán sexualmente con los demonios, con el mismo Satán o con íncubos y súcubos, demonios sexuales que también podían copular con inocentes víctimas poseyéndolas en medio del sueño, como cientos de años antes ya hiciera Lilith.

Realmente la bruja será una víctima propiciatoria de la intolerancia e inseguridad en la que se movió Europa en esa época de transformaciones profundas. La persecución llevada a cabo tanto por católicos como por protestantes sirvió al tambaleante sistema feudal y a su principal valedor, la monarquía autoritaria, para reordenar su poder sobre el conjunto de la sociedad. La mayoría de las personas procesadas pertenecían a estratos marginales o a capas populares de la población. En algún caso, fueron miembros de la élite intelectual —como ocurrió con Giordano Bruno o Miguel Servet- e, incluso, pudieron ser encartados algunos nobles o clérigos, pero el porcentaje de todos estos fue insignificante.

Como nos recuerda Harris (1982: 206) la caza de brujas fue parte integral en la defensa de la estructura institucional y no hemos de verla como un rebrote de barbarie medieval, sino como la manifestación de una nueva manera de concebir el poder con rasgos de una inquietante modernidad. Los tribunales inquisitoriales tuvieron ámbito universal y se impusieron sobre la compleja y loca- 
lista administración anterior. Su obsesión por el control ideológico, su irrupción en los aspectos más íntimos de la vida privada, su terquedad en obtener confesiones, su meticulosidad procesal, el uso que hicieron de la delación, comprometiendo en la persecución a toda la sociedad, y su voluntad de extirpar la lacra de raíz son algunas de las notas que van a definir un nuevo sentido del orden público que tiene que ver más con la contemporaneidad que con el pasado.

Nos quedaría por comentar por qué la mujer fue la más perjudicada en todo este proceso y aquí nos encontramos con una variada gama de explicaciones. Según Midelfort (cit. en Russell, 1998: 146), durante este período aumentó el número de mujeres que vivían solas por razones distintas: guerras, disolución de los conventos de monjas en áreas protestantes, etc. $\mathrm{Al}$ ser ese segmento uno de los más vulnerables en una sociedad patriarcal, por carecer, solteras y viudas, de la protección de un marido, se habrían convertido en presa fácil para los inquisidores.

Algunas autoras (Ehrenreich y English, 1984) han señalado otros motivos, poniendo en relación las prácticas curanderiles e incluso los procedimientos anticonceptivos —-saberes que tradicionalmente se atribuían a las mujeres - con la forzada implantación de una ciencia médica en manos sólo de hombres. Margaret Murray, a comienzos del siglo Xx, puso en circulación la teoría de que la brujería era la supervivencia de una antigua religión de la fertilidad que las mujeres habrían mantenido ocultamente viva durante siglos y que el cristianismo se habría empeñado en extirpar en los orígenes de la modernidad.

La explicación más sencilla es, tal vez, la más acertada: la mujer desde época ancestral había sido la aliada del Mal. Durante siglos la sociedad patriarcal fue amontonando los haces de leña para encender la hoguera en la que miles de mujeres ardieron como producto de esa representación social, fraguada durante generaciones a través de un complejo proceso de elaboración semiinconsciente en el que terminaron por integrarse elementos de orden muy distinto: filosóficos, religiosos, morales, fisiológicos...

En ese proceso había intervenido el poder por medio de la legislación civil y de la ley divina, pero también había participado la 
sociedad. En ocasiones parecía reflejar un sentir mayoritario, pero en otras, como ocurrió en los inicios del cristianismo, había sido una minoría activa la que había conseguido hacer prevalecer sus normas de comportamiento. El estereotipo se había nutrido en las relaciones de interacción que se dieron entre las teorías elaboradas por unas élites cultas y las más antiguas creencias, nacidas en el seno mismo del pueblo. Todo, finalmente, se había superpuesto, desplazado y sedimentado hasta dar como resultado una imagen que parecía ser cierta para el conjunto social y lo terrible era que, en la medida que lo parecía, llegó a serla, ya que la percepción terminó por configurar la misma realidad.

La bruja fue la plasmación vulgar de esa vieja creencia que asociaba a cualquier mujer con Pandora, con Eva o con la serpiente del Mal. Pero frente a ella, una mujer singular había sido enaltecida desde su misma concepción para aplastarla.

El dogma de la virginidad de María no se impondrá hasta 1854, aunque podemos encontrar alusiones, un tanto forzadas, en textos cristianos de los primeros siglos en relación con su nacimiento virginal. Esa idea se irá abriendo paso, gracias a las especulaciones de los teólogos a lo largo de toda la Edad Media, junto con la de la Virgen como una nueva Eva, lo que permitió el desarrollo de una rica simbología que iba a perfeccionar y ennoblecer el culto que se le rendía a la madre de Dios. A la configuración de esa imagen contribuyeron dos textos bíblicos, uno, extraído del Antiguo Testamento, convertía a María en la mujer que había profetizado el Génesis como la destinada a aplastar la cabeza de la serpiente; otro era el que hacía de la Virgen el personaje que aparece en el Apocalipsis $(12,1)$ como «una mujer vestida del sol, con la luna bajo sus pies y una corona de estrellas sobre su cabeza...». Las dos contribuyeron a ilustrar la idea de su inmaculada concepción, al menos entre un sector del clero, sobre todo franciscano, hasta que por fin la doctrina terminó siendo aceptada por la Universidad de la Sorbona en 1476, lo que suponía un espaldarazo intelectual.

No obstante, con la Reforma protestante y el cuestionamiento por parte de los luteranos del culto a María, será la Roma contrarreformista la que se encargará de impulsar la creencia y, aunque 


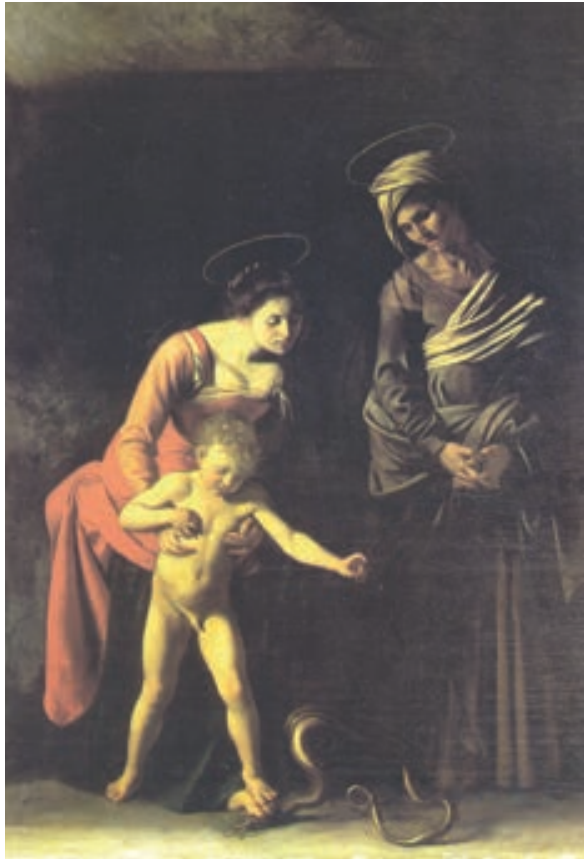

La exaltación de la mujer por parte del cristianismo a través de la figura de la Virgen permitió que con la Contrarreforma se elaborara la imagen de María aplastando a la serpiente, personificación del Mal y símbolo de la herejía protestante, dando así cumplimiento a la profecía del Génesis. El barroco difundirá ese icono que Caravaggio será uno de los primeros en abordar, de modo naturalista, en su Madonna dei Palafrenierii (1605).

ésta no quede sancionada en el Concilio de Trento, el papado terminará por integrarla en sus programas iconográficos dentro de la campaña propagandística que el catolicismo emprendió por medio del arte.

Las primeras representaciones de la Inmaculada ya habían aparecido, a mediados del siglo $\mathrm{XV}$, en miniaturas y en xilografías insertas en libros impresos, pero fue con la difusión del nuevo estilo barroco cuando la Iglesia utilizó esta imagen de modo profuso para plasmar simbólicamente su victoria sobre la herejía. Como nos dice un historiador del arte (Sebastián, 1985: 197), era una imagen destinada a glorificar a la nueva Eva, que haría olvidar la falta de la primera y aplastaría la cabeza de la serpiente.

Entonces el reptil ya no representaba la fértil feminidad sino simplemente la desviación teológica que la religión consideraba como el mismo Mal. Sobre la mujer seguían pesando todos los rece- 
los, pero se había conseguido que su imagen, aunque semidivinizada, renegara de ese poder primitivo del que gozó cuando aún se encontraba en el Paraíso.

Volvemos al principio. Cinco años después del escandaloso estreno de Gilda en España, se reeditaba en Roma el Diccionario de Derecho Canónico, que aún estaría vigente más de diez años antes de ser revisado. En él (cit. en Tunc, 1999: 133), bajo la voz «mujer», se podía leer: «El derecho canónico profesa respecto a la mujer una cierta reserva... que parece inspirada, bien sea por la consideración de la imbecillitas sexus, bien por el recuerdo del papel que la mujer desempeñó en el pecado original y por la ocasión de pecado que ella representa...».

Todo un resumen de la misoginia proyectada en lo sobrenatural que ha dominado desde hace más de dos mil quinientos años la cultura occidental.

Frente a eso apenas unas décadas de lucha desigual para intentar acabar con una representación social de tan enorme influencia. Tardará todavía mucho tiempo hasta que la serpiente vencida se yerga del suelo y recupere su imagen como auténtico símbolo de la vida. Sólo entonces el ser humano podrá acariciar el sueño de alcanzar de nuevo el Paraíso perdido, del que nos habló el poeta.

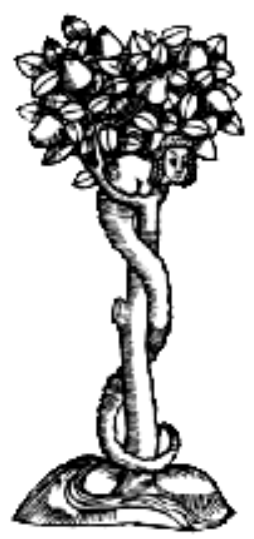




\section{BIBLIOGRAFÍA CITADA}

\section{Fuentes}

Agustín de Hipona, La ciudad de Dios, trad. de S. Santamarta y M. Fuertes, Madrid, BAC, 2 vols., 2001.

Antología temática de la poesía lírica griega, ed. de J. L. Navarro y J. M. ${ }^{a}$ Rodríguez Adrados, Madrid, Akal, 1990.

Apócrifos del Antiguo Testamento (AAT), dir. de A. Díez Macho, Madrid, Cristiandad, 5 vols., 1982-1987.

APUlEYo, El asno de oro, trad. de L. Rubio, Madrid, Gredos, 1995.

ARISTÓfanes, Comedias: Pluto o la riqueza. Las nubes. Las ranas, trad. de J. Pallí, Barcelona, Bruguera, 1979.

ARISTÓteles, Obras, trad. de F. de P. Samaranch, Madrid, Aguilar, 1977.

- Acerca de la generación y la corrupción; tratados breves de historia natural, trad. de E. La Croce y A. Bernabé, Madrid, Gredos, 1998.

Atanasio de Alejandría, Vida de Antón, Sevilla, Apostolado Mariano, 1991.

BASILIO OBISPO, Florilegio de sus escritos, Sevilla, Apostolado Mariano, 1991.

Berceo, G. de, Milagros de Nuestra Señora, ed. de D. Devoto, Madrid, Castalia, 1991.

Biblia de Jerusalén, nueva ed. revisada y aumentada, Bilbao, Desclée de Brouwer, 1998.

Bucólicos griegos: Teócrito, Bion, Mosco, trad. de M. Brioso, Madrid, Akal, 1986.

Cicerón, Sobre la naturaleza de los dioses, trad. de Á. Escobar, Madrid, Gredos, 1998.

- Sobre la adivinación. Sobre el destino, trad. de Á. Escobar, Madrid, Gredos, 1999.

- Cartas de Cicerón y Epigramas de Marcial, trad. de J. Víctor, Madrid, Gredos, 1986.

- La República. Las Leyes, ed. de J. M. Núñez, Madrid, Akal, 1989.

Clemente de Alejandría, Pedagogo, trad. de J. Saviola, Madrid, Gredos, 1998. 
Clemente de Alejandría, Stromata, trad. de M. Merino, Madrid, Ciudad Nueva, 3 vols., 1996-2003.

Demóstenes, Discursos políticos y privados, trad. de A. López y J. M. Colubí, Madrid, Gredos, 2000.

Diógenes Laercio, Vidas de filósofos, trad. de J. Ortiz, Barcelona, Iberia, 2002.

Doctrina pontificia (tomo IV). Documentos marianos, ed. de H. Marín, Madrid, BAC, 1954.

El Libro de los muertos, prólogo, trad. y notas de L. Calvera, Buenos Aires, Leviatán, 1987.

- ed. de J. M., Blázquez y F. Lara, Madrid, Editora Nacional, 1984.

El Zohar o Libro del esplendor (Moisés de León), trad. de E. Cohen y A. Castaño, Barcelona, Azul Editorial, 1999.

El Zohar, Libro del esplendor, trad. de C. Giol, Barcelona, Obelisco, 1996.

Epicteтo, Pláticas, trad. de P. Jordán de Urríes y Azara, Madrid, Consejo

Superior de Investigaciones Científicas, 4 vols., 1963-1973.

- Disertaciones, trad. de P. Ortiz, Barcelona, Planeta, 1996.

Epicuro, Obras completas, trad. de J. Vara, Madrid, Cátedra, 1995.

Esquilo, Tragedias, trad. de B. Pérez, Madrid, Gredos, 2002.

EuRíPIDEs, Tragedias, trad. de A. Medina et ál., Madrid, Gredos, 3 vols., 2001. Filón de Alejandría, Obras completas, trad. de J. M. ${ }^{a}$ Triviño, Buenos Aires, 5 vols., Acervo Cultural,

Flavio Josefo, La guerra de los judíos y destrucción del templo y ciudad de Jerusalén, trad. de J. Martín, Barcelona, Orbis, 2 vols., 1985.

- Antigüedades de los judíos, Barcelona, 3 vols. Libros CLIE.

Gregorio Magno, Morales, Valencia, Universidad de Valencia, 1993.

- Homilías sobre los Evangelios, Madrid, Rialp, 2000.

Hекорото, Historia, trad. de C. Schrader, Madrid, Gredos, 5 vols., 2002.

Hesíodo, Obras y fragmentos: Teogonía; Trabajos y días; Escudo; Fragmentos; Certamen, trad. de Aurelio Pérez, Madrid, Gredos, 2000.

HipócRates, Tratados hipocráticos, trad. de J. de la Villa et ál., Madrid, Gredos, 8 vols., 2003.

Homero, Obras completas, trad. de L. Segalá, Barcelona, Montaner y Simón, 1955.

- Ilíada, trad. de E. Crespo, Madrid, Gredos, 2001.

- Odisea, trad. de J. M. Pavón, Madrid, Gredos, 2001.

Horacio, Sátiras, trad. de H. Silvestre, Madrid, Cátedra, 1996.

IgnaCio de Antioquía, Cartas, trad. de J. J. Ayán, Madrid, Ciudad Nueva, 1999. Ireneo de Lyon, Contra las herejías, trad. de J. Garitaonaindía, Sevilla, Apostolado Mariano, 1994. 
JÁmblico, Sobre los misterios egipcios, trad. de E. Á. Ramos, Madrid, Gredos, 1997.

Justino MárTir, Apologías, trad. de H. Yabén, Sevilla, Apostolado Mariano, 1990.

Juvenal, Sátiras, trad. de M. Balasch, Madrid, Gredos, 1991.

Kraemer, H., y J. Sprenger, Martillo de brujas, Madrid, Quatto, 1976.

La Biblia, Madrid, La Casa de la Biblia, 1992.

La Misná, trad. y notas de C. del Valle, Salamanca, Sígueme, 1997.

La sabiduría del Antiguo Oriente, ed. de J. B. Pritchard, Barcelona, Garriga, 1966.

LaCtancio, Instituciones divinas, trad. de E. Sánchez, Madrid, Gredos, 2 vols., 1990.

- Sobre la muerte de los perseguidores, trad. de R. Tejada, Madrid, Gredos, 1982.

Los evangelios apócrifos, ed. de A. Santos Otero, Madrid, BAC, 2000.

Los gnósticos, ed. J. Montserrat, Madrid, Gredos, 2 vols., 2002.

LuCRECIO, De la naturaleza de las cosas, trad. abate Marchena, introd. de A.

García Calvo, Barcelona, Folio, 2002.

Marco Aurelio, Meditaciones, trad. R. Bach, Madrid, Gredos, 1999.

Menandro, Proverbios griegos, trad. de F. García et ál., Madrid, Gredos, 1999.

Minucio Félix, Octavio, trad. de V. Sanz, Madrid, Ciudad Nueva, 2000.

ORíGEnEs, Tractat dels principis, trad. de J. Rius, Barcelona, Alpha, 2 vols., 1999.

Padres apostólicos y apologistas griegos (siglo II), ed. de D. Ruiz, Madrid, BAC, 2002.

Padres apostólicos, ed. de J. B. Lightfoot, Barcelona, CLIE, 2 vols., 1990.

Padres de la Iglesia, ed. de J. Vives, Barcelona, Herder, 1971.

Paladio, Tratado de agricultura. Medicina veterinaria. Poema de los injertos, trad. M. Moure, Madrid, Gredos, 1990.

PíndARo, Odas y fragmentos, trad. de A. Ortega, Madrid, Gredos, 1995.

Platón, Obras completas, trad. y notas de M. Araujo et ál., Madrid, Aguilar, 1969.

Plinio EL Viejo, Historia natural. Libros I y II, trad. A. Fontán y A. Moure, Barcelona, Planeta, 2 vols., 1996.

Plutarco, Obras morales y de costumbres (Moralia), trad. C. Morales y J. García, Madrid, Gredos, tomo II, 1986.

Ruiz, D. (ed.), Padres apostólicos, Madrid, BAC, 1985.

Santiago de la Vorágine, La leyenda dorada, Madrid, Alianza, 2 vols., 1990.

- Cuestiones naturales, trad. de C. Codoñer, Madrid, Consejo Superior de Investigaciones Científicas, 1979. 
SÉnECA, Epístolas morales, trad. de I. Roca, Madrid, Gredos, 2 vols., 1994. SÉNECA, Tratados morales, trad. de P. Fernández, Madrid, Espasa Calpe, 1987. Sófocles, Tragedias completas, trad. de A. Alamillo, Madrid, Gredos, 1998. - Fragmentos, trad. y notas de J. M. Lucas de Dios, Madrid, Gredos, 2003. TÁcito, Historias, trad. de C. Colonia, Madrid, Espasa Calpe, 1965.

Talmud, ed. del Grupo Aleph, Madrid, EDAF, 2002.

Teofrasto, Caracteres. Cartas: de pescadores, campesinos, parásitos y cortesanas, trad. de E. Ruiz, Madrid, Gredos, 1988.

Tertuliano, Apologético, trad. de J. Andino, Madrid, Ciudad Nueva, 1997.

- El adorno de las mujeres, trad. de V. Alfro y V. E. Rodríguez, Málaga, Servicio de Publicaciones de la Universidad de Málaga, 2001.

Textos de magia en papiros griegos, trad. y notas de J. L. Calvo y M. D. Sánchez, Madrid, Gredos, 1987.

Textos de Qumrán, trad. de F. García, Madrid, Trotta, 1992.

Tito Livio, Historia de Roma desde su fundación, trad. de J. A. Villar, Madrid, Gredos, 1999.

\section{Obras generales}

Álvaro, J. L. (1995), Psicología Social: perspectivas teóricas y metodológicas, Madrid, Siglo XXI.

Althusser, L. (1968), La revolución teórica de Marx, México, Siglo XXI.

- (1970), «Idéologie et appareils idéologiques d'Etat», La Pensée, París.

ANDERson, B. S., y J. P. ZINSSER (1991), Historia de las mujeres: una historia propia, Barcelona, Crítica.

ARDREy, R. (1974), El contrato social, Barcelona, Plaza \& Janés.

ARON, R. (1955), El opio de los intelectuales, Buenos Aires, Siglo XXI.

Aubert, J.-M. (1975), La femme: Antiféminisme et christianisme, París, Cerf.

BACHOFEN, A. J. (1861/1987), El matriarcado, Madrid, Akal.

BAMBeRger, J. (1979), «El mito del matriarcado», en O. Harris y K. Young (comps.), Antropología y feminismo, Barcelona, Anagrama.

BARNAY, S. (1999), El cielo en la tierra: Las apariciones de la Virgen en la Edad Media, Madrid, Encuentro.

Bataille, G. (1981), Las lágrimas de Eros, Barcelona, Los 5 sentidos.

Berger, P., y T. LUCKMANn (1968), La construcción social de la realidad, Buenos Aires, Amorrortu.

Bernand, A. (1991), Sorciers grecs, París, Fayard.

BERNARDI, A. (1975), «Los problemas económicos del Imperio Romano en la época de su decadencia», en C. M. Cipolla et ál., La decadencia económica de los imperios, Madrid, Alianza. 
BiAnchI, R. (1981), Historia y civilización de los griegos, Barcelona, Icaria/Bosch.

Biedermann, H. (1993), Diccionario de símbolos, Barcelona, Paidós Ibérica. BláZqueZ, J. (1989), Eros y Tanatos. Brujería, hechicería y superstición en España, Toledo, Arcano.

BláZqueZ, J. M. et ál. (1993), Historia de las religiones antiguas, Madrid, Cátedra.

BorRENSEN, K. R. (1968), Subordination et équivalence. Nature et rôle de la femme d'après Augustin et Thomas d'Aquin, París, Mame.

Bouisson, M. (1976), La magia, Barcelona, Caralt.

Bouteiller, M., y P. Monin (1967), «Mitología de América del Norte», en

P. Grimal (dir.), Mitologías de las estepas de los bosques y de las islas, Barcelona, Planeta.

Bouthoul, G. (1971), El fenómeno guerra, Barcelona, Plaza \& Janés.

Bultmann, R. (2000), Historia de la tradición sinóptica, Salamanca, Sígueme. BurguiÈRe, A. (dir.) (1988), Historia de la familia, Madrid, Alianza, tomo I. CAMPBell, J. (1994), Los mitos, Barcelona, Kairós.

- (1991), Las máscaras de Dios: Mitología primitiva, Madrid, Alianza.

Camus, A. (1947/1996), El mito de Sísifo, Madrid, Alianza.

CASTORIADIS, C. (1983), La institución y lo imaginario: primera aproximación, Barcelona, Tusquets.

Chard, C. S. (1976), El hombre en la Prehistoria, Estella, Verbo Divino.

CHARTIER, R. (1992), El mundo como representación: Historia cultural. Entre la práctica y la representación, Barcelona, Gedisa.

Childe, G. (1936/1973), Los orígenes de la civilización, México, Fondo de Cultura Económica.

Chochod, L. (1975), Historia de la magia, México, Roca.

Cirlot, J. E. (1978), Diccionario de símbolos, Barcelona, Labor.

Cooper, J. C., (2000), Diccionario de símbolos, México, Ediciones G. Gili.

Crossan, J. D. (1996), Jesús: biografía revolucionaria, Barcelona, Grijalbo Mondadori.

DANiÉLoU, J. (1965), «Desde los orígenes al Concilio de Nicea», en L. J. Rogier et ál., Nueva Historia de la Iglesia, Madrid, Cristiandad, tomo I.

DaXelmüller, C. (1997), Historia social de la magia, Barcelona, Herder.

D’Eaubonne, F. (1977), Les femmes avant le patriarcat, París, Payot.

De La Barre, P. (1984), De l'égalité des deux sexes, París, Fayard.

Delumeau, J. (1989), El miedo en Occidente, Madrid, Taurus.

Di Nola, A. M. (1992), Historia del diablo: las formas, las vicisitudes de Satanás y su universal y maléfica presencia en los pueblos desde la Antigüedad a nuestros días, Madrid, EDAF. 
DíEz DE Velasco, F. (1998), Introducción a la historia de las religiones: Hombres, ritos, dioses, Madrid, Trotta.

DodDs, E. R. (1999), Los griegos y lo irracional, Madrid, Alianza.

Donovan, F. (1985), Historia de la brujería, Madrid, Alianza.

Drewemann, E. (1996), El mensaje de las mujeres, Barcelona, Herder.

Duby, G., y M. Perrot (dirs.) (1992), Historia de las mujeres, Madrid, Taurus, tomo I.

DuRAND, G. (1982), Las estructuras antropológicas de lo imaginario, Madrid, Taurus.

DuRKHeIM, E. (1898), «Représentations individuelles et représentations collectives», Revue de Métaphisique et de Morale, vI, pp. 273-302.

Ehrenreich, B., y D. English (1984), Brujas, comadronas y enfermeras. Historia de las sanadoras, Barcelona, Lasal.

Eliade, M. (1973), Lo sagrado y lo profano, Madrid, Guadarrama.

- (1975), Tratado de Historia de las religiones, México, Era.

- (1978), Historia de las creencias y de las ideas religiosas. De la Prehistoria a los misterios de Eleusis, Madrid, Cristiandad, tomo I.

- (1983), Historia de las creencias y de las ideas religiosas. De Mahoma al comienzo de la Modernidad, Madrid, Cristiandad, tomo III.

ENGELS, F. (1894/1977), La subversión de la ciencia por el señor Eugen Dühring. «Anti-Dühring»(OME-35), Barcelona, Crítica.

- El origen de la familia, la propiedad privada y el Estado (OEME-III), Moscú, Progreso.

Esteban J. F. (1998), Tratado de iconografía, Madrid, Istmo.

Evans-Pritchard, E. (1982), La religión nuer, Madrid, Taurus.

- (1997), Brujería, magia y oráculos entre los azande, Barcelona, Anagrama.

Fantoni, B. (1974), Magia y parapsicología, Buenos Aires, Troquel.

FARR, R. M. (1986), «Las representaciones sociales», en S. Moscovici (dir.), Psicología Social. Pensamiento y vida social. Psicología Social y problemas sociales, Barcelona, Paidós, tomo II, pp. 495-506.

Filoramo, G. et ál. (1973), Historia de las religiones, Barcelona, Crítica, 2000.

FlaceliÈRe, R. (1973), «La mujer en Creta y en Grecia», en P. Grimal (dir.), Historia mundial de la mujer, Barcelona, Grijalbo, tomo I.

Foucart, P. F. (1900/1999), Les mystères d'Éleusis, París, Puiseaux Pardès. Frade, C. (1996), «Miles de años de sexo», El Mundo (15-XII-1996).

Frankfort, H. et ál. (1973), El pensamiento prefilosófico: Egipto y Mesopotamia, México, Fondo de Cultura Económica.

Frazer, J. (1890/1974), La rama dorada, México, Fondo de Cultura Económica. 
Freud, S. (1937/1974), Obras completas, Madrid, Biblioteca Nueva.

Fromm, E. (1975), Anatomía de la destructividad humana, Madrid, Siglo XXI. Frossard, A. (1992), 36 pruebas de la existencia del diablo, Madrid, Rialp.

GEERTZ, C. (1995), La interpretación de las culturas, Barcelona, Gedisa.

GÉRIN-RICARD, L. (1975), Historia del ocultismo, Barcelona, Caralt.

GiEdion, S. (1981), El presente eterno: los comienzos del arte, Madrid, Alianza.

Gimbutas, M. (1991), Diosas y dioses de la vieja Europa, 7000-3500 a. C. Mitos, leyendas e imaginería, Madrid, Istmo.

GIRARD, R. (1978), Historia de las civilizaciones antiguas de América, México, Hispanoamérica E., tomos I, II, III.

GRIMAL, P. (1993), Diccionario de mitología griega y romana, Barcelona, Paidos.

- (dir.) (1973), Historia mundial de la mujer, Barcelona, Grijalbo, tomo I.

GugeL, L. (2000), Culturas de los indios norteamericanos, Colonia, Könemann.

Guignebert, C. (1966), El cristianismo antiguo, México, Fondo de Cultura Económica.

Godelier, M. (1985), Economía, fetichismo y religión en las sociedades primitivas, Madrid, Siglo XXI.

GolDBERG, S. (1976), La inevitabilidad del patriarcado, Madrid, Alianza.

Gómez Tabanera J. M. ${ }^{a}$ (1977), «El enigma de las venus paleolíticas», Historia 16, n. ${ }^{\circ}$ 17, año II, pp. 65-78.

Haldas, G. (1997), Marie de Magdala, París, Nouvelle Cité.

HaLE, J. R. (1993), La Europa del Renacimiento, 1480-1520, Madrid, Siglo XXI.

Hamilton, E. (1976), La mitología, Barcelona, Daimon.

HARRIS, M. (1994), Bueno para comer, Madrid, Alianza.

- (1982), Vacas, cerdos, guerras y brujas, Madrid, Alianza.

Harris, O., y K. Young (comps.) (1979), Antropología y feminismo, Barcelona, Anagrama.

Hawkes, J., y S. L. Woolley (1977), «Prehistoria y los comienzos de la civilización», en P. Marchand (dir.), Historia de la Humanidad, Barcelona, Planeta, tomo I.

HAY, D. (1980), Europa en los siglos XIV y XV, Madrid, Aguilar.

HERgEMÖLLER, U. (1992), «Transformaciones sociales en el Imperio hacia 1400 en Europa», en F. Seibt y W. Eberhard, La crisis de la Baja Edad Media, Barcelona, Crítica.

Hoebel, A., y T. Weaver (1985), Antropología y experiencia humana, Barcelona, Omega. 
Husain, S. (2001), La diosa, Colonia, Taschen.

Huyghe, R. (dir.) (1977), El arte y el hombre, Barcelona, Planeta, 3 vols. IBÁÑEZ, T. (1988), Ideologías de la vida cotidiana, Barcelona, Sendain.

IzzI, M. (1996), Diccionario ilustrado de los monstruos, Palma de Mallorca, Alejandría.

JAMES, E. O. (1962), Los dioses del mundo antiguo, historia y difusión de la religión en el antiguo Oriente Próximo y el Mediterráneo oriental, Madrid, Guadarrama.

- (1973), Introducción a la historia comparada de las religiones, Madrid, Cristiandad.

- (1975), Historia de las religiones, Madrid, Alianza.

- (1991), Historia de las religiones: orígenes de la religión, Madrid, Compañía Europea de Comunicación e Información.

- (1974), La religión del hombre prehistórico, Madrid, Guadarrama.

JoDELET, D. (1986), «La representación social: fenómenos, concepto y teoría», en S. Moscovici (dir.), Psicología Social. Pensamiento y vida social. Psicología Social y problemas sociales, Barcelona, Paidós, tomo II, pp. 469-495.

Jolly, A. (1999), Lucy's legace sex and intelligence in human evolution, Cambridge (Massachusetts), Harvard University Press.

KaY, M., y B. VoorhiEs (1979), La mujer, un enfoque antropológico, Barcelona, Anagrama.

KonING, F. (1975), Historia del satanismo, Barcelona, Bruguera.

- (1979), Satán y sus demonios, Barcelona, Plaza \& Janés.

Kovaliov, S. I. (1975), Historia de Roma, Madrid, Akal, 2 vols.

KRYvelev, A. (1982), Historia atea de las religiones, Barcelona, Júcar.

LAMBert, M. (1986), La herejía medieval, Madrid, Taurus.

LANG, A. (1901/1969), Magic and religion, Nueva York, Greenwood Press.

Latouche, R. (1957), Orígenes de la economía occidental. (Siglos IV-XI), México, UTEHA.

Laurentin, R. (1987), «María», en P. Poupard (dir.), Diccionario de las religiones, Barcelona, Herder.

LAVIosA, P. (1977), «La revolución agraria», en R. Huyghe (dir.), El arte y el hombre, Barcelona, Planeta, vol. I.

LECARMe, P. (1968), L'Église et l'État contre la femme, París, Épi.

Leflaive, A. (1968), La Femme et l'Église, París, France-Empire.

LE GoFF, J. (1980), «Las mentalidades. Una historia ambigua», en J. Le Goff.

y P. Nora (dirs.), Hacer la Historia, Barcelona, Laia, tomo III, pp. 81-98.

LERNER, G. (1990), La creación del patriarcado, Barcelona, Crítica.

LEROI-GourHAN, A. (1987), Las religiones de la prehistoria, Barcelona, Lerna. 
LÉVI-Strauss, E. (1949/1993), Las estructuras elementales del parentesco, Barcelona, Planeta-Agostini.

LÉVY-BRUHL, L. (1922), Les fonctions mentales dans les sociétés inférieurs, París, Librairie Félix Alcan.

- (1985), Alma primitiva, Madrid, Sarpe.

LiNTON, S. (1979), «La mujer recolectora: sesgos machistas en antropología», en O. Harris y K. Young (comps.), Antropología y feminismo, Barcelona, Anagrama.

Lorenz, K. (1976), La agresividad. El pretendido mal, Madrid, Siglo XXI. LowIE, R. (1920/1972), La sociedad primitiva, Buenos Aires, Amorrortu.

MACEK, J. (1967), ¿Herejía o revolución? El movimiento husita, Madrid, Ciencia Nueva.

Maerth, O. K. (1972), El principio era el fin, Barcelona, Seix Barral.

MaGGi, A. (2000), Jesús y Belcebú, Bilbao, Desclée de Brouwer.

MARKALE, J. (1989), Druidas, Madrid, Taurus.

MARTin, R., y H. METZGER (1977), La religión griega, Madrid, EDAF.

McGinn, B. (1997), El Anticristo, Barcelona, Paidós.

McLaren, A. (1996), Histoire de la contraception, París, Noesis.

MeEKs, W. A. (1994), Los orígenes de la moralidad cristiana. Los dos primeros siglos, Barcelona, Ariel.

Messadí́, G. (1994), El diablo: Su presencia en la mitología, la cultura y la religión, Barcelona, Martínez Roca.

MÉtraux, A. (1973), Religión y magias indígenas de América del sur, Madrid, Aguilar.

Minois, G. (1994), Historia de los infiernos, Barcelona, Paidós.

MontAGU, A. (1988), La naturaleza de la agresividad humana, Madrid, Alianza. Morgan, L. (1877/1987), La sociedad primitiva, Madrid, Endymión.

Morghen, R. (1987), «Problemas en torno al origen de la herejía en la Edad Media», en J. Le Goff (comp.), Herejías y sociedades en la Europa preindustrial. Siglos XI-XVIII, Madrid, Siglo XXI.

MorRIs, D. (1972), El mono desnudo. Un estudio del animal humano, Barcelona, Plaza \& Janés.

MoscovicI, S. (1998) «The history and actuality of social representations», en U. Flick (ed.), The Psichology of the social, Cambridge, Cambridge University Press, pp. 209-247.

- (1961/1979), El psicoanálisis, su imagen y su público, Buenos Aires, Huemal.

- (1981), «One social representation», en J. P. Forgas (comp.), Social cognition. Perspectives in everyday life, Londres, Academic Press.

- (1984), «The phenomenon of social representations», en R. M. Farr y S. Moscovici (comps.), Social representations, Cambridge, Cambridge University Press. 
Mossé, C. (1971), Las doctrinas políticas en Grecia, Barcelona, Redondo. Muchembled. R. (2000), Une histoire du Diable, París, Seuil.

Mylonas, G. (1974), Eleusis and the eleusinian mysteries, Princeton (New Jersey), Princeton University Press.

Nilsson, M. (1969), Historia de la religiosidad griega, Madrid, Gredos.

- (1954), La réligion populaire dans la Grèce antique, París, Plon.

Noonan, J. T. (1969), Contraception et mariage, París, Cerf.

Ochshorn, J. (1981), The Female Experience and the Nature of the Divine, Bloomington.

Oestereicher, M. (1983), Símbolos, Madrid, Rioduero.

Отто, R. (1917/1991), Lo santo: lo irracional y lo racional en la idea de Dios, Madrid, Alianza.

PAGELS, E. (1990), Adán, Eva y la serpiente, Barcelona, Crítica.

- (1999), L'origine de Satan, París, Hachette.

Patai, R., y R. Graves (1988), Los mitos hebreos. Madrid, Alianza.

PerdRIZET, P. (1900), Negotium perambulans in tenebris: études de démonologie gréco-orientale, París, Ophrys.

Pérez Rioja, J. A. (1971), Diccionario de símbolos y mitos, Madrid, Tecnos.

Pericot, L. y R. Martín (1973), La Prehistoria, Barcelona, Salvat.

PuECH, H.-C. (dir.) (1977), Las religiones antiguas, Madrid, Siglo XXI.

Puente, G. (1974), Ideología e Historia: El fenómeno estoico en la sociedad antigua, Madrid, Siglo XXI.

Quere-Jaulmes, F. (1968), La Femme. Les grands textes des Pères de l'Église, París, Centurion.

RADIN, P. (1960), El hombre primitivo como filósofo, Buenos Aires, EUDEBA. RATZinger, J. (1974), Dogma e predicazione, Brescia, Queriniana.

REEVES, S. P. (1986), Poder femenino y dominio masculino: sobre los orígenes de la desigualdad sexual, Barcelona, Mitre.

Risco, V. (1985), Satanás: historia del diablo, Vigo, Edicións Xerais de Galicia.

RobBins, R. H. (1992), Enciclopedia de la brujería y demonología, Madrid, Debate.

Robert, J.-N. (1999), Eros romano: Sexo y moral en la antigua Roma, Madrid, Editorial Complutense.

Rodríguez Moreno, I. (1998), Los seres intermedios entre el hombre y la divinidad en el pensamiento griego de época helenística e imperial, archivo de ordenador. Tesis doctoral.

Rohde, E., U. von Wilamowitz-Moellendorff y R. WAGNeR, (1918/1994), Nietzsche y la polémica sobre "El nacimiento de la tragedia», ed. de Luis de Santiago Guervó, Málaga, Ágora. 
Rops, D. (1961), La vida cotidiana en Palestina en tiempos de Jesús, Buenos Aires, Hachette.

Russell, J. B. (1998), Historia de la brujería, Barcelona, Paidós.

- (1995), El diablo: Percepciones del mal: de la Antigüedad al Cristianismo primitivo, Barcelona, Laertes.

- (1995), Lucifer: El Diablo en la Edad Media, Barcelona, Laertes.

SAFranski, R. (2000), El mal o El drama de la libertad, Barcelona, Tusquets. Sahlins, M. (1976), Uso y abuso de la biología, Madrid, Siglo XXI.

Sallmann, J.-M. (1989), Les Sorcières fiancées de Satan, París, Gallimard.

SANAHUJA, E. (1982), «Sobre las venus paleolíticas», Poder y Libertad, n. ${ }^{\circ} 4$.

SARTRE, J. P. (1947), La náusea, Buenos Aires, Losada.

SAUvy, A. (1969), Los mitos de nuestro tiempo, Barcelona, Labor.

Schaller, G. (1984), La vida del gorila, México, Fondo de Cultura Económica.

Schmidt, W. (1941), Manual de Historia comparada de las religiones: origen y formación de la religión. Teorías y hechos, Madrid, Espasa-Calpe.

Schmitт, J.-C. (1992), Historia de la superstición, Barcelona, Crítica.

Sebastí́n, S. (1981), Contrarreforma y barroco, Madrid, Alianza.

Seignolle, C. (1995), Los evangelios del diablo, Barcelona, Crítica.

SkovgaARD, J. S. (1966), Dualism and demonology the function of demono-

logy in pytagorean and platonic thought, Copenhague, Munksgaard.

Starobinski, J. (1976), La posesión demoníaca. Tres estudios, Madrid, Taurus.

SuREDA, J. (1985), «La prehistoria», en J. Milicua (dir.), Historia Universal del Arte, Barcelona, Planeta, tomo I.

TABANERA, J. M. ${ }^{a}$ (1977), «El enigma de las venus paleolíticas», Historia 16, n. ${ }^{\circ} 17$, pp. $65-78$.

Testas, G., y J. Testas (1970), La inquisición, Barcelona, Oikos-Tau.

Tiger, L., y R. Fox (1973), El hombre, animal imperial, Buenos Aires, Emecé.

Tókarev, S. (1990), Historia de la religión, Moscú, Progreso.

ToRREGrosa, J. R. (1968), «El estudio de las actitudes: Perspectivas psicológicas y sociológicas», Revista Española de Opinión Pública, n. ${ }^{\circ} 11$, pp. 155-165.

TriLling, W. (1970), Jesús y los problemas de su historicidad, Barcelona, Herder.

Trocmé, E. (1972), «El cristianismo desde los orígenes hasta el concilio de Nicea», en H.-C., Puech (dir.), Las religiones en el mundo mediterráneo y el Oriente Próximo, Madrid, Siglo XXI.

Tunc, S. (1999), También las mujeres siguieron a Jesús, Maliaño, Sal Terrae. TYLOR, E. (1871/1981), Cultura primitiva, Madrid, Ayuso. 
Ussher, J. (1997), La psicología del cuerpo femenino, México, Grijalbo.

Van De Walle, B. (1967), «Mitología de Egipto», en P. Grimal (dir.), Mitologías del Mediterráneo al Ganges, Barcelona, Planeta.

Van Der Leeuw, G. (1964), Fenomenología de la religión, México, Fondo de Cultura Económica.

Velasco, J. M., et ál. (1984), Ángeles y demonios, Madrid, Fundación Santa María.

Vermes, G. (1984), Jesús el judío, Barcelona, Muchnik.

ViAn, F. (1977), "La religión griega en la época arcaica y clásica», en H. C. Puech (dir.), Las religiones antiguas, Madrid, Siglo XXI.

Vovelle, M. (1985), Ideologías y mentalidades, Barcelona, Ariel.

VRissimtzis, N. (1997), Amor, sexo y matrimonio en la antigua Grecia, Atenas, Polygrama.

Whitrow, G. (1990), El tiempo en la historia, Barcelona, Crítica.

WitTFoGel, K. (1966), Despotismo oriental: estudio comparativo del poder totalitario, Madrid, Guadarrama.

Worsley, P. (1976), La trompeta sonará. Un estudio de los cultos «Cargo» en Melanesia, Madrid, Siglo XXI. 


\section{ÍNDICE}

PRÓLOGO .................................................................... 9

INTRODUCCIÓN …….................................................... 15

I LA MUJER Y EL MAL .................................................. 19

Algo más que tópicos ...................................................... 19

La mujer, el Diablo y la serpiente..................................... $\quad 25$

II EVA EN EL PARAÍSO ..................................................... 33

Te trataré como a una reina............................................... 34

Yo te controlo, tú me dominas .......................................... 46

III LAS TRES CARAS DE EVA …......................................... 61

La Eva fértil ................................................................. 62

La Eva generatriz ........................................................ 71

La otra cara de Eva ....................................................... 86

IV LA MUJER EN EL PANDEMONIUM ORIENTAL .......... 99

Una legión de demonios... ............................................. 100

... Y algunas diosas terribles......................................... 114

V UNA GRAN CALAMIDAD PARA LOS MORTALES ........ 133

Fatalismo y razón ............................................................ 135

Sobre daimones y maleficios .......................................... 150 
Pandora la esfinge ...................................................... 172

Falocracia y palingenesia ................................................. 196

VI LAS HIJAS DE LOS HOMBRES .................................... 227

Un dios patriarcal........................................................ 228

Satán: de funcionario a rebelde integrado ....................... $\quad 240$

Pondré enemistad entre ti y la mujer............................. 256

VII LA PUERTA DE SATANÁS............................................... 289

Y vosotros, ¿quién decís que soy?.................................... 292

No nos dejes caer en la tentación ..................................... 304

No fue Adán el que se dejó engañar... .......................... 318

UN LARGO EPÍLOGO ...................................................... 341

BIBLIOGRAFÍA ............................................................... 367 
Este libro se terminó de imprimir en los talleres Calidad Gráfica, S. L., de Zaragoza, en enero de 2005, año de la entrada en vigor de la Ley Integral contra la Violencia de Género 


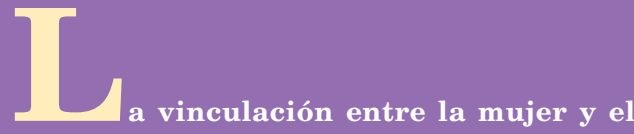

Mal ha sido un hecho cotidiano con el que hemos convivido y cuya evidencia en los diferentes órdenes de la vida se ha asumido como si fuese algo natural e incuestionable, cuando, en realidad, no es sino una manifestación más en la larga historia cultural de la dominación masculina.

La serpiente, símbolo de la fertilidad y de la vida en muchas religiones antiguas, estuvo asociada a la mujer. Sin embargo, en Occidente terminó por ser relacionada con el pecado y el Mal; por eso, debía ser reducida en el mundo de lo sagrado y la mujer sometida en la sociedad patriarcal.

La serpiente vencida es un trabajo de arqueología cultural que tiene como propósito fundamental indagar en los orígenes de esa imagen simbólica y desvelar cómo se fue gestando una visión misógina en el orden de lo sobrenatural dentro del pensamiento occidental. Para ello sus autores se han servido del concepto de representación social, desde los presupuestos teóricos del profesor Serge Moscovici, como un modelo que revela los mecanismos psicológicos y sociales de su producción, sus operaciones y funciones.

A lo largo de sus páginas el lector conocerá cómo desde hace más de dos mil quinientos años, la cultura religiosa ha ido fraguando y consolidando una representación social tan nefasta para la mujer. Frente a esa losa milenaria, la esperanza surge gracias a la lucha emprendida por las feministas que denodadamente desean que el ser humano alcance de nuevo la unidad de género, que debió existir en esa edad de oro de la que también nos hablan los mitos.
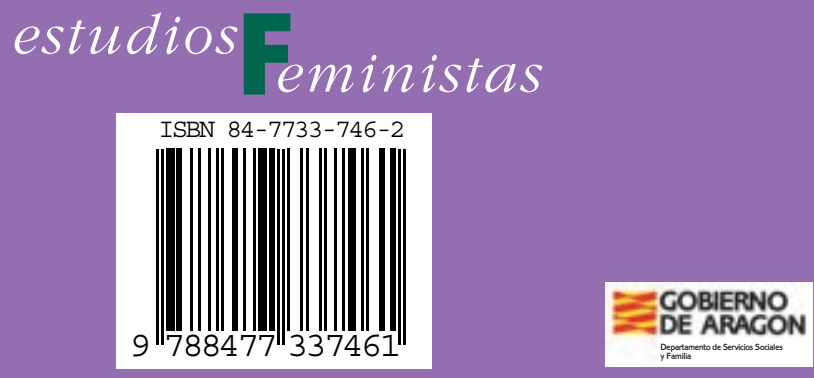